. 


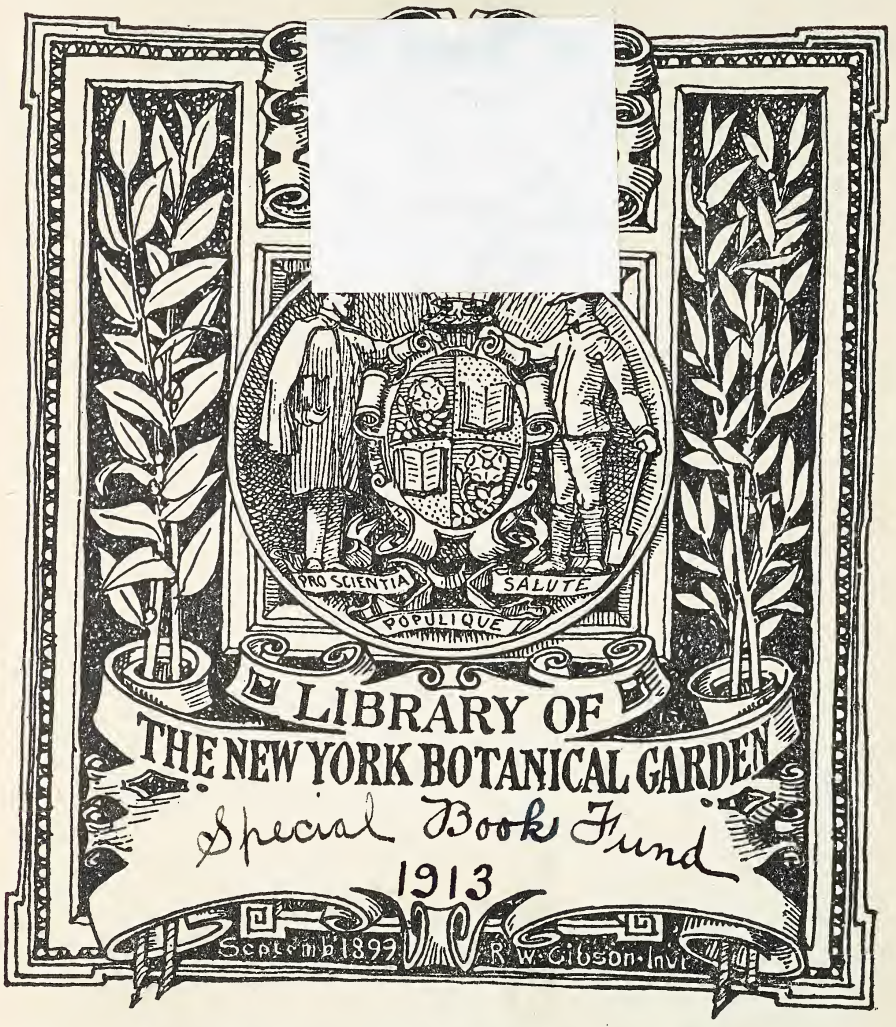








\section{SVENSK FLORA.}

BESKRIFNING ÖFVER SVERIGES

FANEROGAMER OCH ORMBUNKAR

N. C. KINDBERG. 
$Q K 289$
.$K 53$

NORRKÖPING 1877.

M. W. WALLBERG \& COMP. BOKTRYCKERI. 


\section{Anmälan.}

I afseende på planen öfverensstämmer detta arbete mest med Prof. Wahlenbergs Flora Suecica, som med uppfyllande af vetenskapens fordringar förenar en synnerlig tydlighet $\mathrm{i}$ beskrifningarne, så att både botanisten och nybörjaren finna en säker vägledning.

För att få materialier härtill har jag flitigt aktgifvit på de vexlande växtformerna i naturen, studerat nödig literatur och såväl genom resor som genom förbindelser med andra botanister bragt min växtsamling i godt skick. För att öka kännedomen om vårt lands växtgeografi har jag af atskilliga botanister förskaffat mig vigtiga upplysningar.

Det är en kär pligt att till mina vänner och gynnare aflägga min hjertligat tacksägelse för det understöd, de lemnat mig, utan hvilket jag ej skulle hafva vågat utgifva detta arbete, som i alla fall eger brister, hvilka andra forskare kunna med tiden afhjelpa.

I främsta rummet står jag i förbindelse hos min vördade lärare, Professorn och Kommendören m. m. Elias Fries.

För öfrigt är jag skyldig att här med tacksamhet omnämna följ. herrar: Akad. Adj. F. Areschoug, Akad. Doc. H. W. Arnell, Akad. Konservatorn Kandid. A. Blytt, Akad. Adj. F. J. Björnström, Professorn Th. M. Fries, Akad. Adj. R. F. Fristedt, Apotek. C. O. Hamnström, Lärov. Adjunkterna S. Hardin, R. Hartman och J. Hulting, Generaldir. och Kommend. Mr. Huss, Lärov. Kollega T. O. B. N. Krok, Lärrov. Adj. C. P. Lcestadius, Lektorerna L. IIT. Larsson, C. J. Lindeberg och P. Olsson, Lärov. Adj. P. Olsson, Prosten C. Sommerfelt, Lärov. Adj. O. A. Westöö och Lekt. J. E. Zetterstedt.

Anmärkningar och upplysningar mottagas med tacksamhet.

Linköping i Mars 1877. 



\section{Erinringar.}

1. Växtens blomningstid finnes angifven vid beskrifningen af arterna på följande sätt.

Siffran 1 utmärker våren. Denna tid kan räknas till löfsprickningens slut, då Askens löf börja utspricka och Rågen börjar gå i ax.

Siffran 2 utmärker försommaren. Denna kan anses räcka till den tid, då Äpleträden slutat blomma och $R \stackrel{\text { ă- }}{\text { a }}$ gens blomning begynner.

Siffran 3 betyder den egentliga sommaren, sorn kan räknas till fruktskördens början.

Siffran 4 betyder hösten.

Dessa årstider tillhöra egentligen Göta och Svea land. I de öfriga delarne af landet kan man äfven urskilja motsvarande årstider, som betecknas på samma sätt.

2. Den naturliga familj, hvartill ett växtslägte hänföres i Prof. E. Fries' naturliga system, angifves vid beskrifningen af slägtena, t. ex. Umbelliferce, Valerianea, Chenopodiacea o. s. v.

3. Såsom ruderatväxter har författaren velat utmärka åtskilliga växter, som isynnerhet förekomma i grannskapet af menniskoboningar, helst på icke uppodlade ställen, såsom vid vägar, på stenören o. s. v. Somliga af dessa äro ursprungligen införda från andra länder, men kunna dock anses såsom vilda; dervid har förf. sökt följa Prof. Fries' grundsats: "vild är den vegetation, som af naturen är sjelfsådd inom hvarje arts naturliga utbredningsregion". Bot. Utfl. I. 105.

4. Förkortningar. Boh. betyder Göteborgs län, $V g$. den del af Vestergötland, som ej tillhör nämnde län, Göt. Götaland, Sv. Svealand, Dal. Dalarne, Ög. Östergötland, $\nabla b$. Vesterbotten, $n$. nästan.

5. För att finna arternas beskrifning fram i boken, uppsökes slägtets nummer. 


\section{Linnés sexual-system.}

A. Fanerogamer. Växter med hjertblad i fröet.

a. Samkönade: med ståndare och pistiller i samma blomma.

+ Med fria ståndare.

1. Monandria med 1 ståndare.

2. Diandria med 2 ståndare.

3. Triandria med 3 ståndare.

4. Tetrandria med 4 lika långa ståndare.

5. Pentandria med 5 ståndare.

6. Hexandria med 6 lika långa ståndare.

7. Heptandria med 7 ståndare.

8. Octandria med 8 ståndare.

9. Enneandria med 9 ståndare.

10. Decandria med 10 ståndare.

11. Dodecandria med 12 ståndare.

12. Icosandria med 20 eller flera ståndare, fästade på det'sambladiga blomfodret.

13. Polyandria med 20 eller flera från blomhyllet skilda ståndare.

14. Didynamia med 4 tvåväldiga ståndare (2 längre, 2 kortare).

15. Tetradynamia med 6 fyrväldiga ståndare (4 längre, 2 kortare).

++ Med sammanväxta stăndare.

16. Monadelphia med alla strängarne sammanväxta (i 1 stam).

17. Diadelphia med strängarne sammanväxta i 2 stammar (grupper).

18. Polyadelphia med strängarne sammanväxta i 3 eller flera stammar.

19. Syngenesia med knapparne sammanväxta till ett rör.

20. Gynandria med ståndare och pistill förenade. 
b. Skildkönade: med alla eller somliga blommor enkönade.

21. Monoecia sambyggare (med han-och honblommor på samma stand).

22. Dioecia tvåbyggare (med han- och honblommor på olika stånd).

23. Polygamia mångbyggare (med hanblommor, honblommor och samkönade blommor).

B. Kryptogamer. Växter med sporer (frön utan hjertblad).

24. Cryptogamia (Ormbunkar, Mossor, Alger och Svampar).

Ordningarne bestämmas i klasserna $1-13$ efter pistillernas (stiftens) antal (Monogynia, Digynia, Trigynia, Tetragynia, Pentagynia, Hexagynia med 1-6 pistiller, Decagynia med 10, Polygynia med talrika pistiller), i klasserna 16-18 och 20-22 efter ståndarnes antal (Monandria, Diandria, Triandria, Tetrandria, Pentandria, Hexandria med 1-6 ståndare, Octandria med 8, Decandria med 10, Polyandria med talrika standare). I 14:de klassen äro 2 ordningar: Gymnospermia (med 4 fruktämnen i hvarje blomma) och Angiospermia (med ett fruktämne i hvarje blomma). I 15:de klassen äro 2 ordningar: Siliquósa (med långa och smala skidor) och Siliculósa (med korta och breda skidor). I 19:de klassen äro 2 ordningar: Monoclinia (alla med köndelar försedda blommor samkönade) och Polyclinia (somliga blommor enkönade). I 23:dje klassen äro 2 ordningar: Monoecia (med samkönade och enkönade blommor på samma stånd) och Dioecia (med hanblommor, honblommor och samkönade blommor på skilda stånd).

Anm. I klassen Syngenesia äro somliga växter skildkönade, i Polygamia äro somliga blommor samkönade. 


\section{Öfversigt af de vigtigaste fanerogama familjerna i Fries' naturliga system.}

I. DIKOTYLEDONER. Blad oftast grenigt nerviga.
A. Blommor vanligen fullständiga.

a. Ståndare fästade på den sambladiga blomkronan.

1. Synanthéreæ (Blomkorgväxter). Blommor samlade i korg. Hela klassen Syngenesia i Linnés system.

2. Boragineæ (Sträfbladiga). Blomkrona regelbunden; karpeller 4 rötlika. Åtskilliga växter i Pentandria Monogynia.

3. Labiảtæ (Läppblommiga). Blomkrona läppformig; karpeller 4 nötlika. De flesta växter i Didynamia Gymnospermia.

b. Ståndare skilda från blomhyllet. Blomkrona vanligen fribladig.

1. Umbelliferæ (Parasollväxter). Med blommor i flock och med dubbel skalfrukt. De flesta växterna i Pentandria D $i$ gynia.

2. Ranunculăceæ (Ranunkellika). Karpeller talrika. Alla växterna i Polyandria Polygynia.

3. Cruciferæ (Kålväxter). Frukt bestående af en skida; blomkrona korslik. Klassen Tetradynamia.

c. Ståndare fästade på det sambladiga blomfodret. Blomkrona vanligen fribladig.

1. Senticósæ (Rosartade). Ståndare omkring 20 eller flera; blomkrona rosartad. Icosandria Polygynia.

2. Leguminósæ (Ärtväxter). Blomkrona fjärillik. Diadelphia Decandria.

3. Ericíneæ (Ljungväxter). Ljunglika halfbuskar med vanl. läderartade blad och regelbunden blomkrona. Alla växter i Decandria Monogynia och några i Octandria Monogynia.

B. Blommor ofullständiga, vanligen samlade i hängen. Ofta träd eller buskar.

1. Cupuliferæ. Löfträd med nötlik frukt, omgifven af ett bägarfoder. Höra till Monoecia.

2. Betulineæ. Löfträd med nötlik frukt utan bägarfoder. Höra till Monoecia.

3. Salicineæ (Pilartade). Löfträd eller buskar med kapsellik frukt. Höra till Dioecia.

4. Coniferæ (Barrträd). Höra till Monoecia eller Dioecia.

II. MONOKOTYLEDONER. Blad enkelt nerviga. Blommor alltid ofullständiga.

1. Orchídeæ (Orkisartade). Blomkalk oregelbunden och högfärgad. Gynandria.

2. Liliáceæ (Litjeväxter). Kalk regelbunden och vanl. högfärgad. Många växter i Hexandria Monogynia.

3. Cyperáceæ (Halfgräs). Strå oledadt; blomkalk otydlig. De flesta i Triandria Monogynia samt slägtet Carex.

4. Gramineæ (Gräs). Stră ledadt. Triandria Digynia. 


\section{Beskrifning af slägtena.}

\section{Klassen. MONANDRIA.*)}

Örter med ofullständiga blommor.

\section{Ordn. MONOGYNIA. Pistill 1.}

1. Salicórnia. Ståndare och pistill inom ett köttigt hölster, (liknande en blomkalk). Märken 2-3. Med köttig, ledad stam, motsatta grenar och motsatta fjäll i st. f. blad; blommor i kolf; frukt enfröig nötlik. Chenopodiáceæ.

2. Hippúris. Blomkalk foderlik, fastväxt vid fruktämnet. Stift enkelt. Stjelk enkel och ledad med kranssittande biad och blommor; frukt nötlik. Halorhágeæ.

3. Zostéra. Utan blomkalk. Ståndare skild från pistillen. Märken 2. Gräslika växter med nedtill rotslående stjelk; blommor tvåradiga i kolf inom ett gemensamt hölster; frukt enfröig kapsellik. Potamogetóneæ.

\section{Klassen. DIANDRIA. ***)}

Örter (utom Ligustrum och Veronica saxatilis). Blommor fullständiga (utom hos Lemna).

\section{Ordn. MONOGYNIA. Pistill 1.}

\section{A. Blommor ofullständiga, sällan utvecklade.}

4. Lemna. Blommor inom ett hölsterlikt skärmfjäll utan kalk. Mycket små vattenväxter utan egentliga blad, men med bladlika, ofta sammanhängande stammar (stamblad). Aroideæ.

B. Blommor fullständiga; krona fribladig.

5. Circæa. Blomfoder 2-klufvet; krona 2-bladig. Meả motsatta stjelkblad och hvitröda blommor i klasar; frukt nötlik under blomkronan. Onagrariéæ.

*) Till denna klass kunna äfven hänföras följ. örter: Festuca sciuroides gräs, Eriophorum halfgräs, Stellaria med hvita kronb]ad, Callitriche vattenväxter med motsatta blad, Zannichellia vattenväxter med kranssittande blad, Alchemilla med handnerviga blad, Chenopodium och Blitum med gyttrade blommor och fjädernerviga blad.

**) Till denna klass kunna äfven hänföras ett träd, Fraxinus, samt följ. örter med ofullständiga blommor: Anthoxanthum, Catabrosa algida och Hierochloa, gräs: Cyperus, Cladium, Scirpus och Rhynchospora, halfgräs; Salicornia med bladlös och grenig stam; Alchemilla med handnerviga blad; Chenopodium med hela och fjädernerviga blad utan stipler; Lepidium med parbladigt delade blad; Ruppia med borstlika blad; Viola med stipler och enstaka hlommor. Dessutom Stellaria media med bvita kronblad. 
C. Blommor fullständiga; krona sambladig.

a. Frukt af 4 nötlika karpeller. Blomkrona läppformig. Stjelk fyrkantig med korsvis motsatta blad och kranssittande blommor. Labiátæ.

6. Sálvia. Kronans öfverläpp stor och hvälfd. Blomfoder läppformigt. Med stora blå blommor i axlikt närmade kransar.

7. Ly'copus. Kronans öfverläpp föga längre än den undre. Foder regelbundet, grundt 4-5-flikigt. Med små hvita rödprickiga blommor i skilda kransar.p

b. Kapsel enrummig. Krona läppformig med sporre. Ståndareknappar enrummiga. Lentibulariéæ.

8. Pinguícula. Kapsel upptill uppbristande. Foder 5 -klufvet, n. läppformigt. Krona gapande. Med enblommiga rotblomskaft, blåaktiga eller hvita blommor och hela klibbiga blad.

9. Utriculária. Kapsel kringskuren. Foder 2-bladigt. Krona stundom maskerad. Med krypande stjelk och stängellika blombärande grenar; blommor gula i klase; blad pardelade med $n$. hårlika flikar. Emot blomningstiden upplyftes växten till vattenytan, emedan de på växtens nedre del sittande blåsorna blifva fylda med luft.

c. Kapsel tvårummig. Krona utan sporre. Kronbräm och foder 4-delade. Personátæ.

10. Verónica. Med stjelk och med vanl. blåaktiga blommor; blad ofta motsatta.

d. Frukt bärlik. Kronbräm 4-klufvet. Foder otydligt tandadt. Oleíneæ.

11. Ligustrum. Bär tvårummigt inom den trattlika kronan. Buske med hvita blommor i vippa och stela, helbräddade och motsatta blad.

\section{Klassen. TRIANDRIA. (Örter).}

\section{Ordn. MONOGYNIA. Stift $\left.1 .{ }^{*}\right)$}

A. Dikotyledoner med sambladig trattlik (och högfärgad) blomkrona ofvanpå den enfröiga skalfrukten. Märken 3, blommor i knippen, blad motsatta. Valeriáneæ.

12. Valeriảna. Frukt enrummig med fjäderpensel. Blad vanl. delade, blommor ljusröda eller hvita; stjelk upptill grenig.

13. Valerianella. Frukt trerummig utan pensel. Blad hel-

*) Till denna ordning kunna äfven räknas de egentliga gräsen, som hänföras till följ. ordning, en låg buske, Empetrum, samt följ. örter: a) med fullständ. blommor: Asperula och Galium, b) med ofullständiga blommor: Alchemilla med handnerviga blad, Juncus med strålik stam, Chenopodium och Thesium. 
bräddade eller tandade, blommor ljusblå eller hvita, oskaftade; stjelk klynnedelad.

B. Monokotyledon med högfärgad kalk ofvanpå den kapsellika frukten. Märken 3 kronbladlika, blad strödda. Irideæ.

14. Iris. Kalkblad $i$ a kransar, de yttve nedböjda. Blad svärdlika enkelnerviga; blommor gula eller blå, hvarje inom ett hölster; kalk djupt delad.

C. Halfgräs med oledadt, icke ihåligt strå. Blad smala, oskaftade och slidomfattande: stundom utbildas blott slidorna. Blommor inom skärmfjäll i ax: kalk saknas eller antydes genom borst (kalkborst). Frukt enfröig nötlik. Cyperáceæ.

a. Småax plattade; skärmfjäll tvåsidigt stälda.

15. Schœnus. De nedre skärmfjällen tomma. Småax 1-3blommiga. Strån blott nedtill bladiga; småax svartbruna, tätt sittande; kalkborst sträfva.

16. Cypérus. Alla skärmfjäll vanl. med blommor. Småax mångblommiga. Strån nedtill bladiga; småax svartbruna i ctt eller flera flocklika hufvud; kalkborst inga; ståndare 2.

b. Småax (eller ensamma ax) trinda; skärmfjäll tegellagda.

1. De nedre skärmfjällen mindre än de öfriga och tomma; ax sammansatt af gyttrade småax.

17. Rhynchóspora. Med kalkborst. Stift ledadt. Med låga och fina strån; ståndare stundom två.

18. Cládium. Utan kalkborst. Stift oledadt. Med grofva strån, taggsågade blad och 2 ståndare; axsamling mycket grenig; ax bruna.

2. De nedre skärmfjällen ej mindre än de öfriga. 19. Scirpus. Kalkborst sällan felande, men alltid korta. Med bladiga eller bladlösa strån; ax vanl. bruna (stundom grönaktiga), ensamma eller förenade.

20. Erióphorum. Kalkborst slutligen långa oct ullika. Med bladiga eller bladlösa strån; ax vanl. gråaktiga, ensamma eller flera àtskilda.

\section{Ordn. DIGYNIA.}

Stift (märken) 2, nedtill ofta hopväxta.

Egentliga gräs med ihåligt, ledadt strå (hos Melica och Enodium n. oledadt). Blad smala, oskaftade och slidomfattande. Blommor stundom àtskilda, men vanligen förenade $\mathrm{i}$ ax (s. $\mathrm{k}$. småax). Kalk agnlik, bestående af $1-2$ fjäll (kronskal): vid basen af hvarje småax sitta $1-2$ skärmfjäll (foderskal). Frukt hinnfrukt. 
Anm. Hos Nardus sakna blommorna foderskal och sitta åtskilda sinsemellan, stälda $i$ ett enkelt ax. Af de öfriga hafva somliga åtskilda blommor, stälda $\mathrm{i}$ ax eller vippa; dessa sägas hafva "enblommiga småax". Stundom händer, att dylika blommor hafva jemte sig ämnen till 1-2 felslagna blommor.

\section{Öfversigt af gräsens hufvudafdelningar.}

A. EURYA'NTHÉE. Blommor under blomningen öppna med nedtill framskjutande märken. Stift korta (utom hos Phragmites).

Anm. Hos hithörande växter äro småaxen sällan enblommiga: hos afdelningen Agrostidea, som dock alltid har tydlig blomvippa, samt stundom hos Hordeacea. Hos följ. afdelning, Clisanthece, hafva småaxen vanligen (utom hos Nardus och Hierochloa) mycket korta skaft och sitta tätt hopträngda.

a. Småax utan (eller med mycket kort) skaft sittande på ett gemensamt, enkelt och ledadt fäste (stråets förlängning:)

\section{Hordeáceæ.}

b. Småax med (vanligen utdragna) skaft fästade på stråets grenar-och sålunda stälda $\mathrm{i}$ vippa.

Anm. Vippan är hopdragen hos Cynosurus, Dactylis, Holcus, Airopsis, Trisetum, Koeleria, Psamma, Festuca ovina och Melica ciliata.

* Småax tvåblommiga *) eller flerblommiga (hos Catabrosa algida och Melica uniflora enblommiga, hos Holcus och oftast hos Avena elatior med blott en samkönad blomma).

II. Festucáceæ. Foderskal kortare än närmaste blomma; blommor med inga eller korta hår.

III. Avenáceæ. Foderskal långa, ofta nästan omslutande småaxet; blommor stundom med teml. korta hår.

IV. Arundináceæ. Foderska] kortare än småaxet; blomhår mycket långa.

* Småax enblommiga eller med ämne till en andra blomma.

V. Agrostideæ. Blommor ofta med hår.

B. CLISA'NTHEA. Blommor alltid slutna med utdragna stift och upptill framskjutande märken.

*) Om det nedre kronskalet har borst, kan blommornas antal vanligen räknas efter borstens. 
a. Småax med två eller flera samkönade blommor; märken två. Blomsamling (ax) tätblommig.

VI. Sesleriáceæ. Foderskal omslutande småaxet och nedtill omgifna af ett borstlikt svepe.

b. Småax med blott en samkönad blomma; märken två. Blomsamlingar tätblommiga.

VII. Paníceæ. Nedre foderskalet mycket litet. Blommor gyttrade antingen $\mathrm{i}$ en $\mathrm{n}$. jemntjock (valsformig) axlik vippa (axvippa eller "ax") och försedda med borstlikt svepe, eller i flera ensidiga ax utan svepe.

VIII. Alopecúreæ. Foderskal omslutande småaxet utan svepe. Blommor gyttrade $\mathrm{i}$ en tät, n. jemntjock axlik vippa (ax).

IX. Phalarídeæ. Foderskal af småaxets längd. Småax förenade $\mathrm{i}$ utbredd eller hopdragen vippa, stundom $\mathrm{n}$. oskaftade $i$ ett icke valsformigt ax.

c. Blommor ensamma i ett enkelt ax; märke ett.

X. Nárdeæ. Utan foderskal; stråets öfre del ledad.

\section{Hordeaceæ.}

A. Småax alldeles oskaftade.

a. Småax ensamma (åtskilda) och tvåsidigt stälda.

21. Triticum. Småax 3-5-blommiga, stälda med bredsidan mot fästet. Foderskal 2. Liknar Hvete.

22. Lólium. Smãax 3-5-blommiga, vända med kanten mot fästet. Foderskal ett (utom i toppaxet).

23. Leptúrus. Småax enblommiga. Foderskal 2 utåtvända. Litet gräs, hvars axsamling i början är föga tjockare än strået; blad mycket smala.

b. Småax 2-4 tillsammans vid hvarje led af fästet (strået).

24. Hórdeum. Småax enblommiga. Kronborst laingt. Med tågig rot. Liknar odladt Korn.

25. E'lymus. Småax 2-4-blommiga (stundom blott med en fullt utbildad b) Jomma). Kronskal oftast utan borst. Vanligen med lång rotstock, sällan med tågig rot. Liknar något Råg.

B. Småax kortskaftade.

26. Brachypódium. Småax n. trinda, flerblommiga. Småax tvåsidigt stälda; foderskal två. 


\section{Festucaceæ.}

A. Nedre kronskalet vanl. med borst (utom hos Schedonorus inermis, Festuca silvatica och pratensis). Frukt vanl. (utom hos Dactylis) med bihang i spetsen.

a. Småax hopgyttrade och n. oskaftade.

27. Cynosúrus. Småax hoptryckta, ensidigt sittande på det enkla axfästet och nedtill försedda med kamlikt svepe. Strån spensliga. Nedre kronskalet trindryggadt och långspetsigt.

28. Dáctylis. Småax gyttrade utan svepen på strảets utdragna grenar. Med grofva strån och breda blad. Nedre kronskalet med hvass köl och lång spets.

b. Småax vanl. spridda $\mathrm{i}$ en utbredd vippa.

29. Festúca. Nedre kronskalet trindryggadt och spetsigt. Bladslidor delade, småax upptill afsmalnande.

30. Schedonórus. Nedre kronskalet med en hvass köl och utdragen spets. Bladslidor klufna, småax vanl. upptill bredare.

31. Bromus. Nedre kronskalet trindryggadt och trubbigt. Bladslidor klufna, småax nedtill uppsvälda.

B. Kronskal utan borst. Frukt utan bihang.

32. Poa. Nedve kronskalet köladt och med kort spets. Småax små, hoptryckta och n. äggrunda samt tätblommiga; foderskal föga hinnaktiga.

33. Briza. Nedre kronskalet upptill afrundadt, nedtill $n$. hjertlikt. Småax teml. små, hoptryckta och bredt äggrunda samt tätblommiga.

34. Catabrósa. Nedre kronskalet $n$. aflångt, upptill trubbigt. Småax mycket små med blott 2 skilda blommor eller stundom (hos en art) enblommiga.

35. Glycéria. Nedre kronskalet aflaingt, upptill trubbigt och hinnaktigt. Småax ofta utaragna med flera närsittande blommor.

36. Enódium. Nedre kronskalet lansettlikt, trindryggadt och spetsigt. Småax vanl. blåaktiga i smal vippa med blott 2 fullt utbildade, skilda och kägellika blommor.

\section{Avenaceæ.}

A. Nedre kronskalet med från ryggen utgående borst. a. Nedre kronskalet tvåklufvet med knäböjdt borst. 37. Avéna. Foderskal trindryggade. Småax teml. stora, vippa vanl. utbredd, strån höga. Hithörande arter likna odlad Hafre. 38. Trisétum. Foderskal kölade. Nedre kronskalet köladt. Småax små, vippa teml. hopdragen, strån teml. spensliga.

39. Airópsis. Foderskal kölade. Nedre lkronskalet trindryggadt. Småax små, vippa vanl. hopdragen, stundom utbredd; strån låga och spensliga; blad borstlika. 
b. Nedre kronskalet i spetsen helt eller fintandadt med rakt eller stundom knäböjdt borst. Foderskal kölade. Småax tvåblommiga.

40. A'ira. Nedre kronskalet upptill fintandadt. Kronborst hårlikt. Strån teml. höga med små småax i vanl. utbredd vippa samt med smala blad.

41. Corynéphorus. Nedre kronskalet helt. Kronborst midtpå ledadt och upptill klubblikt. Strån teml. låga och spensliga med små småax $i$ slutl. hopdragen vippa samt med borstlika blad.

42. Vahlódea. Nedre kronskalet helt. Kronborsthårlikt. Strån teml. låga och spensliga med utbredd fảblommig vippa och smala platta blad.

B. Nedre kronskalet (i den öfre blomman) med borst nära spetsen. Den nedre blomman utan kronborst, den öfre utan pistill.

43. Holcus. Foderskal kölade. Småax mycket små och tvâblommiga, vippa slutl. tätt hopdragen, blad mjuka.

C. Kronskal utan eller med otydligt borst.

44. Triódia. Småax flerblommiga. Foderskal trindryggade och n. hinnaktiga. Strả lågt, småax få i klaselik vippa.

45. Graphéphorum. Småax flerblommiga. Foderskat kölade och hinnaktiga. Strå högt och bredbladigt med stor rotstock, småax talrika och slutl. hvitgula i utbredd vippa.

46. Mélica. Småax 1-2-blommiga. Foderskal trindryggade, hinnaktiga och högfärgade. Strå spensligt och smalbladigt, småax $\mathrm{i}$ klase eller $\mathrm{i}$ klaselik vippa.

47. Koeléria. Småax 2-3-blommiga. Foderskal kölade och hinnaktiga. Strå spensligt med borstlika blad och rikblommig, snart hopdragen och smal vippa.

\section{Arundinaceæ.}

48. Phragmites. 'Kronskal utan borst.] Foderskal kölade. Strå högt och bredbladigt, småax i början brunaktiga, vippa yfvig.

\section{Agrostideæ.}

A. Nedre kronskalet vanl. med borst. Foderskal vanl. hinnaktiga, kölade och längre än kronskalen. Småax teml. närsittande.

a. Nedre kronskalet med hårlikt eller intet borst.

49. Calamagrostis. Blommor med teml. långa hår nedtill. Kronskal hinnaktiga. Öfre foderskalet kortast. Teml. höga gräs med något grofva strån.

50. Psamma. Blommor med tydliga hår nedtill. Kronslial läderartade. Nedve foderskalet kortast. Liknar föreg. slägte, men har hopdragen vippa och slutl, hoprullade blad. 
51. Agrostis. Blommor n. utan hår. Öfre foderskalet minst. Med hinnaktiga kronskal: det öfre stundom felslående; småax mycket små. Spensliga gräs.

52. Apéra. Blommor utan här. Nedre foderskalet minst. Med icke hinnaktiga kronskal; småax mycket små, vanligen gröna, sällan brunaktiga; kronborst mycket långt.

b. Nedre kronskalet med upptill fjäderlikt borst.

53. Stipa. Foderskal med lång borstlik udd. Kronborst nedtill vridet. Med inrullade borstlika blad och af bladslidorna n. helt och hållet täckt strå.

B. Kronskal vanl. utan borst. Foderskal bladartade och n. lika långa med kronskalen. Vippa gles. Blommor utan hår.

54. Milium. Foderskal trinaryggade och trubbiga. Kronskal utan borst. Välluktande, hög och bredbladig med mycket gles vippa.

55. Cinna. Foderskal kölade och spetsiga. Nedre kronskalet med ett kort borst. Liksom den föreg. hög, bredbladig och välluktande, men med smärre blommor.

\section{Sesleriaceæ.}

56. Sesléria. Nedre kronskalet med 5 borstuddiga nerver. Lågt och daggblått gräs med kort och aflångt ax.

\section{Paniceæ.}

57. Setåria. Småax försedda med svepe och stälda $i$ ett ax (axvippa). Strå lågt med tumslångt ax och långa svepeborst.

58. Pánicum. Småax utan svepe, ensidigt stälda $i$ flera $a x$, som tillsammans bilda en vippa (eller ett sammansatt ax). Strå lågt.

59. Digitária. Småax utan svepe, ensidigt stälda $i$ flera ax, som vanl. utgå från samma punkt nära stråets spets. Strå lågt med smala ax.

\section{Alopecureæ.}

60. Alopecúrus. Foderskal utan borst. Kronskal 1 med borst. Mjuka gräs med mjukt ax.

61. Phleum. Foderskal med borst. Kronskal 2 utan borst. Med styfva strån och sträft ax.

\section{Phalarideæ.}

62. Digraphis. Småax skaftade. Blommor utan borst. Strå högt, styft och bredbladigt; vippa tätblommig.

63. Anthoxanthum. Smáax n. oskaftade. Kronskalet hos de felslående blommorna med laingt borst. Lågt, mjukt, smalbladigt och välluktande gräs med tätblommigt och $n$. lansettlikt ax (axlik vippa). Den samkönade blomman har blott 2 ståndare, liksom hos följ. slägte. 
64. Hieróchloa. Småax skaftade. De felslående blommorna med kort kronborst. Spensliga, smalbladiga och välluktande gräs med stundom gles vippa.

\section{Nardeæ.}

65. Nardus. Ax ensidigt. Strån låga, tufvade och sega med borstlika blad.

\section{Ordn. TRIGYNIA. Stift $3 .{ }^{*}$ )}

66. Móntia. Krona trattlik 5-delad, foder 2-bladigt, frult kapsel. Med klynnedelad stjelk, motsatta blad och små hvita, skaftade blommor i bladvecken. Portulacáceæ.

67. Koenigia. Blomkalk 3-bladig och inuti högfärgad; frult en trekantig nöt. Med låg och enkel eller klynnedelad stjelk, skiftevis sittande blad med stipelslidor och mycket små gulaktiga blommor, gyttrade i grentopparne vid de öfversta bladen. Polygóneæ.

68. Holósteum. Krona och foder af 5 fria blad: kronblad hela. Kapsel med 6 skal. Med enkla och upptill bara stjelkar, motsatta blad och bvita blommor i flock. Alsináceæ.

\section{Klassen. TETRANDRIA. **)}

(Örter, undantag. Cornus sanguinea).

1 Ordn. MONOGYNIA. Pistill 1 (stundom n. tvådelad). A. Fruktämne under den sambladiga blomkronan. Blomfoder hopväxt med frukten, stundom otydligt.

a. Stift utdraget. Blommor i korg eller hufvud med gemensamt svepe. Hvarje blomma vanl. med enskildt svepe. Skalfrukt. Blad motsatta. Dipsáceæ.

69. Knáutia. Blomfäste utan fjäll. Svepeblad upprätta. Stjelkblad vanl. parklufna, blomkorg n. platt, blomkrona blekröd 4-klufven.

70. Scabiósa. Blomfäste fjälligt. Svepeblad upprätta. Blomhufvud slutl. n. klotrundt, krona blå 4-5-klufven.

*) Hit kunna äfven räknas Elatine triandra, en liten vattenväxt, och Stellaria media, som har 5 tvådelade kronblad.

**) Till denna klass kunna äfven räknas: a) Ulmus träd, Evonymus buske, b) örter med ofullständ. blommor: Thesium och Sagina med n. trådlika stjelkblad, Chenopodium och Herniaria med gyttrade blommor, c) örter med fullständ. hlommor: Cuscuta utan blad, Littorella sambyggare, Myosurus med stängel och samkönade blommor, Mentha m. fl. i klassen Didynamia, Stellaria och Cerastium med hvita kronblad, Gentiana med blàaktiga blommor, Draba och Cardamine med skidor, Adoxa med gröna blomhufvud. 
b. Stift kort med 2 märken. Frukt af 2 nötlika karpeller. Blad kranssittande och helbräddade. Stjelk fyrkantig. Rubiáceæ.

71. Gålium. Kronbräm platt, foder utan bräm. Blommor hvita eller gula utan svepe.

72. Aspérula. Krona trattlik, foder utan bräm. Blommor hvita eller rödaktiga utan svepe.

73. Sherárdia. Krona trattlik, foder med tandadt bräm. Blommor gredelina i hufvud inom svepe.

B. Fruktämne inom den sambladiga kronan, slutl. enfröig skalfrukt. Blad strödda. Blommor i korg (hufvud). Globulariéæ.

74. Globulária. Foder 5-klufvet. Krona läppformig. Med låga enkla stjelkar, n. hela blad samt vanl. blå blommor; stift utdraget.

C. Fruktämne inom den sambladiga kronan, slutl. kringskuren kapsel. Blommor i ax eller enstaka.

75. Plantágo. Foder 4-deladt. Krona hinnaktig och trattlik med 4-deladt och utböjdt bräm. Med stängel, blommor i ax och helbräddade eller tandade blad. Plantagíneæ.

76. Centúnculus. Foder 4-klufvet. Krona med n. klotrund pip och 4-klufvet bräm. Med enstaka blommor i bladvecken och med mycket små och helbräddade blad. Primuláceæ.

D. Fruktämne under den fribladiga kronan.

77. Cornus. Foder 4-tandadt, krona 4-bladig. Stenfrukt. Med motsatta och hela blad; buske eller ört. Córneæ.

78. Trapa. Foder med kort pip och 4-deladt bräm. Krona 4-bladig. Frukt nötlik. Vattenväxt med de nedsänkta bladen hårlikt pardelade och motsatta; de öfre bladen likna björklöf. Halorhágeæ.

E. Med blomkalk (utan blomkrona). Blad strödda.

79. Majánthemum. Kalk hjulformig 4-delad. Frukt bär. Med hjertlika bågnerviga blad och hvita blommor i klase. Liliáceæ.

80. Alchemilla. Kalk 8-klufven. Frukt nötlik. Med handnerviga blad och gröna gyttrade blommor. Senticósæ.

81. Sangvisorba. Kalk med hopdragen, slutl. hairdnande och fyrlkantig pip och \&-deladt bräm. Frukt nötlik. Med parbladiga blad och rödbruna (blodröda) blommor i bredt ovala ax i spetsen af grenarne. Senticósæ.

82. Thésium. Kalk trattlik 3-4-klufven. Frukt nötlik. Med n. trådsmala blad och blommor i klase; kalk invändigt hvit, utvändigt grön. Santaláceæ.

2 Ordn. TETRAGYNIA. Pistiller omkr. 4.

A. Blommor vanl. fullständiga. Foder 4-deladt. Krona 4-bladig. Frukt kapsellik. Blad motsatta. Småörter. 
83. Radiola. Kapsel 8-rummig. Med små, men breda blad, klynnedelad stjelk och små hvita blommor, gyttrade i spetsen af grenarne. Gruináles.

84. Bulliảrda. Karpeller \& kapsellika. Med syllika blad och små ljusröda, blommor, ensamma i bladvecken. Crassuláceæ.

B. Blommor ofullständiga. Frukt vanl. af flera nötlika karpeller. Alla eller de nedre bladen spiralstälda (hos en art motsatta). Vattenväxter. Potamogetóneæ.

85. Potamogéton. Karpeller vanl. 4, oskaftade. Med blommor i ax (kolf). De tvårummiga ståndarnes knappband bilda 4 fjäll, som likna en blomkalk.

86. Rúppia. Karpeller 3-7, skaftade. Liknar några arter af föreg. slägte och har trådlik, krypande stjelk, n. hårfina blad med stipelslidor och mycket små frukter. Kalk saknas. Ståndarne äro egentligen 2 med skilda knapprum.

\section{Klassen. PENTANDRIA.}

De flesta hithörande växterna äro örter.

\section{Ordn. MONOGYNIA. Pistill (stift) 1. *)}

Öfversigt af afdelningarne.

I. Blomkalk sambladig och högfärgad. Slägtet N:o 87.

II. Blomkrona sambladig. Ståndare fästade på blomkronan.

A. Med 4 nötlika karpeller inom blomfodret. 88-97.

B. Med ett fruktämne inom blomkronan, slutl. enkelgömmigt med centralt fröfäste. Märke ett (hos N:0 105 två, hos N:o 107 tre).

a. Ståndare motsatta kronflikarne. Kapsel enrummig. 98-102.

b. Ståndare stälda skiftevis med kronflikarne. Kapsel flerrummig. 103-107.

c. Ståndare stälda skiftevis med kronflikarne. Frukt bär. 108.

C. Med ett fruktämne inom blomkronan, sluti. enkelgömmig tvåskalig kapsel med på skalen fästade frön. Märken två (hos N:o 111 ett). 109-111.

D. Med ett fruktämne inom blomkronan, slutl. fiergömmig kapsel. Märken två. 112.

E. Med ett fruktämne, sittande åtm. till en del under blomkronan.

a. Örter. 113-116.

b. Buskar. 117.

*) Till denna ordning kunna äfven räknas Ulmus träd, Viburnum och Samzucus buskar, Rhododendrum halfbuske, samt följ. örter: a) med fullständiga blommor: Adoxa och Cynanchum, b) med ofullst. blommor: Polygonum med stipelslidor, Chenopodium, Kochia, Schoberia och Salsola. 
III. Blomkrona sambladig. Ståndare fästade i blomfodrets botten. Halfbuske. 118.

IV. Blomkrona fribladig, stundom otydlig.

a. Buskar. 119-12.2.

b. Örter. $123,124$.

I. Blomkalk sambladig och högfärgad. Ört.

87. Glaux. Kalk klocklik 5-klufven. Kapsel enrummig. Blommor ljusröda, enstaka i bladvecken; blad köttiga. Primuláceæ.

II. Blomkrona sambladig, vanl. med 5 lika stora flikar (undantag. Echium, Lobelia, Lonicera och Gentiana campestris). Ståndare fästade på blomkronan. Örter (utom Lonicera och Solanum Dulcamara).

A. Med 4 nötlika karpeller inom blomfodret.

Stjelk vanl. upprätt (utom hos Asperugo och Stenhammaria) och n. trind. Blad spiralstälda, vanl. helbräddade nch håriga. Blommor i ensidiga knippen, som likna ax eller hlasar och före utslåendet äro inrullade (utom hos Asperugo, som har gyttrade blommor). Blomfoder med 5 flikar. Ståndare inneslutna (utom hos Echium och stundom hos Pulmonaria). Boragíneæ.

a. Kronans svalg öppet utan knölar eller fjäll. Nötter skilda från stiftet.

88. Ėchium. Krona med uppåt vidgad pip och snedt bräm. Sträfhårig med stora ljusblå blommor; foder deladt.

89. Lithospermum. Krona trattlik med naigot hopdraget svalg och deladt bräm. Foder deladt. Sträfhărig med små hvitaktiga blommor.

90. Pulmonária. Krona trattlik med ej hopdraget svalg och med klufvet bräm. Foder grundt klufvet. Blad något sträfva; blommor stora rödblå.

91. Stenhammária. Krona trattlik med ej hopdraget svalg och med klufvet bräm. Foder djupt klufvet. Nedliggande eller uppstigande med köttiga och ej sträfva blad samt teml. små blommor; karpeller med tunnt och hinnaktigt skal.

b. Kronans svalg slutet af knölar eller fjäll. Nötter stundom fästade vid stiftet.

1. Nötter $n$. fria från stiftet samt utan hullingborst. Blommor i ax eller klasar.

92. Sy'mphytum. Krona bägarlik med syllika tänder $i$ svalget. Nötter undertill urhailkade (med qvarsittande ringformig bas). Med stora sträfva blad, stora hlommor och deladt foder. 93. Anchúsa. Krona trattlik med trubbiga knölar. Nötter undertill urhålkade. Med smala sträfva blad och klufvet foder.

94. Myosótis. Krona trattlik eller tallriksformig med tandlika fjäll. Nötter undertill ej urhålkade. Med föga sträfva blad och små, vanl. blå blommor. 
2. Nötter fästade vid stiftet samt utan hullingborst. Blommor gyttrade i bladvecken.

95. Asperúgo. Krona trattlik med trubbiga knölar (fjäll). Foder olikformigt klufvet $i 2$ slutl. gaisfotlika flikar. Stjelk snärjande med mycket små blå blommor.

3. Nötter fästade vid stiftet samt försedda med hullingborst (krökta taggar). Blommor i klasar.

96. Cynoglossum. Nötter öfverallt taggiga och nedplattade. Hög och i början gråluden, med teml. stora smutsröda, slutl. violetta blommor, trattlik krona och deladt foder.

97. Echinospermum. Nötter taggiga $i$ kanten och trekantiga. Föga grof och något sträfhårig med små blå blommor; foder deladt, krona trattlik eller tallriksformig. Liknar Myosotis.

B. Med ett fruktämne inom blomkronan, slutl. enkelgömmigt med centralt fröfäste. Märke ett (hos $D a$ tura två, hos Polemonium tre).

a. Ståndare motsatta kronflikarne. Kapsel enrummig. Primuláceæ.

1. Kronpip utdragen.

98. Prímula. Foder tandadt. Kapsel uppbristande med tänder. Med stängel, blommor i flock och hela blad.

99. Hottónia. Foder deladt. Kapsel 5-stalig. Ned blommor i kransar på stängellika grenar och med pardelade blad; kronbräm platt.

2. Kronpip kort. Blad hela.

100. Lysimáchia. Foder deladt. Kapsel uppbristande med tänder. Med stjelk, motsatta eller kranssittande blad och gula blommor.

101. Anagallis. Foder deladt. Kapsel kringskuren. Med nedliggande stjelk och mönjeröda eller blå blommor, ensamma i bladvecken; blad motsatta eller kranssittande; krona hjulformig.

102. Andrósace. Foder klufvet. Kapsel 5-skalig. Med stängel, i rosett samlade blad och små hvita blommor i flock; krona trattlik med upptill hopdragen pip.

b. Ståndare stälda skiftevis med kronflikarne (och fria). Kapsel flerrummig.

1. Märke vanl. ett. Foder utan svepe. Solanáceæ.

103. Verbascum. Foder djupt klufvet. Kronpip kort. Höga ludna växter med hela blad och gula, sällan hvita blommor; kapsel 2-rummig och 2-skalig; kronbräm platt eller skållikt. 104. Hyoscy'amus. Foder tandadt bägarlikt. Kronpip vid och utdragen. Klibbig illaluktande växt med inskurna, om. fattande blad och smutsgula blåădriga blommor i ensidiga ax; kapsel 2-rummig och kringskuren; kronbräm klocklikt. 
105. Datura. Foder tandadt och kantigt: den öfre delen affallande. Kronpip mycket lång. Glatt illaluktande växt med stora långskaftade blad och mycket stora, hvita blommor, ensamma i bladvecken; kapsel 4-rummig och 4-skalig; kronbräm klocklikt; märken tvci.

2. Märke ett. Blomfoder med 3-bladigt svepe (foderholk).

106. Diapénsia. Foder deladt. Krona tallriksformig med utdragen pip. Tufvad ört med nedtryckta, hårda och ständigt gröna (eller rodnande) blad; öfver dessa uppskjuta 1-2 tum långa blomskaft med teml. små, ensamma och snöhvita blommor. Polemoniáceæ.

3. Märken tre. Blomfoder utan svepe.

107. Polemónium. Foder djupt klufvet. Krona hjulformig med kort pip eller klocklik. Stjelk hög med parbladigt delade blad och blå (eller hvita) blommor i qvastlik vippa. Polemoniáceæ.

c. Ståndare stälda skiftevis med kronflikarne. Ståndareknappar sammanhängande. Frukt bär.

108. Solánum. Krona hjulformig med kort pip. Med blågredelina eller hvita blommor. Solanáceæ.

C. Med ett fruktämne inom blomkronan, slutl. enkelgömmig tvåskalig kapsel med på skalen fästade frön. Märken 2 (hos Menyanthes 1). Krona oftast trattlik, stundom n. klocklik.

109. Gentiảna. Märken 2 utan stift. Kronflikar $i$ knoppen vridna. Blad motsatta helbräddade; blomkrona blảaktig (eller gulhvit) och inuti stundom försedd med hårfransade fjäll; foder deladt eller flikigt. Gentiáneæ.

110. Erythræa. Märken 2 med utdraget stift. Kronfikar $i$ knoppen vridna. Liknar föreg. slägte, men har röd blomkrona utan fjäll samt slutl. vridna ståndareknappar. Gentiáneæ.

111. Menyánthes. Stift utdraget med 1 märke. Kronflikar kantlagda. Med stängel och rotstock, trefingradt delade blad samt blommor i klase. Blomkrona rödlett och trattlik med inuti håriga flikar; foder deladt. Menyántheæ.

D. Med ett fruktämne inom blomkronan, slutl. flergömmig kapsel. Märken 2 med utdraget stift. Blomkrona n. trattlik med utdragen och uppåt vidgad pip.

112. Convólvulus. Blomkrona längsefter veckad. Stjelk slingrande, blommor stora långskaftade, blomkrona hvit eller rödlett, foder deladt, blad med pillik"eller spjutlik bas. Convolvuláceæ.

E. Med ett fruktämne, sittande åtminstone till en del under blomkronan.

a. Örter med kapsel och deladt foderbräm. 
113. Campánula. Krona klocklik och klufven eller tandad. Blommor vanl. blå, ståndare fria, märken 3. Campanuláceæ.

114. Iasióne. Krona hjulformig och delad. Blommor mycket små och blå i hufvud inom svepe, ståndareknappar nedtill hopväxta, märken 2, blad jemnbreda. Campanuláceæ.

115. Lobélia. Krona läppformig. Med stängel, blăhvita blommor i ensidig klase, hopväxta ståndareknappar, 2-3 märken och tvåpipiga. blad. Lobeliáceæ.

116. Sàmolus. Krona med kort pip samt klocklikt och klufvet bräm. Med (bladig) stjelk, små hvita blommor i klasar, fria ståndare, helt märke och breda helbräddade blad. Utom de 5 mot kronflikarne motsatta ståndarne finnas 5 andra utan knappar. Primuláceæ.

b. Buskar med bär och tandadt blomfoderbräm.

117. Lonicéra. Märke helt. Blad hela motsatta, blommor vanl. gulaktiga. Caprifoliáceæ.

III. Blomkrona sambladig. Ståndare fästade i blomfodrets botten, ej på kronan. Halfbuske.

118. Azálea. Foder deladt. Krona klocklik. Märke ett. Kapsel 2-3-rummig. Med nedliggande stam, små läderartade blad och små rosenröda blommor. Ericíneæ.

IV. Blomkrona fribladig (stundom otydlig eller felslående).

A. Buskar med regelbunden blomkrona och fria ståndare. a. Frukt bärlik.

119. Ribes. Kronblad liknande fjäll, kortare än det klufna fodret, som sitter ofvanför frukten. Med mjuka bär och handnerviga, skiftevis stälda blad. Ribesiáceæ.

120. Rhamnus. Kronblad och foder som hos föreg. slägte, men med fritt fruktämne inom blomfodret. Med stenfruktartade bär och hela fjädernerviga blad. Franguláceæ.

121. Hédera. Kronblad längre än det tandade fodret. Med krypande eller klängande, med luftrötter försedd stam och svarta bär. På de blommande grenarne äro bladen hela och fjädernerviga, eljest flikiga och handnerviga. Araliáceæ.

b. Frukt kapsellik.

122. Evónymus. Foder deladt. Ståndare stundom 4. Fruktämne inom blomman. Med motsatta fjädernerviga blad och fyrkantiga grenar. Celastrineæ.

B. Örter med kapsel, oregelbunden krona och sammanhängande ståndareknapjar.

123. Víola. Krona fembladig (stundom felslående). Frön fästade på fruktbladen. Vanl. med blå blommor, det nedre kronbladet bredast och försedt med sporre; kapsel 3-skalig; foder 5-bladigt med bihang nedtill. Violariéæ. 
124. Impátiens. 2 och 2 kronblad hopväxta, ett fritt. Fröfäste centralt. Med gula hängande och långskaftade blommor; kapsel elastiskt uppspringande. Af foderbladen äro 2 små och gröna, 2 otydliga och 1 stort och gult med sporre. Balsamineæ.

\section{Ordn. DIGYNIA. *)} nanchum).

Stift 2, någongång med gemensamt märke (hos $C y$ I. Örter med foderlik kalk (hos Salsola och Kochia högfärgad) och torr enfröig frukt. Blommor små.

A. Utan stipler. Chenopodiáceæ.

a. Blad platta och breda. Kalk delad.

125. Chenopódium. Ståndare vant. 5. Blad fjädernerviga. Med gyttrade blommor och ofta mjöliga blad.

126. Blitum. Ståndare vanl. 1. Blad fjädernerviga. Med slutligen smultronlika blomgyttringar och ej mjöliga blad.

b. Blad n. trådlika och köttiga. Ståndare 5 .

127. Sálsola. Kalkblad fria, hvita eller rödletta, slutl.på ryggen vingade. Med $1-3$ blommor i bladvecken; blad med tagglik udd.

128. Kóchia. Kalk 5-klufven och slutl. försedd med små tagglika bihang. Blommor parvis stälda i bladvecken och bildande långa ax; blad trubbiga och ludna.

129. Schobéria. Kalk 5-delad utan bihang. Blommor gyttrade i bladvecken; blad syllikd, men ej stickande.

B. Med hinnaktiga stipler. Paronychiéæ.

130. Herniária. Ståndare 10, hvaraf 5 utan knappar. Kalk delad. Nedliggande med små blad och gyttrade blommor.

II. Träd med högfärgad kalk och med vingfrukt.

131. Ulmus. Kalk trattlik och klufven. Med sträfva, sågade och fjädernerviga blad; blommor brunröda, utvecklade ur egna knoppar på bar quist. UImáceæ.

III. Örter med sambladig krona och kapsellik frukt.

132. Cynánchum. Karpeller vanl. 2, kapsellika med fritt fröfäste. Blad helbräddade och motsatta; blommor hvitgula i knippen; krona hjulformig med en bikrona, som betäcker de nedtill hopväxta ståndarne. Contortæ.

133. Cuscúta. Kapsel kringskuren flergömmig. Trådlika, bladlösa och slingrande, oäkta parasiter (som gro i jorden) med blommor i hufvud. Convolvuláceæ.

*) Till denna ordning kunna äfven räknas följ.örter: a) med fullständiga blommor: Gentiana, b) med ofullst. blommor: Scleranthus med syllika blad, Atriplex, liknande Chenopodium, samt Polygonum med stipelslidor. 
IV. Örter med blomkrona af 5 fria blad och dubbel skalfrukt. Blomfoder vanl. otydligt och hopväxt med fruktämnet. Parasollväxter, Umbellater. Umbelliferæ.

Alla här beskrifna hafva bladig stjelk, som blott hos $H y$ drocotyle är krypande, eljest upprätt eller (stundom hos Bupleurum och Helosciadium) nedliggande. Bladen hafva oftast slidor. Blommorna äro ganska smă och sitta vanligen i en sammansatt flock (utom hos Bupleurum, Hydrocotyle och Eryngium). De enskilda blomskaften felslå ofta hos Sanicula och Hydrocotyle. Hos Sanicula förblifver frukten odelad.

A. Blad hela sköldnerviga (med strålformigt utgående hufvudnerver).

134. Hydrocótyle. 'Frukt glatt, bred och hoptryckt. Stjelk trådlik och krypande, blommor hvitaktiga i $2-3$ öfver hvarandra stälda hufvud.

B. Blad handnerviga och delade eller inskurna. Blommor med inga eller mycket korta skaft.

135. Sanicula. Frukt n. klotrund och kroktaggig. Stjelk n. bladlös; blommor rödletta i vanl. flera och flocklikt stälda hufvud; blad djupt klufna eller delade. Med både allmänt och enskilda svepen.

136. Ery'ngium. Frukt fjällig, omvändt äggrund och något hoptryckt. Stjelk grof och grenig med läderartade veckiga och n. slidlösa blad; blommor blå $j$ stora långskaftade hufvud med svepe.

C. Blad helbräddade, smala och enkelt nerviga.

137. Bupléurum. Frukt grynprickig och n. klotrund. Stjelk grenig och trådlik, ofta nedliggande; flockstrålar få $(2-4)$ och ganska korta; blommor gula, vanl. stälda i enkla flockar.

D. Blad dubbelt fingerlikt delade (åtm. de nedre). Blommor skaftade i sammansatt flock. Frukt glatt.

Glatta växter med stora bladflikar och hvita blommor.

138. Fgopódium. Frukt äggformig med höga åsar. Blomflock utan svepen.

139. Imperatória. Frukt bred, upptill och nedtill intryckt, med låga åsar. Med svepen, åtm. enskilda, och stora bladslidor.

140. Halóscias. Frukt aflång med vingkantade isar. Blomflockar med allmänt och enskilda svepen; blad något köttiga.

141. Falcária. Frukt smal, aflàngt klubblik och hoptryckt, med låga åsar. Blomflockar med allm. och enskilda svepen; bladflikar långa och teml. smala.

E. Blad parbladigt delade (atm, de nedre). Blomflock sammansatt.

a. Frukt kort och taggig eller luden. Med allmänna och enskilda svepen. 
142. Tórilis. Allmänna svepets blad få och hela. Sträf med röda eller hvita blommor; frukt borsttaggig, äggrund och hoptryckt.

143. Libanótis. Allmänna svepets blad talritka och hela. Finluden med hvita blommor; frukt luden och äggformig.

144. Dáucus. Allmänna svepets blad pardelade. Sträfhårig med hvita blommor; frukt borsttaggig, oval och hoptryckt.

b. Frukt lång och smal (lansettlik eller jemnbred) samt glatt (hos Anthriscus vulgaris n. äggrund och krokhårig). Blott med enskilda svepen. Blad findelade. Blommor hvita.

145. Anthriscus. Frukt med kort spröt och utan åsar. Något hårig eller glatt med 2-5-bladiga svepen.

146. Chærophyllum. Frukt utan spröt.och med låga åsar. Mjukluden med 5-8-bladiga svepen.

147. Myrrhis. Frukt utan spröt och med höga åsar. Mjukhårig med 5-7-bladiga svepen och stora frukter.

148. Scandix. Frukt med långt och styfhärigt spröt och med låga åsar. Nästan glatt med 5-bladiga svepen.

c. Frukt kort och hoptryckt (med platta sidor) och glatt. Med allmänna och enskilda svepen (utom hos Pastinaca, som saknar svepen).

1. Allmänna svepet qvarsittande och mångbladigt.

149. Laserpítium. Frukt oval med likformiga hinnaltiga åsar. Nästan glatt med stora bladflikar och hvita blommor.

150. Levisticum. Frukt aflaing med hinnaktiga åsar, de $i$ kanten sittande bredast. Glatt med stora bladflikar och gula blommor. Luktar starkt.

151. Peucédanum. Frukt oval eller n. rund med låga åsar och med hinnaktiga kanter. Glatt med findelade blad och hvita blommor.

2. Allmänna svepet fabladigt och affallande. Blad findelade (med små eller smala flikar).

152. Selinum. Frukt oval och föga hoptryckt med hinnaktiga assar, de yttre bredast. Glatt med n. slidlösa blad och hvita blommor.

153. Silaus. Frukt aflång och föga hoptryckt samt med kölade åsar. Glatt med teml. utdragna bladslidor och blekgula blommor. Luktar starkt.

154. Cnidium. Frukt oval och föga hoptryckt samt med likformiga och hinnaktiga åsar. Glatt med långsidiade blad med smala och teml. långa flikar; blommor hvita.

3. Allmänna svepet fäbladigt och affallande. Blad med stora och breda flikar. Växter med stark lukt.

155. Angélica. Frukt bredt oval med de inre àsarne trådlika, de yttre hinnaktiga. Med stora bladslidor och hvitröda blommor. 
156. Archangélica. Frukt bredt oval med de inre åsarne hvassa, de yttre hinnaktiga. Liknar föreg. slägte, men har fröet fritt frăn frögömmet, tydliga fodertänder och grönhvita blommor.

157. Heracléum. Frukt $n$. oval och tunn med låga åsar och vingad kant. Sträfhårig med grönhvita blommor; de flesta bladen enkelt parbladigt delade.

\section{Utan svepen.}

158. Pastínaca. Frult oval och tunn med låga åsar. Vanligen glatt med enkelt parbladigt delade blad och gula blommor.

d. Frukt kort, kullrig och glatt. Blommor vanl. hvita.

1. Med (qvarsittande) allmänt och enskilda svepen. Frukt n. äggformig.

159. Sium. Svepen mångbladiga. Frukt med trådlika åsar. Vattenväxter med enkelt parbladigt delade stjelkblad.

160. Pleurospermum. Svepen maingbladiga. Frukt med 5 ihåliga vingade åsar utanpå de 5 smärre inre. Stjelk n. oledad; blad n. slidlösa med stora flikar; blommor något stora. 161. Conium. Allmänna svepet 5-bladigt, de enskilda 3-bladiga. Frukt med rynkiga åsar. Illaluktande med fläckig stjelk och findelade blad.

2. Blott med enskilda svepen. Giftiga växter.

162. Cicúta. Småfrukter klotrunda och n. åtskilda med låga åsar. Svepen mängbladiga. V'Tattenväxt med teml. smala och långa bladflikar och mångstråliga flockar.

163. Fthúsa. Frukt äggformig med hvassa åsar. Svepen 3bladiga. Med findelade blad och fåstråliga flockar.

164. Enanthe. Frukt n. aflaing, uppait smalare, eller klubblik, med låga åsar. Svepen màngbladiga. Vattenväxter med små bladflikar och hufvudlika småflockar; allmänna blomskaft få.

165. Helosciádium. Frukt aflàng med höga åsar. Svepen 3bladiga. Vattenväxt med de nedre (vanl. nedsänkta) bladen hårlikt delade; de öfre bladen enkelt parbladigt delade med vigglika flikar;; blomflockar små och fåstråliga.

3. Utan svepen (någongång med allmänt). Blommor stundom ljusröda.

166. Carum. Frukt n. aflång med något upphöjda åsar. Med n. trådsmala bladflikar.

167. Pimpinella. Frukt rundadt äggformig med föga upphöjda åsar. De flesta bladen äro vanl. enkelt parbladigt delade.

168. A'pium. Frukt n. klotrund med något upphöjda åsar. De nedre bladen enkelt parbladigt delade, de öfre trefingradt delade, alla med breda flikar; blommor grönhvita. 


\section{Ordn. TRIGYNIA. Pistiller (märken) $3 .^{*}$ )}

Buskar eller ört med hvita eller rödletta blommor i qvastlika knippen, bärlik frukt och motsatta blad. Valeriáneæ. 169. Viburnum. De yttre blommorna (i hvarje blornsamling) ofruktsamma (gallblommor), de inre med klocklik krona. Buske med handnerviga blad nch stora platta gallblommor. 170. Sambúcus. Alla blommor likformiga med hjulformig krona. Med parbladigt delade blad.

\section{Ordn. TETRAGYNIA. Pistiller (märken) 4.**)}

171. Parnássia. Foder och krona 5-bladiga. Enhlommig med enbladig stjelk, talrika rotblad och enrummig kapsel. I blomman sitta 5 fjäll (bikronblad), som uppbära talrika falska ståndare (utan frömjöl). Droseráceæ.

5 Ordn. PENTAGYNIA. Pistiller 5, stundom 3 eller $\left.6-10 .^{* * * *}\right)$

A. Blomfoder trattlikt med klufvet bräm. Krona djupt delad. Frukt enfröig nöt. Plumbagíneæ.

172. Arméria. Blommor $i$ hufvud. Blad vantigen 1-nerviga. Tufvad med stängel och med ljusröda blommor, omgifna af bruna hinnaktiga svepeblad; stift håriga.

173. Státice. Blommor $i$ ax, samlade $i$ ett grenigt knippe (vippa). Blad fjädernerviga. Med stängel och ljusblå blommor med hinnaktiga svepeblad; stift glatta.

B. Blomfoder deladt. Krona fribladig. Kapsel flerfröig. Ståndare fästade på en fri torus.

174. Drósera. Med stängel, klibbhâriga blad och hvita blommor i klase (ensidigt knippe). Droseráceæ.

C. Blomfoder klufvet. Krona rosartad. Karpeller 5-10. Ståndare fästade på blomfodret.

175. Sibbáldia. Foderfikar 10, hvar annan mindre. Fruktfäste torrt. Liknar năgot en Potentilla. Senticósæ.

*) Hit kunna äfven räknas följ. örter: Polygonum med ofullständiga blommor, Drosera med stängel samt Stellaria medic med motsatta stjelkblad.

**) Till denna ordning kunna räknas följ. örter: Drosera med stängel, Adoxa med handnerviga blad samt Stellaria, Spergula och Cerastium med hvita blommor och hela stjelkblad.

***) Hit kunna räknas följ. örter: Erodium och Geranium med röda blommor, Cerastium, Spergula och Linum med hvita blommor. 
6 Ordn. POLYGYNIA. Pistiller (och frukter) talrika. 176. Myosúrus. Foder och krona 4-5-bladiga. Liten ört med n. trådlika rotblad, enblommiga rotblomskaft och nötlika karpeller på ett utdraget fäste. Ranunculáceæ.

\section{Klassen. HEXANDRIA.*)}

Monokotyledona örter (undantag. Berberis, Peplis, Oxyria och Rumex).

\section{Ordn. MONOGYNIA. Pistill 1.}

A. Med fjädernerviga blad och vanligen fullständiga blommor.

177. Bérberis. Foder och krona 6-bladiga. Buske med gula blommor i klasar och aflånga bär. Bladens skifvor felslå stundom, så att hufvudnerven blir tagglik. Berberídeæ.

178. Peplis. Foder klocklikt 12-tandadt; krona 6-bladig. Liten nedliggande ört med vanl. motsatta blad och små röda blommor, ensamma i bladvecken; kapsel klotrund. Lythrariéæ.

B. Lökväxter med enkelnerviga blad, kapsellik frukt och högfärgad kalk af 6 fria blad. Liljeväxter.

a. Kapsel sittande under blomkalken. Narcissíneæ. Med enblommig stängel; blomma hvit med höıster.

179. Leucójum. Kalkblad ovala. Med lutande blomma.

180. Galanthus. De yttre kalkbladen aflinga och kupiga, de inre kortare och omvändt hjertlika. Liknar föreg. slägte, men har smärre blommor.

b. Kapsel inom blomkalken. Liliáceæ.

1. Stjelk flerbladig.

181. Túlipa. Kalkblad utan honingsfäll. Stift intet. Med en ensam, stor och gul blomma.

182. Fritillária. Kalkblad med honingsfäll. Stift upptill tjockare. Märken 3. Med ensam och stor blomma med rutiga kalkblad.

183. Lilium. Kalkblad med honingsfäll. Stift n. jemntjockt. Märke helt. Flerblommig med stora blommor.

2. Stam stängellik (blott med skärmblad).

184. A'llium. Frön kantiga eller klotrunda. Starkt luktande växter med små blommor i flock inom hölster.

*) Hit kunna äfven räknas ett träd, Ulmus, samt följ. örter: Elatine hexandra liten vattenväxt med motsatta blad, Sempervivum med talrika pistiller, Lysimachia gulblommig, Trientalis hvitblommig, samt Polygonum och Scleranthus med ofullständiga blommor. 
185. Gágea. Frön äggformiga. Ståndareknapp fästad med basen vid strängen. Med gula blommor utan hölster, men med bladlika skärmar.

186. Ornithógalum. Frön äggformiga. Ståndareknapp fästad med ryggen vid strängen. Liknar föreg. slägte, men har hvita blommor.

C. Växter med enkelnerviga blad och med rotstock eller blott med birötter (utan lök).

a. Fruktämne med utdraget (eller hos Narthecium och stundom hos Juncus kort) stift. Blommor antingen spridda eller (stundom hos Juncus och Luzula) gyttrade $\mathrm{i}$ ax eller hufvud.

1. Liljeväxter med högfärgad kalk och flergömmig frukt. Stift utdraget. Liliáceæ.

187. Convallária. Kalk 6-tandad. Märke n. helt. Fruktbär. Med hvitaktiga hängande blommor.

188. Aspáragus. Kalk 6-delad. Märken 3. Frukt bär. Med borstlika smågrenar utan blad.

189. Anthéricum. Kalk fribladig. Märke helt. Frukt kapsel. Med hvita stjernlika blornmor, stängellik stjelk och gräslika blad.

2. Gräslika växter med rotstock eller med tågig rot, torrhinnig (grön eller brunaktig) och fribladig kalk samt enkelgömmig kapsellik frukt. Stift vanl. utdraget, stundom kort. Juncáceæ.

190. Juncus. Kapsel trerummig och mångfröig. Med trådlika eller inga blad och klufna bladslidor.

191. Lúzula. Kapsel enrummig och trefröig. Med platta blad och hela bladslidor.

3. Liljelik växt med högfärgad kalk och enkelgömmig kapsellik frukt. Stift kort. Nartheciáceæ.

192. Narthécium. Kalk fribladig. Märke trekantigt. Med stängel, gula stjernlika blommor i klase och svärdlika blad. b. Fruktämne utan stift. Blommor gyttrade i kolf. Frukt oöppnad. Aroideæ.

193. Calla. Blommor utan kalk inom ett invändigt hvitt hölster. Frukt bär. Med stängel och hjertlika rotblad.

194. A'corus. Kalk fribladig. Blommor utan hölster. Frukt nötlik. Med stängel, på sidan bärande den oskaftade kolfven, oçh svärdlika blad.

2 Ordn. DIGYNIA. Pistiller 2.

195. Oxy'ria. Blomkalk 4-bladig; de 2 inre kalkbladen (fruktfoderskalen) utväxande och omslutande en plattad och vingad nöt. Märken pensellika. Ört med stipelslidor och njurlika blad; blommor i kransgrenig vippa. Polygóneæ. 
6. HEXANDRIA. 7. HePtANDRIA. 8. OCtANDRIA. 27

\section{Ordn. TRIGYNIA.}

Pistiller 3 (hos Triglochin maritimum 6).

Hos Scheuchzeria och Triglochin saknas stift.

A. Dikotyledoner med fjädernerviga blad.

Kalk bestående af $6 \mathrm{n}$. fria blad, af hvilka de 3 inre slutligen utväxa och omsluta en trekantig nöt.

196. Rumex. Märken pensellika. Med knutigt ledad stjelk med stipelslidor; blad skiftevis stälda; blommor i kransgrenig vippa. Polygóneæ.

B. Monokotyledoner med enkelt eller otydligt nerviga blad. Kalk 6-bladig.

a. Karpeller nötlika. Alismáceæ.

197. Tríglochin. Märken fjäderlika. Med stängel, trådlika blad och små grönaktiga blommor i ax; karpeller i början hopväxta, slutligen åtskilda.

198. Scheuchzéria. Märken enkla. Med stjelk, trådlika blad och små gröngula blommor i fåblommig klase; karpeller nedtill hopväxta.

b. Karpeller kapsellika, mångfröiga och upptill åtskilda. Nartheciáceæ.

199. Tofiéldia. Märken enkla. Med stängellik stjelk, smala svärdlika blad och små gulaktiga blommor i ax.

4 Ordn. POLYGYNIA. Pistiller talrika.

200. Alisma. Kalk af 6 fria blad, de yttre gröna, de inre kronlika. Karpeller talrika och nötlika. Vattenväxter med stängel. Alismáceæ.

\section{Klassen. HEPTANDRIA.*)}

1 Ordin. MONOGYNIA. Pistill 1.

201. Trientális. Foder och krona delade. Med nedtill bar stjelk, fjädernerviga blad, hvita stjernlika och långskaftade blommor och enrummig kapsel. Primuláceæ.

\section{Klassen. OCTANDRIA.**).}

\section{Ordn. MONOGYNIA. Pistill $1 .^{* * *}$ )}

A. Buske med högfärgad kalk samt stenfrukt.

*) Hit kunna äfven räknas Scleranthus med 2 pistiller och Sempervivum med talrika pistiller.

**) Till denna klass kunna räknas ett träd, Acer, samt följ. örter: Monotropa utan blad, Herniaria med ofullständiga blommor och Sempervivum med talrika pistiller.

***) Till denna ordning kunna äfven räknas Adoxa och Polygonum samt de i föreg. not nämnda Monotropa och Herniaria. 
202. Daphne. Kalk trattlite och fyrklufven. Med ljusröda blommor på bar qvist och med skiftevis stälda blad. Daphnoídeæ.

B. Halfbuskar med sambladig blomkrona. Ståndareknappar med sporrelika bihang. Ljungväxter. Ericíneæ.

203. Vaccínium. Fruktämne under blomkronan, slutl. bär. Med åtskilda och spiralstälda blad.

204. Callúna. Kapsel inom blomman. Blomfoder högfärgadt, längre än kronan. Med smă nch fyrsidigt tegellagda blad, blommor med svepe (foderholk) i ensidiga klasar, foder och krona fyrdelade, vanl. röda.

205. Eríca. Kapsel inom blomman. Foder grönt och mycket kortare än kronan. Med små och kranssittande blad samt jjusröda blommor i hufvudlik flock; foder fyrdeladt, krona utdraget äggformig.

C. Örter med blomkrona af 4 fria blad. Foderbräm fyrdeladt. Kapsel srnal och fyrkantig under kronan. Onagrariéæ.

206. Chamænérium. Frön med hår i spetsen. Blomkrona något oregelbunden. Blommor stora och röda i klase; ståndare och pistill nedböjda; foder med kort pip; kronblad $\mathrm{n}$. hela; de flesta bladen strödda.

207. Epilóbium. Frön med hår $i$ spetsen. Krona regelbunden. Blommor små och vanl. röda frăn bladvecken; stăndare och pistill upprätta, foderpip kort; kronblad tvåflikiga; de flesta b]aden motsatta.

208. Enothéra. Frön utan hår. Krona regelbunden. Blommor stora och gula i bladigt ax; foderpip utdragen.

\section{Ordn. DIGYNIA. Pistiller 2.}

209. Chrysosplénium. Kalk vanl. 4-klufven. Ört med njurlika blad och nedtill enrummig kapsel, som egentligen består af 2 hopväxta karpeller. Saxifrágeæ.

3 Ordn. TRIGYNIA. Pistiller 3, stundom hopväxta. 210. Poly'gonum. Kalk af vanl. 5 n. fria blad. Stjelk knutig med stipelslidor; frö med brodd (växtämne) på sidan och med platta hjertblad; nöt trekantig, sällan plattad. Polygóneæ.

4 Ordn. TETRAGYNIA. Pistiller 4, sällan 3 eller 5.*)

211. Paris. Kalk af 4 större samt 4 mindre och $n$. trådlika blad. Med rotstock, nedtill bladlös stjelk, stora helbräddade blad, en grönaktig blomma och bärlik frukt; ståndaresträng förlängd ofvan knappen. Liliáceæ.

*) Hit kan äfven räknas Rhodiola, som har tjocka köttiga blad. 
8. octandria. 9. enneandria. 10. decandria. 29

212. Adóxa. Foder 2-3-flikigt. Krona 4-5-delad. Myskluktande med gulgröna blommor $\mathrm{i}$ hufvud och bärlik frukt. Ståndare egentligen $4-5$ tvådelade. Adóxeæ.

213. Elatíne. Foder 3-4-deladt. Krona 3-4-bladig, stundom felslående. Mycket små vattenväxter med motsatta helbräddade blad och enstaka blommor i bladvecken. Elatíneæ.

\section{Klassen. ENNEANDRIA.*)}

1 Ordn. HEXAGYNIA. Pistiller 6.

214. Bútomus. Kalk 6-bladig. Karpeller 6 kapsellika. Med stängel och hvitröda blommor i flock. Alismáceæ.

\section{Klassen. DECANDRIA.}

1 Ordn. MONOGYNIA. Pistill 1.**)

A. Ljungväxter. Buskar eller halfbuskar med läderartade blad. Ericíneæ.

a. Blomkrona sambladig; frukt bär; blommor kortskaftade.

215. Arctostáphylos. Kronpip äggformig. Foder deladt. Nedliggande med hvita blommor.

b. Blomkrona sambladig; frukt kapsel; blommor långskaftade.

216. Andrómeda. Kronpip äggformig eller klocklik. Foder deladt. Ständareknappar med hornlika (sporrelika) bihang. Blommor hvita eller ljusröda.

217. Phyllódoce. Kronpip äggformig. Foder deladt. Stiondareknappar utan hornlika bihang. Blommor rödvioletta, stälda i flock i spetsen af grenarne.

218. Rhododendrum. Krona trattlik och flikig. Foder klufvet. Ständareknappar utan hornlika bihang. Blommor rödvioletta, ensamma eller parvis stälda i spetsen af grenarne; blad breda, men teml. små.

c. Blomkrona af 5 fria blad. Kapsel femrummig.

219. Ledum. Blomfoder tandadt. Kapsel nedböjd. Buske med hvita blolurnor i enkla florkar.

220. Py'rola. F'oder deladt eller klufvet. Kapsel slutl. nedböjd, uppobristande pa midten med hàriga fogar. Örtlika halfbuskar med blommor $i$ klase.

*) Hit kunna äfven räknas Herniaria med 2 pistiller och Sempervivum med många pistiller.

**) Hit kunna hänföras ett träd, Acer, Vaccinium halfbuske, Adoxa med fingerlikt delade blad och Herniaria med ofullständiga blommor. 
221. Chimáphila. Foder deladt. Kapsel upprätt, uppbristande från midten med glatta fogar. Örtlika halfbuskar; blomma ensam eller flera blommor i flock.

B. Bladlös och fjällig ört. Ericíneæ.

222. Monótropa. Foder och krona 5-4-bladiga. Hela växten gulaktig med kapsellik frukt.

\section{Ordn. DIGYNIA. Pistiller 2.*) Örter.}

A. Blomkalk foderlik. Blad motsatta trådlika.

223. Scleránthus. Kalk 5-klufven. Frukt nötlik. Med nedtill hinnaktiga blad saint små blommor. Paronychiéæ.

B. Krona af 5 fria blad. Stjelkblad spiralstälda (hos en art motsatta). Blomfoder djupt klufvet eller deladt.

224. Saxífraga. Karpeller 2 kapsellika, nedtill hopväxta. Med saftfulla blad. Saxífrágeæ.

C. Krona nejlikeartad. Blad motsatta. Blomfoder tandadt.

Med knutiga stjelkar och enrummig kapsel med centralt fröfäste. Silenáceæ.

225. Diánthus. Kronblad utan bikrona. Foder rörformigt eller uppåt smalare. Med smala blad och vanl. röda blommor med svepe.

226. Gypsóphila. Kronblad utan bikrona. Foder n. klocklikt med kantig pip. Stjelk och blad n. trådlika; blommor små och rödletta eller hvita utan svepe.

227. Saponária. Kronblad med bikrona. Foder rörformigt. Med breda blad och teml. stora, ljust rödletta blommor.

\section{Ordn. TRIGYNIA. Pistiller (stift) $3 .^{* *}$ )}

Örter med hela motsatta blad och kapsel med centralt fröfäste. A. Blomfoder tandadt; krona nejlikeartad; kapsel nedtill trerummig. Silenáceæ.

228. Siléne. Blommor vanl. med bikrona. Med blommor vanl. i knippen.

B. Blomfoder fribladigt; kronblad 5, fria med kort klo; kapsel enrummig. Alsináceæ.

a. Utan stipler.

229. Stellária. Kronblad tvådelade eller klufna. Kapsel med 6 skal. Med hvita blommor.

230. Arenária. Kronblad hela. Kapsel med 6 stkal. Med hvita blommor.

*) Hit kunna äfven hänföras Acer, träd, och Chrysosplenium samt Agrimonia, örter.

**) Hit kan äfven Cerastium trigynum räknas; se följ. ordning. 
231. Ammadénia. Kronblad hela. Kapsel fïfröig med 3 sleal. Med breda köttiga blad och hvita blommor.

232. Alsíne. Kronblad n. hela. Kapsel maingfröig med 3 skal. Med trådlika blad och hvita eller blekröda blommor.

b. Med hinnaktiga stipler.

233. Lepígonum: Kronblad hela. Kapsel med 3 skal. Blad trådlika; blommor rödaktiga.

\section{Ordn. PENTAGYNIA.}

\section{Pistiller 5 (stundom 4-6). Örter.*)}

A. Blomfoder sambladigt med lang pip. Krona nejlikeartad.

Med knutig stjelk, hela motsatta blad och kapsel med centralt fröfäste. Silenáceæ.

a. Foder bladartadt med långa brämflikar.

234. Agrostemma. Foder bägarlikt. Kapsel enrummig. Med stora, violettröda och intryckta kronblad utan bikrona.

b. Foder $n$. hinnaktigt och femtandadt. Blommor med bikrona.

235. Viscária. Kronblad n. hela. Kapsel nedtill 5-rummig, uppbristande med 5 tänder.

236. Melándrium. Kronbladens skifva tvåklufven. Tvåbyggare; kapsel enrummig med 10 tänder.

237. Vahlbergella. Kronbladens skifva tvaiklufven. Kapsel enrummig med 5 tvåklufna tänder; frön bredt hinnkantade; blommor samkönade; stjelkar vanl. enblornmiga.

238. Lychnis. Kronbladens skifva fyrklufven. Kapsel enrummig med 5 tänder.

B. Blomfoder 5-bladigt. Kronblad 5 med korta klor.

Med hela motsatta blad, enrummig kapsel med centralt fröfäste och hvita kronblad (som hos Sagina kunna felslå). Alsináceæ.

a. Kronblad tvådelade, klufna eller urnupna.

239. Cerástium. Kapsel rörformig med 10 lika stora tänder. Kronblad vanl. klufna. Lăga och småbladiga växter.

240. Maláchium. Kapsel rundadt äggformig, uppbristande med 5 tvaitandade fikar. Kronblad delade. Teml. stor och klibbhårig växt med breda blad.

b. Kronblad hela eller felslaende. Kapsel uppbristande med 4-5 hela skal.

*) Hit kunna äfven hänföras följ. örter: Adoxa med blommor i hufvud, Oxalis, Geranium och Erodium med nedtill något hopväxta ståndare, Sempervivum med talrika pistiller, Stellaria borealis och Spircea. 
241. Sagína. Blad utan stipler. Kapsel äggformig eller rundad. Små växter med korta trådlika blad.

242. Spérgula. Blad med hinnalktiga stipler. Kapsel rundad. Med trådlika blad och gyttrade bladknippen i bladvecken.

C. Blomfoder 5-deladt eller djupt klufvet. Krona 5bladig. Karpeller 5 kapsellika. Crassuláceæ.

243. Sedum. Kronblad hela. Med köttiga blad och vanl. gula, stundom hvita eller rödaktiga blommor i knippen eller ax.

\section{Klassen. DODECANDRIA. Örter *).}

1 Ordn. MONOGYNIA. Pistill 1.

244. Lythrum. Kapsel fri från det 12-tandade fodret. Med helbräddade, motsatta eller kranssittande, blad och röd sexbladig blomkrona. Lythrariéæ.

245. A'sarum. Frukt vidväxt den trefikiga blomkalken och slutl. oregelbundet söndersprickande. Med njurlika blad och enstaka, invändigt svartbruna blommor. Aristolochiáceæ.

\section{Ordn. DIGYNIA. Pistiller 2.}

246. Agrimónia. Blomkrona rosartad; foder sambladigt med hairdnande pip. Blommor gula i axlik klase; blad olikparigt parbladigt delade; frukt nötlik. Senticósæ.

3 Ordn. TRIGYNIA. Pistiller (märken) 3-6.

247. Reséda. Blomfoder 4-6-bladigt. Kronblad 4 6, smalfikiga och olikformiga. Kapsel upptill något öppen. Med strödda blad och med små blommor i axlika klasar.

4 Ordn. POLYGYNIA. Pistiller talrika.

248. Sempervívum. Karpeller kapsellika. Foder vanl. 12-deladt. Mycket köttig och saftfull med platta blad; blomkrona vanl. 6-bladig, rödbrun. Crassuláceæ.

\section{Klassen. ICOSANDRIA.}

Blomkrona vanl. rosartad (utom hos Geum rivale). Enligt somliga författare hafva Rosa $\mathrm{m}$. fl. fribladigt blomfoder.

1 Ordn. MONO-PENTAGYNIA. Pistiller 1-5.**)

Träd eller buskar med vanl. hvita blommor.

A. Stenfrukt fri från blomfodret. Stift 1 med 1 märke. Blommor hvita. Blad hela. Drupáceæ.

*) Till denna klass kan man äfven räkna Euphorbia, mjölksaftiga örter, och Lysimachia.

$\left.{ }^{* *}\right)$ Hit skulle äfven Agrimonia och Spirca kunna räknas. 
249. Prunus. Frultens sten (frögömmets innersta lager) plattad. Frukt blå- eller hvitdaggig (af vaxafsöndring); de outslagna bladen hoprullade.

250. Cérasus. Fruktens sten klotrund. De outslagna bladen dubbelvikna.

B. Äplefrukt sammanhängande med blomfodret. Blommor hvita (hos Pyrus rödletta). Pomáceæ.

a. Buskar med hårda rum i frukten.

251. Cratægus. Foderflikar bladartade och utböjda. Med tornar, 1-2 stift, röda frukter och blommor i qvast.

252. Cotoneaster. Foderflikar köttiga och inböjda. Utan tornar, med helbräddade blad, $2-3$ stift och $1-3$ blommor i bladvecken.

b. Träd med mjuk frukt med tunnväggiga rum.

253. Sorbus. Stift vanl. 3. Utan tornar, med blommor i qvastlika knippen och röda frukter.

254. Pyrus. Stift vanl. 5, fria eller nedtill hopväxta. Med hela blad och stora grönaktiga frukter.

\section{Ordn. POLYGYNIA. Pistiller flera än 5.}

Växter med stipler; frukt sammansatt af karpeller. Senticósæ

A. Foderflikar och kronblad vanl. 5.

255. Spiræa. Karpeller få och kapsellika. Örter med olikparigt delade blad och små blommor i knippen.

256. Rosa. Karpeller nötlika inom ett njupon. Taggiga buskar med parbladiga blad och stora blommor. Njuponet bildas enligt somliga författare af fodrets pip, enligt andra af en ihålig torus.

257. Rubus. Karpeller stenfruktartade och sammanhängande. Vanligen taggiga buskar, stundom örter.

B. Foderflikar och kronblad 8-10.

258. Dryas. Karpeller nötlika med fjäderlikt spröt. Låg och nästan buskartad fjellväxt med enkla tandade blad och stora hvita blommor, ensamma på långa skaft.

C. Foderbrämets flikar dubbelt så många som kronbladen. Örter (sällan buskar) med nötlika karpeller.

a. Karpeller med krokuddigt spröt.

259. Geum. Fruktfäste torrt. Med parbladigt delade rotblad.

b. Karpeller utan spröt.

260. Fragạaria. Fruktfäste zärrlikt. Kronblad omvändt äggrunda. Örter med trefingradt delade blad och hvita blommor. 261. Cómarum. Fruktfäste svampaktigt. Kronblad aflånga, spetsiga och kortare än fodret. Ört med parbladigt delade blad, brunaktigt foder och mörkbruna kronblad. 
262. Potentilla. Fruktfäste torrt. Kronblad n. omvändt äggrunda. Örter (eller sällan buskar) med oftast fingerlikt (stundom parbladigt) delade blad och vanl. gula (hos en art hvita) blommor.

\section{Klassen. POLYANDRIA.}

Örter, undantag. Tilia och Helianthemum. Blomkrona vanl. bestående af flera fria blad (utom hos Delphinium) eller felslående. Blomfoder fribladigt, ofta snart affallande.

\section{Ordn. MONOGYNIA. Pistill 1.*)}

A. Kronblad 4. Foderblad 2, snart affallande. Mjölksaftiga örter. Papaveráceæ.

263. Papáver. Märke sköldlikt utan stift. Kapsel ofullständigt flerrummig, öppnande sig med hål. Blommor vanl. röda, sällan gula; mjölksaft hvit.

264. Chelidónium. Märken 2 med kort stift. Kapsel skidlik och enrummig, uppbristande nedifrån. Blommor gula i flock; mjölksaft gul; blad helt och hållet delade.

265. Gláucium. Märken 2 med otydligt stift. Kapsel skidlit och tvairummig, uppbristande $i$ spetsen. Blommor stora och gula; mjölksaft gul; rotblad pardelade.

B. Träd. Foderblad och kronblad 5 .

266. Tília. Stift utdraget. Frukt nötlik. Blommor hvitgula, välluktande och stälda i knippen; blad snedt hjertlika och vanl. fjädernerviga. Tiliáceæ.

C. Örtlika halfbuskar. Kronblad 5. Foderblad 5, af hvilka 2 äro mindre.

267. Heliánthemum. Stift utdraget. Kapsel enkelgömmig med sidofästade frön. Med små, motsatta och helbräddade blad samt gula blommor. Cistíneæ.

D. Kronblad talrika. Frukt bärlik.

Vattenväxter med rotstock, simmande blad och enblommiga rotblomskaft. Nymphæáceæ.

268. Nymphæa. Kronblad i flera kransar. Med undertill lefverbruna blad, hvit blomma och fyrbladigt foder.

269. Nuphar. Kronblad $i$ en krans. Med gul blomma och fembladigt foder.

E. Foderblad och kronblad 4. Frukt bärlik.

270. Actæa. Märke nästan utan stift. Med små hvita blommor i axlika klasar och svarta bär. Ranunculáceæ.

*) Hit kunde äfven Delphinium räknas: se följ. ordning. 
2 Ordn. DI-PENTAGYNIA. Pistiller 2-5, stundom 1.*)

Med 2-5 (stundom 1) kapsellika karpeller. Både blomkronan och det fembladiga fodret högfärgade. Ranunculáceæ.

A. Blad dubbelt trefingradt delade.

271. Delphínium. Pistill vanl. 1. Blad snalflikiga; blommor blå i klaselik vippa; det öfversta foderbladet med en sporre, inneslutande den sporrebärande kronan, som (genom felslagning eller hopväxning) synes bestå af ett enda blad.

272. Aquilégia. Pistiller 5. Blad bredflikiga; blommor lutande, stora och vanl. blå; foder utan sporre; alla fem kronbladen med sporre.

B. Blad fingerlikt klufna eller delade.

273. Aconitum. Pistiller 3. Blommor i klase, vanl. blåaktiga; det öfversta foderbladet hjelmlikt, inneslutande två långt skaftade, strutlika och med honingssporre försedda kronblad; de 3 öfriga kronbladen förkrympta eller felslående.

\section{Ordn. POLYGYNIA. Pistiller talrika.}

Hithörande växter sakna vanl. stipler. Ranunculảceæ.

A. Blommor ofullständiga med blomkalk, som är högfärgad och liknar en blomkrona.

a. Karpeller nötlika och enfröiga.

274. Thalictrum. Karpeller med åsar och utan spröt (stift). Med fyrbladig, ljusgul eller grönaktig, snart affallande blomkalk samt helt och hållet delade blad, vanl. talrika på stjelken (som blott hos en art är stängellik); blommor små och talrika.

275. Pulsatilla. Karpeller utan åsar och med laingt hårigt spröt. Med enblommig stängel med smalflikigt svepe.

276. Anemóne. Karpeller utan åsar och med mycket kort och glatt spröt. Med enblommig stängellik stam.

b. Karpeller kapsellika och mångfröiga.

277. Caltha. Kalkblad 5--6, stora, n. ovala och glatta. Stjelk med njurlika blad och gula långskaftade blommor.

B. Blommor fullständiga. Växter med stjelk. Stundom felslå de första kronbladen, då fodret blir kronlikt.

a. Karpeller nötlika. Foderblad vanligen 5 .

278. Ficária. Foderblad 3. Kronblad lansettlika 6-10. Med hela, hjertlika eller njurlika blad, stora gula blommor samt tjocka rotknölar; märke utan stift.

279. Ranúnculus. Foderblad 5. Kronblad vant. 5 och omvändt äggrunda. Med gula eller hvita (sällan rodnande) blommor; blad ofta handnerviga och delade eller inskurna, stundom hela och smala, stundom hårlikt delade; stift mer eller mindre tydligt.

*) Hit kan äfven räknas Hypéricum, som har gula blommor. 
280. Adónis. Foderblad 5. Kronblad lansettlika 10-15. Blad findelade med trådlika flikar; blommor stora och guldgula; stift krökt.

b. Karpeller kapsellika och mångfröiga. Foderblad talrika och kronlika. Kronblad ståndarelika.

281. Tróllius. Kronblad mycket smala, men platta, kortare än fodret. Med stora gula och klotformiga blommor samt handnerviga och delade blad.

\section{Klassen. DIDYNAMIA. Örter (undantag. Linnea).}

1 Ordn. GYMNOSPERMIA.

Med 4 nötlika karpeller i blomfodrets botten.

Örter med fyrkantig stjelk och korsvis motsatta, vanl. fjädernerviga blad; blomkrona och blomfoder sambladiga; stift ett. I. Karpeller i början omslutna af ett hinnaktigt skal. Stift fästadt i spetsen af fruktämnet. Märke ett. Blomkrona olikformigt 5 -flikig (ej tydligt läppformig). Blommor i bladlösa ax. Verbenáceæ.

282. Verbéna. Foder 5-klufvet. Stjelk grenig; blommor teml. små och ljusröda; blad inskurna, ofta tredelade.

II. Karpeller fria. Stift sittande mellan karpellerna. Märken två. Blomkrona vanl. (utom hos Mentha) tydligt läppformig samt gapande. Blommor sittande i bladvecken (vanl. förenade i kransar), stundom blott i toppen af grenarne. Labiátæ.

A. Blomfodrets tänder (flikar) 5 likformiga.

a. Krona n. regelbundet 4-flikig, dess öfre flik (öfverläpp) platt och urnupen.

283. Mentha. Ståndare utspärrade med parallela knapprum. Kryddluktande växter med små, vanl. violetta blommor; kronans 3 nedre flikar hela; blomkransar rikblommiga.

b. Kronans öfverläpp mycket liten eller otydlig.

284. A'juga. Öfverläpp urnupen; underläppens mellanflit omvändt hjertlik. Ståndare parallela. Med blå och tätt sittande blommor i kransar.

285. Téucrium. Öfverläpp tvådelad med nedböjda fikar; underläppens mellanflik rundad. Ståndare parallela. Starkt luktande med blekvioletta rödprickiga blommor, parvis stälda i de öfre bladvecken; stjelk nedtill krypande.

c. Kronans öfverläpp platt och upptill inskuren. Växter med stark kryddlukt. 
286. Oríganum. Underläppens flikar smala och n. likformiga. Ståndare slutl. utspärrade med ej parallela knapprum. Stjelk upptill mycket grenig med n. trådlika grenar; blommor små och röda (sällan hvita), sittande i hufvud i spetsen af grenarne och stödda af vanl. blà blomskärmar.

287. Népeta. Underläppens mellanflik stor och njurtik. Ståndare parallela med skilda knappar. Gråluden med hvita rödprickiga blommor i närmade kransar; stjelk upprätt och vanl. upptill grenig.

288. Glechóma. Underläppens mellanflik omvändt hjertlik. Ståndare parallela med vanl. korsvis samstående knapprum. Stjelk krypande med upprätta enkla grenar samt med örtrefvor (grenskott); blommor teml. långa och blå i skilda och fåblommiga kransar.

\section{d. Kronans öfverläpp hel (eller urnupen) och hvälfd.}

1. Underläpp tydligt treflikig med n. fyrkantiga sidoflikar och med två ihåliga knölar vid svalget.

289. Galeópsis. Underläpp med rundad mellanfik. Stjelk vanl. upptill grenig; fodrets tänder tagglikt spetsade och stickande; blommor röda eller gulaktiga i kransar.

2. Underläpp med otydliga sidoflikar samt utan knölar i svalget.

290. Lámium. Underläpp med omvändt hjertlik mellanflik och n. trådlika sidoflikar. Stjelk enkel eller nedtill grenig; fodertänder ej stickande; blommor röda eller hvita i kransar.

3. Underläpp tydligt treflikig utan knölar. Fodertänder tagglikt spetsade och vanl. stickande. Foder med 5 (stundom otydliga) nerver.

291. Leonúrus. Underläppens fikar smala och trubbiga. Med klufna handnerviga blad; blomkrona hvitröd med utvändigt luden öfverläpp.

292 Galeóbdolon. Underläppens fitkar n. lika stora, något breda och spetsiga. Stjelk vanl. enkel eller nedtill grenig samt med grenskott; blommor gula i kransar; ståndare långt utskjutande.

293. Stachys. Underläppens mellanflik större än sidoflikarne och trubbig, hel eller urmupen. Standare slutl. utböjda med knapprummen förenade $i$ en rät linie. Stjelk ofta enkel; blommor röda eller hvita $\mathrm{i}$ vanl. axlikt förenade och $\mathrm{n}$. bladlösa kransar; ståndare ofta inneslutna.

294. Betónica. Underläppens mellanflik störst och omvändt äggrund. Ståndare raka med parallela knapprum. Stjelk vanl. enkel; blommor röda; de öfversta blomkransarne axlikt förenade och $\mathbf{n}$. bladlösa; ståndare vanl. föga utskjutande.

4. Underläpp tydligt treflikig utan knölar. Fodertänder teml. veka. Foder med 10 upphöjda nerver. 
295. Ballóta. Underläppens mellanflik störst och omvändt äggrund-hjertlik, sidoflikar ovala. Stjelk vanl. mycket grenig blummor blekröda i skilda kransar.

B. Blomfodrets tänder 10 , hvarannan mindre.

296. Marrúbium. Öfverläpp tvåklufven; underläppens mellanfik rundad. Filtluden med små hvita blommor.

C. Blomfoder klufvet i 2 större, vanl. olikformiga flikar och sålunda läppformigt.

a. Fodrets läppar helbräddade. Kronans öfverläpp hvälfd och treflikig, underläpp hel.

297. Scutellária. Foder slutl. tillslutet. Med blå och ensidigt stälda blommor.

b. Fodrets öfverläpp med 3, underläpp med 2 tänder (flikar). Kronans öfverläpp hel, urnupen eller tvåflikig, underläpp treflikig.

1. Blommor med skärmar. Stjelk n. upprätt.

298. Prunella. Blomfoder hoptryckt och rakt. Med njurlika blomskärmar och vanl. blå (stundom violetta eller hvita) blommor i axlikt hufvud.

299. Dracocéphalum. Blomfoder rörformigt och rakt. Med lansettlika blomskärmar och blå blommor i axlikt hufvud.

300. Clinopódium. Foder rörformigt och krökt. Med borstlika blomskärmar och röda blommor i skilda kransar.

2. Blommor utan skärmar. Stjelk nedliggande.

301. Calamintha. Blomfoder rörformigt och krökt. Med blåvioletta blommor $i$ närmade kransar eller $i$ hufvud.

302. Thymus. Blomfoder rörformigt och rakt. Med röda blommor nästan i hufvud; ståndare upptill isärstående.

\section{Ordn. ANGIOSPERMIA. Fruktämne ensamt.}

I. Frukt nötlik under den regelbundna blomkronan. Caprifoliáceæ.

303. Linnæa. Blomkrona klocklik. Nedliggande halfbuske med lutande, rödletta och välluktande blommor samt motsatta blad; allm. blomskaftet med 2-4 skaftade blommor.

II. Kapsel inom blomkronan, tvårummig (utom hos Lathrea och Orobanche). Personátæ.

A. Blomkrona n. regelbunden och trattlik.

304. Limosella. Blomfoder 5-tandadt. Med krypande stjelk (rotstock) och små hvita enstaka blommor.

B. Blomkrona läppformig; kapsel enrummig. Bladlösa och fjälliga parasiter.

305. Lathræa. Blomfoder likformigt 4-klufvet. Hela växten ofvan jord ljusröd med blommor i ensidig klase. 
306. Orobánche. Blomfoder olikformigt 4-klufvet, bestående af två 2-klufna blad. Stam brunaktig med blekgula eller brungula blommor i ax.

C. Blomkrona läppformig; kapsel tvårummig.

Stjelk med motsatta blad (utom hos Linaria, Euphrasia och Pedicularis, som hafva åtm. de öfre bladen spiralstälda).

a. Blomfoder 5-deladt med omärklig pip. Kronans öfverläpp 2-klufven. Ståndareknappar utan borstlika bihang.

307. Scrophulária. Kronpip klotrund eller äggformig utan sporre och honingsgömme. Kronsvalg öppet eller slutet. Blommor brungröna eller gröngula; blad breda och tandade. Illaluktande.

308. Linária. Kronpip n. rörformig med sporre. Kronsvalg mer eller mindre slutet genom underläppens uppsvälda bas (gom). Blommor gula eller violetta; blad smala och helbräddade. 309. Antírrhinum. Kronpip nedtill vidgad och försedd med honingsgömme, men utan sporre. Kronsvalg slutet. Blommor röda; blad smala och helbräddade.

b. Blomfoder med rörformig pip och fyrklufvet bräm. Ståndareknappar med borstlika bihang nedtill. Kronpip rörformig utan sporre. Parasiter.

310. Melámpyrum. Öfverläpp hel och hjelmlit med nedvikna kanter. Kapsel fåfröig. Med långa orh smala blad. Svartnar lätt vid torkning.

311. Euphrásia. Öfverläpp kort och 2-klufven. Kapsel mångfröig. Med korta blad och ljust violetta blommor.

312. Odontítes. Öfverläpp hel eller urnupen, längre än underläppen. Kapsel mångfröig; frön med àsar. Med smala blad och röda ensidiga blommor.

313. Bártsia. Frön vingade. Eljest lik föreg. slägte. Med breda blad och mörkblă blommor i ax med violetta skärmar. Svartnar vid torkning.

c. Blomfoder med uppblåst pip. Ståndareknappar utan bihang. Öfverläpp hjelmlik. Kronpip rörformig utan sporre.

314. Rhinánthus. Foder med 4 tänder, slutl. hoptryckt. Kapsel rund och hoptryckt. Blad sågade, blommor gula.

315. Pediculáris. Foder med 5 (sällan 4) fikar (tänder), ej hoptryckt. Kapsel klot- eller äggformig. Med pardelade eller parklufna blad och röda, sällan gula blommor.

D. Kronbräm snedt och otydligt tvåläppigt. Kronpip uppblåst och n. klocklik. Ståndareknappar utan bihang. Kapsel tvårummig.

316. Digitális. Blomfoder 5-deladt. Med stora, purpurröda och invändigt håriga blommor, hängande i ensidig axlik klase ; blad spiralstälda. 


\section{Klassen. TETRADYNAMIA.}

Örter med fyrbladigt blomfoder och korslik blomkrona. Frukt bestående af en skida. Blad spiralstälda utan stipler. Blomställning i början qvastlik. Kålväxxter. Crucíferæ.

Anm. Hos Lepidium ruderale äro ståndarne blott 2: hos densamma samt hos ett par arter af Cardamine felslår blomkronan. Hos Dentaria utbildas sällan mogna skidor.

\section{Ordn. SILIQUOS无.}

Skida lång och smal (hos arter af Nasturtium kort).

Hos Raphanus, Sinapis, Brassica och Diplotaxis äro hjertbladen (i fröet) på längden hop vikna, hos de öfriga äro de platta. Hos Nasturtium, Cardamine, Dentaria, Hesperis, Barbarea, och Arabis (utom hos A. Thaliana) är fröets rotämne kantliggande (då det berör båda hjertbladens kanter), hos de öfriga är det ryggliggande (då det blott berör det ena hjertbladets ryggsida). Hos Raphanus, Hesperis och Arabis arenosa och A. alpina äro 2 eller alla foderblad nedtill kupiga.

I. Skida slutligen på tvären ledad.

317. Ráphanus. Foderblad tilltryclta. Stift utdraget. Blad lyrformiga; blommor ljusgula violettådriga.

II. Skida oledad, uppbristande längsefter.

A. Skidans skal nervlösa. (Stift vanl. kort).

318. Cardamine. Skidans skal platta. Foderblad något utstående. Med parbladigt delade (hos en art hela) blad och hvita eller violetta blommor; frön enradiga med trådlika frösträngar.

319. Dentária. Skidans skal platta. Foder tilltryckt. De nedre bladen parbladigt delade, de öfre hela och försedda med brunsvarta groddlinoppar; blommor ljusröda; frön enradiga med vingade frösträngar.

320. Nastủrtium. Skidans skal kullriga. Foder n. utstiende. Blommor gula eller hvita; frön tvåradiga.

B. Skidans skal ennerviga (hos Arabis Thatiana otydligt nerviga).

a. Märke med 2 skiflika flikar.

321. Hésperis. Skida nästan fyrkantig. Foder tilltryckt. Med hela blad och violetta eller hvita blommor.

b. Märke helt eller urnupet.

1. Kronblad rent gula.

322. Ery'simum. Stift omärkligt; skida fyrkantig. Med hela blad och tilltryckt blomfoder.

323. Barbaréa. Stift kort; skida tvåeggad. De nedre bladen lyrformiga; foder tilltryckt. 
324. Brássica. Stift utdraget; skida n. trind eller fyrkantig.

De nedre bladen lyrformiga; foder öppet.

325. Diplotáxis. Stift kort eller något utdraget; skida $n$. plattad. Atm. de nedre bladen pardelade; foder öppet.

2. Kronblad hvitaktiga, gulhvita eller violetta.

326. A'rabis. Stift mycket kort; skida plattad. Med tilltryckt blomfoder; hlommor vanl. små.

327. Bráya. Stift mycket kort; skida n. trind och teml. kort. Med tilltryckt blomfoder; blommor små och hvita, vid torkning violetta; frön i två rader: märke urnupet.

C. Skidans skal flernerviga (hos Sisymbrium Sophia otydligt nerviga).

328. Sinápis. Stift utdraget; skida trind. Sträfhåriga växter; de nedre bladen vanligen lyrformiga; blommor gula; foderblad utspärrade.

329. Sisy'mbrium. Stift kort. Skida n. trind eller fyrkantig. Blommor gula eller hvita; foderblad föga utstående.

\section{Ordn. SILICULOSAE. Skida kort och bred. *)}

Hos Thlaspi, Alyssum, Cochlearia och Draba är fröets rotämne kantliggande, eljest ryggliggande.

A. Skidans skiljevägg smal och tvärstäld mot skalen.

Kronblad gula hos Isatis, violetta hos Cakite, hos de öfriga hvita.

a. Skida hoptryckt, mångfröig. Hjertblad platta.

330. Thlaspi. Skida vingad. Glatta växter.

331. Capsella. Skida ovingad. Blad vanl. gleshåriga.

b. Skida hoptryckt med fåfröiga rum.

332. Lepidium. Skidans rum enfröiga.

333. Hutchinsia. Skidans rum tvåfröiga. Kronblad likformiga. Ståndare utan bihang. Med parbladigt delade blad och mycket små blommor i korta klasar.

334. Teesdália. Kronblad något olikstora. Ståndare med ett kronbladslikt bihang. Stjelk n. bladlös. Eljest lik föreg. slägte.

c. Skida uppsväld med mångfröiga rum. Hjertblad på längden hopvikna.

335. Subulária. Skida aflång och ovingad. Med ungefär tumshög stängel och syllika blad.

d. Nötskida 1-2-fröig.

336. I'satis. Skida vingad och vigglitkt aflìng. Blågrön växt med hela blad och hängande skidor; hjertblad platta.

*) Somliga arter af Nasturtium kunna äfven räknas hit. 
337. Corónopus. Skida njurlik, stundom med n. åtskilda rum. Med pardelade blad; hjertblad på tvären veckade.

338. Cakile. Den på tvären ledade stidans öfre rum spetsigt, affallande. Köttig växt med vanl. pardelade blad; blommor violetta.

339. Crambe. Den på tvären ledade stidans öfre rum klotrundt och affallande. 'Mycket köttig och hög växt med inskurna, stundom fotsbreda blad.

B. Skidans skiljevägg parallel med skalen och ungefärr lika bred som dessa.

a. Skidans rum flerfröiga (sällan tvåfröiga). Hjertblad platta. Blad hela.

340. Camelina. Skida uppblåst och päronformig. Stift utdraget. Med pillika stjelkblad och blekgula blommor.

341. Alyssum. Skida mer eller mindre plattad med utdraget stift. Gråludna smalbladiga växter; frön vingade; ståndaresträngar (åtm. somliga) med bihang nedtill.

342. Cochleária. Skida uppblåst, rundadt äggformig eller klotrund. Stift kort. Glatta, saftfulla och hredbladiga växter med hvita blommor.

343. Draba. Skida plattad, aflång-oval. Stift vanl. omärkligt. Antingen med stjelk eller med stängel. Blornmor smả, hvita eller gula; blad teml. små.

344. Lunária. Skida plattad, oval och nedtill afsmalnande. Stift kort. Med hög stjelk, stora blad och rödvioletta blommor; ståndare utan bihan $\tilde{\text {. }}$.

b. Nötskida enfröig eller med enfröiga rum.

345. Búnias. Skida uppblåst, snedt äggformig. Med stor och lång rot, gula blommor och 2-4-rummig skida; hjertblad på tvären hoprullade; stift kägellikt.

346. Néslia. Skida n. klotrund och enfröig. Med pillika stjelkblad och gula blommor; hjertblad platta; stift trådlikt.

\section{Klassen. MONADELPHIA. *)}

Örter, undantag. Myricaria.

1 Ordn. PENTANDRIA. Ståndare 5, föga hopväxta. 347. Linum. Stift 5. Kapsel femrummig. Glatt växt med små helbräddade blad utan stipler; blommor hvita; foder och krona fembladiga. Gruináles.

2 Ordn. DECANDRIA. Ståndare 10.

Hos Erodium och somliga arter af Geranium äro 5 ständare utan knappar.

*) Hit kunna äfven hänföras följ. örter: Polygala, Ononis, Anthyllis, Genista och Sarothamnus med oregelbunden blomkrona samt Lysimachia oc h Cynanchum. 
A. Stift 5. Örter vanl. försedda med stipler. Gruináles. 348. 0'xalis. Kapsel femrummig. Stift föga hopväxta. Foder och lerona 5-delade. Blommor ensamma på rotblomskaft; blad trefingrade.

349. Geránium. Karpeller 5 nötlika. Stift $i$ början upptill fria, slutl. urfjäderlikt hoprullade. Foder och krona of 5 fria blad. Blad handnerviga. Blomskaft vanl. 2-blommiga, hos en art oftast enblommiga:

350. Eródium. Stift slutl. nedtill skruflikt vridna. Eljest lik föreg. slägte. Med parbladigt delade blad och röda blommor i flock.

B. Märke ett utan stift. Buske. Tamariscíneæ.

351. Myricária. Kapsel enrummig! och treskalig med fjunbärande frön. Foder 5-deladt; krona 5-bladig. Cypresslik buske med små barrlika blad och med ljusröda blommor i ax.

\section{Ordn. POLYANDRIA. Ståndare flera än 10, nedtill rörformigt hopväxta.}

Blad handnerviga. Foder 5-klufvet med svepe (foderholk) af 3 blad. Kronblad 5 nedtill förenade. Stift talrika och upptill fria. Karpeller talrika och nötlika, kaklikt förenade. Malváceæ.

352. Malva. Foderholkens blad fria.

353. Lavatẻra. Foderholkens blad till hälften hopväxta. Gråluden med stora ljusröda blommor.

\section{Klassen. DIADELPHIA.}

Örter (sällan halfbuskar eller buskar) med oregelbunden, till en del sambladig blomkrona.

\section{Ordn. HEXANDRIA. Ståndare 6.}

Ståndare hopväxta 3 och 3 . Foderblad 2, stundom felslående. Kronblad 4, det öfre med sporre. Blad skiftevis stälda utan stipler. Blommor i klase, vanl. röda. Fumariáceæ.

354. Fumária. Sporre kort. Nöt enfröig. Med grenig stjelk, enkel rot och hinnaktiga blomskärmar.

355. Cory'dalis. Sporre utdragen. Kapsel mångfröig. Med enkel stjelk, löklik stamknöl och bladartade blomskärmar.

2 Ordn. OCTANDRIA. Ståndare 8.

Ståndare hopväxta 4 och 4 , med enrummiga knappar. 356. Poly'gala. Foderblad 5, de 2 inre slutl. omslutande den tvåfröiga kapseln. Kronblad 3 , nedtill rörformigt hopväxta. Med hela blad och blommor i klasar. Polygáleæ.

\section{Ordn. DECANDRIA. Ståndare 10.}

Ärtväxter. Med vanl. sammansatta och med stipler försedda blad, femtandadt (eller klufvet) blomfoder, fjärillik krona samt 
ärtbalja (som hos Onobrychis och Medicago lupulina samt somliga arter af Trifolium är oöppnad). Leguminósæ (Papitionáceœ).

Anm. Stiplerna äro otydliga hos Lotus, hos ett par arter af Genista saknas de.

I. Alla ståndare nedtill hopväxta.

A. Blad parbladiga med uddblad (udda blad).

357. Anthyllis. Blomfoder tandadt och uppbläst. Blommor vanl. gula i 1-2 hufvud inom fingerlikt delade skärmblad; balja 1-2-fröig.

B. De nedre bladen trefingrade; hos de öfre felslå sidosmåbladen.

358. Onónis. Foder djupt klufvet. Blommor rosenröda; balja fåfröig.

359. Sarothamnus. Foder tvåläppigt med tandad öfverläpp. Buske med stora gula blommor i bladiga klasar; balja mångfröig

C. Alla blad enkla.

360. Genista. Foder tvåläppigt med delad öfverläpp. Buske med gula blommor i bladiga klasar; balja flerfröig.

II. En ståndare fri eller skiljbar från de öfriga 9, som äro hopväxta.

A. Blad parbladiga utan uddblad (udda blad). Balja enrummig.

a. Ståndaresträngarnes rör upptill snedt tvärhugget. Blad försedda med klänge och flerpariga. Balja vanl. mångfröig, stundom fåfröig.

361. Vicia. Balja upptill snedt tvärhuggen och med spröt. Balja vanl. mångfröig; foder likformigt tandadt (eller hos en art klufvet i borstlika flikar); frön klotrunda, stundom något hoptryckta; blommor ofta blaaktiga.

362. Ervum. Balja upptill afrundad utan spröt. Balja vanl. fyrfröig; foder olikformigt tandadt; frön klotrunda; blommor blåhvita, ensamma eller 2-3 tillsammans.

b. Ståndaresträngarnes rör upptill jemnt tvärhugget. Blad enpariga med klänge eller flerpariga med eller utan klänge. Balja mångfröig.

363. Láthyrus. Balja upptill snedt tvärhuggen med utdraget spröt. Blomfoder olikformigt tandadt; frön n. klotrunda, något hoptryckta; blommor i klasar; blad stundom utan klänge. 364. Pisum. Balja upptill snedt tvärhuggen med kort spröt. Blomfoder n. likformigt klufvet; blommor stora, ensamma eller parvis stälda; blad med klänge och stora stipler.

B. Blad parbladiga med uddblad. Balja stundom tvårummig. 
a. Stipler tydliga. Balja flerfröig och vanl. tvårummig, stundom med ofullständig skiljevägg.

365. Astrágalus. Blomkronans köl trubbig utan udd. Balja (mer eller mindre fullständigt) tvårummig. Blommor blekt gröngula, blåaktiga eller hvita, och tätt sittande i korta klasar; baljans nedre kant inviken; småblad talrika, vanl. trubbiga och teml. breda.

366. Phaca. Blomkronans köl trubbig utan udd. Balja enrummig utan skiljevägg. Med stora stipler och stora, men fä och trubbiga småblad; blommor blëkgula i klasar.

367. Oxy'tropis. Kronköl med klolik udd. Balja tvårummig. Blommor gula eller blå och tätt sittande i ax; småblad talrika och teml. smala; balja rak och utskjutande, dess öfre kant (fog) inviken.

b. Stipler tydliga. Balja enfröig och oöppnad.

368. Onobry'chis. Kronköl snedt tvärhuggen. Blommor ljusröda och strimmiga i axlika klasar; småblad smala, isynnerhet de öfre, och talrika.

c. Stipler tydliga. Balja på tvären försedd med leder och uppbristande i lederna.

369. Coronilla. Blomkronans köl med sprötlik udd. Blommor gula och kortskaftade, 2-3 tillsammans på ett utdraget gemensamt skaft; bladpar 2-3.

370. Ornithopus. Blomkronans köl trubbig utan spröt. Blommor hvitaktiga och mycket små, 3-7 tillsammans på det utdragna gemensamma skaftet; småblad talrika.

d. Stipler otydliga. Balja uppbristande och enrummig. 371. Lotus. Kronköl med sprötlik udd. Blommor gula i flocklika hufvud; balja rak och långt utskjutande; smáblad få, vanligen 5 .

C. Blad trefingrade. *)

a. Blomkrona qvarsittande. Balja innesluten eller föga utskjutande ur fodret.

372. Trifólium. Blomfoder tandadt eller klufvet. Balja rak. Blommor små, sittande i täta eller stundom flocklika hufvud.

b. Blomkrona snart affallande. Balja utskjutande.

373. Melílotus. Blomfoder tandadt. Balja rak, kort och ovingad. Blommor i utdragna klasar.

374. Medicágo. Foder klufvet. Balja krökt eller hoprullad. Blommor i hufvud eller hufvudlika klasar.

375. Tetragonólobus. Foder tandadt. Balja rak, utdragen och försedd med 4 vinglika kanter. Blnmmor enstaka, sällan parvis stälda.

*) Till denna afdelning räknas vanligen äfven slägtet Lotus. 


\section{Klassen. POLYADELPHIA. Örter.}

1 Ordn. POLYANDRIA. Ståndare talrika.

Ståndare nedtill förenade i 3-5 knippen.

376. Hypéricum. Foder 5-deladt; krona 5-bladig; stift 3-5. Ned motsatta helbräddade blad och gula blommor i knippen, som vanl. äro förenade i vippa; kapsel 3-5-rummig. Hypericineæ.

\section{Klassen. SYNGENESIA. *)}

Örter (sällan halfbuskar) med blommor (nästan alltid) i blomkorg, blad utan stipler, en pistill och enfröig skalfrukt. Blomkorgväxter. Synanthéreæ.

Anm. Hos Echinops sitta blommorna i hufvud.

\section{Ordn. MONOCLINIA. **)}

Alla med könsdelar försedda blommor samkönade. Blomkorg antingen tungblomstrig eller rörblomstrig.

I. Blomkorg tungblomstrig.

Mjölksaftiga örter (utom Lapsana) med vanl. gula blommor. Endast hos Hypocharis och Cichorium är blomfästet försedt med fjäll. Hos Cichorium och Mulgedium äro blommorna blå, hos Hieracium aurantiacum och arter af Tragopogon rödaktiga.

A. Fruktens penselhår nedtill tjockare och vanligen fjäderlika. (Blomkorgar stora).

a. Blomfäste med fjäll.

377. Hypochæris. Pensel skaftad med skilda småhår. Holkfjäll tegellagda. Stjelk n. bladlös och stängellik.

b. Blomfäste utan fjäll.

378. Tragopógon. Pensel skaftad. Holkfjäll $i$ en krans. Glatta växter med långa och hela stjelkblad.

379. Scorzonéra. Pensel oskaftad med sammanhängande småhär. Holkfjäll tegellagda och breda. Stjelk i början ullig, vanl. enblomstrig; stjelkblad hela; rotstock stor och svart.

380. Leóntodon. Pensel oskaftad med skilda här. Holkfjäll tegellagda och smala. Med stängel, parklufna rotblad och kort rotstock; blomkorgar få, ofta ensamma.

381. Picris. Pensel oskaftad med skilda här. De inre holkfjällen $i$ en krans, de yttre tegellagda och utböjda. Sträfhårig med $\mathrm{n}$. hela stjelkblad och flera blomkorgar i qvast.

*) Hit kunna räknas följ. örter, som igenfinnas i Pentandria: Lobelia, Iasione, Solanum, Impatiens, Gentiana, Viola.

**) Hit kunna äfven räknas Bidens, Linosyris och Eupatorium. - Cirsium arvense och Serratula äro vanligen tvåbyggare. 
B. Penselhår enkla, ej tjockare nedtill.

a. Pensel oskaftad. Blommor gulaktiga, sällan rödaktiga. 382. Sonchus. Holk nedtill uppblåst. Frukt hoptryckt. Stjelkblad parklufna eller taggbräddade; pensel mjuk och snöhvit; holk upptill hopdragen; de flesta holkfjällen tegellagda.

383. Hierácium. Holk ej uppbliist. Frukt jemntjock samt trind eller kantig. Blad ej taggbräddade; pensel teml. skör och vanl. grå; holk upptill (vanligen) föga eller icke hopdragen; de flesta holkfjällen vanl. tegellagda.

384. Crepis. Holk ej uppblåst. Frukt n. trind och vanl. upptill afsmalnande. Blad ej taggbräddade; pensel teml. mjukoch ofta snöhvit; holk upptill ej hopdragen; de inre holkfjällen jemnhöga $\mathrm{i}$ en krans, de yttre liorta; blomkorgar talrika.

b. Pensel oskaftad. Blommor blå, sällan hvita.

385. Mulgédium. Holk ej uppblåst. Frukt n. trind ochjemntjock. Stjelk med talrika blomkorgar; pensel skör; holk $+n$. rörformig; de yttre holkfjällen korta och tegellagda.

c. Pensel skaftad. Blommor gula.

386. Lactúca. Frukt plattad. Stjelk med små, smala och talrika blomkorgar i vippa.

387. Taráxacum. Frukt nästan trind. Stängel med en ensam och stor blomkorg.

C. Frukt utan pensel. Holkfjäll i tva kransar.

388. Lápsana. Blomfäste utan fjäll. Frukt utan fruktkrona.

Stjelk med små blekgula blomkorgar i qvastlik vippa.

389. Arnóseris. Blomfäste utan fjäll. Frukt med fruktkrona.

Med flera greniga stänglar; blomkorgar små i spetsen af grenarne;

blommor blekgula..

390. Cichórium. Blomfäste med fjäll. Frukt med fruktkrona.

Stjelk med stora blå och oskaftade blomkorgar i bladvecken.

II. Blomkorg rörblomstrig. Tistelväxter.

A. De yttre småblommorna utan könsdelar. Inga holkfjäll med tagglik udd.

391. Centauréa. De yttre småblommornas bräm snedt och flerklufvet. Blad och holk (hos våra vilda arter) icke stickande.

B. Inga blommor utan könsdelar. Holkfjäll (åtm. de yttre) med tagglik eller (hos Lappa) krökt udd. Bladflikar stundom med tagglik udd.

a. Blommorna hvar för sig med svepe och förenade i hufvud.

392. E'chinops. Penselhår hopväxta. Med stickande blad, filtluden stjelk och ljusblå blommor.

b. Blommor i korg. Blomfäste med fjäll. Ståndareknappar med 2 trådlika bihang nedtill. 
393. Lappa. Frulet med hårpensel; yttre holkfjäll kroluddiga. Blad icke taggiga; blommor rödaktiga.

394. Carlína. Penselhår fjäderlika; yttre holkfjäll med rak $u d d$. Blad taggiga; holk skållik; blommor vanl. gula, de yttre stundom blåaktiga.

395. Saussúrea. Fruktens yttre penselhair enkla, de inre fjäderlika. De yttre holkfjällen med mycket kort och rak, ej stickande udd, de inre utan udd. Bladens tänder veka och ej stickande; holk äggformig; blommor violetta.

c. Blommor i korg. Blomfäste med borst eller (hos Onopordon) n. bart. Ståndareknappar utan bihang. Blommor rödaktiga, sällan (hos Cirsium oleraceum) gula.

396. Serrátula. Penselhår enkla, åtskilda och quarsittande. Blad och holkfjäll ej stickande.

397. Círsium. Penselhår fjäderlika. De yttre holkfjällen stickande, ofta äfven bladen.

398. Cárduus. Penselhår enkla, nedtill ringformigt förenade, och affallande. Blad och yttre holkfjäll stickande.

399. Onopórdon. Penselhår n. enkla. Blomfäste gropigt och n. bart. Med bredt vingad och derigenom bladlik stjelk.

\section{Ordn. POLYCLINIA. *)}

Somliga (eller alla) blommor enkönade. Blomkorg antingen rörblomstrig eller strålblomstrig.

*) Till denna ordning skulle äfven Serratula och Cirsium arvense kunna räknas: dessa äro tvåbyggare, liksom Petasites och Antennaria. - Eupatorium och Linosyris hafva alla blom. morna samkönade: hos Bidens utbildas sällan de enkönade strål. blommorna.

Till lättnad vid examinerıngen bifogas följ. öfversigt af slägtena.

A. Växter med stängel: blomkorgar i vippa N:o 405, blomk. enstaka med gula strålblommor 406, blomk. enstaka med hvita eller rödletta strålólom. 414.

B. Stjelk med motsatta blad: blad handnerviga delade 400, blad fjädernerv., frukt med tagglika borst 417, blad fjädernerv., frukt med pensel 407 .

C. Stjelk med strödda blad.

a. Frukt utan pensel. Blomkorgar rörblomstriga: i vippa 410, i qvast 411 ; blomk. (n. alltid) strălblomstriga: blomfäste med fjäll 415, 416, utan fjäll 412, 413.

b. Frukt med pensel.

1. Blad hela; blomkorg rörblomstrig: alla blommor samkönade 401, alla blom. enkönade 422, somliga blom. enkönade $420,421,423$. 
I. Ståndareknappar utan bihang. Blomfäste utan fjäll.

A. Frukt med hårpensel.

a. Holkfjäll tegellagda. Blad motsatta, handnerviga och tredelade. Blomkorg rörblomstrig.

400. Eupatórium. Alla blommor samkönade. Med små ljusröda blomkorgar och rörformig holk.

b. Holkfjäll tegellagda. Blad strödda och hela. Blomkorg rörblomstrig.

401. Linósyris. Alla blommor samkönade. Med gula blommor, halfrund holk och liniebreda blad; penselhår i två kransar; frukt hoptryckt utan åsar.

c. Holkfjäll tegellagda. Blad strödda och hela. Blomkorg strailblomstrig.

402. Solidágo. Strålblommor gula $i$ en krans. Blad breda; holk äggformig; penselhår $\mathrm{i}$ en krans; frukt trind med åsar. 403. Erígeron. Strålblommor violetta $i$ flera kransar. Blad smala helbräddade; holk halfrund; penselhår i en krans, grå och sköra; frukt hoptryckt utan åsar.

404. Aster. Strålblommor violetta $i$ en krans. Blad köttiga, smala och n. helbräddade; holk halfrund; penselhår i flera kransar, hvita och mjuka; frukt som hos föreg. slägte.

d. Holkfjäll i 2 (sällan 3) kransar. Stängel fjällig. 405. Petasítes. Blomkorg vanl. rörblomstrig. Blomkorgar i klaselik vippa; blommor röda, hvita eller gula. Samkönade blommor (hanblommor) rörformiga och ej fruktbärande; honblommor vanl. trådlika (stundom tunglika), fruktbärande; dessa blommor förekomma vanl. på olika stånd. Bladen framkomma året före blomningen och blifva slutl. mycket stora.

406. Tussilágo. Strålblommor gula. Hvarje stängel med en gulblommig blomkorg. Blad som hos föreg. slägte. Ej tvåbyggare.

e. Holkfjäll i 2 kransar. Stjelk (bladig).

407. Arnica. Strålblommor brandgula $i$ en krans. Penselhår $i$ en krans. Blad motsatta och n. helbräddade.

408. Senécio. Srålblommor gula $i$ en krans, stundom felslående. Penselhair $i$ flera kransar. Blad strödda, vanl. parklufna-pardelade; de yttre holkfjällen mycket små.

f. Holkfjäll i en krans. Stjelk (bladig).

409. Cinerária. Strålblommor gula $i$ en krans. Penselhår $i$ flera kransar. Blad hela; holk klocklik; hlomkorgar platta.

2. Blad vanl. parklufna (hos en art hela); holkfjäll i två kransar; blomkorg stundom strålblomstrig 408.

3. Blad hela; holkfjäll i en krans; blomk. strălblomstrig 409.

4. Blad hela; holkfjäll tegellagda; blomkorg rörblomstrig; strålblommor violetta 403, 404, strålbl. gula 402, 418, 419. 
B. Frukt utan pensel.

a. Blomkorg rörblomstrig. Holkfjäll tegellagda.

410. Artemisia. Frukt utan asar och fruktkrona. Blomkorgar små, klaselikt stälda i vippa; blad ofta parbladigt delade.

411. Tanacétum. Frukt med asar och hinnaktig fruktkrona. Blomkorgar teml. små, n. platta och gula, stälda i qvast; blad pardelade; holk halfrund.

b. Blomkorg strålblomstrig. Holkfjäll tegellagda.

412. Chrysánthemum. Blomfäste n. platt. Blomkorgar vanl. stora och ensamma i spetsen af grenarne, stundom smärre och stälda i qvast; holk skålformig eller halfrund.

413. Matricăria. Blomfäste slutl. kägellikt. Blomkorgar stora och ensamma i spetsen af grenarne; holk skålformig; strålblommor hvita; frukt med fruktkrona.

c. Blomkorg strålblomstrig. Ḣolkfjäll i 2 kransar. 414. Bellis. Blomfäste kägellikt. Hvarje stängel med en blomkorg; strålblommor hvita eller rödletta; blad sågade.

II. Ståndareknappar utan bihang nedtill. Blomfäste öfverallt besatt med fjäll. Frukt utan pensel.

A. Frukt utan fjun eller borst. Blomkorg (n. alltid) strålblomstrig. Holkfjäll tegellagda.

415. A'nthemis. Strålblommor teml. långa och smala. Blomfäste slutl. kullrigt. Blomkorgar stora, ensamma på grenarne; blad parbladigt delade med smala platta flikar; holk skăllik; frukt med åsar.

416. Achillæa. Strålblommor korta. Blomfäste platt. Blomkorgar teml. smă, stälda i qvastlik vippa; holk äggformig eller halfrund; frukt utan åsar; strålblommor hvita.

B. Frukt med 2-4 småtaggiga borst i spetsen.

Strålblommor gula eller inga. Holkfjäll i 2 kransar.

417. Bidens. Holk halfrund eller n. rörformig. Med motsatta blad och gulaktiga blomkorgar.

III. Ståndareknappar nedtill försedda med 2 trådlika bihang. Blomfäste utan fjäll eller (hos Filago) blott i kanten med fjäll. Frukt med hårpensel.

A. Med gula strålblommor. Holk halfrund; holkfjäll tegellagda. Stjelkblad hela. Blomkorgar ensamma spetsen af grenarne.

418. I'nula. Penselhair $i$ en krans. Blomkorgar teml. stora; strålblummor utdragna.

419. Pulicária. Penselhår $i$ två kransar, den yttre mycket kort (liknande en krans af fjäll). Blomkorgar temil. små; strålblommor ej utskjutande.

B. Blomkorgar rörblomstriga (och små), stälda i ax, hufvud eller flock. Stjelkblad smala och helbräddade. 
a. Holk klocklik med tegellagda och hinnaktiga holkfjäll. Blomfäste utan fjäll.

420. Gnaphálium. Blomfäste platt. De inre blommorna samkönade. Honblommor i flera kransar. Med brunaktiga eller gulaktiga blomkorgar i hufvud eller ax; holkfjäll slutl. stjernlikt utbredda.

421. Helíchrysum. Blomfäste platt. De inreblommorna samteönade; honblommor $i$ en krans. Med gulglänsande torrhinniga holkfjäll, som ej blifva stjernlikt utbredda; blomkorgar i flock.

422. Antennária. Blomfäste kullrigt. Blommor tvåbyggare. Med hvita, röda eller brunaktiga blomkorgar i flock.

b. Holk kantigt äggformig; holkfjäll bladartade och stälda i 2-4 kransar. Blomfäste med fjäll i kanten.

423. Filágo. De yttre honblommorna sittande mellan holkfjällen: deras frukter utan pensel. Gråulliga växter med blom. korgar i hufvudlika, i vippa stälda gyttringar.

\section{Klassen. GYNANDRIA.}

Monokotyledona örter med enkel stam och helbräddade (stundom inga) blad. Blomkalk oregelbunden och sexbladig: ett af kalkbladen, läppen, är mycket olika de öfriga och vanl. nedböjdt antingen genom fruktämnets eller (t. ex. hos Epipactis) blomskaftets omvridning. Kapsel treskalig. Blommor vanl. sittande i ax, hos Neottia, Listera, Epipactis och Corallorhiza i klase, hos Calypso och Cypripedium (vanligen) en enda. Orchídeæ.

\section{Ordn. MONANDRIA. Standareknapp 1.}

I. Med 1-3 stamknölar under jordytan.

Ståndareknapp fastväxt vid pistillen. Frömjölsmassor täta och klibbiga. Stjelk (eller stängel) bladbärande, åtm. nedtill.

A. Läpp med sporre. Stamknölar ofta klufna, stundom hela.

424. Orchis. Frömjölsmassor åtskilda och med särskilda skaft. Läpp nedböjd. Fruktämne vridet. Sporre vanl. utdragen; blommor i ax, ofta rödaktiga, stundom hvita eller gulaktiga. 425. Anacamptis. Frömjölsmassor sammanhängande med gemensamt skaft. Läpp nedböjd. Fruktämne vridet. Sporre utdragen; blommor röda i kort och hufvudlikt ax.

426. Nigritella. Frömjölsmassor åtskilda med särskilda skaft. Läpp uppåtvänd. Fruktämne ej vridet. Sporre kort och punglik; blommor svartröda i knrt hufvudlikt ax.

B. Läpp utan sporre. Stamknölar hela, rundade.

427. Herminium. Läpp treklufven med hel mellanfiti. Alla kalkbladen klocklikt samstående. Med stängel och små gul aktiga, teml. tätt sittande blommor. 
428. Ophrys. Läpp nedböjd och treklufven med grundt tvåklufven mellanflik. Kalk vidöppen. Med stängellik stjelk, som nedtill har 2-3 större blad, och grönaktiga, glest sittande blommor med sammetsbrun läpp. Svartnar vid torkning.

429. Chamæórchis. Läpp nedböjd och hel. Kalk hjelmlikt sluten. Liten och spenslig med nedtill bladig, stängellik stjelk, mycket smala blad och små, glest sittande och grönaktiga blommor med brunaktig läpp.

\section{Utan stamknölar under jordytan.}

A. Med en förlängd rotstock och bladig stjelk.

Ståndareknapp nästan skild från pistillen och qvarsittande. Frömjölsmassor mjöllika. Läpp utan sporre.

430. Epipáctis. Läpp från sidorna inskuren. Fruktämne icke vridet, men med kort och vridet skaft. Blommor glest sittande och $n$. hängande.

431. Cephalanthéra. Läpp treflikig. Fruktämne vridet och oskaftadt. Blommor glest sittande, n. upprätta och stora.

432. Listéra. Läpp $i$ spetsen 2-4-klufven. Fruktämne icke vridet, men med vridet och teml. utdraget skaft. Blommor glest sittande; blad 2 n. motsatta.

433. Goodyéra. Läpp hel, kortare än de öfriga kalkbladen. Fruktämne oskaftadt, icke vridet. Blommor närmade och ensidigt stälda; blad, nätådriga, sittande långt ned på stjelken.

B. Birötter tätt hopknippade utan utbildad rotstock. Stängel fjällig utan blad. Eljest som föreg. afdelning. 434. Neóttia. Läpp i spetsen tvåklufven. Fruktämne skaftadt, icke vridet. Blommor och stängel gulbruna.

C. Stängel nedtill bladbärande, med hinnskaliga lökar. Stảndareknapp nästan skild från pistillen. Frömjölsmassor täta och vaxlika.

435. Maláxis. Läpp hel och uppåtvänd utan sporre. Fruktämne oskaftadt, ej vridet. Smă kärrväxter med små gulaktiga blommor i ax.

436. Caly'pso. Läpp skoformig och nedåtvänd med dubbel sporre. Liten växt med ett bredt blad och en enda, stor och rosenröd blomma; könpelare (pistill) med färgadt och hladlikt bihang.

D. Rotstock grenig, korall-lik. Stängel fjällig utan blad. Läpp med punglik sporre.

437. Corallorhiza. Läpp hel och hopväxt med de 2 yttre sidokalkbladen. Fruktämne icke vridet, men med kort och vridet skaft. Blommor små grönhvita, glest sittande och slutl. hängande; sporre kort. Stăndare som hos Malaxis.

438. Epipógium. Läpp treflikig och uppåtvänd. Fruktämne oskaftadt och icke vridet. Blommor fă, stora och gulaktiga samt glest sittande; sporre stor. Ståndareknapp fri och affallande. Frömjölsmassor täta med stora korn. 


\section{Ordn. DIANDRIA. Ståndareknappar 2.}

439. Cypripédium. Kalk med 4 smala blad, det ena tvåklufvet, och en stor skoformig läpp. Fruktämne långskaftadt, icke vridet. Med stjelk, rotstock, stora blad och en rödbrun blomma med gul och rödfläckig läpp.

\section{Klassen. MONOECIA. *)}

Hit höra åtskilliga träd, många halfgräs och få andra örter Blommorna äro vanl. ofullständiga (utom hos Littorella samt stundom hos Myriophyllum).

\section{Ordn. MONANDRIA. Ståndare 1.}

A. Barrträd med blommor i hängen utan kalk.

Frö vingadt och bart (utan frögömme). Hjertblad flera i krans. Coníferæ.

440. Pinus. Kottefjäll med tjock n. sköldlik spets. Kottar ägg formiga; barr parvis sittande och nedtill omgifna af en slida 441. A'bies. Kottefjäll tunnare $i$ spetsen. Kottar n. jemntjocka, blott upptill något afsmalnande; barr åtskilda.

B. Vattenväxter. Karpeller nötlika och fria. Blommor enstaka i bladvecken.

442. Callitriche. Blommor utan kalk. Stift 2. Blad motsatta; karpeller 4. Callitrichíneæ.

443. Zannichéllia. Honblommor med kalk. Stift 2-6. Blad kranssittande (åtm. somliga) och n. hårlika; karpeller lika många som stiften. Potamogetóneæ.

C. Mjölksaftiga örter. Karpeller 3, nötlika och i början nedtill sammanhängande.

444. Euphórbia. Hvarje hanblomma bestiaende blott af ståndaren, som är stödd af ett litet fjäll. Stift 3. Blad spiralstälda och hela. Hvarje blomsamling är omgifven af ett 8-10klufvet svepe, som liknar en blomkalk. Euphorbiáceæ.

2 Ordn. TRIANDRIA. Ståndare 3.

A. Halfgräs. Frukt nötlik med 2-3 märken. Blommor utan kalk. Cyperáceæ.

445. Carex. Märken 2-3. Nöt omgifven af ett flasklikt hölster (fruktgömme). Blommor stälda i ax med tegellagda skärmfjäll (axfjäll).

446. Kobrésia. Märken 3. Nöt utan hölster. Liknar föreg. slägte; nöt trekantig; hanblomma med ett, honblomma med två skärmfjäll (axfjäll).

*) Hit kunna äfven räknas: Atriplex ört med fjädernerviga blad, Calla ört med bågnerviga blad, Empetrum och Salix buskar. 
B. Gräslika vattenväxter. Frukt utan hölster. Märke vanl. 1. Blommor utan kalk. Typháceæ.

447. Typha. Frukt nötlik. Blommor blandade med hår (sannolikt felslagna ståndare eller pistiller). Blommor i valsformiga ax (kolfvar), ett hanax öfver ett brunt honax; stam stängellik; blad styfva och n. svärdlika; frukt långskaftad.

448. Spargánium. Frulkt n. stenfruktartad. Blommor utan hair i hufvudlika ax; honax flera, gröna; stjelk med mjuka jemnbreda blad.

3 Ordn. TETRANDRIA. Ståndare 4.

A. Ört med fullständiga blommor; hanblommor ensamma på rotblomskaft, honblommor samlade vid roten.

449. Littorella. Frukt nötlik. Hanblommornas foder fyrdeladt, honblommornas trebladigt. Plantagíneæ.

B. Örter med brännborst och fjädernerviga blad.

450. Urtica. Frukt nötlik. Blommor i kransar; kalk foderlik fyrdelad; märke ett; blad motsatta. Urticáceæ.

c. Träd (buskar) med blommor i hängen och med fjädernerviga blad. Frukt enfröig nötlik. Betulíneæ.

Hanhängen täła och jemntjocka, utslående på bar qvist; vid hvart hängefjäll sitta 3 blommor, försedda med kalk och omkr. 4 ståndare. Honblommor utan kalk. Stift 2.

451. Bétula. Nöt vingad. Honhängen jemntjocka, utslående samtidigt med bladen. Kottefjäll affallande och treklufna. Ståndareknappar enrummiga.

452. Alnus. Nöt ovingad. Honhängen bildade året före blomningen, slutl. rundade med hela qvarsittande fjäll.

4 Ordn. POLYANDRIA. Ståndare flera än 5.

A. Örter.

a. Blommor tydliga med nötlika karpeller.

453. Sagittária. Kalkblad 6 fria: de yttre foderlika, de inre kronlika, Med stängel, pillika eller hela rotblad, talrika ståndare och karpeller. Monokotyledon. Alismáceæ.

454. Myriophyllum. Blomfoder sambladigt. Kronblad 4, stundom felslående. Med kranssittande, parbladigt delade blad med hårfina flikar; blommor små; ståndare 8; karpeller 4. Halorhágeæ.

455. Potérium. Kalk foderlik med 4-deladt bräm och hårdnande pip. Stjelk med spiralstälda, parbladigt delade blad med breda flikar (småblad); blommor i hufvudlika ax; ståndare talrika; karpeller 2-3. Vanligen mångbyggare. Senticósæ.

b. Blommor med ingen (eller otydlig) kalk och ensam frukt.

456. Ceratophyllum. Frrukt nötlik. Blommor ensamma ibladvecken. Med ledad stjelk och kranssittande findelade (liksom blott af nerver bestående) blad. Hjertblad 4. Ceratophyllex. 
457. Arum. Frukt bärlik. Blommor $i$ kolf inom ett hölster. Stängel med långskaftade, n. pillika blad och knöllik rotstock; somliga ståndare felslående (sterila). Aroideæ.

B. Träd (buskar) med åtm. hanblommor i hängen.

Frukt 1-2-fröig nöt, insänkt i ett bägarfoder, bildadt af hopväxta skärmfjäll. Blad fjädernerviga. Cupulíferæ.

a. Hanblommor utan kalk. Ståndareknappar enrummiga. Stift 2 trådlika. Hanhängen utdragna, $n$. jemntjocka och tätblommiga.

458. Córylus. Bägarfoder rörformigt (klocklikt), ungefär af nötens längd. Blomning på har qvist; honblommornas gyttringar knopplika; stift röda. Blad vanl. dubbelsågade, mjuka och håriga.

459. Carpínus. Bägarfoder treflikigt med mycket stor mellanfit samt på yttre sidan omslutande nöten. Blomning $\mathrm{n}$. samtidig med bladens utsprickning: honblommor samlade i hängen. Blad dubbelsågade, stela och undertill blott på nerverna håriga.

b. Hanblommor med kalk. Ståndareknappar tvårummiga. Stift 1 eller 3. (Blomning samtidig med bladens utsprickning).

460. Quercus. Hanhängen utdragna glesblommiga. Bägarfoder skållikt af tegellagda fjäll samt mycket kortare än nöten. Stift ett. Blad flikiga, slutl. stela och glatta. Honblommor vanl. samlade $\mathrm{i}$ hängen.

461. Fagus. Hanhängen klotformiga och laingskaftade. Bägarfoder slutl. fröhuslikt. Stift tre. Honblommor 1-3, omslutna af 4 till midten hopväxta svepeblad. Blad n. helbräddade, slutl. stela och glatta.

\section{Klassen. DIOECIA.}

Hit höra åtskilliga buskar och träd samt få örter. Blommorna äro ofullständiga utom hos Empetrum, Viscum och Rhodiola.

\section{Ordn. MONANDRIA. Ståndare 1.}

A. Monokotyledon ört, växande i vatten.

462. Najas. Blommor inom ett foderlikt hölster (utan kalk), vanl. enstaka i bladvecken; blad smala, tagglikt tandade; frukt nötlik; ståndareknapp slutl. fyrklufven. Najádeæ.

B. Lägre träd eller buskar med barr.

Hanblommor utan kalk samlade i korta och täta hängen. Honblommor bildande falska bär. Frö bart. Påståndarens sköldlika knappband sitta 3-8 knapprum. Coníferæ.

463. Juníperus. Honblommor tre tillsammans, slutl. hopväxta. Barr stickande och kranssittande; bär slutl. svartblätt; dess yttre beklädnad utgöres af hopväxta skärmfjäll. 
464. Taxus. Honblommor ensamma. Barr breda, spetsiga och tvåsidigt stälda; bär slutl. rödt, bildadt af blomfästet.

\section{Ordn. DIANDRIA.} andra 3).

Ståndare 2 (hos Salix pentandra 4-12, hos S. tri465. Salix. Blommor utan kalk: i dess ställe finnas 1-2 honingsglandler. Buskar eller träd med hängen, hela fjädernerviga blad samt hårbärande frön $\mathrm{i}$ en tvåskalig kapsel med fröfästen på skalens sidor; hängefjäll hela. Salicíneæ.

\section{Ordn. TRIANDRIA. Ståndare $3 .{ }^{*}$ )}

466. E'mpetrum. Krona trebladig; foder tredeladt med svepe; stift ett. Låg buske. Empétreæ.

4 Ordn. TETRANDRIA. Ståndare vanl. 4, stundom 6.**)

467. Myríca. Blommor utan kalk $i$ korta hängen. Temligen låg buske, blommande på bar qvist; frukt nötlik, omgifven af köttiga skärmfjäll; märken 2-3. Myríceæ.

468. Viscum. Blommor $i$ hufvud. Hanblommor med köttig blomkalk, honblommor med 4 fjällika, $n$. fria kronblad öfver frukten. Ständigt grön parasitbuske med klynnedelad stam och bärlik frukt. Lorantháceæ.

469. Hippóphaë. Hanblommornas kalk tvåbladig, honblommornas sambladig med tvåklufvet bräm. Hanblommor $i$ korta (knopplika) hängen, honblommor ensamma. Tornbärande buske; bela växten beklädd af fjäll, som vid förstoring likna fiskfjäll; frukt enfröigt falskt bär, bildadt genom blomkalkens uppsvällnning; stift ett med hornlikt märke. Elæágneæ.

\section{Ordn. PENTANDRIA. Ståndare 5.***)}

470. Húmulus. Hanblommornas kalk femdelad, honblommornas fjällik och enbladig. Slingrande ört med motsatta handnerviga blad; hanblommor i vippa; honblommor i kottar med hinnaktiga fjäll; nöt enfröig; märken två. Urticáceæ.

\section{Ordn. POLYANDRIA. Ståndare 8 eller flera. $\dagger$ )}

A. Träd med fjädernerviga blad.

*) Hit kunna äfven räknas Valeriana dioica, Salix triandra, Urtica dioica och Carex dioica. hänföras.

**) Hit kunna äfven Urtica dioica och Rhamnus cathartica

***) Hit kunna räknas: 1) buskar: Ribes alpinum, Rhamnus cathartica och Salix pentandra, 2) örter med blomkorg: Cirsium arvense, Serratula, Petasites och Antennaria.

$\dagger$ ) Hit kunna äfven hänföras Salix pentandra samt följ. örter: Rubus Chamcmorus, Melandrium och tre arter af Rumex. 
471. Pópulus. Blomkalk skålformig. Hängen n utdragna och jemntjocka, utslående på bar qvist; kapsel tvåskalig med hårbärande frön, fästade på skalen. Salicíneæ.

B. Ört med fjädernerviga och motsatta blad.

472. Mercuriális. Kalk foderlik och 3-4-delad. Hanblommor i axlikt stälda gyttringar; karpeller 2 (sällan 3 ) nötlika och i början hopväxta. Euphorbiáceæ.

C. Ört med spiralstälda och köttiga blad.

473. Rhodíola. Blomkrona 4-bladig, blomfoder 4-deladt. Karpeller 4 kapsellika, ståndare 8, blommor i knippe i stjelkens spets. Liknar en art af Sedum och har någon gång samkönade blommor. Crassuláceæ.

D. Monokotyledona, i vatten växande örter.

Blommor med hölster; de 3 yttre kalkbladen foderlika, de 3 inre kronlika och hvita. Hydrocharídeæ.

474. Stratiótes. Hölster tvåklufvet. Med rotblomskaft saint långa, tjocka och taggsågade blad.

475. Hydrócharis. Hanblommornas hölster tvåbladigt, honblommornas enbladigt. Stjelk krypande eller simmande, hlad njurlika, tunna och helbräddade, blommor långskaftade.

\section{Klassen. POLYGAMIA.*)}

\section{Ordn. MONOECIA. Örter.}

Enkönade blommor på samma stånd som de samkönade.

Anm. Hos våra vilda arter af Atriplex utbildas sällan samkönade blommor.

Blomkalk foderlik, hos honblommorna slutl. utväxande till ett hoptryckt fruktfoder, hos de öfriga blommorna 3-5-delad. Ståndare vanl. 5, pistiller 2. Frukt enfröig oöppnad. Blad fjädernerviga, strödda eller motsatta. Chenopodiáceæ.

476. A'triplex. Fruktfoder n. tvådeladt. Blad vanl. tandade. 477. Hálimus. Fruktfoder grundt tvåklufvet och hårdnande.

Blad helbräddade.

\section{Ordn. DIOECIA. Träd.}

Enkönade och samkönade klommor på (tre) olika stånd.

478. Fráxinus. Blommor utan kalk, stälda i vippa och utslående på bar qvist; frukt upptill vingad; blad motsatta och parbladiga; ståndare två; pistill en. Oleíneæ.

479. Acer. Blomkrona vanl. fembladig, fästad på en uppsväld skiflik ring (torus); blommor gula, n. samtidiga med bladen; frukt tvårummig (eller af två vingade karpeller); blad motsatta handnerviga; ståndare vanl. 8; stift två. Aceríneæ.

*) Hit kunde äfven räknas: 1) Syngenesia Polyclinia, 2) Calla, Poterium, Hippuris, Sanicula och Asparagus, 3) några gräs, neml. Holcus, Hordeum, Hierochloa, Phragmites och Avena elatior. 


\section{Klassen. CRYPTOGAMIA.}

\section{Ordn. ORMBUNKAR.}

Sporväxter med rot och vanl. bladlik stam (stamblad).

I. Egentliga Ormbunkar eller Bräkenarter. Sporgömmen fästade på baksidan af stambladen eller på ombildade delar deraf. Stamblad utgående från en rotstock.

A. Stamblad i början urfjäderlikt inrullade. Sporgömmen med ring, samlade i gyttringar (fruktplättar) på stambladens baksida. Rotstock utdragen. Polypodiáceæ.

a. Fruktbärande stamblad liknande de öfriga.

1. Fruktplättar runda utan svepefjäll.

480. Polypódium. Fruktplättar merändels åtskilda. Stamblad enkelt pardeladt eller flerajgånger sammansatt.

2. Fruktplättar rundade eller njurlika, åtm. i början med svepefjäll.

481. Aspídium. Fruktplättar rundade eller njurlika, åtskilda eller knappt sammanflytande. Svepefjäll qvarsittande, fästadt ofvanpå fruktplätten eller $\mathrm{i}$ dess kant.

482. Cystópteris. Fruktplättar rundade och åtskilda. Svepefjäll snart försvinnande och fästadt under fruktplätten. Stamblad dubbelt eller tredubbelt parbladigt. Spensliga växter. 483. Woódsia. Fruktplättar rundade, sammanflytande eller slutl. åtskilda. Svepefjäll slutl. härlikt deladt. Stamblad parbladigt. Spensliga växter.

3. Fruktplättar aflånga-jemnbreda med svepefjäll. 484. Asplénium. Svepefjäll fästadt vid fruktplättens yttre kant. Stamblad mer eller mindre sammansatt.

485. Scolopéndrium. Svepefjäll dubbelt. Stamblad enkelt och

n. helbräddadt med hjertlik bas, någon gång klufvet upptill.

4. Fruktplättar smala, sammanflytande i en rad nära bladkanten; svepefjäll otydligt.

486. Pteris. Stamblad 2-3 gånger parbladigt.

b. De fruktbärande stambladen olika de öfriga.

487. Struthiópteris. De fruktbärande stambladens småblad trinda. Stamblad parbladiga, de ofruktsamma strutlikt omgifvande de fruktbärande.

488. Blechnum. Alla stambladens fitkar platta. Stamblad pardelade.

489. Allosúrus. De fruktbärande stambladens småblad med nedvikna kanter, som betäcka sporgömmena. Stamblad låga och 3-dubbelt parbladiga. 
B. Stamblad i början urfjäderlikt inrullade. Sporgömmen utan ring och svepefjäll samt samlade på ett grenigt fruktfäste, bildadt af stambladets ombildade öfre del. Rotstock utdragen. Osmúndeæ.

490. Osmúnda. Stamblad dubbelt parbladigt. Busklik ormbunke.

C. Stamblad ej urfjäderlikt inrullade. Sporgömmen utan ring och svepefjäll; 1-2 stamblad icke fruktbärande, det ofvanför sittande ombildadt till ett enkelt eller grenigt fruktfäste (ax). Rotstock kort. Ophioglósseæ.

491. Ophioglossum. Sporgömmen förenade $i$ ett enkelt ax. De ofruktsamma stambladen hela (vanligen blott ett).

492. Botry'chium. Sporgömmen skilda pa ett grenigt fruktfäste $(a x)$. De ofruktsamma stainbladen delade.

II. Fräken-arter. Sporgömmen kranssittande under sköldlika fjäll och axlikt stälda i spetsen af den vid lederna slidbärande stammen. Equisetáceæ.

493. Equisétum. Sporer försedda med två klubblika och skrufvridna springtrådar. Stam ihålig med sträf yta.

III. Furgräs. Somliga sporgömmen med en stor spor, andra med sma sporer. Sporgömmena inneslutna i ett fruktgömme vid basen af ett blad. Stam krypande. Blad trådlika, i början inrullade. Marsileáceæ.

494. Pilulária. Fruktgömmen fyrrummiga.

IV. Braxengräs. Sporgömmen liksom hos föreg. slägte, men särskilda och inneslutna i bladens slidlika bas. Stam skiflik. Blad syllika. Isoëteæ. 495. Isoëtes. Blad fyrpipiga, i ett knippe.

V. Lummer-arter. Mosslika växter med talrika, tätt sittande och nästan barrlika blad. Lycopodiáceæ. 496. Lycopódium. Sporgömmen njurlika med små och talrika sporer. Blad barrlika och ofta styfva.

497. Selaginella. Sporgömmen af två slag, somlig̣a njurlika med små och talrika sporer, andra knöliga med 3-4 stora sporer. Blad mjuka, platta och hvassågade. 


\section{Beskrifning öfver arterna.}

\section{Klassen. MONANDRIA. \\ 1 Ordn. MONOGYNIA.}

\section{Salicórnia. Glasört.}

1. S. herbácea L.; hölstrets tlikar vid fruktmognaden vingade. 3,4 .

Lăggväxt och sällan $1 / 2$ fot lång med små gröna blommor och grön eller rödaktig, vanligen upprätt ștam.

Hafsstränder; Göt. spr.: Blek. - Ög. r. Gotl. t. r., Sv. Söd. r., Norrl. Vb. r.

- biennis (Afz.); tvåårig med högre stam, nedtill af fástare byggnad.

Göt. Boh. - Sk. Öl. r.

2. Hippúris. Hästsvans, Ledgräs.

1. H. vulgáris L.; blad jemnbreda, omkring 8-10 i hvarje krans. 2, 3.

Omkr. ${ }^{2} / 2$ fot hög, upprätt, nedsänkt under vattnet eller flytande; blommor små och gröna med röda ståndareknappar.

Bäckar, åar och träsk, mångenstädes: Gotl. r.

- maritima; blad lansettlika - aflånga, 4-6 i krans. Hafsstränder vid Östersjön: Ög. Söd. spr., Upl. - Hels. r. 3. Zostéra. Bandtång.

1. Z. marina L.; blad trubbiga 3-5-nerviga, lika breda som hölstret, hvars klaffar upptill äro tvärhuggna. 3.

Stjelk hoptryckt och flera fot lång; blad 1-2 fot långa och ett par linier breda; frö strimmigt.

I hafvet nära kusten: mångenst. vid v. kusten, eljest t. r. upp till Söd.

— angustifólia Hornem.; bladens sidonerver otydliga; hölstrets klaffar upptill rundade.

Mindre och med hälften så breda blad som hufvudformen. Göt. t. r.: Gotl. t. a. Ög. spr. Sk.?, Sv. Söd. t. r.

2. Z. minor Nolte; blad tvärhuggna eller urnupna, ennerviga, smalare än det spetsade hölstret. 3 .

Stjelk n. trådlik, knappt $1 / 2$ fot lång; blad 3-4 tum långa, $1 / 2$ linie breda; frö slätt.

I hafvet i grundt vatten; Göt. Boh. Hall. r. 


\section{Klassen. DIANDRIA.}

\section{Ordn. MONOGYNIA.}

\section{Lemna. Andmat.}

A. Hvarje stamblad undertill lefverbrunt, med ett knippe af rottrådar.

1. L. polyrhiza L.; stamblad n. runda och platta; frukt flerfröig, uppbristande. 3.

Större än de 2 följande arterna: liksom hos dessa uppflyter växten till vattenytan, ungefär samtidigt med svalornas ankomst på våren.

Åar och stillastående sött vatten; Göt. spr.: Sk. a. Boh. r. Dalsl. Gotl. 0, Sv. spr.: Verml. r. Dal. 0; helst i slättbygder.

B. Stamblad på båda sidor gröna, hvarje med en rottråd. 2. L. minor L.; stamblad n. runda och platta; frukt enfröig, oöppnad. 3 .

Stillastående sött vatten, allmän: Vb. r. Lpl. 0 .

3. L. gibba L.; stamblad $n$. runda, undertill svampaktigt uppsvälda; frukt flerfröig, uppbristande. 3.

Stillastående sött vatten, helst.. i slättbygder; Göt. Sk. a. Hall. spr. Boh. Smål. Öl. Gotl. r. Ög. spr., Sv. Söd. Upl. spr. Vestm. Ner. r.

4. L. trisulca L.; stamblad aflångt lansettlika, slutl. afsmalnande till skaft, platta och ennerviga; frukt enfröig, oöppnad. 3 . ytan.

Mera ljusgrön än föreg. arter, sällan simmande pả vatten-

Sjöar, åar och dammar, någon gång grunda hafsvikar; Göt. t. a.: Boh. Gotl. t. r. Dalsl. r., Sv. t. a.: Verml. 0, Norrl. Gestr. Hels. Ång. Vb. r., L L l. r.

\section{Circæa. Hexört.}

1. C. alpina L.; blad hjertlika groftandade; blommor med borstlika skärmar; frukt utdraget klubblik. 2, 3.

Omkr. 3--6 tum hög med ljusgröna, något genomskinliga blad; bladskaft hinnkantade och ofvan plattade; blomskaft glatta ; blomklasar ej stödda af blad; blomfoder hinnaktigt.

Skuggrika fuktiga ställen på berg i skogstrakter; Göt. mångenst.: Blek. Öl. r. Gotl. 0, Sv. Norrl. mångenst.: Vb. r., Lpl.r. 2. C. intermédia Ehrh.; blad hjertlika groftandade; blommor med borstlika skärmar; frukt kort och n. rund eller omvändt äggrund. 3.

Liknar föreg. art, men är omkr. fotshög nch har otydligt hinnkantade, ofvan rännformiga bladskaft, finludna blomskaft och grönt (bladartadt) blomfoder.

Fuktiga skogar, helst af bok; Göt. Sk. Hall. Smål. r.

3. C. lutetiána L.; blad vanl. äggrunda och föga tandade; blommor utan skärmar; frukt omvändt äggrund. 3 . 
1-2 fot hög och mörkgrön med ogenomskinliga blad; bladskaft utan hinnkanter och ofvan rännformiga; blomskaft finludna; blomklasar nedtill stödda af blad; foder grönaktigt, inuti rödaktigt.

Fuktiga lundar; Göt. Sk. spr. Hall. Boh. Vg. Blek. Öl.r.

\section{Sálvia.}

1. S. pratensis L.; blad hjertlikt aflånga naggade. 3.

1-2 fot hög med upptill klibbhårig stjelk, 2-4 tum långa blad samt tumslånga blommor.

Torra ställen nära bostäder, t. ex. på åkerrenar och $\mathrm{i}$ beteshagar, mycket r.; $S v$. Upl. nära Upsala samt vid några byar i Vendels s:n.

\section{Ly'copus. Kloört.}

1. L. europæus L.; blad lansettlika: de nedre parklufna, de öfre tandade. 2, 3 .

Vanligen fotshög, grenig och luden, med små hvita rödprickiga blommor.

Stränder och kärr; Göt. t. a.: Blek. spr. Gotl. t. r., Svv. t. a.: Vestm. Verml. spr. Dal. r., Norrl. Gestr. Hels. r.

\section{Pinguícula. Tätört, Tätgräs.}

1. P. vulgáris L.; blad aflånga; kronans Iäppar med aflånga och hela flikar; sporre n. jemntjock; blomskaft upptill glandelhåriga; blommor blå med ljusare svalg. $2,3$.

Med omkr. 1/2 fot långa blomskaft och n. fingerbreda blad. En varietet med smärre blommor och kortare sporre är funnen i fjellen i Lpl. och Jtl., en annan var. med större blommor i Medelp.

Fuktiga ängar mångenst., i nordligare trakter allm.

- bícolor; blomkrona violett med hvit underläpp.

Ipl. och Göt. Vg. r.

2. P. alpína L.; blad ovala; kronans läppar med rundade flikar; sporre kägellik, upptill n. lika bred som lång; blomskaft glatta; blommor hvita. 2, 3 .

Lika hög som föreg. art; kronans underläpp med stor och något urnupen mellanflik; kronsvalg med 1-2 gula eller rödaktiga fläckar.

Våta ställen; i fjellen i $L p l$. t. a.; Göt. Gotl. spr.

3. P. villósa L.; blad rundade - ovala; kronflikar vigglika, n. likformiga; sporre nållik bakutvänd; blomskaft hårigt; blommor blekvioletta gulstrimmiga. 3 .

Liten och späd med 1-3 tum högt blomskaft och mycket liten blomma.

På tufvor af hvitmossa (Sphagnum) i fjellen, helst ofvan björkregionen; Ipl. spr., Norrl. Jtl. Herj. spr., Sv. Dal. r.; i lägre fjelltrakter: Norrl. Vb. - Med. r. 
9. Utriculária. Blåsört, Vattenblüddra.

A. Blad flera gånger parbladigt delade med hårfina, allsidigt utstående flikar.

1. U. vulgáris L.; kronans öfre läpp lika li̊ng som gommen (underläppens uppsvälda bas); standareknappar förenade. 3.

Teml. grof med fotshög, upptill brunaktig blomstängel, blommor teml. stora och höggula med brandgula ränder, sporre kägellik utstående; blad blẫsbärande och borstbräddade.

Kärr, skogstjärn och mossar, h. o. d.

2. U. neglecta Lehm.; kronans öfverläpp 2-3 gånger längre än gommen; ståndareknappar fria. 3.

Liknar mycket föreg. art; sporre (enl. Hartman) tilltryckt. Ög. Smål.

På dylika ställen som föreg. art r.; Svi. Verml., Göt. Dalsl.

B. Blad 3-delade med upprepadt klynnedelade flikar.

a. Bladflikar platta, tvåsidigt stälda och borstbräddade; sporre utdragen.

3. U. intermédia Hayne; sporre syllik, tilltryckt intill underläppen; blåsor endast förekommande på bladlösa grenar. 3.

Spädare än de föreg. arterna, med smärre, ljusgula och rödstrimmiga blommor; stăndareknappar fria; sțängel grönaktig.

Kärr, mossar och bäckar spr.: Gotl. r. Öl. 0.

4. U. ochroléuca Rob. Hartm.; sporre kägellik och frånstående; blåsor förekommande såväl på bladen som på bladlösa grenar. 3 .

Liknar mycket föreg. art, men är spädare och har blekt smutsgula blommor och rödbrun stängel.

Kärr och bäckar r.; Göt. Blek. Smål. Ög., Sv. Upl. Ner. Verml., Norrl. Hels. Ang.

b. Bladflikar hårlika, allsidigt stälda och borstlösa; sporre mycket kort.

5. U. minor L; kronans öfverläpp lika lång som gommen; svalg n. öppet; underläpp oval med tillbakarullade kanter; blåsor sittande såväl på bladen som på bladlösa grenar. 3.

Ännu spädare än föreg. art; blommor blekgula med mörkare strimmor; foderblad n. äggrunda.

Kärr och mossar spr.: Ö]. 0 .

6. U. Brémii Heer; kronans underläpp n. cirkelrund och platt; foderblad rundadt njurlika med udd; eljest som föreg. art. 3.

Kärr, helst i lägre fjelltrakter, mycket r.; Norrl. Vb. ̊̊ng., Sv. Verml., Göt. Smål. 


\section{Verónica. Ärenpris.}

A. Blommor allsidigt och tätt sittande $\mathrm{i}$ ett långt och bladlöst ax $i$ stjelkens spets (stundom äfven $\mathrm{i}$ dylika ax $\mathrm{i}$ spetsen af grenarne). Kronpip mera lång än bred. 1. V. Iongifolia. 2. V. spicata.

B. Blommor tätt (slutl. n. tvåsidigt) sittande i korta, bladlösa och $\mathrm{i}$ början hufvudlika klasar eller ax $i$ spetsen af stjelken eller af grenarne. Kronpip mycket kort. 3. V. alpina. 4. V. saxatilis.

C. Blommor glest sittande $\mathrm{i}$ bladiga klasar eller ax $i$ spetsen af stjelken eller af grenarne. Kronuip mycket kort. 5. V. serpyllifolia. 6. V. arvensis. 7. V. verna. 8. V. triphyllos.

D. Blommor i bladlösa tvåsidiga klasar eller ax, hvars allmänna blomskaft utgå från bladvecken.

a. Klasar teml. täta axlika, och vanl. skiftevis stälda. Foderflikar kortare än fröhuset. 9. V. officinalis.

b. Klasar vanl. glesblommiga och motsatta. Foderflikar åtm. lika långa som fröbuset. 10. V. Chamædrys. 11. V. Beccabunga. 12. V. Anagallis.

c. Klasar glesblommiga och skiftevis stälda. Foderflikar kortare än fröhuset. 13. V. montana. 14. V. scutellata.

E. Blommor enstaka på långa och slutl. nedböjda skaft, utgående från bladvecken. Stjelk nedliggande. Blad skaftade, blott de nedersta motsatta. Frön på ena sidan urhålkade. a. Foderflikar trubbiga och otydligt nerviga. Blad fjädernerviga sågade. 15. V. agrestis. 16. V. opaca.

b. Foderflikar spetsiga, tydligt nerviga. Blad fjädernerviga sågade. 17. V. polita. 18. V. persica.

c. Foderflikar spetsiga. Blad handnerviga flikiga. 19, V. hederæfolia.

1. V. Iongifólia L.; blad vanligen 3-4 i krans (sällan motsatta), sågade med vanl. spetsiga tänder; foderflikar oliklånga spetsiga. 3 .

Med upprätt, omkr. 2 fot hög stjelk med lång rotstock; blad vanl. med bredare och hjertlik bas lansettlika och långspetsade; blommor blå.

Stränder, helst vid hafvet och större sjöar; $L p l$. på elfstränder a. i Torn. Lpm., Iul. Lpm. r., Norrl. Jtl. r. Vb. i n. delen vid elfvar t. a. Ang. r., vid hafvet i Vb. och Gestr. r., Sv. Upl. Söd. mångenst. vid hafvet, eljest r., Vestm. r. Ner. Verml. spr., Göt. r.: Dalsl. Ög. spr. Öl: Gotl. 0 .

2. V. spicáta L.; blad motsatta (sällan i krans), sågade eller naggade med vanl. trubbiga och korta tänder; foderflikar n. lika långa och trubbiga. 2,3 .

Med uppstigande, omkr. fotshög stjelk med lång rotstock; är till bladformen stundom svår att skilja från föreg. art, men har vanligen de nedre bladen bredare, aflånga och trubbiga; blommor blå.

Öppna fält och berg, helst i slättbygcler; Göt. mångenst. Öl. Gotl. Sk. a. Vg. Boh. r. Dalsl.?, Sv. Söd. Up]. Vestm. mångenst. Ner. r. 
3. V. alpina L.; stjelkar (grenar från rotstocken) enkla och n. upprätta, ofta enstaka; blad ovala, n. helbräddade. $2,3$.

3-6 tum hög och örtartad; fröhus dubbelt längre än stiftet; blommor mycket små, mörkblå och n. oskaftade. Svartnar vanl. vid torkning.

Något fuktig ängsmark i fjellen; $L p l$. t. a., Norrl. Jtl. Herị. t. a., Sv. Dal. r.

4. V. saxátilis L. fil.; halfbuske, nedliggande med talrika $n$. upprätta grenar; blad aflånga - tunglika, upptill finsågade. 3 .

Glatt och risaktig med vanl. fingerhöga grenar; stift af fröhusets längd; blommor (jemförelsevis) stora och blå eller rosenröda med utdragna skaft. Växtens öfre del rodnande.

Steniga soliga ställen i fjellen, helst i fjellregionen; $L p l$. spr., Norrl. Jtl. Herj. r.

5. V. serpyllifólia L.; blad äggrunda - ovala, fint naggade och glatta; blomskaft utdragna. 1, 2.

Omkring $1 / 2$ fot hög eller lägre, n. glatt; stjelk uppstigande : skärmblad aflånga; stift utdraget; foderflikar lika stora, aflånga och slutl. kortare än fröhuset; blommor små, hvita och blåstrimmiga,..i fjellen mörkare blå ; măngårị.

Oppna fält på något fuktiga ställen, allmän.

6. V. arvensis $\mathrm{L}$; blad äggrunda, glest tandade och ludna; blomskaft kortare än skärmbladen. 1, 2.

Ungefär lika stor som föreg. art, men luden; stjelk uppstigande eller upprätt, nedtill på 2 sidor hårig; skärmblad lansettlika; stift kort; foderflikar olika stora, lansettlika och längre än fröhuset; blommor mycket små och ljusblå; de öfre bladen hjertlika; rot enårig.

Vb. 0 .

Öppna fält och åkrar; Göt. Sv. t. a., Norrl. spr.: Ång. r.

7. V. verna L.; stjelkblad 3-fikiga eller parflikiga med stor ändflik, rotblad äggrunda sågade; alla bladen ludna; blomskaft kortare än skärmbladen. 1, 2.

Liten, spenslig och småluden; stjelk upprätt, rundtomkring hårig; stift teml. kort; blomkrona, skärmblad och foderflikar som hos föreg. art; de öfversta bladen smala; rot enårig.

Öppna torra fält och åkrar; Göt. Sv. t. a., Norrl. Gestr. Ång. spr. Vb. r.

8. V. triphyllos L.; mellersta stjelkbladen handlikt delade eller klufna, rotblad äggrunda sågade; hela växten glandelhårig; blomskaft längre än skärmbladen. 1, 2.

Något gröfre än föreg. art och oftare grenig, med mörkgröna blad; stjelk nedtill nedliggande; stift mera utdraget; skärmblad lansettlika; foderflikar n. lika stora, aflånga och trubbiga, af fröhusets längd; blommor små och mörkblå; de öfversta bladen ofta tunglika. Frön på ena sidan med en urhålkning. 
Sandiga åkrar och fält; Göt. Öl. a. Sk. Kalmarl. mångenst., inre Smål. Hall. Blek. Gotl. r. (Ög. tillfällig).

9. V. officinális L., Thé-veronica; stjelk krypande, småluden vanl. rundtomkring; blad omvändt äggrunda eller ovala - aflånga, kortskaftade, sågade och ludna. 2,3 .

Omkr. 1/2 fot lång och mörkgrön med små och n. violetta blommor; foderflikar hälften så långa som fröhuset. I Ångerm. i fjelltrakter är stjelken stundom tvåsidigt hårig och bladen $n$. glatta.

Torra ställen i skogar, vid vägar o. s. v., allm.: Lpl. Vb. och i fjellen $r$.

10. V. Chamædrys L.; stjelk uppstigande och på 2 sidor hårig; blad äggrunda, vanl. oskaftade, inskuret sågade, skrynkliga och håriga. 1, 2.

Omkr. $1 / 2$ fot hög med himmelsblå och strimmiga blommor, större än hos våra öfriga arter; foderflikar längre än det omvändt hjertlika, nedtill afsmalnande fröhuset.

Torra ställen i ängar, vid vägar o. s. v.; Göt. Sv. a., Norrl. a., men ej förek. i fjellen: $\mathrm{Vb}$. $\mathrm{r}$.

11. V. Beccabunga L., Bäckgröna; stjelk uppstigande och nedtill rotslående, glatt; blad ovala - aflanga trubbiga, skaftade, grundt naggsågade, glatta och köttiga. $1-3$.

Omkr. fotshög och mörkgrön med teml. små blå blommor; foderflikar af fröhusets längd; stjelk n. trind.

Källor, bäckar och diken, ymnigast i de södra och ö. landskapen, men mindre ofta i barrskogsbygderna; Göt. mångenst., Sv. spr.: Verml. Dal. r., Norrl. r.: Jtl. t. a. Vb. 0.

12. V. Anagallis L.; stjelk n. upprätt och glatt; blad ovala - lansettlika spetsiga, stjelkomfattande, n. helbräddade, glatta och föga köttiga. 1-3.

Liknar föreg. art, men är blekare grön och har ofta ljusröda eller hvitaktiga blommor; stjelk 4-kantig.

På dylika ställen som föreg. art; Göt. mångenst.: inre Smål. Blek. r. Boh. Dalsl. 0, Sv. Söd. Upl. Vestm. spr. Ner. t. r., Norrl. Gestr. Hels. r.

13. V. montána L.; stjelk uppstigande och nedtill rotslående samt rundtomkring mjukhårig; blad äggrunda - hjertlika, långskaftade och grofsågade, skrynkliga och mjukludna. 2.

Omkr. $1 / 2$ fot hög med teml. små blåhvita och rödådriga blommor; fröhus urnupet och nedtill inskuret; blomskaft n. upprätta.

Skogar, helst af bok, på skuggrika och något fuktiga ställen; Göt. Skăne h. o. d.

14. V. scutelláta L.; stjelk uppstigande och nedtill rot- 
slående; blad jemnbreda - lansettlika eller aflånga spetsiga, oskaftade och $\mathrm{n}$. helbräddade. 2, 3 .

Späd och slankig, ${ }^{1} / 2$ fot eller deröfver, vanl. glatt eller på torra ställen hårig, med teml. små hvita blommor med blå eller röda strimmor; blomskaft långa och utspärrade.

Fuktiga ställen, i eller vid vatten, a.: Vb. Lpl. r.

15. V. agrestis L.; blad äggrunda -- ovala; blomskaft af stödjebladens längd; foderflikar aflånga, på insidan

n. glatta. 1-4.

$0 \mathrm{mkr}$. 1/2 fot lång eller deröfver med rent gröna blad och ljusblå, hvitaktiga eller ljusröda, teml. små blomkronor; fröhus gleshårigt; ståndare fästade i kronpipens nedre kant; stift kort.

Ogräs och ruderatväxt; Göt. Sv. a., Norrl. t. a.: Ang. Vb.r. 16. V. opáca Fr.; blad bredt äggrunda; foderflikar upptill bredare, på insidan håriga; eljest som föreg. art. 1-4.

Liknar föreg. art, men är mörkgrön med rent blå blommor och tätt krushårigt fröhus; ståndare fästade i kronanns svalg.

Ogräs, särdeles i potatisåkrar; Göt. r.: Sk. a. Ög. spr. Dalsl. Boh.?, Sv. Ner. Upl. Söd. r.

17. V. polita Fr.; blad äggrunda - hjertlika; blomskaft slutl. något längre än stödjebladen; foderflikar äggrunda och n. glatta. 1-4.

Något mindre än de båda föreg. med smärre blad och blommor, vanl. n. alldeles glatt; blad något blågröna och vanl. glänsande; blomkrona mörkblå; fröhus omvändt njurlikt och finludet; ståndare fästade i kronpipens nedre kant; stift stundom öfverskjutande fröhuset.

Åkerogräs och ruderatväxt; Göt. Sk. a. Öl. spr. Gotl. t. r. Hall. Boh. Smål. Ög. r., Sv. Upl. r.

18. V. pérsica Poir.; blad hjertlika - aflånga; blomskaft flera gånger längre än stödjebladen; foderflikar äggrundt lansettlika och föga håriga. 1-4.

Umkr. fotslång och rent grön med stora himmelsblå blomkronor, längre än fodret; fröhus gleshårigt och nätådrigt, upptill hoptryckt, och dubbelt så bredt som långt med starkt utspärrade flikar; stift öfverskjutande fröhuset.

Ogräs, helst i trädgårdar; Göt. Sk. Herst.; eljest r. (tillfällig?) i Smål. Jtl. och Stockholmstrakten.

19. V. hederæfólia L.; blad njurlika eller rundadt hjertlika, skaftade och 3-5-flikiga med större ändflik; blomskaft vanl. längre än blomstödjebladen; foderflikar hjertlika. 1, 2.

I början liten, slutl. fotslång eller deröfver, med mörkgröna och något köttiga blad samt teml. små hvita eller ljusblå blommor; fröhus glatt.

Ogräs i åkrar; Göt. a.: inre Smål. Hall. Boh. Vg. r. Dalsl. 0, Sv. r.: Söd. och Stockholmstrakten mångenst. Dal. 0, Norrl. Gestr. r. 


\section{Ligustrum. Liguster.}

1. L. vulgáre L.; blad aflånga - lansettlika, kortskaftade och glatta. 3.

4-8 fot hög med motsatta grenar och slutl. svarta bär.

Steniga ställen i skärgården; Göt. Boh. h. o. d.

\section{Klassen. TRIANDRIA.}

\section{Ordn. MONOGYNIA.}

\section{Valeriána. Vendelrot.}

A. Alla blad (vanl.) parbladigt delade; stjelk upptill fårad; blommor rödletta och samkönade.

1. V. officinális L.; blad 5-10-pariga med lansettlika, glest sågade eller helbräddade småblad (flikar). 2, 3 .

Stjelk 2-6 fot hög och vanligen rödbrun, ofta utan rotskott; de nedre bladens ändflik vanl. mindre än de öfriga flikarne; blommor tätt gyttrade i 3-delade knippen i stjelkens topp: rotstock kort, tjock och starkt luktande. Frukt på båda sidor kullrig samt knappt mer än dubbelt så lång som bred.

Stränder och något fuktiga ängar, mångenst.: Dalsl. $\longrightarrow$ Lpl. trol. något $r$.

2. V. sambucifólia Mikan; blad 2-5-pariga. 2, 3.

Har vanligen bredare, mera grofsågade bladflikar, ändfliken större än de öfriga, mera grön stjelk och oftare rotskott; frukt längre och dubbelt större än hos föreg. art samt på ena sidan platt, på den andra kullrig. Funnen med hela blad på Lucernholmen vid Vestervik (D:r A. Lund). r. Öl.?

Mera fuktiga ställen, t. a. i skogsbygder, eljest spr.: Gotl.

B. Grenskottens blad hela, öfriga blad parklufna eller lyrformigt pardelade; stjelk ofårad; blommor hvita eller rödletta. Tråbyggare.

3. V. dioíca L.; grenskottens blad bredt eller omvändt äggrunda, ofta helbräddade. 2.

Stjelk $1 / 2-1$ fot hög; hanblommor större än honblommorna.

Fuktiga ängar . och betesmarker; Göt. Boh. Hall. spr. Sk. a. Blek. Kalmarl. r. Öl. spr.

13. Valerianella. Vårsallad.

1. V. olitória (Willd.) Poll.; fruktkrona otydlig; frukt på ryggen svampigt utsväld: de tomma rummen föga mindre än det fröbärande. 1, 2.

Omkring $1 / 2$ fot hög med utbredda grenar och täta qvastlika blomknippen; de nedre bladen aflångt spadlika och helbräddade, de öfre tunglika och nedtill ofta tandade; blomskärmar längre än frukten. Funnen med finhårig frukt på Gotl. samt i Sk. och Söd. 
Ruderatväxt och ogräs i grusiga åkrar, äfven på hafsstränder, sällan inuti landet; Göt. Boh. Hall. r. Sk. spr. Öl. Gotl. a. Blek. - Ög. spr., Sv. Söd. Upl. spr. Vestm. r.

2. V. Morisóni (Spreng.) Koch; fruktkrona tydlig; frukt ej utsväld: de tomma rummen mycket mindre än det fröbärande. 3 .

Något högre än föreg. art med smalare blad, de nedre aflånga, de öfre jemnbreda; blomskärmar kortare än frukten.

Åkrar; Göt. Öl. t. a. Gotl. flerst. Sk. Smål. Vg. r.

\section{Iris. Svärdstilja.}

1. I. Pseud-A'corus L., Gul Svärdslilja; blommor gula; stjelk upptill grenig. $2,3$.

2 fot hög eller deröfver, med tjock rotstock; de yttre kalkbladems skifvor äggrunda rödstrimmiga, de inre flikarne jemnbreda och kortare än märkena; blad vanl. tumsbreda. Förekommer på Gotl. med hälften smalare blad och smärre, ljusare blommor.

Stränder; Göt. Sv. t. a. åtm. vid sjöstränder, Norrl. Gestr. Hels. r. Vb.?

2. I. sibírica L., Blå Siberisk Svärdstilja; blommor blå; stjelk enkel. 2, 3.

Omkr. 11/2 fot hög med kort rotstock; de yttre kalkbladens skifvor omvändt äggrunda och blekblå med violetta strimmor, de inre flikarne lansettlika, violetta och längre än märkena; blad omkr. 4 linier breda.

Kärr, mycket r. och måhända förvildad; Göt. Vg. vid Slättås i Larf, Sk.?, Sv. Vestm. vid Fåsjöhyttan i Nora, Söd. vid Landsort?

\section{Schœnus. Knapp-ag.}

1. S. ferrugíneus L.; blomhufvud smalt af $2-3$ aflanga småax; det nedersta skärmbladet knappt så långt som blomhufvudet. 2,3 .

Strån 1/2 fot höga, hoptufvade och sega med korta blad, bruna slidor och glänsande skärmfjäll; kalkborst längre än frukten.

Kärr, helst pä kalkgrund; Göt. Gotl. Öl. t. a. Ög. mångenst. Sk. Hall. t. r. Smål. Vg. r., Sv. r.: Vestm. Dal. 0, Norrl. Herj. spr. Jtl. Hels. r. Vb.?

2. S. nígricans L.; blomhufvud bredt äggformigt af talrika (5-10) lansettlika småax; det nedersta skärmbladet långspetsadt, öfverskjutande blomhufvudet. 2,3 .

Strån omkr. en fot höga och hoptufvade med korta blad och svarta slidor och skärmfjäll; kalkborst mycket korta.

Kärr på silurisk formation; Göt. Gotl. mångenst. Öl. t. r.

\section{Cypérus. Cypergräs.}

1. C. fuscus L.; strå trekantigt. 3 .

2-6 tum hög och spenslig med knappt en linie breda blad och ett par linier långa småax med mycket långa skärmblad.

Uttorkade sjöstränder och kärr, mycket r.: Göt. Sk. Gotl. 


\section{Rhynchóspora. Myr-ag.}

1. R. alba (L.) Vahl, Hvit Myrag; småax hvita i jemnhöga knippen. 2, 3.

Strån löst hoptufvade och omkr. 1/2 fot höga med teml. korta och n. plattade blad; skärmblad ej öfverskjutande blomknippena; kalkborst $n$. kortare än frukten och med nedåt rigtade småhår; ståndare 2.

Kärr och torfmossar, n. alltid på granitformation, helst i skogsbygder; Göt. spr.: Gotl. Öl. r., Sv. mångenst., Norrl. mångenst.: Vll. a., Lpl. r.

2. R. fusca (L.) Röm. o. Sch., Brun Myrag; småax bruna i hufvudlik gyttring. 3 .

Liknar föreg. art, men har rotstock och grenskott, enstaka strån och borstlika blad; skärmblad långt öfverskjutande blomhufvudet; kalkborst dubbelt så långa som frukten och med uppåt rigtade småhår; ståndare 3 .

Kärr och torfmossar; Göt." spr.: Dalsl. Boh. Vg. Gotl. r. Öl. 0, Sv. r.: Söd. Upl. spr., Norrl. Gestr. Hels. Jtl. r., Lpl.?

18. Cládium. $A g$.

1. C. Mariscus (L.) R. Br.; blad kölade, upptill trekantiga. 3.

3-4 fot hög med 5-7 linier breda blad.

Sjöar och kärr; Göt. r.: Gotl. a. Öl. spr. ${ }_{2} H a l l$. Dalsl. 0.

19. Scirpus. Säf.

A. Ax sammansatt af tvåsidigt stälda småax. Strå smalbladigt. 1. S. compressus. 2. S. rufus.

B. Ax vanl. flera i knippe (eller hufvud) i stråets spets med närsittande och vanl. långa skärmblad (sällan ett för hvarje axgyttring).

a. Strå bladigt med platta och teml. breda blad. 3. S. silvaticus. 4. S. maritimus.

b. Strå nästan bladlöst. 5. S. lacustris. 6. S. carinatus. 7. S. setaceus.

c. Ax ensamma i spetsen af det greniga och bladiga stråts grenar. 8. S. fluitans.

D. Ax ensamt i det enkla stråets spets. Strå bladlöst (eller blott den öfversta slidan med ämne till bladskifva).

a. De två nedersta skärmfjällen längre än de öfriga. Stift trådlikt, helt och hållet affallande. Märken tre. 9. S. cæspitosus. 10. S. pauciflorus.

b. Det nedersta skärmfjället icke längre än de öfriga. Stiftets nedre del uppsväld och qvarsittande. Märken två eller tre. 11. S. palustris. 12. S. multicaulis. 13. S. acicularis.

1. S. compressus (Pers.) Panz.; småax 6-8-blommiga; kalkborst med nedåt rigtade småhår. $2,3$.

Omkr. ${ }^{1} / 2$ fot hög med n. platta, kölade och ljusgröna blad; strå n. 3-kantigt; ax ljusbrunt. Liknar Carex disticha. 
Fukt. ängar, helst i slättbygder; Göt. spr: Gotl. Öl. Sk. t. a. Blek. inre Smål. Boh. Vg. t. r. Dalsl. 0, Sv. spr.: Ner. Dal. t. r. Verml. 0, Norrt. Gestr. r.

2. S. rufus (Schrad.) Link; småax 2-5-blommiga; kalkborst hårlika eller felslående. 3 .

Lägre än föreg. art med n. trinda blad, trindt strå och rödbrunt ax.

Hafsstränder; Göt. r:] Sk. Blek. Smål. Öl. spr. Gotl. t. r., Sv. r.

3. S. silváticus L., Skogssäf; småax stälda i ett mycket utbredt och mer än dubbelt sammansatt knippe; skärmfjäll hela och med kort udd. 2, 3 .

Omkr. 2 fot hög med enstaka, upprätta och trubbigt trekantiga strån; blad breda, kölade och ljusgröna; småax små, brunaktiga eller grönaktiga, äggrunda; axgyttringar vanl. runda, med eller utan skaft.

Stränder och kärr, helst i skogstrakter; Göt. Sv. t. a.: Öl. Gotl. 0, Dal. r., Norrl. Gestr. spr. Hels. Ang.r. Vb. spr., Lpl. r. 4. S. maritimus L., Hafssäf; småax tätt gyttrade i ett (stundom flera) föga utbredt knippe; skärmfjäll i spetsen urnupna och med lång udd af den utlöpande medelnerven. 3 .

Omkr. 2 fot hög med tufvade, upprätta och hvasst trekantiga strån; blad teml. breda och kölade; småax stora, aflånga och bruna; axgyttringar vanl. oskaftade.

Hafsstränder; Göt. Sv. t. a., Norrl. Gestr. Med. r. Hels.?

5. S. lacustris L., Kolvass, Insjösäf; strå trindt; skärmfjäll utan veck och i spetsen urnupna, med kort udd; märken 3; rotstock krypande. 3.

Omkr. 4 fot hög med sörkgröna strån, nedtill omgifna af slidor, som stundom hafva ett kort ämne till bladskifva; ax brunaktiga och äggformiga, mindre än hos föreg. art; knippets grenar utdragna; frukter gula.

Stränder af åar och insjöar, allmän.

* S. Tabernæmontáni Gmel.; strå blågrönt; skärmfjäll sträfprickiga; märken vanl. 2; axgyttringar af mörkare färg; skärmblad teml. korta; knippets grenar korta.

Göt. t. a. vid hafvet, t. r. vid Vettern i Ög. och Vg., Sv. t. a. vid hafvet, Vestm. r., Norrl. Gestr. Hels. vid hafvet r.

6. S. carinátus Sm.; strå nedtill trindt, upptill trubbkantigt; skärmfjäll utan veck samt urnupna med kort udd; märken 2; rotstock krypande. 3.

Liknar föreg. art, men är lägre och har oftare utbildade bladskifvor på de nedre slidorna; strån ljusgröna; ax gulaktiga och n. äggformiga; knippets grenar mer eller mindre utdragna: frukter bruna.

Hafsstränder; Göt. Gotl. mycket r. 
7. S. setáceus L.; skärmfjäll veckade på längden (i torrt tillstand) och flernerviga, trubbiga med kort udd; rot tågig. 3.

1-4 tum hög med borstlika tufvade strån, hvars slidor stundom hafva ett litet ämne till bladskifva; småax $2-3$ oskaftade och tätt gyttrade, äggformiga, bruna och mycket små; frukt strimmig; ståndare 1-2.

Sandiga sjöstränder; Göt. Hall. Sk. mångenst. Blek. Smål. Vg. r. Boh. t. r. Ög.?

8. S. fuúitans L.; skärmfjäll hela och $\mathrm{n}$. utan udd. 2,3. Strå flytande eller nedliggande och nedtill rotslående; blad trådsmala; ax grönaktiga; kalkborst saknas.

I åar och sjöar; Göt. Smål. t. r. Hall. r., Sv. Verml. r.

9. S. cæspitósus L.; det nedersta skärmfjället utlöpande

$\mathrm{i}$ en lång udd och längre än axet; kalkborst längre än frukten; den öfversta stråslidan med bladämne; ax aflångt. 3.

Strån vanl. 1/2 fot höga, sega, trinda och strimmiga, tätt hoptufvade och nedtill försedda med gulaktiga glänsande fjäll; ax rödbrunt. Liknar Eriophorum alpinum, men axet saknar ull. Torfmossar och myrar; Lpl. a., Norrl. a.: Hels. spr. Gestr. r., Sv. r.: .Verml. Ner. Vestm. spr., Göt. r.: Vg. Dalsl. -- Sk. Smål. spr. Öl. 0.

10. S. pauciflórus Lightf.; det nedersta skärmfjället längre än halfva axet och utan udd; kalkborst något kortare än frukten; ax äggformigt. 3 .

Strån knappt $1 / 2$ fot höga, trinda, strimmiga och hoptufvade; de nedersta slidorsa rödbruna; skärmfjäll mörkbruna med bred hvit hinnkant.

Kärr och stränder; Göt. mångenst., Sv. t. r.: Söd. Upl. mångenst., Norrl. r.: Hels. Med.?

11. S. palustris L.; ax aflangt-lansettlikt; det nedersta skärmfjället bredare än de öfriga och halft omfattande strået; rotstock utdragen; märken två. $2,3$.

Strån trinda och omkr. fotshöga, sällan högre, med ljust rödbruna slidor, ljusbruna ax och gula frukter.

Stränder och kärr, allmän: Lpl. r.?

* S. uniglúmis Link; ax äggformigt-aflångt; det nedersta skärmfjället bredare än de öfriga och helt omfattande strået; rotstock mycket lång. $2,3$.

Liknar mycket hufvudarten, men har vanl. lägre och finare strå, mera krypande rotstock, mera lifligt färgade och rödbruna slidor, kortare, tjockare och mörkare ax med spetșiga skärmfjäll.

Våta ställen, helst stränder, i synnerhet vid Östersjön, h. o. d.: i de vestra landskapen trol. mindre vanlig.

12. S. multicáulis Fr.; ax aflångt; det nedersta skärmfjället bredt och helt omfattande strået; rot tågig med föga utbildad rotstock; märken vanl. tre. $2,3$. 
Liknar föreg. art, men är tättetufvad med finare, talrikare, på torrare ställen bảgböjda strån samt bredare skärmfjäll och mörkbruna frukter.

Sjöstränder r.; Göt. Boh. - Sk. Blek. Smål., Sv. Upl.

13. S. aciculáris L., Nålsäf; ax äggformigt-lansettlikt; nedersta skärmfjället bredare, helt omfattande strået; rot tågig; märken tre. $2,3$.

Strån nålfina, fyrkantiga och strimmiga, tufvade och ofta blott tumshöga med mycket sma brunaktiga ax; skärmfjäll n. utan hinnkant; frukt med fina åsar; stråslida ensam och blek.

Stränder af sjöar och åar, trol. allm.: Vb. r. Gotl. 0.

20. Erióphorum. Ängull, Mad-dun.

A. Ax flera i stråets spets (sällan ett enda genom felslagning), stödda af bladlika skärmar; stråens slidor bladbärande.

1. E. angustifólium Roth; ax stora och mycket ulliga med glatta skaft. 1.

Strån omkr. fotshöga och n. trinda; blad mörkgröna, rännformiga och vanl. längre än stråets afdelningar (mellan bladen); skärmfjäll och nötter spetsiga; rotstock lång med grenskott.

Kärrängar, allmän: Got1. spr.

2. E. latifólium Hoppe; ax stora och mycket ulliga med sträfva skaft. 2.

Liknar föreg. art. Strån trubbigt trekantiga; blad bredare, platta och ljusgröna, vanl. kortare än stråets afdelningar; ax något mindre och med ej så yfvig ull; skärmfjäll teml. spetsiga; nötter trubbiga; rotstock kort utan grenskott.

Kärrängar; Göt. spr.: Gotl. a. Blek. Boh. Dalsl. t. r., Sv. spr.: Vestm. t. r. Verml. Dal. r., Norrl. Gestr. - Med. spr. Ang. Herj. Jtl. r.

3. E. grácile Koch; ax små med sparsam ull och med af ludd sträfva skaft. 2.

Strån spensliga och trubbkantiga; blad mycket korta, n. trådsmala och trekantiga; skärmfjäll och nötter trubbiga; axskaft vanl. upprätta; rotstock lång, stundom med grenskott.

Myrar; ..Lpl. spr., Norrl. t. r.: Vb. spr., Sv. t. r., Göt. t. r.: Dalsl. Öl. 0.

B. Ax ensamt i stråets spets utan skärmblad och helt och hållet ulligt; stråslidor bladlösa eller med ett kort bladämne.

4. E. vaginátum L.; strån flera tillsammans hoptufvade; bladknippenas slidor upplösande sig i fina trådar; ax (i början) äggrundt-aflångt; skärmfjäll $\mathrm{n}$. lika stora (eller inåt jemnt aftagande $\mathrm{i}$ storlek) och något genomskinliga; ull hvit; ståndareknappar jemnbreda och n. lika långa som strängarne. 1. 
Strån i början omkr. $1 / 2$ fot, slutl. ända till $\mathbf{1}^{1} / 2$ fot höga, bildande täta och hårda tufvor med talrika knippen af inemot trådsmala, upprätta och vanl. i kanten något sträfva blad; rot tågig med teml. hårda och tjocka tågor; skärmfjäll vanl. syl. spetsade.

Kärr och myrar, allmän: Öl. Gotl. t. r.

5. E. Cállithrix Cham.; strån flera tillsammans hoptufvade; bladknippenas slidor upplösande sig i fina trådar; ax kort och n. klotrundt; skärmfjäll n. lika stora och ogenomskintiga; ull hvitaktig eller rodnande; ståndareknappar jemnbreda och betydligt (omkr. 6 gånger) kortare än strängarne. 1.

Strån ofta högre än hos föreg. art och mera spensliga, föga tufvade; blad glatta; rottågor något finare; skärmfjäll trubbiga.

Euktiga ängar nära myrar i fjellen och i lägre fjelltrakter: Lpl. flerst., Norrl. Jtl. Herj. mångenst. Vb. Ång. r.

6. E. russéolum Fr.; strån enstaka med rotskott och n. hårfina rottågor; bladslidor hela; ax aflångt; skärmfjäll n. lika stora och något genomskinliga; ull rödaktig eller brandgul; ståndareknappar jemnbreda, betydligt kortare än strängarne. 1 .

Ofta lika hög som $E$. vaginatum; blad glatta och mjuka de yttre skärmfjällen trubbiga.

Myrar i fjellen r.; Lpl., Norrl. Vb.

7. E. capitátum Host; ax n. klotrundt; skärmfjäll ogenomskinliga, de yttre mycket bredare; ull hvit eller något rodnande; ståndareknappar aflånga; eljest som föreg. art. 1.

Vanl. mycket lägre än närstående arter och med smärre ax.

Kärr i fjellen, stundom i lägre fjelltrakter; Lpl. a., Norrl. Jtl. Herj. spr. Vb. t. r. Ång. Hels. r., Sv. Dal. Verml. r.

C. Ax ensamt i stråets spets med ull endast i spetsen och med skärmblad.

8. E. alpínum L.; ax aflångt; strån treeggade och sträfva.2. Strån omkr. $1 / 2$ fot höga eller lägre, hoptufvade och trådsmala, upptill med mycket korta och trădlika bladämnen och gråaktiga fjäll nedtill; rotstock lång; ax mycket små och brunaktiga, nästan som hos Scirpus pauciflorus.

Kärr, helst i skogsbygder; Lpl. Norrl. a., Sv. t. a., Göt t. r.: Dalsl. Vg. Ög. Sk. spr. Boh. 0.

\section{Ordn. DIGYNIA.}

21. Tríticum. Hete.

A. Nerverna på bladens öfre sida beklädda med en rad af längre borst (hår) samt smala och icke (utom hos T. pungens) upphöjda. Blad vanl. breda och 
platta. Småax ej lossnande från fästet. Kronborst sällan felslående. Foderskal utdraget spetsiga.

a. Rotstock krypande. Kronborst rakt. Småax vanligen tätt sittande.

1. T. repens L., Qvickrot; foderskal bredt hinnkantade; axfäste sträft. 2-4.

Vanl. mörkgrön med styfva, $2-4$ fot höga och sällan tufvade strån, slaka och undertill ej sträfva blad. På hafsstränder är växten stundom blågrön med slutl. hoprullade blad.

Allmänt ogräs och ruderatväxt, äfven på hafsstränder.

- biflórum; småax 2-3-blommiga och violetta; foderskal föga kortare än kronskalen.

Liknar Tritic. violaceum.

Fjelltrakter r.; Norrl. Vb. (Rektor L. Forelius).

2. T. pungens Pers.; foderskal smalt hinnkantade; axfäste glatt. 3.

Lärer mest likna Trit. obtusiusculum. Grågrön, slutl. gulnande; strån styfva, höga och tufvade; blad med stickande spets.

Hafsstränder, mycket r.; Göt. Hall. Boh. i Göteborgstrakten.

b. Rot tågig. Kronborst ofta böjdt. Småax teml. tätt sittande.

3. T. canínum (L.) Schreb., Lundhvete; utan grenskott; ax slakt och lutande; småax $n$. trinda; nedre kronskalet med långt och böjdt borst. 3 .

Strån spensligare, omkr. 2 fot höga och hoptufvade; blad ljusgröna och på båda sidor sträfva; smăax gröna.

Skuggrika lundar med myllrik jordmån; Göt. mångenst.: Öl. Giotl. Sk. a., Sv. t. r.: Söd. Upl. t. a., Norrl. r.: Ång. Vb. spr., Lpl. spr. till björkregionen.

4. T. violáceum Hornem., Fjellhvete; rot med korta bladtofsar; ax styft upprätt eller uppstigande; nedre kronskalet med rakt och teml. kort borst. 3 .

Vanl. lägre än föreg. art med kortare, 1-3 tum långt ax; blad mörkgröna, ofvanpå sträfva; småax violetta.

Lundar och ängsbackar i fjellens björkregion r.; Lpl., Norrl. Vb. Jtl. Herj.

B. Nerverna på bladens öfre sida breda, upphöjda och beklädda med flera rader af fina hår (synliga genom förstoringsglas). Blad vanl. smala, snart inrullade. Småax vanl. glest sittande och ofta lätt lossnande. Kronborst föga utbildadt. Foderskal trubbiga eller teml. kort spetsiga. Rotstock krypande. 5. T. júnceum L.; småax glest sittande; foderskal trubbiga; kronskal trubbiga och glatta; axfäste glatt. 3 . Blekt blågrå med snart hvitgula och lätt lossnande småax; 
strån enstaka, omkr. fotshöga, upptill stundom lutande; blad styfva, ofvanpå mjukhåriga, ej sträfva; kronborst omärkligt.

Hafsstränder; Göt. Boh. Hall. r. Sk. flerst. Öl. Gotl. r.

6. T. strictum Deth.; småax glest sittande; foderskal spetsiga; nedre kronskalet trubbigt och nedtill finludet; axfäste sträft. 3 .

Står nära föreg. art, men småaxen lossna ej alldeles så lätt; stråen äro styfva och stundom dubhelt så höga, foderskalen tydligare kölade.

Hafsstränder r.; Göt. Sk. Gotl.

7. T. obtusiúsculum Lange; småax tätt sittande; foderoch kronskal trubbiga. 3.

Grågrön med styfva, 1-4 fot höga strån; småax ej synnerligen lätt lossnande; blad styfva och ofvanpå sträfva.

Sandiga hafsstränder; Göt. Boh. Hall. r. Sk. flerst. Blek. Gotl. r.

8. T. acútum D. C.; småax glest sittande; foder-och kronskal spetsiga. 3 .

Ljust blågrön med slaka, 2-4 fot höga och vanl. tufvade strån; småax med svårighet lossnande; blad slaka, något breda och ofvanpå sträfva.

Sandiga hafsstränder; Göt. Boh. Hall. r. Sk. flerst. Gutl. Blek. Små?. r.

\section{Lólium. Repe.}

a. Rotstock krypande, med grenskott.

1. L. perenne L., Rajgräs; småax vanl. mycket längre än foderskalet; kronskal utan borst. 2,3 .

Strån omkr. fotshöga, släta, nedtill knäböjda och tufvade; småax alltid tilltryckta till, fästet och mera hoptryckta än hos följ. arter.

Torra ställen, t. ex. åkerrenar, isynnerhet på kalkgrund; Göt. a.: Boh. spr. Dalsl.?, Sv." spr.: Verml. Dal. r., Norrl. Gestr. Ang. Vb. r., Lpi. r. (förvildad?).

b. Rot enårig och tågig utan grenskott.

2. L. linícola Sond., Linrepe; småax ungefär lika långa som foderskalet eller något längre; kronskal utan eller med mycket kort borst. 3 .

Strån 2 fot höga, sträfva, spensliga och upprätta, vanl. enstaka; småax vid mognaden något trinda och då först tilltryckta.

Åkrar, helst bland lin; Göt. spr.: Sk. a. Gotl. Öl. Dalsl. r., Sv. spr.: Dal.?, Norrl. Gestr. - Med. spr. Ang. a. Vb. Jtl. r. 3. L. temulentum L., Dårrepe, Svimmel; småax ungefär lika långa som foderskalet eller kortare; kronskal med vanl. långt borst. 3 .

Strån 3-4 fot höga och styfva och upprätta, vanl. enstaka och upptill sträfva; småax föga hoptryckta, aflånga och alltid tilltryckta. Anses vara giftig. 
Åkrar, isynnerhet bland vårsäd; Göt. spr.: Sk. Öl. t. a., $S v$. spr.: Vestm. Dal. r., Norrl. Gestr. Hels. Herj. Jtl. r.

\section{Leptúrus. Ormax.}

1. L. filiformis Trin.; foderskal ej öfverskjutande kronskalen. 2.

Strån 3-8 tum långa och $n$. trådlika; blad mjuka, slutl. inrullade; rot tågig och enårig.

Hafsstränder; Göt. Skåne v. delen r.

\section{Hórdeum. Korn.}

1. H. murínum L., Slökorn; blad mjuka med sträfva kanter och glatta slidor; foderskal olikformiga: vid de samkönade (i midten sittande) småaxen jemnbredt lansettlika och håriga, vid de öfriga (hanaxen) är nedre foderskalet borstlikt. 2, 3 .

Strån omkr. fotshöga, tufvade och ända upptill bladiga; blad teml. breda; rot tågig och enårig.

Ruderat- och hafsstrandväxt; Göt. Sk. spr. Hall. Boh. Små]. Gotl. r. (Sv. Söd. Upl. r. och tillfällig).

2. H. secálinum Schreb.; blad på båda sidor sträfva; nedre bladslidorna ludna; alla foderskal borstlika. 3.

Högre och spensligare än föreg. med n. trådlikt strå, hvars öfversta ledstycke är långt utdraget; småax smärre; blad smalare; rot tvåårig.

Något fuktiga ängar; Göt. Sk. t. a. i s. v. delen samt på ett ställe i mellersta.

\section{E'lymus.}

1. E. arenárius L., Strandråg; de lansettlika långspetsade foderskalen och det nedre $n$. trubbiga kronskalet utan borst. 3,4 .

Strån n. enstaka, blåaktiga, 3-5 fot höga och grofva, upprätta och sträfva; rotstock lång; blad teml. breda och slutl. inrullade, styfva och i spetsen n. stickande.

Stränder; vid hafvet på v. kusten a., på ö. kusten spr. till Upl. samt på Öl., men Gotl. och Gestr.-Vb. r.; inuti landet vid Vettern i Ög. Smål. och Vg., vid Lagan i Smål. samt vid Vindelelf i Ume Lpm.

- geniculátus; ax nära fotslångt; foderskal mycket smala och $1 / 3$ längre än småaxet.

Göt. Gotl. r. (Hall. tillfällig).

2. E. europæus L.; foderskal jemnbredt syllika och borstbärande; nedre kronskalet med långt borst. 3 .

Ljusgrön med något tufvade, omkr. 2 fot höga och spensliga, upprätta och sträfva strån; rot tågig eller med kort rotstock; blad platta, sträfva och ofta något ludna på öfre sidan samt med ludna slidor. Liknar en Hordeum och har stundom den ena blomman i hvarje småax felslående.

Skogsängar, mycket r.; Göt. Gotl. Öl. Kalmarl. Sk. 


\section{Brachypódium. Axlosta.}

1. B. pinnátum (L.) P. B.; ax upprätt, sammansatt af tätt sittande och mangblommiga småax; yttre kronskal med kort borst; rotstock krypande. 2, 3.

Strån 1-2 fot höga och hopknippade; blad ljusgröna, n. styfva och korthåriga.

Torra magra ängar och backar; Göt. Gotl. a. Öl. spr. Sk. Smål. t. r. Vg. spr.? Dalsl. spr. på slätten, Ög. på silur. form. spr. eljest r., Sv. Verml. Vestm. Söd. r. Upl. spr.

2. B. silváticum R. o. Sch.; ax upptill slakt, med glesa fåblommiga småax; de öfre blommornas yttre kronskal med borst längre än skalet; rot tågig. 2,3 .

Strån 2-3 fot höga och hopknippade; blad mörkgröna, mjuka och håriga; kronborst pensellikt förenade.

Lundar, helst i skärgårrden, inuti landet vid Venern, Vettern och Mälaren; Göt. Gotl. Öl. t. a. Ög. r. Smål. t. r. Sk. spr. Hall. Boh. Vg. r., Sv. Upl. r.

\section{Cynosúrus. Kam-äxing .}

1. C. cristátus L.; ax tätblommigt; bladsnärp kort. 2,3. Strån hopknippade, 1-2 fot höga och fina med smala blad och tågig rot; ax vanl. grönt och fingerlångt.

Torra ängar; Göt. t. a. åtm. i slätthygderna; $S v$. Söd. Upl. Ner. spr. Verml. r., Norrl. Med. Ång. r.

\section{Dáctylis. Hund-äxing.}

1. D. glomeráta L.; rotblad vid blomningen bortvissnande. 2,3 .

Strån omkr. 2-3 fot höga; blad vanl. sträfva, mindre ofta glatta; småax gröna eller violetta.

Torra ängar och åkrar; Göt. a.: Boh. Dalsl. spr., Sv. a.: Verml. Dal. spr., Norrl. r.: Jtl. spr.

29. Festúca. Svingel.

A. Alla blad platta; bladsnärp helt.

a. Kronborst längre än nedre kronskalet; bladsnärp kort och tvärhugget.

1. F. gigantéa (L.) Vill.; vippa yfvig och lutande; småax aflånga; rot tågig. 3 .

Strån $2-t$ fot höga med breda, ljusgröna och af ljusare nerver strimmiga blad.

Skuggrika och fukt. lundar, helst på kalkberg; Göt.r.: Gotl. Öl. Sk. Hall. spr., Sv. r.: Verml. Dal. 0 .

b. Kronskal utan borst; bladsnärp aflångt och utdraget.

2. F. silvática Vill.; vippa i början yfvig och upprätt, sedan hopdragen och lutande; småax ovala; rotstock laing och krypande. 3 .

Strån 2-4 fot höga, nedtill med bladlösa slidor; blad breda, 
ofvan blågröna, undertill ljusgröna, le vid roten sittande hopknippade; småax mycket små.

Berg, helst vid hafvet och större sjöar, men hlott på några få ställen; Göt. Vg. Boh. Sk. Blek. Ög., Sv. Ner., Norrl. Hels.(?).

c. Nedre kronskalet med kort eller intet borst; bladsnärp kort och tvärhugget.

3. F. pratensis Huds., Ängsvingel; vippa före och efter blomningen hopdragen och ensidig; nedre kronskalet med mycket kort spets samt intet eller mycket kort borst; småax jemnbreda; rotstock kort. 2, 3 .

Strån 2-4 fot höga med smal och föga lutande vippa; småax vanl. mångblommiga.

Feta ängar, allmän: Jtl. Lpl. r.

4. F. arundinácea Schreb., Strandsvingel; vippa före blomningen yfvigt utbredd; nedre kronskalet med $n$. utdragen spets och kort borst; småax aflånga; rotstock lång och skottalstrande. 3 .

Liknar föreg. art, men är högre, med lutande vippa och fåb]ommiga småax.

Hafsstränder; Göt. Sv. spr., Norrl. Gestr. Med. r.

B. Rotblad hoprullade, hoptryckta eller borstlika; bladsnärp vanl. tvåöradt. Nedre kronskalet med utdragen spets och tydligt borst.

a. Nedre kronskalet kortare än sitt borst.

5. F. sciuróides Roth; rot tågig och enårig; blad borstlika; ståndare vanl. en enda. 2, 3.

Strån omkr. ${ }^{1 / 2}$ fot höga, n. trådlika och löst tufvade; det öfversta ledstycket långt och bart; bladsnärp kort och tvärhugget; småax små, aflånga och gröna, slutl. gulnande; vippa $\mathrm{n}$. enkel; öfre foderskalet och nedre kronskalet ungefär dubbelt så långa som nedre foderskalet. Liknar något Festuca ovina.

Torra sandiga backar, mycket r.; Göt. Sk. Blek.

b. Nedre kronskalet längre än sitt borst.

6. F. rubra L.; rotstock krypande och skottalstrande; stråblad platta; rotblad hoprullade. 2, 3 .

Strån 1-2 fot höga och vanl. löst tufvade, strimmiga och trinda; småax vanligen violetta och aflånga eller ovala; nedre kronskalet tydligt nervigt.

Torra ängar och backar, allmän, äfven i fjellen.

- dumetórum; strån tätt hoptufvade.

Hafsstränder; Göt. t. r.: Öl.?, Norrl. Gestr. Hels. Ång. t. r.

7. F. duriúscula L.; rot tågig; alla blad kölade och hoptryckta. 2, 3.

En mellanform mellan föreg. och följ. art. Strån löst tufvade, strimmiga och trinda; småax vanl. gröna och ovala; nedre kronskalet otydligt nervigt. 
Torra ängar h. o. d"; Göt. spr.: Dalsl. Boh. t. r., $S v$. spr.: Vestm. Verml. Dal. t. r. Ner.?, Norrl. Hels. r., Lpl. r.

8. F. ovina L., Fårsvingel; rot tågig; alla blad borstlika, icke kölade. 2, 3.

Strån vanligen lägre och finare än hos föreg. art, tätt hoptufvade och upptill kantiga; småax vanl. gröna och aflånga; nedre kronskalet otydligt nervigt. I fjellen äro axen stundom försedda med groddknoppar.

Torra sandiga backar, allmän.

30. Schedonórus. Svingel-losta.

A. Nedre kronskalet med utdraget borst.

a. Alla blad breda och platta; vippa lutande.

1. S. tectórum (L.) Fr., Taklosta; kronborst något längre än sitt kronskal; vippa ensidig, nedre vippgrenarne omkr. 5 tillsammans. 2 .

Omkr. fotshög och spenslig med på båda sidor mjukludna blad med mjukludna slidor; småaxen (med kronborsten) omkr. en tum långa; foderskal ${ }^{6}$ med bred hinnkant; rot enårig. På Gotl. (vid Slite) förekommer en alldeles glatt form af denna art.

Ruderatväxt på torra backar, torftak och murar; Göt. Sv. t. r.: Gotl. Öl. t. a. Blek. - Upl. spr. Dal.?

2. S. stérilis (L.) Fr., Väglosta; kronborst längre än sitt kronskal; vippa allsidig; nedre vippgrenarne vanl. parvis stälda. $2-4$.

Liknar föreg. art, men är något högre med mindre rikblommig vippa och längre vippgrenar; småaxen (jemte kronborsten) ofta två tum långa; blad finhåriga och i kanten sträfva, de nedre slidorna stundom mjukludna; foderskal med smal hinnkant; strån glatta; enårig.

Ruderatväxt: Göt. Gotl. r. Hall. Sk. t. r. (Ög. tillfällig).

3. S. asper (Murr.) Fr., Lundlosta; kronborst kortare än sitt kronskal; vippa ensidig; nedre vippgrenarne vanl. parvis stälda. 2,3 .

2-3 fot hög med (särdeles ofvanpå) sträfhåriga blad; de öfre bladslidorna glatta, de nedre håriga; foderskal n. utan hinnkant, det öfre $\mathrm{i}$ kanten hårigt; nedre kronskalet ända till spetsen starkt hårigt; flerårig.

Lundar, helst nära hafvet samt vid större sjöar; Göt. Vg. Boh. r. Sk. spr. Gotl. t. r. Öl. spr. Smål. Ög. r., Sv. Söd. Upl.r. * S. serótinus Benek; alla bladslidor håriga, nedre kronskalet blott nedtill hårigt, öfre foderskalet glatt. 3 . Synes vara föga skild, men har något större småax och blommar senare.

Göt. Sk. Gotl. Öl. Ög. r.:

b. Alla blad smala, föga bredare än strået; de nedre hopvikna, de öfre platta; vippa upprätt.

4. S. erectus (Huds.) Fr.; kronborst hälften kortare än sitt kronskal; nedre vippgrenar vanl. parvis stälda. 2,3. 
Omkr. 2 fot hög med sträfva hårbräddade blad; de nedre bladens slidor ludna, de öfres glatta; vippa smal och hopdragen med ofta färgade småax, stundom något slak.

Torra ängar och åkerrenar, helst vid hafvet eller vid Mälaren, r.; Göt. Boh. Gotl. Ög., Sv. Söd. Upl. Vestm.

B. Kronborst otydligt eller intet. Blad breda. Vippa upprätt.

5. S. inermis (L.) R. S., Borstlös Losta; nedre vippgrenarne $3-5$ i krans. 3 .

Strån omkr. 2 fot höga och sträfva med n. glatta och i kanten sträfva blad; vippa föga blomrik; småax omkr. tumslånga ; flerårig med skottalstrande rotstock.

Torra ängar, mycket r.; $S v$. Upl. pă 4 ställen (månne verkligt vild?).

\section{Bromus. Losta.}

A. Blommor åtskilda vid fruktmognaden; vippa slutl. lutande; kronborst böjdt, stundom felslående.

1. B. secálinus L., Råglosta; kronskal lika långa; nedre vippgrenar 4 eller flera tillsammans. 2, 3 .

Omkr. 2 fot hög eller deröfver med glatt strå och vanl. glatta bladslidor; småax äggrunda-lansettlika, gröna och vanl. glatta; vippgrenar slutl. utstånde.

Allmänt ogräs i rågåkrar: Vb. Lpi. Herj. r.

B. Blommor alltid tätt tegellagda; vippa vanl. upprätt, stundom lutande; kronborst rakt.

2. B. commutátus Schrad.; vippa slutl. lutande, dess nedre grenar $2-7$ tillsammans; nedre kronskalet längre än det öfre, ofvan midten bredare med trubbvinklig kant; kronborst n. lika långt som sitt kronskal. 2, 3.

Liknar föreg. art, men har mjukhăriga bladslidor och smalare, lansettlika småax.

Akerrenar; Göt. r.: Sk. spr. Dalsl. 0, Sv. Upl. r. - Är i Ög. Vg. och Üpl. trol. blott tillfällig.

3. B. racemósus L.; vippa slutl. upprätt med vanl. ensamma och korta grenar (stundom 2-3 tillsammans); nedre kronskalet längre än det öfre och med bågformigt rundad kant; kronborst $n$. lika långt som sitt kronskal. 2, 3.

Liknar de båda föreg. arterna, men är vanl. lägre; bladslidor håriga; småax äggrundt aflånga; strå glatt.

Ruderatväxt på något fuktig ängsmark; Göt. Boh. spr. Vg. Hall. Blek. r. Sk. t. a. på slätten.

4. B. arvensis L., Ałerlosta; vippa slutl. något lutande, dess nedre grenar $3-8$ tillsammans; kronstal vanl. lika långa; kronborst lika långt som sitt kronskal. 3. 
1-2 fot hög med glatt strå, mjukhåriga blad och bladslidor, lansettlika och glatta vanl. violetta småax samt slutl. yfvig vippa med långa grenar; ståndareknappar guldgula.

Ảkrar och torra backar på slätten; Göt. Sv. r.: Sk. t. a. Gotl. Söd. Upl. a.; Norrl. Gestr. Hels. Ang. Vb. r., Lpl. r.

* B. pátulus M. K.; vippa slutl. ensidig; blommor upptill mera utstående; nedre kronskalet något längre än det öfre.

Göt. Skåne t. r.

5. B. mollis L., Luddlosta; vippa slutl. upprätt och hopdragen, dess nedre grenar 2-4 tillsammans; nedre kronskalet längre än det öfre; kronborst något kortare än sitt kronskal. 2, 3 .

Vanl. fotshög med strå, blad och ax vanl. mjukludna; småax äggrunda-kägellika och gröna; vippgrenar korta; enårig.

Torra backar, torftak o. s. v.; Göt. a.: Dalsl. t. r., ${ }_{0} S v$. t. a.: Verml. Dal. spr., Norrl. Gestr. Hels. spr. Med. r. (Ang. Vb. tillfällig).

- hordeáceus Wahlenb.; lågväxt och något tufvad; småax vanl. glatta, på mycket korta skaft; tvåårig. 2.

Mera sandiga ställen; Göt. spr., Sv. Upl. Söd. Vestm. t. r. 32. Poa. Ängs-gröe.

A. Rotstock krypande med rotskott (grenskott); bladsnärp kort.

a. Blad slutligen platta samt mer eller mindre breda.

1. P. sudética Hænke; alla bladslidor tvåeggadt hoptryckta; strå hoptryckt; nedre kronskalet tydligt nervigt. 3 .

Den största af detta slägtes arter, $3-5$ fot hög och ljusgrön med 5-6 linier breda och slutl. platta blad; vippa under blomningen utbredd, rikblommig och slutl. något lutande; de nedre vippgrenarne $3-5$.tillsammans, nedtill långt bara; småax äggrundt lansettlika, hoptryckta, 3-5-blommiga utan ludd och vanl. gröna; foderskal olika långa.

Fukt. lundar, helst i bergstrakter; Lpl. r., Norrl. r.: Ang. spr., Sv. r.: Söd. 0, Göt. Ög. t. r. Vg. Smål. Blek. Sk. r.

2. P. compressa L.; strå och slidor hoptryckta; nedre kronskalet otydligt nervigt. 2, 3 .

1-2 fot hög och blågrön med slutl. platta blad; vippa hopdragen, teml. rikblommig och vanl. upprätt samt 1-2 tum lång: de nedre vippgrenarne 2-3 tillsammans och teml. korta nedom axsamlingen; småax aflånga-lansettlika, hoptryckta och 5-9blommiga, vanl. brokiga; nedre kronskalet med ludd; foderskal något olika långa.

Torra stenbundna eller sandiga ställen; Göt. spr.: Boh. Hall. r. Sk. Öl. t. a., $S v$. spr.: Söd. Upl. a. Dal. t. r., Norrl. Gestr. Jtl. spr. Hels. Vb. r. 
3. P. pratensis L.; strå och slidor vanl. trinda; nedre kronskalet tydligt nervigt. 2,3 .

Omkr. 1-2 fot hög och vanl. ljusgrön med platta blad; vippa äfven efter blomningen utbredd, vanl. rikblommig och upprätt samt utdragen; de nedre vippgrenarne omkr. 5 tillsammans och teml. korta nedom axsamlingen; småax n. äggrunda 3-5-blommiga med ludd mellan blommorna; foderskal nästan lika lănga. Är $\mathrm{i}$ hög grad föränderlig.

Ängar, allmän.

b. Blad n. borstlika och hopvikna. Vippa fåblommig. 4. P. flexuósa Wahlenb.; strå och slidor något hoptryckta; nedre kronskalet otydligt nervigt. 3.

Knappt $1 / 2$ fot hög och ofta blăgrön; vippa hopdragen, dess nedre grenar vanl. parvis sittande och teml. korta; småax äggrunda 2-3-blommiga.

Något fuktiga ställen högt upp i fjellen r.; Lpl., Norrl. Jtl.

B. Rot mangårig och tågig med rotskott.

a. Bladsnärp utdraget.

5. P. triviális L.; strå trindt; rotskottens slidor hoptryckta; nedre kronskalet tydligt nervigt. 2, 3.

1-3 fot hög och vanl. mörkgrön med stundom ganska breda och platta blad; vippa utbredd, rikblommig och upprätt; de nedre vippgrenarne $3-6$ tillsammans oeh nedtill långt bara; småax ovala eller omvändt äggrunda, 2-4-blommiga med ludd, vanl. mycket små och gröna; foderskal olika långa.

Fuktiga ängar, allmän.

6. P. bulbósa L., Lökgröe; strå och rotskott nedtill lökformigt uppsvälda; nedre kronskalet otydligt nervigt. 2.

Omkr. fotshög och grågrön med korta, smala och platta blad; vippa hopdragen, rikblommig och n. upprätt; de nedre vippgrenarne ensamma eller parvis stälda och korta; småax ovala, gyttrade $i$ spetsen af grenarne, och 4-6-blommiga med ludd samt brokiga och ofta med groddknoppar; foderskal n. lika långa.

Berg och torftak nära Östersjộn samt vid Vettern (på Omberg); Göt. Gotl. t. r. Öl. a. Sk.-Ög. r., Sv. r.

b. Bladsnärp teml. kort. Nedre kronskalet otydligt nervigt. Vippgrenar teml. korta. Blad smala.

7. P. laxa Hænke; strå och slidor föga hoptryckta; småax bredt ovala, 2-3-blommiga. 3 .

Omkr. $1 / 2$ fot hög eller lägre, ofta blågrön, med hopvikna och mycket korta blad; vippa hopdragen, fåblommig och lutande; nedre vippgrenar enstaka eller parvis stälda; ax vanl. högfärgade; stråets öfversta ledstycke förlängdt.

Torra klippor i fjellregionen; Lpl. t. r. Norrl. Jtl. Herj. r.

8. P. stricta Lindeb.; strå och stråslidor föga hoptryckta; rotskottens slidor hoptryckta; småax lansettlika, 1-2blommiga och oftast försedda med groddknoppar. 3. 
Omkr. fotshög och $n$. ljusgrön med slutl. platta och teml. långa blad; vippa under blomningen utbredd, teml. rikblommig och upprätt; nedre vippgrenar enstaka eller 2-3; ax brokiga; stråets öfversta ledstycke vanl. förlängdt.

Fjelltoppar, mycket r.; Norrl. Jtl. på Åreskutan.

C. Rot mångårig och tågig utan (hos $P$. casia stundom med) rotskott. Nedre kronskalet otydligt nervigt. a. Strå ej uppsväldt nedtill. Blad smala.

9. P. serótina Ehrh.; strå och slidor trinda; bladsnärp utdraget; blommor sammanhängande genom ludd. 3.

Omkr. 1-2 fot hög och ljusgrön, föga tufvad, med långa och platta blad; vippa utbredd, rikblommig och slutl. lutande; de nedre vippgrenarne $3-5$ tillsammans och nedtill långt bara: småax äggrunda, 2-5-blommiga och upptill färgade; strå nedtill ofta nedliggande och knäböjdt; foderskal olika långa.

Stränder och andra fukt. ställen, teml. allmän.

10. P. nemorális L., Lundgröe; strà och slidor trinda; bladsnärp kort; blommor föga sammanhängande och $\mathrm{n}$. utan ludd. 2, 3 .

Omkr. 2 fot hög och ljusgrön, tätt tufvad, med långa, smala och platta blad samt vanligen mycket fina strån; vippa lång och snart hopdragen, rikblommix och något lutande; de nedre vippgrenarne $2-5$ tillsammans; småax äggrundt lansettlika, $2-5$ blommiga och vanl. gröna; strå upprätt; foderskal n. lika långa. Lundar och skogar, allmän.

11. P. gláuca Vahl; strå och slidor hoptrycicta; bladsnärp kort; vippa teml. utbredd; strå slätt. 3 .

Omkr. fotshög eller högre, blågrön och tätt tufvad med teml. långa och platta blad; vippa vanl. rikblommig och upprätt; de nedre vippgrenarne vanl. enstaka eller parvis stälda; småax äggrundt lansettlika, 2-4-blommiga och vanl. brokiga; stråets öfversta ledstycke mycket långt utdraget.

Helst i fjelltrakter; Lpl. spr., Norrl. Jtl. Herj. Vb. Ång. t. r., Sv. Dal. r., Göt. Boh. vid Strömstad (Beurling).

12. P. áspera Gaud.; strå och slidor hoptryckta; bladsnärp kort; vippa teml. hopdragen och fåblommig; strâ sträft. 3.

Liknar föreg. art, men är blågrå och föga tufvad med korta och slutl. platta blad; småax 3-7-blommiga.

I fjellen, helst i björkregionen, t. r.; Lpl., Norrl. Jtl. Herj.

* P. cæ'sia Sm.; småax bredt ovala, 5-7-blommiga; stundom med rotskott.

I fjellen $r$.

b. Strå nedtill knutigt uppsväldt. Blad något breda. 13. P. alpina L., Fjellgröe; strå och slidor trinda; bladsnärp teml. kort. 2, 3 .

0 mkr. fotshög med slätt, vanl. ända upp mot vippan bladigt strå; blad teml. korta och platta; vippa under blomningen 
utbredd och upprätt, vanl. pyramidformig och rikblommig; nedre vippgrenar teml. korta, vanl. enstaka eller parvis stälda; småax äggrundt aflånga, brokiga och vanl.3-5-blommiga, stundom med groddknoppar.

Ängar, helst i fjellen; Lpl. a., Norrl. Jtl. Herj. a. Vb.Hels. spr., Sv. Dal. spr. Upl. r., Göt. Gotl. t. r. Öl. spr. Smål. Vg. Boh. r.

D. Rot enårig och tågig med rotskott.

14. P. ánnua L.; strå och slidor hoptryckta; det öfversta bladsnärpet något utdraget; nedre kronskalet otydligt nervigt. $2-4$.

Hela växten mycket mjukare än hos de öfriga arterna, omkr. $1 / 2$ fot hög och ljusgrön med platta och ofta på tvären vågiga blad; vippans grenar under blomningen horisontelt utstående, de nedre ensamma eller parvis stälda och nedtill långt bara; smáax vanl. gröna och äggrunda; foderskal olika långa.

Ruderatväxt och ogräs, allmän.

\section{Briza. Darrgräs.}

1. B. média L.; rot tågig; bladsnärp kort. 2-3.

Strån fotshöga; vippa utbredd och upprätt med hårfina och krusiga grenar; småax hoptryckta och vanl. violetta; nedre kronskalet bătformigt; foderskal med bred hinnkant.

Torra ängar; Göt. Sv. a.: Dalsl.-Dal. spr., Norrl. spr.: Med.-Vb. r.

\section{Catabrósa. Narfgräs.}

\section{C. aquática (L.) Pal. Beauv.; vippans grenar slutl.} mycket utspärrade, 4-10 tillsammans; smăax tvaiblommiga; foderskal năgot kortare än kronskalet. 3 .

Omkr. fotshög och spenslig, nedtill krypande med lång rotstock; klad ljusgröna, korta breda och trubioiga; småax gröna eller violetta; kronskal trubbiga, tydligt nerviga; bladsnärp kort.

I vatten, helst i större slättbygder; Göt. r.: Sk. t. a. Öl. Ög. spr. Dalsl. 0, Sv. Söd. Upl. spr. Vestm. t. r. Ner. Dal. r., Norrl. Jtl. Hels. - Ang. r.

2. C. álgida (Wahlenb.) Fr., Snövattengräs; vippa făgrenig och hopdragen; småax enblommiga; foderskal mycket kortare än kronskalet, ofta feelslående. 3,4 .

Omkr. tumshög, sällan ända till $1 / 2$ fot hög med tågig rot; blad små och ljusgröna; kronskal trubbiga, det nedre stundom med kort udd; ståndare 2.

Vattenpölar på de högsta fjelltopparne i $L p l$. r.

\section{Glycéria. Vattengröe.}

A. Nedre kronskalet tydligt 7-nervigt.

a. Strå upprätt med upprätta, icke flytande blad samt små, alltid hoptryckta småax.

1. G. aquática (L.) Wahlb., Jettegröe; vippa upprätt med sträfva grenar, 5-9 tillsammans; blad kortspetsade med trinda slidor. 3 . 
Omkr. 4-6 fot högt och rörlikt gräs med tjock rotstock och omkr. $1 / 2$ tum breda, ljusgröna blad; småax jemnbredt lansettlika och gulgröna, i spetsen brunaktiga.

I vatten, vid stränder, helst $\mathrm{i}$ de större sjöarne, sällan $\mathrm{i}$ grunda hafsvikar; Göt. Dalsl. a. vid Venern, Vg. Boh. spr. Hall. r. Sk. Blek. spr. Smål. r. Ög. spr., Sv. r.: Verml. a. vid Venern, Söd. Upl. spr., Norrl. Med. vid Sundsvall (planterad?). För öfrigt planterad mảngenstädes.

2. G. remóta Fr.; vippa lutande med något sträfva grenar, 3-5 tillsammans; blad, jemnt afsmalnande med något hoptryckta slidor. 3 .

Spensligare och lägre än föreg. art med mindre yfvig vippa och ej så tätt sittande, gröna eller violetta småax; rotstock smalare; blad teml. mjuka, 2-3 linier breda och ljusgröna; stråets leder täckta af slidorna. Liknar Poa sudetica. Med. Sättna.

Bäckdalar i lägre fjelltrakter, mycket r.; Norrl. Ång. Bjertrå,

b. Strå nedliggande eller uppstigande; de nedre bladen flytande; bladslidor tvåggadt hoptryckta; småax stora, före blomningen trinda, sedan hoptryckta.

3. G. flúitans (L.) R. Br., Mannagrynsgräs; vippa upprätt och klaselik, med n. glatta grenar, blott 2 tillsammans; nedre kronskalet nästan spetsigt. $3,4$.

Omkr. 2-4 fot hög och vanl. nedliggande; blad 2-3 linier breda och rent gröna; småax jemnbreda, tilltryckta och vanl. blekgröna.

I sött vatten vid stränderna, allmän till s. delen af $\mathrm{Vh}$. och Dal.; Herj. Jtl. spr.

4. G. plicáta Fr.; vippa yfvig och i spetsen lutande, med n. glatta grenar, de nedre omkr. 5 tillsammans; nedre kronskalet trubbigt. 3, 4 .

Liknar mycket föreg. art, men har mera uppstigande strå, något bredare och mera ljust gröna blad samt utstående vippgrenar.

I sött vatten, helst i bäckar; Göt. r.: Sk. a: Ög. t. r. Öl. Dalsl. 0, $S v$. Verml. r.

B. Nedre kronskalet otydligt 5-nervigt. Blad icke flytande; småax små och hoptryckta.

5. G. distans (L.) Wahlenb.; vippa under blomningen utbredd med utstående och slutl. nedböjda grenar, 3-5 tillsammans (sällan parvis stälda); småax aflånga; rot tågig; blad platta. 3, 4 .

Frăn ett par fot till blott ett par tum hög, ofta nedliggande eller uppstigande, med spensliga och tätt hoptufvade strån och smala blågröna blad; småax grönaktiga eller blågröna, stundom brokiga, samt lätt affallande; foderskal n. helt och hållet hinnaktiga. Liknar något Poa anmua. 


\section{TRIANDRIA. $35-37$.}

Ruderat- och strandväxt, helst vid hafvet och vid större sjöar; Göt. spr.: Sk. Blek. t. a. Vg. r. Dalsl. inre Smål.?, Sv. Söd. Upl. spr. Vestm. t. r. Ner. Verml. r., Norrl. r.: Gestr. spr. Med. Herj.?

6. G. maritima Wahlb.; vippgrenar slutl. tilltryckta, de nedre parvis stälda; småax ovala-aflånga; rotstock krypande; blad i kanterna inrullade. 3, 4.

Liknar föreg. art, men är mera upprätt med mjukare blad, brokiga (sällan gröna) och längre qvarsittande småax samt blott i kanterna hinnaktiga foderskal.

Hafsstränder; Göt. r.: Boh.-Sk. mångenst.

C. Nedre kronskalet med en tydlig nerv. Småax små och aflånga.

7. G. pendulína Læst.; vippa yfvigt utbredd och lutande med hängande grenar, $3-7$ tillsammans. 3 .

Omkr. 2-3 fot hög och vanl. upprätt med tjocka och nedtill bladlösa strån, lång rotstock och slaka, 2-3 linier breda blad; småax krokiga af gult och violett.

Öfversvämmade stränder; Norrl. Vb. t. ex. vid Tornioelf t.r.

\section{Enódium. Blåtîtel.}

1. E. cœrúleum (L.) Gaud.; rot tågig; vippa rikblommig med parvis stälda, nedtill delade grenar. 3 .

Strån omkr. 2-3 fot höga och styfva, nedtill lökformigt uppsvälda och försedda med blott en ledknut; nästan alla bladen samlade vid roten; småax vanl. blå, stundom blekare och gröngula, med mycket bräckligt fäste.

Våta ställen på ängar, stundom i skogar, teml. allmän.

\section{Avéna. Hafre.}

A. Rot enårig utan rotskott; småax hängande; foderskal 5-9-nerviga, längre än kronskalet.

1. A. fátua L., Flyghafre, Vildhafre; vippa allsidig och yfvig; axfäste ludet; kronskal nedtill med hår. 3 .

Strån 3-4 fot höga med ludna leder; nedre kronskalet vanl. finhårigt med mycket kort och tvåklufven spets, stundom n. glatt; småax grönaktiga, 2-3-blommiga.

Ogräs bland vårsäd, helst i större slättbygder; Göt. spr.: Sk. Öl. Gotl. a. Dalsl.?, Sv. spr.: Ner. Verml. 0, Norrl. spr., Lpl. r. 2. A. strigósa Schreb.; vippa ensidig och klaselik; axfäste n. glatt; kronskal (åtm. nedtill) utan hår. 3.

Lik föreg. art och lika hög med glatta stråleder'; nedre kronskalet med 2 långa spetsar; småax grönaktiga.

Ogräs bland vårsäd; Göt. r.: Smål. Öl. mångenst. Gotl. Dalsl. 0, Sv. Verml. r.

B. Rotstock vanl. med rotskott; småax upprätta; foderskal 1-3-nerviga; det nedre foderskalet kortare än kronskalet. 
a. Nedre kronskalet trindryggadt och n. läderartadt; alla blommor samkönade med långa kronborst; småax lansettlika; axfäste ludet; bladsnärp utdraget.

3. A. pubescens L., Luddhafre; vippa under blomningen utbredd och teml. yfvig med talrika småax; nedre foderskalet 1-nervigt. 2,3 .

Strån släta och omkr. 2 fot höga med vanl. mjukludna blad och slidor; blommor vanl. nedtill violetta, upptill silfverglänsande; småax 2-3-blommiga; vippans nedre grenar vanl. 4 tillsammans; blad i spetsen hopdragna. Lpl. r.

Torra ängar; Göt. Sv. a., Norrl. spr.: Gestr. Hels. a. Vb.0,

4. A. pratensis L., Änghafre; vippa alltid hopdragen och klaselik med få småax; båda foderskalen 3-nerviga. 2,3 .

Liknar föreg. art, men är mera tätt tufvad med sträfva strån, blad och slidor; småax 3-5-blommiga; vippans nedre grenar vanl. parvis stälda; blad ofta hopvikna och styfva.

Torra ängar; Göt. a.: Dalsl. t. r. Boh. spr.?, Sv. t. a.: Verml. r. Dal. r.?, Norrl. Gestr. t. a. Hels. Ang. t. r..

b. Nedre kronskalet köladt och bladartadt; den nedre blomman vanl. hanblomma med långt kronborst, den öfre samkönad med intet eller mycket kort borst; småax aflånga; axfäste glatt; bladsnärp kort.

5. A. elátior L., Knylhafre; vippa under blomningen utbredd och yfvig med talrika 2-blommiga småax. $2,3$.

Strån 3-4 fot höga och glatta; blad sträfva med n. glatta slidor; smảax blekgröna, mindre än hos föreg. arter.

Ängar och backar, ofta bland buskar, helst i skärgården; Göt. mångenst.: Dalsl. 0, Sv. Söd. Upl. t. a. Vestm. spr. Ner. r., Norrl. Gestr. Hels. r.

\section{Trisétum. Hafreäxing.}

\section{a. Rotstock skottalstrande.}

1. T. flavescens (L.) Pal. Beauv.; vippa teml. tätblommig, under blomningen utbredd, slutl. hopdragen, med sträfva grenar, de nedre omkr. 4 tillsammans; stri̊ glatt; de nedersta bladen jemte deras slidor mjukludna; småax 2-3-blommiga, gulaktiga. 2,3 .

Omkr. 2 fot hög och n. upprätt; blad platta med kort och tvärhugget snärp; det ena forderskalet dubbelt längre än det andra.

Ängar och lundar, helst på slätten; Göt. Gotl. r. Sk. t. r. Blek. r. Smål. Ög. t. r., Sv. Söd. r. Upl. t. r. men mångenst. i Stockholmstrakten, Vestm.? 
b. Rot tågig med bladtofsar.

2. T. subspicátum (L.) P. B., Fjellhafre; vippa tät och axlik med håriga grenar; strå och blad mjukludna; småax brokiga. 3 .

Omkr. $1 / 2$ fot hög och styft upprätt; bladsnärp något utdraget; foderskal n. lika långa.

Klippor och öppna fält i fjellen; Lpl. i högfjellen a., Norrl. Jtl. Herj. spr.

3. T. agrostídeum Fr.; vippa gles och under blomningen utbredd, slutl. hopdragen med n. glatta grenar; stråets nedersta del och de nedersta bladen finludna; småax gröngula. 3 .

Högre än föreg. art och med finare strå; vippa smalare och mera upprätt än hos Triset. flavescens.

I fjellens björkregion, mycket r.; Lpl. på två st. i Torn. Lpm.

39. Airópsis. Dverg-tàtel, Smile.

1. A. præcox (L.) Fr.; vippa axlik och hopdragen; småax längre än skaften; foderskal föga längre än blommorna. 2.

2-5 tum hög och vanl. upprätt med spensliga hoptufvade strån och tågig enårig rot; strån och ax grơngula.

Hafsstränder; Göt. spr.: Sk. a. Gotl. Ög. r., Sv. Söd. r.; inuti landet: Göt. Sk. a. Vg. på Kållandsö, Smål. t. ex. vid Jönköping. 2. A. caryophylléa (L.) Fr.; vippa utbredd; småax vanl. kortare än skaften; foderskal längre än blommorna. 2.

Är något högre än föreg. art och har liksom denna spensliga tufvade strån, enårig rot, utdraget bladsnärp, spetsiga foderskal och tvåblommiga småax, men de senare äro silfverglänsande och grönaktiga (eller violetta); vippa triangelformig med tredelade grenar; strån rodnande eller violetta.

Sandiga ställen; Göt. Skåne t. r. Smål. r.

40. A'ira. Tâtel, Tåda.

A. Kronborst rakt; småax med ämne till en 3:dje blomma.

1. A. cæspitósa L., Tuf-tåtel; blad vanl. platta; kronborst inneslutet. 3.

Omkr. 2 fot hög och tufvig med utbredd, i spetsen lutande vippa med sträfva grenar; småax mindre än hos offiga arter, aflånga och n. trubbiga, violetta eller gröngula; blad ofvanpå sträfva. Något fuktiga ängar, allmän.

- brevifólia; vippa hopdragen, lansettlik med glatta krusiga grenar; blad korta och slutl. inrullade; kronborst năgot krökt; småax rödvioletta.

Liknar Aira flexuosa.

Norrl. Jtl. r.

2. A. bóttnica Wahlenb., Hafs-tåtel; blad rännformiga och inrullade; kronborst lingt utskjutande. 3. 
Ofta högre än föreg. art med längre, n. upprätt och något hopdragen vippa med glatta grenar; småax lansettlika-aflånga och n. spetsiga. Hela växten blekgul och utan rotskott.

Hafsstränder; Norrl. Sv. spr., Göt. Ög. Smål. r.

3. A. alpína L., Fjelltåtel; blad rännformiga, inrullade och släta; kronborst inneslutet. 3 .

Omkr. fotshög med utbredd och någòt lutande vippa med glatta grenar; småax större än hos föreg. arter, äggrunda, spetsiga och brokiga, n. alltid med groddknoppar. Hariofta rotskott.

Fuktiga ställen, stundom vid vägar, högt upp i fjellen; $L p l$. spr., Norrl. Jtl. Herj. spr.

B. Kronborst krökt; småax utan ämne till en 3:dje blomma.

4. A. flexuósa L., Krus-tåtel; blad trinda och borstlika; kronborst utskjutande. 3 .

Inemot 2 fot hög med utbredd, gles, äggrund och lutande vippa med glatta och krusiga grenar; småax äggrunda, bruna och grönhvita, något längre än de olikstora foderskalen; bladsnärp utdraget och tvärhugget.

Torra berg och backar, allmän.

- montána; vippa något hopdragen; småax större och mera rödaktiga.

Helst i fjelltrakter; Lpl. Norrl. spr.: Gestr. 0, Sv. Dal. spr. Verml. r., Göt. Boh. r.

— uliginósa Fr. (Weihe?); vippgrenar kortare och sträfva; bladsnärp spetsigt; strå upptill slätt; kronborst långt; blad n. hårlika.

Fuktiga ställen r.; Göt. Smål. vid sjöar i F'emsjö.

\section{Corynéphorus. Sandborst.}

1. C. canescens (L.) P. B.; vippa upprätt, blott under blomningen utbredd och aflång; småax brokiga, slutl. hvitglänsande; foderskal längre än blommorna. 3, 4.

5 -8 tum hög och blågrön; strån teml. spensliga, tätt tufvade och vanl. knäböjda; foderskal lansettlika spetsiga; bladsnärp utdraget och spetsigt.

Sandiga ställen, helst vid hafvet; Göt. Hall. t. r. Sk. Öl. a. Gotl. Kalmarl. Blek. spr. inre Smål. r. (Ög. tillfällig vid Motala).

\section{Vahlódea.}

1. V. atropurpúrea (Wahlenb.) Fr.; blad platta och mjuka; kronborst inneslutet af foderskalen. 3 .

Omkr. fotshög, spenslig och n. glatt med rotskott, knappt liniebreda blad och slak mörkröd vippa.

Fuktiga ställen i fjellen, helst bland enbuskar på stränder af bäckar och sjöar; Lpl. t. a., Norrl. Vb. Jtl. Herj. r., Sv. Dal.r. 43. Holcus. Taitcl.

1. H. lanátus L., Luddtåtel; blad och slidor tätt gråludna; hanblommans borst vanl. inneslutet inom de trubbiga foderskalen; rot tågig. 2,3 . 
Omkr. 2 fot hög med tufvade, upprätta och småludna strån, vippa aflång och rikblommig; småax äggrunda, hårkantade och hvitaktiga, upptill rödaktiga.

Fuktiga ängar; Göt. spr.: Blek. Sk. - Boh. a., Sr. r.: Söd. spr. Upl. t. r. Dal. 0, Norrl. Gestr. Ång. r.

2. H. mollis L., Mjuktåtel; strået och öfre bladslidorna glatta; kronborst knäböjdt, utskjutande; rotstock. 3.

2-3 fot hög med slankiga strån; vippa slutl. hopdragen och teml. smal; småax gröngula.

Sandiga skogar eller åkrar, stundom på hafsstränder; Göt. (helst nära hafvet) Boh. Hall. t. r. Sk. t. a. (äfven inuti landet) Gotl. r. Öl. spr. Blek. r. Kalmarl. t. r. Ög. r. (i skärgården), inre Smål. r., Sv. Söd. r.

\section{Triódia. Tandsvingel, Kinägräs.}

1. T. decumbens (L.) Pal. Beauv.; småax aflånga eller omvändt äggrunda; rot tågig. 3 .

Ljusgrön och tufvad med omkr. $1 / 2$ fot höga, uppstigande strån; blad något styfva, slutl. hoprullade, med håriga slidor och en hårkrans i st. f. snärp; småax omkr. 6, gröna och teml. tjocka.

Torra ängar och hedar; Göt. a., Sv. spr.: Söd. Upl. Vestm. a., Norrl. Gestr. Hels. r.

\section{Graphéphorum. Vass-svingel.}

1. G. festucáceum (Link) Asa Gray (enl. Anders.); småax omvändt äggrunda; vippa lutande. 3.

4-6 fot hög och ljusgrön, mycket liknande Glyceria aquatica, men med något smalare blad, utdraget och tvärhugget snärp, större och blekgröna samt mot spetsen af grenarne samlade småax. Flumínia arundinácea Fries.

Sjöstränder nch åmynningar, si̊ långt som sjöarnes vårvatten uppstiger; Göt. Östergötl. a. i Roxens, Dåfverns och Glans alluvialland från Kungsbro i Vreta till Johannisborg vid Norrköping.

46. Mélica. Slokgräs, Floke.

A. Nedre kronskalet glatt; vippa glesblommig, upptill något lutande.

1. M. nutans L., Berg-slok; småax med 2 utvecklade blommor och hängande på korta skaft i enkel och ensidig klase. 2, 3 .

Omkr. fotshög med lång rotstock och teml. breda, mjuka och ljusgröna blad; snärp kort och afrundadt; småax äggrunda; foderskal trubbiga och rödaktiga.

Bergväggar och lundar t. a., dock mindre ymnig i fjellen.

2. M. uniflóra Retz., Lund-slok; småax med blott en utvecklad blomma, upprätta på utdragna skaft i en grenig vippa med långa grenar. 3 .

Liknar föreg. art, men är spensligare; snärp långspetsadt, motsatt bladet; foderskal n. spetsiga, ljusare röda.

Bergväggar och lundar, helst vid hafvet samt vid Venern och Vettern; Göt. Vg. spr. Boh. r. Hall. t. r. Sk. a. inre Smål. 
vid Grenna, Blek. Kalmarl. Öl. spr. Gotl. t. r. Ög, r., Sv. Söd. Upl. r.

B. Nedre kronskalet i kanterna långhårigt; vippa tätblommig, axlik och upprätt.

3. M. ciliáta L., Grus-slok; småax med blott en utvecklad blomma, upprätta p̊̊ mycket korta skaft; axsamling jemnbred. 2,3 .

Omkr. $1^{1 / 2}$ fot hög med lång rotstock och hopknippade strån samt stela och slutl. hopvikna blad; snärp utdraget; småax lansettlika violetta, slutl. halmgula och silfverglänsande; foderskal spetsade; nedre kronskalet n. hinnaktigt.

Torra klippor nära Östersjön och Vettern; Göt. Gotl. a. Öl. spr.' Kalmarl. Ög. t. r., Sv. Söd. Upl. t. r., dock flerst. omkr. Stockholm.

\section{Koeléria. Tofs-äxing.}

1. K. gláuca D. C.; blad rännformiga och n. borstlika, jemte stråets öfre del finludna; nedre kronskalet trubbigt och vanl. försedt med ett litet borst. 3 .

Grågrön och omkr. fotshög; småax grönhvita, 2-3-blommiga; de nedre bladslidorna upplösta $\mathrm{i}$ trådar; vippa slutl. n. jemntjock; mångårig.

Torra sandfält; Göt. Sk. (helst i ö. delen) Hall. Öl. mångenst. Blek. r.

\section{Phragmites. Vass, Bladvass, Sjövipp.}

1. P. commúnis Trin.; småax 4-5-blommiga. 3 .

Det största bland alla svenska gräs, stundom öfver 6 fot högt, med krypande rotstock och mycket breda, i kanterna sträfva blad med en kort hårkrans i st. f. snärp; småax mer än $1 / 2$ tum långa; foderskal spetsiga och $\mathrm{i}$ spetsen hela.

Stränder, i och vid vattnet, allmän, äfven i skärgården; dock Jtl. t. r. och (åtm. i norra) Lpl. r. i fjellens barrskogsregion.

A. Kronborst rakt.

\section{Calamagrostis. Rörhven.}

a. Småax gyttrade på viupgrenarnes utsida; foderskal n. broskartad̄e och efter blomningen slutna. 1. C. epígejos.

b. Småax allsidigt fästade på vippgrenarne; foderskal hinnaktiga och efter blomningen öppna. 2. C. litórea. 3. C. Halleriana. 4. C. Ianceolata.

c. Småax allsidigt fästade på vippgrenarne; foderskal hinnaktiga och efter blomningen slutna. 5. C. neglecta. 6 . C. Hartmaniana.

B. Kronborst knäböjdt, fästadt nära kronskalets bas. Småax allsidigt fästade pă vippgrenarne; foderskal efter blomningen slutna.

a. Foderskal hinnaktiga. 7. C. arundinacea. 8. C. varia. 9. C. Iapponica.

b. Foderskal n. bladartade. 10. C. chalybæa.

1. C. epígejos (L.) Roth; foderskal smalt lansettlika och afsmalnande till en lång och syllik spets, lika 
stora, nästan dubbelt så långa som det nedre kronskalet, som har borstet fästadt nedom den djupt klufna spetsen; blomhår n. lika långa med foderskalen. 3.

4-5 fot hög, mycket sträf och styf med teml. breda blad och omkr. 3 linier långa foderskal.

Torra ställen, helst i bergstrakter, äfven på stränder, teml. allmän: Lpl. r. i fjellens barrskogsregion.

2. C. litórea D. C.; foderskal smalt lansettlika och långspetsade, olikstora och $n$. dubbelt så långa som det längre kronskalet, som har det teml. långa borstet fästadt i eller nedom den grundt klufna spetsen; blomhår lika långa som foderskalen. 3 .

3-4 fot hög, teml. styf, sträf och blågrön med n. upprätt och något gles vippa. Liknar temligen C. Hartmaniana.

Stränder och berg i lägre fjelltrakter, mycket r.; Norrl. Jtl. Herj. Hels., Sv. Verml.

3. C. Halleriána D. C.; foderskal aflångt lansettlika och tillspetsade, vanligen nästan lika stora och $1 / 3$ längre än det längre kronskalet, som har borstet fästadt nedom den grundt klufna spetsen; blomhår kortare än foderskalen och vanl. föga längre än kronskalen; bladsnärp vanl. utdraget. 3 .

Något lägre än föreg. art, med teml. upprätt vippa och smala, något sträfva blad.

Fuktiga ängar, helst vid stränder, r.; Lpl. Norrl. Sv., Göt. Dalsl. Boh. Vg. Smål. Ög.

* C. eláta Blytt; foderskal oliklånga och tillspetsade; vippa mycket yfvig med slaka grenar och lutande topp; blomhår n. lika långa med foderskalen; blad smala och blågröna; strå $4-5$ fot högt.

Helst i fjelltrakter; Lpl. Torn. Lpm. spr. i björkreg., Norrl. Vb. Ang. flerstädes.

* C. phragmitóides Hartm.; foderskal oliklånga, något smalare och med något längre spets (än hos hufvudarten); vippa utbredd och yfvig med lutande topp; blad breda.

Stränder, i samma landskap, som för hufvudarten uppgifvits; Lpl. - Herj. Vb. Ång. t. a., eljest t. r.

** C. Langsdórfii Trin.; foderskal n. oliklånga och tillspetsade; vippa upprätt (föga lutande) och något hopdragen; blad teml. breda och blågröna.

Fuktiga ängar; Sv. Verml. r.

4. C. lanceoláta Roth; foderskal aflångt lansettlika med teml. lång spets, vanligen lika stora och $1 / 3$ längre än det längre kronskalet, som har det n. omärkliga bor- 
stet fästadt i den grundt klufna spetsen; blomhår n. lika långa med foderskalen; bladsnärp kort. 3.

Omkr. 4 fot högt, mjukt och slakt gräs med smala, slaka och ljusgröna blad samt lutande, något gles vippa. Teml. lik föreg. art.

Fuktiga ställen, helst i skogar, t. a., dock mindre ofta i fjellen.

5. C. neglecta Fr.; foderskal aflånga och kortspetsade, lika stora och föga längre än de föga oliklånga kronskalen; kronborst fästadt nedom midten af kronskalet; blomhår föga kortare än kronskalen; bladsnärp kort. 2,3 .

1-3 fot hög eller stundom deröfver, spenslig, styf och $n$. glatt (någongång sträf); rotskottens och stråets nedre blad vanl. trådlikt hoprullade; vippa vanl. smal och aflång-lansettlik med korta grenar; småax mindre än hos de öfriga arterna, knappt linielånga och brokiga.

Kärr och fukt. ängạ, helst på stränder; Lpl. Norrl. Sv. a., Göt. t. r.: Dalsl. Vg. Ög. Smål. mångenst.

- boreális Læst.; kronborst fästadt ofvan kronskalets midt; blomhår något kortare än kronskalen; rotskottens blad platta.

Fjelltrakter r.; Lpl. Torn. Lpm., Norrl. Vb.

6. C. Hartmaniảna Fr.; foderskal aflångt lansettlika med utdragen spets $0 \mathrm{ch} 1 / 3$ längre än det längre kronskalet, som har borstet fästadt nedom midten; blomhår hälften kortare än det längre kronskalet; bladsnärp kort. 3 .

Omkr. 4 fot hög, styf och något sträf med mycket långa och smala blad, glesare vippa och dubbelt längre småax än hos föreg. art.

Fuktiga ängar och stränder; Norrl. Jtl. r., Sv. r.: Upl. 0, Göt. Smål. Boh. r.

7. C. arundinácea (L.) Roth; foderskal vanl. brunaktiga med ljusare kant, aflångt lansettlika med utdragen spets och föga längre än det längre kronskalet; blomhår dubbelt kortare än det kortare kronskalet; kronborst dubbelt längre än foderskalen. 3.

2-3 fot hög och styf med sträfva, slaka, breda och platta blad; vippa slutl. tätt hopdragen och smal, n. jemnbred.

Berg och torra ofruktbara ställen i skogar, allmän.

* C. acutiflóra Schrad. enl. Fr.; foderskal smalt lansettlika med mera utdragen spets och mycket längre än kronskalen; blomhår vanl. föga kortare än det kortare kronskalet; kronborst lika långt med foderskalen eller något längre. 
Med violett vippa och bredare, kortare och något stela blad. Förmodảs vara bastard af C. arundinacea och C. epigejos. Hall. Ög.

På dylika ställen som hufvudarten, r.; Norrl. Jtl., Göt. Boh.

8. C. vária P. B.; foderskal violetta, aflånga, kortspetsiga och något längre än kronskalen; blomhår ungefär lika långa som det längre kronskalet; kronborst ej öfverskjutande foderskalen. 3 .

Liknar C. acutiflora, men har bredare foderskal, kortare och $\mathrm{i}$ början mera utbredd vippa; blad teml. breda, midtpå bredast. Berg och kullar; Göt. Gotl. a. i n. delen, eljest t. r.

9. C. lappónica Wahlenb., Lapskt Rörhven; foderskal brunaktiga med ljusare kant (stundom n. violetta), bredt aflånga och kortspetsiga (ofvan midten bredast), något längre än kronskalen; blomhår något längre än det kortare kronskalet; kronborst ej öfverskjutande foderskalen. 2, 3.

Vanl. lägre än Calam. arundinacea och styf med sträfva och styfva, smala, teml. platta och blekgröna blad; vippa tätı́ hopdragen och smal. Liknar Calam. neglecta.

Skogar och backar, helst i fjelltrakter; Lpl. spr., Norrl. Vb. Ång. spr. Med. Jtl, r.

- opima; vippa gråbrun och teml. yfvig.

Norrl.' Vb. Ång. r.

10. C. chalybæa Fr.; foderskal blygrå med mörkbrun kant, bredt aflånga med teml. kort spets, föga längre än det längre kronskalet; blomhår något kortare än det kortare kronskalet; kronborst ej öfverskjutande foderskalen. 2, 3 .

Högre än föreg. art med bredare, blågröna och något slaka blad, talrikare; och smärre småax; vippa något gles och i spetsen lutande.

Torr skogsmark i lägre fjelltrakter; Norrl. Ång. spr. Jtl. r., Sv. Verml. r.

50. Psamma. Marhalm, Sandrör.

1. P. arenária (L.) R. S.; foderskal spetsiga; vippa tät och axlik. 3.

3-4 fot hög med rotstock, tjocka halmgula, i början hvitaktigt blågröna ax och snart inrullade blad; nedre kronskalet med kort borstlik udd. Gotl. r.

Sandiga hafsstränder; Göt. Sk. Hall. t. r. Boh. Smål. Öl.

2. P. báltica (Fr.) R. S.; foderskal sylspetsade; vippa grenig och hopdragen. 3.

Något högre än föreg. art med rödviolett vippa och senare inrullade blad; nedre kronskalet med utskjutande borstlik udd. Liknar Calamagrostis epigejos.

Sandiga hafsstränder, mycket r.; Göt. Sk. Boh. 


\section{Agrostis. Hven.}

A. Kronskal 2; foderskal n. lika långa; alla blad platta. Kronborst oftast felislående, eljest fästadt nära spetsen af skalet.

1. A. alba L., Kryp-hven; vippa efter blomningen hopdragen, nedtill bredare, upptill mycket afsmalnande; nedre kronskalet kortare än foderskalen; bladsnärp utdraget. 3 .

Omkr. 2 fot hög, ofta med skottalstrande rotstock; vippa vanl. blekgul, sällan rödbrun; foderskal efter blomningen vanl. slutna, äggrundt lansettlika och spetsiga.

Fuktiga ängar, teml. allmän.

2. A. vulgaris With., Rödhven; vippa efter blomningen utbredd, p̊ midten bredare; nedre kronskalet $\mathrm{n}$. lika langt med foderskalen; bladsnärp mycket kort. 3.

Năgot lägre än föreg. art, ofta med skottalstrande rotstock och vanl. rödbrun, sällan blekgul vippa; foderskal efter blom. ningen vanl. öppna, äggrundt lansettlika och spetsiga.

Ängar, allmän.

B. Kronskal ensamt; foderskal olika långa; rotblad borstlika och vanl. hoprullade. Kronborst lingt och knäböjdt, fästadt nedom midten af kronskalet, sällan felslående.

3. A. canína L., Brunhven; vippa efter blomningen hopdragen, aflång och vanl. i spetsen lutande; kronskalet kortare än foderskalen; bladsnärp utdraget; stråblad platta och bredare än de öfriga. 3 .

Omkr. fotshög eller derutöfver, ofta med rotskott, men icke tufbildande; vippa vanl, mörkbrun, stundom blekgul; foderskal efter blomningen slutna, äggrundt lansettlika och spetsiga.

Ängar, allmän: i fjellen r.?

- alpestris Læst.; alla bladen n. lika smala och borstlika; vippa upprätt med glatta grenar.

Omkr. ${ }^{1 / 2}$ fot hög utan rotskott, men tätt tufvad; vippa stundom något gles.

Fjelltrakter, t. ex. i Lpl.

4. A. rubra L., Fjellhven; vippa efter blomningen föga hopdragen samt upprätt; rotblad snart inrullade; stråblad bredare och platta. 3 .

Omkr. fotshög eller lägre utan rotskott, stundom tufvad: vippa rödviolett med vanl. sträfva grenar; foderskal efter blomningen slutna.

Helst i fjellen, stundom i lägre fjelltrakter: $L p l$. a. i fjellen, Norrl. Jtl. Herj. a. i fjellen, Vb. Ang. t. r., Sv. Dal. r.

* A. hyperbórea C. P. Læst.; alla blad platta; foderskal efter blomningen öppna. 
Omkr. fotshög med rotskott, men icke tufvad.

I fjellen; Lpl. Torn. I pm. r.

\section{Apéra. Åkerhven.}

1. A. spica venti (L.) Pal. Beauv.; vippa yfvigt utbredd och ofta lutande; nedre kronskalet längre än foderskalen; bladsnärp utdraget. 3 .

Omkr. 2 fot hög, upprätt och tufvad med tågig rot och platta blad; foderskal lansettlika.

Akrar, temi. allmän: Lp]. r.

\section{Stipa. Fjädergräs.}

1. S. pennáta L.; bladsnärp äggrundt. 2, 3.

Omkr. 2 fot hög och tufvad; kronborst nära en fot långt: hlad blågröna; foderskal gulgröna.

Torra ängar och åkerrenar, mycket r.; Göt. Vg. nära Stenåsen $1 / 4$ mil från Dala kyrka.

54. Milium. Luktgräs, Amur, Hässlebrodd.

1. M. effúsum L.; småax äggrunda trubbiga; bladsnärp utdraget. 2,3 .

Omkr. 2-4 fot hög och ljusgrön med slaka blad och skottalstrande rotstock; vippa stor och pyramidformig med utstäende, slutl. nedböjda grenar, de nedre långt bara nedtill; foderskal ljusgröna; nedre kronskalet hărdt och hvitglänsande.

Lundar; Göt. t. r.: Sk. spr. Öl. Ög. t. a., Sv. spr.: Söd. Upl. t. a. Yerml. r. Dal. t. r., Norrl. Lppl. spr.

\section{Cinna. Sötgräs.}

1. C. péndula Trin.; vippa rikblommig, slak och hängande. 3, 4 .

Omkr. 4 fot hög med slaka blad och gröna småax; lironskal föga kortare än foderskalen.

Skuggrika lundar på berg, mycket r.; Norrl. Hels. på Elfåsen $\mathrm{i}$ Hassela.

56. Sesléria. Elfdansgräs, Elfüxing.

1. S. cœrúlea (L.) Ard.; blad trubbiga, de öfre mycket korta; rot tågig och mångårig. 1, 2.

Bildar nedtryckta tufvor; strån omkr. 1-2 fot höga med 1--2 leder orh det öfversta ledstycket mycket förlängdt; bladslidor långa och hoptryckta, slutl. upplösande sig i trådar; snärp kort och hårlikt; foderskal ofta med ett kort borst.

Något fukt. ängar och betesmarker; Göt. Gotl. Öl. a. Sk. Hall. r. Smål. t. r. Ög. spr., Sv. Söd. Upl. t. a. Vestm. spr. Ner. r., Norrl. Gestr. Med. Jtl. r.

\section{Setária. Kafvelhirs.}

1. S. viridis (L.) P. B.; svepeborstens taggar uppåt rigtade; rot enårig. 3.

Omkr. ${ }^{1} / 2$ fot hög med nedtill knäböjdt strå; blad ljusgröna, hvitnerviga och tillspetsade, med täthårigt snärp; smảax ovala och hoptryckta. 
Ruderatväxt och ogräs i sandiga åkrar, ofta sporadisk; Göt. r.: Sk. Hall. t. a. Smål. Öl. spr. Ög. Boh. t. r., Sv. r.: Ner. Dal. 0. 58. Pánicum. Hönshirs.

1. P. crus galli L.; blad sträfva utan snärp; strån och slidor släta; vippgrenar sträfva; rot enårig. 3 .

Mörkgrön med uppstigande, omkr. fotshöga strån och håriga, gröna eller rodnande, småax.

Ruderatväxt och ogräs; Göt. Sk. Hall. t. r. Blek. r.

59. Digitária. Blodhirs.

1. D. humifúsa Pers.; blad och slidor glatta; rot enårig. 3 .

Ända till fotshög, tufvad och vanl. nedliggande med ofta rodnande blad.

Sandiga åkrar och betesmarker; Göt. Sk. Hall. spr. Blek. r. 60. Alopecúrus. Ängtrafle.

1. A. pratensis L.; foderskal n. till midten hopväxta; rotstock kort med korta grenskott; kronborst rakt och utskjutande; ax jemntjockt. 2.

Omkr. 2-3 fot hög, vanl. upprätt och ljusgrön; foderskal ludna, spetsiga och något längre än kronskalet; ax i början ljusgrönt, slutl. gråludet, stundom glatt och svartnande, hvarje med 4--6 småax.

Fuktiga ängar och stränder; Göt. a.: Dalsl. r., Sv. a.: Verml. Dal. spr., Norrl. spr.: Ång. Vb. r., Lpl. r.

* A. nígricans Horn.; rotstock längre med större grenskott; kronborst inneslutet.

Blågrön med kort och tjockt, alltid svartnande ax, bredare blad och något truhbiga foderskal.

Hafsstränder; Göt. (vid Östersjön) Blek. Smål. Öl. spr. Gotl. Ög. r., Sv. r., Norrl. Vb. r.

2. A. geniculátus L.; foderskal föga hopväxta; rot tågig; kronborst knäböjdt och långt utskjutande. $2-4$.

Strå och ax mindre och smalare än hos föreg. arter, allitid knäböjdt och nedtill nedliggande, med gröna bladslidor; foderskal ludna, något trubbiga och lika långa med det spetsiga kronskalet.

Fuktiga ställen och torftak, allmän.

* A. fulvus Sm.; kronborst föga krökt och knappt utskjutande; bladslidor blågrå; kronskal trubbigt. Lika allmän som hufvudarten.

3. A. agrestis L.; foderskal n. till midten hopväxta; rot encirig (tågig); kronborst rakt och utskjutande; ax ât båda ändar afsmalnande. 2 .

$1-2$ fot hög, upprätt eller uppstigande; foderskal n. glatia, spetsade och kortare än det något trubbiga kronskalet; ax blåaktigt, slutl. rödbrunt: hvarje gren med vanl. blott ett småax. Småaxen affalla lätt vid torkning.

Sandiga åkrar; Göt. Gotl. t. r. Öl.? - För öfrigt tillfällig i flera andra landskap, t. ex. Sk. Boh. Vg. Smål. - Upl. 


\section{Phleum. Ängkampe.}

a. Småax med blott en blomma. Foderskal tvärhuggna med utdraget borst.

1. P. pratense L., Timotej; foderskal längre än borsten; ax jemntjockt; bladslidor tilltryckta, ej uppblasta, 3 . Omkr. 2 fot hög med teml. smalt och vanl. grönt ax; strå nedtill ofta lökformigt uppsväldt.

Ängar utom fjellen: lupl. r.

2. P. alpínum L., Fjellkampe; foderskal lika lainga med

borsten; ax ovalt-aflångt; de öfversta bladslidorna något uppblåsta. 3 .

Omkr. fotshög med vảnl. grönviolett ax, tjockare än hos föreg: art och terml. kort.

Ängar, helst i fjellen; Lpl. a., Norrl. spr.: Vb. t. a. åtm. nära fjellen, Hels. r. Gestr. 0, Sv. Dal. Verml. spr. Vestm. r., Göt. Dalsl. r.

b. Småax med ämne till en andra blomma. Foderskal afsmalnande uppåt (eller snedt tvärhuggna) med mycket kort eller otydligt borst. Öfversta bladslidan något uppblåst.

3. P. phalaróides Köl.; småax ofta med groddknoppar; ax lansettlikt. 3 .

Något högre än föreg. art med något blågröna blad och smalare, vanl. blekgrönt ax.

Torra back:ır, helst pâ kalkhaltig jordmån i slättbygder; Göt. spr.: Hall. Sk. t. a. Gotl. Öl. a. Blek.? Dalsl. inre Smål. 0, Sv. Söd. Upl. spr. Vestm. spr. (i s. delen) Ner. r., Norrl. Gestr. r. 4. P. arenárium L., Sandkampe; småax utan groddknoppar; ax afiingt kilubblikt. 2.

Några tum hög och $\mathrm{i}$ början ljust blågrön, snart vissnande och gulnande; foderskal på ryggen håriga.

Sandiga hafsstränder t. r.; Göt. Boh. Sk. Öl. Gotl.

\section{Dígraphis. Rörflen.}

1. D. arundinácea (L.) Trin.; bladsnärp utdraget; foderskal äggrunda, kölade, spetsiga och 3-nerviga; kronskal n. broskartade, nedtill hårbärande; foderskal med ovingad köl. 3.

4--5 fot hög med lång rotstock; vippa endast under blomningen utbredd; småax grôna eller grönvioletta, ensidigt gyttrade på vippgrenarne.

Stränder och andra fuktiga ställen, t. a.: Jtl. Lpl. t. r.

- coloráta, Randgräs, Menniskolif; blad hvitrandiga.

Allmänt planterad, dock funnen någon gång vild i Jtl. Dalsl. Vestm. och Vg.

63. Anthoxanthum. Vårbrodd.

1. A. odorátum L.; småax lansettlikt syllika med spetsiga foderskal. 1, 2. 
Omkr. 1/2 fot hög och tufvad med tågig rot, slutl. gulglänsande ax och ljusgröna blad; de ofruktsamma blommurna föga längre än den fruktsamma.

Ängar och backar, allmän.

\section{Hieróchloa. Myskgräs.}

1. H. boreális R. o. Sch.; vippa gles; hanblommor med mycket kort och rakt borst; alla bladen platta med glatta slidor. 2 .

1-2 fot hög med upptill långt bara strån; småax n. runda, blekbruna och glänsande; hanblommornas nedre kronskal föga klufna i spetsen, hvarifrån borstet utgår.

Kärr, stränder och fukt. ängar, men ej alla år på samma lokal; Lpl. spr., Norrl. spr.: Ång. r., Sv. r.: Söd. Upl. spr., Göt. Ög. spr. Smål. Vg. t. r. Dalsl. Hall. Sk. r.

2. H. alpina (Sw.) R. S.; vippa hopdragen; hanblommor med långt utskjutande och knäböjdt borst; rotskottens blad inrullade och trådlika, de öfriga platta. $2,3$.

Omkr. fotshög med i början aflånga småax, som äru större än hos föreg. art; öfre hanblommans nedre kronskal klufvet nedom midten med dubbelt så långt borst; den nedre hanblommans borst kortare och $n$. rakt.

'I'orra sandiga backar högt upp i fjellen; I pl. Torn. Lpm. a. i fjellregionen, spr. i hjörkreg.

\section{Nardus. Stålgräs, Stagg.}

1. N. stricta L.; nedre kronskalet utlöpande i ett kort borst, det öfre borstlöst. 2,3 .

Strån omkr. $1 / 2$ fot höga, borstlika och upptill bara, förlängda of van axet; småax vanl. stålblå, i hörjan tilltryckta, sedan utstående från strået.

Magra, ofruktbara och något fukt. ställen, helst i skoggtrakter, t. a.: Gotl. t. r.

\section{Ordn. TRIGYNIA.}

\section{Móntia. Källört.}

1. M. fontána L.; blad aflånga -- tunglika. Enårig eller mångårig. 3 .

På dyiga ställen omkr. fingerhög, upprätt, enårig och stundom rodnande; $i$ kallsällor omkr. fotslång, flytande, mångårig och mörkgrön.

Våta ställen, helst källdrag och dypölar, mångenst.: Öl. Gotl.r.

\section{Kœnígia.}

1. K. islándica L.; blad aflånga — spadlika; rot enårig. 3,4 .

Liknar en liten Polygonum eller Peplis och är 1-4 tum hög, späd och ofta rorlnande.

Văta ställen, helst källdrag, högt upp i fjellen; $L p l$. r., Norvl. Jit. r. 
III. triandria. 68. IV. tetrandria. 69, 70, 101

\section{Holósteum. Fogelnarf.}

1. H. umbellátum L.; blad vanl. aflånga; rot 1-2-årig. $1,2$.

Stjelkar omkr. fingerhöga; flock vanl. 5-blommig; kronblad vanl. 3-tandade; blomskaft slutl. nedböjda. Liknar năgot Cerastium semidecandrum och vissnar snart.

Torra backar; Göt. Gotl. r. öl. a. Kalmarl. Blek. r. Sk. spr helst i ö. delen.

\section{- 4 Klassen. TETRANDRIA.}

1 Ordn. MONOGYNIA.

69. Knáutia. Åkerrëdd.

1. K. arvensis (L.) Coult.; de yttre blommorna i blomkorgen vanligen större än de öfriga; fruktkrona af 8-10 borstlika tänder. 3 .

Stjelk omkr. 2 fot hög och sträfhårig med välluktande blommor och sträfhåriga blad; rotblad odelade. Någon gång äro alla blommorna lika stora; blad stundom n. hela.

Åkerrenar och torra ängar, Göt. Sv. a., Norrl. Gestr. Med. t. a. Ång. spr. Vb. r. Herj. spr. Jtl. t. r.

\section{Scabiósa. Ängvädd.}

a. De yttre blommorna i blomhufvudet större än de inre. De flesta bladen parbladigt delade.

1. S. Columbária L.; svepeblad stälda i en krans, n. jemnbreda och kortare än blommorna; blomkrona 5klufven; rotskott kortskaftade med trubbiga, mer eller mindre inskurna blad. 3,4 .

Stjelk omkr. 2 fot hög och vanligen föga hårig; de nedre bladen lyrformiga, de öfre parbladigt delade med jemnbreda flikar; småsvepe upptill hinnaktigt och n. helt; blommor ljusblå eller blekt violetta.

Torra backar och berg, helst (alltid?) på silurisk formation; Göt. Gotl. spr. Öl. a. Sk. t. a. Blek. r. Smål. t. r. Ög. Vg. spr., $S v$. Sö̉. r.

2. S. svavéolens Desf.; svepeblad smalt lansettlika spetsade, stälda i $2-3$ kransar och hälften så långa som blommorna; blomkrona stundom 4-klufven; rotskott långskaftade med vanl. hela och spetsiga blad. 3, 4.

Liknar föreg., men har smärre blomhufvud på kortare skaft, omkr. fotshög och äfven nedtill finhårig stjelk; smăsvepe upptill tandadt; fruktkronans tänder blott dubbelt så långa som småsvepets bräm; blommor blekt violetta, välluktande.

Sandfält; Göt. Skåne spr. helst i ö. delen.

b. Alla blommor lika stora. Alla blad hela. 
3. S. Succisa L., Blåhattar; svepeblad i $2-3$ kransar, lansettlika och kortare än blommorna; blomkrona 4. klufven. 3,4 .

Stjelk omkr. 2 fot hög och upptill småludèn; de öfre bladen lansettlika och ofta tandade, de nedre aflånga och helbräddade; småsvepe med 4 bladartade tänder; blommor vanl. blåaktiga; rot afstympad.

Något fukt. ängar; Göt. Sv. a., Norrl. Herj. Jtl. spr. Gestr. - Med. t. a. Ång. Vb. r.

71. Gálium. Måra.

A. Blad utan nållik udd, vanl. (isynnerhet de mellersta) 4 i hvarje krans. Blommor hvita. Mångåriga växter.

a. Blad 3-nerviga, bredare än den icke taggiga stjelken. Frukt vanl. hărig. 1. G. boreale. 2. G. rotundifolium. b. Blad ennerviga, bredare än den fintaggiga, slaka och trådlika stjelken. Frukt glatt. 3. G. palustre. 4. G. trifidum.

B. Bladens medelnerv förlängd till en nållik udd, vanl.omkr. 6 eller flera i hvarje krans. Blad ennerviga.

a. Blomknippen utgående både från bladvecken och vanl. äfven från stjelkens spets, ofta förenade till en vippa. Mångåriga växter.

1. Stjelk sträf af fina taggar, slak, trådlik och smalare än bladen. Blommor hvita. 5. G. uliginosum.

2. Stjelk utan taggar. Eljest som föreg. - 6. G. silvestre. 7. G. saxatile.

3. Stjelk utan taggar, teml. grof och styf (ofta upprätt), lika bred som bladen eller bredare. Blommor gula eller gulhvita. 8. G. verum. 9. G. erectum.

b. Blomknippen fåblommiga, långt skilda och blott utgående från bladvecken. Stjelk nediiggande och taggig.

1. Stjelk fint och glest taggig, trådlik och mycket smalare än bladen. De allmänna blomskaften öfverskjutande bladen. Nötter af blommans storlek. Mångårig växt. 10. G. triflorum.

2. Stjelk tätt taggig och snärjande, mycket mjuk och oftast smalare än bladen. De allm. blomskaften föga öfverskjutande bladen. Nötter mycket större än blomman. Rot enårig. 11. G. Aparine.

1. G. boreále L., Hvitmåra; blad lansettlika; stjelk upprätt och styf. 3 .

Omkr. fotshög och ljusgrön; vippa teml. tätblommig; stjelk något smalare än bladen, glatt eller finluden; rotstock rödaktig.

Magra ängar och backar, a. till fiellens barrskogsregion.

2. G. rotundifólium L., Bredbladig Måra; blad bredt ovala; stjelk nedliggande och skör. 2.

Stjelkar några tum långa och trådlika; blad ljusgröna och ett par linier breda; vippa mycket gles; fruktens hắr krökta. Liknar något en form af Gal. Aparine, men saknar taggar.

Barrskog, helst af tall bland ormbunkar (Pteris); Göt. Öl. r. Gotl. t. r. 
3. G. palustre L., Kärrmåra; blad aflanga-lansettlika; frukt nästan slät; frukı̈amne mindre än den vanl. 4klufna (säl lan 3-klufna) kronan. 2, 3.

Späd, vanl. fotslång och föga sträf med vid torkning lätt svartnande blad; vippa rikblommig med utstående blomskaft.

Våta ställen, allmän.

- elongátum (Presl.); 2-3 fot lång med större blommor och frukter; blad ofta 6 i krans, mera sträfva; frukt småknottrig.

På sarnma ställen som hufvudarten, troligen ej r.; uppgifven för Sk. - Upl.

4. G. trífidum L.; blad aflånga-lansettlika; frukt slät;

fruktämne n. lika stort som den 3-klufna kronan. 3.

Lik föreg. art, men mera sträłi och ej svartnande; vippa fåblommig med slutl. nedböjda blomskaft.

Stränder; och kärr; Lpl. spr., Norrl. spr.: Jtl. Herj. r., Sv. spr.: Ner. t. r. Dal. Vestm. r., Göt. Boh. Dalsl. Vg. Smål. Ög. Gotl. $r$.

5. G. uliginósum L.; blad lansettlika-aflanga, 4-6 i krans; frukt småknottrig. $2,3$.

Liknar de båda föreg. arterna, icke svartnande vid torkning; vippa rikblommig. Är ganska föränderlig nch liknar stundom de båda följ. arterna, stundom $G$. Aparine, men har smärre blad och smärre frukter än den sistnämnda samt bladens medelnerv föga sträf.

Mer eller mindre fuktiga ställen, allmän.

6. G. silvestre Poll.; blad jemnbredt lansettlika-aflånga, 6--8 i krans; frukt nästan slät; stjelk och blad vanl. glatta. 2,3 .

Liknar mycket föreg. art, vanl. omkr. $1 / 2$ fot lång, ej svartnande vid torkning; vippa mindre rikhlommig.

Fuktiga. ställen pă berg; Göt. Öl. t. a. Gotl. Sk. Blek. r. Smål. t. r. Ög. Vg. r., $S v$. Upl. r.

- hirtum; stjelk och blad ludna.

Troligen mycket r.; Göt. Vg. på Kinnekulle (förf.)

7. G. saxátile L., Stenmaira; blad 4-6 i krans, de nedre omvändt äggrunda, de öfre jemnbredt lansettlika; frukt småknottrig; stjelk glatt. 3 .

Stjelkar talrika, 3-8 tum långa och tufbildande; vippa teml. rikblommig; blomkrona i början rödaktig; blad omkr. liniebreda. Svartnar lätt vid torkning.

Steniga fuktiga ställen; Göt. Vg. Boh. r. Hall. Sk. Smål. spr. Blek. r.

8. G. verum L., Gulmiira, Jungfru Marie sünghalm; blommor gula; blad 8-12 i krans, jemnbreda med nedböjda kanter; vippa tätblommig med korta fruktskaft; frukt slät och glatt eller finluden. 3, 4. 
Stjelk omkr. fotshög, oftast upprätt, finluden och otydligt kantig; blad n. trådlika, undertill silkesludna med tydlig medelnerv och vid torkuing lätt svartnande; kronflikar trulibiga med kort udd.

Torra ängsbackar och åkerrenar: Göt. Sv. a., Norrl. spr.: Gestr.-Med. a. Vb. r.

* G. elátum Thuill.; blommor gulhvita; blad 6-8 i krans, aflånga-lansettlika med icke nedböjda kanter; vippa något glesblommig med teml. korta och utstående fruktskaft; frukt smăknottrig. 3 .

Stjelk omkr. 2 fot hög och uppstigande, fyrkantig och vanl. glatt; bladens medelnerv otydlig. Står midt emellan föreg. orh följ. art, mellan hvilka äfven bastarder förekomma, isynnerhet i Bohus]. skärgård.

Ängsbackar: Göt. Vg. Boh.-Sk. Smäl. Ög. t. r.

9. G. erectum Huds.; blommor nästan hvita; blad 8 i krans, lansettlika med icke nedböjda kanter; vippa glesblommig med utdragna och upprätta fruktskaft; frukt nästan slät. 2,3 .

Liknar något $G$. boreale, men är omkring 2 fot hög; stjelk uppstigande eller upprätt, fyrkantig och vanl. glatt; lilad med tydlig medelnerv, glatta och icke svartnande; kronflikar spetsiga. Blommar tidigare än föreg. art.

Ängsbackar och åkerrenar; Göt. t. r.: Da!sl. 0, Vg.?, Sv. spr.: Ner. Verml. Dal. t. r. Norrl. Gestr. Hels. Ång. Jtl. t. r.

10. G. triflórum Mich., Välluktande Måra; blad aflånga eller aflångt lansettlika, omkr. 8 i krans; blommor grönhvita; frukt med krökta hår; allmänna blomskaft 2-3-blommiga. 2, 3.

Liknar Asperula odorata och är liksom denna välluktande, särdeles vid torkning; stjelk omkr. fotslång.

Skuggiga klippor, helst i lägre fjelltrakter, r.; Lpl., Norrl. Vb. - Hels. Jtl., Sv. Ner. Verml., Göt. Dalsl.

11. G. Aparíne L., Snärjgräs; blad vanl. lansettlika, omkr. 8 i krans med taggig medelnerv; blommor hvita; frukt krokborstig. 2, 3 .

Stjelk 3-4 fot lång med uppsvälda leder; frukt på ytan knölig. Någon gång, t. ex. på skuggrika ställen på berg, kunna bladen vara ganska breda och ovala.

Helst på hafsstränder och i steniga lundar, stundnm ogräs i åkrar; Göt. Sv. spr., Norrl. r. - Utbredningen ej säkert känd. - infestum; med smärre blommor och frukter; blommor gulgröna; frukter föga grynprickiga.

Allmänt ogräs: Lpl. r.

* G. spúrium L.; frukt vanl. glatt och glänsande, ej knölig; stjelkleder ej uppsvälda; blad $6 \mathrm{i}$ krans; blommor hvitgula. 
Ogräs i åkrar, helst bland lin och potates; Göt. t. r.: Sk. Smål. spr. Dalsl.?, Sv. t. r.: Dal. 0, Norrl. Gestr. r.

\section{Aspérula. Madra.}

1. A. odoráta L., Myskmadra, Amur; blad aflíngalansettlita; de nedre 6 , de öfre vanl. 8 i krans; frukt krokborstig; kronpip nedtill vidgad. 1, 2.

stjelk omkr. fotshög, n. upprätt och glatt (saint utan taggar); blad ennerviga uddspetsiga med sträfva kanter och nerv, eljest glatta; blommor hvita i upprepadt 3-greniga knippen trån stjelkens öfre del.

Lundar; Göt. spr : Sk. a. Hall. Smål. Ol. Gotl. t. r. Boh. 0, Sv. t. r.: Söd. Upl. spr. Dal. 0, Norrl. Gestr. Hels. Ång. Jtl.t. r. 2. A. tinctória L., Färgmadra; blad jemnbrecta, omkr. 6 eller färre i krans, de öfre stundom motsatta; frukt glatt och slät; kronpip nedtill afsmalnande. 2,3 .

Omkr. fotshög, upprätt och glatt; blommor rödaktiga i täta qvastlika knippen; blomskärmar äggrunda spetsiga; rotstock röd; blommor stundom tretaliga. Svartnar lätt vid torkning.

Berg och backar; Göt. Gotl. Öl. a. Ög. spr. Smål. Vg. r, Sv. Söd. Upl. Ner. r.

\section{Sherárdia. Alermadra, Madd.}

1. S. arvensis L.; blad sträfva, de nedre motsatta och korta, de öfre $4-6$ i krans och aflånga-lansettlika, uddspetsiga. 3 .

Stjelk omkr. 1/2 fot lång eller lerunder, nedliggande och grenig med enkel enårig rot.

I åkrar, helst i slättbygder, stundom i lundar; Göt.r.: Sk. a. Hall. Öl. t. a., Sv. r.: Ner. Dal. 0, Norrl. Jtl. r.

\section{Globulária. Bergstirabba.}

1. G. vulgaris L.; rotblad spadlika, kortare än skaftet och upptill tretandade; stjelkblad talrika, smalt lansettlika. 2 .

2-6 tum bög, tufvad och glatt med en blomkorg i toppen af hvarje stjelk, små och blå (någon gång hvita) blommor och läderartade blad.

Tem]. ofruktbara ställen på kalkberg; Göt. Öl. mångenst., Gotl. allmän i n. och mell, delen.

75. Plantágo. Kämpar, Groblad.

A. Blad mer eller mindre breda, bågnerviga. Kronpip glatt.

1. P. major L., Groblacl, Läkeblackor; ax långt, smalt och jemntjockt; ståndareknappar brunvioletta; de hinnaktiga kronflikarne och skärmbladens hinnkanter bruna. 2,3 .

Onkkr. 1/2 fot hög; stänglar upprätta och icke fårade; blad mycket breda och stora, äggrunda-ovala och gỉest tandade, van]. 
glatta och långskaftade och ofta lika långa som stängeln; fröhusets rum med $3-4$ frön.

Ruderatväxt, allmän.

- scopulórum; blad långa och groftandade; stänglar $2-3$ tum höga.

Hafsstränder spr. åtm. i Göt. och Sv.

2. P. média L., Slåsstämpar; ax aflångt eller n. jemntjockt; ståndare ljusröda med hvita knappar; kronflikarne och skärmbladens hinnkanter silfverlıvita. 2, 3.

Omkr. fotshög; stänglar nedtill bågböjda och sedan upprätta, föga fårade; hlad breda, ovala och helbräddade, mjukludna, n. oskaftade och mycket kortare än stängeln.

Torra öppna fält; Göt. t. a.: Öl. r. Blek. inre Smål. Bol. t. r., Sv. t. a., Norrl. r.: Gestr. Jtl. spr., Lpl. r.

3. P. lanceoláta L.; ax vanl. äggformigt; ståndare hvita med blekgula knappar; kronflikarne och skärmbladens hinnkanter bruna. 1-3.

Från några tum till 2 fot hög; stänglar uppstigande eller upprätta, fårade: hlad lansettlika-aflånga och glest tandade, vanligen långskaftade och kortare än stängeln

Torra ängar och åkerrenar; Göt. a., Sv. t. a : Dal. t. r., Norrl. spr.: Jtl. r. Herj. r.?, Lpl. r.

- dúbia; nedtill hvitullig; ax n. klotrundt; lågväxt.

Hafsstränder; Göt. spr.: Smål. Ög. r. Boh.?, Sv. r.; stundom äfven inuti landet, t. ex. Smål. Upl.

B Blad smala och otydligt nerviga. Ax vanl. smalt och n. jemntjockt.

a. Kronpip glatt. Ståndareknappar brunaktiga. Stift kort. Stängel otydligt färad.

4. P. tenuiflóra Kit. (enl. F. Areschoug); blad vanl. trådlika och helbräddade, sällan liniebreda och tandade; kronflikar blekgula; skärmbladens hinnkanter hvitaktiga. 2, 3 .

Vanl. blott 1-2 tum hög och n. glatt; ax stundom mycket kort; stänglar föga öfverskjutande bladen samt ofta nedtryckta mot marken; fröhus flerfröigt. $P$. minor Fries.

Ufruktbara och torra, dock under vintern ofta öfversvämmade ställen; Göt. Öl. spr. på Alfvaren.

b. Kronpip finhårig. Ståndareknappar gula. Stift långt. Stängel ej fårad.

5. P. marítima L.; blad vanl. halftrinda, stundom platta och glest tandade; kronflikarne och skärmbladens hinnkanter bruna. 3, 4 .

Omkr. $1 / 2$ fot hög, n. glatt och tufvad med köttig rotstock: stänglar vanl. upprätta och föga öfverskjutande bladen; fröhus tvåfiöigt.

Hafsstränder; Göt. Sv. a., Norr?. spr.: Hels. Med.? 
6. P. Corónopus L; blad platta, parklufna eller delade; kronflikar blekgula; skärmbladens hinnkanter hvitaktiga. 3 .

2-6 tum hög och hårig med tvåårig, lång pålrot; ax stundom mycket kort; stänglar längre än bladen och ofta nedtryckta; fröhus sexfröigt och trerummigt.

Dyiga hafsstränder; Göt. r.: Blek. Sk. spr. Hall. t. r. Ög. 0 . 76. Centúnculus.

1. C. mínimus L.; blommor n. oskaftade; blad ovala. 3. Stjelk omkring en tum hög, enkel eller grenig; de nedre bladen motsatta, de öfre skiftevis stälda och spetsiga; blommor hvita eller rödaktiga, utslagna vid middagstiden.

Fuktig sandjord, helst på hafsstränder, mindre ofta på sjö. stränder; Göt. r.: Sk. t. a. Hall. Blek. spr., Sv. Verml. r.

\section{Cornus. Kornell.}

1. C. suécica L.; blad äggrunda oskaftade; hlornmor svartröda i flock inom ett svepe at 4 ovala och spetsiga blad. 2,3 .

Ört med $1 / 2$ fot hög, enkel eller nära hlommorna grenig stjelk med bågnerviga ljusgröna blad. Blomflockens hvita svepe liknar en blomkalk. De röda bären kallas Hönsbär.

Fukt. ängar och mossar; Lpl, a., Norrl. mångenst.: Vb. Jtl. a. Gestr. t. r., Sv. Dal. Verml. mångenst. helst nära norska fjellryggen, Vestm. r. Upl. och Söd. t. r. (helst i skärgården), Göt. Dalsl. Boh. mångenst. (mot norska gränsen a.) Hall. Sk. inre Smål. Vg. spr. Ög. r. (i skärgården och vid Vettern) Kalmarl. Blek. Goti. r. - Saknas i Ner. och på Öland.

2. C. sanguínea L., Benced; blad äggrunda-ovala skaftade; blommor hvita i qrastlika knippen utan svepe. 3.

5-6 fot hög buske med hård ved samt på hösten rodnande hark; stenfrukter svarthlå.

Lundar, helst pâ silur. formation; Göt. Öl. a. Gotl. spr. Blek. r. Sk. spr. Boh. Dalsl. Vg. r. Ög. spr. på șilur. form.

\section{Trapa. Sjönöt.}

1. T. natans L.; blommor kortskaftade, samlade i de öfre bladvecken; nöt med 4 tagglika bihang. 3 .

Stjelk 1-2 fot lång; rot enårig; de öfre (flytande) bladen rutformiga och upptill tandade; blommor hvita; nötter stora och svarta.

Grundt vatten i sjöar, mycket r.; Göt. Skåne sjön Immeln (fordom äfren funnen i Smål.).

\section{Majánthemum.}

1. M. bifólium (L.) D.C.; blad vanl. två, skiftevis stälda och skaftade. 2.

Stjelk $1 / 2$ fot hög, enkel och vid bladens fäste bågböjd. De rödaktiga iären kallas Ekorrbär.

Skogsängar, allmän. 


\section{Alchemilla.}

A. Rotstock tjock; blomknippen i spetsen af grenarne. Stjelk fảbladig.

1. A. vulgaris L., Daggliåpa, Daggskålar; blad rundadt njurlika, kupiga, strålformigt veckade och inskurna i rundade och öfverallt sågade flikar; blomknippen jemnhöga. 1, 2.

Omkr. $1 / 2$ fot hög, mer eller mindre hårig, stundom n. glatt; blomkalkens pip klocklik; de nedre bladen med 7-9 flikar, de öfre med 3-5.

Ängar och betesmarker, allmän.

2. A. alpina L.; blad fingerlikt delade; bladflikar (småblad) n. aflånga och upptill tandade. $2,3$.

Lika hög som föreg. och silkeshårig med of vanpå vanl.glatta blad; blomkalkens pip n. klotrund; blomknippen ofta äfven sittande nedpå grenarne.

Helst i fjellen, stundom nära hafvet; Lpl.-Dal. a. i fjellen, dock Torn. Lpm. r.; Vb. a. i fjelltrakter, Ang. r.; Göt. Boh. spr. i skärgården, Hall. Sk. r.

B. Pålrot smal och enårig. Blommor gyttrade i blomnystan, motsatta mot bladen.

3. A. A'phanes Leers; blad n. vigglika, klufna i 3 vigglika tandade flikar. 3.

Stjelk i början nedtryckt till marken och ett par tum lång, sedan uppstigande och ända till inemot fotslång: hlomkalkens pip klocklik; stjelk och blad småludna; yttre kalkflikar otydliga.

Sandiga fält och åkrar; Göt. Vg. Hall. t. r. Sk. Gotl. Öl. a. Blek._Ög. mångenst.

\section{Sangvisorba. Blodtopp, Pimpinell.}

1. S. officinális L.; ståndare lika långa som kalkens flikar. 3.

1-2 fot hög och upprätt med omkr. 4-pariga blad, de flesta stälda vid stammens bas; småblad tandade; blomhufvud omkr. $1 / 2$ tum långa.

Något fuktiga ängar; Göt. Gotl. t. r., dock mycket ymnig i vissa trakter.

\section{Thésium. Spindelört.}

1. T. alpinum L.; kalkens brämflikar lika långa med frukten; stjelkar n. enkla; blomklase slutl. ensidig; blad ennerviga. 2,3 .

Stjelkar vanl. flera tillsammans, $1 / 2$ fot höga, uppstigande; blommor mycket små, inuti hvita; blad skiftevis stälda.

Torra ängsbackar; Göt. Vg. r. Ög. mångenst. (helst i Sommabygden och södra Stăngådalen) n. ö. Smăl. spr. (helst onkr. Vimmerby) Blek. $r$. 


\section{Ordn. 'TETRAGYNIA.}

\section{Radíola. Dverg-lin.}

1. R. linóides Roth; blad ovala oskaftade. 3, 4 .

1-3 tum hög med mycket små blad.

Sandiga stränder; Sv. Verml. helst vid Venern, Göt. Dalsl. Vg. helst vid Venern, Boh.-Sk. (helst i skärgården) t. a., Blek. t. a. Smål. mångenst. (äfven i skärgården) Ög. r. (vid Roxen) Öl. spr.

1. B. aquática (L.) D.C.; blommor oskaftade. 3, 4 .

Stjelk 1-4 tum lång, nedliggande eller upprätt, ofta grenig, i vatten grön, på uttorkade ställen rödaktig. Liknar en liten Callitriche, men skiljes bl. a. genom de syllikt spetsiga bladen.

Dyiga stränder; Göt. r.: Sk. Blek. mångenst. Öl. Gotl. 0, Sv. r.: Söd. Upl. mångenst. Dal.?, Norrl. Gestr.-Vb. r.

\section{Potamogéton. Nate.*)}

A. Blad vanl. omkring fingerbreda eller bredare (hos P. gramineus och $P$. nitens stundom smalare), de nedre eller alla spiralstälda.

a. Alla bladen, isynnerhet de öfre, långt skaftade, de öfre flytande (på vattenytan) och läderartade: blad helbräddade.

1. De nedre bladens skifvor förvissnade vid blomningen. 1. P. natans.

2. De nedre bladens skifvor qvarsittande vid blomningen. 2.P. sparganiifolius. 3. P. fluitans. 4.P. polygonifolius.

b. Både de flytande och de nedsärikta bladen kort skaftade, tunna och hinnaktiga med $n$. hjertlik bas samt helbräddade. 5. P. coloratus.

c. De nedsänkta bladen tunna och hinnaktiga med afsmalnande bas och finsågade samt (åtm. de flesta) kortskaftade. Flytande blad sällan utbildade. 6. P. lucens.

d. De nedsänkta bladen tunna och hinnaktiga med afsmalnande has samt helbräddade och oskaftade. Flytande blad (som stundom felslå) $n$. läderartade ooh vanl. långt skaftade. 7. P. rufescens. 8. P. gramineus.

e. De nedsänkta bladen tunna och hinnaktiga med afrundad och ofta omfattande bas samt helbräddade och oskaftade. Flytande blad (som kunna utbildas hos $P$. nitens och $P$. salicifolius) n. läderartade och kortskaftade. 9. P. nitens. 10. P. salicifolius. 11. P. prælongus. 12. P. perfoliatus. 13. P. decipiens.

f. Alla blad nedsänkta, tunna och hinnaktiga med afrundad bas, sågade, krusiga och oskaftade. 14. P. crispus.

B. Alla blad motsatta och omkr. fingerbreda, nedsänkta, hinnaktiga och stjelkomfattande. 15. P. densus.

C. Blad oskaftade jemnbreda, mycket långa och smala (omkr. en linie breda eller smalare), alla nedsänkta och hinnaktiga. Gräslika växter med grenig stjelk.

*) Dessa växter blomma på eftersommaren. 
a. Stipler nedtill hopväxta till en loort slida; fruktbärande ax med tätt sittande nötter. 16. P. compressus. 17. P. acutifolius. 18. P. obtusifolius. 19. P. pusillus.

b. Stipler nedtill hopväxta till en kort slida; fruktbärande ax med glest sittande nötter. 20. P. mucronatus. 21. P. gracilis. 22. P. trichoides.

c. Stipler hopväxta med bladets neủre del till en lång slida; fruktbärande ax med glest sittande nötter. Stjelk trådlik med mycket långa axskaft. 23. P. pectinatus. 24. P. marinus.

1. P. natans L., Gäddnate, Bläcker; de flytande bladen ovala-aflånga, vanl. med rundad eller något hjertlik bas och med kort spets; de nedsänkta lansettlika.

De flytande bladen tumsbreda, mörkgröna eller lefverbruna; stjelk enkel; nötter hoptryckta med trubbig rygg och gröna.

Sjöar och sakta rinnande vatten, allmän: Lpl. r.?

2. P. sparganiifólius Læst.; flytande blad larsettlika och spetsiga (uppåt och nedåt betydligt afsmalnande), de nedsänkta jemnbredt lansettlika.

De flytande bladen fingerbreda och flera tum långa, de nedsänkta mer än en fot långa; axskaft mycket tjockare än den vanl. enkla stjelken.

Strömmar, mycket r.; Ipl., Norrl. Vb.

3. P. flúitans Roth; flytande blad aflänga-lansettlika och trubbiga, de nedsänkta lansettlika.

Blad 2-3 tum långa, de flytande $1 / 2$ tum breda och lefverbruna; nötter på ryggen kölade. Liknar $P$. natans.

Rinnande vatten, mycket r.; Göt. Sk. Gotl. Smål. (Ög.?), Sv. Upl.

4. P. polygonifólius Pourr.; de flytande bladen äggrunda eller aflånga-lansettlika med kort spets; de nedsänkta aflånga - lansettlika.

Blad föga mer än fingerbreda, mörkgröna eller brunaktiga; axskaft smalare än hos $P$. natans; stjelk något grenig; nötter foga hoptryckta med trubbig rygg, tätt sittande och slutl. rodnande. De nedersta bladens skaft äro stundom ganska korta.

Skogsbäckar; Göt. t. r.: Smål. Blek. spr. Öl. Gotl. 0, Sv. Verml. Dal. r.

5. P. colorátus Vahl; blad ovala-äggrunda; nötter med kölad rygg.

Liknar mest former af $P$. gramineus (då dennes "nedre" blad felslagit) eller $P$. polygonif., men är utmärkt genom de ljusgröna, hinnaktiga och nätådriga, teml. stora bladen; ax tätblonımiga; axskaft föga tjockare än den korta (2-4 tum långa) och n. enkla stjelken.

I grundt sött vatten r.; Göt. Sk. Blek. Gotl.

6. P. lucens L., Grofnate; blad aflånga-lansettlika, vanl. trubbiga med udd, nedtill afsmalnande till ett kort skaft; axskaft tjockare än den greniga stjelken. 
Stor och grof med glänsande gröna, tumsbreda och ofta $1 / 2$ fot långa, nätådriga blad; nötter med något trubbig rygg; ax tätblommiga.

Helst i sjöar, stundom i rinnande vatten; Göt. Ög. t. a. Smäl. spr. Blek. r. Sk. Hall. a. Boh. Dalsl. r. Vg. spr., Sv. Söd. Upl. t. a. Ner. t. r. Vestm. Dal. r., Norrl. Med. r.

acuminátus (Schum.); blad långspetsade och mycket långa.

Sällsynt; Göt. Ög. vid Stångåns utlopp i Roxen.

- Zízii (M. K.); de öfre bladen smärre, längre skaftade och flytande.

Sällsynt; Sv. i Mälaren vid Stockholm.

7. P. rufescens Schrad.; de flytande bladen aflånga och trubbiga, nedåt spetsiga, längre än skaften; de nedsänkta lansettlika, nedtill afsmalnande, upptill med utdragen och trubbig spets; axskaft föga tjockare än stjelken.

De flytande bladen vid torkning rodnancie; de nedsänkta omkr. fingerbreda; nötter platta med hvass rygg; stjelk n. enkel. Stillastående och rinnande vatten; Lpl. Norrl. Sv. t. a., Göt. Dalsl. t. a. Vg. spr. Boh. Hall, inre Smål. t. r. Ög. Sk. t. a. Blek. r. Kalmarl. spr.

nigrescens Fr.; flytande blad kortare än skaften, slutl. svartnande; nötter (i torrt tillstind) med kölad rygg.

Rinnande vatten, mycket r.; Lpl., Göt. Smål. Hall.

8. P. gramíneus L.; de flytande bladen ovala-aflånga och spetsiga, vanl. nedtill afrundade och kortare än skaften; de nedsänkta smalt lansettlika och n. spetsiga, nedtill afsmalnande; axskaft tjockare än stjelken.

De nedsänkta bladen något sträfva i kanten; nötter något plattade med trubbig rygg; stjelk mycket grenig; ax något glesa. I grundt vatten felslå stundom "de nedre" bladen.

I vatten, helst i rinnande, allmän.

9. P. nitens Web.; de flytande bladen (ofta felslående) aflånga-lansettlika och $n$. trubbiga, nedtill afsmalnande och längre än skaften; de nedsänkta lansettlika och spetsiga, nedtill rundade, breda och halft stjelkomfattande; axskaft tjockare än stjelken.

De nedsänkta bladen utböjda och i kanten sträfva; nötter något hoptryckta med trubbig köl; stjelk mycket grenig; ax något glesa. Liknar föreg. art.

Rinnande vatten, stundom i sjöar; Göt. r.: Gotl. t. a. Öl. Ög. Kalmarl. Sk. spr. Hall. Blek.?, ${ }_{\text {Sv }}$. r.: Söd. Upl. spr., Norrl. Herj. Jtl. Hels. r., Lpl. r.

10. P. salicifólius Wolfg.; de nedsänkta bladen nedtill breda och halft omfattande, uppåt jemnt spetsade; axskaft föga tjockare än den n. enkla stjelken. 
De flytande bladen (som sällan utbildas) ovalit, vanl. nedtill afrundade och längre ân skaftet: de nedsänkta bladen omkr. fingerbreda och i kanten släta; nötter något hoptryckta med trul. big rygag.

Sjöar och rinnande vatten r.: $L p l$, Norr. V'b. Ang. Stl.

11. P: prælongus Wulf.; blad vanligen smalt lansettlika, nedtill breda och halft stjullomfattande, jemnt afsmalnande och med trubbad huflik spets; axskaft af den greniga stjelkens tjocklek.

Mycket grof med ljusgröna, ofta tumsbreda och öfver $1 / 2$ tot långa, i kanten släta blad; nötter med hvass rygg: ax något glesblommiga. På hösten blifva de öfre grenarnes blad stundom aflånga--ovala, sedan de Jånga nedre bladen förvissnat.

Sjöar och strömmar; Göt. r.: inre Smål. Ög. spr. Bôh.? Gotl. öl. 0, Sv. r.: Söd. Upl. spr.; Norrl. Gestr. spr. Hels.-Ång.? Vl,. spr. Herj. Jtl. r., Lpl. t. r.

12. P. perfoliátus L., Alnate; blad vanl. bredt ovala och trubbiga (stundom aflånga), nedtill hjertlika och halft stjelkomfattande; axskaft af den greniga stjelkens tjocklek.

Stjelk med tätt sittande och vanl. ganska kortc blad; nötter med kort stift och trubbigt trekölad rygg; ax tätblommiga.

Sjöar och rinnande vatten, allmän, stundom i hafvet: Gotl.r.

13. P. decípiens Nolte; blad lansettlikt aflånga, trubbiga

eller kort uddspetsiga, ej stjelkomfattande; axskafı tjockare än den greniga stjelken.

Liknar både $P$. prelongus och $P$. lucens och fïmodas var: bastard af dessa (eller af $P$. lucens och $P$. perfolicatus), helst som den ej sätter mogna frukter; blad åtm. tumsbreda, 3-4 tum långa och glänsande; fruktämnen med trubbig rygg.

Sjöar och rinnande vatten, mycket r.; $S v$. Upl. lilott i trakten af Stockholm och Upsala.

14. P. crispus L., Krusnate; blad jemnbredt aflånga. trubbiga och vanl. med kort udd, föga omfattande; axskaft knappt så tjocka som den greniga stjelken.

Teml. spenslig med ej fullt fingerbreda, ljusgrüna eller brumaktiga blad och korta glesblommiga ax; nötter med långt och nedböjdt stift samt $n$. trubbig och trekölad rygg.

Sjöar (helst grunda och leriga), dammar och bäckar: Göt. r.: Ög. Șk. Hall. mångenst. Smảl. t. 1. Öl. Grotl. 0, Sv. Süd. Upl. spr. Vestm. Ner. r.

15. P. densus L.; blad spetsiga, ovala-lansettlika, stundom smalt lansettlika.

Stjelk grenig; ax kortskaftade 2--3-blommiga; nötter med hvass rygg; stipler omrändt äggrunda. Torkad ̈̈r växten olivbrun.

I bäckar, mycket r.; Göt. Hall. i Söndrums s:n i Möllegård bäck (Neuman). 
16. P. compressus L.; stjelk platt, bladlik och nästan lika bred som bladen; blad trubbiga med udd; fruktbärande ax aflånga eller n. jemntjocka, mycket kortare än axskaftet och maingblommiga.

Blad ljusgröna, 3-5-nerviga och $1 \frac{1}{2}$ linie breda; nötternas köl trubbig; stift rakt. P. zostercefolius Schum.

Sjöar och åar, helst i slättbygder: Göt. ${ }^{\circ}$ Ör. t. r. Smål. Blek. r. Sk. spr. Boh. r., Sv. Söd. Upl. Vestm. spr. Ner. r., Norrl. Gestr. Med. r. Hels.?

17. P. acutifólius Link; stjelk som hos föreg. art; blad med utdragen och hvass spets; fruktbärande ax n. klotrunda, vanl. lika långa med axskaftet och fäblommiga.

Liknar föreg. art med n. lika så breda blad; nötter med hvass köl nch krölkt, qvarsittande stift.

Åar och sjöar i slättbygder; Göt. Boh. Hall. r. Sk. Ög. t. r., Sv. Söd. Upl. Ner. r.

18. P. obtusifólius Mert. o. Koch; stjelk n. tridlite och något plattad, mycket smalare än bladen; blad trubbiga med kort udd; iruktbärande ax äggformigt aflånga, af axskaftets längd eller något längre samt fîblommiga.

Blad något mörkare gröna, 3 -5-nerviga, något smalare än hos föreg. arter; nötter 3-kölade.

Sjöar, åar och dammar, helst ${ }^{7}$ i skogsbygder; Göt. r.: SkÖg. t. r. Hall. Öl. Gotl. 0, Sv. r.: Söd. Upl. spr., Norrl. Ang.r. 19. P. pusillus L.; stjelk n. tagelsmal och n. trind, smalare än bladen; blad trubbiga med udd eller kortspetsiga; fruktbärande ax n. klotrunda, mycket kortare än axskaftet och fảblommiga.

Blad mörkgröna, otydligt nerviga och $1 / 2$ linie breda; nötternas rygg 3-kölad.

Dammar och rölar, stundom åar och mindre sjöar, helst i slättbygder; Göt. spr.: Sk. a. Bolı. Ö]. Gotl. r., Sv. spr., Norrl. r.: Gestr. Hels. spr., Lpl. r.?

20. P. mucronátus Schrad.; stjelk trådlik och något plattad, mycket smalare än, bladen; blad trubbiga med kort udd; fruktbärande ax n. jemntjocka eller aflånga, kortare än axskaftet och fåblommiga.

Liknar mycket $P$. obtusifolius, men är ofta rodnande och har stundom smalare blad; nötternas rygg 3-kölad.

Sjöar, åar och dammar; Göt. Sk. a. Blek. r. Ög. spr., Sv. Söd. Upl. spr. Vestm. r., Norrt. Gestr. r. - Troligen äfven annorstädes.

- angustifólius; blad en half linie breda.

Sv. vid Stockholm (förf.) 
21. P. grácilis Fr.; stjelk tagelsmal och $\mathrm{n}$. trind, naigot smalare än de långspetsade bladen; fruktbärande ax n. jemntjocka, omkr. hälften så långa som axskaftet och fåblommiga.

Liknar P. pusitlus, men är finare och antingen ljus- eller mörkgrön eller något rodnande; blad vid torkning ofta upptill vridna eller liksum inrullade; nötter med trubbig rygg.

Grundt vatten, stundom i hafsvikar; Göt. Öl. Blek. Ög. Vg. r. Gotl.?, Sv. Upl. r., Norrl. Ang. r.

* P. rútilus Wolfg.; stjelk halftrind, styf liksom de slutl. (vanligtvis) rodnande bladen, som äro tydligt trenerviga. Sv. Upl. i Fasterna s:n.

22. P. trichóides (Cham. o. Schlecht.) Rchb.; stjelk trådlik och trind, ungefär lika bred som de tillspetsade bladen; ax jemntjocka, fåblommiga och betydligt kortare än axskaftet.

Liknar mycket 'följ. art och är utmärkt genom stora, n. runda nötter, hvaraf blott en utvecklas i hvarje blomma; blad otydligt tr enerviga.

I sött vatten r.; Göt. Sk. vid Lund.

23. P. pectinátus L.; axskaft utgående från spetsen af stjelken och grenarne; stjelkens öfre del flytande och blommande ofvan vattenytan.

Hela växten vanl. rodnande; blad tagelsmala, spetsade och 1-3-nerviga; nötter vid mognaden stora som mindre ärter, vanl. enstaka, i torrt tillstảnd på ryggen kölade och n. halfmånlika, nedtill tjockare.

Hafsvikar t. a.: Boh. Med.-Vb. r.?; sjöar och åar t. r. i Sk. Vg. Ög. Söd. Upl. Vestm. Jtl.

- zosteráceus (Fr.); de äldre grenarnes blad 3-5-nerviga, liniebreda och trubbiga, med kort udd. Vb. $r$.

Hafsvikar; Göt. Gotl. Blek. Smål. r., Sv. spr., Norrl. Ång.

24. P. marínus L.; axskaft vanl. utgående från stjellens nedre del och ofta mycket längre än stjelken; hela växten alltid nedsänkt och blommande under vattenytan.

Vanl. mörlgrön, stundom rodnande; blad något bredare än hos föreg. art (hvarifrån den är svår att skilja) och mindre spetsiga; nötter mindre än hampfrön, 2-4 tillsammans, torra rynkiga och n. omvändt äggrunda.

Hafsvikar t. r., dock mångenst. i Östersjön; sjöar r., neml. Ög. i Vettern och Tåkern, Jtl. flerst.; åmynningar på Gotl. flerst. 
IV. tetranidia. 86. V. Pentandria. 87-89. 115

86. Rúppia. Trådnate.*)

1. R. marítima L.; ståndareknappar (knapprım)n. klotrunda; nötter vanl. n. halfmånlika, stundom äggformiga; fruktskaft åtm. 4 gånger så långa som frukten. Liknar Potamogeton pectinatus till örten, men är alltid nedsänkt; det gemensamma blomskaftet kort, ej spiralvridet.

Hels. $r$.

Göt. spr.: Boh. Hall. t. r. Ög. r., Sv. spr., Norrl. Gestr.

2. R. bráchypus Gay; skild från föreg. genom n. äggformiga ståndareknappar, fruktskaft felslående eller korta (högst af fruktens längd), gemensamma blomskaftet föga längre.

Fruktens skal är hårdare än hos de öfriga arterna.

Göt. Boh. t. r. Hall. Sk. Blek. Ög. Gotl. r.

3. R. spirális L.; ståndareknappar aflånga; nötter vanl. äggformiga; fruktskaft mer än 4 gånger så långa som frukten.

Gröfre än de föreg. arterna, med ett mycket li̊ngt gemensamt blomskaft, som uppstiger till vattenytan och slutl. sammandrager sig spiralformigt.

Göt. spr.: Blek.-Ög. r., Sv. Söd. r.

\section{Klassen. PENTANDRIA.}

1 Ordn. MONOGYNIA.

\section{Glaux. Strandling.}

1. G. maritima L.; blad motsatta och oskaftade, lansettlika-aflånga, helbräddade och n. tegellagda. 3.

Stjelk vanl. fingerhög, nedliggande eller upprätt, glatt och ofta grenig; blommor oskaftade, ensamma i bladvecken.

Hafsstränder; Göt. Sv. a., Norrl. spr.; dessutom vid Mälaren på Upsala kungsäng.

88. E'chium. Blåtistel, Blåkunt.

1. E. vulgare L.; kronpip kortare än fodret; blad lansettlika med tilltryckta hår; stjelkens hår utstånde. 2,3 .

Stjelk omkr. 2 fot hög, upprätt och enkel med blommor i en af tätt sittande och korta ax sammansatt vippa.

Ruderatväst och ogräs; Göt. spr.: Sk. a. Gotl. t.a. Ö1. Smål. Boh. r. Dalsl. 0, Sv. t. r.: Söd. Upl. Verml. spr., Norrl. r.: Herj.?

\section{Lithospermum.}

1. L. arvense L., Sminkrot; foderflikar spetsiga; kronpip utdragen; nötter skrynkliga och mörkgrå. 1, 2.

*) Dessa växter förekomma vid hafsstränder och blomma frampå eftersommaren. 
Stjelk n. enkel och fotshög; de nedre bladen spadlika-tung. lika, de öfre aflånga-lansettlika, de flesta trubbade och utan tydliga sidonerver; blommor hvita med blåaktig pip, (sällan blå) i korta hladiga ax i stjelkens spets; rot röd och enårig.

Åkrar; Göt. a.: Dalsl. r., So. a.: Verml. Dal. spr., Norrl. spr.: Vb. Jtl. r. Herj.?, Lpl. r.

2. L. officinále L., Perlgräs, Stenfrö; foderflikar trubbiga; kronpip kort; nötter släta och slutl. glänsande hvita. 2, 3 .

Stjelk omkr. 2 fot hög, teml. grof och upptill mycket grenig; l)lad finhåriga, aflånga-lansettlika, spetsade och med tydliga sidonerver; blommor gulhvita $\mathrm{i}$ ax; rotstock tjock.

I bergsbranter och lundar, stundom ruderatväxt, helst nära hafvet samt vid Venern, Vettern och Mälaren, sällan (t. ex. i Ög.) annorstädes; Göt. t. r.: Öl. a. Dalsl. 0, Sv. Söd. Upl. Vestm. t. r., Norrl. Gestr. r.

\section{Pulmonária. Lungört.}

1. P. officinális L.; de öfre stjelkbladen äggrunda kort spetsade, de nedre n. tunglika eller med bredt vingadt skaft; rotskottblad n. hjertlika och skaftade, efter blomningen utväxande; nötier spetsiga. ' 1, 2.

Omkr. $1 / 2$ fot hög med blommor i korta ax (eller klasar) i stjelkens spets; rotstock teml. tjock; blommor i början röda, slutl. blåaktiga, sällan hvita; hlad mer än 1/2 tum breda.

Skuggrika lundar; Göt. Sk.-Ög. t. a. Öl. a. Vg. spr. Hall. inre Smål. t. r., Sv. Söd. Upl. t. a. Ner. Vestm. (i s. delen) spr., Norrl. Gestr. Hels. r.

2. P. angustifólia L., Smalbladig Lungört'; de öfre stjelkbladen äggrundt lansettlika spetsade, de nedre jemnbredt lansettlika; rotskottblad aflångt lansettlika, afsmalnande mot skaftet; nötter trubbiga. 2 .

Har slutl. himmelsblå blommor och tjockare rotstock äl föreg. art; stjelkblad $2-3$ linier breda.

Skogsängar; Göt. Sk. Șmål. r. Vg. t. r.

\section{Stenhammária.}

1. S. maritima (L.) Rchb.; blad ovala eller omvändt äggrunda. 3,4 .

1-2 fot lång, blådaggig och glatt med mycket grenig stjelk. Hafsstränder; Göt. Boh. h. o. d. helst i n. delen.

\section{Sy'mphytum. Vallört.}

1. S. officinále L.; de öfre bladen äggrundt lansettlika tillspetsade och nedlöpande; ståndareknapp i början dubbelt längre än strängen. 2, 3 .

Stjelk 1-2 fot hög och grof och liksom bladen glest sträfhårig; blommor vanl. livitgula, sällan violetta, nedhängande korta klasar och med korta utböjda kronbrämflikar.

Ruderatväxt och ogräs; Göt. t. r.: Sk.-Ög. spr., Sv. t. r.: Söd. Upl. Vestm. spr. 
2. S. orientále L.; blad icke eller knappt nedlöpande: de öfre äggrunda, de nedre skaftade; ståndareknapp lika. lång med strängen. . 2, 3 .

Liknar föreg., men är mera sträthårig; blommor röda eller violetta; kronans brämflikar upprätta.

Ruderatväxt r.; Göt. Sk. Smål. Ög. Vg., Sv. Söd. Upl. Vestm., Norrl. Hels.

\section{Anchúsa. Rast.}

1. A. officinális L., Oxtunga; blad lansettlika och helbräddade; blomkrona mörkblå med rak pip. 2, 3 .

Stjelk 2 fot hög och liksom bladen med utstående sträfva hår; blommor i täta ax (eller klasar') och teml. stora, utanpå violetta och inuti mörkblå med ljusblå och ludna knölar i svalget.

Ruderatväxt och ogräs i ålkrar, helst i slättbygder; Göt. a.: jnre Smål. Boh. Dalsl. r., Sv. a.: Ner. t. a. Verm]. r. Dal. t. r., Norrl. Gestr. Hels. Vb. r. (Ång. tillfällig).

2. A. arvensis (L.) Bieb., Ákerrast; blad aflånga eller lansettlika, bugtbräddade och smattandade; blomkrona ljusblå med krökt pip. 2, 3 .

Omkr. 1/2 fot hög och skarpt sträfhårig med mycket små, i börjạn röda hlommor; krnnans svalgknölar hvita sträfhăriga.

Åkrar; Göt. Sv. a., Norrl. r.: Gestr. Hels. spr., Lpl. r.

94. Myosótis. Förgät mig ej, Ögonblomma.

A. Krona tallriksformig (med platt bräm). Blomskaft vid fruktmognaden ej kortare än fodret.

1. M. palustris With.; rotstock krypande; blomfodrets hår raka och tilltryckta; foder tandadt eller klufvet. $2-4$.

Omkr. $1 / 2$ fot hög med större blommor än hos de öfriga arterna; kronpipens längd mindre än bredden af brämet; stift utdraget; stjelk kantig.

Fulktiga ställen, isynnerhet diken, 't. a.: Lpl. Ång. Boh. och v. Smål. t. r.?

2. M. cæspitósa Schulz; rot svag och lodrätt nedgående; blomfodrets hår raka och tilltryckta; foder deladt. $2-4$.

Liknar föreg. art och är måhända ej nog skild: den har dock mindre blommor, hvars pip är lika lång som brämets bredd, kort stift och vid fruktmognaden ofta nedböjda blomskaft. Blomklasar slut]. mycket längre än den öfriga delen af stjelken: hvilket sällan förekommer hos föreg. art. Stjelken är otydligt kantig.

Fukt. ställen, helst på stränder, särdeles vid Östersjön, nångenst.: Hall. Herj.?

3. M. silvática Hoffm.; rot teml. svag och sned; somliga af blomfodrets nedre hår raka, de öfriga i spetsen krökta, de flesta utstående; foder deladt. 2, 3. 
Stundom fotshög med n. lika să stora blommor som hos M. palustris; blomklasar kortare än den öfriga delen af stjelken; rotblad länge quarsittande och n. spadlika; kronpip af fodrets längd.

Fukt. ställen, helst vid bäckar i fjellen och andra bergstrak. ter; Lpl. a., Norrl. Herj. Jtl. spr. Ång. Med. r., Sv. Dal. åtm. i fjellen, Göt. Sk. a. Hall. Smål. Ög. r.

B. Krona trattlik (med skålformigt bräm). Fodrets nedre hår i spetsen krökta. Rot enårig.

a. Blomskaft (åtminstone de nedre) vid fruktmognaden lika långa med fodret eller längre.

4. M. arvensis Hoffm.; blomfoder slutl. upptill hopdraget, stundom (vid pressning;) något öppet; de nedre blomskaften slutl. längre än fodret och raka; kroupip kortare än fodret. 2,3 .

Omkr. $1 / 2$ fot hög med små blommor; blomklasar kortare än den öfriga delen af stjelken, hvars hår vanl. äro föga utstående.

Ruderatväxt och ogräs i åkrar, stundom i ängar, allmän.

- grandiflóra; mer än fotshög med dubbelt så stora blommor som hos hufvudarten; blomklasar vanl. längre än den öfriga delen af stjelken. 1, 2.

Blommar tidigare och liknar mycket $M$. silvatica, men har snart vissnande och ej så korta rotblarl.

Göt. Ög. mångenst. Dalsl. t. r. - Troligen äfven annorstädes.

5. M. hispida Schlecht.; blomfoder öppet; blomskaft lika linga som fodret och nedat bågböjda; kronpip kortare än fodret. 1, 2.

Stjelk spensligare än hos föreg. art, ofta fotshög vid fruktmognaden, och slankig samt vanl. med utstående hår; blomklasar slutligen längre än den öfriga delen'af stjelken; rotblad stundom spadlika; blommor mycket små.

Torra backar; Göt. t. a., Sv. spr.: Söd. Upl. a., Norrl. Herj. r. Jtl. t. a. - Troligen äfven annorstädes.

b. Blomskaft alltid kortare än fodret.

6. M. stricta Link; blomskaft slutl. tilltryckta till stjelken; kronpip kortare än fodret. 1, 2.

Stjelk vanl. mycket grenig vid roten, upprätt och styf, vanl. blott några tum hög med mycket små blommor; klasar vanl. bladiga nedtill.

Akrar och torra backar; Göt. a.: Boh.?, Sv. t. a., Norr Ipl. r.

7. M. versícolor Pers.; blomskaft utstående; kronpip slutl. dubbelt längre än fodret. 1, 2.

Spenslig och omkr. 1/2 fot hög med mycket små, i början gula blommor; stift längre än kronpipen.

Sandfält; Göt. Sk. t. a. Hall. r. Boh. t. r. Vg. inre Smål.r. Ög.-Blek. Öl. spr. Gotl. r., Sv. Söd. r. 
95. Asperúgo. Paddfot, Ormögon.

1. A. procumbens L.; blad aflånga-lansettlika trubbiga. $1,2$.

Stjelk omkr. fotslång; de öfre bladen i krans eller motsatta. Ruderatväxt och ogräs, mångenst.: Dalsl.-Lpl. t. r.

96. Cynoglossum. Hundtunga, Munklüss.

1. C. officinále L.; de öfre bladen lansettlika och mjukludna; blommor i korta och täta klasar med stora foderflikar; blomskaft bågformigt nedböjda. 2, 3.

$2-3$ fot hög och illaluktande; nötter omvändt äggrunda.

Ruderatväxt; Göt. a. åtm. i slättbygderna: inre Smål. Boh. Dalsl. r., Sv. t. a.: Verml. t. 1. Dal. r., Norrl. Gestr. Hels. r.

97. Echinospermum. Piggfrö.

1. E. Láppula (L.) Lehm.; blomskaft upprätta; nötter med 2 rader af taggar. 3.

Stjelk omkr. fotshög, styf och upptill grenig, stundom med utspärrade grenar; blad aflånga-lansettlika, de nedre afsmalnande till skaft och snart förvissnande; blomkrona trattlik. Liknar i blommande tillstånd Myosotis arvensis.

Ruderatväxt, helst i slättbygder; Göt. spr.: Gotl. Ol. a. inre Smål. Hall. Boh. r. Dalsl. 0, Sv. Söd. Upl. Vestrı. spr. Ner.t.r., Norrl. Gestr. Hels. Vb. r.

2. E. deflexum (Wahlenb.) Lehm.; blomskaft slutl. nedböjda; nötter med en rad af taggar. 2, 3 .

1-2 fot hög och styf med vanl. utspärrade grenar; de nedre bladen teml. varaktiga och breda; hlomskärmar vanl. aflägsnade från blomskaften; blomkrona tallriksformig, n. lika stor som hos Myosotis palustris.

Helst på skuggrika och något fuktiga ställen, stundom på mera öppna och torra ställen vid vägar, r. och mest förekommande i lägre fjelltrakter; Lpl., Norrl. Jtl. Herj. Med., Göt. Smål. på Tảberg.

\section{Prímula. Vifva.}

A. Blomfoder starkt nervigt och derigenom kantigt. Blad mjukludna och skrynkliga. Blommor gula.

a. Stängel utdragen och mycket längre än blomskaften. Blad tvärt hopdragna mot det vingade skaftet. Blommor lutande.

1. P. veris L., Guldvifva, Majnycklar, Oxläggor; blomfoder slutl. uppblåst, med äggrunda tänder; kapsel kortare än foderpipen. 1, 2.

Stängel omkr. $1 / 2$ fot hög; blommor talrika och välluktande, stälda i flock; blomkrona ljusgul med koukavt (uppstående) liräm och brandgula fläckar i svalget; hela växten finluden. P. officinális Jacq.

Ängar; Göt. a.: Vg. spr. Boh. t. r. Dalsl. spr. (i bergstrakten), Sv. a.: Verml. t. r. Dal. spr.. Norrl. Jtl. t. r. Gestr. spr. Hels. r. Med. t. r. Ång. r. 
2. P. elátior Jacq.; blomfoder smalt och tilltryckt, med lansettlika tänder; kapsel öfverskjutande foderpipen. $1,2$.

Liknar föreg. art, men blomkronan är svafvelgul med platt och bredt bräm; blommorna sakna lukt.

Löfskogar, helst af ek och bok; Göt. Skåne r.

b. Stängel vanl. föga utbildad; blomskaft mycket långa. Blad småningom afsmalnande mot det vingade skaftet. Blommor upprätta.

3. P. grandiflóra Lam.; blomfodrets tänder smalt lansettlika och långspetsade; kapsel af foderpipens längd. $1,2$.

Blomskaft flera tum långa, skenbart utgående från rotstocken; blomkrona ljusgul med bredt bräm, hvars bredd är dubbelt större än pipens längd; blomskaft ullhăriga.

Ängar, mycket r.; Göt. Skåne omkring Kullaberg.

B. Blomfoder otydligt nervigt och icke kantigt. Blad glatta och ofvan släta, oftast tunglika och naggade. Blommor blä- eller rödaktiga och upprätta med platt kronbräm.

a. Blad undertill betydligt hvitmjöliga. Kronflikar stälda tätt intill hvarandra. Hlock mångblommig.

4. P. farinósa L., Blivifva, Majrosor; blomfoder nedåt afsmalnande; kronpip lika lång som kronflikarne och icke öfverskjutande fodret. 1, 2.

Omkr. 1/2 fot hög eller lägre; blomkrona ljust rödviolett. Någon gång blir stängeln föga utvecklad.

Fuktiga ängår och mossar, helst på kalkformation; Göt. spr.: Gotl. Öl. Sk. a. Ög. t. a. på silur. form., Hall. inre Smål.r. Boh. Dalsl. 0, Sv. spr.: Söd. Upl. a. Verml. r., Norrl. Herj. Jtl. Gestr. spr. Hels. r., Lpl.?

5. P. scótica Hook.; blomfoder nedtill bukigt; kronpip dubbelt si lång som kronflikarne och till hälften öfverskjutande fodret. $1,2$.

Liknar föreg. art, men har. mörkt rödhlå blommor och något tjockare stängel.

Fuktiga ängar och bergssluttningar i fjellen, sällan (i Jtl.) i lägre fjelltrakter; Lpl. r., Norrl. Jt!. t. r. Herj. r.

b. Blad undertill föga eller icke hvitmjöliga. Kronflikar isärstående. Flock fảblommig.

6. P. stricta Hornem.; blomfoder nedtill bukigt; kronpip 2-3 gånger så lång som kronflikarne och till hälften öfverskjutande fodret. 1, 2.

Liknar de båda föreg., men har ofta högre och spensligare stängel; bloinmor smärre och blekare rödvioletta. 
Fuktiga ängar, helst i fjellens barrskogrsegion, äfven högre upp, stundom i lägre fjelltrakter; Lpl. spr., Norrl. Jtl. t. a. Herj. r.

7. P. sibírica Jacq., Siberisk Blarvifva; blomfoder bukigt; kronpip inemot dubbelt så lång som kronflikarne och något öfverskjutande fodret. 1,2 .

Olik de tre föreg. arterna genom äggrunda---ovala helbrärdade och ej mjöliga blad med smala utdragna skaft samt genom större blommor; stängel spenslig och omkr. $1 / 2$ fot hög.

Ängar nära hafvet, mycket r.; Norrl. Vb. i Lule skärgåard på Uddskär (Backman och Holm).

99. Hottónia. Vattenvioler, Vuttenrölleka.

1. H. palustris L.; blommor skaftade i skilda kransar i stängelns spets, hvita eller rödletta med gult svalg. 1, 2 .

Stänglar fotshöga och upprätta, utgående från en nedliggande stam; bladflikar smala jemnbreda.

I vattengrafvar och kärr, stundom i bäckar; Göt. t. a.: Gotl. r. Hall. - Dalsl. spr., Sv. spr.: Dal.?, Norrl. Gestr. Hels. r. 100. Lysimáchia. Videört.

A. Ståndaresträngar nedtill hopväxta till $1 / 3$ af sin längd. Stjelk hårig med blomvippa i spetsen.

1. L. vulgáris L., Guldspira; stjelk upprätt; blad kortskaftade; foderflikar äggrundt lansettlika. 3, 4 .

Omkr. 2 fot hög med aflänga-lansettlika och spetsiga blad, af hvilka de öfre ofta sitta i krans; blomkrona teml. stor, hjulformigt klocklik med ovala flikar.

Vattendiken och stränder; Göt. Sv. a., Norrl. Gestr. a. Hels. r. Vib. "t. a.", Lpl. r.

B. Ståndaresträngar föga eller icke hopväxta. Stjelk glatt.

a. Stjelkar (grenar) krypande; blad kortskaftade; blommor stora och utdraget skaftade i bladvecken, enstaka eller någon gång parvis stälda.

2. L. Nummuláría L.; foderflikar hjertlika; blad n. runda; blomskaft föga längre än blomman. 3 .

Stjelkar omkr. fotslånga; blomkrona n. hjulformig, större än hos föreg. art.

Stränder, diken och fukt. ängar; Göt. r.: Sk. a. Vg.? Dalsl. 0, Sv. Söd. Upl. Ner. r., Norrl. Gestr. r.

3. L. némorum L.; foderflikar syllika; blad äggrunda spetsiga; blomskaft flera gånger längre än blomman. 3 Liknar föreg. art, men stjelkarne äro något uppstigande, blomskaften fina och trådlika, slutl. båghöjda.

Fuktiga lundar; Göt. Skåne t. r. Smål. r.

b. Stjelk upprätt och enkel; blad stjelkomfattande; bloinmor mycket sma och teml. kort skaftade i klasar (vippor) i de mellersta bladvecken. 
4. L. thyrsiffóra L.; foderflikar jemnbreda; blomkrona bägarlik med jemnbreda flikar. 3.

Stjelk omkr. fotshög med utdraget lansettlika, korsvis motsatta blad. Ståndarne äro vanl. 6 med och 6 utan knappar.

I vatten vid stränder; Göt. t. a.: Öl. Boh. r. Gotl. $0, S v$. Norrl. t. a., Lpl. r.

\section{Anagallis. Rödnarf.}

1. A. arvensis L.; blad äggrunda oskaftade och undertill svartprickiga. 2,3 .

Stjelk omkr. 1/2 fot lång; blomskaft längre än bladen och slutl. bågböjda; blommor mönjeröda.

Hafsstränder och åkrar; Göt. Sk. a. Hall. Boh. t. a. Dalsl. Vg. r. Ög. - Blek. Gotl. spr. Öl. a., Sv. Söd. spr. Upl. Vestm. r. (Dessutom tillfällig i Verml. och Ang.)

- cœrúlea Schreb.; foderflikar otydligt sågade; blad stundom äggrundt lansettlika; blommor blå.

Åkrar och trädgårdar r.; Göt. Sk. Smål.

\section{Andrósace. Hillsko.}

1. A. septemtrionális L.; blomkrona och kapsel föga öfverskjutande fodret; blad lansettlika-aflånga och något tandade. 1, 2. rotskott.

Sällan mer än $1 / 2$ fot hög med en eller flera stänglar utan

Grusbackar och sandåsar: Göt. Gotl. spr. Öl. a. Sk. t. a. (i ö. delen) Blek. Smål. r. Ög. Vg. spr., Sv. Söd. Upl. Ner. t. r., Norrl. Gestr. r.

\section{Verbascum. Kungsljus.}

A. Blomsamling axlik. Ståndare olika långa, 3 hvitulliga och 2 glatta. Ståndareknappar olika stora. 1. V. Thapsus L.; blad ovala-aflånga, de öfre nedlöpande, de nedersta skaftade; blomkronans bräm skållikt; märke klotformigt. 3. kantig.

2-6 fot hög och gulaktigt ullig; blad n. helbräddade; stjelk

Torra backar och berg; Göt. mångenst.: Öl. t. r., Sv. t. a., Norrl. spr.: V.b. 0.

2. V. thapsiforme Schrad.; blad aflänga-lansettlika, de öfre nedlöpande, de nedre skaftade; kronbräm platt; märke omvändt $V$-formigt, nedlöpande på stiftet. 3. Liknar föreg., men har tydligt naggade blad.

Ruderatväxt på torra ställen; Göt. Sk. Smål. Gotl. r. Öl. spr. (Sv. Upl. tillfällig).

3. V. phlomóides L.; blad icke nedlöpande, de öfre aflångt äggrunda, de nedre äggrunda skaftade; kronbräm platt; märke omvändt V-formigt och nedlöpande. 3. Liknar de föreg. arterna, men har något glesblommigt ax och trind stjelk.

Ruderatväxt, mycket r.; Göt. Sk. Blek., Sv. Söd. Upl. 
B. Blommor skaftade och stälda i kransar (knippen). Ståndare n. lika långa med lika stora knappar, alla med ulliga strängar. Blad ej nedlöpande.

4. V. nigrum L.; de nedre bladen hjertlika långskaftade, de öfversta oskaftade, vanl. äggrunda och spetsiga; ståndarnes ull vanl. violett, sällan hvit. 3 .

Vanl. 4-6 fot hög med svartaktig och n. trind stjelk; blad mycket stora, ofvan n. glatta, undertill vanl. grågrönt filtludna, i kanten naggade, vid torkning lätt svartnande; blommor gula; blomsamling långt utdragen.

Ruderatväxt, helst i slättbygder; Göt. Sv. t. a.: Boh.... Dal. t. r., Norrl. Gestr. - Med. r.

5. V. Lychnítis L.; de nedre bladen ovala-aflånga, afsmalnande mot skaftet, de öfre oskaftade och äggrundt lansettlika; ståndarnes ull hvit. 3 .

Stjelk 2-4 fot hög, mjöligt filtluden och upptill kantig; blad naggade och undertill hvitt filtludna; blomsamling stundom liknande en vippa; blommor hvita.

Ruderatväxt, mycket r; Sv. Söd. på 2 ställen.

Anm. Mellan dessa arter förekomma stundom bastarder, helst mellan de båda vanligaste.

\section{Hyoscy'amus. Bolmört.}

1. H. niger L.; blomskärmar oskaftade. 3.

1-2 fot hög; hela växten mycket giftig, särdeles roten, som liknar palsternackans.

Ruderatväxt; Gröt. Sv. mångenst., Norrl. r. Lpl.?

\section{Datúra. Spikilubba.}

1. D. Stramónium L.; blad äggrunda tandade med stora spetsade tänder. 3,4 .

$1 / 2-2$ fot hög och giftig; frukt med stora och starka, qvarsittande taggar.

Ruderatväxt och ogräs i trädgårdar; Göt. Hall. Sk. spr. Gotl. Blek. Smål. r. Ög. t. r., Sv. r.: Dal. 0, Norrl. Hels. Med. r.

\section{Diapénsia. Polört.}

1. D. lappónica L.; blad tunglika liniebreda. 1.

Torra blåsiga ställen i högfjellen; Lpl. Norrl. Jtl. Herj. a. i fjellregionen, sällan lägre ned.
107.
Polemónium.
Blåguld, Jakobs stege.

1. P. cœrúleum L.; bladflikar talrika, lansettlika; blomkrona n. hjulformig, bla med guldgul botten (sällan hvit); foder och blomskaft finhåriga. $2,3$.

Stjelk omkr. 2 fot hög och trind, glatt eller finhårig.

Stränder och något fuktiga ängar i (helst lägre) fjelltrakter; Lpl. r., Norrl. r.: Jtl. t. a. Gestr. 0.

P. campanulátum Th. Fries; bladflikar färre och glesare; blomkrona n. klocklik med spetsade flikar; foder och blomskaft ulliga; ståndareknappar runda.

Lpl. (helst i Torn. Lpm.) t. r., Norrl. Vb. t. r. 


\section{Solánum.}

A. Nedliggande eller n. klängande halfbuske med blågredelina blommor och röda, aflånga bär. Blommor i knippen, hvilkas gemensamma skaft sitter nästan midt emot bladfästet.

1. S. Dulcamára L., Qvesved, Matledsqvistar; blad hjertlika--äggrunda och helbräddade, de öfre spjutlika. 3,4 . Stam ända till 4-6 fot lång och mycket krokig. Giftig.

Ruderat- och strandväxt; Göt. Sv. t. a., Norrl. Gestr. Hels. spr. Med. r.

B. Örter med n. upprätt stjelk, hvita blommor och runda bär. Blommor n. i flockar, utgående nedom bladets fästepunkt.

2. S. nigrum L.; blad äggrunda, vanl. bugttandade; blomkrona dubbelt så, lång som fodret; bär slutl. svarta, mindre ofta gröngula. $3,4$.

Omkr. en fot hög, stundom myskluktande.

Ruderatväxt och ogräs, helst i trädgårdar; Göt. Sv. a.: Boh. - Dal. t. r., Norrl. Gestr. r. (Hels. tillfällig).

* S. miniátum Willd.; bär små och röda; stjelk med skarpa vårtfulla kanter.

Helst på hafsstränder; Göt. Sk. spr. Kalmarl. r. Boh.?

3. S. villósum Lam.; blad rutformigt äggrunda och groftandade; blomkrona 3-4 gånger så lång som fodret; bär slutl. saffransgula. 3 .

1-2 fot hög och luden med utstående hår; stjelk föga kantig Ruderatväxt, mycket r.; Göt. Skåne flerst.

\section{Gentiána. Stcilört.}

A. Blomkrona trattlik eller bägarlik (med uppåt vidgad pip) samt inuti bar (utan fjäll).

1. G. Pneumonánthe L., Höstlilocka; blad jemnbreda och trubbiga; blomkrona n. klocklik eller vidgadt bägarlik. 3,4 .

$1 / 2$ fot hög med rotstock och omkr. tumslånga, knappt liniehreda blad; blommor stora, tumslånga, himmelsblå och inuti fläckiga, ofta enstaka i spetsen af stjelkarne; foder 5-flikigt; krona grundt 5-flikig och veckad mellan flikarne; ståndareknappar förenade.

Helst på stränder bland buskar eller ljung; Göt. Blek. r. Sk. Smål. (i s. och v. delen) Hall. Vg. spr. Boh. Dalsl. r. Ög.? $S v$. Verml. r.

2. G. nivális L.; blad ovala-aflånga spetsiga; blomkrona trattlik. 3 .

Omkr. fingerhög (sällan högre), späd och enårig med små blad; blomskaft vanl. kortare än de smala, omkr. liniebreda och nära tumslånga himmelsblå blommorna; foder knappt till midten 5 -flikigt, tilltryckt intill kronan. 
Fuktiga och gräsrika ställen; helst i fjellen, stundom i lägre fjelltrakter; Lpl. t. a., Norrl. Jtl. Herj. mångenst. Vb. - Hels. r., $S v$. Dal. r.

B. Blomkrona trattlik med hårfransade fjäll i svalget.

a. Blomskaft föga öfverskjutande bladen eller kortare; foderflikar tilltryckta.

3. G. campestris L.; blomfoder olikformigt 4-deladt med 2 stora och breda flikar, som innesluta 2 mycket smalare; stjelkblad äggrunda och vanl. spetsiga; rotblad omvändt äggrunda. 3 .

Omkr. $1 / 2$ fot hög med oskaftade blad; blomkrona vanl. blå, 4-klufven; ståndare 4. Stundom är växten blekgrön med gulhvita blommor.

Ängar (utom fjellen); Göt. t. a.: Gotl. 0, So. t. a., Norrl. t. a.: Ang. r. Vb. o.

4. G. Amarella L., Ängsöta, Hållgräs; blomfoder likformigt 5-fikigt med jemnbreda flikar; stjelkblad utdraget äggrunda och spetsiga. 3,4 .

Ofta något högre än föreg. art och med smalare blommor. Något fukt. ängar; Göt. spr.: Gotl. Öl. a. inre oSmål. Boh. r. Blek. Dalsl.?, Sv. spr.: Verml. r., Norrl. r.: Med. Ång. 0, Lpl.?

* G. linguláta Ag.; blad tunglika och trubbiga. 3.

Blommar tidigare än hufvudarten.

Ängar; Lpl. r.?, Norrl. Jtl. spr. Herj. a. Vb. r.? Ång... a. Med. spr. Hels. Gestr. r., Sv. spr.: Verml. t. r. Ner. r., Göt. Ög. spr. Gotl. Öl. Smål. Sk. Vg. r.

b. Blomskaft flera gånger längre än bladen och stjelken; foderflikar utstaende.

5. G. tenella Rottb.; foder n. likformigt och djupt 4-5deladt; stjelkblad äggrunda-aflånga trubbiga; rotblad spádlika-tunglika. 3 .

Ganska liten och späd, ofta mycket qrenig; den egentliga stjelken sällan mer än 1-2 tum hög, men ofta med flera tum långa blomskaft ; blommor mindre än hos de 2 föreg. arterna, ej rent blå, ofta (i vackert väder) med utstående brämflikar. Herj. $r$.

Fuktiga grässika ställen högt upp i fjellen; $L p l$. t. r., Norrl.

110. Erythræa. Tusengyllen.

A. Blommor kortskaftade med 2 skärmblad; kronflikar trubbiga; rotblad samlade i rosett.

1. E. littorális Fr.; blad utan tydliga sidonerver och trubbiga, de öfre n. jemnbreda, rotbladen n. tunglika. 3 .

Stjelkar vanl. flera tillsammans och 3-8 tum höga, trubl)kantiga och upptill stundom något greniga.

Hafsstränder; Göt. Sv. t. a., Norrl. Gestr. Med. r.

2. E. Centáurium (L.) Pers.; blad 3-5-nerviga; de öfre 
aflånga-jemnbreda spetsiga, rotbladen omvändt äggrunda. 3.

Liknar föreg., men har längre kronpip, som långt öfverskjuter fodret; stjelk n. enkel, eller från basen ..grenig.

Fukt. ställen och åkrar; Göt. Hall. Sk. Öl. spr. Blek. Ög. Gotl. r., Sv. Söd. r.

B. Blommor med utdragna skaft utan skärmblad; kronflikar spetsiga; rotblad motsatta.

3. E. pulchella Fr.; blad otydligt nerviga och äggrundaaflånga, de öfre n. spetsiga. 3.

Vanl. ett par tum hög, stundom alldeles enkel och enblommig, stundom mycket grenig och mångblommig; blommor mycket mindre än hos föreg. arter.

Vid eller nära hafvet; Göt. spr.: Boh. a. Gotl. t. r., Sv. spr., Norrl. Gestr. r.

\section{Menyánthes. Vattenklöfver.}

1. M. trifoliáta L.; blad långskaftade med trubbiga, vanl. ovala flikar. 1, 2.

Omkr. ${ }^{1 / 2}$ fot hög. Blomkronan är någongång inuti glatt. Kärr allmän, äfven i bäckar h. o. d.

\section{Convólvulus. Vinda.}

1. C. arvensis L., Åkervinda; blomskärmar aflägsnade från blomman, små och jemnbreda; blad spjutlika eller pillika; foderflikar trubbiga med udd och hinnkant. 3.

Stjelk omkr. 2 fot lång med tumsvida, välluktande och utanpå rosenröda, blommor.

Åkrar; Göt. a. åtm. i slättbygderna: inre Smål. Boh. r. Vg. Dalsl. spr. på slätten, Sv. t. a.: Verml. Dal. r., Norrl. Gestr. Med. r. (Hels. tillfällig).

2. C. sépium L., S7ogsvinda; blomskärmar omslutande blomfodret, stora, hjertlika och spetsiga; blad hjertlikt pillika; foderflikar spetsiga. 3 .

Stjelk längre än hos föreg. art; blommor dubbelt vidare och snöhvita.

Vid hafvet på stränder eller i lundar: Göt. t. r.: Boh. Sk. Blek. spr., Sv. spr.; på.. sjöstränder vid Mälaren mångenst., vid Hjelmaren, Vettern (i Ög.) och Venern r., Vg. vid Hornborgasjön, mångenst. i Skåne äfven vid dammar.

113. Campánula. Blåitocka.

A. Blommor med utdragna skaft.

a. Stjelkblad smala (lansettlika-jemnbreda), vanl. glatta (sällan finludna).

1. C. rotundifólia L.; rotblad knippevisa, hjertlikt rundade, tandade och långskaftade; blomkrona inskuren i spetsiga flikar; kapsel lutande. 2, 3. 
Stjelk spenslig, vanl. omkr. fotshög, i fjellen lägre (och der ofta enblommig); blommor vanl. rent blå; foderflikar syllika ; stjelkblad vanl. helbräddade; stift längre än märkena.

Ängar, allmän.

2. C. persicæfólia L.; rotblad tunglika, glest naggade och afsmalnande mot skaftet; blomkrona grundt inskuren i nästan rundade och uddiga flikar; kapsel upprätt. 2,3 .

Gröfre än föreg. och öfver 2 fot hög; blommor stora och mörkblå i enkel klase; foderflikar lansettlika; stjelkblad glest naggade; stift kortare än märkena.

Ängsbackar och berg; Göt. t. a.: Boh. t. r., Sv. t. a., Norrt. Gestr. Hels. t. a. Med. spr. Ang. t. r. Jtl. r. Herj. spr.

3. C. pátula L.; rotblad spadlika-tunglika, naggade och kortskaftade; blomkrona djupt kifufven i lansettlita och utstående flikar; kapsel upprätt. 2, 3.

Omkr. 2 fot hög och något grof; blommor rödgredelina i rikblommig och qvastlik vippa; foderflikar lansettlikt syllika; stjelkblad naggade.

Ängar och åkrar; Göt. Hall. Blek. inre Smål. r. Kalmarl. Ög. Vg. spr., Sv. spr.: Vestm. a., Norrl. Herj. spr. Jtl. t. a. Gestr. Hels. a. Med. spr. Ång. Vb. r.

4. C. uniflóra L., Enblommig Blik7ocka; blad aflångalansettlika naggade; blomkrona inskuren $i$ smala $\mathrm{Ai}$ kar; kapsel upprätt. 3 .

Späd och låg, sällan 6 tum hög, med liortskaftade rotblad och en enda liten mörkblå blomma, som det långa fröhuset slutligen öfverskjuter; foderflikar n. tunglika.

Torra ofruktbara ställen, helst bland renlaf o. dyl., högt upp i fjellregionen i högfjellen; Lpl. t. r.

b. Alla blad breda och håriga eller sträfva. Kapsel lutande.

5. C. rapunculóides L.; de nedre bladen långt skaftade och hjertlika, de öfre äggrundt lansettlika och oskaftade; blommor lutande i en ensidig och bladiös klase. 3.

Stjelk 2 fot hög och jemte bladen kort och sträft grăluden med n. dubbelt sågade blad: foderflikar lansettlika och slutl. nedböjda; blommor teml. stora och blågredelina; fröhus hårigt; rotstock med krypande skott.

Ruderatväxt och ogräs i trädgårdar; Göt. Sv. mångenst.: Boh.-Dal. r., Norrl. r.: Herj.?

6. C. Trachélium L., Nü̈sselklocka; de nedre bladen skaftade och hjertlika, de öfre äggrunda n. cskaftade; blommor upprätta $i$ de öfre bladvecken med 1-3-blommiga skaft. 3 .

Stjelk mer än 2 fot hög och kantig, jemte bladen mycket sträthårig; blad liknande nässlans och djupt dubbelsågade; foder- 
flikar äggrundt lansettlika, upprätta och sträfhåriga; blommor stundom så stora som hos följ. art, blå eller blågredelina; fröhus styfhårigt; rotstock kort utan skott.

Lundar och busksnår; Göt. t. a., Sv. t. a.: Verml. Dal. r., Norrl. Gestr. Med. r.

7. C. Iatifólia L.; alla bladen äggrunda-lansettlika, de nedre med korta och vingade skaft; blominor upprätta och ensamma i de öfre bladvecken. 3 .

Stjelk mer än 2 fot hög, trind och mycket bladig och jemte bladen mera mjukhärig än de båda föreọ.; blad n. dubbelsågade; foderflikar lansettlika, upprätta och glatta; blommor stora och rödgredelina; fröhus glatt.

Lundar, helst vid bäckstränder; Göt. mångenst.: Boh. Hall. t. r. Gotl. 0, $S v$. mångenst.: Vestm. t. r. Dal. 0, Norrl. Gestr.Med. Jtl. r.

B. Blommor oskaftade och gyttrade i hufvud. Blad sträfhåriga eller ludna.

8. C. Cervicária L.; alla bladen jemnbreda-lansettlika, de nedre med vingade skaft; stift utskjutande ur kronan; blommor vanl. ljusblå. 3 .

Stjelk tjock, styf och 2 fot hög eller deröfver samt mycket sträfhắrig (jernte bladen); blad vågiga och smånaggade, de öfre n. omfattande; blomhuf'vud både i stjelkens spets och nedanför, stödda af skärmblad; foderflikar korta och trubliga.

Berg och ängsbackar, helst i skogshygder; Göt. r.: Ög. Smål. Vg. Dalsl. spr. Sk. t. r., Sv. spr.: Dal. r., Norrl. Gestr.-Vb. r. - subalpína; de nedre bladen teml. breda, aflangt lansettlika eller tunglika samt långt uppåt stjelken skaftade; sidoblomhufvud talrika; blommor ofta hvita; blomfoder föga styfhårigt.

Liknar mycket följande art.

Lägre fjelltrakter, mycket $\mathrm{r}$.; $S v$. Verml. i n. delen vid elfven Tåsan midtemot Tjärbacksstrand i N. Finnsknga s:n.

9. C. glomeráta L.; blad äggrundt aflånga-lansettlika, de nedre långskaftade; stift inneslutet inom kronan; blommor mörkblå. 3 .

Stjelk lägre och smalare än hos föreg. art; hela växten mindre sträf och med kort grått ludd; blad finsågade, de öfre med hjertlik bas stjelkomfattande; foderflikar långt tillspetsade.

Ängsbackar; Göt. Gotl. Sk. Hall. spr. Boh. Smål. Ög. r., Sv. r.: Söd. Upl. spr., Norrl. Gestr.-Med. r. Ang.?

\section{4. lasióne. MLonke.}

1. I. montána L.; blad oskaftade och vågiga. 3 .

Omkr. $1 / 2$ fot hög eller deröfver, med upptill bladlös och vanl. enkel stjelk.

'Torra ängar och berg; Göt. mångenst., i skärgården t. a.: Gotl. t. r., $S v$. r.: Söd. spr. Vestm. Dal. 0. 
- littorális; med uppstigande talrika stjelkar (grenar),

n. glatta blad och smärre blomhufvud.

Hafsstränder i Göt. spr., helst på v. kusten.

\section{Lobélia. Notblomma.}

1. L. Dortmanna L.; blommor nedhängande. 3.

Omkr. fotshög mer tjocka blad i rosett.

Grundt vatten i sjöar och kanaler; Göt. t. a.: Öl. r. Gotl.0, Sv. t. a., Norrl. spr.: Jtl. r.

\section{Sámolus. Punge.}

1. S. Valerandi L.; blad n. omvändt äggrunda och skaftade; stjelkblad skiftevis stälda; rotblad i rosett; krona föga längre än fodret. 3 .

Omkr. ${ }^{1} / 2$ fot hög och glatt med kort och afstympad rot, n. enkel stjelk och knäböjda blomskaft.

Hafsstränder; Göt. Sk. r. Blek. Smål. spr. Ög. r. Öl. Gotl. t. r., Sv. r.

\section{Lonicéra. Try, Benved.}

A. Stam upprätt. Blommor blekgula, parvis stälda. Blad öfverallt håriga.

1. L. Xylósteum L.; blomkrona läppformig med pipen kortare än brämet; blomskaft af blommans längd; bär mörkröda, 2 tillsammans och åtskilda. 2.

4--6 fot hög med mycket hård ved och gråaktiga grenar; blad blekgröna, ovala med något utdragna skaft: kronpip nedtill bukig; bär klotrunda och blott nedtill förenade.

Lundar och ängshackar; Göt. Sv. t. a.: Boh. Dal.t.r. Verml. spre., Norrl. r.

2. L. coerúlea L.; blomkrona nästan regelbunden med pip af brämets längd; blomskaft vanl. mycket kortare än blomman; bär svartblitt och ensamt. 2 .

Högre än föreg. art med bruna grenar; blad mörkare gröna och aflănga med mycket korta skaft; kronpip rörformig; bär klotrundt, bildadt genom de båda fruktämnenas sammanväxning med skärmfjällen.

Kalkberg r.; $S v$. Dal. flerst. (mest i Ore s:n) Vestrn. Nora s:n.

B. Stam nedliggande eller uppstigande (utefter bergväggar och andra stöd); blommor utvändigt rosenröda, inuti hvitgula, gyttrade i hufvud i spetsen af grenarne; äldre blad glatta.

3. L. Pericly'menum L., Rosenbenved, Svensk Kaprifolium; krona läppformig med pipen längre än brämet; bär röda. 3, 4 .

Liknar den odlade Kaprifoliebusken, men har ej de öfre bladen hopväxta; blomhufvud långskaftade; hlommor välluktande; blad ovala spetsiga, kortskaftade och vanl. helbräddade, de yngre stundom bugtbräddade. 
Klippor, helst vid hafvet; Göt. Boh. Hall. mångenst. Sk. t. a. Blek. mångenst. Smål. Ög. Vg. Dalsl. r., Sv. Söd. r.

\section{Azálea. Krepling.}

1. A. procumbens L.; blad aflånga med nedvikna kanter, undertill hvitaktiga. 1, 2.

Har vanl. några tum långa, mattlikt utbredda grenar och knappt en linie breda blad.

Hedar i fjellen, helst ofvan barrskogsregionen; Lpl. t. a., Norrl. Jtl. Herj. t. a., Sv. Dal. t. r.

119. Ribes. Ribs.

A. Buske med taggar; blommor enstaka eller 2-3 tillsammans i bladvecken.

1. R. uva crispa L., Krusbär, Stickelbür; blomfoder med klocklik pip och ludna tillbakaböjda flikar; blad med n. rund omkrets, 3--5-flikiga och i början finludna, slutl. n. glatta, knippevis förenade; bär klot- eller äggformiga, slutl. glatta och gulaktiga. 1, 2.

Temligen låg buske med styfva och tätt sittande grenar, små slutl. stela blad, grönaktiga eller rödaktiga blommor samt större bär än hos följande arter.

Nära bostäder och vid vägar, stundom på berg, troligen oftast förvildad; Göt. Sv. spr., ymnigare mot söder: Dal.?, Norr. Gestr. Hels. spr.

Grossulária; bär gröna och glandelhåriga.

Förvildad h. o. d.

B. Buskar utan taggar; blommor i klasar från bladvecken.

2. R. rubrum L., Röda Vinbär; blomfoder med skålformig pip och glatta utstående flikar; blad 3-5-flikiga och undertill småludna (sällan glatta); blomklasar nedhängande; bär runda och röda. 1, 2.

Onıkr. 4 fot hög buske med mjuka blad och talrika grönaktiga hlommor; blomskärmar bredt äggrunda och mycket kortare än blomskaften.

Lundar och stränder, äfven i skärgården; Göt. Sv. spr., Norrl.? - petræum (Wulf.); foderflikar hårbräddade; blad och klaseskaft mera ludna; klasar vid blomningen upprätta; skärmblad något större.

Lpl. a., Norrl. t. a.?: Jtl. spr., Sv. spr.?, Göt. Ög. Smål. Sk. Boh. Dalsl. r.

3. R. nigrum L., Svarta Vinbär; blomfoder finludet med klocklik pip och tillbakaböjda flikar; blad 3-5-flikiga och undertill finludna med gula hartsprickar; blomklasar nedhängande; bär runda, svarta och gulprickiga. 1, 2. 
Lika hög som föreg. art med mjuka, starkt luktande blad och brunaktiga blommor; blomskärmar äggrunda, spetsade och kortare än blomskaften.

Stränder, helst vid hafvet, stundom äfven vid gårdar och vägar samt i ängar; Göt. r.: Sk. t. r. Blek. Ög. spr. Öl. Gotl. 0, Sv. spr.: Ner. Verml. r. Dal?, Norrl. r., Lpl. r. - Torde vara verkligt vild blott $\mathrm{i}$ skärgården på östra kusten.

4. R. alpínum L., Måbär, Kungsbär; blomfoder glatt med skalformig pip och utstaende flikar; blad vanl. djupt 3-flikiga och n. glatta; klasar upprätta under blomningen; bär n. runda och röda. 1, 2.

Något högre än föreg. och glatt med gröngula blommor; blomskärmar lansettlika, längre än blomskaften; bär med fadd smak. Är ofta tvåbyggare ined omkr. 20-blommiga hanblomklasar och 2-5-blommiga honblomklasar.

Lundar och ängar; Göt. Sk. t. a. Blek. r. Smål. Öl. Gotl. spr. Ög. t. a. Vg. spr. Hall. t. r. Boh. r., Sv. Verml. r. Dal. t. r. Vestm. Ner. spr. Söd. Upl. a., Norrl. Gestr. a. Hels. spr. Med. a. Ång. Jtl. Herj. r.

\section{Rhamnus.}

1. R. Frángula L., Brałeved; blad helbräddade; stift enkelt; grenar utan tornar. 2.

6-8 fot hög buske med smala och bräckliga grenar; blad ovala eller omväudt äggrunda, skiftevis stälda; blommor samkönade och 5-taliga; bär klotrunda, i början röda, slutl. svarta.

Backar och skogsängar; Göt. Sv. a., Norrl. spr., Lpl. r.

2. R. cathártica L., Getapel, Valbjörk; blad finsågade; stift 2-klufvet; grenar tornbärande. 2.

Något högre buske eller träd; blad ovala-aflånga och knippevis stälda, på årsskotten motsatta; blommor tvåbyggare och 4-taliga med 4 ståndare; bär klotrunda och i början gröna, slutl. svarta.

Lundar och skogsängar; Göt. Sv. mångenst.: Boh.-Verml. t. r. Dal. 0, Norrl. Gestr. Hels. r.

\section{Hédera. Murgröna.}

1. H. Helix L.; blommor i enkel flock. 4.

Kan vid hög ålder antaga form af ett stort träd; blad qvarsittande och ständigt gröna; bär klotrunda.

Lundar vid bergväggar och trädstammar; Göt. spr.: Sk. a. Boh. Vg. r. Dalsl. Ög. t. r., Sv. Söd. Upl. r., Norrl. Gestr. r.

\section{Evónymus. Alster, Benved.}

1. E. europæus L.; blad äggrunda-lansettlika, finsågade och glatta. 3.

Några fot hög med gröngula blommor och slutligen rosenröda frukter.

Skogsängar; Göt. Gotl. t. r. Öl. Sk. Hall. spr. Blek. Smål.r. 123. Víola. Viol, Violblomma.

A. Alla blommor på rotblomskaft från rotstocken.

a. Blomskaft alltid upprätta, $\mathrm{i}$ spetsen båghöjda. Kapsel 
glatt. Foderblad trubbiga. Blad n. glatta. 1. v. palustris. 2. V. uliginosa.

b. Blomskaft efter blomningen nedliggande. Kapsel luden. Foderblad trubbiga. Blad ludna elier finhåriga. 3. v. odorata. 4. V. hirta. 5. V. collina.

c. Blomskaft efter blomningen nedliggande. Kapsel glatt. Foderblad spetsiga. Blad glest finhåriga. 6. v. umbrosa.

B. De första blommorna fullständiga på långa rotblomskaft, de senare kronlösa på korta skaft från bladvecken' af en utbildad stjelk. Foderblad spetsiga. Stipler helbräddade. 7.

\section{V. mirabilis.}

C. Blommor på utdragna skaft trån hladvecken af en stjelk. Foderblad spetsiga.

a. Växter med rotstock. Blommor blåaktiga. Stipler tandade eller (grundt) inskurna. Kronblad någon gång felslående. 8. V. silvatica. 9. V. canina. 10 . V. persicæ. folia. 11. V. elatior.

b. Rot enårig. Blommor 2-3-färgade. Stipler n. lyrformiga (pardelade med stor ändflik). 12. V. tricolor.

c. Blommor gula med violetta strimmor. Stipler helbräddade. 13. v. biflora.

1. V. palustris L., Kärrviol; alla bladen njurlika och glatta; blomskärmar vid eller nedom blomskaftets midt. $1,2$.

Blomskaft 2-3 tum höga; blad glest naggade med ovingade skaft; kronblad vanl. små och blekvioletta med mörkare ådror. Har stundom grenskott.

Kärrängar och stränder, allmän: Got]. r.

* V. suécica Fr.; det första bladet med något utdragen spets, de öfriga njurlika, alla undertill något finhåriga på nerverna och med upptill något vingade skaft; blomskärmar ofvan blomskaftets midt; blommor något större (än hufvudartens); blomskaft $2-4$ tum höga.

Denna form afviker väl genom ofvan anförda kännetecken, men påstås genom odling öfvergå $\mathrm{i}$ hufvudarten.

Kärr och bäckar; Ipl. a., Norrl. spr: Jtl. t. a. Ång. Hels. Gestr. r.?, Sv. Dal. Vernī. t. r. Ner. t. a. Vestm. r. Upl. spr. Söd. t. r., Göt. Vg. Ög. spr. Smål. Öl. r. Sk.?

- epipsíla Ledeb.; med större blad och blommor samt 4-7 tum höga blomskaft, på hvilka blomskärmarne vanl. äro fästade nedom midten.

Källdrag; Göt. Sk. Hall. t r. Smål. Ög. r., Sv. r.: Upl.? Norrl. Gestr. Hels. Ang. r.. I pl.? - Är trol. stundom förvexlad med föreg.

2. V. uliginósa Bess.; alla bladen utdraget hjertlika och undertill något finhåriga på nerverna; blomskärmar ofvan blomskaftets midt. 1, 2.

Blomskaft omkr. 6 tum långa; blad glest naggade med upptill något vingade skaft; kronblad teml. stora, blekvioletta med otydliga ådror. 
Elf- och bäckstränder; Göt. Sk. Ö]. Ög. r. Kalmarl. flerst., Sv. Upl, t. r., men flerst. vid Dalelfven.

3. V. odoráta L., Luktviol; årsskottens blad njurlika, de öfriga bredt och djupt hjertlika, alla finhåriga; rotstock med långa och hårda grenskott. 1, 2.

Blomskaft omkr. 3-4 tum långa; blad naggacle och vanl. trubbiga, slutl. n. glatta; blommor blå och välluktande.

Ruderatväxt och ogräs i trädgårdar, sällan i ängar, vanl. förvildad; Göt. r.: Öl. Sk. Ög. spr. Vg. Dalsl. 0, Sv. Söd. Upl. spr. Ner. r., Norrl. Gestr. r. - Synes vara verkligt vild på Öl. och Got].

4. V. hirta L., Luden Viol; de slutligen (vid fruktmognaden) utväxta bladen tätludna, äggrunda eller hjertlika, från eller nedom midten småningom afsmalnande uppåt; stiplernas tänder korta; rotstock utan grenskott. $1,2$.

Blomskaft 1-6 tum långa; blad tätt ragggade och vanl. spetsiga, de yngre hredt hjertlika eller njurlika och stundom n. glatta; blommor luktlösa och blå, någon gång hvita; kronblarl stundom felslående; rotstock teml. tjock.

Iundar och ängsbackar; Göt. mångenst.: Gotl. Öl. Sk. a. inre Smål. Vg. Boh. r. Dalsl. 0, Sv. Söd. Upl. t. a. Vestm. spr. Ner. $r$.

5. V. collína Bess.; de slutl. utväxta bladen undertill mindre tätt ludna (än hos föreg. art), ofvan glest och svagt håriga, bredt hjertlika och ofvan midten tvärt afsmalnande uppåt, stundom n. njurlika; stiplernas tänder längre än stiplernas bredd; rotstock utan grenskott. 1, 2.

Liknar föreg. art, men har välluktande blommor.

Lundar, mycket r.; Norrl. Ned. på Sundsvallsberget, enl. ex. tagna 1858 af D:r E. Ährling och meddelade af' I):r C. Lönnherg, samt på Siljeherget (Læstadius 1824, enl. Th. Fries).

6. V. umbrósa Fr.; blad bredt och djupt hjertlika; rotstock utan grenskott. 1.

Blomskaft 2-3 tum långa; biad sågade och n. spetsiga; hlommor lukttösa; kronblad blå, ofta felslående; rotstock smal.

Skuggrika och fuktiga ställen, helst i lägre fjelltrakter, r.; Lpl., Norrl. (utom Gestr.), Sv. Dal. Verml.

7. V. mirábilis L.; blad bredt lijertlika och gleshåriga; rotblomskaft upprätta; kapsel glatt. 1, 2.

Stjelk slutl. omkr. $1 / 2$ fot hög eller nâgot deröfver, med glest naggade blad, större än hos de öfriga arterna; kronblad b]åhvita och välluktande; stjelkar utgående från sidorna af rotstocken, då den stjelk, som skulle sitta i midten, blir förkrympt och en bladrosett utvecklas $\mathrm{i}$ dess ställe. De fullständiga blommorna sätta sällan mogen frukt, de kronlösa nästan alltid.

Lundar; Göt. mångenst.: Blek. Smål. Boh. t. r., Sv. spr.: Dal. t. r., Norrl. r.: Jtl. t. a., Lpl. r. 
8. V. silvática Fr., Skogsviol; i st. f. den outvecklade midtstjelken en bladrosett (såsom hos föreg. art); blad bredt hjertlika och $n$. glatta; stipler $n$. hinnaktiga, mycket kortare än bladskaften. 1, 2.

Vanl. blott några tum hög med talrika stjelkar och ljusblå blommor.

Skogsängar; Göt. Sv. a., Norrl. Gestr. Hels. Jtl. t. a. (utom fjellen) Ang. Vb. r. Herj. Med.?

* V. arenária De Cand., Sandviol; blad njurlika ellel rundadt hjertlika, tätt finludna. 1, 2.

Vanl. blott 1-2 tum hög med små nagelstora blad, mera violetta blommor samt stjelk och kapsel finludna.

Hedar och sandbackar; Göt. spr.: Sk. t. a. Smål. t. r. Blek. Vg. Boh. r. Dalsl. 0, Sv. spr.: Ner. Verml. Dal. t. r., Norrl. Gestr.-Ang. t. a. Jtl. r.

9. V. canína L.; alla stjellarne utvecklade; blad utdraget hjertlika-äggrunda och n. glatta; stipler vanl. något hinnaktiga och kortare än bladskaften. 1, 2.

Vanl. högre än $V$. sitvatica och med längre blad; stjelkar talrika, vanl. uppstigande; blommor ljusblå: kapsel trubbig.

Ängar och skogar; Göt. Sv. a., Norrl. t. a.?: Vb. 0. - Torde mot norden ersättas af varieteten montana.

- montána (L.); stjelk högre och upprätt, blommor större, stipler större, bladartade och gröfre tandade; kronsporre teml. kort.

Ängar; Lpl. t. a., Norrl. spr.: Vb. t. a., Sv. r.: Ner. Vestm. 0, Göt. Ög. Blek. Hall. Boh. r.

- stricta (Hornem.); stjelk upprätt; blommor teml. små; stipler bladartade, de öfre af bladskaftets längd; blad mera utdragna; sporre grönaktig.

Vanligen på något fuktiga ställen, stundom på sandfält, t. r.; Göt. Sk.-Ög. Dalsl., Sv. Söd. Upl., Norrl. Gestr. Med. Jtl. 10. V. persicæfólia Schreb.; alla stjelkarne utvecklade och stundom med grenskott; blad från hjertlik eller n. rundad bas aflinga-lansettlika och glatta; de öfre stiplerna bladlika och af bladskaftets längd. 1, 2.

Lika hög som föreg. art, någon gång fotshög, men glatt och mera ljusgrön med hvitaktiga eller blåhvita blommor, upprätt och ofta enstaka stjelk samt något vingade bladskaft; kapsel något spetsig. V. stagnina Kit.

Stränder, stundom i sjelfva vattnet, helst vid de större sjöarne; Göt. Gotl. t. a. Öl. a. Sk. t. r. Hall. Blek. r. Smål. Ög. spr. Vg. spr.? Dalsl. t. r., Sv. spr.: Dal.?, Norrl. Gestr. Jtl. r.

* V. pratensis Mert. o. Koch; stipler längre och bredare: blad bredt nedlöpande; kronsporre jemntjock, af foderbihangens längd.

Fulstiga ängar; Göt. Öl. allmän (?) Gotl. t. r. Vg.? 
11. V. elátior (Clus.) Fr.; alla stjelkar utvecklade; blad äggrundt lansettlika och finludna; stipler bladartade, de mellersta längre än bladskaftet. 1, 2.

Ofta inemot en fot hög med mycket stora blommor och stipler, de förra blekvioletta och försedda med lansettlikt jemnbreda blomskärmar.

Fuktiga skogsängar: Göt. Öl. h o. d., t. ex. vid Vickleby. 12. V. trícolor L., Styfimorsblommor, Penséer; blad hjertlikt aflånga-lansettlika, trubbiga och naggade; blomkrona vanl. hvit, gul och violett. 1-4.

Stjelk ända till fotshög, mjukare än hos de öfriga arterna; rot enårig eller perennerande.

Ruderatväxt och ogräs; Göt. Sv. a., Norrl. spr., Lpl. r.

- arvensis; krona hvitgul, af fodrets längd eller kortare. Allmännare än hufvudarten, dock i Lpì. r.

13. V. biflóra L., Gulblommig Viol; blad njurlika naggade; stipler äggrunda-aflănga. 1, 2.

Omkr. fingerhög, mycket späd och n. glatt; stjelkar oftast tvåblornmiga; blomskaft långt öfverskjutande hladen; märke platt nch $\mathrm{n}$. tvåklufvet.

Något dolda och fuktiga ställen i fjelltrakter; Lpl. a., Norrl. r.: Jtl. t. a: (i fjellen) Herj. spr. Gestr. 0, $S v$. Dal. r.

124. Impátiens. Springkorn, Gula Balsaminer.

1. I. noli tángere L.; blad äggrunda-ovala, sågade och skaftade. 3 .

Stjelk omkr. 2 frt hög och glatt med uppsvälda och vattenklara leder; blommor inuti rödprickiga med lăng och i spetsen krökt sporre.

Vid och på stränder, helst på skuggrika ställen; Gö'. spr.: Blek. r. Gotl. Öl. 0, Sv. spr.: Upl. Vestm. t. r. Dal. r., Norrl. Gestr.-Ång. spr. Vb. r.

\section{Ordn. DIGYNIA.}

\section{Chenopódium. Molia, Mcll.}

A. Blad helbräddade, spjutlikt eller pillikt triangelformiga; blomgyttringar bildande en lång och bladlös blomtofs i stjelkens spets.

1. C. Bonus Henricus L., Stolt Henrit; ; blad undertill (i yngre tillstånd) mjöliga. $2-4$.

Stjelk omkr. fotshög och upprätt med tjock rotstock; frön upprätta.

Ruderatväxt; Göt. t. a : Boh. spr. Dalsl. r., Sv. t. a.: Verml. r. Dal.?, Norrl. Gestr. Hels. r.

B. Blad helbräddade, äggrunda - lansettlika; blomgyttringar (blomnystan) frảu bladvecken.

a. Blad gråmjöliga. 
2. C. Vulvária L., Stinkmolla; blad äggrunda-rutformiga och trubbiga; blomnystan i korta bladlösa ax. 3,4 .

Stjelk nedliggande och grenig med mycket små blommor och blad. Hela văxten med stinkande lukt liksom af sillake.

Ruderatvåxt; Göt. Sk. spr. Blek.-Ög. Gotl. r., Sv. Sörl. Upl. r. (Norrl. Hels. tillfällig).

b. Blad icke mjöliga.

3. C. polyspermum L.; blad äggrunda-ovala och trubbiga eller lansettlika och något spetsiga; blomnystan i bladiga vippor. 3,4 .

Stjelk grenig, nedliggande eller uppstigande, med mörkgröna r ch ofta rodnande, tunna blad.

Ruderatväxt, strandväxt och ogräs; Güt. spr.: inre Smål. Hall. Boh. Vg. r. Dalsl. 0, Sv. spr.: Verml. Dal. r., Norrl. Gestr.Med. r.

C. Alla eller de flesta bladen vanligen tandade.

a. Blad mjöliga.

4. C. album L.; blad äggrunda-rutformiga, de öfre lansettlika; blomnystan i enkla eller något gr eniga, utstiende och föga bladiga ax. 3,4 .

Stjelk upprätt; hlad och l)lomnystan hvitmjöliga; frön glänsande. Någon gång äro alla bladen helbräddade.

Ruderatväxt och ogräs, allmän.

5. C. opulifólium Schrad.; blad rutformiga, nästan lika så breda som långa, inskurna i 3 tandade flikar, af hvilka den mellersta är störst; blomnystan i vanl. enkla, något utstående och (isynnerhet nedtill) bladiga ax. 3,4 .

Liknar föreg. art, men har smärre blad.

Ruderatväxt och ogräs, mycket r.; Göt. Ög. vid Ö. Skrukeby prestgård (förf.) Blek. (enl. Aspegrén). - Förvildad i Up)sala botan. trädgård.

6. C. murále L.; blad äggrunda, ovala eller rutformiga; blomnystan i utbredda och n. bladlösa vippor. 3, 4. Stjelk vanl. grenig med utbredda grenar; blad i yngre till. stånd mjöliga, de àldre glatta, mera grofsågade än hos föreg. art; frön glanslösa fiuprickiga.

Hafsstränder; Göt. r., dock Gotl. t. a. och i Ög. blott funnen såsom ogräs och ruderatväxt, Sv. Upl. r., Norrl. Gestr. r. 7. C. úrbicum L.; de nedre bladen triangelformiga, de öfre rutformiga - aflånga eller lansettlika; blomnystan i enkla eller greniga, till stjolken tätt tryckta och n. bladlösa $a x$, bildande en pyramidformig vippa. 3, 4 . Stjelk upprätt med blekgröna och hvitmjöliga blad.

Ruderat văxt, helst i slättliygder; Göt. t. a.: inre Smål. Boh. t. r. Ög. spr. Dalsl. 0, Sv. spr.: Verml. Dal. r., Norrl. Gestr. r. 
8. C. gláucum L.; de nedre bladen aftinga och bugttandade, de öfre lansettlika och n. helbräddade; blomgyttringar axlika, korta och bladlösa. 3,4 .

Till växten mindre än de båda föreg. arterna; stjelk ned. liggande, saftfull och slutl. rodnande; blad tjocka, undertill med blăgrått mjöl; frön stundom upprätta.

Ruderatväxt, helst på gator och i rännstenar; Göt. t. a.: Blek.-Ög. spr. Boh. Vg. Dalsl. r., Sv. spr.: Verml. r. Ihal.?, Norrl. Gestr. Hels. r. (Ång. 1illfällig).

b. Blad icke mjöliga.

9. C. rubrum L.; blad rutformiga eller stundom med spjutlik bas, de ïfre smalare och n. helbräddade; blomnystan i upprätte och bladigu ax. 3, 4.

Stjelk upprätt med mörkgröna blad och sluti. rodnande ax; de flesta fröen upprätta.

Ruderatväxt, helst i slättbygder; Göt. mångenst.: inre Smál. Dals]. r., Sv. mångenst.: Verml. r. Dal.?, Norrl. Gestr. Heis. r. (Ång. tillfällig).

10. C. hy'bridum L.; blad äggrundt-hjertlikt triangelformiga, groftandade eller grundt klufna; blomnystan i bladlös vippa med utbredda grenar. 3, 4 .

Till växten större än de ofriga arterna och med stora ljusgröna blad, liknande lönnlöf; stjelk upprätt; blomnystan stundom rodnande.

Ogräs och ruderatväxt; Göt. t. r.: Hall. sk. Öl. Gotl. spr. Boh.? Dalsl. 0, Sv. t. r.: Vestm. 0.

\section{Blitum. Rödmolla.}

1. B. virgátum L.; blad kortskaftade, aflånga-lansettlika och groftandade; blomnystan ensamma $i$ bladvecken. 3,4 .

Stjelk omkr. fotshög, grenig och blarig ända upptill, upprätt eller.stundom nedliggande.

Ruderatväxt, troligen förvildad; Göt. Sk. Smål. Vg. r. Ög. t. r., Sv. Söd. OUpl. Vestm. r. (Ner. Verml. tillfällig), Norrl. Gestr. Hels. r. (Ång. tillfällig).

2. B. capitátum L.; blad lingskaftade, n. spjutlika och vanl. helbräddade; blomnystan i spetsen af stjelken och grenarne, upptill bildande bladlösa ax. 3, 4 . bladlös.

Stjelk vanl. lägre än hos föreg. art, upprätt och upptill

Ruderatväxt, trol. förvildad; Göt. Sk. Smål. Ög. r., Sv. r.: Verml. 0 .

\section{Sálsola. Sodaört.}

1. S. Kali L.; skärmblad hinnkantade uddspetsiga. 3, 4. Omkr. ${ }^{1} / 2$ fot hög och grenig med l,lekhvita eller rödaktiga kalkblaã; midtstjelken upprätt; sidostjelkar nedliggande eller uppstigande.

Hafsstränder; Göt. r.: Boh._Sk. Öl. spr., Sv. Söd. r. 


\section{Kóchia.}

1. K. hirsúta (L.) Nolte; rot enårig. 4.

Stjelkar omkr. $1 / 2$ fot långa, mycket greniga och ofta nerliggande; nästan hela växten gråluden, äldre n. glatt, vid torkning gulaktig.

Hafsstränder, mycket r.; Göt. Öl. vid Ottenby.

129. Schobéria.

1. S. marítima (L.) C. A. Mey.; blomgyttringar 2-3blommiga och mycket små. 3,4 .

Stjelk 2-10 tum lång, ofta grenig och nedliggande; hela växten blågrön och glatt.

Sandiga hafsstränder; Göt. Boh. Hall. t. r. Sk. spr. Blek. r. Öl. spr. Gotl. t. r.

\section{Herniária. Vügört.}

1. H. glabra L.; blad helbräddade, aflånga och nedåt afsmalnande; blomnystan motsatta de öfre bladen. 3 .

Stjelk mycket grenig och några tum lång.

Öppna sandiga fält nch vägar; Göt. Sv. t. a. åtm. i sandiga trakter: Verml. r. Boh. Ualsl. 0, Norrl. Gestr. Hels. t. a. Med. $r$.

- pubérula (Peterm); finluden.

Göt. Skåne vid Limhamn.

\section{Ulmus. Alm.}

A. Blomskaft mycket korta.

1. U. montána Sm.; de unga grenarne ludna; blad $n$. omvändt äggrunda-aflånga eller äggrunda, tvärt afsmalnande till en lång spets; vingfrukt n. oval, i spetsen grundt tvaklufven, med fröet nedom midten, aflägsnadt från inskärningen; ståndare fem eller sex. 1. Högt träd med brun, snart söndersprickande bark.

Skogøängar; Göt. Sv. mångenst.: Gotl. Dal.r., Norrl. Gestr.Ång. Jtl. r.

2. U. campestris Sm.; unga grenar n. glatta; blad n. ovala spetsiga (men sällan spetsade) samt n. glatta och föga sträfva; vingfrukt omvändt äggrund och klufven, med fröet invid inskärningen; ståndare fyra. 1.

Har smärre frukter än föreg. art; harken är stundom slăt, stundom mycket sprickfull och korkartad.

Skogsängar, Göt. Gotl. Öl. spr.

B. Blomskaft utdragna och hängande i flock.

3. U. effúsa Willd.; grenar glatta; blad ovala och något spetsade; vingfrukt oval, i kanten långhårig, grundt klufven, med fröet vid midten, aflägsnadt från inskärningen; ståndare vanl. åtta. 1.

Med mjukludna blạd och teml sinå frukter.

Skogsängar; Göt. Öland h. o. d. 


\section{Cynánchum. Tulkört.}

1. C. Vincetóxicum (L.) R. Br.; de öfre bladen lansettlika, de mellersta hjertlika spetsade; de nedersta ofta njurlika; kronflikar ovala-aflånga trubbiga; bikronans flikar förenade genom en hinna. 3.

Omkr. 2 fot hög; bladen likna syrenens och äro någongång kranssittande: karpeller mer än tumslånga och lansettlika; frön hårspetsade; frömjölsmassor snart utskjutande ur ståndareknapparne, förenade genom en fin tråd och slutl. fästande sig vid märket.

Berg och steniga backar, helst i skärgården; t. a. vid Östersjön, spr. vid Öresund; inuti landet: Göt. Sk. spr. Ög. mångenst., Sv. Söd. Upl. t. a. Vestm. spr.

\section{Cuscúta. Snarrefua.}

A. Stift kortare än fruktämnet; ståndare ej utskjutande.

1. C. europæa L.; kronpip vid blomningen n. rörformig, lika lång som brämet; hvarje blomma med ett skärmfjäll. 3 .

Spiralformigt slingrande; blommor hvitröda, vanl. med små tilltryckta fjäll i kronpipen; märken spetsiga; stjelk vanligen grenig.

P̊̊ nässla och humle, stundom på vinbärsbuskar, gräs, Fralium verum m. m.; Göt. Sv. mångenst.: Gotl. 1. Sk. a., Norrl. Gestr.-Med. spr. Ang. Vb. r.

* C. halophy'ta Fr.; kronpip vid blomningen klocklik; stjelk n. enkel; blomfoder djupt klufvet.

Hafsstränder r.; Göt. Boh. Små̀l. Gotl.

2. C. Epilínum Weihe, Linbinda; kronpip vid blomningen rundad och längre än brëmet; blommor utan skärmfjäll. 3.

Vanl. gulaktig med samma växesätt som hos föreg. art. Blommor hvitgula med små kronfjäll; märken klubblika; stjelk n. enkel; foder djupt klufvet.

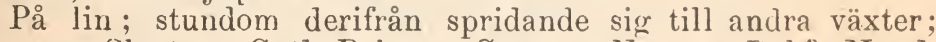
Göt. spr.: Sk. t. a. Gritl. Boh. r., Sv. spr.: Ner.t. a. Dal.?, Norrl. Jtl. spr. Gestr.-Ång. t. r.

B. Stift längre än fruktämnet; ståndare utskjutande. 3. C. Trifólii Bab. och Gibs., Klöfverbinda; kronpip vid blomningen $n$. rörformig och lika lång som brämet; hvarje blomma med ett skärmfjäll. 3 .

Nästan cirkelformigt omslingrande och förqväfvande klöfverstånden; blommor ljusröda, hälften mindre än hos föreg. arter samt med stora fjäll, som tillsluta kronans svalg; foder- och kronflikar spetsiga. Ett mycket skadligt ngräs.

På. klofver, sporadisk och troligen införd; Göt. r.: Sk. t. a. Smål. Ög. spr. Öl. Boh. 0, Sv. Söd. Upl. spr. Ner. Verml. r. 


\section{Hydrocótyle. Spikblad.}

1. H. vulgáris L.; blad långskaftade, runda och naggade. 3 .

Sijelk $1 / 2-1$ fot lång.

Vid och i åar eller sjöar eller nära hafvet; Göt. r.: Gotl. (̈). a. Sk. t. a. Blek. Smål. Hall. spr.

135. Sanicula. Sårlälia.

1. S. europæa L.; rotblad långskaftade, glänsande och 3 -5-delade med vigglika och inskurna flikar. 2,3 .

Stjelk omkr. fotshög; allmänna svepeblad 1-2, parflikade, enskilda svepen flerlladiga; somliga hlommor enkönade.

Skug-rika lundar nch hergsrötter; Göt. Gotl. Öl. a. Sk.t.a. Blek. Smål. t. r. Ög. Vg. spr. Hall. Boh. r. Dalsl. spr., Sv. r.: Söd. Upl. spr. Dal. 0, Norrl. Gestr. r.

136. Ery'ngium. Martorn, Manskraft.

1. E. maritimum L.; de nedre bladen njurlika långskaftade, de öfre oskaftade och mera inskurna eller delade; svepeblad n. rutformiga. 3,4 .

Omkr. 2 fot hög, styf och hlåaktig; bladtänder tagglikt spetsade

Hafsstränder; Göt. r.: Hall. Sk. spr. Smål. Ög. 0.

\section{Bupléurum. Harfoka.}

1. B. tenuíssimum L.; blad smalt lansettlika spetsiga. 3.

Från ett par tum till en fot hög, nedliggande eller uppstigande, till färgen erggrön; blommor små. Bladen bestå egentiigen af bladskaft, hvars skifvor felslagit.

Sandiga betesnıarker nära hafvet, någon gång i åkrar: Göt. Sk. spr. (helst vid v. kusten) Blek. Kalmarl. r. Gotl. t. r. Öl.spr.

\section{8. Ægopódium. Kirskål, Sqvallerkĩl.}

1. E. Podagrária L.; de nedre bladens flikar aflånga si̊gade, de öfres lansettlika. 2, 3 .

Stjelk 2-3 fot hög, grof och fărad; blad undertill blekgröna, de öfre oskaftade, sällan n. hela; blomflockar månystråliga, endast den i midten sittande frukthärande; rotstock krypande.

Ruderatväxt och ogräs isynnerhet $\mathrm{i}$ trädgårdar, någongång i ängar: Göt. a.: inre Smål. Boh. Dalsl. spr., Sv. a.: Vestm. Verml. spr. Dal.? Norrl. Gestr. t. a. Hels.-Äng. r.

\section{Imperatória. Mästerrot.}

1. I. Ostrúthium L.; bladflikar dubbelsågade. 3.

Stjelk omkr. 2-3 fot hög, glatt och glänsande med mycket stora blomflockar och tjock, starkt luktande rotstock.

Skogsängar och vid gårdar; Sv. r.: Ner. 0, Göt. Ög. Smål. Hall. t. r. Vg. Boh. Dalsl. r.

\section{Halóscias. Strandsticlá.}

1. H. scótica (L.) Fr.; bladflikar (småblad) snedt äggrunda med vigglik bas och omkr. tumsbreda. 3 .

Omkr. fotshög och föga grenig med lukt och smak af Libbsticka; frukter stora, slutl. omkr. 4 linier långa; stjelk trind.

Hafsstränder; Göt. Boh. a. Hall. spr. Sk. i m, v. delen r. 


\section{Falcária. Skürfloka.}

1. F. Rivíni Host; bladflikar jemubreda sågade; svepeblad borstlika. 3 .

Blågrön och omkr. 2 fot hög med trind stjelk, utspärrade grenar och trădlika flockstrålar; blad styfva med broskartade sågtändęr, de nedre stundom nästan parbladigt delade. Visby.

Åkrar, mycket r.; Göt. Skåne vid Glemminge, Gotl. nära

\section{Tórilis. Rïdfloka.}

1. T. Anthriscus (L.) Gmel.: bladtlikar iuskurna; blomflockar konkava och fåstråliga. 3, 4 .

Stjelk omkr. 2 fot hög med mörkgröna och sträfva blad.

Ruderatväst och på berg; Göt. spr.: Gotı. Öl. Sk. a. Boh. t. r., $S v$. spr.: Dal. r. Verml. 0 .

\section{Libanótis. Süfferot.}

1. L. montána Crantz; bladtlikar lansettlika-vigglika. 3.

Stjelk 2-3 fot hög, finluden och fåradt kantig; blad ofvan ljusợơna, undertill n. blåaktiga; blomflockar mycket täta.

Ruderatväxt' och på ängsbackar; Göt. Gotl. t. r. Öl. a. Kalmarl. Ög. spr. Sk. inre Smål. r. Vg. r.?, Sv. spr.: Verml. Dal.0, Norrl. Gestr. r.

\section{Dáucus. Mlorot.}

1. D. Caróta L.; bladens småflikar inskurua och uddspetsiga. 3.

Stjelk omkr. 2 fot hög och strimmig med lảnga mjuka och ljusgrơna blad; blomflockar stora, tätblommiga och konkava.

Ruderatväxt och ogräs; Göt. spr.: Gotl. Sk. a. Blek. Hall.Dalsl. r., Sv. r.: Dal. 0, Norrl. Jtl. r.

\section{A. Frukt glatt.}

\section{Anthriscus.}

1. A. silvestris (L.) Hoffm., Hundlax; svepen 5-bladiga; fruktspröt kort (1/4 så långt som frukten); alla blomflockar långskaftade och mingstriliga. 2, 3.

Stjelk 2-4 fot hög, fărad och med ludna leder; frukt aflångt jemnbred.

Ruderatväxt och i ängar, allmän, äfven i fjellen: Jtl. t. r.

2. A. Cerefólium (L.) Hoffm., Kyrfvel; svepen 2-3bladiga; fruktspröt utdraget (hälften så långt som frukten); blomflockar fistrioliga, sidoflockar n. oskaftade. 2 .

Lägre och spädare än föreg. och n. glatt med strimmig stjelk; bladflikar vid torkning n. hivitaktiga; frukt n. jemnbred, af aromatisk smak; rot tvåărig.

Ruderatväxt och ogräs; Göt. 1’: Blek.? Vg. 0, Sv. Söd. Upl. r.

B. Frukt krokhårig.

3. A. vulgaris Pers.; fruktspröt mycket kort; blomflockar fästráliga, kortskaftade. 2, 3. 
Stjelk 1-2 fot hög och vek, fårad och glatt; blad håriga och temligen små; bladens småflikar trubbiga med udd; blomflockar omkr. en half tum breda och vanl. motsatta bladen; rot tvåårig.

Rưderatväxt; Göt. Gotl. t. r. Öl. Sk. spr. Hall. Blek.-Ög.r. 146. Chærophyllum. Floka.

1. C. témulum L.; rot späd och tapplik; bladflikar äggrunda-aflånga, trubbiga och inskurna; stift utdragna och slutl. utböjda. 3.

Omkr. fotshög med fläckig, strimmig och ej ihålig stjelk; blad mjukludna och blekgröna, vid torkning blågröna; flockar mångstråliga, i början lutande; rot tvåårig.

Ruderat- och lundväxt; Göt. Hall.. spr. Sk. a. Blek. Kalmarl. spr. (vid kusten) Gotl. spr. Öl. t. a. Ög. r. (vid Bråviken, Vettern och Svartån) Vg. på Kinnekulle.

\section{Myrrhis. Spansk Kyrfvel.}

1. M. odoráta (L.) Scop.; bladflikar lansettlika parklufna. $2,3$.

Stjelk mer än 2 fot hög, fårad och ihålig med ljusgröna blad och småludna flockskaft; frukter glänsande gulbruna, slutl. svartnande.

Ruderatväxt och i ängar, trol. förvildad; Göt. spr.: Sk. t.a. Blek. Hall. Dalsl. r. Boh.?, Sv. Söd. Upl. spr. Ner. t. r. Verml. r., Norrl. Hels. r.

\section{Scandix. Nailkyrfvel, Kamkyrfvel.}

1. S. Pecten Véneris L.; rot enårig; bladflikar små och jemnbreda, smalare än den sträfva stjelken. 2,3 .

Omkr. 1/2 fot hög med kamlik fruktsamling: blommor små, länge qvarsittande på fruktens spröt, som slutligen blir $1^{1} / 2$ tum långt och mer än 3 gånger så långt som sjelfva frukten; stift utdragna.

Åkrar; Göt. Gotl. allm. Öl. spr.

\section{Laserpitium. Spenört.}

1. L. latifólium L.; blad med triangelformig omkrets och med rundadt hjertlika, naggade flikar. 3.

Stjelk 4-5 fot hög, finstrimmig och upptill grenig med mycket stora blomflockar; de nedre bladens ändflik stundom 3flikig; bladslidor uppblåsta. Hela växten gråblå.

Torra ängar; Göt. Gotl. t. r. Öl. a. Blek. Sk. r. Hall. t. r. Smål. Ög. spr. Vg. r.?, Sv. spr.: Dal. r. Ner. Verml. 0, Norrl. Gestr. r.

\section{Levísticum. Libbsticka.}

1. L. officinále Koch; bladflikar rutformiga, upptill inskurna. 3.

Stjelk 2-3 fot hög, trind, strimmig och upptill grenig; blad glänsande och mörkgröna med ej uppblåsta slidor.

Ruderatväxt, ursprungl. förvildad och t. r., dock Sk. Söd. Upl. spr.; Lpl. 0. 


\section{Peucédanum. Mjölkrot, Mossrot.}

1. P. palustre (L.) Mönch; stjelk fărad och trubbkantig; bladflikar n. jemnbreda och kort uddspetsiga; de enskilda svepenas blad hinnkantade; frukt äggrund. 3.

Stjelk öfver 2 fot hög med de nedre bladen slidomfattande, till omkretsen triangelformiga; flockstrålar 20-30, finludna; bladskaftets förgreningar framåtrigtade.

Kärrängar och stränder, helst i skogstrakter; Göt. Sv. a., Norrl. spr.: Jtl. r. Vb. t. r., Lpl. r.

2. P. Oreoselínum (L.) Mönch; stjelk trind och strimmig; bladflikar vigglika-aflånga och inskurna med uddspetsiga tänder; de enskilda svepenas blad ej hinnkantade; frukt n. rund. 3.

Omkr. 2 fot bög och glatt; de nedre bladen till omkretsen triangelformiga; flockstrålar 10-20; bladskaftets förgreningar utspärrade.

Torra grusiga betesmarker; Göt. Sk. spr. (i ö.delen t. a.) Öl. tr. 152. Selínum. Kruffrö.

1. S. Carvifólia L.; stjelk fårad med hvassa, hinnaktiga och n. genomskinliga kanter; bladflikar lansettlika och spetsiga med hrit udd. 3. aflånga.

Stjelk omkr. 2 fot hög med de nedre bladen till omkretsen

Skogsängar och bergssluttningar, stuudom på stränder; Göt. spr. (helst $i$ slättbygder): Öl. t. a. Gotl. t. r. Hall. $r$ Dalsl. t. a., Sv. spr.: Ner. t. r. Vestm. r. Dal. 0.

\section{Silaus. Ängsticka.}

1. S. pratensis Bess.; stjelk upptill kantig; bladflikar lansettlika uddspetsiga. 3,4 .

Glatt och teml. spenslig, 3-4 fot hög; flockar omkr. en tum breda; flockstrålar olika långa; allmänna svepeblad 1-2. Liknar en Peucedanum, men luktar niästan som Libbsticka.

Torra skogsängar eller pilvallar, mycket r.; Göt. Sk. Gotl.

\section{Cnídium.}

1. C. venósum Koch; stjelk enkel, n. trind och strimmig. 3,4 .

2 fot hög, vanl. blott med 3 blomflockar; svepeblad borstlika; bladflikar spetsiga.

Busksnår; Göt. Öl. mångenst. Kalmarl. spr. i s. delen.

155. Angélica. Siöke, Björnpipa.

1. A. silvestris L.; stjelk (upptill) och flockstrålar hvitaktigt finludna; de nedre bladen med triangelformig omkrets och med äggrunda-aflanga och hvasst sågade flikar. 3.

Stjelk 3-4 fot hög, vanl. tjock och mycket pipig, med stora och undertill blekgröna blad; blomflockar täta, stora och mångstråliga. 
Sumpiga skogsängar och stränder, helst i skogsbygder; $L p$. Norrt. Sv. a., Göt. t. a.

- major; gröfre och högre med större bladflikar och föga ludna flockstrålar. Liknar följ. art.

Hafsstränder h. o. d., t. ex. vid Östersjön och i Boh.

\section{Archangélica. Qvanne.}

1. A. officinális Fr.; stjelk glatt; bladflikar n. äggrunda, olikformigt sågade och ofta 3-flikiga; allmänna bladskaftet ofvan plattadt. 3.

Stjelk saftig och, i förhållande till sin storlek och tjocklek, teml. kort och omkr. 2 fot hög; flockstrålar något sträfva, icke gråludna. Hela växten har en aromatisk lukt, stjelkarne äro atliga.

Något dolda och fuktiga ställen vid bäckar i fjelltrakter; Lpl. a., Norrl. Jtl. Merj. a. (i fjellen) Vb. t. r., Sv. Dal. a. i fjellen.

* A. littorális Fr.; bladflikar mera olikformigt sågade; flockstrålar stundom något gråludna; bladskaft trinda; stjelk mera fårad och stundom rodnande; bladslidor mera hinnaktiga; växtens smak kärf.

Blommar tidigare än Angelica silvestris.

Hafsstränder; Göt. t. r.: Boh. Hall. Ög. spr. (̈). 0, Sv. t. r., Norrl. Vb. r.

\section{Heracléum. Björnram.}

1. H. sibíricum L.; kronblad äggrundt lansettlika tillspetsade och i spetsen inböjda; den mogna frukten n. omvändt hjertlik (i spetsen djupt urnupen). 3.

Stjelk grof, ornkr. 3 fot hög; bladflikar vanl. inskurna i atlånga småflikar; blommor gröna eller gröngula; fruktämmen n. glatta ; oljeränderna på delfrukternas insida korta och icke nåend (' till deras midt, på yttre sidan 2 klubblika; blomflockens alla hommor lika stora. Stundom äro bladens srnåflikar utdragna och n. jemnbreda.

Ängar och åkerrenar; Göt. spr.: Sk. t. r. I)assl. Vg. Ög. t.a., Sv. a., Norrl. spr.: Gestr. Hels. t. a. Vb. r.

2. H. suécicum Fr.; kronblad i spetsen djujt inskurna och omvändt hjertlika med utstaende sidoflikar och inböjd mellanflik; frukt n. aflång och i spetsen trubbig. 3 .

Liknar föreg. art, men har hvita blommor och småludna fruktämnen; oljeränderna på delfrukternas insida utdragna öfver nidten, på yttre sidan trådlika och flera än hos föreg. art.

Äng:ır; Göt. Sk. a. Blek. spr. Smål. r. Ög. t. r. Dalsl. r. Bok. t. r.; trol. äfven annorstädes; Sv. Söd. Upl. Verml. r.

\section{Pastínaca. Palsternacka.}

1. P. satíva L.; blad med äggrunda-aflånga och inskurna flikar och 3 -flikiga ändflikar.' 3. 
Omkr. 2 fot hög med på öfra sidan glänsande blad.

Ruderatväxt, trol. oftast förvildad; Göt. spr.: Sk. Hall. a. Gotl. Blek. Dalsl. r. Boh.?, Sv. Söd. Upl. spr. Ner. Verml. r.

\section{Sium. Strätta.}

1. S. latifólium L.; rotblad dubbelt parbladiǵt delade; stjelkbladens flikar (småblad) långa, från äggrund bas utdraget lansettlika och hvasst sågade. 3 .

Stjelk 3-4 fot hög, pipig och djupt fårad; blad ofvan ljusgröna, undertill blekare; blomflockar stnra med långa skaft och flockstrålar; frukt på ryggen kullrig. Stundom äro bladflikarne mycket smala, n. jemnbreda och något krökta.

I åar, stundom i sjöar; Göt. spr.: Sk. Smål. Ög. Öl.t. a. Gotl.?, $S v$. Söd. Upl. Ner. t. a. Vestm. spr. Verml. t. a. i Venerstrakten: Norrl. "vid Bottn. viken:" Wahlenl.

2. S. angustifólium L.; rotblad enkelt parbladigt delade: bladflikar (småblad) korta, stjelkbladens äggrundt aflånga och olikformigt inskurna. 3 .

Stjelk 1-2 fot hög, pipig, strimmig och bräcklig; i)lar mörkgröna; blomflockar motsatta de öfre bladen och små med korta skaft och flockstrålar; frukt på båda sidor kullrig.

Åar; Göt. Boh. r. Hall. spr. Sk. a. Bjek. r. Ög. i Skenaån r.

\section{Pleurospérmum. Slökrsticlia.}

1. P. austríacum (L.) Hoffm.; blad med triangulär omkrets med aflånga-vigglika och inskurna flikar. 3.

Stjelk omkr. 4--5 fot hög, fårad och alltigenom pipig; de nedre bladen skaftade, de öfre oskaftade; de öfre grenarne oft: kranssittande; blomflockar mångstråliga. Liknar en Angeticu, som dock lät.t skiljes genom de stora hladslidorna.

Skogsängar, mycket r.; Göt. Ög. på Kolmorden flerst.

\section{Coníum. Oclört.}

1. C. maculátum L.; blad med triangulär omkrets och lansettlika flikar. 3 .

Stjelk 3-4 fot hög, glatt, pipig och strimmig med mjuk: nch glänsande blad. Mycket giftig.

Ruderatväxt, helst i slättbygder; Göt. spr.: Gotl. Blek. inre Smål. Vg. Dalsl. r., Sv. spr.: Verml. r. Dal. 0, Norrl. Gestr. r.

\section{Cicúta. Sprüngört.}

1. C. virósa L.; bladflikar långa, lansettlika och hvasst sågade. 3 .

Stjelk pring och 2-3 fot hög; flockstràlar lika långa; småflockar kullriga och åtskilda; rot och ort mycket giftiga. Stundom äro bladflikarne blott linieloreda.

Sjöar, åar och kärr; Göt. spr.: inre Små]. t. r. Gotl. r. Öl.0. Sv. spr.: Söd. Upl. t. a., Norrl. spr.?: Vb. t. a. Jtl.?, Ippl, spr. 163. Ethúsa. Tildpersilja.

1. Æ. Cynápium I.; bladens smäflikar lansettlika vch kort uddspetsiga. $2-4$. 
Stjelk 1-2 fot hög, späd, nedtill vanl. fläckig och blåaktig med glänsande och mörkgröna blad. Giftig.

Ruderatväxt och ogräs i köksträdgårdar; Göt. Sv. a., Norrl. Gestr. spr. Hels. Ång. r.

\section{Enánthe. Stäkra.}

\section{E. Phellándrium Lam., Häststäkra; alla blommorn`a}

lika stora, skaftade och fruktbärande; stift mycket kortare än den aflånga, upptill afsmalnande frukten. 3,4 .

Stjelk omkr. fotshög med talrika utspärrade grenar samt nedtill mycket tjock och uppblåst och försedd med $i$ krans sit. tande rottrådar; rot tjock och tapplik; blad 2-3 gånger parbladigt delade; de nedsänkta bladens flikar smala, de öfrigas lansettlika parklufna; flockar kortskaftade och motsatta bladen; småflockar små. Anses giftig för hästar.

I ảar, vattengrafvar och sjöar; Göt. mångenst.: Sk. a. Hall. inre Smål. r. Gotl. 0, Sv. spr.: Dal. r.?, Norrl. Gestr. spr. Vb.? 2. CE. fistulósa L., Pipig Stäkra; blott de inre oskaftade blommorna i småflockarne fruktbärande, de yttre (gallblommorna) skaftade och större än de öfriga; stift lika långt som den klubblika frukten. 3 .

Blågrön och 1-2 fot hög; stjelk teml. smal, alltigenom pipig, vek och skör, med fă och föga utstående grenar; blad med långa pipiga skaft; stjelkblad enkelt parbladigt delade med jemnbreda flikar; rotblad dubbelt parbladigt delade med ovala trul-biga flikar; rotskott utdragna.

Stränder af âar och bäckar, ofta i sjelfva vattnet; Göt. Sk. a. (utom i furubygden) Hall. Blek. r. Goti. t. r. Smål.?

\section{Helosciádium. Kärrfloka.}

1. H. inundátum (L.) Koch; stjelk flytande eller krypande; småblad (bladflikar) vanl. upptill 3-tandade. 3.

Liknar något Enanthe fistulosa, men är till alla delar mindre, frăn ett par tum ända till en fot lång.

Våta ställen helst nära hafvet, stundom i åar; Göt. Dalsl. Hall. r. Sk. spr. Blek. r. Smål. t. r. Öl. r.

\section{Carum. Kummin.}

1. C. Carvi L.; blad till omkretsen aflånga, de nedre skaftade, de öfre med stora slidor. 2, 3 .

Stjelk omkr. fotshög, strimmig och spenslig.

Ängar och lackar, allmän: Lpl. t. r.

\section{Pimpinella. Bockrot.}

1. P. Saxífraga L.; stjelk finstrimmig och trind; stift kortare än fruktämnet. 3 .

Stjelk knappt 2 fot hög, vanl. glatt och upptill bladlös eller med bladlösa slidor; de nedre bladens flikar vanl. trubbiga, rundadt äggrunda och sågade; stundom äro alla bladflikarne smali och jemnbreda; blommor hvita, sällan rödletta. 
Torra ängar och backar; Göt. Sv. a., Norrl. spr.: Ang. a. Vb. t. r., Ipl. r.

2. P. magna L; stjelk färad och kantig; stift längre än fruktämnet. 2,3 .

Något högre och gröfre än föreg. och vanligen långt upp hladig; bladflikar vanl. spetsiga; blommor hvita eller ljusröda; frukter större än hos föreg. art.

Fuktiga ängar och lundar; Göt. Sk. spr. Blek.-Ög. Gotl. Öl. r., Sv. Söd. Vestm. r.

168. A'pium. Selleri.

1. A. gravéolens L.; småblad vigglika. 3, 4 .

Starkt luktande, glatt och ljusgrön med $1-2$ fot hög, fårad och upptill grenig stjelk; flockarne och de öfre bladen n. oskaftade. Fuktiga ställen nära hafvet, mycket r.; Göt. Sk. Gotı.

\section{Ordn. TRIGYNIA.}

\section{Viburnum. Olvon, Ulftry.}

1. V. O'pulus L.; blad 3-flikiga med spetsiga och hvasstandade flikar. 2.

4-8 fot hög buske med mergfull stam, välluktande blommor och röda bär; bladskaft med vårtor; stipler borstlika.

Något fuktiga lundar och skogsängar; Göt. Sv. t. a., Norrl. r.: Gestr. spr. Herj.?, Lpl. r.

\section{Sambúcus. Hyll.}

1. S. nigra L., Fläder; buske (eller mindre träd); blomknippe 5-stråligt; stipler borstlika eller otydliga; bladflikar äggrunda-ovala och tandade. 3 .

Stam med hvit merg; blommor gulhvita, starkt luktande; bär svarta. Năgon gång äro bladflikarne pardelade med smala småflikar. vildad.

Nära bostäder; Göt. spr., troligen vild, Sv. t. r., trol. för-

2. S. E'bulus L., Sommarhyll. Mannublod; ört; blomknippe 3-stråligt; stipler äggrunda-lansettlika och bladartade; bladflikar smalt lansettlika och sågade. 4.

Stjelk upprätt och grenig, 3--6 fot hög och glatt med krypande rotstnck; blommor blekröda, starkt luktande, alla skaftade; bär svarta.

Något fuktiga ställen nära trädgårdar, trol. förvildad, r.; Göt. sk. Blek. Kalmarl., Sv. Söd. Upl.

\section{Ordn. TETRAGYNIA.}

\section{Parnássia. Slåtlerblomma.}

1. P. palustris L.; rotblad skaftade, stjelkblad omfattande, alla hjertlika. 3 .

Omkr. 1/2 fot hög; blomma vanl. nära en tum hred; kronblad hvita och ådriga. Stundom (t. ex. i fjellen och på Gotl.) äro blomimorna teml. små med fåstråliga honingsgömmen.

Fuktiga ängar, allmän, äfven uppe i fjellen. 


\section{Ordn. PENTAGYNIA. 172. Arméria. Trift.}

1. A. elongáta Koch; blomfodrets åsar håriga; de yttersta skärmbladen tillspetsade, de inre trubbiga och uddspetsiga. 3.

Stänglar vanl. fotshöga och glatta samt flera gånger längre än bladen; rotstock tjock; blad mörkgröna, smalt jemnbreda, $n$. spetsiga och vanl. haärbräddade; kronbladens spets rundad eller svagt urnupen.

Torra sandiga backar och stränder vid eller nära hafvet: Göt. Sv. t. a.: Gotl. r.; inuti landet: vid Mälaren mångenst., vid Vettern (i Og. och Smål.) samt i det inre Smål. t. r., Dal. på ett ställe, Sk. h. o. d., Vg. vid Venersborg?

2. A. pubescens Boiss.; blomfoder nästan öfverallt hårigt; de yttersta skärmbladen trubbiga, de inre utan udd. 3 .

Stänglar omkr. 1/2 fot höga och omkr. dubbelt längre äı bladen samt vanl. tätludna; blad ofta ludna; kronblad urnupna. Växter i större och tätare tufvor än föreg. art.

Hafsstränder, sällan något längre inuti landet; Göt. Boh. t. a. Halls spr. Sk. t. a. Goti.?

\section{Státice. Marrisp.}

1. S. bahusiensis Fr.; stängel kantig; ax glesblommiga. 4. Omkr. fotshög med fasta, $n$. aflånga eller omvändt äggrunda blad; skärmfjäll trubbiga med röd hinnkant.

Hafsstränder; Göt. Boh. t. r. Sk. på Torekowö.

2. S. Behen Drej.; stängel $n$. trind; ax tätblommiga. 4 . Omkr. 1/2 fot hög; blad n. aflånga, vanl. spetsade med udd: skärmfjäll spetsiga med hvit hinnkant.

Hafsstränder; Göt. Skåne t. r. på v. kusten.

\section{Drósera. Daggört, Silhår.}

1. D. rotundifólia L., Rundbladig Daggört; blad 1. cirkelrunda, tryckta till mârken; stängel rak och upprätt, mycket längre än bladen. 3 .

Stängel omkr. 4 tum hög; blad tvärt afsmalnande mot skaftet. Kärr och myrar, teml. allmän.

2. D. Iongifólia L., Långbladig Daggört; blad utdraget tunglika och upprätta; stängel rak och upprätt, mycket längre än bladen; fröhus längre än fodret. 3 . aktigt.

Något högre än föreg. art; märke klubblikt, helt och hrit-

Kärr och myrar, teml. allmän: Blek. Öl. r.

* D. obováta Koch; blad korta och n. omvändt äggrunda: fröhus kortare än fodret.

Göt. t. r.: Öl. Blek. Dalsl.?, Sv. Söd. Upl. r., Norrl. Hels. Ång. Vb. r., $L_{p l}$. r.

3. D. intermédia Hayne; blad omvändt äggrunda och 
upprätta; stängel nedtill bågböjd, eljest upprätt, lika lång med bladen eller föga längre. 3 .

Lägre än de föreg. arterna; märke urnupet och rödaktigt; frön omgifna af ett fast och grynprickigt skal (hos de föreg. af en lös och nätlik hinna).

Kärr och myrar mångenst.: Sk. Blek. a. Ö1. 0.

\section{Sibbáldia.}

1. S. procumbens L.; blad trefingrade och håriga; småblad vigglika och. upptill tretandade; kronblad kortare än fodret. 2,3 .

Stänglar 1-2 tum höga med tjock rotstock och små gyttade blommor.

Ängsmark i fjellen, helst ofvan barrskogsregionen; Lpl. a., Norrl. Jtl. Herj. spr., Sv. Dal. t. r.

\section{Ordn. POLYGYNIA.}

\section{Myosúrus. Riit'svans.}

1. M. mínimus L.; blommor gröngula. 1, 2. 1-8 tum hög med långa blad.

Åkrar och fält; Göt. Sv. t. a.: Buh.-Dal. spr., Norrl. Gestr. - Med. spr. Ång. r.

\section{Klassen. HEXANDRIA.}

1 Ordn. MONOGYNIA.

\section{Bérberis. Surtorn, Berberisbuske.}

1. B. vulgaris L.; blad omvändt äggrunda och taggbräddade; blomklasar nedhängande. 2.

4-8 fot hög med glänsande röcla, 2-fröiga och mycket sura bär. Ståndarne draga sig intill pistillen, då de vidröras.

Torra ställen i skogar och hetesmarker, stundom på berg; Göt. r.: Hall, t. a. Blek. Kalmarl. spr. Ög. t. a., Sv. Söd. Upl. t. a. Vestm. Ner. spr. Verml. I)al. r., Norrl. Gestr. Hels. r., Lpl.? 178. Peplis. Rödlånke.

1. P. Pórtula L.; blad omvändt äggrunda, kortskaftade. $3,4$.

Några tum lång och ofta rödaktig med n. oskaftade blommor.

Fuktiga ställen; Göt. spr.: Sk. Öl. a. Gotl.?, Sv. spr., Norrl. Gestr. Hels. r., Lpl. r.

179. Leucójum. Vårlolocka, Klostcrlilja.

1. L. vernum L.; rotblad flera och gröna, bredt jemnbreda och trubbiga. 1, 2.

Omkr. $1 / 2$ fot hög; kalkblad i spetsen gröna.

Gamla parker, trol. sedan medeltiden förvildad, ganska r.; Ög. Upl. Gestr. 


\section{Galanthus. Snödroppe.}

1. G. nivális L.; rotblad 2, blågröna, smalt jemnbreda och trubbiga. 1.

Omkr. 3-4 tum hög; inre kalkblad utanpå med en halfmånformig grön fläck och invändigt med gulgröna ränder; yttre kalkblad hvita.

Ängar och parker; Göt. r.: Sk. Öl. spr. Blek. Boh. Vg. 0, Sv. Söd. Upl. r.

\section{Túlipa. Tulpan.}

1. T. silvestris L.; ståndarsträngar nedtill håriga; blomma före utslåendet lutande, med olika breda kalkblad; kapselns längd dubbelt så stor som bredden. 1, 2.

$1 / 2-1$ fot hög med upptill bladlös stjelk och lansettlika spetsiga, .rännformiga och blågröna hlad.

Ängar; Göt. Gotl. Blek. Ög. r., men trol. vild (Sk. Hall. förvildad), $S v$. Söd. Upl. r. (Vestm. förvildad).

\section{Fritillária. Damspelslilja.}

1. F. Meleágris L.; blad rännformiga, jemnbreda och spetsiga. 1, 2.

Vanl. fotshög; kalkblad brunröda, sällan hvita, och rutiga, liknande ett schackluräde.

Fuktiga ängar; Göt. Gotl. Blek. Og. r., Sv. r.: Ner. Dal. 0, Norrl. Gestr. Jt1. r.

\section{Lilium. Lilja.}

1. L. bulbíferum L., Brandgul Lilja; blommor upprätta och klocklika med raka kalkblad; blad strödda och jemnbredt lansettlika med bruna groddknoppar i bladvecken. 2,3 .

1-2 fot hög med bladrik stjelk och mycket stora, brandgula, inuti mörkrödt fläckiga blommor, enstaka eller i flock i stjelkens spets. Dal. 0.

Ängar och parker; Göt. Vg. Smål. r. Ög. spr., Sv. r.: Ner.

\section{A'llium. Lök.}

A. Blomflock med knopplökar; stängel beklädd af bladens slidor och trind; kalkblad klocklikt samstående. Lökar tjocka och rundade.

a. Ståndaresträngar enkla; lök enkel.

1. A. oleráceum L., Ängslök; blomhölster 2-bladigt; blad smala, halftrinda eller plattade; ståndare knappt utskjutande. 3 .

Omkr. 2 fot hög med smutsröda blommor och små knopplökar; kalkblad kort uddspetsiga.

Ruderatväxt och ogräs, äfven på berg; Göt. t. a.: Dalsl. r., $S v$. Söd. Upl. a. Vestm. Ner. spr. Verml. r., Norrl. Gestr. spr. Hels._Ång. Jtl. r. 
* A. carinátum L.; ståndare längre än de ljusröda och trubbiga kalkbladen; blad teml. breda.

Lundar; Göt. Skåne r.

b. Hvarannan ståndaresträng 3-uddig; lök sammansatt.

2. A. arenárium L., Åkerlök, Sandlök; blomhölster enbladigt; blad trinda; ståndare utskjutande. 3, 4 . lökar.

Omkr. 2 fot hög med blekröda blommor och små knopp-

Ruderatväxt och ogräs i șandiga åkrar; Göt. Boh. Hall. spr. Sk. t. r. Blek. t. a. Smål. Ög. t. r. Öl. a. Gotl. spr., Sv. Söd. Upl. spr.

3. A. Scorodóprasum L., Skogslök; blomhölster 2-bladigt; blad platta; ståndare inneslutna. 3 . lökar.

Omkr. 3 fot hög med purpurröda blommor och stora knopp-

Berg, lundar och skogsängar, äfven ruderatväxt; Göt. spr.: Gotl. Öl. t. a. Vg. Dalsl. r., Sv. Söd. Upl. spr. Vestm. t. r.

B. Blomflock utan knopplökar; stängel $\mathrm{n}$. bar eller blott nedtill beklädd af bladslidor, trind eller halftrind och kantig. Ståndaresträngar enkla. Lök smal.

a. Kalkblad klocklikt samstående; lök öfvergående till en lång rotstock.

4. A. montánum Schm., Berglök; blomskaft långa; ståndare utskjutande; blad platta jemnbreda och teml. smala. 3,4 .

Liknar de föreg. arterna; 1-2 fot hög med röda blommor; flock mårgblommig med 2--3 trubbiga hölsterblad, som äro dubbelt kortare; kalkblad n. trubliga; stängel mer eller mindre skarpkantig.

Skogsbackar och berg; Göt. Sk. r. Dalsl. mångenst. i v. delen, $S v$. Verml. r. i s. v. delen.

b. Kalkblad utstående; lök smal och enkel.

5. A. sibíricum L., Gräslök; stängel nedtill beklädd af bladslidor och trind; blad $\mathrm{n}$. trinda, ofvan plattade med syllik spets; blomflock klotformig och hufvudlik. 3 .

Omkr. fotshög med rosenröda blommor och pipiga blad; ståndare mycket kortare än kalken. Stånden äro ofta hopgyttrade liksom i tufvor.

Ängar och berg r.; Norrl. Jt1., Göt. Gotl.

- schœnoprasóides (Fr.); 3-6 tum hög med trinda syllika blad.

Hafsstrằnder, helst vił Östersjön; Göt. a.: Blek. spr. Hall. r Boh. r.? Sk.?, Sv. t. a.

6. A. ursínum L., Ramslök; stängel nästan bar, halftrind 
och kantig; blad bredt lansettlika, spetsiga och långskaftade; blomflock n. platt med n. jemnhöga blomskaft 2,3 .

Omkr. $1 / 2$ fot hög med snöhvita blommor och stora blad; ståndare kortare än kalken; fr ön klotformiga.. Luktar som hvitlök.

Fuktiga ställen i lundar (någon gång i skogar), helst iskärgården, stundom ogräs i trädgårdar; Göt. r.: Sk. Gotl. spr. Smål. Og. t. r., Sv. Söd. Upl. t. r.

\section{Gágea. Viorlök, Vi̊rfrudagslök.}

A. Kalkblad och blomskaft glatta.

1. G. lútea (L.) Ker; lök ensam och enkel; kalkblad trubbiga; den n. oskaftade flockens blomskaft enkla. 1.

Omkr. fingerhög med ett jemnbredt lansettlikt, platt och uppåt tvärt afsmalnande rotblad: skärmblad 2 nästan motsatta; kalkblad aflångt lansettlika.

Lundar och ängar; Gööt. a.: v. Smål. t. r., Sv. a.: Verml. t. r. Dal. 0, Norr?. Gestr. Hels. r.

2. G. spathácea (W.) Salisb.; lök enkel; kalkblad mycket kort spetsade; blomflock skaftad med enkla blomskaft. 1.

Liknar föreg., men har stundom några smålökar invid den stora löken; rothlad n. trådlika, 2 eller flera; kalkblad lansettlika-aflånga; flock vanl. fåblommig.

Lundar; Göt. Blek. Sk. spr. Smăl. Boh. Dalsl. r. Hall.?

3. G. stenopétala Fr.; lökar 3 tillsammans (den ena något större) och något sammanhängande; kalkblad trubbspetsade eller trubbiga; den vanl. oskaftade flockens blomskaft enkla. 1.

Liknar föreg., men här något större blommor; rotblad vanl. 1, stundom 2, blågröna och teml. breda (nästan såsom hos G.lutea); de öfre 2 skärmbladen nästan motsatta.

Åkrar; Göt. Sk. spr. Blek.-Ög. r., Su. Söd. Upl. r.

4. G. mínima (L.) Schult.; lök dubbel, åtföljd af flera smålökar; kalkblad spetsiga med utdragen och utböjd spets; den skaftade flockens grenar vanl. förgrenade. 1.

Spensligare än de föreg. med ensamt, smalt jemnbredt rot. blad; de unga lökarnes blad trådlika.

Lundar och åkrar; Göt. Sv. spr: Gotl. Öl. Kalmarl.-Upl. a. Ner. t. a. Boh.-Dal. r., Norrl. Gestr.-Ång. r.

B. Kalkblad och blomskaft småludna.

5. G. arvensis (Pers.) Schult.; lök dubbel; kalkblad aflångt lansettlika spetsiga. 1.

Rotblad vani. 2, rännformign, mycket långa och smala; flock vanl. 5-10-blommig och oskaftar; blomskaft enkla eller greniga. Alkrar, mycket r.; Göt. Sk. Blek.

186. Ornithógalum. Stjernö̈l.

1. 0. nutans L., Aftonstjerna; blommor lutande i axlik och ensidig klase med skaften 3-4 ganger kortare 
än blomskärmarne; blad platta, lansettlikt jemnbreda. $1,2$.

Omkr. fotshög med teml. tjock stängel; blommor stora, omkr. 2 tum vida; kalkblad silfverhvita, på ryggen gröna.

Parker, ursprungligen förvildad; Göt. sk. t. r. Hall. Blek. Smål. Ög. r., Sv. Upl. Vestm. r.

2. O. umbellátum 'L., Morgonstjerna; blommor upprätta i flock eller qvast med skaften lüngre än blomskärmarne; blad jemnbreda rännformiga. 1, 2.

Omkr. $1 / 2$ fot hög med smal stängel; blommor tumsvida; kalkblad inuti snöhvita, utvändigt grönaktiga; blad med en silfverhvit rand i midten.

Parker och åkrar, trọl. på de flesta ställena (utom Ölanıl) förvildad; Göt. r.: Sk. Öl. flerst. Boh. Vg. Dalsl. 0, Sv. Söd. Vestm. r.

\section{Convallária. Konvalje.}

A. Blommor hvita och klocklika med tillbakaböjda tänder; stängel bladlös; stindare fästade på kalkens botten.

1. C. majális L., Litjekonvulje; blommor klotrundt klocklika i ensidig klase. 1, 2.

Omkr. $1 / 2$ fot hög med smal rotstock, stora bredt lansettlika och ljusgröna rotblad, särdeles välluktande blommor och röda bär.

Lundar och skogsängar; Göt. Sv. a., Norrl. t. a.: Jtl. spr. Vb. t. 1., Lpl. r.

B. Blommor rörformiga, hvita med gröna och raka tänder, och sittande i stjelkens bladveck; ståndare fästade midt på kalken. Blad oskaftade.

a. Blad skiftevis sittande, äggrunda-aflånga.

2. C. Polygónatum L.; stjelk kantig; kalk nedtill afsmalnande; ståndaresträngar glatta. 1, 2.

Omkr. fotshög med tjock rotstock och svartblå bär; blomskaft van]. enblommiga, stundom 2-blommiga; stjelk med slidor nedtill.

Lundar och berg; Göt. Sv. t. a.: Boh.--Verml. spr. Dal. r., Norrl. r.: Gestr. Herj. Jtl. spr.

3. C. multiflóra L.; stjelk trind; kalk nedtill något vidgad; ståndaresträngar ludna. 2.

Något högre äl föreg., med smalare blommor; bloinskaft 2-5-blommiga; stjelk utan slidor nedtill. Någon gång (i Söd. Upl. och V..) har man funnit en form med de gemensamma blomskaften utdragna, grenlika och försedda med små skärmblad.

Lundar; Göt. spr.: Gotl. Öl. inre Smål. Boh. Dalsl. t. r., Su. t. r.: Söd. Upl. spr. Dal. 0, Norrl. Gestr. r.

b. Blad jemnbredt lansettlika, stälda i kransar.

4. C. verticilláta L.; stjelk kantig: 2 . 
Omkr. 2 fot hög med smärre blommor och smalare blad än hos de båda föreg.; blomskaft 2-3-blommiga; bär röda.

Lundar och skuggrika bergssluttningar; Göt. Sk. Hall. t. a. inre Smål. Vg. Dalsl. t. r., Sv. Verml. t. r., Norrl. Herj. Jtl. Ång. r., Lpl. r.

188. Aspáragus. Sparris.

1. A. officinális $L$.; bär röda. 3 .

1-4 fot hög; ståndaresträngar föga längre än knapparne. Hafsstränder; Göt. Sv. r.; inuti landet någon gång förvildad.

189. Anthéricum. Sandlitja.

1. A. Liliágo L.; stjelk enkel; frukt äggformig spetsig; stift krökt. 2.

Eotshög med tufbildande blad, som äro föga kortare än stjelken; skärmblad nästan af blomskaftens längd; kalkblad n. aflånga, längre än stiftet.

Sandfält; Göt. Öl. Blek. r. Sk. t. r. helst i ö. delen.

2. A. ramósum L., Grenig Sandlilja; stjelk grenig; frukt klotrund; stift rakt. 3 .

Har hälften så stora blommor som föreg. art och något högre stjelk, som vanl. är betydligt längre än bladen; skärmblad mycket korta; kalkblad uppåt bredare, kortare än stiftet. delen.

Sandfält och kalkberg; Göt. Gotl. Öl. spr. Sk. t. r. i ö.

\section{0̊. Juncus. To̊g.*)}

A. Somliga strån blombärande, andra blomlösa: alla utgående från en lång rotstock och nedtill slidbärande.

a. Blomknippe stödt af ett långt skärmblad (som liknar en förlängning af strået). Frön nätådriga utan bihang. Strån vanl. bladlösa.

1. Kalkblad likformiga, längre än fröhuset. Skärmblad betydligt kortare än strået. Blomknippe mångblommigt. Bladslidor ofta (hos $J$. conglomeratus) glanslösa. 1. J. conglomeratus. 2. J. diffusus. 3 . J. glaucus.

2. Kalkblad olikformiga, kortare än fröhuset. Skärmblad betydligt kortare än strået. Blomknippe stundom fåblommigt. Bladslidor glänsande. 4. J. balticus. 5. J. arcticus.

3. Kalkblad likformiga, n. lika långa med fröhuset. Skärmhlad föga kortare än strået. Blomknippe fåblommigt. Bladslidor glänsande. 6. J. filiformis.

b. Blomknippe stödt af flera skärmblad. Frön i båda ändar hinnkuntade. Strån stundom nedtill bladiga. 7. J. maritimus.

B. Alla strån blombärande nch nedtill försedda med bladtofsar. Frön nätådriga utan bihang. Strån vanl. bladiga (utom hos $J$. capitatus och $J$. squuirosus). Blomsamling vanl. stödd af ett kort skärmblad.

*) Dessa växter hlomma frampå sommaren. 
a. Blad tydligt ledade af trärväggar*). Blommor i små hufvud, förenade i knippe i stråets spets. Rotstock utdragen. 8. J. articulatus. 9. J. obtusiflorus.

b. Blad otydligt ledade. Blommor i hufvud, ofta förenade i knippe i stjelkens spets. Rotstock utdragen. 10. J. alpinus. 11. J. supinus.

c. Blad oledade. Blommor spridda eller (mindre ofta) förenade i hufvud.

1. Med rotstock. Blommor alltid spridda. 12. J. compressus 13. J. Gerardi.

2. Med tågig rot. Blommor stundom hufvudlikt förenade. 14. J. bufonius. 15. J. capitatus. 16. J. squarrosus.

C. Alla strån blombärande och nedtill försedda med bladtofsar. Strån bara eller med 1-2 blad. Frön i båda ändar försedda med bihang (hinnkant) och streckade på längden. Blormmor vanl. förenade i hufvud. Blad oledade.

a. Rotstock lång med talrika blommande strån och bladtofsar, bildande små hårda tufvor. 17. J. trifidus.

b. Rot tågig. Strån enstaka eller löst tufvade. 18. J. stygius. 19. J. castaneus. 20. J. triglumis. 21. J. biglumis.

1. J. conglomerátus L., Knapptåg; fröhus omvändt äggformigt med otydligt stift; kalkblad lansettlika spetsiga.

Strån omkr. 2 fot höga och något tjocka (n. som en dufpenna), finstrimmiga och inuti täta; hlomskaft mycket korta; stift vårtlikt; bladslidor rödaktiga utan glans; ståndare 3 ; blommor brunaktiga.

Våta ängar och diken; Göt. Sv. a., Norrl. Gestr. a. Hels. spr.

* J. effúsus L.; blomskaft utdragna; stift något tydligare, men ej framskjutande; strå i friskt tillstånd slätt; blommor brungröna.

Göt. a.: Gotl.?, $S v$. a.: Verml. spr. Dal. t, r., Norrl. Gestr. spr. Hels. r., Lpl. r.

2. J. diffúsus Hoppe; fröhus omvändt äggrundt med tydligt stift; kalkblad lansettlika sylspetsade.

Strån omkr. 2 fot höga, gröna, finstrimmiga och inuti täta; blomskaft utdragna; bladslidor svartröda glänsande; blommor något mindre än hos föreg. art.

Våta ställen, mycket r.; Göt. Sk. Smål.

3. J. gláucus Ehrh.; fröhus ovalt-aflångt med något utdraget stift; kalkblad lansettlika sylspetsade.

Lika hög som de föreg., men med blågröna starkt strimmiga och inuti hẩr och der ihåliga strån; blomskaft utdragna; bladslidor svartröda glänsande; fröhus svart glänsande.

Kärr; Göt. Gotl. Öl. r. Sk. spr. i s. och v. delen.

4. J. bálticus Willd.; fröhus aflångt-äggformigt med

*) Detta kan man känna, om bladen dragas mellan fingrarne; äfven blifva lederna synliga vid växtens torkning. 
tydligt stift; kalkblad något olikformiga, de yttre äggrundt lansettlika spetsiga, de inre trubbiga med kort udd; blomknippe vanl. mångblommigt.

Strån omkr. 2 fot höga och släta, inuti täta; blomskaft mer eller mindre utdragna; bladslidor gulbruna; blommor mörkbruna; skärmblad 3-4 tum långt.

Sandiga hafsstränder: Göt. r.: Sk. Hall. spr. Blek.? Smål. Öl. 0, Sv. Upl. r., Norrl. r.: Med.?; för öfrigt i myrar: Lpl. r. i fjelleñ, Norrl. Jtl. på Frösön.

5. J. árcticus Willd.; fröhus omvändt äggformigt med mycket kort stift; kalkblad olikformiga, de yttre äggrunda och föga spetsiga, de inre $n$. ovala och mycket trubbiga utan udd; blomknippe fảblommigt.

Strån omkr. fotshöga och släta, inuti något pipiga; blonskaft mycket korta; bladslidor gulbruna; blommor mörkbruna; fröhus svart; skärmblad vanligen kortare än hos föreg. art, som denna mycket liknar. stl. Herj.

Fuktiga ställen i fjellen, helst i fjeilreg., r.; Lpl., Norrl.

6. J. filiformis L.; fröhus n. klotrundt med mycket kort stift; kalkblad smalt lansettlika spetsiga.

Strån omkr. 1/2 fot höga och trådlika, ljusgröna och finstrimmiga; blomskaft mer eller mindre utdragna; bladslidor gulbruna; blommor grönaktiga ; fröhus brunt; skärmblad năgot bö̀dt. Vàta ställen, temligen allmän.

7. J. maritimus Lam.; fröhus ovalt med kort stift; kalkblad lansettlika of fröhusets längd, de yttre spetsiga, de inre något trubbiga.

Strån 2-3 fot höga, hlågröna och styfva: de icke blombärande (liksom bladen) med stickande spets; blomknippe teml. rikblommigt med upprätta, mer eller mindre utdragna grenar; bladslidor gulbruna glänsande; blominor gulbruna; fröhus ljusbrunt. Liknar năgot följ. art.

Sumpiga haf̀stränder; Göt. Blek. r. Smål. t. r.

8. J. articulátus L.; blomknippets grenar utstående; kalkblad lika långa och något kortare än det vanl. kortspetsade fröhuset, de yttre med kort udd, de inre trubbiga; blad vanl. hoptryckta.

Strå vanl. uppstigande och öfver fotshögt med svart glänsande fröhus; blomhufvud talrika.

Văta ställen; Göt. Sv. a., Norrl. a.: Jtl. spr. Ång.?, Lpl.r. - silváticus (Rchb.); alla kalkbladen spetsiga och betydligt kortare än det tillspetsade fröhuset, de inre längre än de yttre; strå upprätt; blad n. trinda.

Kan svårligen skiljas som art från föreg., som stundom har likadant fröhus.

* J. atricapillus Drej.; blomsamlingens grenar upprätta; 
strå upprätt; för öfrigt som hufvudarten; fröhus ofta som hos $J$. silvaticus.

Liknar J. alpinus och har mycket mörka blommor och fröhus.

Våta ställen; Göt. Hall. Små̉l. Ög. Gotl. r.

Anm. Enligt E. Wahlén (Bot. Not. 1868) skola fröen vara hos $J$. articul. vaxgula, J. silv. vaxgula med rosthruna spetsar, hos $J$. atricap. rostbruna med svarta spetsar, hos $J$. alpin. blekt rostbruna; enligt bifogade figurer (som ej fullt motsvara beskrifningen) skola fröen vara bredast hos $J$. artic., hos de 3 öfriga smalare.

9. J. obtusifórus Ehrh.; blomknippets grenar nedböjda eller utspärrade; kalkblad trubbiga, lika långa med det aflångt äggrunda och spetsiga fröhuset; blad trinda.

Strå n. upprätt och 1-2 fot högt med teml. liten blomsamling, gulgröna kalkblack och ljusbrunt fröhus; de nedre bladskifvorna felslående, slidor stora och glanslösa.

Kärr; Göt. Gotl. t. r. Sk. spr. i s. delen.

10. J. alpinus Vill.; blomknippets grenar upprätta; kalkblad lika långa och något kortare än det nästan sprötlösa fröhuset, alla trubbiga, de yttre med kort udd.

Strå vanl. upprätt, spensligare och lägre än hos föreg. arter, med kort rotstock och svartglänsande fröhus samt föga talrika, svartbruna blomhufvud.

Mossar och kärr; Lpl. Norrl. a., Sv. spr., Göt. t. r.: Ög. Öl. Gotl. spr.

11. J. supinus Mönch; blomknippets grenar n. upprätta eller något utstående; kalkblad lika långa och föga kortare än det nästan tvärhuggna fröhuset, de yttre spetsiga, de inre trubbiga.

Strå omkr. $1 / 2$ fot långt, upprätt, nedliggande, krypande eller flytande, nedtill lökformigt uppsväldt med ofydlig rotstock, få, långt åtskilda och grönbruna blomhufvud samt borstlika blad: ståndare 3. Stundom utbildas bladtofsar på strået.

Fuktiga ställen, äfven i vatten; Göt. Sv. a.: Gotl.?, Norrl. spr., Lpl. r.

12. J. compressus Jacq.; blomknippets grenar upprätta ; kalkblad rundadt trubbiga och mycket kortare än det klotrunda fröhuset.

Omkr. $1 / 2$ fot hög eller deröfver med enkelt, fåbladigt och något hoptryckt strå; blommor bruna.

Fuktiga ställen, äfven i skärgården: Göt. Sv. a., Norrl. spr.: Gestr. Hels. a. Ång. Vb. r.

13. J. Gerardi Lois.; blomknippets grenar upprätta; kalkblad rundadt trubbiga och nästan lika långa med det aflånga fröhuset.

Liknar mycket föreg. art, men har finare och trindt strå samt mera krypande rotstock; stift vanl. föga kortare än fröhuset. Hafsstränder; Göt. Sv. a., Norrl. Gestr. Hels. a. Med. spr. Ang. Vb. r. 
14. J. bufónius L.; kalkblad smalt lansettlika och sylspetsade, mycket längre än det aflånga fröhuset; blommor på grenarnes sidor, vanl. enstaka eller stundom $2-4$ hufvudlikt förenade; strå bladigt.

Strå omkring $1 / 2$ fot högt och vanl. klynnedeladt med n. oskaftade blommor. Hela växten mera grön än hos de öfriga arterna.

Våta ställen, allmän: Lpl. t. r.

15. J. capitátus Weig.; kalkblad äggrundt lansettlika sylspetsade, mycket längre än det n. klotrunda eller bredt äggformiga fröhuset; blommor i ett (sällan 2-3) hufvud i det bladlösa stråets spets, stödda af långa skärmblad.

Strån 1-5 tum höga, enkla och nålfina, mycket längre än de borstlika rotbladen; blommor bruna; ståndare 3 .

Sandiga öfversvämmade ställen eller fuktiga åkrar nära hafvet; Göt. Sk. spr. Hall. Blek. Öl. Gotl. r.

Anm. Juncus pygmæus Thuill., lik föreg. art, men med grenigt strå och med skärmbladen förvandlade till hinnaktiga slidor, är fordom funnen på sandiga betesmarker längs hafskusten i Skåne mellan Hvellinge och Klagstorp.

16. J. squarrósus L.; kalkblad äggrundt lansettlika, nîgot spetsiga, lika långa med (och omslutande) det omvändt äggrunda fröhuset; blommor spridda i ett eller 2-3 öfver hvarandra stälda, fåblommiga knippen mot stråets spets.

Strå omkr. fotshögt, styft och nästan bladlöst med borstlika bladtofsar; kalkblad med hvit hinnkant.

Kärr, helst nära hafvet och större sjöar; Göt. spr.: Sk. Hall. t. a. Kalmarl. r. Ög.? Dalsl. Gotl. 0, Sv. Ner. r., Norrl. Jtl. r. 17. J. trifidus L.; strån med vanl. 2 , mycket långa, nålfina och syllika skärmblad, nedtill med ett blad; kalkblad äggrundt lansettlika spetsade och ungefär lika långa med fröhuset; blommor oskaftade ensamma eller i 1-3 hufvud med $2-3$ blommor.

Vanl. omkr. fingerhög, stundom ända till 8 tum hög med trådsmala strån, nedtill med stora rödaktiga slidor; fröhus mörklirunt (liksom blommorna), äggformigt, naggot spetsigt med tydligt stift.

Torra steniga och blåsiga ställen i fjellen; Lpl. a., Norrl. .tt. Herj. a., Sv. Dal. t. r.

18. J. sty'gius L.; strå 1-2-bladigt med trådsmala blad; kalkblad lansettlika och mycket kortare än det 8 vala och spetsiga fröhuset, de yttre spetsiga, de inre trubbiga.

Strå (vanl. enstaka) omkr. $1 / 2$ fot högt, n. trådsmalt och enkelt med röda leder och $2-3$ blomhufvud i eller nära stråets 
spets; blomhufvud med 2--3 oskaftade och hvitgula blommor, vanl. stödda af ett längre och långspetsadt skärmblad; fröhus teml. stora och mörkgula.

Kärr och myrar, helst i skogstrakter; Lpl. spr., Norrl. r.: Vb. Jtl. spr. Herj. a., Sv. r.: Ner. Verml. t. r. Söd. 0, Göt. Ög. Vg. r. Hall. Smàll. t. r.

19. J. castáneus Sm.; strå 2-3-bladigt; de nedre bladen rännformiga och hopvikna, de öfre syllika; kalkblad spetsiga och mycket kortare än det spetsiga fröhuset; blomhufvud 1-2 (sällan 3), flerblommiga med oskaftade blommor.

$1 / 2-1$ fot hög och mycket gröfre än föreg. art med vanl. âtskilda och teml. stora blomhufvud; blommor kastanjebruna, vanl. med ett längre och långspetsadt skärmblad af samma färg; fröhus mörkbruna, större än hos ïfriga arter.

Fuktiga ängar och kärr i fjellen; Norrl. Jtl. Herj. t. r.

20. J. triglúmis L.; strå n. bart; blad n. rännformiga och syllika; kalkblad trubbiga och vanl. lika långa med det trubbiga (med kort stift försedda) fröhuset (sällan ända till dubbelt kortare); blomhufvud ensamt, vanl. 3-blommigt med oskaftade blommor.

Omkr. ${ }^{1 / 2}$ fot hög eller lägre med trådsmala, vanl. något tufvade strån; blommor brungula med korta trubbiga skärmblad; fröhus brungula, teml. små och smala.

Kärr i fjellen; Lpl. a., Norrl. Jtl. Herj. mångenst.

21. J. biglúmis L.; strå n. bart; blad n. rännformiga och syllika; kalkblad trubbiga och mycket kortare än det $i$ spetsen intryckta fröhuset; blomhufvud ensamt med en (sällan 2) oskaftad och en skaftad blomma.

Lik föreg. art, men vanl. lägre och föga tufvad; blommor mörkare bruna, vanl. med ett långt och trådlikt skärmblad; fröhus brungröna, upptill något tjockare.

Sumpiga ställen i fjellen mångenst.; Lpl. Norrl. Jtl. Herj.

\section{Lúzula. Bladtiog.}

A. Blommor spridda i knippe; blad platta.

1. L. pilósa (L.) Willd.; det flocklika blomknippets grenar enkla, hvarje gren med en oskaftad och $1-2$ skaftade blommor; blad i kanten mycket hiriga; rot tìgig. 1, 2 .

Omkr. $1 / 2$ fot hög med långbladiga rotskott (bladtofsar).

Barrskogar och hedar, allmän.

2. L. parviflóra (Ehrh.) Desv.; blomknippets grenar åter förgrenade, smågrenar bärande flera skaftade blommor; blad glatta; rotstock krypande och skottalstrande; blomskärmar helbräddade; kalkblad smalt hinnkantade. 2. 1-2 fot hög, alldeles glatt och isynnerhet upptill rodnande, meal mycket smärre blommor än hos föreg. art och bredare blad. 
- Något skuggiga ställen, t. ex. vid fuktiga bergväggar bland huskar i fjellen, helst i hjörkregionen, stundom i fjellregionen: Lpl. r., Norrl. Herj. på Rutstöten.

3. L. Wahlenbérgii Rupr.; blomskärmar upptill franslikt tandade; kalkblad bredt hinnkantade; eljest som föreg. art. 2.

Lik föreg. art, men lägre och spensligare med mindre krypande rotstock, något större blommor, dubbelt smalare blad och längre uppiill bart strå.

$\mathrm{På} \mathrm{hårdare} \mathrm{mark} \mathrm{i} \mathrm{fjellregionen;} \mathrm{Lpl.} \mathrm{t.} \mathrm{r.,} \mathrm{Norrl.} \mathrm{Jtl.} \mathrm{r.}$

B. Blommor gyttrade i hufvudlika ax.

a. Ax stälda i flocklikt knippe, stundom ett enda. 4. L. campestris (L.) De Cand.; ax vanl. 3-5, maingblommiga och nedhängande; kalkblad lansettlika spetsiga och längre än fröhuset; rotstock krypande och skottalstrande. 1-2.

I början några tum, slutl. öfver $1 / 2$ fot hög; blad långspetsade och platta, kantade med långa hvita hår och slut]. glatta; kalkblad brunglänsande i fjellen stundom svarta) med smal hinnkant; ståndaresträngar flera gånger kortare än knapparne; stift länge qvarsittande; skärmfjäll tillspetsade och vanl. glatta.

Skogar, ängar och backar, allmän.

* L. multiflóra Lejeune; ax vanl. talrika med upprätta skaft; kalkblad tillspetsade och n. lika långa med fröhuset; rot tufvig och tågig. 2.

Denna form påstås vid odling öfvergå till ofvan beskrifna art. Dock är străet högre, ståndaresträngarne lika lånพฺ med knapparne, kalkbladen bredt hinnkantade, stiftet snart aftallande.

Torra gräsrika och solöppna ställen, allmän.

* L. pallescens Wahlenb.; ax taliika och smärre, hvitgula eller ljusbruna; skärmfjäll n. hinnaktiga; kalkblad utdraget spetsiga, eljest som L. multiflóra. 2.

Liknar mycket den nyss beskrifna och påstås öfvergå dertill genom odling:

Något fuktiga ställen i ängar och åkrar; Lpl. spr., Norrl. spr.: Yrb.?, $S v$. spr.: Upl. Söd. t. r., Göt. Dalsl. t. r. Ög. Smål. Blek. Sk. Gotl. r.

5. L. arcuáta Wahlenb.; ax vanl. talrika och fäblommiga med vanl. bågböjda skaft; kalkblad lansettlika spetsiga, längre än fröhuset; rotstock skottalstrande. 2. $3-5$ tum hög; strå, axskaft och blad smalare än hos föreg. art; blad rännformiga, ofta bågböjda, n. glatta; skärmfjäll upptill lânghåriga.

Något fuktiga och ofruktbara ställen uppe i fjellen; Lpl. t. a., Norrl. Jtl. Herj. spr.

* L. confúsa Lindeb.; ax få och mångblommiga med upprätta skaft; kalkblad lika långa som fröhuset; rotskott vanl. utböjda. 
Står liksom midt emellan L. campestris och L. arcuata; skiljer sig från den förra genom kortare, upptill håriga skärmfjäll och smärre blommor och har vanl. alla ax skaftade; olik den senare genom något tjockare axskaft, mera håriga och vanl. platta blad samt färre ax, men med talrikare blommor. Jtl. $r$.

Något torrare ställen, högt upp i fjellen; Lpl. spr., Norrl.

6. L. árctica Blytt; ax vanl. ensamt (mycket sällan 2-3) och teml. rikblommigt med upprätt skaft; kalkblad äggrunda trubbiga, kortare än fröhuset; rotstock med korta skott. 2 .

Liknar mest $L$. campestris, vanl. 3-4 tum hög: blad vanl. bredare än hos föreg. art och jemte skärmfjällen glatta.

Något fuktiga ställen högt upp i fjellregionen, mycket r.; Lpl. Lul. Lpm. på fjellet Jägnafo.

b. Blomhufvud förenade $\mathrm{i}$ ett lutande ax.

7. L. spicáta (L.) D.C.; kalkblad lansettlika spetsiga, längre än fröhuset; rot tågig. 2,3 .

4-8 tum hög med korta och smala, rännformiga och gleshåriga blad; ax omkr. tumslångt; skärmfjäll och kalkblad med breda, glänsande hinnkanter; blommor mörkbruna.

$\mathrm{P}_{a}^{\circ}$ torr och hård mark i fjellen, helst i fjellregionen; $L p l$. a., Norrl. Jtl. Herj. a., Sv. Dal. r.

\section{Narthécium. Kärrlitja, Ilagräs.}

1. N. ossífragum (L.) Huds.; blommor tätt sittande, upprätta och n. platta; ståndare med hvitludna strängar och brandgula knappar. 3 .

$1 / 2-1$ fot hög och glatt; blad omkr. 2 linier breda.

Mossar; Göt. Kalmarl. Blek. r. Sk. spr. Hall. Smål. (i v. delen) Boh. t. a. Vg. Dalsl. t. r., Sv. Ner. t. r. Söd. r., Norrl. Jtl.r.

\section{Calla. Missne.}

\section{C. palustris L.; hölster ovalt. 1, 2.}

Stängel $1 / 2$ fot hög och tjock med tjock rotstock; blad ljusgröna, ett par tum breda; kolf kort och aflång; bär röda.

Kärr och myrar, helst i skogstrakter, mångenst., dock i fjellen t. r., Öl. Gotl. 0 .

\section{A'corus. Kalmus.}

1. A. Cálamus L.; stängel ofvan kolfven bladlik. 3.

Omkr. 3-4 fot hög; rotstock tjock, starkt luktande och till smaken bitter.

Stränder och dammar; Göt. Sv. spr.: Sk, Ner. t. a. inre Smål. Boh.-Dal. t. r. Gotl. Öl. 0.

\section{Ordn. DIGYNIA.}

195. Oxy'ria. Fjellsyra.

1. O. dígyna (L.) Campd.; de flesta bladen samlade vid stjelkens bas och långskaftade. 2, 3 . 
1/2 -1 fot hög med nästan handnerviga blad, något liknande en Rumex, samt med syrlig smak.

Fuktiga ställen, helst vid bäckar, i fjellen; Lpl. a., Norrl. Jtl. Herj. a., Sv. Dal. r.

\section{Ordn. TRIGYNIA.}

\section{Rumex. Syra.}

A. Tvåbyggare. Blad med pillik eller spjutlik bas. 1. R. Acetosa. 2. R. thyrsoides. 3. R. Acetosella.

B. De flesta blommorna samkönade. Bladens bas vigglik, afrundad eller hjertlik.

a. Fruktfoderskal*) smala med större längd än bredd samt försedda med aflånga eller äggformiga gryn ***).

1. Fruktfoderskal tandade. 4. R. maritimus. 5. R. pa. lustris. 6. R. Steinii. 7. R. obtusifolius.

2. Fruktfoderskal helbräddade (eller någongång svagt naggade). 8. R. Hydrolapathum. 9. R. maximus. 10. R. sanguineus. 11. R. conglomeratus.

b. Fruktfoderskal breda och helbräddade (eller någongång svagt naggade) med runda gryn. 12. R. crispus.

c. Fruktfoderskal stora, breda och helbräddade utan gryn. 13. R. domesticus, 14. R. Hippolapathum.

1. R. Acetósa L., Angsyra, Syrgräs; de inre kalkbladen (fruktfoderskalen) slutl. utväxande, hinnaktiga och mycket större än nöten; blad aflånga ined vanl. pillik bas; fruktfoderskal rundadt hjertiki, med ett litet rundadt gryn; de yttre kalkbladen nedböjda.

Omkr. 1 -2 fot hög med något gles vippa.

Ängar, allmän.

- alpestris; blad mycket breda (ofta öfver en tum) med n. spjutlik bas.

I fjellen t. r.: Lpl., Norrl. Jtl. Herj.

2. R. thyrsóides Desf.; blad aflångt lansettlika med spjutlik eller pillik bas; fruktfoderskal rundadt njurlika; eljest lik föreg. art.

Omkr. 3 fot hög med tätblommig vippa; hanväxten lägre. Ängar; Göt. r.: Boh. Dalsl. 0.

3. R. Acetosella L., Bergsyra; fruktfoderskal föga utväxande, knappt så långa sum nöten och ej hinnaktiga; blad lansettlika och spjutlika; fruktfoderskal äggrunda utan gryn; de yttre kalkbladen tilltryckta.

*) Med fruktfoderskal menas de inre kalkbladen, som utväxa mot sommarens slut eller bäst pả hösten. Af dessa växter böra derföre höstexemplar vid fruktmognaden insamlas. Blommorna utvecklas under sommaren.

**) Dessa gryn utvecklas stundom blott på ett af skalen: i synnerhet hos $R$. sanguineus och $R$. crispus samt hos bastardformerna i detta slägte. 
Omkr. fotshög och spenslig med gles eller tät vippa.

Berg, backar och magra ängar, allmän, stundom i åkrar.

4. R. maritimus L.; rotblad smalt lansettlika; blomkransar sammanflytande (tätt sittande); fruktfoderskal smalt triangelformiga med långa tänder; blad krusiga.

Omkr. fotshög med slutl. guldgula kalkblad, de yttre utstående; blad och stjelk vid fruktmognaden gulnande; blad ej tumsbreda; fruktfoderskal små.

Dyiga stränder, helst vid hafsvikar och större sjöar; Göt. spr.: Ög. Smål. t. r. Blek. Vg. Boh. r., Sv. Söd. Upl. t. r. Ner. Verml. r. (Norrl. Ang. tillfällig).

5. R. palustris Sm.; blad smalt lansettlika; blomkransar tätblommiga och något åtskilda; fruktfoderskal aflånga med teml. korta tänder; blad i kanten släta.

Liknar föreg. art, men blir slutl. brunaktig eller rödaktig; de yttre kalkbladen föga utstående.

Sandiga och sumpiga hafsstränder; Göt. Sk. spr. Gotl. r.

6. R. Stéinii Beck. (enl. F. Areschoug); rotblad bredt aflånga med hjertlik bas; stjelkblad smala lansettlika; blomkransar glesblommiga och åtskilda; fruktfoderskal aflånga med teml. korta tänder; blad ej krusiga.

Är mera grenig än de föreg. arterna; förmodas vara bastard af föreg. art och $R$. conglomeratus, hvilken denna form mest lärer likna.

Fuktiga ställen, mycket r.; Göt. Skåne vid L. Hammar (S. Almqvist).

7. R. obtusifólius L.; de nedre bladen äggrunda-hjertlika; blomkransar något åtskilda och ej sammanflytande; fruktfoderskal triangelformiga med mer eller mindre långa tänder.

3-4 fot hög med stora och breda blad och slutl. bruna kalkblad (såsom hos följ. arter); stjelkblad vanligen ej krusiga, vid fruktmognaden qvarsittande friska och lifligt gröna eller något rodnande; vippans grenar utstående.

Ruderatväxt; Göt. a.: Gotl. Boh. Dalsl. spr., Sv. spr.: Dal. Vestm. Verml. r., Norrl. Gestr. Hels. r.

8. R. Hydrolápathum Huds.; blad från äggrund bas lansettlika och ej krusiga; fruktfoderskal äggrundt triangelformiga och helbräddade med aflånga gryn.

4-6 fot hög med mycket grof stjelk och ända till 2 fot lainga rotblad samt mycket stor hlomsamling med vanl. föga utstående grenar och tätt sammanflytande blomkransar; de yttre kalkbladen nedböjda; fruktfoderskal stora.

Stränder; Göt. spr.: Sk. Hall: t. a. Smål. t. r. Dalsl. r. Got]. Öl. 0, Sv. r.: Söd. Upl. spr.

9. R. máximus Schreb.; blad från hjertlik bas aflånga eller utdraget äggrunda, vanl. ej krusiga; fruktfoderskal hjertlika och otydligt naggade. 
Liknar föreg. art, men har kortare och bredare rotblad, något utstående vippgrenar och föga sammanflytande blomkransar; de yttre kalkbladen nedböjda.

Stränder; Göt. Boh. Sk. Smål r. Ög.?, Sv. Vestm. r. Söd. Upl. t. r., dock mångenst. omkr. Stockholm.

10. R. sanguíneus L.; blad aflångt lansettlika med hjertlik bas; fruktfoderskal aflånga och helbräddade (blott ett grynbärande); blomkransar glesblommiga och långt àtskilda.

2-4 fot hög, spenslig och grenig; grenar upprätta eller ut-

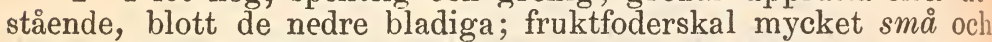
omkr. 1/2 linie breda; blad omkr. en tum breda; blomskaft utdragna. Liknar något $R$. obtusifolius till vippan.

Fuktiga ställen i skogar, helst af bok; Göt. Öl. t. r. Små!. r. Hall. t. r. Sk. t. a. åtm. i hokskog.

11. R. conglomerátus Murr.; blad lansettlika eller äggrundt lansettlika, stundom med hjertlik bas; fruktfoderskal aflånga och helbräddade (alla grynbärande); blomkransar tätblommiga och åtskilda.

Liknar föreg. art, men är något lägre och har ännu smärre blommor; grenar något utspärrade.

Fuktiga ställen, stundom nära bostäder; Göt. Sk. r.

12. R. crispus L.; blad lansettlika och krusiga; fruktfoderskal n. runda med afrundad (ej utdragen) spets och stundom med hjertlik bas.

Omkr. 2 fot hög med mörkgröna, snart vissnande blad och tätblommig vippa med ej utstående grenar.

Ruderattväxt; Göt. a., Sv. t. a.: Dal.?, Norrl. Gestr. Hels. spr. Med. Ang. r.

13. R. domésticus Hartm.; blad äggrunda--aflånga, krusiga, rotblad hjertlika; fruktfoderskal njurlika eller rundade med något hjertlik bas.

$2-4$ fot hög med breda ljusgröna blad; vippa tätblommig med ej utstående grenar.

Ruderatväxt, allmän: Gotl.?

14. R. Hippolápathum Fr.; blad från hjertlik bas utdraget äggrunda och krusiga; fruktfoderskal bredt äggrunda eller triangelformiga med tvär bas och trubbig (ej utdragen) spets.

4-6 fot hög med mycket stora, ljusgröna blad och tätblommig vippa med något utstående grenar.

Stränder; Göt. Vg. r. Boh. t. r. Hall. spr. Ög. (vid Skeninge)?, L v r. r.

Anm. Utom dessa märkas följ. former, som sannolikt äro bastarder:

R. acútus L.; blad krusiga, de nedre teml. smala, aflångt lansettlika, stundom med hjertlik bas; fruktfoderskal stora och 
hjertlika med utdragen spets, tandade, med äggformiga gryn; vippans grenar utstăende; llomkransar teml. ătskilda. Synes vara bastard af $R$. obtusifolius och $R$. crispus och är omkr. 4 fot hög.

Göt. Sk. spr. Blek. Ög. r. Smål.?, Sv. Up]. r. (vid Upsala: N. F. Ahlberg enl. exemplar).

R. conspersus Hartm.; blad krusiga, de nedre äggrundahjertlika; fruktfoderskal stora och bredt hjertlika med kort spets, fintandade, med runda gryn eller ofta utan gryn; vippans grenar icke utstående; blomkransar sammanflytande. Synes vara hastard af $R$. crispus och $R$. domesticus; torde ofta vara förvexlad med föreg. och följ. form. Omkr. 3 fot hög.

Göt. Sv. r.: Gotl. Dal.?, Norrl. Gestr. r.

R. hy'bridus Kindb.; blad stundom krusiga, ofta släta, de nedre teml. breda och äggrunda--hjertlika; fruktfoderskal stora och bredt hjertlika, tvärt hopdragna till en något utdragen spets, tandade, med äggformiga gryn; vippans grenar något utstående; blomkransar föga åtskilda. Synes vara bastard af $R$. obtusifolius och $R$. domesticus; är $3-4$ fot hög.

Göt. Dalsl. flerst. i Gunnarsnäs s:n (t. ex. vid Rostock) samt i Fröskogs s:n vid Kristinedal (förf.), Ög. vid Medevi (enl. ex. af Prof. Fr. Holmgren) och vid Linköping (förf.), Skåne?, Sv. Stockholmstrakten (enl. ex. af Lektor Thedenius och Akad. Adj. F. J. Björnström). 'Troligen äfven annorstädes.

R. platyphyllus F. Aresch.; blad icke krusiga, äggrundt lansettlika med hjertlik bas; fruktfoderskal stora och hjertlika spetsade, fintandade (eller naggade) med aflånga gryn; vippans grenar utstående; blomkransar åtskilda. Synes vara bastard af $R$. Hippolapathum och R. maximus; är 4-6 fot hög.

Sv. Stockholm på Djurgården, Upsala vid Fyrisån nedom slottet.

\section{Tríglochin. Sülting.}

1. T. palustre L., Kärrsälting; frukt jemnbred, nedåt afsmalnande och bestående af 3 småfrukter. 3.

Stängel omkring fotshög, längre än bladen.

Kärr och andra fuktiga ställen, allmän.

2. T. marítimum L., Hafssülting; frukt äggformig, bestående af 6 småfrukter. 3,4 .

Liknar föreg. art, men har gröfre och köttiga blad och tjockare stängel; blad n. lika långa som stängeln.

Stränder; vid hafvet: Göt. a., Sv. Norrl. spr.: Vb. r.; vid Mälaren: Upl. Söd. Vestm. spr.

\section{Scheuchzéria. Kallgräs.}

1. S. palustris L.; stjelk trådlik. 3 .

Stjelk omkr. ${ }^{1} / 2$ fot hög; frukter stora som ärter.

Kärr och myrar; Lpl. spr., Norrl. spr.: Vb. t. r.?, So. spr.: Verml. t. a., Göt. spr.: Boh. Blek. Öl. r. Gotl.?

\section{Tofiéldia.}

1. T. boreális Wahlenb., Björnbrodd; svepe aflägsnadt från blomman; rotblad trenerviga. 2, 3. 
Tufvad och 3-5 tum hög med trådsmal stjelk, knappt en tum långt ax samt liniebreda, omkr. tumslånga blad; blommor hvitgula.

Kärr i fjellen, stundom i lägre fjelltrakter; Lpl. a., Norrl. Jtl. Herj. spr. Vb. t. r. Ang. Hels. r., Sv. Dal. flerst. (i fjellen) Verml. r.

2. T. calyculáta (L.) Wahlenb.; svepe sittande nära intill blomman; rotblad mångnerviga. 3 .

Liknar föreg., men är $1 / 2-1$ fot hög med tjockare stjelk, något längre ax samt ett par linier breda och fingerlånga blad; hlommor rent ljusgula.

Fuktiga ängar; Göt. Gotl. allmän.

\section{Ordn. POLYGYNIA.}

\section{Alísma. Svalting.}

1. A. Plantágo L.; stängel upprätt; rotblad vanl. äggrunda och långskaftade; blommor i grenig och pyramidformig vippa; rotstock uppsväld och lökformig. 3, 4 .

Omkr. 2 fot hög med kranssittande vippgrenar, stödda af skärmblad; de inre kalkbladen hvita eller rödletta och mycket längre än de yttre; småfrukter upptill hoptryckta och stälda i en krets, i hvars midt en trattlik fördjupning uppkommer; blad stundom lansettlika - jemnbreda, då de växa i rinnande vatten.

Stränder, stundom i vattnet; Göt. Sv. a., Norrl. spr.: Gestr. a. Med.-Vb. r., Ipl. r.

2. A. ranunculóides L.; stängel upprätt eller nedliggande; rotblad lansettlika eller n. jemnbreda, åt båda ändar afsmalnande, långskaftade; blommor i en enkel flock eller två öfver hvarandra stälda flockar; rot tågig. 3,4 .

Stänge] omkr. $1 / 2$ fot lång och föga öfverskjutande de smala bladen; de inre kalkbladen blekt rosenröda; småfrukter kantiga och hufvudlikt gyttrade.

Bäckar, grundt stillastående vatten och (någon gång) grunda hafsvikar; Göt. Gotl. Öl. Sk. spr. Smål. Hall. r.

\section{Klassen. HEPTANDRIA.}

1 Ordn. MONOGYNIA.

201. Trientális. Dufkulla.

1. T. europæa L.; blad bredt lansettlika. 1, 2.

Knappt $1 / 2$ fot hög med rotstock och nästan hårfina blomskaft. Högre upp på fjellen blifva blommorna n. röda.

Skogar och bland enbuskar, allmän till fjellregionen. 


\section{Klassen. OCTANDRIA.}

\section{Ordn. MONOGYNIA.}

\section{Daphne. Källerhals, Tibast.}

1. D. Mezeréum L.; blad glatta, lansettlika och nedåt afsmalnande; blommor oskaftade på grenarnes sidor. 1 .

Stam 1-4 fot hög, nedtill bladlös, ofvan fruktsamlingen bladig, med seg, grå och brunprickig bark; blad enåriga: blommor välluktande, stälda i kransar eller parvis; bär röđa och mycket giftiga, använda till gift för räfvar i st. f. räfkaka.

Lundar och fuktiga ställen på berg; Göt. r.: Sk. t. r. Smål. Ög. Öl. spr. Gotl. Boh. 0, Sv. spr., Norrl. r.. Jtl. spr., Lpl. r.

\section{Vaccínium.}

A. Blad enåriga; bär blåaktiga; blomskaft lutande, enstaka eller få i flock.

1. V. Myrtillus L., Bläbärsris; grenar kantiga; blad äggrunda finsiigade; blomkronans pip klotrund och rödbrun. 1, 2.

Fotshög med grön bark, ljusgröna blad och enstaka blomskaft; blomfodrets bräm helbräddadt; bär klotrunda, i början rodnande, slutligen blådaggiga och svartblå: någongång kunna de vara hvita.

Skogar och något fuktiga ställen på berg, allmän.

2. V. uliginósum L., Odon, Öbür, Svalbär; grenar trinda ;

blad omvändt äggrunda och helbräddlade; blomkrona äggformigt klocklik, hvit eller rödlett. 1, 2.

Något högre än föreg. art, med gråbrun bark och blåaktiga blad; blomskaft vanl. flera tillsammans i spetsen af fjolårsgrenarne; blomfodrets bräm 4-5-klufvet; bär aflånga, slutl. blådaggiga och blåaktiga.

Fuktiga och ofruktbara ställen, helst på skogsmark, allmän: Öl. t. r. Gotl. O.

B. Blad läderartade, äfven under vintern gröna; bär röda och klotrunda.

3. V. vitis idæa L., Lingon, Kröser; blommor i lutande klase i spetsen af grenarne; krona klocklik och grundt klufven, hvit eller rödlett. 2, 3 .

$1 / 2$ fot hög med omvändt äggrunda - aflånga, ofvan glänsande gröna, undertill blekare och prickiga blad med nedoöjda kanter; blomskaft kortare än blommorna; blomfoder med triangulära flikar.

Skogar och hedar, allmän: Öl. t. r.

4. V. Oxycóccos L., Tranbär; blommor enstaka eller $2-3$ i spetsen af grenarne; krona hjulformig, delad (n. till basen) och ljusröd. 3 . 
Liten och krypande med trådsmala grenar; blad små och äggrunda, ofvan glänsande gröna, undertill gråhvita med nedböjda kanter; blomskaft omkr. 6 gånger så långa som blommorna och upprätta, finludna; blomfoder finludet med korta och rundade flikar.

\section{Myrar, allmän: Gotl. r.}

- microcarpum (Turcz.); blomskaft och foder glatta.

Till alla delar, särdeles till bär och frön, mindre än hufvudarten: lärer blomma tidigare. Detta oaktadt kan denna form icke anses såsom egen art.

Myrar, ofta i sällskap med hufvudarten, helst i fjellen; Lpl. spr., Norrl. Vb. Jtl. Gestr. r., Sv. Dal. Verml. Üpl. r., Göt. Dalsl. Ög. Blek. r. - Troligen äfven annorstädes.

\section{Callúna. Ljung.}

1. C. vulgaris (L.) Salisb.; blommor nedhängande; blad motsatta och jemnbreda med pillik bas. 3,4 .

Låg och grenig med upprätta grenar; hvita blommor förekomma mindre ofta.

Hedar, helst i skogar, allmän.

\section{Erica. Klockljung.}

1. E. Tétralix L.; blad smalt lansettlika och i kanten långhåriga, vanligen $4 \mathrm{i}$ hvarje krans. 2, 3 .

$1 / 2-1$ fot hög och upprätt; blomskaft och foder hvitulliga; blommor någongång hvita.

Torfkärr; Göt. Dalsl. Vg. spr. Boh. vestra Smål. Hall. a. Sk. t. a. Blek.-Ög. r., Sv. Söd. Ner. r. Verml. spr.

\section{Chamænérium. Råmjölkegräs.}

1. C. angustifólium (L.) Scop.; blad lansettlika. 3.

Omkr. 4-5 fot hög, vanl. enkel och upptill rodnande; blad glatta, undertill blekare och ådriga; pistillens märke 4-klufvet.

Stenbundna ställen, helst i skogar, och svedjeland, allmän.

\section{Epilóbium. Dunört.*)}

A. Blomknoppar upprätta. Blad smala, de flesta oskaftade.

a. Stjelk trind och utan upphöjda ränder; blad icke nedlöpande. Märke vanligen 4-klufvet.

1. E. parviflórum Schreb.; foderflikar lansettlika och spetsiga utan udd; kronblad vanl. af fodrets längd.

Omkr. 2 fot hög och vanl. mjukluden, stundom (då den växer $i$ vatten) glatt; stjelk vanl. enkel; blad fintandade med rundad, ej omfattande bas; grenskott (som utvecklas mot hösten) korta.

Fuktiga ställen: Göt. t. r.: Sk. Öl. t. a. Kalmarl. Ög. spr. Dalsl. 0, Sv. t. r.: Verml. Dal. 0.

2. E. hirsútum L.; foderflikar lansettlika med borstlik udd; kronblad längre än fodret.

*) Dessa växter blomma frampå sommaren. 
Liknar något föreg. art, men är 2-3 fot hög och beklädd både med långa utstående hår och korta glandelhắr; stjelk grenig; blad aflảngt lansettlika och tandade, de öfre stjelkomfattande; grenskott utdragna; blommor stora, inemot tumsvida.

Bäckstränder; Göt. Sk. spr. Smål. Hall. Boh. Vg. r. Gotl.?, Sv. Söd. Upl. r. (Verml. tillfällig).

b. Stjelk med upphöjda ränder af de nedlöpande bladen. Märke vanl. helt.

3. E. tetrágonum L.; foderflikar utdraget spetsiga; blad tätt sågtandade; stjelk tydligt kantig.

Omkr. 2 fot hög och n. glatt; stjelk upprätt, vanl. mycket grenig; blad glänsande, med rundad bas; grenskott korta; frön finprickiga.

Fuktiga ställen, stundom på åkerrenar; Göt. r.: Sk. Blek. Ög. Öl. spr. Gotl. t. r. Vg.?, Sv. Söd. spr. Upl. Ner. r.

4. E. virgátum Fr.; foderflikar nästan trubbiga; blad glest sågtandade; stjelk otydligt kantig.

Omkr. 2 fot hög och upptill småluden; stjelk uppstigande och vanl. mycket grenig; blad glanslösa och mörkgröna med något afsmalnande bas; grenskott utdragna; frön n. släta. Denna art är svår att skilja från föreg., men liknar mera E. palustre.

Fuktiga ställen; Göt. Boh. r. Hall. Sk. Smål. t. r. Blek. Gotl. r. Ög. spr., Sv. Söd. r.

B. Blomknoppar lutande.

a. Blad icke nedlöpande; bladskaft inga eller korta; stjelk med inga eller otydliga ränder.

5. E. montánum L.; märke vanl. fyrklufvet; blad äggrunda med rundad bas, fintandade och vanl. kortskaftade; foderflikar n. trubbiga; fröhus finludet; frön aflånga och prickiga.

Omkr. fotshög med rundtomkring småluden, upprätt och föga grenig stjelk utan ränder; blad vanl. gröna och finludna; blommor ljusröda; grenskott utdragna med något skilda blad.

Berg, helst i skogar; Göt. Sv. a., Norrl. a. (utom fjellen): Vb. Jtl. Herj. spr., Lpl. r.

6. E. origanifólium Lam.; märke helt; blad äggrunda, nästan alla fintandade och föga skaftade (de nedre bladskaften stundom något utdragna); fröhus n. glatt eller glest hårigt; frön tapplikt äggrunda-aflånga och n. släta.

Stjelk vanl. låg, stundom ända till fotshög och ofta krokig, sällan grenig, nästan glatt med 2-4 svagt upphöjda och finludna ränder, hvarigenom den stundom blir kantig; hlad vanl. glatta; blommor vanl. röda och lika stora som hos föreg. art; stjelkar vanl. enstaka, icke tufvade; grenskott trådlika med små fjällika blad i och nedom spetsen. Varierar med smalare och n. lansettlika frön, liknande dem, som vanligen förekomma hos följ. art. 
Fuktiga ställen, helst i snöbäckar, i och nedanför fjellen, sällan utom fjellen; Lpl. a., Norrl. r.: Jtl. Herj. spr. Gestr. 0, Sv. Dal. t. r.

7. E. alpínum L.; märke helt; blad aflånga och nedåt afsmalnande, oftare skaftade, de flesta helbräddade; fröhus n. glatt eller glest hårigt (sällan tätludet); frön vanl. tapplikt, lansettlika och $n$. släta.

Är ofta svår att skilja från föreg. art, men har tunnare, mindre glänsande och mera trubbiga blad, smalare fröhus och smärre, vanl. hvita blommor; bladen äro stundom nästan lansettlika; stjelkar vanl. tufvade; grenskott korta med bladrosetter. Varierar (vid Karesuando i Torn. Lpm. enl. exemplar af C. P. Læstadius) med kortare frön, liknande dem hos föreg. art.

$\mathrm{P}_{a}$ samma ställen som föreg. art; Lpl. a., Norrl. Jtl. Herj. spr. Ång.-Hels. r., $S v$. Dal. r.

8. E. palustre L.; märke vanl. helt; blad smalt lansettlika-jemnbreda med något invikna kanter och vigglik bas, vanl. helbräddade, stundom glest tandade, de öfre oskaftade; fröhus finludet; frön tapplikt lansettlika och släta.

Omkr. fotshög merl rundtomkring småluden, uppstigande och vanl. föga grenig stjelk utan ränder; blad glanslösa och mörkgröna, finludna eller glatta; blommor ljusröda och teml. små, sällan hvita; grenskott trådlika med bladknoppar eller med något spridda blad nedom spetsen.

Fuktiga ställen, allmän: dock mindre vanlig i fjellen.

- angustum; blad smalare; blommor vanl. hvita.

I fjellen vanligare än hufvudarten, för öfrigt i Norrl. mera sparsam ned till Gestr.

9. E. lineáre Mühl.; märke helt; blad utan invikna kanter: de nedre bladen korta och tunglika, de öfre smalt lansettlika-jemnbreda och oskaftade, helbräddade eller glest tandade; fröhus n. glatt; frön tapplikt lansettlika och n. släta.

Hela växten glattare än föreg. art, vanl. lägre och enkel; stjelk stundom med svagt upphöjda ränder; blad vanl. mot spetsen bredare; blommor små och oftast hvita; grenskott korta med bladrosetter.

Fuktiga ställen i fjellen, sällan i lägre fjelltrakter; $L p l$. t. r., Norrl. Jtl. Herj. r. Ång. Hels.?

b. Stjelk med upphöjda långsgående ränder af de nedlöpande, utdraget skaftade bladen.

10. E. róseum Schreb.; märke vanl. helt; blad aflånga eller bredt lansettlika med vigglik bas, fintandade; foderflikar utdraget spetsiga.

Omkr. 2-3 fot hög med småluden, upprätt och mycket grenig stjelk; blad n. glatta och ofta rödaktiga; grenskott korta; fröhus finludet; frön n. släta. 

Dal. 0 .

Fukt. ställen; Göt. t. r.: Sk. Öl. Ög. spr. Gotl. 0, Sv. t. r.

\section{Enothéra. Gultraf.}

1. E. biennis L.; stjelkblad strödda, äggrunda-lansettlika och kortskaftade; kronblad längre än ståndarne. 3.

$2-3$ fot hög med rotbladen i rosett, omvändt äggrunda-aflånga, trubbiga och uddspetsiga; frukter tilltryckta intill stjelken.

Ruderatväxt, ursprungl. förvildad; Göt. t. r.: Sk. Hall. spr. Boh.?, Sv. r.: Söd. spr. Vestm. Dal.?

\section{Ordn. DIGYNIA.}

\section{Chrysosplénium. Guldpudra.}

1. C. alternifólium L.; blad naggade och ofvan gleshåriga: rotblad långskaftade, stjelkblad få, skiftevis stälda; skärmblad talrika, halfrunda-äggrunda, sittande n. i krans tätt under blommorna; ståndare 8-10. 1 .

Omkr. fingerhög, späd och ljusgrön med guldgula blommor. Skuggrika ställen vid bäckar och källdrag; Göt. spr.: Gotl. Ö1. r., Sv. spr., Norrl. spr.: Med.-Vb. r., Lpl. r.

* C. tetrándrum Th. Fries; blad ofvan glatta ; skärmblad vigglika; ståndare 4 .

Mindre och spädare med mera grönaktiga blommor.

Vid bäckar och källor i fjellen; Lpl. r.

\section{Ordn. TRIGYNIA. \\ 210. Poly'gonum. Knäfva.}

A. Blommor 2-4 tillsammans, kortskaftade i bladvecken.

1. P. aviculáre L., Trampgräs; stipelslidor sargade eller flikiga; blad ovala-lansettlika kortskaftade; frukt finprickig, svartbrun och glanslös, innestuten inom kalken, med nedtill bredare sidor; blomskaft kortare än kalken. 3, 4 .

Vanl. nedliggande och grenig, helt och hållet örtartad; blad något blågröna; stipelslidor hvita; blommor invändigt hvita eller ljusröda; ståndare vanl. 8 ; rot enärig.

Ruderatväxt, stundom pả hafsstränder, allmän.

2. P. Raji Bab.; blad vanl. smalt lansettlika; frukt slät, ljusbrun och glänsande, långt utskjutande ur kalken, med nedtill afsmalnande sidor; blomskaft längre än kalken. 3,4 .

Liknar mycket föreg. art, men har stammen nedtill af fastare byggnad, mera röda llommor, mångårig rot och större frukter.

Hafsstränder; Göt. Skåne r.

* P. Robértii Lois.; frukt svartbrun, lika lång som kalken. Hafsstränder; Göt. Skåne r. 
B. Blommor i tätt ax, ensamt i stjelkens spets; stjelk upprätt och enkel; stipelslidor hårlösa; de nedre bladen långskaftade, de öfre oskaftade; stift fria.

3. P. vivíparum L.; Höfrö, Mortog; ax nedtill med groddknoppar; de nedre bladen aflånga-ovala med ovingade skaft, de öfre lansettlika. $2,3$.

Omkr. $1 / 2$ fot hög med tjock rotstock, hvita blommor, undertill gråludna blad och bruna stipelslidor.

Ängar och betesmarker; Lpl. Norrl. Sv. a., Göt. Dalsl. a. Vg. Ög. norra Smål. spr. Boh.-Sk. Blek. r.

4. P. Bistorta L., Ormrot; ax utan groddknoppar; de nedre bladen äggrunda-hjertlika och nedlöpande på skaftet, de öfre äggrunda stjelkomfattande. 3.

Omkr. 2 fot hög med mycket tjock rotstock, blekröda blommor och undertill blekgröna, stundom nära tumsbreda blad.

Fuktiga ängar och kärr; Göt. Hall. r. Sk. t. r. Blek. Smål. r. Ög.?, Sv. Söd. Upl. Vestm. r.

C. Blommor i klasar från bladvecken; stjelk slingrande; blad hjertlika-pillika.

5. P. Convólvulus L., Binda; stjelk kantig; de utväxta kalkbladen ovingade; frukter glanslösa; blomskaft mycket korta. 3.

Omkr. 2 fot lång med gröna, inuti hvita blommor.

Ruderatväxt och ogräs, allmän.

6. P. dumetórum L., Löfbinda: stjelk trind; de utväxta kalkbladen på ryggen bredt hinnvingade; frukter glänsande; blomskaft utdragna. 3 .

Lik föreg. art, men ofta $5-6$ fot lång, med gröna och hvitkantade blommor.

Lundar, skogsbackar och berg, ofta i skärgården; Göt. spr.: Dalsl. t. r. Gotl. 0, Sv. spr.: Verml. t. r. Dal. 0, Norrl. Gestr. Med. Ang. r., Lpl. r.

D. Blommor i ax i spetsen af grenarne eller från bladvecken, utan groddknoppar; stjelk vanl. grenig, ej slingrande.

a. Ax tätblommiga och tjocka.

7. P. amphibium L., Vatten-kinäfva; blad aflånga-lansettlika, vid basen rundade eller hjertlika; axskaft glatta och farade; rotstock krypande; blommor ljusröda med 5 ståndare. 3,4 .

a. aquáticum; blad flytande på vattnet, långskaftade och glatta; stipelslidor utan hår.

I vatten; Göt. Sv. t. a.: Gotl. Öl. Boh.-Dal. spr., Norrl. spr., Ipl. r. 
b. terrestre; blad upprätta, mera kortskaftade, sträfva och håriga; stipelslidor med hår i spetsen.

Fuktiga ställen nära vatten $h$. o. d.

8. P. lapathifólium L., Röd-knäfva; blad lansettlika och nedàt spetsiga; axskaft sträfva; rot trådig; stipelslidor med inga eller korta hår; blommor rödaktiga eller grönaktiga med 6 ståndare. 3,4 .

Omkr. fotshög; kalkblad med glandler; frukter platta med urhålkade sidor.

Ruderatväxt på fukt. ställen, stundom ogräs; Göt. Sv. a., Norrl. t. a., Lpl. r.

9. P. Persicária L.; blad lansettlika och nedåt spetsiga; axskaft glatta; rot trådig; stipelslidor med långa hår; blommor röda eller hvitaktiga med 6 standare. 3,4 .

Liknar mycket föreg. art, men är af renare färg; kalkblad utan glandler; somliga frukter trekantiga, de öfriga rundade med kullriga sidor; ax stundom något glesblommiga.

Fukt. ställen, mest såsom ruderatväxt och ogräs; Göt. spr.: Sk. Hall. Blek. a., Sv. spr.: Ner. Dal. r., Norrl. Gestr.-Med. r.

b. Ax glesblommiga och smala.

10. P. strictum All.; blad jemnbredt lansettlika; stipelslidor med långa hår; ax vanl. upprätta; kalkblad utan glandler. 3,4 .

Några tum hög och småbladig, af mild smak, vanl. ända från roten grenig med utbredda grenar, röda blommor och glänsande frukter. Hela växten ofta rödaktig.

Fuktiga ställen, isynnerhet hafsstränder samt vid Venern, Vettern, Hjelrnaren och Mälaren; Göt. spr.: Sk. t. a. Blek. inre Smål. r. Gotl.?, Sv. spr.: Vestm. r. Dal. 0, Norrl. Gestr. Hels. Vb. r.

- mite; blad lansettlika; ax slaka och lutande; blommor ljusröda eller hvitaktiga.

$1 / 2$ fot hög eller deröfver, mera grön, med upptill mera grenig stjelk.

Stränder; mindre vanlig än hufvudarten.

11. P. Hydrópiper L., Vattenpeppar, Jungfrutvål; blad lansettlika; stipelslidor med korta hår; ax lutande; kalkblad med glandler. 3,4 .

Omkr. fotshög, af skarp och brännande smak, med ljusgröna och vågiga, slutl. rodnande blad; frukter icke glänsande.

Fukt. ställen och stränder, stundom i vatten; Göt. $S v$. a., Norrl. Gestr. a. Hels. Med. spr. Ång. Vb. r.

\section{Ordn. TETRAGYNIA.}

\section{Paris. Trollbär.}

1. P. quadrifólia L.; blad omvändt äggrunda eller ovala och spetsiga, vanl. 4, stundom $5-6$, i en enda krans. $1,2$. 
174 VIII. octandria. 212,213. IX. enneandric. 214.

Stjelk $1 / 2$ fot hög och enkel; bär svartblått.

Skuggrika och myllrika lundar; Göt. Sv. t. a., Norrl. spr.: Jtl. t. a., Ipl. t. r.

\section{Adóxa. Desmansknopp.}

1. A. Moschatellína L.; rotblad långskaftade och dubbelt fingerlikt delade med flikiga flikar (småblad); stjelkblad 2, motsatta och enkelt trefingrade; blomhufvud i stjelkens spets. 1, 2 .

Omkr. fingerhög med hvit, krypande och upptill fjällig rotstock; toppblomman har 8 (egentligen 4) standare; sidoblommorna 10 (egentl. 5).

Myllrika lundar; Göt. spr.: Hall. Sk. a. Got]. inre Smål. r., Sv. spr.: Dal. r., Norrl. r.: Gestr. spr. Ång. Vb. 0 .

\section{Elatíne.}

1. E. Hydrópiper L.; bladens skaft längre än skifvan; blommor oskaftade; foderflikar och kronblad 4; ståndare 8; kronblad ljusröda; fröhus 4-rummigt med vanl. hästskoformigt krökta frön. 3,4 .

Stränder, vanligen i vattnet: Göt. spr.: Ö1.? Gotl. 0, Sv. spr., Norrl. spr.: Ang. r. Jtl. Herj.? Lpl. spr.

2. E. triandra Schk.; blad nästan utan skaft; blommor oskaftade; foder 3-deladt; kronblad och ståndare 3; kronblad ljusröda; fröhus vanl. 3-rummigt med nästan raka frön. 3,4 .

Någon gång är fröhuset 4-rummigt, ett och annat blad kan vara tydligare skaftadt.

Stränder, helst af sjöar, r.; Göt. Blek. Ög. Boh. Dalsl., Sv. Söd. Vestm. Ner. Verml., Norrl. Gestr. Ang. Vb.

3. E. hexándra D.C.; blad kortskaftade; blommor långskaftade; foderflikar och kronblad 3, ståndare 6 ; kronblad hvita; fröhus 3-rummigt med n. raka frön. 3,4 . Stränder r.; Göt. Vg. Boh. Dalsl., Sv. Verml.

\section{Klassen. ENNEANDRIA.}

1 Ordn. HEXAGYNIA.

214. Bútomus. Blomvass.

1. B. umbellátus L.; blomflock med 3-bladigt och brunt svepe; rotstockens blad långa och $n$. jemnbreda. 3 Stängel trind och 2-4 fot hög.

I åar och strömmar, stundom i sjöar och hafsvikar; Göt. spr.: Ög. t. a. inre Smål. t. r. Blek. Gotl. Öl. r. Sk. Hall. ot. a. Boh. r. Dalsl. t. r., Sv. t. a.: Verml. t. r. Dal. r., Norrl. r.: Ang. Herj.? 


\section{Klassen. DECANDRIA.}

1 Ordn. MONOGYNIA.

\section{Arctostáphylos.}

1. A. officinalis Wimm. o. Grab., Mjölonris; blad fleråriga och läderartade, omvändt äggrunda-vigglika; blommor i fảblommig klase i spetsen af grenarne. $1,2$.

Ofta mer än fotslång med släta blad; blomkrona hvit, nedtill ğenomskinlig och upptill rödaktig; bär runda, röda och mjöliga samt af en fadd smak. Liknar lingonris, men bladens kanter äro ej nedvikna.

Skogshedar och berg; Lpl. Norrl. a., Sv. t. а., Göt. t. a.: Boh. spr. Öl. 0.

2. A. alpína (L.) Spr., Ripbär; blad enåriga, omvändt äggrunda eller spadlika, upptill rodnande; blommor $2-3$ i spetsen af grenarne. 1 .

Liknar föreg., men blommorna äro upptill grönaktiga, utslående före de skrynkliga, på båda sidor nätådriga bladen; bär runda och svartblå, saftiga och syrliga.

Hedar i fjellen; Lpl. a., Norrl. Jtl. Herj. spr., Sv. Da].t.r.

\section{Andrómeda.}

A. Blad platta och åtskilda; kronpip äggformig.

1. A. polifólia L., Rödpors; blad smalt lansettlika och n. oskaftade med nedvikna kanter; blommor i flock i spetsen af grenarne. 1, 2 .

Omkr. $1 / 2$ fot hög och upprätt; blommor och blomskaft ljusröda.

Myrar; Lpl. Norrl. a., Sv. t. a., Göt. t. a.: Öl. Gotl. r.

B. Blad barr- eller nållika och tätt tegellagda; kronpip klocklik.

2. A. tetrágona L., Lummerljung, Lummerkräkling; blad barrlika, n. trekantiga med pillik bas; blommor på långa ensamma skaft, utgående från sidan af grenarne. 2. 1-2 fot hög och ljunglik med utbredda grenar; blommor hvita, liknande Liljekonvaljer; blad omkr. 2 linier långa och genom kanternas invikning trekantiga. Af de korsvis motsatta bladen äro grenarne fyrkantiga och uppåt tjockare.

Hedar i fjellregionen; Lpl. spr.: Torn. Lpm. a.

3. A. hypnóides L., Mosskräkling; blad nållika; blommor på långa ensamma skaft, utgående från spetsen af grenarne. $1,2$.

Liten, mycket fingrenig och liknande Björnmossa, bildande knappt tumshöga tufvor med hvita, upptill rödletta blommor; blad linielånga. 
Torr och hård mark i fjellregionen h. o. d.; Lpl., Norrl. Jtl. Herj.

\section{Phyllódoce. Blicljung, Fjell-ljung.}

1. P. coerúlea (L.) Salisb.; blad barrlika tegellagda, jemnbreda och trubbiga samt undertill blekgröna. 1,2.

Omkr. $1 / 2$ fot hög eller lägre, grenig och risaktig, något lik Erica Tetralix, men med något större, slutl. blåaktiga blommor. Dal. t. r.

Hedar i fjellen; Lpl. a., Norrl.| Jtl. Herj. mångenst., Sv.

\section{Rhododendrum. Alpros.}

1. R. lappónicum (L.) Wahlenb., Lapst Alpros; blad enåriga, ovala och trubbiga, undertill gulgröna och slutl. rostbruna af kadprickar. 1, 2.

Låg, vresig och nedtryckt; grenar nedtill bara, upptill beklädda med teml. tätt sittande, spiralstälda och $1 / 2$ tum långa blad; blomfoder mycket litet; ståndare stundom 5 .

Hedar i fjellen; Ipl. r., helst omkr. Qvickjock.

\section{Ledum. Sqvatram, Vildpors.}

1. L. palustre L.; blad n. jemnbreda med nedvikna kanter och undertill rostbrunt ulliga; blomflockar täta och rikblommiga. 2 .

2-4 fot hög med starkt luktande blad och blommor.

Tufviga kärr, helst i skogstrakter; Lpl. a., Norrl. a.?: Jtl.? Sv. a., Göt. spr.: Dalsl. a. Ög. t. a. Hall. Boh. Gotl. r. Sk. t. r. 220. Py'rola. Vintergröna. *)

A. Pistillens stift nedböjdt och i spetsen bågböjdt; kronblad utstående. Blommor i allsidig klase; blad n. helbräddade.

1. P. rotundifólia L.; foderflikar lansettlika och teml. länga, 2 gånger kortare än kronan; blommor snöhvita eller rödletta.

blommor.

Omkr. fotshög med n. runda, ljusgröna blad och välluktande

Skogar; Lpl. Norrl. Sv. a., Göt. spr.: Dalsl. Ög. a. Boh. Sk. t. r. Blek. r.

2. P. chlorantha Swartz; foderflikar triangelformiga och 4 gånger kortare än kronan; blommor grönhvita.

$0 \mathrm{mkr}$. fotshög med smärre och runda, mörkgröna blad och luktlösa blommor.

Skogar, helst af gran; Norrl. spr.: Jtl. Herj. r. Ång. t. r. Vb. 0, Sv. spr., Göt. spr.: Blek. Sk.-Boh. t. r.

B. Pistillens stift rakt; kronblad samstående.

a. Blommor i allsidig klase, snöhvita eller rödletta; blad n. helbräddade.

*) Dessa växter blomma under sommaren. 
3. P. média Sw.; foderflikar lansettliza; stift öfverskjutande kronan.

Omkr. fotshög med n. rundade och ljusgröna blad; blommor välluktande, med upptill åtskilda kronblad.

Skogar (vanligen i fà exemplar); Göt. t. r.: Blek.-Ög. spr. Gotl. t. a. Öl. 0, Sv. t. r.: Söd. Upl. Verml. spr., Norrl. r.: Herj. Med.?

4. P. minor L.; foderflikar triangelformiga och korta; stift inneslutet inom kronan.

Lägre än föreg. arter med smärre, rundade eller ovala, blekgröna blad och luktlösa blommor med nästan hopslutna kronblad. Skogar, teml. allmän: Öl. Boh. Jtl. t. r.

b. Blommor i ensidig klase, grönhvita; blad finsågade.

5. P. secunda L.; foderflikar triangelformiga, korta och fintandade.

Omkr. $1 / 2$ fot hög med mera bladig stjelk än hos de föreg. arterna; blad smärre, ovala-lansettlika och ljusgröna; blommor' luktlösa.

Skogar, teml. allmän.

\section{Chimáphila. Vintergröna.}

1. C. uniflóra (L.) Fr., Enblommig Vintergröna ; blomma ensam och lutande i stjelkens spets med n. platta och utstående kronblad; blad rundade-spadlika och sågtandade. 3.

Omkr. fingerhög, n. örtartad och enkel, med en stor hvit och mycket välluktande blomma med rakt och utdraget stift; blad skaftade, mjuka och ljusgröna.

Barrskogar, helst af gran; Göt. mångenstädes: Blek. Sk. r., Sv. t. a., Norrl. mångenst.: Ang. a. Vb. r.?, Lpl. r.

2. C. umbelláta (L.) Pursh, Flockblommig Vintergröna; blommor i enkel flock i spetsen af grenarne, med utstående kronblad; blad kranssittande, lansettlikt vigglika och tandade. 3.

Omkr. fingerhög och n. buskartad med ljusröda blornmor utan stift; blad oskaftade, hårda ocì läderartade, ofvan mörkgröna.

Skogar; Göt. t. r.: Smål. Ög. spr. Blek. 0, Sv. t. r.: Söd. Upl. Verml. spr., Norrl. Gestr. Hels. r. Herj.?

\section{Monótropa. Tallört.}

1. M. Hypópitys L.; blommor kortskaftade i slutligen upprätt klase. 3,4 .

Omkr. 5 tum hög och köttig, vid torkning svartnande; blomdelar vanl. håriga; ståndareknappar enrummiga.

Skogar, parasit på tallrötter; Göt. spr.: Boh. Blek. Öl. r. Gotl. t. r., Sv. spr.: Dal.?, Norrl. Gestr. Hels. r. 
2 Ordn. DIGYNIA.

223. Scleranthus. Knafvel.

1. S. ánnuus L.; kalkens flikar spetsiga utstående och nästan utan hinnkant. 3.

Omkr. fingerhög, ljusgrön och klynnedelad; blommor gyttrade både i grentopparne och i biadvecken; rot enårig eller tvåårig.

Sandåkrar och andra dyl. ställen; Göt. Sv. a., Norrl. spr.

2. S. perennis L.; kalkens flikar rundadt trubbiga med bred hvit hinnkant och slutl. inböjda. 3.

Lik föreg. art, men blågrön; blommor gyttrade i grentopparne; rot mẳngårig.

Grusbackar och berg; Göt. a., Sv. spr.: Söd. Upl. a. Dal. 0, Norrl. Gestr.-Med. r.

\section{Saxifraga. Stenbräcka.}

A. Med nyskott till växtens förökning. Mångåriga örter. Kronblad ofta gula, stundom rödaktiga eller hvita.

a. Blad odelade (antingen helbräddade eller tandade). 1. S. Cotyledon. 2. S. Aizoon. 3. S. oppositifolia. 4. S. stellaris. 5. S. Hirculus. 6. S. aizoides.

b. Blad fingerlikt klufna. 7. S. cæspitosa.

B. Utan nyskott. Antingen mångåriga örter, vanligen försedda med groddknoppar vid roten (stundom äfven $i$ bladvecken), eller 1-2-åriga utan groddknoppar. Kronblad vanJigen hvita.

a. Blad naggade. Rot mångårig. Utan groddknoppar. 8.S. nivalis.

b. Blad fingerlikt klufna eller flikiga, de nedre stundom naggade. Med groddknoppar. 9. S. granulata. 10. S. cernua.

c. Blad fingerlikt klufna eller flikiga, de nedre stundom naggade, sällan alla nästan hela. Utan groddknoppar.

11. S. rivularis. 12. S. tridactylites.

1. S. Cotylédon L.; stjelk med năgra spridda blad; rotblad tunglika; kronblad rent hvita, aflånga-tunglika. dubbelt så långa som foderflikarne. 3 .

Stjelk klibbluden, $1 / 2-2$ fot hög med stora och talrika bladrosetter vid basen; grenar talrika, utstående och rikblommiga i en stor pyramirformig vippa nästan efter hela stjelkens längd: blad tjocka och läderartade, tätt kantade med små hvita broskartade tänder. Liknar en Sempervivum.

Fuktiga klippväggar, helst i fjellregionen, stundom i fjellens björkregion; Lpl. r., Norrl. Jtl. r.

2. S. Aizóon Jacq.; stjelk med några spridda blad; rotblad vanl. aflånga; kronblad grönhvita och ofta rödprickiga, omvändt äggrunda, dubbelt så långa som foderflikarne. 3 .

Liknar föreg., men är spensligare och vanl. blott några tum hög; stjelk upptill klibbhårig, nedtill glatt med teml. små blad- 
rosetter: grenar få och fåblommiga, i början bildande en blomqvast, sedan en $\mathrm{n}$. jemnbred vippa, knappt upptagande stjelkens öfre tredjedel; blad som hos föreg. art.

Klippväggar i fjellen, mycket r.; Lpl. Piteå Lpm. (enl. ex. af L. L. Læstadius i Linköpings el. läroverks museum).

3. S. oppositifólia L.; stjelkblad tätt tegellagda, omvändt äggrunda (eller aflånga-tunglika), nästan alla motsutta; kronblad rödvioletta, aflånga-lansettlika och trubbiga, 11/2 gång så långa som foderflikarne. 1, 2.

Bildar låga rikblommiga tufvor med vanl. nedliggande grenar; blad mycket små och läderartade, $\mathrm{i}$ kanten håriga; hvarje gren i spetsen försedd med en teml. stor och n. klocklik, i början rosenröd, slutl. violett blomma.

Af snövatten fuktiga ställen högt upp i fjellen; $L p l$. t. a. i högfjellen, Norrl. Jtl. Herj. t. a. på de högsta fjellen.

4. S. stelláris L.; stjelk $\mathrm{n}$. bladlös och stängellik; rotblad aflånga-vigglika, upptill sågade; kronblad hvita, nedtill med 2 gula prickar, och smalt lansettlika, spetsiga och dubbelt så långa som foderflikarne. $2,3$.

Stjelk späd och knappt 5 tum hög, ofta lägre, bar eller nedtill beklädd af inemot tumslånga spetsiga blad, upptill med få, n. enblommiga och i hörjan nedböjda grenar. Blomfodret är fritt från fruktämnet, djupt deladt och slutl. nedböjdt. Växten är vanligen finhårig.

Fuktiga och năgot dolda ställen i fjellen, t. ex. vid bäckar, i fjell- och björkregionen; Lpl. a., Norrl. Jtl. Herj. mångenst., Sv. Dal. r.

comósa; stam enblommig, upptill delad i flera utdragna och utstående grenar med gytiringar af fjälllika blad; blomfoder mycket litet.

I fjellregionen; Lpl. r.

5. S. Hírculus L.; stjelk mångbladig med àtskilda och jemnbredt lansettlika blad; kronblad guldgula med mörkare punkter, aflånga och trubbiga, omkr. 3 gånger så långa som foderflikarne; blommor n. klocklika. 3 .

Stjelk spenslig och omkr. ${ }^{1 / 2}$ fot hög, upprätt och vanl. enstaka, med få sidoskott, upptill med 1-3 stora och långskaftade blommor; stjelkens öfre del jemte blomskaften brunulliga; blad glatta, omkr. tumslånga och platta. Blomfodret är fritt från fruktämnet, djupt deladt och slutl. nedböjdt.

Torfkärr; Lpl. spr., Norrl. Vb. Ång. Jtl. r., Sv. Vestm. Upl. r., Göt. Ög. Smål. Sk. r.

6. S. aizóides L.; stjelk mångbladig med åtskilda, jemnbreda-syllika blad; kronblad vanl. ljusgula med mörkare prickar, aflånga-lansettlika och trubbiga, dubbelt så långa som foderflikarne; blommor platta. 3. 
Stjelkar (grenar) 3-6 tum långa, nedliggande eller uppstigande med talrika nyskott, upptill med năgra få enblommiga och finbåriga blomskaft; blad i kanten finhåriga, n. barrlika och knappt $1 / 2$ linie breda: fröhus $n$. klotrundt; kronblad àtskilda, högre upp på fjellen stundom mörkgula, sällan (i Jtl.) rödaktigt pomeransgula.

Våta ställen i fjellen, helst på klippväggar; $L p l$. a., Norrl. Jtl. Herj. t. a.

7. S. cæspitósa L.; stjelk n. bladlös och stängellik; rotblad vigglikt afsmalnande till skaft, upptill med 3-5 korta och jemnbreda-aflånga flikar; kronblad grönhvita eller blekgula, omvändt äggrunda och dubbelt så långa som foderflikarne. 2, 3 .

Bildar låga och mjuka, vanl. mycket täta tufvor, hvarifrån flera, 1-3 (sällan ända till 6) tum höga stjelkar uppskjuta med 1-4 upprätta, kortskaftade blommor i toppen; bladflikar trubbiga eller spetsiga.

Högländta, solöppna och vanl. torra klippor, helst i fjellregionen; i fjellen: Lpl. spr., Norrl. Jtl. t..r. Herj. r.; utom fjellen: Norril. Ång. r. (äfven på hafsklippor) Med. r.

8. S. nivális L.; stjelk n. bladlös och stängellik; rotblad omvändt äggrunda eller spadlika; kronblad hvita eller något rödvioletta, aflånga och af foderflikarnes längd. 2,3 .

Stjelk teml. spenslig och vanl. 2-3 tum hög (med smärre blad), stundom năgot tjockare och ända till 8 tum hög (med större blad), oftast enstaka, upprätt eller bågböjd, upptill delad $i$ en- eller flerblommiga, upprätta eller utstånde blomskaft; blad undertill rödaktiga, tvärt afsmalnande till skaft; blomfoder ofta rödaktigt.

Något dolda klippor och andra af snövatten fuktiga ställen i fjellen, helst i fjellregionen, sällan i lägre fjelltrakter; $L p l$. t. a., Norrl. Jtl. Herj. mångenst. i fjellen, Med. r.

9. S. granuláta L., Knylbräcka; stjelk flerbladig; de nedre bladen skaftade, njurlika och naggade, de mellersta n. oskaftade, vigglika och flikiga med 8-3 flikar, de öfversta hela och smala; kronblad omvändt äggrunda och 3 gånger så långa som foderflikarne. 2.

Omkr. fotshög med rotbladen vanligen i rosett; stjelk med få blad nedtill och vanl. bladlös upptill; blommor stora med lukt af mandel, i rikblommig och qvastlik vippa.

Solöppna backar och。ängar; Göt. Sv. a.: Hall.-Dal. spr., Norrl. Gestr. spr. Hels. Ång. r.

10. S. cérnua L.; stjelk flerbladig, försedd med groddknoppar både nedtill och vanl. äfven i bladvecken; de nedre bladen skaftade njurlika och flikiga, de mellersta oskaftade vigglika och flikiga, de öfversta hela och 
smala; kronblad hvita, omvändt äggrunda och $3-4$ gånger så långa som foderflikarne. 3.

Stjelk enkel (stundom flera tillsammans) och spenslig, ${ }^{1} / 2-1$ fot hög, ofta ullig och teml. rikbladig med flera mörkröda groddknoppar i hvarje veck af de öfre bladen; blomma vanl. ensam, stor och Jutande i stjelkens topp, sällan fruktbärande; blomfoder fritt från fruktämnet. Har sällan (i Torn. och Lul. Lpm.) 3-6 blommor i klase.

Nägot dolda klippor och andra af snövatten fuktiga ställen i fjellen, helst i fjellregionen; Lpl. teml, vanlig, Norrl. Jtl.spr. Herj. t. r.

11. S. rivuláris L.; stjelk stängellik enbladig; rotblad långskaftade njurlika och flikiga; stjelkbladet vanl. oskaftadt och omvändt äggrundt med utdragen bas; kronblad hvita, aflånga eller omvändt äggrunda, dubbelt så långa som foderflikarne. 3.

Stjelkar mycket späda och vanl. blott $1 / 2-2$ tum höga, enkla eller upptill delade i 2 långa enblommiga och håriga blomskaft med obetydliga blommor; rot tvåårig. Liknar Ranunculus pygmaus.

Sumpiga och dolda ställen, t. ex. i klippspringor samt i och vid bäckar i fjellen; Lpl. spr., Norrl. Jtl. Herj. spr., Sv. Dal.r. 12. S. tridactylites L.; stjelk mångbladig; alla bladen oskaftade och viggtika, de nedre langt afsmalnande; kronblad vigglika eller omvändt äggrunda, tvärhuggna eller urnupna, dubbelt så långa som foderflikarne; fruktskaft utstående, fina och trådsmala, fera gånger längre än det n. klotrunda blomfodret. 1, 2.

Omkring fingerhög och spenslig, vanl. grenig frân roten och oftast rödaktig, med rosettlikt gyttrade, snart vissnande rotblad, de första hela; stjelkblad stundom hela.

Berg och backar; Göt. spr.: Gotl. Öl. a. Blek. Boh. r. Hall. Smål. t. r., Sv. t. r.: Söd. Upl. spr. Dal. 0, Norrl. Jtl. r.

* S. adscendens L.; kronblad 3 gånger så långa som foderflikarne; fruktskaft upprätta och korta, sällaı längre än det bredt äggformiga fodret; eljest som hufvudarten.

Liknar hufvudarten, men är vanl. grön (sällan rödaktig) med något högre, styf och upptill grenig stjelk och mera varaktiga rotblad.

Torra solbelysta klippor eller åkrar; Lpl. r., Norrl. Jtl. t.r. Herj. Med. r., Sv. r.: Ner. t. r. Dal.?, Göt. Dalsl. Vg. r. Ög.?

\section{Dianthus. Nejlita.}

A. Kronbladens skifva hel eller upptill tandad.

a. Blommor långskaftade i qvastlik vippa.

1. D. deltóides L., Ängsnejlika, Gräsnejlika; blomfoder rörformigt med mycket korta svepeblad; rotstock skottalstrande. 3 . 
Vanl. ljusgrön, omkr. $1 / 2$ fot hög; stjelk småluden; kronblad röda med omvändt äggrund, $i$ spetsen tandad skifva. a. Vb. r.

Torra ängar och ăkerrenar; Göt. Sv. a., Norrl. spr.: Gestr.

gláucus; blågrön med hvita cller blekröda kronblad. Göt. r.: Blek. Vg??, Sv. r.: Ner. Dal.?, Norrl. Gestr. Hels. Ång.r.

B. Blommor med korta eller inga skaft.

2. D. Arméria L., Tofsnejiika; blomfoder upptill afsmalnande, med mycket långa och lansettlika, borstbärande svepeblad; rot tvåarig och svag, utan rotskott. 3 .

Omkr. $1 / 2$ fot hög och sträfluden; kronblad röda med smalt aflång och n. helbräddad skifva.

Ruderatväxt nära hafvet; Göt. r.: Sk. Öl. spr., Sv. r.

Anm. Vid Kudby i Ög. (enl. ex. af Studer. G. Adlerz) är en märklig, närstående form funnen med teml. utdragna blomskaft, men eljest mest lik nyss beskrifna art; torde vara bastard of $D$. deltoides och D. Armeria.

3. D. prólifer L., Hylsnejlika; blommor inom gemensamt torrhinnigt och borstlöst svepe; blomfoder utan enskildt svepe; rot svag och enårig utan rotskott. 3,4 .

Lika hög som de föreg. arterna och n. glatt; kronblad ljusröda, föga framskjutande ur fodret, med mycket kort, omvändt äggrund och i spetsen tandad skifva.

Ruderatväxt; Göt. Sk. Öl. r. Gotl. t. r. Ög. r.

B. Kronbladens skifva djupt mångflikad.

4. D. arenárius L., Sandnejlika; rotstock med tätt tufvade grenskott; svepeblad $1 / 4$ så långa som foderpipen. 3.

Stjelkar vanl. fingerhöga och enblommige; blad omkr. ${ }^{1 / 2}$ linie breda och en tum långa, blågröna och stela, vanl. spetsiga; blommor mer än tumsbreda, snöhvita och särdeles under natten välluktande.

Sandfält, helst på flygsand; Göt. Boh. r. Hall. t. r. Sk. spr. (helst vid ö. kusten) Blek. $r$.

5. D. superbus L., Praktnejlika; rotstock med glesa grenskott; svepeblad $1 / 3$ så långa som foderpipen. 3 , 4 .

Stjelkar vanl. fotshöga, stundom mycket lägre, upptill vanl. greniga och flerblommiga; blad mer än en linie breda och omkr. 3 tum långa, rent gröna och något veka, vanl. något trubbiga; blommor omkr. $1^{1 / 2}$ tum breda, vanl. ljusröda, stundom hvita.

Ängar; Göt. Sk. spr. Hall. t. r. (för öfrigt nära svenska gränsen på Tornio kyrkogård i Finland).

\section{Gypsóphila. Fünting.}

1. G. murális L.; blad n. platta, något afsmalnande at båda ändar; blommor lutandẹ, spridda på hårfina skaft i bladig vippa; pålrot utan rotskott. 3,4. 
Omkr. 2-4 tum hög och glatt, blågrön eller rodnande, med mycket spenslig och upprätt stjelk, stundom med utbredda och n. nedliggande grenar, utgående från stjelkens midt eller från dess bas; kronblad rödletta och hela eller urnupna.

Torra sandiga backar; Göt. Vg. Hall. r. Sk. t. r. Blek. spr. Smål. r. Ög. t. r., Sv. Söd. Upl. r. Vestm. t. r., Norrl. Hels. r. 2. G. fastigiáta L.; blad n. trådsmala, något plattade och trubbiga; blommor upprätta, kortskaftade och n. jemnhöga $\mathrm{i}$ knippen, bildande en qrastlik vippa; rotstock skottalstrande. 3 .

Blågrön eller rodnande med styfva och uppstigande, ${ }^{1} / 2-1$ fot höga, upptill klibbludna stjelkar; vippan utgaende ofvan stjelkens midt; kronblad 2 linier långa och hvita; blad smalare än stjelken.

Torra sandiga ställen, helst (blott?) på kalkformation; Güt. Öl. spr. Gotl. t. r. Sk. r., Sv. Dal. mellan Mora och Garberg.

\section{Saponária. Såpört.}

1. S. officinális L.; blommor kortskaftade i täta knippen; blomfoder glatt, vid fruktmognaden uppblåst på midten; blad bredt lansettlika. 3,4 .

1-2 fot hög, upprätt och n. glatt; kronblad hela eller något urnupna med fjällika bikronblad.

Ruderatväxt, trol. förvildad; Göt. spr.: Gotl. Smål. Vg. r. Dalsl. 0, Sv. t. r.: Verml. Dal. 0.

\section{Ordn. TRIGYNIA.}

\section{Siléne. Glim.}

A. Blomfoder redan under blomningstiden uppblist, nätådrigt och äggformigt. Hela växten glatt.

1. S. infláta Sm., Smällor, Tarald; blommor lutande; kronbladens skifvor klufna nedom midten, med obetydlig bikrona; blomskärmar hinnaktiga. 3 .

Fotshög och deröfver, vanl. upprätt; blad vanl. äggrundt lansettlika och blågröna; blommor stora, vanl. i rikblommig vippa, med hvit krona och violett foder; fröhus rundadt äggformigt.

Torra ängar och berg, stundom ruderatväxt och ogräs; Göt. a.: Ög. inre Smål. Boh. Dalsl. spr., Sv. a.: Verml. Dal. spr., Norrl. Lpl. spr.

2. S. marítima With.; blommor nästan upprätta; kronbladens skifvor klufna till midten samt försedda med tydlig bikrona; blomskärmar bladartade. 3.

Lägre än föreg. art, som denna mycket liknar, och mera grenig med uppstigande och fåblommiga grenar, ofta tufbildande; fröhus n. klotrundt; blad smalt lansettlika och ljust blågröna.

Hafsstränder; Göt. r.: Boh. a. Hall. t. a. Ög. 0, Sv. t. r., Norrl. r.: Med.? 
B. Blomfoder under blomningstiden icke uppblåst.

a. Foder i början rörformigt; växten vanl. luden. Blommor blott på aftonen och under natten utslagna. Kronbladens skifva delad.

3. S. nutans L., Backglim; blommor nedböjda i ensidig vippa med motsatta och utstående 5-1-blommiga grenar; blad platta; rotblad lansettlika-tunglika, stjelkblad smalt lansettlika. 2,3 .

Upprätt och fotshög, nedtill småluden och upptill klibbluden, med talrika rotskott ofta tufbildande; blomfoder slutl. uppblåst upptill, med korta och spetsiga tänder; kronblad gulhvita. Nlindre ofta är hela växten glatt.

Torra ängar, backar och berg; Göt. t. a.: vestra Smål, r. Boh. spr. Dalsl. t. r., Sv. t. a.: Verml. Dal. t. r., Norrl. Gestr. spr. Hels. - Vb. r.

4. S. viscósa (L.) Pers.; blommor upprätta i allsidig vippa med motsatta, upprätta och $1-5$-blommiga grenar; rotblad lansettlika-tunglika; stjelkblad från bred bas lansettlika eller äggrunda, i kanten vaigiga. 3.

Upprätt och lika hög som föreg. art, öfverallt klibbluden, utan rotskott; blomfoder slutl. uppblåst nära midten, med korta och trubbiga tänder; kronblad hvita utan bikrona; stjelk mycket tjockare än hos föreg.; hlomskaft korta.

Hafsstränder vid Östersjön; Göt. Öl. r. Blek. Smål.spr. Ög. r., Sv. Söd. spr. Upl. r.

5. S. noctiflóra L.; blommor upprätta, ensamma eller i fåblommig och klynnedelad vippa (knippe); blad platta; rotblad omvändt äggrunda, stjelkblad aflånga-lansettlika. 3.

Upprätt och omkr. ${ }^{1 / 2}$ fot hög, klibbigt mjukluden och ljusgrön, utan rotskott; blomfoder slutl. uppblåst på midten, med långa syllika tänder; kronblad innantill ljusröda, utantill gulaktiga. Liknar Melandrium vespertinum, men har samkönade hlommor och svag enårig rot.

Ruderatväxt och ogräs i åkrar; Göt. r.: Sk. Öl. t. a. Gotl. Hall. Kalmarl. Ög. spr., Sv. r.: Söd. Upl. spr., Norrl. Gestr. Jtl.r.

b. Foder päronformigt eller klocklikt; växten ofta glatt; blommor utslagna under dagen. Kronbladens skifva djupt urnupen.

6. S. rupestris L.; foder päronformigt; blommor upprätta och n. jemnhöga i klynnedelad och rikblommig vippa. 2,3 .

Omkr. $1 / 2$ fot hög, glatt och blågrön, upprätt och vanl. från rotstocken mycket grenig och tufbildande; blommor snöhvita på långa och hårfina skaft; blad lansettlika eller äggrundt lan-
settlika. 
Gråstensberg; Göt. mångenst.: Blek. inre Smål. r. Sk. Öl. Gotl. 0, Sv. spr.: Verml. Ner. t. a. Dal. t. r., Norrl. r.: Gestr. Jtl.?, Lpl. t. r.

7. S. acáulis L.; foder klocklikt; blommor n. upprätta, ensamma på korta skaft i spetsen af grenarne. 2, 3.

Bildar stora och låga, ljusgröna tufvor med talrika rosenröda hlommor; blad små hårbräddade och knappt liniebreda, de flesta tätt hopgyttrade; stjelk föga utvecklad. Är vanl. tvåbyggare.

Fuktiga ställen i fjellen, helst i fjellregionen eller vid vägkanter och på klippor i björkregionen, sällan lägre ned; Lpl.a., Norrl. Jtl. Herj. a. uppe i högfjellen.

\section{Stellária. Stjernblomma.}

A. Kronblad klufna (till midten). Blad smala oskaftade.

1. S. holóstea L.; blad lansettlikt jemnbreda eller mot spetsen afsmalnande, stundom aflånga; blomknippe i stjelkens spets; kronblad längre än fodret; skärmblad bladartade; fröhus klotrundt af fodrets längd. 2, 3. Fotshög, n. glatt och rent grön med uppstigande, styf, bräcklig och"sträfkantig stjelk öch stora blommor; blad i kanten strüfva; ståndare fästade n. under fruktämnet (liksom hos de båda följ. arterna). Liknar något Cerastium arvense.

Lundar och ängar, helst i skärgården; Göt. Boh. t. r. Sk. t. a. Hall. Blek. Kalmarl. Öl. spr. inre Smål. Ög. r.. Sv. Söd. vid Mariefred.

B. Kronblad delade (till eller nära basen). Blad breda, de nedre skaftade. - Blomknippe i stjelkens topp. Frön knöliga.

2. S. némorum L., Lundstjerna; de nedre bladen hjertlika, de öfre äggrunda; blomskaft flera ginger längre än fodret; fröhus jemntjockt och utdraget, dubbelt så långt som fodret; kronblad längre än fodret. 2, 3.

Fotshög och deröfver, ljusgrön och småluden med rotstock, uppstigande, vek och trind stjelk samt stora blommor; blad stora. Liknar Malachium.

Bäckdalar och lundar, helst i skogsbygder och i fjellen; Lpl. t. a., Norrl. spr.: Vh. t. a. Hels. Gestr. r., Sv. spr.: Vestm. 1. Ner. t. r. Upl. 0, Göt. spr.: Sk. a. Ög. Boh. t. r. Kalmarl.? öl. Gotl. 0.

3. S. média (L.) Vill., Narf, Vätnarf; blad äggrundaovala; blomskaft vanl. föga lüngre än fodret; fröhus äggformigt och något längre än fodret; kronblad ej öfverskjutande fodret, vanl. kortare. 1-4.

Mycket grenig, saftfull och ljusgrön med vanl. utbredda och nedliggande grenar; stjelk trind med en hărig rand; blad och blommor smärre än hos föreg. art; ståndare ofta $3-5$; rot enårig.

Ogräs och ruderatväxt, allmän. 
C. Kronblad delade (till basen). Blad smala oskaftade. Blomskärmar hinnaktiga. Stjelk kantig.

a. Blomknippe $i$ stjelkens topp; foderblad tydligt 3 . nerviga; kronblad längre än fodret; frön knöliga. Blad ej sträfva i kanten.

4. S. palustris Retz.; kronblad vanligen dubbelt så långa som fodret; fröhus knappt utskjutande ur fodret. 2, 3 .

Vanl. blågrön, mindre ofta rent grön, och alldeles glatt med upprätt stjelk och upprätta blomskaft; blad n. jemnbreda. På torrare ställen och under torra somrar blifva kronbladen stundom förkrympta och ej utskjutande ur fodret.

Fuktiga ängar och stränder; Göt. t. a.: Boh. r. Gotl. 0, $S v$. t. a., Norrl. Gestr. spr. Hels. -Ang. r.

5. S. graminea L.; kronblad föga längre än fodret; fröhus $1 / 3$ längre än fodret. 2,3 .

Något mörkgrön och glatt med utbredd och slak stjelk och slutl. nedböjda blomskaft; blomskärmar hårbräddade; blad jemnbreda eller stundom aflångt lansettlika.

Ängar, allmän.

b. Blomknippen frain bladvecken; foderblad otydligt nerviga; kronblad af fodrets längd; frön släta. Blad lansettlikt jemnbreda, i kanten finsågade och sträfva.

6. S. Friesiána Ser.; fröhus $1 / 3$ längre än fodret. 2, 3. Ljusgrön med sträfva, utbredda och slaka stjelkar, stundom tufvad; blomskaft slutl. nedböjda. Liknar de båda föreg. arterna.

Fuktiga ställen i skogar och på svedjeland; $L p l$. spr., Norrl. spr.: Gestr. t. r., Sv. spr.: Verml. t. a., Göt. t. r.: Dalsl. inre Smål. Ög. (i skogsbygderna) spr. Boh.? Öl. Gotl. 0.

* S. alpestris Fr.; stjelk glatt; blad lansettlika, n. glatta; kronblad kortare än fodret; blomskaft utstånde.

I fjellen t. r.; Lpl., Norrl. Med. Herj., Sv. Dal.

c. Blommor ensamma i bladvecken och stödda af blad eller af gröna blomskärmar.

7. S. boreális Big.; blad aflånga eller aflångt lansettlika och nedtill hårbräddade; kronblad hälften kortare än fodret, hvarur fröhuset långt utskjuter. 3 .

Ljusgrön och 1-2 fot lång med glatta och uppstigande (stundom n. upprätta) stjelkar; blad n. glatta, tunna och ofta spetsade; blomskaft teml. korta och slutl. upprätta; foderblad otydligt nerviga; frön släta; pistiller vanl. 5 ; kronblad ofta felslå̉ende.

Våta ställen i fjellen, sällan i lägre fjelltrakter; Lpl. a., Norrl. Jtl. Herj. spi. Ång. r., Sv. Dal. r.

8. S. crassifólia Ehrh.; blad aflånga-lansettlika glatta; kronblad längre än fodret; fröhus betydligt kortare än fodret. 3 . 
Blågrön med något spröda och uppstigande, vanl. 1/2 fot långa och glatta stjelkar; blad något tjocka och köttiga, trubbade eller mycket kort spetsade; blomskaft teml. korta, slutl. nedböjda; foderblad otydligt nerviga; frön knöliga.

Hafsstränder; Göt. Boh. r. Hall. t. r. Sk. spr. Öl. Gotl. r., Norrl. Vb. r.

- paludósa; ljusgrön och nästan upprätt.

Kärr och källdrag, helst i fjellens björkregion, sällan utom fjellen; Lpl. t. r., Norrl. Jtl. Vb. Ång. r., Göt. Vg. r.

d. Blomknippen biade $i$ bladvecken och $i$ stjelkens topp, eller stundom enstaka blommor; kronblad liortare än fodret; frön knöliga. Blad lansettlikaaflånga och glatta.

9. S. uliginósa Murr.; fröhus af fodrets längd; foderblad 3-nerviga. 2, 3.

Blågrơn och glatt med utbredda och slaka stjelkar; blomskaft utstående, omkr. dubhelt så långa som fodret.

Källdrag och bäckar; Göt. mångenst.: Gøtı. 0, Sv. spr.: Ner. t. a., Norrl. Gestr. -Med. Herj. spr.

\section{Arenária.}

1. A. trinérvia L., Skogsnarf; blad äggrunda, de nedre skaftade; foderblad lansettlika och spetsade, mycket längre än kronan; blomskaft slutl. nedböjda. 2, 3.

$1 / 2$ fot hög och ljusgrön med utbredda och upptill klynnedelade stjelkar; blad 3-5-nerviga och $i$ kanten hariga; blomfoder vanl. n. glatt; fröhus kortare än fodret; frön släta.

Skogar och lundar; Göt. Sv. t. a., Norrl. spr.: Jtl. Ång. Vb. r.

2. A. serpyllifólia L., Sandnarf; blad äggrunda oskaftade; foderblad äggrundt lansettlika och spetsade, med $1 / 3$ längre än kronan; blomskaft slutl. upprätta. 2, 3.

Omkr. 1/2 fot hög, mörkgrön och finluden med utbredda och upptill klynnedelade stjelkar; blad mycket små; blomfoder finhărigt; fröhus något längre än fodret; frön knöliga.

Torra grusiga ställen; Göt. Sv. a., Norrl. spr.: Vb.?, Lpl.r. 3. A. ciliáta L., var. humifúsa (Wahlenb.); blad äggrunda-aflånga kortskaftade; foderblad aflånga-trubbiga; blomkrona med $1 / 3$ längre än det otydligt nerviga fodret; blomskaft slutl. upprätta. 2,3 .

$2-4$ tum lång och glatt med nedliggande grenar; blad mycket små; fröhus betydligt längre än fodret. Liknar föreg. art. Torra klippbranter i fjellregionen, mycket r.; $L p l$. Unna Toki vid Virihaure.

* A. góthica Fr.; vanl. upprätt; blad hårbräddade; stjelk utan grenskott; rot svag och enårig.

Torra kalkberg, mycket r.; Göt. Gotl., Vg. på Kinnekulle (ymnigt). 


\section{Ammadénia. Saltnarf.}

1. A. peplóides (L.) Gmel.; blad oskaftade, äggrundaaflånga och spetsiga; blommor skaftade, ensamma i bladvecken. 3 .

Nedliggande (eller i början upprätt), myeket saftfull och ofta fyrkantig af de tätt sittande, mycket tjocka bladen; blomskaft 11. af fodrets längd; fröhus stort, $1 / 3$ längre än fodret; kronblad kortare än fodret (hos honblommorna). r.: Med??

Hafsstränder; Göt. spr.: Sk. a. Blek. Ög. r., Sv. Söd. r., Norrl.

\section{Alsíne.}

A. Stjelk klynnedelad med blommor i vippa och nedtill bar med enårig rot.

1. A. tenuifólia (L.) Crantz, var. viscósa; blad plattade, vid basen 5-nerviga; foderblad syllika, kortare än fröhuset och betydligt längre än kronbladen. 3 .

Upprätt, fingerhög och klibbhårig med hvita blommor.

Sandfält; Gö̀t. Skåne spr. i ö. delen.

B. Stjelkar mycket korta och tufvade med långa och 1-3-blommiga grenar.

2. A. stricta (Sw.) Wahlenb.; blad u. nervlösa och otydligt trekantiga; foderblad spetsiga, lika långa med fröhuset och kronbladen. $2,3$.

Glatt med ofta mer än en tum långa blomskaft och 2-5 tum höga, trådlika grenar. Herj.

Torrare ställen i fjellen, helst i fjellreg., r.; Lpl., Norrl. Jtl.

3. A. biflóra (L.) Wahlenb.; blad n. nervlösa, ofårade och plattade; foderblad trubbiga, kortare än fröhuset och kronbladen; blomskaft finludna. $2,3$.

Lika hög som föreg. art med något tjockare grenar än hos de öfriga arterna; kronblad stundom urnupna.

Något fuktiga ställen i fjellen, helst i fjellregionen, stundom i björkreg.; Lpl. Norrl. Jtl. Herj., a. i högfjellen.

4. A. rubella Wahlenb.; blad trenerviga, färade och plattade; foderblad spetsiga, längre än kronbladen, men kortare än fröhuset; blomskaft vanl. finludna. 2, 3.

Vanligen lägre än de båda föreg.; grenar styfva, 1-3 tum långa; kronblad stundom blekröda.

Nâgot fuktiga, grusiga ställen i fjellen, helst i fjellreg.; $L p l$.r.

$$
\text { 233. Lepígonum. Fjällnarf. }
$$

A. Alla frön likformiga.

1. L. rubrum (L.) Fr.; frön knöliga och aldrig vingkantade, tresidiga och omvändt äggrunda; fröhus knappt utskjutande ur fodret; stipler äggrundt lansettlika, $\mathrm{n}$. åtskilda med otydlig slida. 3. 
I början ofta upprätt, slutl. utbredd och nedliggande. Blågrön och småluden med svag rot, stundom öfvervintrande; hlomknippe vipplikt med talrika blomstödjeblad; stjelk trind; blomskaft 2-3 gånger längre än fröhuset; foderblad utan svart fläck nedtill; kronblad rödvioletta ; rot enårig.

Ruderatväxt, helst på torra sandiga ställen, sällan vid hafvet; Göt. a., $S v$. t. a., Norrl. Gestr.--Med. spr. Ảng. Vb. r.

- perennans; öfvervintrande och omkr. en fot lång med utbredda grenar; stipler n. hela, föga glänsande och aflångt lansettlika.

Fuktigà och leriga ställen t. r.; Göt. Boh. Smål. Blek., Sv. Verml., Norrl. Gestr.

- radicans (Presl.); öfvervintrande med något tjock rot; stjelk 1-3 tum lång, täckt af de närsittande bladen; stipler hela, bredt äggrundt lansettlika och glänsande; vippa n. bladlös.

Sandiga och gräsbevuxna ställen, helst vid hafvet, r.; Göt. Gotl. Smål. Hall. Boh.

B. Frön af 2 slag*): somliga plattade, rundade och vanl. vingkantade, de öfriga något kantiga och bredt omvändt äggrunda; stipler nedtill hopväxta till en kort slida.

2. L. salínum (Presl.) Fr.; fröhus utskjutande ur fodret; stiplernas fria del kort och äggrund. 3.

Är liksom föreg. art i början mera upprätt och blir slutl. ofta utbredd och nedliggande. Rent grön och vanl. glatt med svag enårig rot; blomknippen ofta klaselikt utdragna och upptill med vanl. felslående blomstödjeblad; stjelk något hoptryckt: blomskaft af fröhusets längd eller dubbelt längre; foderblad vanligen med svart fläck nedtill; kronblad vanl. hvita, i spetsen violetta.

Denna art förekommer under följ. former, mellan hvilka sannolikt ínligt J. A. Lefflers observationer) ingen gräns kan bestämmas. **)

a. úrbicum Leffl; fröhus föga utskjutande ur fodret; blomskaft vanl. af fröhusets längd; de flesta fröen kantiga och icke knöliga; rot något tjock, stundom tvåårig.

Ruderatväxt på fuktiga ställen, helst inuti landet nära större sjöar, t. ex. Venern, Mälaren och Roxen, mindre ofta vid hafvet; Göt. r.: Boh. spr. Hall. Vg.?, Sv. r.: Upl. spr. Ner. Söd. 0.

b. Ieiospermum Kindb.; fröhus omkr. $1^{1 / 2}$ gång så långt som fodret; blomskaft vanl. dubbelt längre än fröhuset, stundonı

*) På somliga exemplar äro fröen lika till formen.

**) I afseende på dessa formers utbredning i Sverige må anmärkas, att leiospermum, sperguloides och neglectum aldrig förekomma utom hafsstränderna; deremot finnes urbicum sällan vid hafvet; leiospermum är här allmännast, ehuru temligen sällsynt i andra länder, der neglectum åter är mycket allmän. 
lika långa dermed; de flesta fröen plattade och otydligt eller icke knöliga; rot svag och enårig.

Hafsstränder; Göt. a., Sv. spr., Norrl. spr.: Ång. r.

c. neglectum Kindb.; frön tydligt knöliga, eljest som nyss beskrifna form: dock äro blomskaften vanl. korta och fröhuset långt utskjutande.

Hafsstränder: Göt. Boh. Hall. Blek. spr. Ög. r., Sv. Upl. r., Norrl. Gestr. r. - Skall äfven vara funnen inuti landet på ett ställe i Dalarne.

d. spergulóides (Lehm.) Fisch. o. Mey.; fröhus föga utskjutande, rundadt och trubbigt; frön ovingade och knöliga, de flesta plattade; blomskaft vanl. utdragna, de flesta bladlösa; blomknippen långa och klaselika; kronblad röda eller violetta; foderblad bredt hinnkartade.

Leriga hafsstränder r.; Göt. Boh.

3. L. marínum Wahlb.; fröhus ungefär dubbelt så långt som fodret; stiplernas fria del kort och äggrund. 3, 4 .

Liknar något föreg. art, men hàr tjock mångărig rot, mycket större fröhus (ungefär så stora som ärter) samt $\mathrm{n}$. bladlöst, ofta klaselikt, men teml. kort (vanl. omkr. tumslångt) blomknippe; stjelk något hoptryckt eller kantig; blomskaft vanl. dnbbelt så långa som fröhuset; foderblad sällan med svart fläck nedtill; kronblad vanl. rent hvita eller i spetsen svagt violetta; alla frön släta, plattade och rundade samt vanligen alla vingade och bruna. Hafsstränder; Göt. Boh. t. a. Hall. spr. Sk. a.

- fasciculáre (Lönnr.); alla frön ovingade och svarta. Helst vid Östersjön; Göt. Sk. Smål. Öl. Gotl. r.

\section{Ordn. PENTAGYNIA.}

\section{Agrostemma. Rödklätt, Kornnejlika.}

1. A. Githágo L.; blad jemnbreda; blomskaft enblommiga. 3.

Umkr. 2 fot hög och sträfluden; foderflikar längre än kronan; rot svag och enårig.

Ogräs i råg- eller kornåkrar, teml. allmän: Lpl. r.

\section{Viscária.}

1. V. purpúrea Wimm., Tjärblomma; kronblad naggade eller urnupna; foder långt och klubblikt med spetsiga tänder; fröhus aflångt. $2,3$.

Stjelk fotshög, nedom de öfre lederna klibžig liksom af tjära; blad smala jemnbreda, de öfre håriga; blommor purpurröda (sällan hvita), kortskaftade i åtskilda knippen, som bilda en aflång vippa. V. vulgaris Röhl.

Torra och solöppna ställen, t. ex. på berg och åkerrenar; Göt. a., Sv. spr.: Söd. Upl. a. Dal. t. r.?, Norrl. spr.: Gestr. Hels. t. a. Vb. 0 .

2. V. alpína (L.) Fr.; kronbladens skifva tvåklufven; foder kort och $n$. klocklikt med trubbiga tänder; fröhus n. klotrundt. $2,3$. 
Vanl. ${ }^{1} / 2$ fot hög, något blågrön och upptill rodnande, glatt; stjelk icke klibbig; blad mycket smala; blommor vanl. rosenröda och närsittande i qvastlikt stälda knippen. På Öland blir ofta stjelken föga utvecklad.

Ängsbackar, helst i fjellen; Lpl. a., Norrl. Jtl. Herj. a. Vb.Hels. r., Sv. Dal. spr. Vestm. Söd. r., Göt. Öl. mångenst. Blek. Hall. Boh. r.

\section{Melándrium. Klintblära.}

1. M. diúrnum Fr.; växtens hår utan glandler; foderflikar lansettlika spetsiga; fröhusets tänder tillbakaböjda. 2,3 .

$1-1 \frac{1}{2}$ fot hög, ljusgrön (eller rodnande) och mjukbårig; stjelkblad äggrundt lansettlika; hlommor vanl. purpurröda, sällan blekröda eller hvitaktiga, öppna om dagen och luktlösa.

Myllrika lundar, helst i fjellen; Lpl. a., Norrl. spr.: Jtl. a., Sv. spr.: Ner. t. a., Göt. spr.: Sk. a. inre Smål. t. r. Gotl. 0.

2. M. vespertínum (Sibth.) Fr.; upptill glandelhårig; foderflikar korta och trubbiga; fröhusets tänder raka. $2,3$. $2-3$ foi hög och gråluden med klibbhåriga (glandelhåriga) blomskaft och foder; stjelkblad lansettlika; blommor vanligen hvita (sällan ljusröda), välluktande och öppna mot aftonen. Liknar Silene noctiflora, men har rotstock liksom föreg. art.

Ruderatväxt, äfven på stränder, och ogräs i åkrar, helst i slättbygder; Göt. t. a.: Smål. Boh. spr. Dalsl. r., Sv.t. a.: Vestm. Dal. spr. Verml. t. r., Norrl. spr.: Jtl. r. Herj.? Vb. 0.

\section{Vahlbergella.}

1. V. apétala (L.) Fr.; blommor ensamma, i början lutande; foder äggformigt uppblåst, vanligen inneslutande blomkronan. 2, 3 .

Grön eller rodnande, 2-8 tum hög, stundom med flera n. bara stjelkar från rotstocken; kronblad ljusröda.

Ängshackar högt uppe i högfjellen; Lpl. r.

2. V. affínis (Vahl) Fr.; blommor 1-3, upprätta; foder aflångt, kortare än kronan. 2, 3.

Spensligare än föreg. med smalare blad och hvita eller rödletta kronblad.

Ängsbackar högt upp i fjellen, mycket r.; Lpl. Torn. Lpn . på Nuljalaki.

\section{Lychnis. Gökblomma.}

1. L. flos cucúli L.; blomfoder n. klocklikt och 10-nervigt. 3 .

Omkr. fotshög eller deröfver med rotstock och smalt lansettlika, ..oskaftade stjelkblad; kronbladens flikar jemnbreda.

Ängar; Göt. Sv. a., Norrl. spr.: Gestr. Hels. a. Ång. r. Vb. 0. 239. Cerástium. Hönsnarf.

A. Rot mångårig med talrika tufbildande rotskott; stjelkar uppstigande eller (hos $C$. alpinum) äpprätta. 
1. C. vulgátum L.; kronblad af fodrets längd eller föga längre; blomskärmar teml. smalt hinnkantade; fröhus krökt och något längre än fodret; fruktskaft utstående och bågböjda. 2, 3.

Omkr. 1/2 fot hög eller deröfver, vanl. sträfluden och med utbredda stjelkar; talrika hlommor i vipplikt knippe; blad vanl. aflånga. I fjellen äro kronbladen stundom mer än vanligt utskjutande.

Ängar och backar, allmän.

2. C. arvense L.; kronblad 2-3 ginger längre än fodret; blomskärmar bredt hinnkantade; fröhus nästan rakt och knappt utskjutande ur fodret; fruktskaft upprätta. $2,3$.

Ända till fotshög och vanl. luden med glandelhåriga blomskaft och teml. talrika blommor i knippe, större än hos föreg. art; blad lansettlika-jemnbreda; fröhus smalt och omkr. 3 linier långt.

Ruderatväxt och ogräs i torra, helst sandiga åkrar, troligen införd med säd eller gräsfrö; Göt. r.: Gotl. a. Skk. spr. Hall. Boh. 0, Sv. Söd. Upl. Verml. r., Norrl. Gestr.?

3. C. alpínum L.; kronblad omkr. dubbelt längre än fodret; de öfre blomskärmarne smalt eller otydligt, de nedre icke hinnkantade; fröhus föga krökt och dubbelt längre än fodret; fruktskaft raka och vanl. upprätta, sällan nedböjda. 2,3 .

Stjelkar omkr. ${ }^{1 / 2}$ fot höga och upprätta med ensamma eller 2-3 stora blommor (sällan flera i vippa), hvars kronblad äro omkr. $1 / 2$ tum långa; fröhus teml. tjockt och omkr. $1 / 2$ tum långt. Bladformen och växtens beklädnad äro mycket föränderliga; ju bredare bladen äro, desto mer håriga blifva de: stundom är växten n. alldeles glatt med smala blad.

Teml. torra, stundom något fuktiga ställen i fjellen, sällan (i Vg.) utom fjellen; Lpl. a., Norrl. Jtl. Herj. a. Med. r., St. Dal. r., Göt. Vg. på Halleberg.

* C. latifólium L.; glandelhårig; blomskärmar utan hinnkant; fruktskaft vanl. nedböjda; blad breda rundadeovala och gröna; fröskal (enl. Grenier) uppblåst och föga sammanhängande med växtämnet (frökärnan).

Högt upp i fjellregionen vid snöbäckar; $L p l$. $r$.

4. C. trígynum Vill.; pistiller vanl. 3, sällan 4; kronblad dubbelt längre än fodret; blomskärmar utan hinnkant; fröhus rakt och något längre än fodret; fruktskaft snart nedböjda. 2,3 .

Löst tufvad, glänsande mörkgrön, nästan glatt och fåblommig; blad smala, ofta ensidiga och trubbiga, med vanl. otydlig medelnerv; stjelk mycket grenig, omkr. ${ }^{1 / 2}$ fot lång och vanl. nedliggande; fröhus kort och tjockt. 
Våta ställen, helst vid bäckar, högt upp i fjellen; Lpl. och Norrl. Jtl. Herj. t. a. (åtm. i fjellregionen), Sv. Dal. r.

B. Rot enårig utan rotskott; stjelkar nästan upprätta. Ståndare ofta 5; blommor små.

a. Blomskärmar och foderblad med bred hinnkant; ståndare och kronblad glatta. Blomknippe ofta flocklikt.

5. C. semidecandrum L.; blomskaft straxt efter blomningen nedböjda, 2-4 gånger längre än fodret. 1, 2. Fingerhög eller deröfver, blekgrön och vanligen med kort klibbigt ludd; blad ovala-aflånga.

Ängar och backar; Göt. t. a., Sv. t. a.: Verml. t. r. Dal. r., Norrl. Gestr. t. r.

b. Blomskärmar och foderblad med smal eller otydlig hinnkant; ståndare och kronblad glatta; foderblad upptill glatta.

6. C. glutinósum Fr.; skärmblad och foderblad smalt hinnkantade; blomskaft straxt efter blomningen utstäende, af fodrets längd eller dubbelt längre. 1, 2.

Liknar föreg. art, men är mera klibbig.

Ängsibackar,.. helst nära hafvet och stồrre sjöar; Göt. Hall. Sk. Blek. spr. Öl. a. Gotl. Ög. t. r. Vg. r.

* C. púmilum Curt.; blomskärmar och foderblad utan hinnkant; blomdelar stundom fyrtaliga; fruktskaft stundom mera utdragna; blomskärmar ofta breda.

Hafsstränder, mycket r.; Göt. Boh. flerstädes.

c. Blomskärmar utan hinnkant; ståndare eller kronblad håriga; foderblad upptill håriga.

7. C. viscósum L.; kronblad nedtill håriga; ståndare glatta; blomskaft utstående och kortare än fodret eller lika långa dermed. $2,3$.

Fingerhög eller deröfver, ljusgrön och klibbhårig med korta hår; blommor gyttrade $i$ spetsen af grenarne; blad rundadeovala; fröhus krökt och n. dubbelt längre än fodret. Blommar något sent.

Ruderatväxt på fuktiga ställen, stundom äfven i skogar; Göt. spr.: Blek. Boh. Dalsl. r. Gotl. 0, Sv. t. r., Norrl. Gestr. Ång. Jtl. r., Lpl, r.

8. C. strigósum Fr.; kronblad glatta; ståndare långhåriga; blomskaft utstående, de flesta $2-3$ gånger så långa som fodret. 2,3 .

Liknar något $C$. vulgatum och är stundom $1 / 2$ fot hög, sträfhărig med aflångt äggrunda blad och rakt fröhus, som föga utskjuter ur fodret.

Torra ängsbackar, helst nära hafvet samt vid Vettern; Göt. Hall. Sk. t. r. Blek.-Ög. Öl. Gotl. r., Sv. Söd. r. 


\section{Maláchium. Vattennarf.}

1. M. aquáticum (L.) Fr.; de nedre bladen skaftade, de öfre stjelkomfattande; kronblad längre än fodret. 3.

Ljusgrön med nedliggande eller uppstigande, 1-2 fot lång och nedtill fyrkantig (upptill trind) stjelk, grofådriga, vågbräddade och hjertlika blad, klibbludna blomskaft och foder; fröhus föga längre än fodret; blomskaft slutl. utstående. Liknar Stellaria nemorum. Varierar på torrare ställen med nästan hela stjelken fyrkantig samt de flesta bladen skaftade.

Stränder och andra vấta ställen; Göt. spr.: Hall. Blek. r. Smål. t. r. Dalsl. r. Gotl. Öl. 0, -Sv spr.: Dal. r. Verml. 0, Norrl. Gestr. r.

\section{Sagina.}

A. Stjelkar utgående från rotstocken och ej tufvade. Blomkrona omkr. 3 gånger så lång som fodret. Blommans delar femtaliga (anordnade efter femtalet).

1. S. nodósa (L.) Fenzl; blomskaft och fröhus alltid upprätta. 3.

Vanl. fingerhög och upprätt, knutig af små bladknippen i de öfre bladvecken; stjelkar enkla eller klynnedelade.

Stränder och andra våta ställen; Göt. t. a.: inre Smål. t. r., Sv. t. a., Norrl. t. r.: Gestr. Jtl. spr. Herj.?, Lpl. r.

B. Stjelkar tufvade, utgående från sidorna af en tät bladrosett. Blommans delar stundom fyrtaliga: foderblad trubbiga, kronblad kortare eller föga längre än fodret, stundom felslående. Rot flerårig. Låga växter med små blommor.

2. S. procumbens L.; kronblad vanl. felslående; blomdelar vanl. 4-taliga; blomskaft snart bågböjda; fröhus lutande; foderblad slutl. utspärrade; fröhusets skal breda och ovala och något längre än fodret. 2-4.

1-6 tum lång, vanl. nedliggande; fröhus $\mathrm{n}$. klotrundt osh trubbigt; blad vanl. uddspetsiga.

Năgot fuktiga ställen, helst såsom ruderat- och hafsstrandväxt, a. till fjellens björkregion.

3. S. saxátilis Wimm.; kronblad föga kortare än fodret, sällan felslående; blomdelar vanl. 5-taliga; blomskaft snart bågböjda; fröhus lutande; foderblad tilltryckta intill fröhuset, hvars skal äro smala lansettlika, dubbelt längre än fodret. 2, 3 .

Lik föreg. art, men vanl. mindre och mycket ljust grön; fröhus aflångt och något spetsigt; blad n. utan udd.

Fuktiga ställen i fjellen, helst i barrskogsregionen; Lpl. a., Norrl. Jtl. a. Herj. spr. Ang. Med. r., Sv. Dal. r.

4. S. nivális Fr.; kronblad nảgot längre än fodret; blomdelar vanl. 5-taliga; blomskaft nästan raka; fröhus 
upprätt; foderblad tilltryckta; fröhusets skal breda ovala och föga längre än fodret. 2,3 .

Vanl. ännu mindre än de båda föreg. och tätt tufvad, sällan med utdragna och nedliggande grenar, samt af mörkare färg, n. brungrŏn eller rodnande; fröhus klotrundt och trubbigt; blad med kort udd.

Grusiga och något fuktiga ställen högt upp i fjellregionen r.; Lpl., Norrl. Jtl. Herj.

5. S. subuláta (Sw.) Wimm.; krona af fodrets längd; blomdelar 5-taliga; blomskaft ofta bågböjda; fröhus slutl. något lutande eller nästan upprätt; foderblad tilltryckta; fröhusets skal äggrunda och något längre än fodret. 3 .

Olik de tre föreg. arterna genom de styfva, med lång borstlik udd försedda bladen, som i likhet med stjelkens öfre del stundom äro glandelhåriga; fröhus $\mathrm{n}$. klotrundt och trubbigt.

Fuktiga klippor nära hafvet, sällan (i Smål. och Vg.) inuti landet; Göt. Boh. a. Hall. spr. Sk. (i n. v. delen) spr. Smål. (i v. delen) t. r. Öl. r. Vg. vid Alingsås.

C. Stjelkar vanl. utan bladrosetter, sällan tufvade. Blorndelar vanI. 4-taliga. Foderblad stundom spetsiga. Kronblad ej längre än fodret, vanl. felslående. Rot enårig.

6. S. stricta Fr.; kronblad vanl. felslående; blomskaft n. raka; fröhus slutl. upprätt; foderblad äggrunda-ovala, något trubbiga och slutl. utspärrade; fröhusets skal äggrunda-ovala, föga längre än fodret. $2,3$. Liknar S'. procumbens, men är vanl. upprätt; fröhus äggformigt och trubbigt; blad glatta borstlösa; bladrosetter sällan förekommande; foderblad stundom något spetsiga.

Hafsstränder; Göt. spr.: Boh.-Sk. t. a. Gotl. t. r. Ög. 0.

- marítima (Don); stjelkar utbredda eller nedliggande, stundom utgående från en bladrosett; kronblad stundom utbildade, föga kortare än fodret.

Hafsstränder, r.; Göt. Boh. vid Kyrkesund (förf.). Troligen äfven annorstädes.

7. S. ciliáta Fr.; kronblad n. felslående; blomskaft ofta bågböjda; fröhus vanligen n. upprätt; foderblad äggrunda spetsiga och tilltryckta, de yttre med borstlik udd; fröhusets skal lansettlika, längre än fodret. 3.

Liknar S. saxatilis, men har hårfina blomskaft och saknar bladrosetter; stjelkar ofta mycket greniga och utbredda eller n. upprätta, ända till $1 / 2$ fot höga; frôhus äggformigt och spetsigt; blad med borstlik udd, stundom glandelhåriga.

Torra betesmarker och trädesåkrar; Göt. Boh. r. Sk. flerst. i s. delen. 
8. S. apétala L., var. cæspitosa (F. Aresch.); kronblad n. felslående; blomskaft vanl. upprätta; foderblad äggrunda-aflånga spetsiga och slutl. utspärrade; fröhusets skal aflånga, längre än fodret. 3 .

Liknar föreg. art, men är lägre och alldeles upprätt samt vanl. tufvad, dock utan några nedtryckta bladrosetter; fröhus bredt äggformigt och $\mathrm{n}$. trubbigt; blad med borstlik udd.

Sandiga trädesåkrar, mycket r.: Göt. Skåne mellan Stens Hufvud och Rörum.

\section{Spérgula. Spergel.}

1. S. arvensis L.; frön n. klotformiga och knöliga med slät och vanl. smal hinnkant. 3 .

1/2 -1 fot hög och vanl. klihbhårig med undertill fårade blad; kronblad trubbiga (liksom hos följ. art); stipler teml. stora.

Ogräs i åkrar, teml. allmänt: Lpl. spr.

2. S. vernális Willd. (enl. Anders.); frön platta och släta med stråligt strimmig och bred hinnkant. 2, 3. Omkr. $1 / 2$ fot hög med styfvare och glatt stjelk samt ej fårade blad; stipler mycket små; ståndare ofta 5 .

Berg; Göt. spr.: Boh. Sk. r. inre Smål. Gotl. t. r., Sv. spr.: Ner. t. r. Dal. 0, Norrl. Hels. Ång. Jtl. t. r.

\section{Sedum. Fetknopp, Taklök.}

A. Blad platta, stora och breda, tandade.

1. S. Teléphium L.; kronblad lansettlika blekgröna. 3, 4 .

$1 / 2-1$ fot hög med styfva, ofta rödaktiga och vanl. enkla stjelkar; blad omkr. tumslånga, motsatta eller strödda, vanl. aflånga, de öfre ofta omfattande; blommor små och tätt sittande i tregrenigt knippe.

Berg, murar och stenbundna ställen; Göt. Sv. t. a.: Dal.?, Norrl. Gestr.-Med. spr. Ång. t. r. Vb. r.

- angustifólium; blad lansettlika, nedåt afsmalnande. Göt. Skåne r., Sv. Söd. r.

* S. purpurascens Koch; kronblad röda;-blad vanl. omvändt äggrunda.

Ruderatväxt på stenb. ställen; Göt. Boh. Sk. Gotl. r.

B. Blad n. trinda eller äggformiga, små och helbräddade, spiralstälda ( $p \AA$ gr grenskotten tätt tegellagda). a. Utan grenskott.

2. S. ánnuum L.; kronblad gröngula, nästan lika långa med fodret och lansettlika; blad jemntjocka trubbiga. 3 . Glatt, vanl. upprätt och 2-3 tum hög, mörkgrön och brunfläckig; foderflikar trubbiga; blomknippets grenar axlika.

Berg; Göt. spr.: Dalsl. Boh. a. Smål. t. r. Sk. r. Öl. Gotl. 0, Sv. t. a.: Dal. r., Norrl. r., Lpl. r.

3. S. villósum L.; kronblad rödvioletta, längre än fodret, ovala-äggrunda; blad aflångt trinda. 2, 3. 
Glandelhårig, upprätt och 2-4 tum hög samt rodnande; foderflikar trubbiga; blommor teml. stora i qvastlikt knippe, de flesta utdraget skaftade; ståndareknappar mörkvioletta; karpeller upprätta.

Fuktiga klippor i fjellen, mycket r.; Lpl.

b. Med tätbladiga och fortvarande grenskott. Kronblad längre än fodret och lansettlika (hos S. anglicum och $S$. album n. aflånga).

4. S. album Li.; kronblad hvita eller rödletta och trubbiga; blad jemntjocka trubbiga. 3.

Omkr. ${ }^{1 / 2}$ fot hög eller lägre, vanl. rödaktig med utböjda blad och n. upprätta stjelkar: blommor teml. små och skaftade i qvastlikt knippe med klynnedelade grenar; ståndareknappar mörkvioletta.

Berg, helst på stränder; Göt. Gotl. Öl. a. Ög. (i ö. delen) a. Kalmarl. (i n. delen) spr. Blek. t. r. Hall. r. Vg. Boh. Dalsl. spr., Sv. Söd. a. Ner. Upl. spr. Vestm. r., Norrl. Hels. r.

S. bálticum C. Hartm.; blommor hälften mindre; ståndareknappar gula; blad ljusgröna.

Vid Östersjön; Sv. Söd. r., Göt. Gotl. t. r.

5. S. ánglicum Huds.; kronblad rödletta och n. aflånga; blad bredt äggformiga. 3 .

Blågrön eller rodnande med teml. slaka stjelkar och grenskott; blommor större än hos föreg. art, sittande i knippe med axlika grenar; foderflikar äggrunda trubbiga; karpeller utstående; ståndareknappar mörkvio!etta. Liknar mycket följ. art.

Hafsklippor: Göt. Boh. t. r.

6. S. acre L.; kronblad guldgula; blad äggformiga; foderflikar äggrunda trubbiga; karpeller utstående. 3 .

Några tum hög och ljusgrön med uppstigande grenar; ståndareknappar gula; blommor i knippe med axlika grenar.

Ruderatväxt på murar, tak m. fl. andra torra ställen, äfven på berg utom fjellen; Göt. Sv. a., Norrl. spr.: Gestr. a. Ång. Vb. t. r.

7. S. sexanguláre L.; kronblad guldgula; blad n. jemntjocka, trubbiga, ofta tätt tegellagda äfven på de blommande stjelkarne; foderflikar n. jemntjocka och trubbiga; karpeller utstående. 3 .

Liknar föreg., men är spädare och blågrön med något mindre blommor: grenskottens blad i 6 rader.

Stenbundna och grusiga ställen, helst nära hafvet samt vid större sjöar, t. ex. Mälaren, Vettern och Glan; Göt. Gotl. spr. Ög. t. r. Kalmarl. Sk. Hall. r. Dalsl. r. vid sjön Animmen, Sv. spr.: Ner. r. Verml. Dal. 0, Norrl. Gestr. r. Jtl. vid Storsjön r. 8. S. rupestre L.; kronblad guldgula; blad syllika uddspetsiga; foderflikar lansettlika spetsiga; karpeller upprätta. 3. 
Omkr. 1/2 fot hög och blågrön eller rodnande med uppstigande grenar; blad nedtill med sporrelikt bihang (liksom hos föreg. art); llomknippets grenar axlika; blommor teml. stora; ståndareknappar gula.

Berg, helst nära hafvet och större sjöar; Göt. Gotl. Öl. spr. Ög. t. r. Smål. Sk. r. Hall. t. r. Boh. Vg. spr. Dalsl. t. r., Sv. Verml. spr. Ner. Söd. r.

\section{Klassen. DODECANDRIA.}

1 Ordn. MONOGYNIA.

\section{Lythrum. Fackelblomma.}

L. L. Salicária L.; blad lansettlika stjelkomfattande; de nedre blomkransarne åtskilda; de öfre axlikt förenade. 3 .

Omkr. 2 fot hög och upprätt med kantig stjelk. 6 ståndare äro längre än de öfriga.

Stränder; Göt. Sv. a., Norrl. r.: Gestr.-Med. spr.

\section{A'sarum. Hasselört.}

1. A. europæum L.; kalk finluden och kortskaftad. 1.

Rotstock upptill delad $\mathrm{i}$ ett par korta grenar, hvarifrån ett par mer än tumsbreda blad och blott en enda lutande blomma uppskjuta; kalk utvändigt grön, inuti mörkbrun.

Fuktiga lundar, mycket r.; Göt. Vg. (fordom äfven i Sk.), $S v$. Söd. Upl. Vestm. Verml.

\section{Ordn. DIGYNIA.}

\section{Agrimónia. Småborre.}

1. A. Eupatória L.; fruktfoder omvändt kägellikt och ända nedtill fåradt, upptill med utstående borst. 3 .

Omkr. 2 fot hög med undertill ludna och djupt sågade bladflikar; stjelkens blombärande del vanligen betydligt längre än den bladbärande. En större form, liknande följ. art, törekommer stundom i skärgården.

Ängar och backar; Göt. a.: inre Smål. Boh. Dalsl. spr., Sv. spr.: Söd. Upl. t. a. Verml. r. Dal. 0, Norrl. Gestr. spr. Hels.r. 2. A. odoráta Mill.; fruktfoder halfklotrundt-klocklikt, till midten svagt färadt, upptill med nedböjda borst. 3 .

Liknar föreg. art, men är större och omkr. dubbelt högre med kortare fruktfoder och stark lukt af de undertill glandelhåriga bladen; stjelkens blombärande del betydligt kortare än den bladbärande.

Ängar; Göt. t. r.: Ög. spr. Vg. Öl. Gotl. 0, Sv. Upl. r.

3 Ordn. TRIGYNIA.

247. Reséda.

1. R. Lutéola L., Wau; blad lansettlika-aflånga, helbräddade och oskaftade; foder 4 -flikigt. 3,4 . 
XI. DOdecandria. 248. XII. icosandria. 249, 250.

1-2 fot hög och ofta grenig med upprätta grenar; blommor blekgula.

Ruderatväxt på sandiga ställen, helst nära hafvet; Göt. r.: Sk. spr. Dalsl. Vg. Ög. 0 (Sv. Söd. Upl. tillfällig).

\section{Ordn. POLYGYNIA.}

\section{Sempervívum. Taklök.}

1. S. tectórum L.; blomhyllets blad utstående; kronblad n. jemnbreda spetsade, finludna och dubbelt längre än fodret; bikronfjäll mycket små. 3 .

Omkr. ${ }^{1 / 2}$ fot hög och upptill glandelhårig med stora n. tumsbreda, kortskaftade blommor i ensidiga klasar; stjelk med tegellagda, äggrundt lansettlika blad och nedtill utskjutande stora bladrosetter, hvars blad äro n. ovala och i kanten håriga. Dal. 0.

Ruderatväxt på torftak och murar; Göt. spr. Sv. r.: Boh.--

\section{Klassen. ICOSANDRIA.}

\section{Ordn. MONO-PENTAGYNIA.}

\section{Prunus.}

1. P. spinósa L., Slånbuske, Stärkbür; blomskaft glatta; blad äggrunda-lansettlika, sågtandade, undertill slutl. glatta; frukt upprätt. 1, 2.

Omkr. 6 fot hög med långa tornar; blommor utslagna före bladen; frukter af en ärts storlek, svarta, blådaggiga och beska, med mycket korta skaft, vanligen enstaka.

Ängar, berg och backar; Göt. a.: Dalsl. r. Vg. spr. vestra Smål. 0, Sv. Söd. Upl. a. Vestm. spr. Verml. r.

* P. frúticans Weihe; blomskaft något finhåriga; blad ovala-aflånga. 2.

Något högre än hufvudarten med större frukter och mera ludna blad, som utslå nästan samtidigt med blommorna; blomskaft längre och vanl. parvis stälda.

Göt. Ög. Gutl. r. - Trol. äfven annorstädes.

2. P. insititia L., Krikon; blomskaft finludna; blad ovala sågtandade, undertill finludna; frukt hängande. 1, 2.

Omkr. 8 fot hög med kortare, mindre hvassa tornar; blommor utslagna före bladen; frukter stora, rödaktigt svartblå med något utdragna skaft, vanl. parvis stälda; yngre qvistar finludna, liksom hos föreg. art.

På berg och vid gårdar, trol. oftast förvildad; Göt. r.: Vg. Dalsl. 0, Sv. Söd. Upl. Vestm. r., Norrl. Gestr. r.

\section{Cérasus.}

1. C. ávium (L.) D.C., Fogelbär; blommor i enkla flockar; blad tätt hopade i spetsen af grenarne och undertill finhåriga; bladskaft med 2 vårtor i spetsen. 1, 2. 
Teml. högt träd; blad omvändt åggrunda spetsade: frukter klotrunda, söta och vanl. röda.

Dal. 0.

Skogsängar; Göt. t. r.: Sk. spr. Öl. 0, $S v$. t. r.: Söd. spr.

2. C. Padus (L.) D.C., Hägg; blommor i hängande klasar; blad skiftevis stälda och glatta; bladskaft med 2 vårtor i spetsen. 2.

Mindre träd; blad omvändt äggrunda spetsade; frukter klotrunda, bittra och svarta; blommor starkt luktande i n. jemntjocka klasar.

Skogsängar; Lpl. Norrl. Sv. a., Göt. spr.: Öl. Gotl. r. Ög. Sk. Dalsl. a.

\section{Cratægus. Hagtorn.}

1. C. monógyna Jacq.; blad med aflång omkrets partandade eller djupt parklufna; foderflikar från bred bas långt utdragna och smala; stift vanl. 1; blomskaft och fruktämnen ludna; frukter tjockast ofvan midten. 2,3 .

Teml. hög buske; frukter med 1 nöt; bladens sidonerver utböjda från hufvudnerven; stipler vanligen breda.

Skogsängar; Göt. spr., Sv. t. r.: Söd. Upl. mångenst. Dal.0, Norrl. Gestr. r.

- intermédia (Kindb.); blad, foderflikar och stift lika med hufvudartens; blomskaft och fruktämnen glatta; frukter n. äggformiga, på midten tjockast. C. monogyna var. denudáta Schum.?

Troligen vanligare än hufvudarten; Göt. Sk. Smål. Ög. Dalsl., Sv. Ner. Upl.

2. C. Oxyacantha L.; blad bredt omvändt äggrunda och upptill flikiga eller inskurna (stundom pardelade); foderflikar korta och slutl. i spetsen nedböjda; stift vanligen 2; blomskaft och fruktämnen glatta; frukter äggformiga, nedtill tjockast. 2 .

Vanl. högre än föreg. och omkr. 14 dagar tidigare blommande; frukter vanl. med $2-3$ nötter; bladens nedre sidonerver vanligen inböjda mot hufvudnerven; stipler vanligen smala.

Skogsängar; Göt. a.: inre Smål. Dalsl. r. Vg. Boh. Ög. spr., Sv. Söd. Upl. a. Vestm. t. r. Ner. spr.

\section{Cotoneaster. Oxbür.}

1. C. vulgaris Lindl.; blad ovala kortskaftade och undertill gråludna; frukter nedböjda blodröda. 2 . fodret.

3-6 fot hög; bark svartbrun; kronblad föga längre än

Berg och backar; Göt. t. r.: Gotl. t. a. Öl. Ög. mångenst. Kalmarl. Blek. spr., Sv. Söd. Upl. spr. Vestm. spr. i s. delen, Norrl. Gestr. Herj. Jtl. r. Hels.? 
- nigra; frukter svarta; blomskaft mera utdragna. Göt. r.: Öl. Smål. 0, Sv. Upl. r.

- lútea; frukter gula; blad n. lansettlika.

Göt. Hall, r. vid Varberg på strandklippor.

\section{Sorbus.}

1. S. aucupária L., Rönn; blad parbladigt delade med lansettlika, sågade och slutl. glatta flikar. 2.

Med små, starkt luktande blommor och runda sura frukter. I skogar och vid gårdar, allmän.

2. S. scándica Fr., Svensk Oxel: blad ovala-aflånga, grundt parfikade och undertill gråludna med sågade flikar, de mellersta längre än de öfriga. 2.

Med större och mera snöhvita blommor samt aflånga, mjöliga och ätbara frukter; yngre grenblad djupare klufna.

Helst vid gårdar, stundom på berg; Göt. Sv. spr.: Sk.-Boh. t. r. Dal. r. Gotl. Ög. -Upl. t. a. Vestm. i Mälaretrakten t. a., Norrl. Gestr.-Med. r.

3. S. fénnica Kalm, Finsk Oxel; blad ovala, nedtill parbladigt delade och undertill grågrönt ludna med upptill sågade flikar, de nedersta vanl. längst. 2.

Med sötsura frukter af rönnbärs storlek.

Berg, helst nära hafvet; Göt. Gotl. (och omkringliggande - öar) t. r. Smål. (i Öjaby s:n) r. Boh. (n. om Marstrand) r., $S v$. Söd. Upl. t. r.

4. S. A'ria (L.) Crantz, Norsk Oxel; blad omvändt äggrunda eller n. ovala med vigglik bas (stundom aflånga), ojemnt sågade och undertill snöhvitt ludna. 2. frukter.

Teml. högt träd med ett par tum långa blad och teml. stora

Berg, helst vid hafvet r.; Göt. Gotl. (och omkringliggande öar) Sk. (vid Kullaberg) Boh. flerst. Dalsl. vid sjöarne Näsöl och Stora Le (enstaka träd), Sv. Söd. vid Landsort.

\section{Pyrus.}

1. P. Malus L., Vildapel; blommor i enkla flockar. 2.

Med kortskaftade, sågade, glatta (sällan ludna) och vanl. äggrunda blad samt grona och sura, nedtill intryckta frukter; stift vanl. hopväxta nedtill. Har vanl. tornar.

Skogsängar; Göt. t. a.: Dalsl. r., Sv. spr.: Söd. Upl. t. a. Verml. t. r. Dal. 0, Norrl. Gestr. Med. r.

2. P. commúnis L., Vildpäronträd; blommor i qvastar. 2.

Med långskaftade, fintandade, undertill på nerverna och i kanten håriga, vanl. rundade eller ovala blad samt gröna och heska, nedtill föga intryckta frukter; stift fria. Har vanl. mycket långa och hvassa tornar.

Skogsängar; Göt. r.: Sk. Öl. Gotl. spr. Vg.? Dalsl, 0, Sv. Söd. Upl. spr. Vestm. t. r. Ner. r. 


\section{Ordn. POLYGYNIA.}

\section{Spiræa.}

1. S. Ulmária L., Mörtgräs, Elggräs, Mjödört; kronblad med lång klo och kortare än ståndarne; karpeller glatta och vridna. 3.

Stjelk omkr. 2 fot hög, fårad och laingt upp bladig; bladflikar stora ovala, vanl. undertill hvitludna, stundom $\mathrm{n}$. glatta och gröna; blommor hvita; rottågor ej uppsvälda.

Fuktiga ängar och skogar, allmän.

2. S. Filipéndula L., Brudbrödsört; kronblad med kort klo och längre än ståndarne; karpeller håriga och raka. 3 .

Lägre än föreg. med blott nedtill bladig stjelk, mycket smalare och på båda sidor gröna blad med talrikare och lansettlika flikar; blommor före utslåendet rödletta, sedan hvita; rottågor med äggformiga knölar.

Ängar, helst i slättbygder; Göt. t. a.: vestra Smål. Vg. Boh. t. r. Dalsl. r., Sv. t. a.: Verml. Dal. r., Norrl. Gestr. Med. r. (Lpl. "Ume Lpm."?).

256. Rosa. Törnros, Njuponbuske.*)

A. Årsskott med tätt sittande taggar och borst. Foderflikar vanl. hela. Blad utan glandler på undra sidan.

1. R. cinnamómea L.; stam med glest sittande (vanligen raka) taggar och borst, som ofta affalla; småblad enkelt sågade, aflånga och undertill grönaktigt gråludna; njupon klotrundt och glatt, sällan päronformigt; blomskaft glatta. 2, 3.

Låg buske med kanelbrun bark; njupon af en ärts storlek, tidigt mjukt och vid mognaden upprätt; foderflikar finludra utan glandler och qvarsittande; kronblad röda; de invid blommorna sittande bladens stipler bredare än de öfriga.

Ipl. spr., Norrl. t. a., Sv. t. a.: Söd. spr., Göt. spr.: Boh. Sk. r. Smål. t. r. Öl. r. Blek. 0.

2. R. carélica Fr.; årsskott och stam med tätt sittande, borstlika, raka och qvarsittande taggar; småblad enkelt sågade, aflånga, n. glatta och undertill föga gråaktiga; njupon aflångt, snedt och upptill glandelhårigt; blomskaft glandelhåriga. 2,3 .

Liknar föreg. art; foderflikar glandelhåriga.

Mycket r.; Norrl. Vb. vid Skellefteå.

3. R. pimpinellæfólia L., Pimpinellros; årsskott och stam med tätt sittande, raka och qvarsittande borst och taggar; småblad vanl. enkelt sågade, ovala, glatta och

*) Detta slägtes arter förekomma i ängar. 
på båda sidor gröna; njupon klotformigt och glatt; blomskaft glatta. 3 .

Mycket grenig och låg med små blommor och småblad, de senare talrika, 5-9; njupon svartröda och sent mogna; de invid hlommorna sittande bladens stipler föga bredare än de öfriga.

Hafsstränder, mycket r.; Göt. Sk. Boh.

B. Arsskott med glesa taggar samt utan borst. Foderflikar vanl. parflikiga.

a. Småblad regelbundet dubbelsågade, undertill med glandler.

4. R. rubiginósa L., Lukttörne; stamtaggar starkt krökta; småblad ovala, undertill gröna och vanligen utan synbara hår; njupon rundadt-ovalt; blomskaft styft glandelhåriga. 3 .

Mycket taggig med af talrika rödaktiga glandler välluktande blad och teml. små, mörkt purpurröda blommor; njupon glandelhårigt eller glatt, läderartadt och vid mognaden upprätt; foderflikar snart affallande; en del af årsskottens taggar stundom föga kröktà. Småblad teml. små.

Göt. spr.: Gotl. Hall. a. Vg. Boh. r. Dalsl.? inre Smål. 0, $S v$. Söd. Upl. spr. Vestm. r. Ner. t. r.

* R. inodóra Fr.; alla taggar starkt krökta; blomskaft glatta; småblad större. 3.

Liknar hufvudarten, men har svagare lukt, emedan småbladen undertill hafva färre glandler; blommor vanl. hvita.

Göt. Vg. Boh. r. Hall. t. r. Gotl. r.

5. R. villósa L.; taggar vanl. raka; småblad ovala-aflånga, undertill gråludna; njupon rundadt, päronformigt eller aflångt; blomskaft glatta eller glandelhåriga. 3.

Med mindre glandulösa blad än hos föreg. art samt mjukare, ofta nedböjda njupon med| stundom qvarsittande foderfikar; kronblad röda eller hvita. Somliga taggar äro på torra exemplar stundom krökta, men sällan $i$ friskt tillstånd.

a. R. pomifera Herm.; småblad bredt aflånga, föga gråludna och oftast trubbiga; njupon styft glandelhårigt; blomskaft slutl. nedböjdt. Med stora och nycket mjuka, tidigt mognande njupon.

Helst i gamla trädgårdar; Göt. r.: Öl. 0, Sv.r.: Verml. Dal.0.

b. R. mollíssima Willd., småblad bredt ovala, undertill grågröna och oftast rundadt trubbiga; njupon glatt eller glandelhårigt; blomskaft vanligen upprätt och ofta glandelhårigt. Med smärre och mycket mjuka, tidigt mogna njupon.

Ängar; Göt. Sv. a.: Dal. 0, Norrl. Gestr. spr. Hels. Jtl. r.

c. R. tomentósa Sm.; småblad aflånga eller lansettlikt aflånga och oftast spetsiga, på båda sidor gråludna; njupon vanligen glatt; blomskaft ofta $i$ flock, vanligen upprätta och stundom glandel håriga, oftare glatta.

Liknar något $R$; canina till taggar och njupon; de förra äro oftare krökta ăn hos andra former af $R$. villosa, de senare läder- 
artade och ofta aflånga; foderflikar ofta utstående och slutligen affallande.

Helst i skärgården; Göt. Boh. spr. Hall. Sk. t. r. Blek. Smål. Öl. Gotl. spr. Ög. t. a. i skärg. (inuti landet i Atvid), Sv. Söd. Upl. spr. Vestm. Ner. t. r., Norrl. Gestr. Hels. r.

b. Småblad enkelsågade eller oregelbundet dubbelsågade, undertill utan (sällan med fina gulaktiga) glandler.

6. R. canína L.; taggar vanl. starkt krökta; småblad ovala - äggrunda, undertill glatta. eller ludna; njupon vanligen glatt och aflångt, stundom rundadt eller päronformigt; blomskaft vanligen glatt. 3 .

Med vanl. upprätta, läderartade och sent mognande njupon, ofta affallande foderflikar och röda eller hvita blommor.

a. R. canina L.; småblad glatta och släta, oftast enkelt sågade; taggar vanl. starkt krökta; foderflikar vanligen nedböjda och affallande; foder och blomskaft vanl. utan glandler. $\mathrm{P}_{a}^{\circ}$ Lilla Carlsön vid Gotl. förekommer en nästan tagglös form.

Göt. a.: Dalsl. Boh. spr., Sv. a.: Verml. Dal. spr., Norrt. Gestr. a. Hels. Med. spr. Ang. t. r.

- Reutéri Godet; foderflikar slutl. upprätta och qvarsittande; blad stundom ludna.

Göt. r.: Dalsl. Sk.?, Sv. Söd. Upl. Vestm. r., Norrl. Gestr.r.

b. R. collína Jacq.; småblad släta, undertill gröna och svagt ludna, oftast dubbelsågade; taggar svagt krökta; foderflikar nedböjda och affallande; foder och blomskaft med talrika glandler. I vissa trakter, t. ex. i Dalsland, är denna form särdeles ymnig och af ett ganska utmärkt utseende utan öfvergångar till den egentliga $R$. canina.

Göt. t. r.: Dalsl. mångenst. Boh. spr., Sv. t. r.: Söd. spr. Verml. Dal. 0.

c. R. dumetórum Thuill.; småblad ludna, oftast enkelt sågade; taggar starkt krökta; foderflikar vanl. nedböjda och affallande; foder och blomskaft vanl. utan glandler.

Göt. a, Sv. t. r.: Söd. Upl. a. Vestm. spr.?, Norrl. Gestr. spr. Hels. Ang. r.

- tomentella Lem.; småblad dubbelsågade.

Teml. r., t. ex. Ög. Smål. Vg.

- coriifólia Fr.; foderflikar slutl. upprätta och qvarsittande; blomskaft teml. korta; blad tjocka och skrynkliga: njupon slutl. något mjukt.

Göt. spr.: Blek. Vg. Dalsl. r., Sv. Söd. Upl. Vestm. t. r., Norrl. Gestr. r.

\section{Rubus.}

I. Buskar med n. jemnbreda, bladskaftet vidvuxna stipler.*)

A. Kronblad upprätta, af fodrets längd eller något kortare. Frukt lätt skiljbar från fästet. Stam upprätt. 1. R. idæus.

*) Dessa växter förekomma på stenbundna ställen och blomma efter försommarens slut. 
B. Kronblad utstảende, längre än fodret.' Frukt qvarsittande och sent mognande. Stam ofta nedliggande eller uppstigande. Blad fingerlika. Björnbärsbuskar, Svarthallon.

a. Årsskott upprätta eller blott i spetsen bågböjda, glatta och med 5-fingrade blañ. Glandelhår högst sällan förekommande hos växtens delar. Kronblad n. äggrunda. 2. R. fruticosus. 3. R. thyrsoideus.

b. Arsskott nedligoande, uppstigande eller bågböjda, ofta med 5-fingrade blad. Glandelhår ofta förekommande på växtens flesta delar. Kronblad n. äggrunda (hos $R$. glandulosus smala och tunglika).

1. Årsskottens stam glatt eller obetydligt finhårig. 4. R. cæsius. 5. R. corylifolius.

2. Årsskottens stam sträfluden (och vanl. nedliggande). 6. R. horridus. 7. R. Radula. 8. R. vulgaris. 9. R. glandulosus.

II. Örter med äggrunda-lansettlika, från bladskaftet nästan fria stipler.

A. Blad trefingrade. 10. R. saxatilis. 11. R. arcticus.

B. Blad enkla, njurlika och flikiga. 12. R. Chamæmorus.

1. R. idæus L., Hallonbuske; stam trind med borstlika och raka taggar; foderflikar utvändigt gröna, i kanten hvitludna och slutl. nedböjda.

4-6 fot hög; blad undertill snöhvitt ludna: stammens vanl. 3 -fingrade, årsskottens vanl. parbladiga, de blommande grenarnes stundom enkla och någon gång rundadt hjertlika; kronblad tunglika-aflånga och hvita; bär vanl. röda, någon gång gula; blomskaft slutl. lutande; foderflikar långspetsade; blommor hvita (på hafsstränder någon gång gulgröna) i fäblommiga qvastar; årsskott trinda, upprätta och i spetsen nedböjda.

Göt. Sv. Norrl. a.: Gotl. 0, Lpl. t. r.

2. R. fruticósus L.; foderflikar utvändigt gröna, slutligen (oftast) nedböjda.

Årsskottens stam kantig, oftast med platta sidor samt starka och oftast krökta taggar; blad vanl. på båda sidor gröna, undertill finhåriga; vippans grenar nästan jemnhöga, utdragna och vanl. enkla; frukt svart; nedersta småbladen med kort eller intet skaft; kronblad vanl. ljusröda.

Helst i skärgården, sällan inuti landet; Göt. spr.: Blek. a. öl. Ög. t. r. Vg. Dalsl. r. Gotl. 0, Sv. Söd. r.

* R. sulcátus Vest. (enl. F. Aresch.); årsskott fårade; taggar vanl. raka; vippa utdragen klaselik; foderflikar med utdragen spets och vanl. utstående; kronblad vanl. hvita.

I skärgården r.; Göt. Hall. Blek. Kalmarl. Ög., Sv.; inuti landet: Göt. Ög. i Stångådalen flerst.

* R. suberectus Anders.; årsskottens stam nedtill trind, upptill trubbkantig, samt med sma och vanligen raka taggar; frukt svartröd; kronblad vanl. hvita. 
Helst inuti landet i skogsbygder, sällan i skärgården; Göt. spr.: Dalsl. inre Smål. t. a. Ög. mångenst. Blek. Sk.-Boh. t. r. Gotl. 0., Sv. Söd. Vestm. t. r. Ner. Verml. spr.

3. R. thyrsoidéus Wimm.; foderflikar utvändigt hvitludna, slutligen nedböjda.

Årsskottens stam kantig med platta eller upptill fårade sidor samt vanligen krökta taggar; blad undertill ludna och med. vanl. hvitt ludd; vippa på längden utdragen med enkla eller ofta 3-delade grenar och korta blomskaft; frukt svart; de nedersta småbladen vanl. med tydliga skaft; kronblad vanl. ljusröda.

Helst i skärgården, stundom (i. Ög.) inụti landet; Göt. Boh. Hall. r. Sk. t. r. Blek. Kalmarl. Öl. spr. Ög. t. r., Sv. Söd. r. 4. R. cæ'sius L.; foderflikar grågröna spetsade, slutl. upprätta och tilltryckta intill frukten.

Årsskottens stam trind och vanl. krypande, med svaga och vanl. raka taggar; blad 3-fingrade, undertill finhåriga och oftast gröna, sällan hvitludna; vippa n. qvastlik, oftast fåblommig, med korta blomskaft; frukt daggblå; de nedersta småbladen skaftade; kronblad hvita.

Både inuti landet, helst i slättbygder, och i skärgården, sällan i skogsbygder; Göt. a.: Dalsl. Vg. inre Smål. r., Sv. Söd. Up]. t. a. Ner. spr. Vestm. a. i Mälaretrakten, Norrl. Gestr. spr. Hels. t. r.

- pséudo-idæus Weihe; årsskottens stam trubbkantig bågböjd; blommor små; blad ofta 5-fingrade, undertill stundom hvitludna, de nedersta småbladen oskaftade. I skärgården, trol. r.; Göt. Boh. (Lindeberg).

5. R. corylifólius Sm.; foderflikar utvändigt hvitludna kortspetsiga, slutl. oftast nedböjda.

Årsskottens stam trubbkantig, bågböjd, med vanl. raka (stundom krökta) taggar och vanl. 5-fingrade blad; blad undertill finludna och oftast blekgröna (och tunna); vippa mer eller mindre sammansatt, med korta blomskaft; frukt svartblå eller något rödaktig; de nedersta småbladen vanl. oskaftade; kronblad hvita.

Något skuggrika ställen i skärgården samt på ett ställe vid Venern; Göt. Boh. spr. Hall. t. r. Sk. Blek.-Ög. r. Vg. vid Venersborg, Sv. t. r.

- Wahlbérgii Arrhen.; årsskottens stam bågböjd med starka och vanl. krökta taggar; blad undertill stundom hvitludna; vippa vanl. mycket sammansatt och rikblommig; foderflikar stundom utstående.

Helst i skärgården, stundom (i Ög. och Dalsl.) inuti landet; Göt. spr.: Dalsl. r. Vg. Gotl. 0, Sv. Söd. spr. Upl. t. r.

- nemorósus Hayne; årsskottens stam oftast nedtryckt och n. krypande, vanligen med svaga och föga krökta taggar; vippa fåblommig; blad undertill stundom hvitludna; foderflikar ofta slutligen tilltryckta.

I skärgården; Göt. spr.: Ög. a. Öl. r. Gotl. 0, Sv. r.; inuti landet: Göt. Ög. mångenst. i Stångådalen. 
- pruinósus Arrhen.; årsskottens stam oftast krypande och ofta med 3-fingrade blad.

I skärgården; Göt. Boh. Hall. spr. Smål. Ög. Öl. r.

6. R. hórridus Hartm.; årsskottens stam trubbkantig med qvarsittande, tät hårighet, få nålborst och talrika, starka och krökta taggar; foderflikar utvändigt hvitludna, slutl. nedböjda; kronblad breda, n. äggrunda.

Den mest taggiga af arterna $i$ detta slägte. Blad undertill gröna och tätludna (sällan gleshåriga), vanl. 3-fingrade (sällan 5-fingrade på årsskotten); äldre stam sällan med glandelhår; vippa rikblommig, mycket sammansatt och utdragen på längden, med 3-delade grenar och korta blomskaft; glandelhår ymnigt förekommande; frukt svart; kronblad hvita eller blekröda.

I skärgården; Göt. Ög. mångenst. Smål. Blek. r.

7. R. Rádula Weihe; årsskottens stam hvasskantig med n. raka taggar och talrika nälborst; foderflikar och kronblad som hos föreg. art.

Är måhända ej nog skild från föreg. art, men bladen äro vanl. undertill hvitludna, årsskottens oftast 5-fingrade; blomgrenarnes taggar $\mathrm{n}$. raka.

I skärgården; Göt. Boh. r. Sk. t. r. Blek. spr. Smål. r.

Anm. På kilgön i Boh. förekommer (enl. F. Areschoug) R. raduloides Aresch., som mest lärer likna $R$. corylifolius, men har de blombärande grenarne gleshåriga och förmodas vara ba'stard af nämnda art och $R$. Radula.

8. R. vulgáris Weihe; årsskottens stam hvasskantig med n. raka taggar och inga nålborst; foder och krona som hos föreg. art.

Liknar föreg., men är föga glandelhårig; blomgrenarnes taggar krokta; frukt svartviolett.

I skärgården r.; Göt. Boh.-Sk. Blek., Sv. Söd.

* R. tæniárum Lindeb.; taggar mera krökta; foderflikar slutl. tilltryckta.

I skärgărden; Göt. Boh. t. r.

9. R. glandulósus Bell.; årsskottens stam nästan trind med teml. tätt sittande hår, talrika nålborst och $\mathrm{n}$. raka taggar; foderflikar utvändigt gröna, slutl. tilltryckta till frukten; kronblad smala, aflångt tunglika.

Blad oftast 3-fingrade (sällan 5-fingrade på årsskotten), undertill gröna och tätludna; vippa klaselik eller qvastlik med utdragna och utspärrade grenar; nästan alla växtens delar glandelhåriga; frukt svart; kronblad hvita.

I skärgården; Göt. Kalmarl. spr. Ög. r.; inuti landet: Göt. Ög. vid Dala i Grebo (Scheutz) Vg. på Kinnekulle (Osk. Sandahl). 10. R. saxátilis L., Stenbär, Jungfru Mrariebär; stjelk flerblommig med örtrefvor; kronblad hvita, upprätta och aflångt lansettlika, af fodrets längd. $2,3$. 
1/2 fot hög och sträfhårig; småbär röda, få, stora och åtskilda blommor i qvastlik klase; småblad hvasst sågade; foderflikar vanl med kort spets.

Stenbundna ställen, allmän.

11. R. árcticus L., Ảkerbär; stjelk 1-3-blommig utan

örtrefvor; kronblad rosenröda (sällan hvita), utstående och omvändt äggrunda, dubbelt längre än fodret. 2.

Något lägre än föreg. och småluden; småbär mörkröda, talrika och tätt sittande (i Lpl. sällan utbildade); foderflikar lång. spetsade; småblad djupt nch trubbigt sågade.

Vid vägar, i ängar och på andra öppna ställen; Lpl. a., Norrl. spr.: Vb.-Med. a. Jtl. (i ö. delen) r., Sv. Dal. Verml. spr. Vestm. Upl. r.

Anm. Bastard eller mellanform af föreg, arter är:

R. castoræ'us Fr.; fåblommig och vanl. sträf utan örtrefvor; kronblad blekröda, något utstående och omvändt äggrunda, vanl. dubbelt längre än fodret; småbär få, rộda och fơga smakliga; småblad hvasst sågade.

- triflórus; kronblad rödletta, något kortare än fodret.

Båda formerna äro sällsynta; Lpl., Norrl. Vb. Hels.

12. R. Chamæmórus L., Hjortron, Multer; stjelk enblommig utan örtrefvor; kronblad snöhvita, utstående och omvändt äggrunda, längre än fodret. 1, 2.

Knappt $1 / 2$ fot hög och 2-3-bladig; bär i början röda, slutl. gula och mycket mjuka; blommor ofta tvåbyggare.

Myrar, allmän: Boh. Blek. t. r. Öl. Gotl. 0 .

\section{Dryas. Fjeilsippa.}

1. D. octopétala L.; blad långskaftade, aflånga-äggrunda med hjertlik eller afrundad bas samt undertill snöhvitt ludna; kronblad dubbelt så långa som fodret. 2.

Rotstocken bildar nedtryckta tufvor med upprätta tumsbreda blommor, som likna Hvitsippor, och, frukter som hos Pulsatilla; blomfoder med svarta glandelhăr.

Ängsmark och solöppna klippor i högfjellen, helst i fjellregionen; Lpl. spr., Norrl. Jtl. Herj. r.

\section{Geum.}

A. Blommor lutande med raka rödbruna foderflikar; kronblad med lång klo.

1. G. rivále L., Fårpungar, Jungfru Marie nycktar; kronblad med omvändt hjertlik skifva. 2.

Mjukhårig med omkr. fotshög och upptill rödbrun stjelk; stipler små och n. hela; blomfoder klocklikt; kronblad gulhvita rödådriga och vanl. lika långa med fodret; de flesta öfre bladen med 3 större och âtskilda flikar.

Ängar, allmän: Torn. Lpm. r.

B. Blommor upprätta med gröna, slutl. nedböjda foderflikar; kronblad n. utan klo.

2. G. urbánum L., Nejlikerot; kronblad omvändt äggrunda. 3. 
Mjukhårig med omkr. 2 fot hög och grön stjelk; stipler stora och inskurna; blomfoder vanl. föga kortare än de gula kronbladen; rotstock under våren med nejlikelukt; blad som hos föreg. art.

Ängar, stundom ruderatväxt; Göt. a., Sv. t. a.: Dal. spr., Norrl. Gestr. spr. Hels. Med. r.

3. G. hispidum Fr.; kronblad bredt omvändt äggrunda. 3.

Liknar föreg art, men är sträthårig med utskjutande kronblad och mycket långa blomskaft; blad pardelade eller parflikiga med n. lika stora flikar.

Busksnår o̊ch ängsbackar nära hafvet; Göt. Hall. Blek. r. Kalmarl. t. r. Ög. r., Sv. Söd. r.

Añm. Af de båda förstnämnda arterna förekommer följ. bastard:

G. intermédium' Ehrh.; blommor vanl. lutande; foderflikar (mer eller mindre) brunaktiga, slutl. utstående; kronblad gula med kort klo och n. rund skifva; till örten mest lik G. urbanum.

Göt. t. r.: Sk. Smål. Öl. Ög. spr., Sv. t. r.: Söd. Upl. spr. Dal. 0, Norrl. Gestr. Hels. r.

\section{Fragária. Smultron.}

A. Bär (fruktfäste) lätt lossnande från det nedböjda fodret; småbladens tänder n. lika stora.

1. F. vesca L., Smultron, Jordbür; bär nedtill tjockare och öfverallt försedt med karpeller; blomskaftens hår tilltrycleto. 1, 2.

Ända till 1/2 fot hög med krypande örtrefvor.

Ängar, backar och svedjeland, allmän: Vb. Lpl, $r$.

2. F, elátíor Ehrh., Jordgubbar; bär nedtill utan kàrpeller och afsmalnande; blomskaftens hår täta och utstiende. $2,3$.

$1 / 2-1$ fot hög och ofta utan örtrefvor. Sätter i vildt tillstånd vanligen ej mogna bär.

Ruderatyäxt, stundom i ängar, ursprungligen förvildad; Göt. r.: Sk. Ög. Öl. spr. Gotl. 0, Sv. spr.: Vestm. Verml. r. Dal. 0.

B. Bär fastväxt vid och omslutet af det upprätta fodret; småbladens uddtand mindre än de närmaste. 3. F. collína Ehrh., Nejkon, Backsmultron; bär nedtill utan karpeller och afsmalnande; blomskaftens hår tilltryckta. $2,3$.

Ända till $1 / 2$ fot hög och ofta utan örtrefvor: blommor större än hos $F$. vesca, blomskaft finare, bladens undersida mera silkeshårig.

Ängsbackar, helst i slättbygder; Göt. t. a.: inre Smål. Boh. r. Vg. t. r.? Dalsl.?, Sv. Söd. Upl. t. a. Vestm. (i Mälaretrakten) spr. Verml. Ner. r. Dal. r.?

\section{Cómarum. Kråkzlöfver.}

1. C. palustre L.; småblad aflånga tandade, undertill blågröna och småludna. 3. 
Stjelk 1-2 fot hög, småluden och flerblommig; stipler vidväxta bladskaftet; småblad 7, 5 eller 3 .

Kärr, allmän: Gotl. spr.

\section{Potentilla.}

A. Stam buskartad. Blad fjädernerviga. Kronblad gula, längre än fodret. 1. P. fruticosa.

B. Örter med rotstock. Alla blad (eller åtm. rotbladen) parbladigt delade. Kronblad gula eller hvita, längre än fodret. 2. $P$. anserina. 3. P. rupestris.

c. Ört med svag enårig eller tvåårig pålrot. Alla eller de flesta bladen trefingradt delade, rotblad stundom parbladigt delade. Kronblad gula, kortare än fodret. Stjelk upprätt. 4. P. norvegica.

D. Örter med rotstock. Alla blad fingerlikt delade. Kronblad gula, längre än fodret.

a. Blommor ensamma (sällan 2 tillsammans) i bladvecken på långa skaft. Stjelkar krypande eller uppstigande. 5.P. reptans. 6. P. procumbens. 7. P. Tormentilla.

b. Blommor i n. qvastlik vippa. Stjelkar ej rotslående.

1. Stjelkar upptill föga bladiga, utgående frân sidorna af en bladrosett. Alla stjelkblad 3-fingrade. 8. P. alpestris. 9. P. verna. 10. P. cinerea. 11. P. opaca. 12. P. nivea.

2. Stjelkar mera bladrika, vanl. utan bladrosett i midten. Alla eller de flesta bladen 5-fingrade. 13. P. argentea. 14. P. collina.

1. P. fruticósa L., Ölands-tok; blad med 5 helbräddade n. ovala flikar, af hvilka de 2 nedre äro alldeless åtskilda. 3 .

Omkr. 2 fot hög eller lägre och mycket grenig, med blommor $i$ vippa; foderflikar lika långa; bladflikar ofvan n. glatta, undertill silkeshåriga.

Något fuktiga och ofruktbara ställen; Göt. Öl. spr.

2. P. anserina L., Gåsört; stjelkar krypande (liknande örtrefvor); kronblad gula; blad ojemnt parbladigt delade, med lansettlik omkrets. 3,4 .

Blomskaft flera tum långa och enstaka; bladflikar (småblad) sågade och vanligen åtminstone undertill silfverhåriga, de större aflånga; fodrets flikar nästan lika långa; karpeller släta.

Ruderatväst på något fukt. ställen, allmär: Vb. r.? Lpl. r. 3. P. rupestris L.; stjelkar upprätta; kronblad hvita; de nedre bladen parbladigt, de öfre trefingradt delade. $2-3$.

1-2 fot hög med talrika, teml. kort skaftade blommor i vippa; småblad ovala, dubbelsågade, det yttersta skaftadt med vigglik bas; karpeller släta.

Berg, helst på lerskiffer och kalk; Göt. Dalsl. Vg. spr. Boh. Hall. Smål. t. r. 
4. P. norvégica L.; rotblad 3-fingrade eller parbladigt delade. 3 .

Stjelk vanl. ensam och upprätt med utstående hår; blommor på teml. korta skaft i qvastlik vippa; småblad aflånga, djupt sågade, på båda sidor grọna och håriga.

Ruderatväxt och på svedjeland; Norrl. t. a.: Herj. Jtl. Vb. r., Sv. t. a., Göt. t. r. och sporadisk: Dalsl. spr. Öl, 0.

* P. intermédia Fr.; rotblad ofta 5-fingrade med teml. breda och omvändt äggrunda småblad; stjelk gröfre. Åkrar; Göt. Öl. Sk.-Ög. r., Sv. Upl. r.

5. P. reptans L., Krypande Femfingersört; stjelkar rotslående; blad 5-fingrade lìngskaftade. 3, 4 .

Stjelkar liknande örtrefvor och ofta ett par. fot långa; småblad omvändt äggrunda eller vigg]ika, nästan öfverallt trubbigt sågade och undertill gröna med tilltryckta hår; de yttre foderflikarne vanl. större ä̉n de inre; karpeller knöliga; blommor teml. stora och 5-taliga; stipler hela eller inskurna.

Ängsbackar och åkerrenar; Göt. t. a.: Vg. inre Smål.r. Boh. Dalsl. 0, Sv. t. a.: Vestm. spr. Dal. t. r. Verml. r., Norrl. Gestr. spr. Hels. $r$.

6. P. procumbens Sibth.; stjelkar rotslaende; blad skaftade, de nedre med utdragna skaft, de öfre med teml. korta skaft, alla vanl. 3-fingrade, (de nedre stundom 5 -fingrade). 3.

Liknar mest följ. art, men stjelkarne äro längre och slankiga, dock ej så veka som hos föreg. art; småblad omvändt äggrunda, grundt parklufna med spetsiga flikar och aflägsnade frăn de nästan hela stiplerna; foderflikar slutl. inböjda, de yttre vanl. längre än de inre; karpeller rynkiga; blommor vanl. 4-taliga, $\mathrm{n}$. dubbelt större än hos följ. art; kronblad betydligt längre än fodret. Smål.?

Något fuktiga betesmarker; Göt. Boh. r. Sk. t. r. Blek. r.

7. P. Tormentilla Scop., Blodrot; stjelkar nedliggande eller uppstigande, ej rotslående; stjelkblad oskaftade 3 -fingrade; rotblad skaftade, vanl. 3 -fingrade. 1-4.

Stjelkar n. glatta och mycket bladiga, omkr. 1/2 fot långa och styfva; rotstock tjock och inuti rödaktig; småblad vigglikt aflånga, på båda sidor gröna, upptill flikiga och liknande de närsittande, inskurna stiplerna; blomdelar vanl. 4-taliga; foderflikar slutl. utstående, de yttre längre än de inre; blommor teml. små; kronblad föga längre än fodret. Hos denna och de båda föreg.. arterna utgå stjelkarne från sidan af en bladrosett.

Ängar och skogar, allmän.

8. P. alpestris Hall. d. y.; rotblad vanl. 5-fingrade; stipler helbräddade, bredt ovala eller äggrunda; småblad bredt vigglika eller omvändt äggrunda med få och nästan lika stora tänder i spetsen. 1, 2. 
Omkr. ${ }^{1 / 2}$ fot hög; stjelkar talrika, mångblommiga, uppstigande och korthåriga; blad pä båda sidor gröna och stundom håriga; kronblad ofta med en mörkare fläck på klon. I fjelltrakter äro stundom småbladen mera och längre ned inskurna.

Ängsbackar; Lpl. Norrl. a., Sv. t. a.: Vestm.. spr. Dal. Verml. t. r., Göt. Boh. Vg. r. Ög. mångenst. Smål.t. r. Öl. t. a. Gotl. spr. 9. P. verna L.; rotblad såsom hos föreg. art; stipler helbräddade, rotbladens jemnbredt syllika och smala; småblad vigglika, till $2 / 3$ tandade med den yttersta tanden minst. 1,2.

Liknar föreg. art, men är mera hårig och i början nedtryckt till marken; kronblad vanl. rent gula utan mörkare fläck; foderflikar n. lika långa.

Ängsbackar;; Göt. t. a.: inre Smål. Boh. Dalsl. r. Vg. spr.?, Sv. Söd. Upl. t. a. Vestm. spr. Verml. Dal. r. Ner.?

10. P. cinérea Chaix; stipler jemnbreda trubbiga; småblad omvändt äggrunda, upptill tandade samt (isynnerhet undertill) gråludna af stjernlika hår; eljest som föreg. art. 1, 2.

Torra backar; Göt. Gotl. r. Öl. t. r. Blek. r. Smål. spr. Vg.r. 11. P. opáca L.; rotblad 5-7-fingrade; stipler helbräddade, rotbladens äggrundt lansettlika; småblad smalt vigglika, till $2 / 3$ tandade med den yttersta sågtanden minst. 1, 2.

2-4 tum hög; hela växten tätt beklädd af långa utstående hår; stjelk i början nedtryckt och vanl. rödaktig; blommor smärre än hos de tre föreg. arterna; de yttre foderflikarne kortast.

Torra backar och betesmarker; Göt. Sk. Blek. r.

12. P. nívea L.; alla blad 3-fingrade; stipler helbräddade och äggrunda; småblad omvändt äggrunda eller aflånga, det mellersta vigglikt, alla n. likformigt sågade. 1, 2.

Stjelkar finludna, $1 / 2-1$ fot höga; småblad vanl. undertill snöhvitt ludna; foderflikar likformiga och lika stora.

Ängsmark, högt upp i högfjellen; Ipl. t. r.

13. $\mathbf{P}$. argéntea $\mathrm{L}$.; kronblad föga längre än fodret; rotblad 5-7-fingrade; småblad smalt vigglika, djupt inskurna med i kanterna nedvikna flikar. 3, 4 .

Stjelkar talrika, mycket bladiga, uppstigande, ofvan midten greniga, stundom fotshöga, och (liksom bladskaften) med kort och tätt ludd; småblad undertill vanl. hvitludna eller stundom grågröna; stiplernas slida mycket kort.

Torra ängar och backar; Göt. Sv. a., Norrl. spr.: Gestr. a., Ipl. r.

14. P. collína Wib.; kronblad mera utskjutande; småblad vigglika och inskurna med platta (ej nedvikna) flikar. 3. 
Stjelkar omkr. $1 / 2$ fot höga, från midten greniga, både filtludna och med långa utstående hår; småblad undertill filtludna och långhåriga; blomskaft bågböjda.

Torra betesmarker; Göt. Öl. t. a. Gotl. Smål. Sk. r.

\section{Klassen. POLYANDRIA.}

1 Ordn. MONOGYNIA.

\section{Papáver. Valmo.}

A. Stjelk med icke omfattande blad; blommor röda (sällan hvita).

1. P. dúbium L.; blomfoder med utstående hår; kronblad n. runda; ståndaresträngar trådlika; fröhus aflångt och något afsmalnande nedåt. 2,3 .

0mkr. 2 fot hög med pardelade blad och inskurna bladflikar; ståndaresträngar röda; fröhus glatt.

Ruderatväxt och ogräs i åkrar, helst i slättbygdèr; Göt. t. a.: Ög. spr. inre Smål. Vg. t. r. Boh. Dalsl. r., Sv. spr.: Ner. Verml. r. Dal. 0, Norrl. Gestr. Med. Jtl. r.

2. P. Argemóne L.; blomfoder n. glatt; kronblad med vigglik klo; ståndaresträngar upptill tjockare och kortspetsade; fröhus smalt klubblikt. 3.

1-2 fot hög med dubbelt pardelade blad; kronblad med en svart fläck på klon; ståndare mörkvioletta; fröhus oftast styfhairigt.

Ruderatväxt och ogräs i åkrar; Göt. t. a. helst i slättbygder: inre Smål. Vg. Boh. r. Dalsl. 0, Sv. Söd. Upl. spr. Vestm. Ner.r.

B. Blommor gula, ensamma på rotblomskaft.

3. P. alpínum L. * nudicáule Rottb., Gul Valmo; blomfoder med långa tilltryckta hår; kronblad rundadeovala; ståndaresträngar syllika; fröhus omvändt kägellikt. 2.

Omkr. $1 / 2$ fot hög eller lägre, sträfhårig med vanl. enkelt pardelade blad; ståndaresträngar gulaktiga ; fröhns styfhårigit.

Högt upp i fjellregionen vid bäckar, mycket r.; Lpl. Torn. Lpm. på fjellet Peltsana (C. P. Læstadius).

\section{Chelidónium. Svalört.}

1. C. majus L.; blad parbladigt delade; bladflikar flikiga och undertill blågröna; blommor i flock. 2, 3.

1-3 fot hög med brandgul mjölksaft; bladflika s stora; kronblad någon gång naggade.

Ruderatväxt pà steniga ställen, särdeles vid murar; Göt. t. a., Sv. t. a.: Dal. spr., Norrl. Gestr. Hels. spr. Vb.?, Lpl.?

\section{Gláucium. Stranct-Valmo.}

1. G. lúteum Scop.; stjelkblad djupt flikiga. 3, 4 . 
1-2 fot hög, grenig och blåaktig samt glatt (utom på fodret); blommor guldgula och mer än tumsbreda.

Hafsstränder; Göt. Boh. teml. r.

\section{Tília. Lind.}

1. T. parvifólia Ehrh.; blomskärmar öfverskjutande blomqvasten; frukt päronformig; blad undertill med brunaktiga hårtofsar. 3 .

Träd med mjuk ved och hvasst sågade (sällan grundt flikiga) undertill blågröna blad; fruktskal vårtfullt och tunnt.

Berg och lundar; Göt. mångenst.: Gotl. r., Sv. spr.: Söd. Upl. t. a., Norrl. Gestr.-Ång. r.

* T. vulgáris Hayne; blomskärmar ej öfversijiutande blomqvasten; frukt n. klotrund; blad undertill med hvitaktiga hårtofsar. 3 .

Liknar föreg., men har undertill blekgröna blad och slätt, hårdt fruktskal.

Förvildad h. o. d. nära bostäder; Boh. vild?

2. T. platyphylla Scop.; blomskärmar ej öfverskjutande den fåblommiga blomqvasten; frukt omvändt äggformig och kantig; blad undertill öfverallt håriga. 3.

Har ludna knoppar och hårdt fruktskal.

I skärgården, mycket r.; Göt. Boh. på öar nära Strömstad. 267. Heliánthemum. Solvända.

1. H. vulgare Gärtn.; blad aflånga-jemnbreda och motsatta med stipler; blommor i gles och ensidig klase på nedböjda skaft. 3 .

Omkr. ${ }^{1 / 2}$ fot hög med till största delen örtartad stam, uppstigande grenar och undertill vanl. gråludna blad; kronblad längre än fodret; foder blott på nerverna hårigt.

Ängsbackar; Göt. a.: Hall. Vg. spr. Boh. Dalsl. 0, Sv. Söd. Upl. t. a. Vestm. Ner. spr. Dal. r., Norrl. Gestr. Hels. r.

2. H. œlándicum (L.) Pers.; blad ovala-lansettlika och motsatta utan stipler; blommor i n. tvåsidig klase på slutl. utspärrade skaft. 2,3 .

Stam mera träaktig än hos föreg. art, nedtryckt och mycket grenig med uppstigande grenar; blad undertill glatta; kronblad stundom föga längre än det ludna fodret. Utblommad redan $i$ början af Juli.

Kalkberg; Göt. Öland mångenst. (jemte följ. varieteter).

- ciliátum; blad hărbräddade. 3,4 .

Blommar på Öland ej förr än fram i Juli samt ända till slutet af Aug., liksom följ. varietet.

canescens; blad (isynnerhet undertill) gråludna.

3. H. Fumána (L.) Mill.; blad barrlika uddspetsiga utan stipler, de öfre skiftevis sittande; blommor vanl. ensamma eller $2-4 \mathrm{i}$ spetsen af grenarne och motsatta bladen på slutl. nedböjda skaft. 3 . 
Stam träaktig med korta och ofta nedtryckta grenar; kronblad längre än det finludna fodret; de yttre ståndarne felslående med korta strängar.

Kalkberg; Göt. Gotl. t. r.

\section{Nymphæa. Hvit Neckros.}

1. N. alba L.; märke 12-20-stråligt och enfärgadt gult; blad rundadt hjertlika (n. pillika) med flikarnes inre kanter parallela. 3.

Sjöar och åar, helst i skogsbygder, allmän: Öl.t. r. Gotl. spr.

- rósea; blommor rosenröda.

$S v$. Nerike i sjön Fagertärn på Tiveden.

* N. biradiáta Sommerauer; märke 5-10-stråligt, i midten med en blodröd stjernlik fläck; blad och blommor mindre; bladflikar något frånstående.

Skogssjö̈ar och gölar; Lpl. spr., Norrl. Vb. Ång. spr., Sv. spr., Göt. Ög. Smål. r. - Trol. äfven annorstädes.

\section{Nuphar. Gul Neckros.}

1. N. lúteum (L.) Sm.; kronblad omvändt äggrunda, nedåt småningom afsmalnande; märke n. helt. 3.

Blad ovala, med hjertlik eller n. pillik bas med föga frånstående flikar. Varierar med mindre blommor.

Sjöar och åar, allmän: Gotl. t. r. Öl. 0.

2. N. púmilum (Wahlenb.) D.C.; kronblad spadlika med smal klo; märket deladt i omkring 10 strålar. 3.

Mindre än föreg.; blommor ungefär lika stora som hos Caltha; blad omkr. 2 tum breda med vanligen frånstånde flikar, glatta eller finludna; bladskaft vanl. trubbigt trekantiga, stundom plattade.

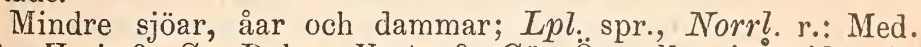
Gestr. Herj. 0, Sv. Dal. r. Vestm.?, Göt. Ög. allm. i Àtvidstrakten, Smål. r. i Gärdserum och Blackstad.

\section{Actæa. Paddbär, Iktebür.}

1. A. spicáta L.; rotblad dubbelt, stjelkblad enkelt trefingrade; bladflikar djupt sågade. 2,3 . darne.

Omkr. 2 fot hög och illaluktande; kronblad kortare än stån-

Lundar; Göt. Sv. t. a.: Gotl. 0, Norrl. spr.: Vb.?, Lpl. r.

\section{Ordn. DI-PENTAGYNIA.}

\section{Delphínium. Riddarsporre.}

1. D. Consólida L.; blad dubbelt trefingradt delade med långa och trådsmala flikar; stift hälften kortare än frukten. 3 .

Öfver fotshög och mycket grenig; rot enårig. Giftig.

Akrar, helst $\mathrm{i}$ slättbygder; Göt. t. a.: Blek. inre Smål. Hall. t. r. Vg. r.? Boh. Dalsl. 0, Sv. t. a.: Vestm. spr. Dal. r. (Verml. tillfällig), Norrl. r.: Ång. Herj.? ( $L p l$. tillfällig). 


\section{Aquilégia. Akleja.}

1. A. vulgáris L.; kronsporrar klolikt böjda inåt. 3 . Omkr. 2 fot hög med upprätta fruktskaft.

Lundar och busksnår; Göt. spr.: Blek. Sk. Boh. t. r., Sv. spr.: Dal. r., Norrl. Gestr.-Med. r.

\section{Aconitum. Stormhatt.}

1. A. Lycóctonum L.; hlibbhairig; hjelm lång och n. rörformig utan tydlig klo och upptill föga krökt med trubbig spets; de båda öfra kronbladen upprätta med i spetsen tillbakarullade sporrar. 3.

4-6 fot hög och grof, illaluktande, med stora mjuka och 5-7-flikiga blad med inskurna flikar; blommor hvitgula. Gittig liksom de öfriga arterna.

Ängar i fjellen, mycket r.: Ipl. Lul. Lpm. vid Kiergevara (Wahlenberg).

* A. septemtrionále Köll.; blommor orent blåvioletta. Ängar, helst i lägre fjelltrakter; Ipl. a., Norrl. Jtl. Herj. a. Ång. Med. spr., Sv. Dal. och Verml. i fjelltrakterna spr., Upl. r.

2. A. Napellus L.; stjelk nedtill n. glatt eller gleshårig, upptill finluden; blad n. glatta; hjelm halfmånlikt krökt med tydlig klo och utdragen näbblik spets; de båda öfra kronbladen $n$. på midten böjda med långa klor och n. raka sporrar. 3 .

Lägre och mindre grof än föreg.; blad mindre, stela och glänsande, 3-5-delade med vigglika, djupt klufna och smalflikiga flikar; hlommor större och bredare, rent blå.

Stränder, mycket r.; Sv. Dal. Söd., Göt. Sk.

3. A. Cámmarum L.; alldeles glatt; hjelm koniskt hvälfd; eljest som föreg. art. 3 .

Liknar föreg. art, men blomklasen är glesblommig, bladen smärre och mera bredflikiga, klufna 'nedom midten; de unga frukterna med hopstötande spetsar.

Nära bostäder, trol. förvildad och mycket r.; Göt. Smål. Hall. (Sv. Söd. Upl. Vestm. i gamla trädgårdar).

\section{Ordn. POLYGYNIA.}

\section{Thalictrum. Angsruta.}

A. Stjelk slutande $\mathrm{i}$ spetsen med en bladlös vippa. a. Blad 3 gånger fingerlikt delade. Karpeller med 3 vingkanter. Ståndaresträngar upptill klubblika. 1. T. aquilegiæ fólium L.; vippa tätblommig; stjelk trind. 2 . $2-3$ fot hög och upptill rodnande; blad mer än ${ }^{1} / 2$ fot långa och breda, något liknande Aklejans; bladskaft med stipler; småblad n. runda; ståndaresträngar violetta; kalkblad grönaktiga eller rodnande; karpeller stora, slutl. hängande.

Fuktiga skogsängar, helst i alkärr; Göt. Sk. t. a. Blek. Smål. t. r. 
b. Blad 3 gånger fingerlikt delade, lika breda som långa. Karpeller ovingade. Standare jemntjocka. 2. T. Kóchii Fr.; vippgrenar utstående; blommor hängande; stjelk n. ofärad och nedtill bladig. 3 .

3-4 fot hög med grenig och krokig stjelk; småblad vanligen rundade och flikiga, undertill något blågröna; ståndareknappar med udd; karpeller äggrunda.

Ängar, helst nära hafvet; Göt. Gotl. a. Ög. på Gräsmarö, Smål. nära sjön Asnen, Sk. på ön Hven.

3. T. minus L.; vippgrenar utspärrade; blommor hängande; stjelk starkt fårad och nedtill bladlös. 3.

Omkr. 2 fot hög, liknande föreg. art, men med vanl. aflånga karpeller.

Sandiga hafsstränder; Göt. Boh.-Sk. t. r.

c. Blad dubbelt (sällan 3-dubbelt) parbladigt delade, mera långa än breda. Karpeller och ståndare som hos föreg. afdelning.

4. T. flavum L.; blommor upprätta i tät och n. qvastlik vippa; stjelk fårad. 3 .

2 -3 fot hög med grenig, vek och rak stjelk; småblad vanl. bredt vigglika, i spetsen 3-klufna och undertill blekgröna; ståndaresträngar upprätta, blekgula eller n. hvita; ståndareknappar utan udd; karpeller äggrunda trubbiga.

Ängar; Göt. a.: Blek. Smål. Dalssl. spr. Boh. r., Sv. a.: Verml. Dal. spr., Norrl. r.: Gestr. Hels. spr. Ned.?, Lpl. r.

- angustátum; stjelk föga grenig; blad stundom 3-dubbelt parbladigt delade; småblad smala n. jemnbreda. Ängar; Göt. Gotl. r. Ög. på Omberg och vid Stegeborg.

* T. angustifólium Jacq.; blad 3-dubbelt parbladigt delade. Liknar nyss nämnda varietet och är trol, ej nog skild.

Skogsängar, mycket r.; Göt. Öl. i Föra s:n (Sjöstrand).

5. T. simplex L.; blommor i gles vippa och nedhängande i klasar på vippans grenar; stjelk med upphöjda ränder, ej fårad. 3 .

1-2 fot hög med enkel, fast och rak stjelk; småblad smalt vigglika, i spetsen 3 -klufna, mörkgröna; ståndaresträngar hängande, mörkgröna; ståndareknappar med udd; karpeller n. tapplika, afsmalnande àt hâda ändar.

Ängar; Göt. spr.: Gotl. a. Blek. Dalsl. r. Boh.?, Sv. spr.: Verml. r., Norrl. spr.?

B. Stjelk bladig ända upptill, med blomklasar eller enblommiga skaft utgående från de öfre bladvecken. Karpeller ovingade. Ståndare jemntjocka. Blad dubbelt parbladigt delade.

6. T. boreále Nyl.; stjelk rak och nedtill enkel, endast upptill med utdragna och bladiga blommande grenar; 
blommor ofta ensamma på lảnga upprätta skaft eller

i fåblommiga klasar. 3.

Liknar föreg. art, men skiljes genom de mera spridda blommorna på ofta tumslånga skaft. Stjelk fåradt kantig; småblad mörkgrờna, antingen smalt vigglika eller breda och omvändt äggrunda; ståndareknappar gröngula och upprätta, n. utan udd; småbladens skaft kantiga.

Ängar; Lppl. r., Norrl. r.: Herj.? Hels. Gestr. 0 (Göt. Ög.?). 7. T. kemense Fr.; stjelk krokig och nedifran grenig; blommor stälda i bladiga vippor på grenarne, i början teml. tätt sittande, slutl. glesnande. 3.

Liknar något föreg. art. Stjelk fåradt kantig, 11/2-4 fot hög; småblad mörkgröna, undertill blekare, de nedre breda och äggrunda-vigglika, de öfre öfvergående till stora äggrundaafănga och kortspetsade skärmblad; ståndareknappar gula, vanl. upprätta, med mycket tydlig udd; småbladens skaft (enligt Fries) trinda.

Ängar, mycket r.; Norrl. Vb. vid Kengis (enl. exemplar af R. F. Fristedt).

C. Stjelk nästan bar och stängellik med enkel och n. bladlös blomklase.

8. T. alpínum L.; blommor lutande på långa bågböjda skaft. 2,3 .

Stjelk omkr. 1/2 fot hüg och n. trådlik; kalk blåaktig; ståndareknappar grönaktiga med udd; allmänna bladskaftet 3-deladt med parbladigt eller fingerlikt stälda, små och ofvan ljusgröna samt $n$. runda och flikiga småblad.

Fuktiga ställen, to ex. i bergsspringor, i fjellen; Lpl. a., Norrl. Jtl. Herj. a. Ang. r., Sv. Dal. r.

\section{Pulsatilla.}

A. Blad enkelt parbladigt delade med breda flikar (småblad); blommor n. upprätta med raka kalkblad. 1. P. vernális (L.) Mill., Mosippa; småblad bredt vigglika, i spetsen 3-klufna eller 3-delade. 1, 2.

Stängel omkr. 1/2 fot hög; svepe med guldglänsande hår, liksom kalkbladens utsida; kalkblad inuti hvita och utanpå rödletta.

Skogshedar, helst bland buskar; Göt. t. r.: 'Smål. spr. Gotl. Boh. Dalsl. 0, Sv. t. r.: Verml. Dal. spr., Norrl. r.: Med.-Vb.0.

B. Blad 3 gånger parbladigt delade med n. trådsmala flikar; blomma snart lutande med i spetsen utböjda kalkblad.

2. P. vulgáris Mill., Backsippa; kalkblad ljust violetta (sällan hvita), dubbelt längre än ståndarne och upptill föga utböjda; blomskaft n. rakt. 1, 2.

Omkr. $1 / 2$ fot hög med n. öppna blommor; svepe med hvita hår (liksom kalkbladens utsida), fästadt ungefär på midten af stängeln. är någon gång nästan glatt. 
Torra backar; Göt. mångenst: Boh. t. r. Dalsl. Gotl.?, Sv. spr.: Vestm. (i s. delen) t. r. Verml. (vid Vestgöta gränsen) r. I)al. 0 .

3. P. pratensis (L.) Mill.; kalkblad mörkt violetta eller blygrå, föga längre än ståndarne och upptill utböjda; blomskaft i spetsen bågböjdt. 2.

Liknar föreg. art, men har mera hopslutna, mindre och kortare blommor; svepe fästadt ofvan stängelns midt.

Torra ängar; Göt. Gotl. Öl. a. Sk. t. a. Blek. Smål. Vg. r. Ög. t. r., Sv. Söd. r.

C. Blad enkelt eller dubbelt fingerlikt delade; blomma något lutande med utstående och raka kalkblad.

4. P. patens (L.) Mill.; kalkblad ljust violetta; småblad teml. breda och djupt klufna i smala och platta flikar. 2 .

Omikr. ${ }^{1 / 2}$ fot hög, liknande Puls. vulgaris, men bladflikarne äro bredare (stundom omkr. en linie) och bladens omkrets i början n. rund; svepe sittande midtpå stängeln.

Ängsbackar, mycket r.; Norrl. Ång., Göt. Gotl.

\section{Anemóne. Sippa.}

A. Svepe aflägsnadt från blomman och bestående af 3 blad, som likna rotbladen; stängel ofta ensam.

1. A. nemorósa L., Hvitsippa; svepeblad delade och med utdragna skaft; kalkblad hvita eller rödletta, glatta; fruktspröt (stift) mer än hälften kortare än den glatta frukten. 1, 2.

Omkr. $1 / 2$ fot hög och vanl. enblommig, sällan tvåblommig; rotstock utdragen; rotblad 3-delade.

Ängar och skogar; Göt. Sv. a., Norrl. r.: Gestr. Hels. a. Med. spr., $L p l$. r.

2. A. ranunculóides L., Gulsippa; svepeblad kortskaftade; kalkblad gula, utvändigt finludna; frukter ungefär lika långa som det krökta sprötet. 1, 2.

Omkr. $1 / 2$ fot hög och 1-4-blommig, lik föreg. art.

Fuktiga ställen i lundar; Göt. t. r.: Gotl. spr. Öl. Sk. a. Boh. Dalsî. 0, Sv. Söd. spr. Upl. Vestm. r.

3. A. silvestris L.; svepeblad med utdragna sinaft; kalkblad hvita, utvändigt finludna; stift mycket kort; frukter ulliga. 1, 2.

Hela växten är något luden, större och gröfre än de föreg., ofta omkr. fotshög, samt med mycket större blommor: rotstock kort; rotblad 5-delade med rutformiga, 3-flikiga och tandade flikar.

Sandiga ställen nära åkrar; Göt. Öl. Gotl. r.

B. Svepe bestående af 3 helbräddade blad och liknande ett blomfoder, sittande helt nära blomman. Rotblad njurlika 3-flikiga, qvarsittande öfver vintern.

4. A. Hepática L., Blåsippa; svepeblad aflånga; kalkblad blå och glatta. 1. 
Omkr. fingerhög, blommande före de nya hladens utveckling; blad mycket långt skaftade, vanl. undertill rödblå eller lefverbruna och håriga med rundade ocb trubbiga flikar; blommor stundom ljusröda eller hvita.

Lundar och skogar; Göt. a.: Daisl. Ög. t. a., Sv. t. a.: Verml. Dal. spr., Norrl. spr.: Ang. t. r. Vb. 0 .

- glabráta; blad glatta; bladflikar med kort udd.

Göt. Ogg. r., Sv. Söd. Upl. Ner. r.

$$
\text { 277. Caltha. Kalf-leka, Kabbelök. }
$$

1. C. palustris L.; blad naggade, de nedre skaftade, de öfre oskaftade, alla med hinnaktiga slidor. 1, 2.

$1 / 2-1$ fot hög, glatt och saftig med pipig stjelk.

Bäckar och kärr, allmän.

278. Ficária. Korståil.

1. F. ranunculóides Roth; blad skaftade, ofta med groddknoppar i bladvecken; blomskaft utdragna enblommiga. 2.

Inemot $1 / 2$ fot hög, saftig, glatt och ljusgrön med n. stjernlikt utbredda blommor.

Lundar, stundom ogräs i åkrar; Göt. a.: Dalsl. spr., Sv. spr.: Söd. Upl. a. Vestm. (i s. delen) t. r., Dal. 0, Norrl. Gestr. Hels.r.

\section{Ranúnculus. Solögon, Smörblommor.}

I. Alla blad platta eller med platta flikar. Blomskaft raka. Kronblad med fjällbetäckt (hos $R$. sceleratus bar) honingsgrop på klon. (Slägtet Ranunculus hos de flesta författare).

A. Kronblad hvita, stundom slutl. rödvioletta, längre än fodret. Karpeller $\mathrm{n}$. klotrunda och okantade, men med kölade sidor. 1. R. platanifolius. 2. R. glacialis.

B. Kronblad gula, kortare än fodret samt utan fjäll på klons honingsgrop. Karpeller äggformiga okantade. Fruktfäste (torus) långt utdraget. Rot enairig. 3. R. sceleratus.

C. Kronblad gula, längre än fodret (utom hos R.pygmaus). Karpeller hoptryckta och kantade. Fruktfäste föga utdraget. a. Alla hlad hela och n. helbräddade. 4. R. Lingua. 5. R. Flammula. 6. R. ophioglossifolius.

b. Rotblad (eller alla blad) helt och hållet delade (med åtskilda flikar). Foderblad slutl. nedböjda. 7. R. bulbosus. 8. R. Philonotis. 9. R. illyricus.

c. Blad helt och hållet delade. Foderblad utstående, ej nedböjda. 10. R. repens. 11. R. arvensis.

d. Blad med sammanhängande flikar. Foderblad icke nedböjda.

1. Stjelk krypande, liknande en rotstock. 12. R. Iappónicus.

2. Stjelk upprätt, vanl. flerbladig och flerblommig; de nedre bladen skaftade. Håriga växter. 13. R. acris. 14. R. polyanthemos.

3. Stjelk upprätt och vanl. flerblommig med flera oskaftade blad. Nästan glatta växter. 15. R. auricomus. 16. R. cassubicus.

4. Stjelk n. upprätt och vanl. enblommig med 1 eller 2 
oskaftade blad. Nästan glatta växter. 17. R. nivalis. 18. R. pygmæus.

II. Alla blad med platta och breda flikar. Blomskaft efter blomningen bågböjda. (Slägtet Batrảchium hos somliga författare).

A. Kronblad gula med fjällbetäckt honingsgrop på klon. 19. R. hyperboreus.

B. Kronblad hvita utan fjäll på klons honingsgrop. 20. R. hederaceus.

III. De nedre (eller alla) $i$ vattnet nedsänkta bladen delade med hårlika flikar, de flytande bredflikiga. Blomskaft efter blomningen bågböjda. Kronblad hvita utan fjäll på klons honingsgrop. (Batráchium Wimm.). 21. R. circinatus. 22. R. leiospermus. 23. $R$. aquatilis.

1. R. platanifólius L.; stjelk styf och upprätt; rotblad 5-7-delade; stjelkblad 3-7-delade; karpeller med krökt spröt (stift). 3.

Stjelk 1-2 fot hög, upptill grenig och mångblommig, med stora blad, som likna Stormhattens; blommor rent hvita, liknande Hvitsippor, sedan de små glatta och rödaktiga foderbladen bortfallit; blomskaft n. glatta och trådlika; skärmblad långspetsade och hela.

Bergsluttningar i fjellen r.; Norrl. Jtl. Herj., Sv. Dal.

2. R. glaciális L., Renblomma; stjelk mjuk, saftfull och uppstigande; rotblad 3-delade med åtskilda flikar; stjelkblad (skärmblad) 1-2 vid hvart blomskaft, vanl. 3delade; karpeller med rakt spröt. 1, 2.

Stjelkar omkr. fingerhöga och enkla, ofta enstaka, med en ensam blomma eller upptill delade i 2-4 (sällan flera) blomskaft; rotblad teml. små; foderblad stora brunulliga och qvarsittande; blommor omkr. en tum vida och n. klotformiga med snöhvita, snart rodnande och slutl. rödvioletta kronblad; blomskaft glatta och tjocka; skärmbladens flikar smala och n. hela.

Fuktiga, länge af snö betäckta ställen, högt upp i fjellen; Lpl. a. (âtm. i fjellregionen), Norrl. Jtl. Herj. spr.

3. R. scelerátus L., Tiggar-ranunkel; stjelk mjuk och pipig; de nedre bladen klufna, de öfre 3-delade med jemnbreda flikar; blomskaft fårade; foderblad nedböjda. 3 , 4 .

Glatt, saftfull och glänsande grön, ända till fotshög och mycket grenig, vanl. upprätt (sällan flytande på vattnet), med skaftade blad och mycket små blommor.

Dyiga ställen vid eller nära sjöar; Göt. t. a.: Boh. Dalsl. spr., Sv. t. a.: Verml. Dal. spr., Norrl. spr.: Ång. Vb. r. Med. Jt1.?, Lpl. r.

4. R. Língua L., Åmöja; stjelk upprätt, med rotskott; blad utdraget lansettlika längspetsade; blomskaft icke fårade; karpeller släta med krökt spröt. 3. 
2-4 fot hög med rotstock, stora blad och teml. stora blommor. Sjöar och ăar; Göt. t. r.: Hall. Sk. Ög. mångenst., Sv. spr.: Dal. r., Norrl. Gestr. Hels. Jtl. r.

5. R. Flámmula L., Ältgräs; stjelk uppstigande utan rotskott (sällan upprätt); blad lansettlika-jemnbreda, de nedre stundom äggrunda, alla med fort och tilltjocknad spets; blomskaft fårade; karpeller släta med föga krökt spröt. 3 .

Omkr. $1 / 2$ fot lång, stundom nedtill rotslående i stjelklederna; blommor mindre än hos föreg. art, rotstock smalare.

Fuktiga ställen, allmän: Ång. r. Vb. r.? Lpl. spr.

* R. reptans L.; stjelk trådsmal och krypande; blad n. jemnbreda och mycket smala; karpellernas spröt utdraget och upptill krökt; blommor mycket små.

Sjöstränder; Lpl. Norrl. Sv. mångenst., Göt. spr.

6. R. ophioglossifólius Vill.; stjelk upprätt utan rotskott; de nedre bladen utdraget hjertlika och trubbiga, de öfre aflånga; blomskaft finstrimmiga; karpeller knöliga, n. utan spröt. 2,3 .

Liknar något föreg. art, men har enårig rot; stjelk pipig; kronblad föga längre än fodret; de nedre bladen långskaftade, stundom svagt tandade.

Kärr, mycket r.; Göt. Gotl. nära Visby.

7. R. bulbósus L.; stjelk nedtill försedd med en lökformig knöl; blomskaft fårade; karpeller släta; fruktfäste hårigt. $2-3$.

Stjelk omkr. ${ }^{1 / 2}$ fot hög med utstående hår; bladflikar breda. Ängsbackar, helst i slättbygder; Göt. a.: Boh. Vg. spr. Dalsl. 0, Sv. Söd. Upl. a. Ner. t. a. Vestm. spr., Norrl. Gestr. spr. Hels. spr. s. om Ljusnan.

8. R. Philonótis Ehrh.; stjelk vanl. upprätt, stundom krypande, utan lökknöl; blomskaft fårade; karpeller knöliga; fruktfäste hårigt. 1-4.

${ }_{1 / 2}-1$ fot lång, luden och năgot lik föreg. art; rot enårig. Akkrar och ängar; Göt. Gotl. spr. Öl. t. r. Blek. spr. Sk. Boh.r. 9. R. illy'ricus L.; stjelk upprätt; blomskaft icke fårade; karpeller släta; fruktfäste glatt. 3 .

Omkr. en fot hög och hvitullig; rottågor knölformiga, n.aflånga; bladflikar smala helbräddade; blommor lika stora som hos Ran. Lingua.

Sandiga ställen; Göt. Öl. r. (Sv. Upl. Verml. förvildad).

10. $R$. repens L.; stjelk krypande (sällan upprätt); blomskaft fårade; karpeller släta; fruktfäste hårigt. 3.

Stjelk omkr. fotslång, glatt eller hårig.

Fuktiga ställen, åkrar och ängar, allmän utom fjellen; $i$ Lp]. trol. blott som ogräs. 
11. R. arvensis L., Akerranunkel; stjelk upprätt; blomskaft icke fårade; karpeller taggiga; fruktfäste hårigt. $2,3$.

$1 / 2-1$ fot hög och n. glatt med enårig rot; karpeller stora och få med långt, n. rakt spröt; småblad smalfikiga; blommor teml. små.

Akrar; Göt. Gotl. Öl. a. Hall. Sk. spr. Blek. Smål. r. (Ög. tillfällig), $S v$. Söd. Upl. r.

12. R. lappónicus L.; stjelk (rotstock) dold i jorden (eller mossan) och utsändande långskaftade, njurlika och djupt klufna blad; skärmblad kortskaftadt och 3-klufvet med $n$. helbräddade flikar; kronblad något längre än fodret. 2.

Blomskaft enblommiga, omkr. fingerhöga; stjelkblad teml. stora med naggade flikar; blommor knappt så stora som hos Ran. Flammula; foderblad glatta, stundom öfvergående till kronblad; karpeller med bihang upptill samt med krökt spröt.

Sumpiga ställen, helst bland hvitmossa vid kallkällor i fiellens skogsregion, sällan nedanför fjellen; Lpl. spr., Norrl. Vb. r. Ång. spr. Med. r. Jtl. spr. Herj. r., Sv. Dal. r.

13. R. acris L.; de öfre bladen föga utvecklade med fa och smala flikar; blomskaft icke fårade; fruktfäste glatt; de nedre bladen delade n. till basen. 2-4.

1-2 fot hög med tilltryckta hår på blomskaften och stjelkens öfre del; de nedre bladens flikar korta och vanl. spetsiga. Är i fjellen ofta enblommig och låg med små blad med trubbiga flikar.

Ängar, allmän.

* R. Friesii Gren.; alla blad nästan likformiga, de nedre djupt klufna; eljest som hos hufvudarten. 3.

liknar något följ. art och är lätt förbisedd; stjelkens nedre del jemte de nedre bladskaften hafva vanligen utstående hår; de nedre bladens flikar äro bredare än hos hufvudarten, de flesta bladen starkt ludna.

Ängar r.; Göt. Sk. Gotl. Ög., Sv. Upl.

14. R. polyánthemos L.; alla blad n. likformiga; blomskaft färade; fruktfäste styfhairigt; de nedre bladen delade n. till basen. 3 .

Stjelk omkr. 2 fot hög med utstående hår; bladens småflikar smala.

Ängar; Göt. t. r.: Öl. a. Ög. mångenst., Sv. spr.: Ner. t. r. Dal. r. Verml. 0, Norrl. Gestr.-Ang. r.

* R. nemorósus D.C.; de nedre bladen djupt klufna. 3. Liknar hufvudarten, men är lägre med bredflikiga rotblad. Ängar och åkerrenar; Göt. Gotl. mångenst. Ög. r.

15. R. aurícomus L.; rotblad glatta eller i kanten håriga, njurlika, vanl. talrika och flikiga, med slidbärande 
skaft; stjelkbladens flikar jemnbreda och talrika; blomskaft icke fårade; fruktfäste glatt. 1-4.

Omkr. fotshög; de första blommorna vanl. kronlösa; karpeller ludna; stjelkbladens flikar vanl. belbrädddade. Ängar, allmän: Lpl. spr.

16. R. cassúbicus L.; rotblad undertill finludet, vanligen ensamt och naggadt med slidlöst skaft inom en bladlös slida; stjelkbladens flikar teml. breda och jemnbredt lansettlika, vanl. tandade; alla blommor vanl. med kronblad; eljest som föreg. art. 2. Gestr.

Ängar r.; Göt. Smål. Ög., Sv. Upl. Vestm. Verml., Norrt.

17. R. nivális L.; rotblad njurlika, vanl. 3-flikiga; stjelk-

blad delade i aflånga flikar; kronblad längre än fodret. 1.

Under blomningen omkr. fingerhög, slutl. inemot fotshög med teml. små (ej tumsbreda) blad; blommor lika stora som hos Ran. acris; foder brunulligt; de föga hoptryckta karpellernas spröt utdraget och i början rakt.

1 fjellregionen på af snövatten fuktiga ställen; Lpl. spr., Norrl. Jtl. r.

18. R. pygmæus Wahlenb.; rotblad njurlika, vanl. 3-de-

lade; stjelkblad delade i smala flikar; kronblad knappt så långa som fodret. 1, 2.

I början 1-2 tum hög, liknande små exemplar af Ran. sceleratus och med lika sinå hlommor, men vid fruktmognaden lik föreg. art, ehuru spensligare och något lägre; foder $n$. glatt; de föga hoptryckta karpellernas spröt krökt och mycket kort.

På fuktig jord högt upp i fjellen; Lpl. a., Norrl. Jtl. Herj. spr. 19. R. hyperbóreus Rottb.; alla bladen skaftade, njurlika och klufna i 3 flikar; kronblad af fodrets längd; fruktfäste glatt. 2,3 .

Ända till $1 / 2$ fot lång med krypande stjelk; frukter rundade med mycket kort spröt; kronblad 2-3; standare omkr. 5 ; blommor något mindre än hos föreg. art. Batrachium hyperboreum Kindb. (N. Sv. Flora).

Sumpiga ställen, teml. högt upp i fjellen; Lpl. spr., Norrt. Jtl. Vb. r., Sv. Dal. r.

20. R. hederáceus L.; kronblad något längre ån fodret; eljest som föreg. art. 3.

Liknar föreg. art, men har något större blommor och blad samt hvita kronblad; frukter slutl. utan spröt; kronblad vanl.5; ståndare 10; stjelk stundom flytande.

Kärr och vattenpölar nära hafvet; Göt. Boh.-sk. Gotl. r.

21. R. circinátus Sibth.; stjelk Kantig; blad med rund omkrets; frukter håriga; ståndare längre än pistillerna. 3.

Omkr. 1-2 fot lång med teml. fin stjelk och långa blomskaft; blommor teml. stora med breda kronblad; alla blad ned- 
sänkta, n. erggröna och oskaftade med styfva och korta flikar, samt omkr. tumsbreda eller mindre; frukternas spröt utdraget; fruktfäste hårigt och klotrundt.

Sjöar och åar; Göt. spr.: Smål.? Öl. Gotl. Boh. Dalsl. 0, Sv. söd. Upl. t. a. Vestm. Ner. spr. Dal. r., Norrl.' Gestr. Hels. r.

22. R. leiospermus Wallr.; stjelk trind; nedsänkta blad med kantig omkrets; frukter vanl. glatta; ståndare kortare än pistillerna. 3,4 .

Ofta 5-6 fot lång med grof och benhvit stjelk och mycket långa blomskaft; de nedsänkta bladen n. oskaftade och styfva; fruktfäste kägellikt och vanl. hårigt.

a. R. marinus Fr.; flytande blad (sällan utvecklade) vanl. kortskaftade; kronblad teml. stora och breda med gul klo.

Helst i grunda hafsvikar; i Östersjön t. a., dock vid Gotl. r.; i Bottn. viken r. i Gestr. Hels. Ang.; i sött vatten r., t. ex. vid Norrtelje, Stockholm och Landskrona.

b. R. hololéucos Lloyd; flytande blad (n. alltid utvecklade) långskaftade; kronblad smärre och alldeles hvita.

Göt. Skåne vid Skanör (enl. S. A. Tullberg).

- confúsus (Schulz) Godrr.; blommor större med gul klo.

Nära hafvet i bräckt vatten eller i hafvet r.; Göt. Sk. vid Malmö (Tullberg) Blek. v. om Carlskrona vid Ramsö (J. Ankarcrona) Smål. nära Vestervik (Prof. A. F. Holmgren).

23. R. aquátilis L. (Tullb.), Vunlig Vattenranunkel; stjelk kantig; nedsänkta blad med liantig omkrets; frukter vanl. håriga; ståndare längre än pistillerna; fruktfäste hårigt. 2,3 .

a. R. peltátus Fr.; flytande blad (sällan felslående) vanl. flikiga; blomskaft mycket (vanl. flera tum) långa; nedsänkta blad vanl. skaftade och styfva; ståndare talrika; blommor teml. stora.

Helst i rinnande vatten; Lpl. Norrl. Sv. a.?, Göt. spr.

- truncátus (Dum.); nedsänkta blad n. oskaftade.

Göt. Skåne t. a. (Tullberg); eljest t. r.?

b. R. paucistamíneus Tausch; flytande blad (ofta felslående) vanl. delade; blomskaft korta (omkr. tumslånga); nedsänkta blad stundom oskaftade och slaka; ståndare få; blommor teml. små.

Helst i sött vatten; Göt. spr.: Ög. r. Öl. Gotl. Hall.?, Sv. t. r.: Verml. Dal.?

- trichophyllus (Chaix); alla blad nedsänkta och styfva; blommor något större.

I sött vatten t. a., i nordligare trakter trol. mindre vanlig. 
226 XIII. polyandria. 280,281. XIV. Didyamia. 282, 283.

- fiáccidus (Pers. enl. Tullb.); alla blad nedsänkta och slaka; blommor små; stjelk smal. Göt. vid Landskrona (Tullberg).

- confervóides (Fr.); alla blad nedsänkta och slaka; blommor mycket små; stjelk trådlik, sällan mer än en fot lăng; frukternas spröt otydligt. Helst i sött vatten i nordligare trakter; Lpl. spr., Norrl. t. r., Göt. Ög. i Tåkern och Vettern.

280. Adónis. Gossen $i$ det gröna.

1. A. vernális L.; stjelk nedtill fjällig. 1,2.

I början 3-4 tum, slutl. omkr. en fot hög med rotstock; blommor ett par tum vida; kronblad tumslånga; frukter af hampfröns storlek.

Kalkklippor; Göt. Öl. spr. Gotl. r.

281. Tróllius. Bullerblomster, Smörbollar.

1. T. europæus L.; de nedre bladen långskaftade, de öfre oskaftade. 2.

Omkr. 2 fot hög och upprätt med mörkgröna, glänsande och mer än tumsbreda blad.

Fuktiga ängar; Lpl. a., Norrl. spr.: Jtl. t...r. Med. -Gestr. r., Sv. spr.: Ner. t. a. Upl. Dal. t. r., Göt. spr.: Ög. Sk. a. Gotl. 0.

\section{Klassen. DIDYNAMIA.}

\section{Ordn. GYMNOSPERMIA.} 282. Verbéna. Jernört.

1. V. officinalis I.; de nedersta bladen aflanga-lansettlika; kronpip något krökt. 4.

Omkr, fotshög med sträfva blad.

Ruderatväxt, mycket r.; Göt. Sk. Hall.

283. Mentha. Mynta.

A. Blomkransar sammanflytande till bladlösa ax i spetsen af stjelken eller grenarne. Blad n. oskaftade.

1. M. silvestris L.; blomkransar sammanfytande; skärmblad och fodertänder jemnbredt syllika; blad oskaftade ovala-aflånga och skrynkliga. 3, 4 .

2-4 fot hög och mjukt gråluden; blad sågtandade med inböjda sågtänder; blommor hvitröda.

Bäckstränder och källdrag; Göt. Sk. t. r. Snıål. Ög. Öl. Gotl. Vg. r. (Sv. Upl. förvildad).

2. M. víridis L.; de nèdre blomkransarne åtskilda; blad n. oskaftade, lansettlika; eljest som föreg. art. 3, 4 . Liknar föreg., men är spensligare och vanl. glatt; bladens sågtänder något utstående; blommor ljusröda eller violetta.

Ruderatväxt på fuktiga ställen r., kanske förvildad; Göt. Sk. Smål. Ög. Öl. Gotl. 
B. Blomkransar atskilda och stödda af blad. Blad skaftade, åtminstone de nedre.

a. Fodertänder lansettlikt syllika och utdragna (sällan korta).

3. M. gentílis L.; blomfoder ofäradt och smalt, nästan klocklikt, upptill hårigt, nedtill jemte skaftet glatt; stjelk med blad äfven i spetsen. 3,4 .

Omkring fotshög eller deröfver och vanl. mycket grenig; blad äggrunda-aflånga, de öfre med kort eller intet skaft; blomkransar talrika, före utslagningen gråludna.

Ruderatväxt på fuktiga ställen och ogräs i åkrar; Göt.t.r., Sv. t. r.: Vestm.? Dal. 0, Norrl. Hels. Jtl. r.

4. M. aquática L.; blomfoder färadt och n. rörformigt, jemte skaftet hårigt, upptill slutl. glatt; stjelk utan blad i spetsen. 3,4 .

Stundom höorre än föreg. art och vanl. enkel; blad ovalaäggrunda skaftade; blomkransar vanl. få (stundom ett enda hufvud), ej gråludna före blomningen.

Vid och på stränder; Göt. spr.: Gotl. Öl. Sk. Hall. a. Dalsl. r. Vg. r.?, Sv. r.: Söd. Upl. spr., Norrl. Gestr. Hels. Ång. r.

* M. satíva (L.) Fr.; stjelk med blad äfven i spetsen; blomkransar talrika och ofta skaftade samt före blomningen gråludna.

Liknar mycket $M$. gentilis.

Bäckstränder och fuktiga åkrar; Göt. t. r.: Sk. a., Sv. Söd. Upl. spr. Ner. Verml. r., Norrl. Gestr. Ång. r.

b. Fodertänder bredt triangelformiga och korta.

5. M. arvensis L., Hästmynta; blomfoder ofåradt, vidgadt klocklikt och hårigt; stjelk med blad äfven i spetsen. 3,4 .

Vanl. omkr. $1 / 2$ fot hög, stundom högre och föga grenig; blad ovala-aflånga och skaftade; blomkransar talrika och glest sittande, något gråludna före blomningen. Blommar tidigare och har mindre god lukt än de föreg. arterna.

Fuktiga ängar och åkrar, stundom i vatten, allmän: Lpl.r. - agrestis (Sole); blad breda och n. hjertlika; blomkransar närsittande.

Åkrar; Göt. Sk. t. r. Blek. r.

Anm. Alla arterna hos detta slägte (liksom åtskilliga andra Labiater) kunna hafva antingen större blommor (hanblommor) med utskjutande ståndare och utan mogna frukter, eller mindre och fruktbärande blommor (honblommor) med inneslutna ståndare.

\section{A'juga. Blåsugi .}

A. Rotblad kortskaftade; stjelkblad (omkr. dubbelt) längre än blommorna.

1. A. pyramidális L.; blomkransar vanl. sammanflytande. 1, 2 . 
Omkr. $1 / 2$ fot hög och korthårig, med uppåt i storlek aftagande blad; rotblad qvarsittande, omvändt äggrunda; vanligen utan ..grenskott.

Ängar: Göt. Sv. a.; Norrl. spr.: Vb. r., Lpl. r.

- glabráta; nästan glatt; stundom med korta grenskott. Göt. Blek. t. r. Smål. Boh. r.

B. Rotblad utdraget skaftade; de öfre bladen kortare än blommorna.

A. reptans L.; nästan glatt; rotblad qvarsittande. 2.

Något högre än föreg. art och ofta försedd med långa grenskott; rotblad mycket trubbiga och vanl. omvändt äggrunda; de öfre blomkransarne sammanflytande.

Fuktiga skuggrika ställen r.; Göt. Boh.-Sk. Blek. Smål. Gotl.

3. A. genevensis L.; ullhårig; rotblad upprätta, vid blomningen vissnade. 3 .

Omkr. $1 / 2$ fot hög eller lägre, utan grenskott; rotblad aflånga; de flesta blomkransarne åtskilda.

På kritformation, mycket r.; Göt. Skåne mellan Malmö och Trelelorg, ymnigt.

\section{Téucrium. Lacklök}

1. T. Scórdium L.; blad oskaftade aflånga och djupt naggade, de öfre mot basen helbräddade och afsmalnande. 3,4 .

Från några tum till en fot hög och mycket bladig med mjukt gråludna, stundom rodnande eller violetta blad.

Fukt. ställen på sillur. form.; Göt. Sk. (i s. och s. v. delen) spr. Öl. a. Gotl. spr. Ög. r. nära Vettern.

\section{Oríganum. Dosta.}

1. 0 . vulgare L.; blomskärmar n. ovala; blad äggrunda skaftade. 3 .

Omkr. 2 fot hög och upprätt; blomhufvud stälda $i$ upprepadt tregrenig vippa; blomkrona dubbelt längre än fodret.

Berg; Göt. spr.: Sk. t. a. Gotl. t. r., Sv. Söd. Upl. t. a. Vestm. spr. Ner. Verml. r., Norrl. Gestr. spr. Hels. Jtl. r.

287. Népeta. Kattmynta.

1. N. Catária L.; foder krökt, med olikstora tänder; kronpip mycket kort; blad teml. långt skaftade, hjertlika och grofsågade. 3,4 .

Omkr. 2 fot hög, upprätt och ofta grenig.

Ruderatväxt, helst i slättbygder; Göt. spr.: Öl. a. Gotl. t. r. inre Smål. Boh. Dalsl. r. Vg. r.?, Sv. r.: Söd. Upl. spr. Dal. 0. 288. Glechóma. Jordrefva.

1. G. hederácea L.; blad skaftade, njurlika och naggade. $1,2$.

Föga hårig; de blombärande grenarne upprätta och omkr. $1 / 2$ fot höga; blommor få och ensidigt stälda.

Steniga ställen, t. ex. i lundar; Göt. Sv. a., Norrl. spr.: Gestr.-Med. a. Vb. 0. 


\section{Galeópsis.}

A. Stjelk styfhårig, uppsväld under lederna; blomkransar upptill sammanflytande; bladskaft utdragna.

1. G. versícolor Curt., Hampört; blomkrona ljusgul med violettfläckig underläpp; kronpip dubbelt längre än fodret. 3.

Omkr. fotshög med större blommor än hos de öfriga arterna; blad vanl. äggrunda med nästan vigglik bas.

Ruderatvẩxt och ngräs i åkrar, allmän: Gotl. t. r.

2. G. Tétrahit L.; blomkrona röd eller hvitgul med mörkfläckig underläpp; kronpip ej längre än fodret. 3.

Vanl. något lägre än föreg. art, som den mycket liknar.

Ruderatväxxt och ogräs i åkrar, äfven på berg, allmän.

- bífida; kronans underläpp med smalare och urnupen mellanflik.

Nästan lika vanlig som hufvudarten.

* G. pubescens Bess.; kronpip längre än fodret; stjelk mindre styft hårig; blomkrona röd.

Berg r.; Göt. Sk. Smål. Ög., Sv. Upl. Vestm., Norrl. Herj. B. Stjelk mjukluden, ej uppsväld under lederna; blomkransar åtskilda; bladskaft korta.

3. G. Ládanum L.; blomkrona röd: pipen dubbelt längre än fodret. 3.

Omkr. $1 / 2$ fot hög med rödaktig stjelk och smalare blad än hos de föreg. arterna.

Ruderatväxt och ogräs i åkrar, helst i slättbygder; Göt. spr.: Gotl. Öl. Sk. t. a. Boh. t. r., Sv. spr., Norrl. Gestr. spr. Hels. Jtl. $\mathrm{r}$.

\section{Lámium. Plister.}

A. Blommor hvita; blad spetsiga och grofsågade.

1. L. album L., Hvitplister, Blindnässla; alla bladen skaftade och äggrunda-hjertlika; blomskärmar små, hårkantade och syllika; rotstock utdragen. 2, 3.

Omkr. fotshög med större blommor än hos de öfriga arterna.

Ruderatväxt, helst i slättbygder; Göt. a.: Gotl. inre Smål. Boh. Dalsl. r. Vg. r.? Ög. spr., Sv. r.: Söd. Vestm. a. Upl. spr. Norrl. Gestr. Hels. Ang. r.

B. Blommor röda; blad vanl. trubbiga och naggade, stundom inskurna. Med enårig pålrot.

a. Alla bladen skaftade. Blomskärmar syllika.

2. L. purpúreum L., Rödplister; blad hjertlika; kronpip öfverskjutande fodret. $1-4$.

Omkr. $1 / 2$ fot hög och vanl. ljusgrön med vanl. tätt sittande blomkransar.

Ogräs; Göt. Sv. a., Norrl. spr.: Gestr. Hels. Jtl. a.

* L. confertum Fr.; blomstödjeblad äggrunda med vigg- 
lik bas, vanl. inskurna; kronpip knappt öfverskjutande fodret. 1-4.

Ogräs; Göt. spr.: Öl. Sk. Hall. a. Vg. Boh. Dalsl. t. r., Sv. spr.: Dal. 0.

3. L. intermédium Fr.; blomstödjeblad njurlika med kort och bredt skaft; kronpip kortare än fodret. 1-4.

Liknar föreg. art, men har oftare åtskilda blomkransar och större, längre och mera utstående fodertänder.

Ogräs, helst i slättbygder; Göt. spr.: Sk. t. a. Blek. Hall.Dalsl. r. Öl ?, Sv. spr.: I)al. r., Norrl. Gestr. Hels. Ång. Jtl. r.

b. Blomstödjeblad oskaftade. Blommor utan skärmar. 4. L. amplexicáule L.; blad njurlika. 1-4.

Spädare än de föreg. arterna. Blomkransar åtskilda; fodertänder samstående och teml. korta; blomkrona antingen med lång pip och öppet bräm eller med kort pip och slutet bräm.

Ogräs; Göt. Sv. a., Norrl. spr., Lpl. r.

\section{Leonúrus. Bonässla.}

1. L. Cardíaca L.; de nedre bladen hjertlika 5-flikiga, de öfre vigglika och upptill 3-klufna. 3.

2 fot hög eller deröfver, upprätt; blad skaftade och undertill hvitludna; blomkransar tätblommiga.

Ruderatväxt, helst i slättbygder; Göt. spr.: Gotl. t. r. Öl. Sk. a. Hall.-Dalsl. t. r., Sv. spr.: Söd. Upl. t. a. Verml. Dal. t. r., Norrl. Gestr. r.

\section{Galeóbdolon. Gulsuga.}

1. G. lúteum (Willd.) Huds.; de nedre bladen bredt hjertlika trubbiga, de öfre äggrunda. 1, 2.

1-2 fot hög och hårig med crrofsågade blad och 6-blommiga blomkransar. Liknar en Galeopsis.

Löfskogar; Göt. Sk. a. Blek. Smål. r. Ög.?

$$
\text { 293. Stachys. Syska. }
$$

A. Med rotstock; blomkrona dubbelt längre än fodret; blommor med n. syllika skärmar; de öfre blomkransarne axlikt förenade och bladlösa.

1. S. silvática L., Stinknässla; blad långskaftade, hjertlika och spetsiga. 3 .

2-4 fot hög, upprätt och sträfhårig med mycket breda blad; kronbräm brunrödt; kransarnes stödjeblad teml. små.

Ruderat- och lundväxt; Göt. spr.: Sk. a. Boh. t. r., $S v$. spr.: Söd. Upl. t. a. Dal. t. r., Norrl. spr.: Ang. r. Vb. 0 .

2. S. palustris L., Svinknyler; blad n. oskaftade, lansettlika med något hjertlik bas. 3 .

Omkr. 3-4 fot hög, upprätt och luden, med ljusröda blommor; blomfoder finludet; rotstockens grenar i spetsen uppsvälda.

$\mathrm{P} a ̊$ och vid stränder af sjöar och åar, trol. något $\mathrm{r}$, t. ex. Sk. Ög. Gotl.

- agrestis; lägre och mera gråluden, isynnerhet på bladens undra sida; blomfoder gråulligt; blad smalare. 
r. $\mathrm{Vb} .0$.

Ogräs i åkrar; Göt. a.: Gotl. t. r., Sv. a., Norrl. spr.: Ång.

B. Rot enårig; blomkrona föga längre än fodret; blommor i skilda kransar i bladvecken utan skärmar. 3. S. arvensis L., Åkersyska; blad skaftade, bredt äggrunda trubbiga, de nedersta med hjertlik bas. 3.

Omkr. fotshög eller ofta lägre, n. upprätt och sträfhårig; blommor små, hvita och rödprickiga eller blekvioletta. Liknar något en Galeopsis.

Sandiga åkrar; Göt. Boh. r. Hall. t. r. Sk. mångenst. Blek. t. r. Smål. r., Sv. Upl. r.

\section{Ballóta. Andorn.}

1. B. ruderális Sw., Svart Andorn; fodertänder afsmalnande mot det med dem lika långa borstet; blad bredt äggrunda med n. hjertlik bas, skaftade. 3, 4 .

2-3 fot hög, upprätt och grenig; blad mjukludna; blomskärmar syllika.

Ruderatväxt; Göt. r: Gotl. Öl. Sk. a. Blek. spr. Dalsl. 0, Sv. Upl. r. (Norrl. Hels. tillfällig).

\section{Betónica. Humlesuga.}

1. B. officinalis L.; blad naggade aflånga-äggrunda med hjertlik bas. 3 .

Stjelk 1-2 fot hög och enkel med styfva nedböjda hår; de flesta blomkransarne axlikt sammanflytande; de nedersta bladen långskaftade. Liknar något Stachys palustris.

Ängar bland liuskar, mycket r.; Göt. Sk. flerst. i v. skogsbygden, Sv. Upl. i Sollentuna.

296. Marrúbium. Hvit Andorn.

1. M. vulgare L.; blad skaftade, rundadt ovala och ojemnt naggade, de öfre nedlöpande på skaften. 3, 4.

Omkr. 2 fot hög, upprätt och grenig, särdeles nedtill, med mycket skrynkliga blad.

Ruderatväxt, helst i slättbygder; Göt. spr.: Öl. a. inre Smål. Hall. Boh. t. r. Vg. t. r.? Dalsl. 0, Sv. Söd. spr. Upl.t.r. Vestm. Ner. r.

297. Scutellária. Gctnosটlomma, Frossört.

1. S. galericuláta L.; blad fint naggade, lansettlika-aflånga med hjertlik (sällan spjutlik) bas; blommor något kortare än bladen, enstaka i bladvecken. 3 .

$0 \mathrm{mkr} .1$ fot hög; kronpip småningom utvidgad; blad och blommor kortskaftade och glest sittande.

Stränder; Göt. Sv. a., Norrl. spr.: Gestr. Hels.t. a., Lpl.t.r.

2. S. hastæfólia L.; blad helbräddade och aflånga, vanligen med spjutlik bas: de öfre skärmlika och aftagande $\mathrm{i}$ storlek; blommor längre än skärmbladen, närsittande i ett kort ax. 3,4 .

Omkr. $1 / 2$ fot hög; kronpip upptill mycket utvidgad; blomfoder med glandelhår. 
Stränder vid Östersjön och Mälaren, sällan vid Kattegat; Göt. Öl. t. a. Gotl. Blek.-Ög. spr. Hall. r., Sv. Söd. Upl. spr. Vestm. t. r.

298. Prunella. Brunört, Skogshumle.

1. P. vulgaris L.; blomfodrets öfverläpp bred med åtskilda, breda, tvärhuggna och kortuddiga tänder, underläpp till midten klufven. 3 .

Stjelk omkr. ${ }^{1 / 2}$ fot hög, stundom grenig; blad äggrundt aflånga skaftade; blommor vanl. blå; ax nedtill ofta försedt med ett par blar, skärmblad bre丸a och n. runda, tvärt afsmalnande till en kort spets; blomfoder brunt.

Betesmarker, allmän utom fjellen: Lpl. r.

2. P. grandifóra L., Storblommig Brunört; blomfodrets öfverläpp med närsittande syllika tänder, underläpp inskuren ofvan midten. 3 .

Något större än föreg. med större, vanl. violetta blommor; ax vanl. skildt från bladen; hlomning senare.

Betesmarker; Göt. Gotl. a. Öl. t. a. Vg. r., t. ex. Kinnekulle och Ålleberg.

\section{Dracocéphalum. Draknos.}

1. D. Ruyschiána L.; blad jemnbredt lansettlika, trubbiga och helbräddade; blomskärmar hela. 3.

Fotshög, upprätt och n. glatt med tumslånga blommor och $1^{1} / 2$ tum långa, omkr. en linie breda blad.

Torra ängsbackar, mycket r.; Göt. Smål. Ög. Vg., Sv. Vestm. 300. Clinopódium. Bergmynta.

1. C. vulgare L.; blad äggrunda, grundt naggade och kortskaftade; blomskärmar kortare än fodret. 3 .

Stjelk enkel och fotshög utan blad i spetsen; foder och skärmblad mycket håriga.

Lundar och berg; Göt. mångenst.: Gotl. Sk. Dalsl. t. a. Boh. r., Sv. spr.: Verml. t. r. Dal. 0. Norrl. Gestr.--Med. r. Ang.? 301. Calamintha. Harmynta.

1. C. A'cinos (L.) Clairv.; blad aflånga skaftade och ofvan midten grundt sågade; blomskärmar vanl. 6-blommiga. 3 .

Stjelk nedliggande, men icke rotslående, med fingerhöga, uppstigande och korthåriga grenar; blomfoder fåradt och med utstående hår samt med svalget slutet af hår.

Berg- och ruderatväxt, stundom ogräs $i$ åkrar, helst i slättbygder; Göt. mångenst.: Öl. Gotl. Sk. a., Sv. t. a.: Verml. Dal. t. r., Norrl. Gestr.-Med. mångenst. Ång. Jtl. r., L $p l$. r.

302. Thymus. Backtimjan.

1. T. Serpyllum L.; stjelk krypande med tätt sittande och upprätta grenar; blad omvändt äggrunda eller tunglika, nästan oskaftade och i kanten håriga, med upphöjda nerver. 3 . 
Bildar låga och täta tufvor; stjelk rundtomkring hvitluden.

Torra backar, helst i slättbygder; Göt. a : Boh. Dalsl. t. r. Ög. mångenst., $S v$. t. a.: Verml. Dal. t. r., Norrl. Gestr.-Vb. r. 2. T. Chamædrys Fr.; stjelk uppstigande (blott nedtill rotslånde); blad bredt ovala, tydligt skaftade, i kanten icke håriga, med otydliga sidonerver. 3.

Föga tufvad med omkr. fotslånga, på 2 eller 4 kanter håriga stjelkar, större blad än hos föreg. art och nedtill åtskilda blomkransar.

Torra hackar; Göt. Boh. r. Smål. Blek. spr. Ög. Gotl. r., Sv. Söd. Upl. r., Norrl. Ång. r.

\section{Ordn. ANGIOSPERMIA.}

303. Linnæa. Iinnéa, Myrtogor.

1. L. boreális L.; blad kortskaftade, n. runda och naggade; blomkrona inuti hårig. 2 .

Stam 2 fot lång eller deröfver med fingerhöga grenar.

Äldre barrskog a., sålunda t. r. i slättbygderna samt i Blek. 304. Limosella. Dyört.

1. L. aquática L.; blad aflånga trubbiga. 3 .

Umkr. tumshög, ljusgrön och glatt; blommornas skaft kortare än bladens.

Vid och på stränder, helst vid sjöar, stundom vid åar; Göt. spr.: Gotl. Blek. inre Smål. r., Sv. spr., Norrl. spr.: Ång. Vb. r. Jtl.?, Lpl. r.

\section{Lathræa. Fjällrot.}

1. L. squamária L.; rotstock grenig. 1.

Omkr. ${ }^{1 / 2}$ fot hög, mycket tidigt blommande.

Lundar (på Hassel och Al); Göt. spr.: Gotl. Blek. Hall. Boh. r., Sv. spr.: Verml. Vestm. r. Dal. 0, Norrl. Gestr. r.

306. Orobánche. Snyltrot.

1. O. major L.; ståndaresträngar håriga, fästade nedom kronpipens midt; de större foderflikarne något hopväxta. 3,4 .

1-2 fot hög med ljusbruna blommor; stam tjockare än en skrifpenna.

Parasit på Centaurea Scabiosa och C. Jacea, mycket r.; Göt. Sk. Hall.

2. O. Círsii Fr.; ståndaresträngar glatta, fästade nära kronans bas; foderblad åtskilda. 3, 4 .

Med blekgula blommor och smalare stam än hos föreg.

Parasit på Cirsium heterophyllum, ytterst r.; Göt. Vg. på Mösseberg (Mathesius)'.

307. Scrophulária. Flenört.

1. S. nodósa L.; rotstock knölig; blad glatta; blommor i vippa; blomkrona med ämne till en femte ståndare. 3. 
Stjelk 2-3 fot hög och nedtill glatt, men med klibbhåriga vippgrenar; blad skaftade, $n$. triangelformiga och grofsågade med ovingade skaft; foderflikar breda, n. runda; växten mörkgrön.

Ruderatväxt påa steniga ställen; Göt. a., Sv. a.: Dal.r., Norrl. Gestr. spr. Hels. - Ång. r.

2. S. vernális L.; klibbhårig; rot tvåårig; blommor i knippen i bladvecken; ståndare fyra. 2 .

Liknar föreg., men är ljusgrön; blad med hjertlik bas; foderflikar aflånga utan hinnkant.

Ruderatväxt; Sv. Upl. t. r., Göt. Smål. Sk. r.

308. Linária. Sporreblomma.

1. L. vulgáris Mill., Flugblomster; blommor i axlik och bladlös klase; stjelkblad spiralstälda, tätt sittande, oskaftade och glatta. 3 .

Stjelk fotshög och glatt med omkr. liniebreda och blågröna, jemnbredt lansettlika och spetsiga blad; blomkrona maskerad, ljusgul med brandgul gom; blomskaft glandelhåriga, kortare än fodret. Har något stinkande lukt.

Har stundom $n$. regelbunden krona med 5 ståndare och 5 sporrar. Ång. Vb. r.

Ogräs i åkrar och ruderatväxt; Göt. Sv. t. a., Norrl. spr.:

2. L. minor (L.) Desf.; blommor n. ensamma $i$ de öfre bladvecken; stjelkblad glest sittande och klibbhåriga, de nedre motsatta. 3 .

Omkr. 1/2 fot hög, spenslig, klibłhårig och vanl. mycket grenig med mycket smala, mörkgröna, lansettlika och trubbiga blad; blommor smâ och violetta med blekgul underläpp och nå. got öppet svalg.

Ruderatväxt och ogräs i åkrar; Göt. Sk. Öl. spr. Gotl. Dalsl. r. Blek.-Ög. t. r., Sv. Söd. Upl. t. r. Ner. Vestm. r., Norrl. Gestr.-Ång. Jtl. r.

3. L. Elatíne (L.) Desf.; blommor ensamma i bladvecken; blad spiralstälda, glest sittande och äggrunda, de öfre med spjutlik bas. 3,4 .

Stjelk nedliggande, grenig och omkr. $1 / 2$ fot lång; hela växten (utom blomskaften) finluden; blad åtm. 1/2 tum breda, de nedre tandade; blommor små och gula med violett öfverläpp och slutet svalg. Påträffas lättast, sedan säden blifvit afmejad.

I åkrar; Göt. Sk. spr. Gotl. r.

309. Antírrhinum. Lejongap, Skalleblomma.

1. A. Oróntium L.; blommor kortskaftade i de öfre bladvecken; de öfre bladen spiralstälda, de nedre motsatta. 3,4 .

Stjelk $1 / 2-1$ fot hög och upprätt, upptill klibbhårig, nedtill långhårig; blad glatta; fröhus stort och hărigt; foderflikar längre än den nära en tum långa kronan.

Åkrar r.; Göt. Gotl. Öl. Smål. Blek. Sk. (Sv?. Söd. förvildad). 
310. Melámpyrum. Kovall.

A. Blommor tätt sittande i ax, ătminstone de öfre; blomskärmar högfärgade.

1. M. cristátum L., Korsört; blomskärmar hjertlikı hopvikna, med långa tänder; ax tätt, kort och fyrkantigt; kronpip dubbelt längre än fodret. 2,3 .

$1 / 2$ fot hög, finhårig och upptill grenig med jemnbredt lan. settlika blad; blomskärmar tuppkamlika; hlommor purpurröda med gul mynning (då blomskärmarne äro brunröda) eller hvitgula liksom hlomskärmarne; frön $2 \mathrm{i}$ hvarje rum.

Torra ängar, helst i slättbygder; Göt. t. a.: inre Smål. spr. Boh. t. r. Dalsl. 0, Sv. spr.: Vestm. blott i s. delen, Verml. Dal. 0 , Norrl. Gestr. r.

2. M. arvense L., Kråkhvete; blomskärmar lansettlika, platta och parflikiga; ax teml. tätt och aflångt; kronpip af fodrets längd. 2,3 .

Omkr. fotshög, kort sträfhårig och grenig med smalt lansettlika blad; blomskärmar röda; blommor purpurröda upptill och nedtill, pả midten hvitgula; frö ett i hvarje rum och liknande hvetekorn.

Ogräs i åkrar i slättbygder, sällan i skogsbygder; Göt. Gotl. a. Öl. Ög. mångenst. Smål. Blek. t. r. Sk. Hall. spr. Boh. Vg. r., Sv. Söd. Upl. mångenst. Vestm. $\mathrm{r}$.

3. M. nemorósum L., Landknektar, Natt och dag; blomskärmar hjertlikt lansettlika, platta och inskurna; de nedre blommorna åtskilda från de öfre; kronpip af fodrets längd. $2,3$.

Mer än fotshög, finhårig och grenig med lansettlika skaftade blad; öfre blomskärmar himmelsblå; blommor vågrätt utstående och $n$. brandgula: frö vanl. ett i hvarje rum.

Ängar och lundar, helst nära hafvet och vid Mälaren: Göt. Hall. r. Sk. t. a. Blek.-Ög. Öl, spr., Sv. Söd. Upl. t. a. vid hafvet och Mälaren, Vestm. spr. i Mälaretrakten, Norrl. Gestr. r.

B. Blommor glest sittande, ej förenade i ax; blomskärmar gröna.

4. M. pratense L., Nyckilgräs, Orengräs; blomkrona maskerad, 3 gånger längre än foderflikarne. 2, 3 .

Omkr. fotshög, n. glatt och grenig med lansettlika blad och vanl. nedtill tandade blomskärmar; blommor vågrätt utstående; krona med vanl. hvit pip och gult svalg, stundom (i Göt., helst på Gotl.) mörkröd och inuti gul; foderflikar smala och olikstora'; frön $2 \mathrm{i}$ hvarje rum.

Ängar och skogar, allmän.

5. M. silváticum L.; blomkrona gapande, föga öfverskjutande fodret. 2,3 .

Spensligare och vanl. något lägre än föreg. art, som den mycket liknar; blommor små och upprätta; krona brandgul med 
nedböjd underläpp; foder likformigt med äggrundt lansettlika flikar; frö ett i hvarje rum.

Skogsängar och lundar, teml. allmän.

311. Euphrásia. Ögontröst.

1. E. officinális L.; blad äggrunda; kronpip af underläppens längd; fröhus uppàt vidgadt och urnupet. 2, 3. $1 / 2$ fot hög eller lägre med hvita eller blårandiga blommor; växtens öfre del samt blomfodret glandelhăriga; frön äggformiga, gråaktiga med hvita åsar.

Ängar och backar, allmän.

* E. nemorósa Pers.; växtens ludd utan glandler; blommor mindre; fröhus uppåt något afsmalnande; frön tapplika, gulaktiga med hvita åsar. 3 .

Ängar och backar, teml. allinän.

** E. salisburgensis Funk; blad smalt lansettlika med få, långa och syllika sågtänder. 3 .

Ängsbackar, mycket r.; Göt. Gotl. på 3 ställen.

2. E. grácilis Fr.; blad aflånga; kronpip längre än underläppen; fröhus n. jemnbredt och tvärhugget. 3.

Spensligare och vanligen högre än föreg., med mindre och n. ljusblå blommor; växtens ludd utan glandler; frön tapplika, gulaktiga med hvita åsar; blad med 3 spetsiga sảgtänder på hvarje sida.

Hedar och ljungbackar; Göt. spr.: Boh. t. r. Hall. Sk. t. a. Blek. Gotl. r., Sv. spr.: Ner. t. a. Vestm. Verml. r. Dal.?, Norrl. Gestr. Hels. r.

312. Odontítes. Rödliulla.

1. O. rubra Pers.; blad smalt lansettlika, glest tandade och nedăt afsmalnande; fröhus inneslutet inom fodret. 3,4 .

$1 / 2$ fot hög eller deröfver, mycket grenig och hårig med lutande ax.

Ogräs i åkrar; Göt. Sv. t. a.: Hall.--Verml. spr. Dal. 0, Norrl. Jtl. r. (Gestr. tillfällig).

2. $\quad$. littorális Fr.; blad nedåt något bredare; fröhus utskjutande ur fodret. 2,3 .

Spensligare och vanl. lägre än föreg. art, oftast enkel med upprätt ax och mindre, mürkare blommor, de nedre kortare än skärmbladen.

Hafsstränder: Göt. t. a.: Gotl. r. Hall. Smål.?, Sv. Söd. t. a. Upl. r., Norrl. Vb. r.

\section{Bártsia. Bergskälle.}

1. B. alpina L.; blad äggrunda, nästan stjelkomfattande, skrynkliga och trubbsågade. 2,3 .

Omkr. fingerhög och enkel med teml. långa blommor och hvithåriga ståndareknappar.

Kärr i f̣ellen eller pà silur. formation; Ipl. t. a., Norrl. Jtl. Herj. spr. Ang. Hels. r., Sv. Dal. t. r., Göt. Ög. spr. Vg. Gotl. r. 


\section{Rhinánthus. Skallergräs, Penninggräs.}

1. R. major Ehrh.; kronpip krökt; skärmblad hinnaktiga, ljusgula och sågtandade. 2,3 .

Öfver fotshög med fläckig stjelk; blad nedåt bredare och med hjertlik bas; blommor blekgula; hjelmens tänder violetta; stift naggot utskjutande och upptill violett; frön rynkiga; fröhus med något större längd än bredd.

Ängar; Göt. Sv. a., Norrl. spr.: Ång. r. Vb.?

2. R. minor Ehrh.; kronpip rak; skärmblad gröna, vanligen med syllika tänder. 2,3 .

Spensligare och mera mörkgrön än föreg. art med vanl. ofläckad stjelk och smalare blad samt mörkgula blommor med gula eller blå tänder; stift inneslutet och blekgult; frön utan rynkor; fröhus lika långt som bredt; krona något öppen.

Något fuktiga ängar, allmän.

\section{Pediculáris. Kallgräs.}

A. Krona maskerad, ljusgul och i spetsen blodröd Stjelk enkel och nästan bar.

1. P. Sceptrum Carolínum L., Kung Carls spira; blommor $3-4$ i hvarje krans inom odelade blomskärmar; fröhus trubbigt och n. klotrundt. 3 .

Omkr. 2 fot hög och upprätt med $1 / 2$ fot långa bredflikiga blad sarnt stora tumslånga blommor.

Fuktiga ängar, helst i fjelltrakter; $L p l$. t. a., Norril. r.: Jtl. t. a. Herj. spr. Med. Gestr. 0, Sv. r.: Vestm. t. r., Göt. Vg. t. r. Dalsl. Smål. Ög. r.

B. Krona gapande och röd eller gul, sällan hvit. Stjelk äfven upptill bladig och vanl. grenig.

a. Kronans hjelm (öfverläpp) med mycket kort näbb (spets) och 2 korta tänder samt med utskjutande pistill. Blad pardelade.

2. P. palustris L.; nästan glatt; krona mörkiöd, sällan hvit; hjelm lika laing med underläppen; blommor åtskilda och stödda af blad. 2,3 .

Mörkgrön och upptill rodnande, ofta fotshög och deröfver, grenig nästan till stjelkens midt; fröhus längre än fodret.

Fuktiga ängar och kärr, allmän, i fjellen sparsammare och på Gotl. t. r.

- boreális; blommor hälften mindre.

Lpl. t. r., Göt. Ög. r.

* P. ochroléuca C. P. Læst.; hjelm kortare än underläppen; krona ljusgul.

Lpl. mycket r. (C. P. Læstadius).

3. P. silvática L.; glatt; krona ljusröd, sällan hvit; hjelm längre än underläppen; blommor stundom tätt sittande och vanl. stödda af blad. 2, 3 . 
Ljusgrön, omkr. 1/2 fot hög eller lägre med vanl. talrika enkla stjelkar, de yttre utbredda och fåblommiga; fröhus kortare än det någongång 4-flikiga (eller tvåläppiga) fudret.

Fuktiga ängar, helst i skogstrakter; Göt. spr.: Sk. a. Smål. Dalsl. t. a. Öl. Gotl. 0, Sv. r.: Ner. Verml. spr. Dal. 0, Norrl. Jtl. $r$.

b. Kronans hjelm med mycket kort och otandad näbb samt utskjutande pistill. Blad pardelade.

4. P. Oedéri Vahl; upptill luden; krona guldgul; blommor i tätt och utdraget ax, stödda af (vanl. föga framskjutande) skärmblad. 2, 3 .

Ljusgrön, omkr. ${ }^{1} / 2$ fot hög eller lägre med enkel och vanl. enstaka stjelk; bladflikar breda, ovala-rundade.

Fuktiga bergssluttningar högt upp i fjellen; Norrl. Jtl. r. Herj. t. r.

c. Kronans hjelm med utdragen och nedböjd näbb samt med utskjutande pistill. Blad vanl. parklufna.

5. P. lappónica L., Lapskt Kallgräs: glatt; krona blekgul; blommor i tätt och kort ax med korta skärmblad. 2, 3 .

Mörkgrön med brunaktig, enkel och vanl. enstaka, omkr. $1 / 2$ fot hög stjelk; kronans läppar ungefär lika långa; näbb upptill inskuren; fröhus dubbelt längre än fodret.

Ofruktbara och mindre fuktiga ställen i fjellen; Lpl. a., Norrl. Jtl. Herj. spr., Sv. Dal. r.

d. Hjelm upptill rundad utan näbb och tänder; pistill ej utskjutande. Blad parklufna med mycket små flikar. Stjelk enkel och vanl. enstaka.

6. P. hirsúta L.; upptill luden; krona blekröd; blommor i tätt ax, de nedersta stödda af blad. 2,3 . Ljusgrön och ända till $1 / 2$ fot hög.

Af snövatten fuktiga ställen högt upp i fjellen; $L p l$. flerst.

7. P. flámmea L.; glatt; krona brandgul med mörkröd hjelm; blommor i tätt ax med föga framskjutande skärmar. $2,3$.

Omkr. fingerhög med smärre och smalare blommor än hos föreg. art.

Fuktiga ställen i fjellen nära snögränsen, mycket r.; Lpl.

316. Digitális. Biskopsmössa, Fingerborgsblomma.

1. D. purpúrea L.; blad ovala-lansettlika, undertill hvitJudna. 3,4 .

2-3 fot hög; de nedre bladen långskaftade; foderflikar tätludna ovala och trubbiga med kort und. Giftig.

Hafsstränder; Göt. Boh. r. (Hall. förvildad? Sk. Blek. förvildad inuti landet). 


\section{Klassen. TETRADYNAMIA.}

\section{Ordn. SILIQUOSAE.}

\section{Ráphanus. Ảkerrättika.}

\section{R. Raphanistrum L.; skidor jemnbreda. 3.} vensis.

Öfver fotshög med ofta uppsväld rot. Liknar Sinapis ar-

Ogräs i àkrır, stundom på hafsstränder; Göt. spr.: Gotl.t. r.: Sk. Blek. inre Smål. a. Boh. r. Dalsl. t. a., Sv. spr.: Verml.t. a., Norrl. r.: Vb. 0.

\section{Cardamíne. Bräsma.}

A. Blommor teml. stora med breda, omvändt äggrunda och utstående kronblad. Blad parbladigt delade.

1. C. amára L., Bäckkrasse; ståndareknappar mörkvioletta; skidor med något utdraget och syllikt stift; småblad teml. breda, aflånga eller omvändt äggrunda, tandade eller inskurna. 2.

Lifligt ljusgrön och af hitter smak; stjelk fotshög, fåradt kantig, nedtill med grenskott; blommor hvita; blad stundom håriga.

Kalla bäckar och källor; Göt. spr.: Gotl. t. r. Sk. Dalsl. t. a., Sv. spr.: Ner. Verml. t. a., Norrl. r.: Jtl. spr. Med.?, Lpl. r.

- æquíloba C. Hartm.; småblad likformiga, ovala-aflånga.
Göt. Vg. nära Finnerödja (Elgenstjerna).

2. C. pratensis L., Braxenblomster; ståndareknappar gula; skidor med kort och tjockt stift; rotbladens småblad rundade och inskurna, stjelkbladens (atm. de öfre) smala, n. jemnbreda och helbräddade. 2.

Stjelk fotshög och trind, nedtill mindre ofta med grenskott; blommor vanl. violetta, stundom dubbla; örtens smak föga bitter Fuktiga ängar, allmän: Lpl. spr.

B. Blommor mycket små med hvita, smala och $n$. tunglika, upprätta kronblad (som stundom felsla). a. Bladskaft nedtill med 2 smala flikar (stipler?). Blad parbladigt delade.

3. C. impátiens L., Lundbräsma; rotbladens småblad rundade, de öfriga ovala-aflånga, de flesta inskurna; skidor utstående. $2,3$.

1-2 fot hög, n. glatt och ljusgrön, rikbladig och ofta grenig; kronblad föga längre än fodret och sällan utbildade; skidor ej öfverskjutande blomsamlingen, med syllikt stift; rotblad ofta rodnande.

Lundar, berg och hafsstränder; Göt. r.: Sk. Ög. spr. Gotl. 0, Sv. spr.: Ner. r. Verml. Dal. 0. 
b. Blad parbladigt delade utan bihang.

4. C. hirsúta L.; rotbladens småblad n. runda och tandade, stjelkbladens aflånga-lansettlika, vanl. helbräddade; skidor upprätta och styfva. 2.

Omkr. $1 / 2$ fot hög och nedtill vanligen luden; ståndare 4; skidor n. utan stift, de nedre öfverslijutande blomsamlingen; kronblad vanl. dubbelt längre än fodret; rot svag, enkel och enårig.

Lundar och berg, helst nära hafvet och större sjöar; Göt. t. r.: Öl. a. Sk. Blek. spr., Sv. t. r.: Söd. Upl. spr. Verml. 0, Norrl. Herj. Jtl. r.

* C. silvática Link. \& Hoffm.; de nedre stjelkbladen n. likformiga med rotbladen, men ofta större.

Liknar mycket hufvudarten, men är ofta högre och af mörkare färg; stằndare 6 ; skidor med utstående skaft och tydligt stift, de nedre föga öfverskijutande blomsamlingen; bladpar mera talrika; rotstuck med talrika birötter.

Fuktiga ställen i lundar, helst nära större sjöar; Göt: Sk. t. r. Blek.-Ög. Vg. r., Sv. Söd. Dal. r., Norrl. Jtı. r.

5. C. parviffóra L.; alla småbladen smala, n. jemnbreda och helbräddade, föga bredare än de utstiende skidorna. $2-4$.

Omkr. $1 / 2$ fot hög och rikbladig med vid blomningen vissnade rotblad och mycket små blommor; skidor med tydligt stift och dubbelt så långa som skaften.

Sjöstränder; Göt. Ög. spr. vid Vettern, Roxen och Glan, Vg. och Dalsl. vid Venern t. r., S $v$. Verml. vid Venern r., Ner. vid Hjelmaren och Qvismaren r., Söd. flerst. Dal. vid Bysjön r.; hafsstränder: Göt. Ög. r.

c. Blad odelade och helbräddade.

6. C. bellidifólia L., Fjellbräsma; de neđre bladen äggrunda-aflånga och långskaftade. 2.

Vanligen 1-2 tum hög med flera trådfina och stängellika stjelkar, som föga öfverskjuta bladen; skidor upprätta, n. jemnhöga och inemot tumslånga, med utdraget skaft och otydligt stift. Jtl. Herj.

Klippspringor högt upp i de högsta fjellen, spr: Lpl., Norrl.

319. Dentária. Tandört.

1. D. bulbifera L.; de nedre bladflikarne och de öfre bladen lansettlika. 2.

Omkr. 2 fot hög och enkel, nedtill bladlös, med få och tem]. stora blommor; rotstock hvit med tandlika fjäll.

Lundar; Göt. spr.: Sk Öl. t. a. Gotl. Boh. Dalsl. r., $S v$. spr.: Verml. Dal. 0.

\section{Nastúrtium.}

A. Skidor korta och n. klotrunda, flera gånger kortare än skaftet. Kronblad längre än fodret.

1. N. Armorácia (L.) Fr.: kronblad hvita; skidor flera gånger längre än stiftet. 3, 4 . 
2-4 fot hög med tjock rot (Pepparrot); rotblad stora och långskaftade, hjertlikt aflånga och naggade; de nedre stjelkbladen parklufna, de öfre $\mathrm{n}$. helbräddade, lansettlika-jemnbreda.

Stränder, troligen förvildad; Göt. mångenst., helst i Sk. Blek. och Ög., Sv. spr.: Ner. Verml. r. Dal. 0, Norrl. Gestr. Hels. r. 2. N. amphibium (L.) R. Br.; kronblad gula; skidor $1-2$ gånger så långa som stiftet. 3,4 .

2-4 fot hög; de nedre bladen kamlikt delade eller pardelade, de öfre mer eller mindre inskurna; rotskottens blad vanl. lyrformiga. I vatten blifva de nedsänkta bladen kamlikt delade, på land blifva stundom alla bladen odelade.

Stränder, helst vid sjöar; Göt. r.: Hall. Sk. t. a. Gotl. Dalsl. 0, Sv. spr.: Ner. Verml. r. Dal. 0.

B. Skidor mer eller mindre utdragna, jemnbredaaflånga.

3. N. palustre (L.) D.C.; kronblad gula af fodrets längd; skidor aflånga, lika långa som skaftet; stift mycket kort. 3, 4 .

1/2 -2 fot hög; alla blad pardelade; skidor uppsvälda.

Vàta ställen, allmän: Norrl. t. a., Lpl. r.

4. N. anceps Wahlenb.; kronblad gula, längre än fodret; skidor n. aflånga plattade, 2-4 gånger kortare än skaftet; stift något utdraget. 3,4 .

2-3 fot hög; blad pardelade och smalflikiga. Liknar både $N$. amphibium och $N$. silvestre, hvaraf den torde vara bastard. Stränder, helst vid Mälaren; Sv. Söd. Upl. Vestm. t. r.; Göt. Sk. t. r. Öl. Gotl. Smål.?

5. N. silvestre (L.) R. Br.; kronblad gula, längre än fodret; skidor n. trådlika och föga plattade, längre än skaftet; stift kort. 3,4 .

Omkr. fotshög med pardelade, smalflikiga blad.

Stränder och andra våta ställen; Göt. t. r.: Sk. spr. inre Smål. Hall. Vg. Dalsl. 0, Sv. spr.: Ner. r. Verml. Dal. 0, Norrl. Gestr. r. (Ång. tillfällig).

6. N. officinále R. Br.; kronblad hvita, längre än fodret; skidor jemnbreda och n. trinda, längre än skaftet; stift teml. kort. 3.

Liknar Cardamine amara äfven till smaken, men har mycket smärre blommor; blad parbladigt eller trefingradt delade; bladskaft omfattande stjelken med två spetsiga bladöron (stipler?); småblad n. hjertlika bugtbräddade; skidor 5-6 linier långa, tjocka och năgot krökta; ståndareknappar violetta.

Vid eller i åar och bäckar; Göt. Hall. Sk. Gotl. spr. Smål.r.

\section{Hésperis. Nattviol.}

1. H. matronális L.; blad äggrundt lansettlika, spetsiga och fint tandade; kronbladens skifva omvändt äggrund; skidor med utstående skaft. 3 . 
Omkr. 2 fut hög och bladrik; blommor mot aftonen välluktande; de nedre bladen skaftade. Sv. t. r.

Ruderatväxt, stundom i ängar, ursprungligen förvildad; Göt.

\section{Ery'simum. Gyllen.}

1. E. cheiranthóides L., Akergyllen; blomskaft dubbelt så långa som fodret; kronbladens skifva omvändt äggrund och lika lång som klon; skidor något bågböjda, tjockare och $1 \frac{1}{2}$ gång längre än de vanl. utspärrade skaften. $2,3$.

Stjelk 1-2 fot hög och teml. spenslig; rot enårig; blad aflånga-lansettlika, helbräddade eller glest tandade, och sträfhåriga; blommor små; frön ovingade.

Torra ställen, belst i åkrar, allmän: Lpl. r.

- nodósum;..skidor tilltryckta.

Göt. Sk. Ög. r.

2. E. hieraciifólium L., Strandgyllen; blomskaft af fodrets längd; kronbladens skifva vigglik och kortare än klon; skidor raka, föga tjockare, men 5-6 gånger längre än de mer eller mindre utstående skaften. 2.

Stjelk 2-3 fot hög, något grof och styf; blad aflånga-lansettlika eller tunglika, helbräddade eller tandade, och sträfva; blommor större än hos föreg.; frön i spetsen vingade; tvåårig.

Helst på hafsstränder, stundom på sjöstränder eller i fjellen på andra fuktiga ställen; Lpl. t. r., Norrl. r.: Med.?, Sv. Verml. r. Ner. flerst. Vestm. t. r. Söd. Upl. (i skärgården) mångenst., Göt. Ög. t. a. vid hafvet och vid Vettern, Kalmarl. mångenst. i skärg., Vg. Gotl. r. Öl. Boh.?

* E. strictum Koch; skidor tilltryckta, kortare och tjockare.

Fuktiga ställen; Göt. r.: Dalsl. Hall. Ög. Öl. 0.

323. Barbaréa. Sommargyllen.

1. B. stricta Fr.; kronblad nästan jemnbreda, i spetsen ej urnupna, något längre än fodret; skidor tilltryckta till stjelken och trådsmala. 2.

Omkr. 2 fot hög med små gulhvita blommor; stift n. lika tjockt som skidan; rotbladens sidoflikar små; de öfversta bladen odelade.

Stränder och fuktiga ängar mångenst.: Blek. r.? Öl.?

2. B. vulgaris R. Br.; kronblad med bred vigglik eller omvändt äggrund skifva, urnupna och mycket längre än fodret; skidor tjockare än både skaft och stift, med bågformigt uppstigande skaft. 2 .

Liknar föreg. art, men har större och lifligt gula blommor; rotbladens sidoflikar nedåt aftagande $\mathrm{i}$ storlek; de öfversta bladen ternl. djupt inskurna; smaken bitter. 
Ogräs i åkrar; Göt. mångenst.: Öl. Gotl. r., Sv. mångenst., Norrl. Gestr. Hels. spr. Ång. t. r. Jtl. r.

* B. præcox Sin.; skidor föga tjockare än det n. raka skaftet; de öfversta bladen grundt inskurna.

Göt. Sk. Hall. Blek. Smål. r. Ög. spr., Sv. Verml. r. Troligen äfven annorstädes.

\section{Brássica. Kål.}

A. Skida trind; blomfoder hälften kortare än blomskaftet; de öfre bladen oskaftade, omfattande och öronflikade; frön bruna.

1. B. campestris L., Akerkil ; blommor under blomningen jemnhöga; skidor nästan upprätta. 2,3 .

Omkr. 2 fot hög med de nedre bladen glest sträfhåriga, de öfre äggrunda med hjertlik bas.

Ogräs i åkrar t. a.: Öl. r.? Lpl. spr.

2. B. Napus L., Rapsat; blommor olika höga; skidor utspärrade. $2,3$. lik bas.

Omkr. 2 fot hög och glatt; de öfre bladen aflånga med pil-

Ogräs i åkrar och på hafsstränder; Göt. Sk.-Ög. r. Öl. spr. Gotl. t. r., Sv. Söd. Upl. t. r.

B. Skida n. fyrkantig; blomfoder längre än blomskaftet; alla blad skaftade; frön svarta.

3. B. nigra (L.) Koch, Svartsenap; skidor teml. korta och tilltryckta; de öfre bladen inskurna eller hela. 3.

2-3 fot hög, nedtill mer eller mindre sträfhårig; frön med skarp smak.

Ruderatväxt och ogräs i åkrar; Göt. Sk. a. Hall. Blek. Öl. Gotl. spr. - Eljest förvildad h. o. d. i Göt. Sv. och Ång.

\section{Diplotaxis. Sandsenap.}

1. D. bracteáta Godr.; de nedre blommorna stödda af pardelade blad; stift kägellikt; foderblad upprätta, af blomskaftets längd; frön i en rad. 3 .

Omkr. fotshög och hårig med gulhvita blommor och pardelade blad med aflằnga och naggade flikar. Tåkern.

Sandiga stränder; Göt. Ög. ymnig i flera socknar vid sjön

2. D. tenuifólia (L.) D.C.; blomklasar bladlösa; stift jemnbredt; foderblad utstående, 3-4 gånger kortare än blomskaftet; frön i 2 rader. $2,3$.

Omkr. fotshög, n. glatt och ljust blågrön med gula blommor och smalflikiga blad, de öfre vanl. hela; stam nedtill af fastare byggnad samt till midten bladig; skidor $n$. af skaftens längd; blommor välluktande.

Hafsstränder; Göt. r.: Boh. Öl.? Ög. 0, Sv. Norrl. r.

326. A'rabis. Glis, Backbränna.

A. Rotstock tjock; frön i en rad; skidor tilltryckta. 
Kronbladens skifva smal och tunglik. Stjelkblad omfattande och öronflikade.

1. A. hirsúta (L.) Scop.; alla bladen tandade; rotblad tunglika; stjelkblad aflånga-lansettlika; blommor längre än skaften. 2.

Stjelk 1-2 fot hög, styf och teml. tjock samt med tätt sittande blad med vanl. enkla hår; skidor 6-7 gånger längre än skaften; kronblad hvita, upprätta och mycket små. Är stundom i Sk. och Vg., oftare på öl. och Gotll, alldeles glatt.

Ängsbackar; Göt. mångenst.: Öl. Gotl. a. Blek. inre Smål Dalsl. t. r., Sv. mångenst.: Verml. Dal. t. r., Norrl. r.: Med. Vb. Herj.?, Lpl. r.

- sagittáta; med bredare och groftandade blad, större och mera tydligt stjelkomfattande öronflikar.

Göt. Ö1. Gotl. spr. Ög. Vg. t. r., Sv. Söd. Upl. r.

* A. Gerárdi Bess., blommor smärre; skidor smalare; frön tydligare prickiga; stjelkblad med basen tätt tryckta intill stjelken och försedda med tydliga öronflikar.

Göt. Gotl. på den uttorkade Akebäcksmyren.

B. Rotstock tjock; frön i en rad; skidor utstående. 2. A. alpina L., Fjellglis; kronbladens skifva teml. smal och n. tunglik; stjelkblad omfattande och öronflikade; alla blad tandade; blommor af skaftens längd eller kortare. 2.

Stjelk omkr. $1 / 2$ fot hög och uppstigande med sterila (icke eller efter hand blommande) grenskott; rotblad tunglika; stjelkblad vanl. äggrunda; skidor n. af skaftens längd; blommor hvita, större än hos de öfriga arterna. Hela växten är n. rent grön eller något gråaktig samt (utom skidorna) starkt stjernluden.

Våta ställen vid bergväggar 0 . s. v. i fjellen, helst ofvan trädgränsen; Lpl. t. a., Norrl. Jtl. Herj. mångenst.

3. A. petræa (L.) Lam.; kronbladens skifva bred och n. spadlik; stjelkblad icke omfattande; rotblad bugttandade eller helbräddade; stjelkblad vanl. helbräddade; blounmor längre än skaften. 2 .

Omkr. fingerhög och ofta nedtryckt, vanl. glatt, stundom nedtill hårig; rotblad lansettlika-tunglika; stjelkblad lansettlika-jemnbreda; skidor 3-5 gånger längre än skaften och teml. tjocka; kronblad vanl. hvita, stundom blekt violetta.

Klippor vid hafvet; Norrl. Ang. t. r., ymnigast omkring Hernösand.

C. Rot svag och 1-2-årig; frön i en rad; skidor utstäende. Stjelkblad ej omfattande.

a. Kronbladens skifva bred, spadlik eller omvändt äggrund. 
4. A. arenósa (L.) Scop.; rotblad lyrformiga; stjelkblad vanl. tandade och tunglika-lansettlika; blommor ungefär af skaftens längd. 2.

Stjelk upprätt, $1 / 2$ fot hög och deröfver samt grön; rotblad med tätt stjernludd; skidor 2-3 gånger längre än skaften; kronblad blekt violetta eller hvitaktiga.

Ruderatväxt; Göt. Öl. Smål. Ög. r., Sv. Söd. Upl. Vestm. t. r. Verml. r., Norrl. Jtl. Med. r.

b. Kronbladens skifva smal och tunglik.

5. A. suécica Fr.; rotblad lyrformiga - bugttandade; stjelkblad vanl. tandade, tunglika-lansettlika; blommor ungefär af skaftens längd. 2 .

Liknar mycket föreg. art, men har hvita, smalare och något mindre kronblad och med sparsammare stjernludd försedda rotblad.

Ruderatväxt, stundom på torftak: Norrl. r.: Herj. Med.?, Sv. r.: Vestm. Ner. spr. Verml. t. r., Göt. Ög. Smål. r.

6. A. Thaliána L.; rotblad svagt tandade eller helbräddade; stjelkblad helbräddade, lansettlika; blommor kortare än skaften. 1, 2.

Stjelk blågrön, spädare, slankigare och högre än hos föreg. art; rotbladens hår vanl. enkla; skidor ofta lika långa med skatten; blommor smärre och hvita.

Berg och steniga ängsbackar; Göt. a., Sv. a.: Verml. Dal. spr., Norrl. spr.: Gestr. a., Lpl. r.

D. Rot svag och tvåårig; frön i 2 rader; skidor tilltryckta. Kronbladens skifva smal och tunglik. Stjelkblad omfattande och öronflikade.

7. A. perfoliáta Lam., Rockentraf; rotblad bugttandade lansettlika; stjelkblad n. lansettlika helbräddade; blommor af skaftens längd. 2 .

Blågrön, med sträfludna rotblad, för öfrigt glatt; stjelk n. enkel, upprätt och 2-4 fot hög; skidor 6 gånger längre än skaften; blommor små och hvitgula. Turritis glabra L.

Berg och andra torra ställen; Göt. Sv. t. a.: Hall.-Dal. spr., Norrl. spr.: Vb. r. Jt1.?, Lpl. r.

\section{Bráya.}

1. B. alpína Sternb. o. Hop.; blad n. helbräddade, lansettlika-jemnbreda; rotblad långskaftade; skidor tätt sittande $\mathrm{i}$ en kort klase. 2.

3-4 tum hög, liknande en förkrympt Arabis petraa, men icke tufvad; rot mångårig; blad omkr. $1 / 2$ linie breda.

Högt upp i fjellen, mycket r.; Lpl. Lul. Lupm. funnen (af D:r Ångström) vid Sähkok 1837, men sedan ej återfunnen.

\section{Sinápis. Senap.}

1. S. arvensis L., Akersenap, Vildsenap; de öfre bladen oskaftade, äggrunda och tandade; skidor utstående, 
trinda och vanl. glatta; spröt kortare än skidan, rakt, kägelformigt och med lika långt aflägsnade nerver. 2,3 .

Upprätt, grenig och omkr. fotshög med affallande fruktspröt och svarta släta frön.

Ogräs i åkrar; Göt. a.: inre Smål. spr., Sv. a., Norrl. a.: Jtl. spr. Vb. t. r.

2. S. alba L., Gulsenap; alla bladen skaftade och lyrformiga med bugttandade flikar; skidor utspärrade, knöliga, vanl. sträfhåriga och fåfröiga; spröt längre än skidan, mot spetsen smalare, skärformigt och med närmade nerver. 3 .

Liknar föreg., men har qvarsittande fruktspröt och gula eller bruna, fint gropiga frön.

Ruderatväxt, ursprungligen förvildad; Göt. t. r.: Sk. Öl.spr. Boh.?, Sv. t. r.: Dal. 0, Norrl. Jtl. r.

\section{Sisy'mbrium.}

\section{A. Blommor i qvast; frön enradiga.}

1. S. Sophía L., Stillfrö; kronblad gula, kortare än fodret; skidor trådlika och utstående, något längre än skaften; blad 2-3 gånger parbladigt delade med trådlika flikar. 3 .

2-3 fot hög, mjukhårig, blekgrön och upptill grenig; skidor inemot tumslånga.

Ruderatväxt, allmän: Jtl. spr. Lpl. r.

2. S. officinále (L.) Scop., Vägsenap; kronblad gula, längre än fodret; skidor syllika och tilltryckta med mycket korta skaft; de nedre bladen nedåt parflikiga, de öfre spjutlika. 2, 3 .

Omkr. 2 fot hög och särdeles upptill hårig samt med utspärrade grenar; skidor $1 / 2$ tum långa.

Ruderatväxt, helst i slättbygder; Göt. t. a.: inre Smål. Dalsl. t. r., Sv. t. a.: Verml. t. r. Dal. 0, Norrl. Gestr. Hels. r. (Ång. tillfällig).

3. S. Alliária (L.) Scop., Hvitlöksrym; kronblad hvita, längre än fodret; skidor jemntjocka, n. fyrkantiga och utstående; blad skaftade och tandade eller naggade: de nedre njurlika, de öfre äggrunda spetsade. 2.

Omkr. 2 fot hög, slutl. något grenig och n. glatt; skidor tjocka; lukt af hvitlök.

Lundar och åkrar, helst vid hafvet samt vid Venern, Vettern, Hjelmaren och Mälaren; Göt. t. a.: Ög. spr. inre Smål. Hall. Boh, r. Vg. t. r.? Dalsl. 0, Sv. Söd. Upl. t. a. Vestm. Ner. flerst:

B. Blommor enstaka i bladvecken, blott de öfversta stälda i qvast; frön tvåradiga. 
4. S. supínum L.; kronblad hvita, föga längre än fodret; skidor jemntjocka och $\mathrm{n}$. trinda med korta tilltryckta skaft; blad pardelade med teml. breda och tandade flikar. 3 .

2-15 tum lång, något sträfhårig, vanl. nedliggande och grenig; skidor teml. tjocka och inemot tumslånga.

Fuktiga ställen, t. ex. i åkrar och diken; Göt. Öl. spr. Gotl. t. r.

\section{Ordn. SILICULOSAE.}

\section{Thlaspi. Skärffrö.}

A. Skida rund och rundtomkring bredt vingad. Stjelkblad tandade och pillikt omfattande (med spetsiga bladöron).

1. T. arvense L., Penninggräs; skidor med djup och smal inskärning; stift otydligt. 1-4.

Omkr. fotshög, glatt och ljusgrön, med löksmak; skidor af 10-örens storlek; stjelkblad aflånga; foderblad upprätta.

Ruderatväxt och ogräs i åkrar, allmän.

B. Skida vigglik och upptill vingad. Stjelkblad $n$. helbräddade, omfattande och öronflikade (med trubbiga bladöron).

2. T. perfoliátum L.; ståndareknappar gula; stift otydligt; stjelkblad aflånga. 2 .

Omkr. fotshög och blågrön med mycket små blommor; rotblad skaftade, omvändt äggrunda och stundom svagt tandade, teml. länge qvarsittande; foderblad upprätta.

Ruderatväxt och ogräs i sandiga åkrar; Göt. Öl. spr., Sv. Upl. r. i Rasbo s:n.

3. T. alpestre L.; ståndareknappar slutl. mörkvioletta; stift något utdraget; stjelkblad lansettlika. 2.

Liknar föreg. art, men har stundom rotstock; foderblad utstående; kronblad stundom något rödletta.

Ängsbackar och bäckstränder, helst i ekskng, r.; Göt. Ög., Sv. Söd. Upl.

\section{Capsella. Lommegräs.}

1. C. bursa pastóris (L.) Mönch; skida trekantig; de öfre bladen med grundare inskärningar eller tandade, stundom helbräddade; alla stjelkbladen pillikt stjelkomfattande. 1-4.

Omkr. fotshög och vanl. gleshårig med rotbladen i rosett. Stundom äro alla bladen helbräddade.

Ruderatväxt och ogräs i ăkrar, allmän.

332. Lepídium. Krasse.

A. Stjelkblad tätt sittande och omfattande.

1. L. campestre (L.) R. Br., Fälttrrasse; skida bredt 
oval, nedtill bukig, upptill vingad; stjelkblad aflinga och pillikt stjelkomfattande. 3 .

Omkr. fotshög och gråluden; rotblad lyrformiga, bugttandade eller hela; stjelkblad vanl. tandade; skida lika lång som det vinkelrätt utstående skaftet, med mycket kort stift; rot tvåårig; kronblad föga längre än fodret.

Ruderatväxt och ogräs i åkrar, helst i slättbygder; Göt. Gotl. t. a. Öl. Ög. Kalmarl. mångenst. Blek. r. Sk. a. inre Smål. Hall. r. Vg. r.?, Sv. spr.: Verml. r. Dal. 0, Norrl. Ång. r. (Gestr. tillfällig).

2. L. Draba L.; skida njurlik och ovingad; de nedre bladen bugttandade, de öfre aflånga och öronflikade. 2,3 .

Omkr. fotshög och blågrön med tilltryckta hår; skida mycket kortare än det utstående skaftet och knappt dubbelt så lång som stiftet; rotstock kort; kronblad dubbelt så långa som fodret.

Ruderatväxt, mycket r. oeh införd från Italien; Göt. Blek. på kronovarfvet i Carlskrona.

B. Stjelkblad glest sittande och ej omfattande. Skidor mycket små utan stift.

3. L. ruderále L., Vägkrasse; skida rundadt oval; de nedre bladen pardelade, de öfversta n. jemnbreda. 3.

$0 \mathrm{mkr}$. $1 / 2$ fot hög, n. glatt och illaluktande; skidor kortare än det utstående skaftet; blommor n. alltid utan kronblad och med 2 ståndare; rot enårig.

Ruderatväxt, helst i slätthygder; Göt. t. a.: inre Smål. Vg. r. Dalsl. 0, Sv. Söd. Upl. t. a. Vestm. spr. Ner. Verml. r., Norrl. Gestr. spr. Hels.-Ång. r.

4. L. latifólium L., Bittersalso; skida rundad; alla bladen hela: de nedre långskaftade, äggrunda och sågtandade, de öfre oskaftade, aflånga-lansettlika och helbräddade. 3 .

3-4 fot hög, glatt och illaluktande, upptill mycket grenig, samt med rotstock; blommor tätt sittande $i$ utbredda vippor; skidor kortare än skaftet; blad stora, de nedre ofta tumsbreda.

Hafsstränder; Göt. Boh. r. Sk. spr. Blek. Gotl.r. Smål. t. r. Öl.? 333. Hutchínsia. Bergkrasse.

1. H. petræa (L.) R. Br.; skida oval och ovingad. 1, 2. 2-4 tum hög och mycket grenig med hårfina blomskaft samt mycket små skidor och bladflikar.

Torra klippor, helst vid hafvet; Göt. Gotl. a. Öl. t. a. Blek. Sk. r. Vg. på Kinnekulle, Sv. Söd. t. r.

\section{Teesdália. Vallkrasse.}

1. T. nudicáulis (L.) R. Br.; skida rund och ovingad, upptill urnupen. 1, 2.

Ända till $1 / 2$ fot hëg med Jyrformiga rotblad och knappt 2 linier breda skidor; stjelkar enkla, utbredda och slutl. uppstigande. 
Sandiga ställen, helst nära hafvet; Göt. Boh. Hall. t. a. Sk. a. Öl. Blek. Kalmarl. spr. inre Smål. Vg. r.

\section{Subulária. Sylört.}

1. S. aquática L.; klasar fåblommiga; skidornas skaft utstående. 3.

På och vid stränder; Lpl. Norrl. Sv. t. a., Göt. spr.: Boh. Sk. t. r. Blek. Kalmarl. r. Öl. Gotl. 0.

\section{I'satis. Weide.}

1. I. tinctória L.; blad aflånga-lansettlika, de öfre pillikt stjelkomfattande. 3 .

3-4 fot hög och glatt; skidor stundom svartnande.

Hafsstränder; Göt. spr.: Sk. r. Ög. t. r. Boh. Hall. 0, Sv. spr., Norrl. Gestr. r.

337. Corónopus. Kråk-krasse.

1. C. depressus Mönch; kronblad längre än fodret; den tandade skidans rum alltid sammanhängande. 3.

Vanligen nedtryckt till marken med glatta, utbredda och ofta fotslånga grenar; fruktskaft mycket korta. och tjocka.

Helst på hafsstränder, stundom (t. ex. i Ög. och Sk.) ruderatväxt inuti landet; Göt. r.: Sk. t. a. Öl. a. Gotl.spr. Vg. Dalsl. 0, Sv. Söd. r., Norrl. Hels.-Ång. r.

2. C. dídymus (L.) Sm.; kronblad korta eller felslående; den otandade skidans rum något åtskilda. 3,4 .

Vanl. uppstigande med finludna, ofta fotslånga grenar; skida kortare än det n. hårfina skaftet. Liknar Lepidium ruderale äfven till lukten.

Hafsstränder r.; Göt. Boh. Hall, Gotl., Norrl. Gestr. Hels. Ång. 338. Cakíle. Marviol.

1. C. maritima Scop.; bladflikar aflånga trubbiga. 3, 4 .

1-2 fot hög, uppstigande och mycket grenig; skidor utspärrade samt utan stift.

Hafsstränder; Göt. Boh.-Sk. t. a. Blek. Smål. r. Gotl. t. r., Sv. r., Norrl. Med. Ång. r.; dessutom inuti landet i Skåne flerst. 339. Crambe. Strandkål.

1. C. maritima L.; blad bredt äggrunda, vågiga och inskurna. 3.

Blåaktig och liknande vanlig kå], 3-5 fot hög med stundom fotsbreda blad; frö ärtlikt. Sandön.

Hafsstränder; Göt. Boh. spr. Hall. r. Sk. t. r., Sv. Söd. på

\section{Camelína. Dodra.}

1. C. fœ'tida Fr., Lindodra; skidor rundadt päronformiga, i spetsen tvärhuggna, med tunna skal; stift kort. 3.

Omkr. 2 fot hög, glesbladig, slät och blågrön; skidans skiljevägg omvändt hjertlik; skida nätådrig med omärkliga kanter. Linåkrar, teml. vanlig: Lpl. Vb.?

2. C. silvestris Wallr.; skidor päronformiga, i spetsen 
rundade, med fasta skal; stift utdraget, af skidans halfva längd. 2,3 .

Liknar föreg. art, men är tätbladig, sträf och mera rent grön med fastare blad och kortare fruktskaft; skidans skiljevägg rundad; skida punkterad, ej nätådrig, med mycket utskjutande kanter.

Ruderatväxt, helst i slättbygder; Göt. spr.: Blek. inre Smål. Dalsl. r., Sv. spr.: Verml. r., Norrl. spr.: Hels. r. Med. Ång.?

3. C. satíva Fr.; skidor omvändt äggformiga, i spetsen rundade med fasta skal; stift $3-4$ gånger kortare än skidan. 3.

Liknar föreg. art och är tätbladig, nedtill gleshårig och upptill glatt, men har vanl. smärre skidor på längre skaft; skidans skiljevägg $n$. vigglik; frön gula och n. släta (hos de föreg. arterna bruna och punkterade); skida nätådrig med föga utskjutande kanter.

Åkrar, helst linåkrar; Göt. Sk. spr. Hall. t. r. Gotl. Ög. r.; Sv. Söd. Upl. spr. Vestm.? - Troligen äfven annorstädes.

\section{Alyssum. Grådodra.}

1. A. incánum L.; kronblad tvåklufna och snöhvita; blad lansettlika; skidor äggformigt aflånga, kortare än det upprätta skaftet. 3 .

${ }_{1}^{1} / 2-1$ fot hög; blad helbräddade eller fintandade; ståndaresträngar med vinglika bihang: skidans rum flerfröiga.

Ruderatväxt och ogräs i åkrar; Göt. r.: Sk. spr. Öl. Dalsl. 0, Sv. Upl. Dal. Verml. r., Norrl. Hels. Jtl. r.

2. A. caly'cinum L.; kronblad hela, i spetsen tvärhuggna eller urnupna, i början gula, slutl. hvita; blad aflånga; skidor plattade och runda, lika långa som det utspärrade skaftet. 2 .

Omkr. $1 / 2$ fot hög; blad hela och stjernludna; de kortare ståndaresträngarne med tandlika bihang; skidans rum tvåfröiga. Ruderatväxt och ogräs i åkrar, sporadisk; Göt. r.: Sk: Gotl. spr. Hall.? Dalsl. 0, $S v$. Upl. Vestm. Verml. r., Norrl. Jtl. r.

\section{Cochleária. Skörbjuggsört.}

1. C. dánica L.; blad skaftade, de nedre njurlika-hjertlika, de öfre spjutlika; skida af skaftets längd. 2 .

Stjelk 2-4 tum hög, ofta med från basen utgående längre och utbredda sidogrenar; blad nagelstora, djupt tandade; fruktbärande klasar korta.

Hafsstränder; Göt. spr.: Gotl. t. r. Hall. r. Boh. r.?, Sv. spr.

2. C. officinális L.; stjelkblad omfattande och öronflikade; rotblad skaftade och n. runda; skida kortare än skaftet. 2,3 .

Större än föreg. med större blommor, frön och skidor; fruktbärande klasar ofta $1 / 2$ fot långa.

Hafsstränder; Göt. r.: Boh. Hall. spr. Ög. 0. 


\section{Draba. Nagelört.}

A. R̂ot mångårig med rosettlika grenskott. Kronblad hela.

1. D. alpína L.; kronblad guldgula; fruktskaft utstående och n. jemnhöga; blad mer eller mindre håriga utan stjernludd; stjelk och blomskaft vanl. håriga. 1, 2.

Vanligen låg af 2-6 tums höjd; stjelk stängellik, bladlös eller med ett helbräddadt blad; skidor vanl. ovala och trubbiga med otydligt stift (mera sällan spetsiga med tydligare stift), oftast glatta; rotblad vanl. ovala och helbräddade.

Klippor och andra något torra ställen, högt upp i fjellen, r., Lpl., Norrl. Herj.

2. D. láctea Adams (Fr.); kronblad mjölkhvita eller något gulaktiga; fruktskaft utstående och i utdragen klase; stjelk och blomskaft glatta; blad håriga eller

n. glatta samt utan stjernludd. 1, 2.

Vanligen lågväxt, sällan mer än ett par tum hög; stjelk stängellik eller med ett helbräddadt blad; skidor vanl. äggrundaaflånga och trubbiga (stundom spetsiga), alltid glatta, vanl. med föga märkligt stift.

Torra grusiga ställen högt upp i fjellen; $L p l$. ganska $r$.

3. D. nivális Liljebl.; stjelk, blomskaft och blad öfverallt stjerntudna; eljest som föreg. art. 1, 2.

Af samma storlek som föreg. art, men med kortare, vanl. omvändt äggrunda blad; skidor vanl. lansettlika och oftast spetsiga, alltid glatta med tydligt stift.

På dylika ställen som föreg. art, r.; $L p l$. flerst.

* D. brachycarpa Zetterst.; blad blott undertill stjernludna; stjelk och blomskaft glatta; skidor ovala trubbiga och glatta med tydligt stift.

Omkr. 2-3 tum hög med smärre skidor än hos de båda föreg. arterna, af hvilka denna förmodas vara en bastard.

Lpl. Torn. Lpm. på fjellet Peltsana (C. P. Læstadius).

4. D. hirta L.; kronblad mjölkhvita eller något gulaktiga; fruktskaft upprätta och i utdragen klase; stjelk vanl. försedd med $3-4$, stundom $1-2$, vanligen tandade blad. 1, 2.

Vanl. $1 / 2$ fot hög eller högre, stundom lågväxt och liknande de föreg. arterna; rotblad helbräddade; skidor teml. långt skaftade, ovala-lansettlika, glatta eller ludna, med mer eller mindre tydligt stift; stjelk och blad alltid häriga och ofta stjernludna. Varierar i hög grad.

Torr stenig ängsmark ofvan trädgränsen i fjellen; $L p l$. spr., Norrl. Jtl. Herj. spr.

5. D. incána L.; kronblad snöhvita; fruktskaft utstående och i utdragen klase; stjelk n. alltid mångbladig; både rotblad och stjelkblad vanl. tandade; skidor kortskaftade. 2. 
$1 / 2$ fot hög och deröfver med mycket tätare stjernludd än hos de öfriga arterna, derföre mycket gråluden; skidor glatta eller ludna, vanl. lansettlika med föga märkligt stift.

T'orra ställen, helst på berg, sällan i fjellen; Göt. Gotl. Öl. t. a. Ög. Vg. r., Sv. Verml. Vestm. r. Söd. Upl. spr., Norrl. Gestr. Ang. Herj. r.

B. Rot enårig utan grenskott.

a. Kronblad tvåklufna. Stängel.

6. D. verna L., Vårrågblomma; kronblad snöhvita; blad stälda i rosett och nedtryckta, lansettlika-aflånga, ofta tandade; skidor vanl. aflånga och glatta, stundom ovala. 1, 2.

Blommande tumshög, slutl. 2-5 tum hög med stundom håriga rotblad.

Torra backar, vägkanter och åkrar; Göt. Sv. t. a., Norrl. Gestr. t. a. Hels. Med. spr. Ang. r.

b. Kronblad hela eller urnupna. Stjelk flerbladig. 7. D. nemorósa L.; stjelk fåbladig; stjelkblad äggrunda, tandade och icke öronflikade; kronblad ljusgula, urnupna och småningom nedåt afsmalnande; skidor aflånga, finhåriga eller glatta, hälften så långa som skaften. ' $1,2$.

I början liten, slutl. ända till $1 / 2$ fot hög och deröfver, nedtill grenig; blommor mycket små; blad håriga, stundom stjernludna. Ög. r.

Ruderatväxt; Norrl. Ång. spr. Med. Gestr. r., Sv. r., Göt.

8. D. murális L.; stjelk vanl. bladrik; stjelkblad äggrunda tandade, öronflikade och stjelkomfattande; kronblad hvita, i spetsen hela och tvärt afsmalnande nedåt; skidor aflånga-ovala, glatta och af skaftens längd. 2.

$1 / 2-1$ fot hög, enkel eller grenig; blommor smärre än hos föreg. art; blad hảriga eller stjernludna.

Berg i lundar, helst nära hafvet samt vid Vettern och Mälaren; Göt. r.: Öl. a. Blek. Kalmarl. spr. Ög. t. r. Dalsl. 0, Sv. Söd. Upl. spr. Vestm. t. r.

\section{Lunária. Månviol.}

1. L. redivíva L.; blad hjertlika skaftade. 1, 2.

3-4 fot hög och finhårig med handsbreda blad och 2 tum långa, vanl. trefröiga skidor.

Lundar; Göt. Sk. spr. Boh. r.

\section{Búnias. Långrofva, Ryssar.}

1. B. orientális L.; rotblad parklufna. 3 .

3-4 fot hög och finhårig med ofta fotslånga rotblad.

Svårt och nästan outrotligt åkerogräs, ursprungl. infördt från Ryssland, äfven ruderatväxt; Norrl. Hels. Gestr. spr. Jtl. r., Sv. Söd. Upl. t. a. Vestm. Ner. spr. Verml. Dal. r., Göt. Ög. t. r. Smål. Blek. Öl. Gotl. r. Sk. spr. Dalsl. r. 


\section{Néslia. Korndodra.}

1. N. paniculáta (L.) Desv.; kronblad vigglika och längre än fodret. 3 .

Omkr. 2 fot hög, rikbladig och spenslig med sträfva, n. hela lansettlika och stjelkomfattande blad; skidornas skaft mycket långa och utstående.

Ogräs i åkrar, .stundom ruderatväxt, helst i slättbygder; Göt. mångenst.: Gotl. Öl. Sk. a. inre Smål. Vg. Boh. Dalsl. r., Sv. Söd. Upl. spr. Vestm. r., Norrl. Gestr. r.

\section{Klassen. MONADELPHIA. \\ 1 Ordn. PENTANDRIA. 347. Linum. Lin.}

1. L. cathárticum L.; blad aflånga-lansettlika, oskaftade och motsatta; stjelk klynnedelad. 2, 3.

Omkr. 1/2 fot hög med små och i början lutande blommor; fröhus stora som hampfrön och klotrunda.

Ängar och backar; Göt. a.: inre smål. Boh. spr., Sv. t. a.: Dal. spr., Norrl. spr.: Gestr. Hels. a. Ång. V'b. r.

\section{Ordn. DECANDRIA.}

\section{0'xalis. Harsyra.}

1. 0. Acetosella L.; blommor vanl. hvita och rödstrimmiga. $1,2$.

Fingerhög med trådlik och upptill fjällig rotstock; blommor lutande; smak syrlig. Är funnen med ljusröda blommor i Sk. Boh. och Vg., med ljust violetta i Smål. Vg. och Dalsl. Skogar och lundar, allmän: Gotl. spr. Lpl. t. r.

349. Geránium. Stork-näf.

A. Blomfoder slutl. hopdraget upptill. Kronbladens klo lika lång som skifvan eller längre. Pålrot svag och enårig. Blommor teml. små. 1. G. Robertianum. 2. G. lucidum.

B. Blomfoder utstående. Kronbladens kjo kortare än skifvan.

a. Pålrot svag och enårig. Blommor teml. små.

1. Karpeller n. glatta samt kölade eller fårade. 3. G. columbinum. 4. G. molle.

2. Karpeller håriga, icke fårade eller kölade. 5. G. rotundifolium. 6. G. dissectum. 7. G. bohemicum.

b. Rotstock grof. Blommor vanl, stora.

1. Blonskaft slutl. upprätta. 8. G. phæum. 9. G. silvaticum.

2. Blomskaft slutl. nedböjda. 10. G. pratense. 11. G. palustre. 12. G. pyrenaicum. 13. G. sanguineum.

1. G. Robertiánum L.; blad helt och hållet delade med kantig omkrets och lansettlika parklufna flikar; kronbladens skifva lika lång med klon; blomfoder hårigt och ovingadt. 2,3 . 
Omkr. fotshög, långhårig, stinkande och starkt rodnande; kronblad smala och hela, rosenröda med hvita ådror; blomskaft slutl. utstående; foderblad med långt borst.

Berg och stenrös; Göt. Sv. allmän, Norrl. spr.

2. G. lúcidum L.; blad kilufna med rund omkrets och vigglika inskurna flikar; kronbladens skifva kortare än klon; blomfoder glatt, hinnvingadt och på tvären rynkigt. 2,3 .

$1 / 2-1$ fot hög och $n$, glatt, starkt rodnande; kronblad med teml. bred och n. hel skifva, rosenröda och små; blomskaft slutl. utstående; foderblad med kort borst.

Skuggrika och stenbundna ställen, helst på berg i skärgården och vid större sjöar; Göt. spr.: Öl. a. inre Smål. Hall. Boh. Vg. t. r., Sv. Söd. Üpl. spr. Vestm. r.

3. G. columbinum L.; blad delade med rund omkrets och smalt vigglika, djupt inskurna flikar; kronblad omvändt äggrunda, urnupna; foderblad med långt borst; karpeller på ryggen kölade. 3.

$1 / 2-1$ fot hög och tilltryckt hårig; kronblad blåröda, n. lika långa som foderhladen; blomskaft slutl. nedböjda och mycket långa.

Berg och steniga backar; Göt. r.: Sk. a. Blek.-Ög. spr. Gotl. öl. t. a., Sv. Söd. spr. Upl. t. r. Ner. r,

4. G. molle L.; blad klufna med rund omkrets och vigglika inskurna flikar; kronblad omvändt hjertlika; foderblad med kort borst; karpeller snedt fårade. 3.

Omkr. $1 / 2$ fot hög med mjuka utstående hår; kronblad violettröda, lika långa med foderbladen eller dubbelt längre; blomskaft slutl. nedböjda; blad små och ljusgröna, de flesta strödda.

Helst på hafsstränder, mindre ofta inuti landet såsom ogräs eller ruderatväxt; Göt. Boh. Hall. spr. Sk. Blek. Öl. Gotl. a. Kalmarl. spr. inre Smål. Ög. Vg. t. r. (Dalsl, tillfällig), Sv. Söd. Upl. spr. (Verml. tillfällig).

5. G. rotundifólium L.; blad klufna med rund omkrets och vigglika inskurna flikar; kronblad omvändt äggrunda urnupna; foderblad med kort borst. 3.

Lika stor som föreg. med fina tilltryckta hår; kronblad blekt violetta och föga längre än foderbladen; blomskaft slutl. nedböjda. 5 ståndare sakna knappar.

Ruderatväxt; Göt. Sv. a.: vestra Smål. Boh.-Dal. t. r., Norrl. Gestr. Hels. Jtl. r. (§̊ng. tillfällig).

6. G. dissectum L.; blad delade med rund omkrets och smala inskurna flikar; kronblad omvändt hjertlika; foderblad med långt borst. 3 .

Omkr. fotshög med nedböjda hår; kronblad violetta och föga längre än foderbladen; blomskaft slutl. nedböjda och korta; blommor hälften så stora som hos $G$. columbinum eller ungefär som. hos de båda föreg. arterna. 
Ogräs i åkrar, helst nära hafvet; Göt. Boh. Hall. r. Sk. t. a. Blek.-Ög. r. Öl. Gotl. spr.

7. G. bohémicum L.; blad klufna med kantig omkrets och snedt rutformiga inskurna flikar; kronblad bredt vigglika, djupt urnupna; foderblad med långt borst. 3 .

Liknar mest $G$. silvaticum och har liksom denna upprätta blomskaft; kronblad blå, teml. små och föga längre än det stora fodret; stjelk $1 / 2-1$ fot hög, upptill glandelhårig, nedtill med utstående hår.

Ruderatväxt, helst på svedjeland eller kolbottnar, eller ogräs i åkrar, sporadisk, isynnerhet i skogsbygder; Norrl. Ång.-Gestr. r., Sv. t. r.: Verml. spr., Göt. Dalsl. spr. Smål. Ög. t. r.

8. G. phæum L.; blad klufna med kantig omkrets och snedt rutformiga inskurna flikar; kronblad bredt omvändt äggrunda, upptill rundade och naggade; foderblad med kort borst; ståndaresträngar syllika. 2, 3.

Omkr. 2 fot hög med utstående hăr, upptill glandelhårig; kronblad mörkbrunt violetta (n. svartaktiga), jemförelsevis små och föga längre än fodret; blomskaft omkring tumslånga och. stundom enblommiga.

Fuktiga bokskogar och gamla trädgårdar, mycket r.; Göt. Skåne vid Krageholm och Tosterup.

9. G. silváticum L.; blad djupt klufna med kantig omkrets och snedt rutformiga inskurna flikar; kronblad omvändt äggrunda, upptill rundade eller tvärhuggna, stundom naggade; foderblad med långt borst; ståndaresträngar smalt syllika. 2,3 .

1-2 fot hög och mer eller mindre finhårig; kronblad rödvioletta (sällan hvita), vanligen stora och dubbelt så långa som foderbladen, stundom smärre och föga längre än foderbladen.

Ängar, allmän utom i vissa delar af Verml. Boh. och inre Smål. 10. G. pratense L.; blad delade med kantig omkrets och snedt rutformiga, djupt inskurna flikar; kronblad bredt omvändt äggrunda, upptill afrundade; foderblad med långt borst; ståndaresträngar nedtill mycket bredare. 2,3 .

Liknar föreg. art, men har mera smalflikiga blad samt bredare foderblad; kronblad blåvioletta eller hvitaktiga; stipler hinnaktiga.

Ängar och parker; Göt. Boh. Sk. Blek. Smål. r. Ög. t. r., Sv. Söd. Upl. spr. Ner. Vestm. t. r., Norrl. Gestr. Hels. r.

11. G. palustre L.; blad klufna med kantig omkrets och snedt rutformiga inskurna flikar; kronblad aflånga eller smalt omvändt äggrunda, upptill afrundade; foderblad med långt borst; ståndaresträngar syllika. 3. Liknar G. silvaticum, men har smalare foderblad och kron- 
blad, de senare rödvioletta; stipler vanl. bladartade; birötter tapplikt uppsvälda.

Fuktiga skogsängar; Göt. sk. t. a. Hall. Boh. r.

12. G. pyrenáicum L.; blad lelufna med rund omkrets och vigglika inskurna flikar; kronblad omvändt hjertlika; foderblad med kort borst. 3 .

Omkr. fotshög och långhårig; kronblad blekt violettröda, n. dubbelt så långa som fodret; blommor smärre än hos föreg. art, ungefär som hos $G$. bohemicum; karpeller ofårade, finhåriga eller glatta; blad större än hos $G$. molle och mörkgröna, de flesta motsatta.

Ängar och parker r.; Göt. Hall. Sk. Smål. Ög. Öl. Gotl., Sv. Söd. Upl. Vestm.

13. G. sanguíneum L.; blad delade med rund omkrets och vigglika, upptill inskurna flikar; kronblad omvändt äggrunda urnupna; foderblad med långt borst. 2, 3 .

Omkr. 2 fot hög och slutl. starkt rodnande, med vanl. utstående hår; kronblad purpurröda, stora och dubbelt så långa som fodret; blomskaft oftast enblommiga och mycket långa (hos de öfriga arterna tvåblommiga); alla bladen motsatta och skaftade.

Berg och stenbundna ängar; Göt. t. a., Sv. Söd. Upl. t. a. Vestm. Verml. spr. Ner. Dal. r., Norrl. Gestr. Med. r.

\section{Eródium. Skatnäfva.}

1. E. cicutárium (L.) L'Herit.; bladflikar pardelade-parklufna; kronblad hela, längre än fodret. $2-4$.

Knappt $1 / 2$ fot lång och ofta nedliggande, med utstående hår; blomskärmar äggrunda spetsade; frukter korthåriga; foderblad med mycket kort borst: ståndaresträngar glatta.

Ruderatväxt och ogräs; Göt. a., Sv. t. a., Norrl. spr.: Jtl. Ång. r. V b. 0 .

\section{Myricária. Strandljung.}

1. M. germánica (I.) Desv.; ståndaresträngar hopväxta till $2 / 3$ af sin längd; somliga blad jemnbredt lansettlika och trubbiga, andra äggrunda kortspetsade; blomskärmar längre än blomskaften. 2, 3 .

2-5 fot hög med blågröna, oskaftade och tätt sittande blad.

Steniga elfstränder; Norrl. Jtl. flerst. Med. Ång. r. (Göt. Ög. vid sjön Tåkern trol. förvildad eller planterad, Smål.?).

\section{Ordn. POLYANDRIA.}

\section{Malva. Kattost.}

A. Blommor stora, enstaka i bladvecken, åtminstone de nedre; stjelk upprätt; karpeller svartnande vid mognaden. De öfre bladen delade.

1. M. moscháta L., Desmansrosor; karpeller ludna och ej skrynkliga; foderholkens blad smala, lansettlikt jemnbreda. 3 . 
1-2 fot hög och vanl. långhårig med stora, hvita eller ljusröda, myskluktande blommor; kronblad med bred klo; rotblad vanl. njurlika och inskurna; stjelkblad vanl. delade med parklufna flikar.

Ruderatväxt, trol. oftast förvildad; Göt. t. r.: Sk. Ög. spr. 0̈. Boh.?, Sv. t. r.: Dal. 0.

2. M. A'lcea L.; karpeller n. glatta och slutl. skrynkliga; foderholkens blad ovala. 3,4 .

2-3 fot hög och gråluden af stjernhår, med stora, ljusröda blommor; kronblad med teml. smal klo; de nedre bladen klufna, de öfre tredelade med n. rutformiga och inskurna (stundom n. hela) flikar.

Ruderatväxt; Göt. Got1. Öl. spr. Sk. t. a. Blek. Smål.r. Ög. t. r. ( $S v$. Söd. Upl. Vestm. förvildad).

Anm. Stundom (isynnerhet i trädgårdar) förekomma former, som trol. äro bastarder af föreg. arter.

B. Blommor i knippen i bladvecken; karpeller gulnande vid mognaden. De öfre bladen flikiga eller inskurna.

a. Stjelk n. upprätt med stora blommor och glatta karpeller; blomskaft upprätta.

3. M. silvestris L.; karpeller rynkiga med hvassa kanter; kronblad 3 gånger längre än fodret. 3, 4 .

1-3 fot hög "och gleshårig med rödvioletta blommor och rundadt njurlika, flikiga blad.

Helst nära hafvet, mindre ofta ruderatväxt eller ogräs i åkrar; Göt. Boh. Hall. r. Sk. a. Blek. Kalmarl. Öl. Gotl. spr. Ög. r., Sv. Söd. Upl. r. Vestm?

b. Sidostjelkar nedliggande; blommor teml. små; karpeller ludna; blomskaft slutl. nedböjda.

4. M. boreális Wallm.; kronblad grundt urnupna och föga längre än fodret; karpeller skrynkliga med upphöjda kanter. 3, 4.

Med omkr. $1 / 2$ fot långa grenar och små hvitaktiga blommor; blad rundadt njurlika, grundt inskurna och tandade. M. pusilla With.

Ruderatväxt; Göt. Sv. t. a.: Gotl.t. r. Hall.-Dal. spr., Norrl. Gestr. spr. Hels. Med. Jtl. r.

5. M. vulgaris Fr.; kronblad djupt urnupna, 2-3 gånger längre än fodret; karpeller släta utan kanter. 3, 4 .

Liknar föreg. art, men har större och rödletta blommor.

Ruderatväxt, helst i slättbygder; Göt. a.: inre Smål. r. Boh. spr. Vg. r.? Dalsl. 0, Sv. Söd. Ner. t. a. Vestm. spr. Upl. t. r. Verml. r., Norrl. Gestr. r.

353. Lavatéra. Stockros.

1. L. thuringíaca L.; blommor ensamma i bladvecken; 
de nedre bladen rundade, de öfre treflikiga med större mellanflik. 3,4 .

3-4 fot hög med blommornas skaft längre än bladens. Ruderatväxt; Sv. Upl. Vestm. Ner. r. Söd. flerst., Gö̈t.Ög. r

\section{Klassen. DIADELPHIA. 1 Ordn. HEXANDRIA. \\ 354. Fumária. Jordrölesblomma.}

1. F. officinalis L.; foderblad äggrundt lansettlika, smalare än kronan och 3 gånger kortare; frukter n. runda, mera breda än långa, i spetsen tvära och intryckta. $2-4$.

Omkr. $1 / 2-1$ fot hög, späd och blågrön; blommor upptill mörkröda; blad dubhelt parbladigt delade med platta, smala och aflångt jemnbreda flikar.

Ogräs i åkrar och trädgårdar; Göt. Sv. a., Norrl. t. a.: Vb. r.?, Lpl. r.

2. F. Vaillántii Lois.; foderblad n. jemnbreda, smalare än blomskaftet och 6-10 gånger kortare än kronan; frukter n. runda, i spetsen afrundade samt vanl. med vårtlik udd. $2,3$.

Liknar föreg., men är ännu mera blâgrön, med smärre och färre blommor och frukter sant smalare och spetsigare bladflikar; blommor blekröda. Ög. r.

Ogräs och ruderatväxt; Sv. Upl. spr. Vestm. Söd. r., Göt.

Anm. F. tenuifóra Fr., som tillfälligtvis blifvit funnen Upl. och Skåne, har lika små blommor som föreg. art, men dessa äro n. hvita och blott i spetsen mörkröda; bladflikar och foderblad som hos $F$. officinalis; frukter klotrunda med kort vårtlik udd.

\section{Cory'dalis. Nunneört.}

A. Lökknöl tät; stjelk med ett fjäll (nedanför nedersta bladet); sporre mot spetsen afsmalnande.

a. Stift nästan rakt utan knä. Sporre n. rak.

1. C. fabácea Pers.; fröhus lansettlikt, 3-4 gånger längre än skaftet; blomskärmar äggrunda-ovala och vanligen hela. 1.

3-6 tum hög och späd; det nedre kronbladet utan knöl nedtill; sidokronbladens köl utlöpande till spetsen; klase i början lutande.

Lundar; Göt. spr.: Öl. Sk. a. Dalsl. r., Sv. Söd. Upl. t. a. Ner. spr. Vestm. spr. i s. delen, Norrl. Gestr.-Med. Jtl. r., Lpl.r.

2. C. púmila Rehb.; fröhus äggrundt lansettlikt, $2-3$ gånger längre än skaftet; blomskärmar omvändt äggrunda och vanl. handfikiga. 1. 
lika hög som föreg. art; det nedre kronbladet utan knöl nedtill; sidokrunbladens köl upphörande nedom spetsen; klase alltid upprätt; blommor bleka.

Lundar, helst i skärgården; Göt. Sk. Blek. Öl. spr. Gotl. Smål. r. Ög. t. r. Vg.?, Sv. Söd.' Upl. r.

3. C. laxa Fr.; fröhus smalt lansettlikt, föga längre än skaftet; blomskärmar som hos föreg. art. 1, 2.

Något högre och gröfre än de föreg. med mera smalflikiga blad och talrikare, starkare färgade blummor; det nedre kronbladet med en knöl nedtill; sidokronbladens köl utlöpande till spetsen; klase i början lutande.

Lundar, helst i skärgården; Göt. Sk. t. r. Gotl. Ög. Vg. r. Smål.?, Sv. Söd. Upl. t. r.

b. Stift knäböjdt. Sporre krökt.

4. C. sólida Sm.; fröhus smalt lansettlikt, lika långt som skaftet; blomskärmar omvändt äggrunda och vanl. handflikiga. $1,2$.

Liknar föreg. art, men har större blommor och upprätt klase; sidokronbladens köl ej nående till spetsen.

Lundar, mycket r.; Göt. Sk. Blek., Sv. Söd. Upl.

B. Lökknöl ihålig; stjelk utan fjäll vid nedersta bladet; sporre i spetsen förtjockad och krökt.

5. C. cava Schweig.; fröhus 3 gånger längre än skaftet; blomskärmar äggrundt lansettlika och hela. 2.

$1 / 2-1$ fot hög och gröfre än de föreg. arterna med purpurröda eller hvita blommor. Kallas i Vadstena Munkar och Nunnor och är i Ög. troligen qvarstående sedan medeltiden.

Lundar och gamla trädgårdar; Göt. Sk. a. Öl. spr. Hall. Smål. Ög. $r$.

\section{Ordn. OCTANDRIA.}

\section{Poly'gala. Fogelört, Jungfru Maric lin.}

A. Blad aflånga-lansettlika, de nedre mindre än de öfre samt snart vissnande.

1. P. vulgaris L.; blomskärmar ovala: de båda på sidorna sittande $1 / 2$ så långa som blomskaftet, den mellersta af blomskaftets längd och ej framskjutande; fröhus omvändt hjertlikt, mera långt än bredt. 2,3 .

$1 / 2$ fot hög, vanligen med blå blommor, mindre ofta med röda eller hvita; sidofoderblad längre, men mindre ofta smalare än fröhuset.

Ängar; Göt. Sv. a., Norrl. r.: Gestr. spr. Jt1.? Ång. Vb. 0 .

2. P. comósa Schk.; blomskärmar lansettlika: de båda på sidorna sittande lika långa som blomskaftet, den mellersta längre och framskjutande före blomningen; fröhus bredt omvändt hjertlikt, nedtill afrundadt, lika långt som bredt. 2,3 . 
Liknar mycket föreg. art, men är något högre, alltid med röda, talrika och mera tätt sittande blommor; sidofoderbladen något kortare än fröhuset.

Ängar, helst på kalkgrund; Göt. r.: Öl. a. Kalmarl. Ög. spr. Vg.? Hall. Boh. 0, Sv. spr.: Verml. r. Ner. t. r. Dal. 0, Norrl. Gestr. r.

B. De nedre bladen varaktiga, spadlika, samlade $i$ rosett och bredare än de öfre vigglika bladen.

3. P. uliginósa Rchb.; sidoblomskärmar kortare än blomskaftet, midtblomskärmar af blomskaftets längd; fröhus omvändt äggrundt, nedåt smalare. 2.

Ornkr. fingerhög med hlå, stundom hvita blommor, smärre än hos de föreg. arterna; sidofoderblad lika långa med fröhuset, men smalare.

Fuktiga ängar, helst i slättbygder; Göt. spr.: Öl. a. Gotl. t. a. inre Smål. Blek. r. Hall.-Dalsl. 0, Sv. spr.: Ner. t. r. Vestm. r. Verml. 0, Norrl. Jtl. t. a. Gestr.-Med. r.

\section{Ordn. DECANDRIA.}

\section{Anthyllis. Örnblomster, Räfklor.}

1. A. Vulnerária L.; de nedre bladens uddblad mycket stort. 3 .

Omkr. $1 / 2$ fot hög, tilltryckt hårig och flerstjelkig med något träakitig rotstock. Förekommer stundom pă Öl. och Gotl. med röda eller ljusgula blommor; den rödblommiga formen är äfven någon gång funnen $\mathrm{i}$ Jtl. och Ög.

Berg, ängsbackar och stränder, helst i slättbygder; Göt. t. a.: Blek.-Ög. Vg. spr. inre Smål. Dalsl. t. r., Sv. Söd. Upl. t. a. Ner. spr. Vestm. spr. i s. delen, Verml. t. r. Dal. r., Norrl. Herj. Jtl. t. r. (Gestr. tillfällig), I $p l$. r.

\section{Onónis. Räfblommor.}

1. O. hircína Jacq., Stallört, Bockört; stam örtartad, uppstigande, oväpnad och allsidigt klibbhårig; småblad äggrundt aflånga, håriga och sågade; stipler äggrunda. 3 .

Inemot 2 fot hög och mycket illaluktande ört med föga grenig stjelk; de nedre blommorna parvis sittande i bladvecken, de öfre i täta ax i spetsen af grenarne.

Ängar och åkerrenar, helst i slättbygder; Göt. spr.: Öl. a. Gotl. inre Smål. Dalsl. 0, Sv. Söd. Upl. Ner. spr. Verml. r. Vestm. spr. i s. delen, Norrl. Jtl. r.

2. O. procurrens Wallr., Puktörne; stam nedtill träaktig, uppstigande eller nedliggande, ofta tornbärande, och allsidigt klibbhårig; småblad ovala-aflånga (någongång lansettlika), håriga och sågade; stipler bredt äggrunda. 3 .

Omkr. 2 fot hög och grenig halfbuske, med nästan alla blommorna stödda af blad och teml. glest sittande nedpå grenarne; balja kortare än fodret. 
Ängsbackar, helst nära hafvet; Göt. Vg. Boh. r. Hall. Sk. t. a. Blek. Kalmarl. spr. Got]. Öl. a. Ög. r. (blott inuti landet), Sv. Söd, spr. Upl. t. r., Norrl. Med. r.

o. campestris Koch o. Ziz; stam nedtill träaktig, vanl. upprätt, tornbärande, vexelvis på en sida hårig; småblad smala, aflångt lansettlika, n. glatta och hvasst sågade; stipler lansettlika. 3 .

Liknar föreg. art; balja lika lång som fodret.

Ängar och åkerrenar; Göt. Skåne t. r. Gotl. r.

359. Sarothámnus. Hareris.

1. S. scopárius (L.) Koch; balja långhårig. 2-3.

2 -5 fot hög och upprätt, svartnande vid torkning; grenar kantiga; småblad aflånga.

Torra sandiga ställen bland huskar, helst nära hafvet; Göt. r.: Sk. spr. Blek.? Öl. Ög. Dalsl. 0, Sv. Upl. r.

\section{Genista. Ginst.}

A. Med tornar (ombildade bladskaft) på de äldre, ej blombärande grenarne. Blommor i bladlösa klasar. Blad utan stipler.

1. G. germánica L., Tysti Ginst; balja luden och hoptryckt; fodrets läppar n. likformiga med smala tänder. 3.

Stammar utbredda, knappt fotslånga (liksom hos de följ. arterna); blombärande grenar upprätta med tätt sittande och mjukhåriga, aflånga-lansettlika blad; blomklasar aflånga; kronsegel ludet, mycket kortare än kölen; blomskärmar små och syllika; tornar ofta pargreniga, stundom med små, n. aflånga blad. 13lommar (liksom de öfriga arterna) bäst i slutet af Juni.

Ljunghedar, mycket r.; Göt. Sk. Saxaljung, Hall. Skedala exercisfält och nära Énslöfs färjeställe, Dalsı. i en tallskog ö. om S:t Doras källa vid Berg i Holms s:n.

2. G. ánglica L., Engelsk Ginst; balja glatt och n. trind; fodrets öfverläpp med äggrunda uddspetsiga flikar, underläpp med lansettlika tänder. 2,3 .

Stammar n. upprätta; blad smärre än hos föreg. och kort uddspetsiga, de blombärande grenarnes omvändt äggrunda, de äldre grenarnes jemubredt lansettlika; blomklasar korta; kronsegel glatt, kortare än kölen; blomskärmar omvändt äggrunda; tornar enkla, sällan tredelade.

Ljunghedar, mycket r.; Göt. Hall. i Veinge s:n.

B. Stam utan tornar. Blommor $1-2$ i bladvecken, närmade till bladiga klasar. Blad med stipler.

3. G. tinctória L., Färgginst; blomskaft af fodrets längd eller kortare samt med två skärmar; kronsegel glatt och lika långt som kölen; foder glatt. $2-3$.

Vanl. alldeles glatt med uppstigande stammar och upprätta grenar: balja jemnbred, något hoptryckt och bågböjd, slutl. brun; blad vanl. lansettlika-aflånga och otydligt uddspetsiga. 
Betesmarker r.; Göt. Hall. vid Halmstad a., Vg. t. r., t. ex. vid Sjötorps kanalstation.

4. G. pilósa L., Hårig Ginst; blomskaft längre än fodret samt utan skärmar; kronsegel ludet, längre än kölen; foder med tilltryckta hår. 2-3.

Stam krypande; unga grenar håriga; balja jemnbredt aflång, slutl. svart; hlad mycket små, aflånga eller n. tunglika, mycket talrika och tätt sittande; blommor något smärre än hos föreg. art. Ljunghedar; Göt. Hall. teml. allm. Sk. Smål. r.

\section{Vicia. Vicker.}

A. Blommor ensamma eller parvis i bladvecken. Balja oskaftad och flerfröig. Småblad vanl. tvärhuggna upptill. 1. V. sativa. 2. V. angustifolia. 3. V. lathyroides.

B. Blomklasar făblommiga och $n$. oskaftade. Balja skaftad och flerfröig. Småblad vanl. tvärhuggna. 4. V. sepium.

C. Blomklasar långskaftade, vanl. mångblommiga. Smmåblad vanl. trubbiga.

a. Stipler klufna eller tandade. Balja flerfröig. Blommor teml. stora. 5. V. silvatica. 6. V. dumetorum. 7. V. pisiformis.

b. Stipler helbräddade och halft pillika. Balja flerfröig. Blad mångpariga; ej längre än blomklasen. Blommor blàaktiga. 8. v. Cracca. 9. v. villosa. 10. V. tenuifolia.

c. Stipler helbräddade och halft pillika. Balja en-eller tvaifröig. Blomklase kortare än det sammansatta, mångpariga bladet. Blommor rödvioletta. 11. V. cassubica.

d. Stipler jemnbredt lansettlika med få och borstlika tänder. Balja tvåfröig. Blommor blåhvita och mycket små. Blad mångpariga. 12. v. hirsuta.

1. V. satíva L., Vicker; balja plattad, luden och vid mognaden gulaktig; frön $n$. trinda, något plattade; blad 5-7-pariga. 3 .

Omkr. 2 fot lång och mer eller mindre luden med oftast parvis stälda blommor med blåaktigt segel nch röda vingar; småblad vanl. omvändt äggrunda, stundom aflånga; stipler tandade, vanl. halfmånlika; klänge grenigt.

Akrar; Göt. Sv. a., Norrl. spr.: Vb. r.

2. V. angustifólia Roth, Sommarvicker; balja föga hoptryckt, glatt och vid mognaden svartnande; frön trinda; blad 3-5-pariga. 3.

Liknar föreg. art, men är föga luden, med vanligen enstaka mörkröda blommor och längre, smalare, lansettlika-jemnbreda småblad; stipler tandade, halft pillika eller lansettlika; baljor knappt tumslånga.

Åkrar; Göt. Sv. spr.: Dal.?, Norrl. Gestr. t. r. Hels. r.

3. V. lathyróides L., Vårvicker; balja plattad, glatt och vid mognaden svartnande; frön $n$. trinda och knottriga; blad 2-4-pariga. 2. 
2 -7 tum hög, spenslig och föga luden, med små rödvioletta enstaka blommor; småblad omvändt äggrunda-lansettlika; stipler helbräddade och halft pillika; klänge enkelt.

Ängsbackar, helst i skärgården, sällan inuti landet; Göt.r.: Hall. Sk.-Kalmarl. Öl. spr. Vg. Dalsl. 0, Sv. Söd. Upl. t. r.

4. V. sépium L., Lundvicker, Tranärter; balja plattad, glatt och vid mognaden svartnande; frön trinda; blad 5 -8-pariga. $2,3$.

Liknar V. sativa till blad och blommor; småblad sällan smala och spetsiga; nedre stipler halft pillika tandade: klänge grenigt; rotstock skottalstrande.

Skogar och ängar; Göt. Sv. a., Norrl. spr.: Gestr. a. Vb. 0. 5. V. silvática L., Skogsvicker; stipler halfmånlika med borstlika tänder; kronseglets skifva längre än klon; blad 6-8-pariga. 3.

2-6 fot lång och slak, ljusgrön och glatt; småblad ovala-aflånga; kronblad hvita med blåstrimmigt segel; klase mångblommig, slutl. längre än det sammansatta bladet.

Skogsängar, helst i bergstrakter; Göt. mångenst.: Gotl. Ö1. Blek. r. inre Smål. Boh. t. r. Dalsl. Ög. t. a., Sv. spr.: Söd. Upl. t. a. Dal. t. r., Norrl. spr.: Vb. r.

6. V. dumetórum L.; stipler halfmainlika fliktandade och tilltryckta; kronseglets skifva kortare än klon; blad 3-4-pariga. 3.

Lika stor som föreg. art och slak, ljusgrön och glatt; småblad äggrunda, större än hos föreg. arter; blommor mörkt rosenröda; klase slutl. längre än bladet, 3-7-blommig.

Vid bergväggar bland buskar, mycket r.; Göt. Hall. Sk. Smål. Ög., Sv. Upl.

7. V. pisiformis L., Artlik Vicker; stipler halft pillika tandade; kronseglets skifva kortare än klon; blad 3-4pariga. 3.

3-6 fot hög och styf, blekgrön och glatt, liknande Sockerärter; småblad större än hos de öfriga arterna, bredt äggrunda och fasta; blommor gröngula; klase omkr. 5-blommig, kortare än bladet.

Berg; Göt. Ög. t. r. Smål. r.

8. V. Cracca L., Krikvicker, Kråkärter; kronseglets skifva lika lång med klon; balja lång och n. jemnbred med skaftet kortare än foderpipen. 2-4.

2-4 fot lång, slak och n. mörkgrön med vanl. tilltryckta hår; småblad aflånga, sällan n. jemnbreda; blommor blá.

Ängar och åkrar, allmän: Vb. spr. Lpl. r.

9. V. villósa Roth, Luddvicker; kronseglets skifva dubbelt kortare än klon; balja kort och n. rutformig med skaftet $n$. längre än foderpipen. 3 .

Liknar föreg. art, men är större och mera ullhårig; blommor något längre och violetta; blomfoder nedtill säcklikt. 
Åkrar, helst j slättbygder; Göt. Sk. t. a. Hall. Blek. spr. Kalmarl. Ög. a. inre Smål. Vg. Gotl. r. Öl. spr., Sv. Söd. Upl. a. Ner. t. a. Vestm. spr. Verml. r. Dal. r.?, Norrl. r.: Gestr.Med. spr. Vb. 0.

10. V. tenuifólia Roth; kronseglets skifva dubbelt längre än klon; balja lång och afsmalnande till ett med foderpipen lika långt skaft. 3 .

Liknar V. Cracca, men är större samt styf, sträf och mera klängande; småblad jemnbredt lansettlika; blommor något större än hos de båda föreg. och blekblå.

Ängar, helst (endast?) på silur. formation; Göt. Öl. spr. Gotl. Og. Kalmarl. Sk. t. r. Bob. r.

11. V. cassúbica L.; balja kort och n. rutformig. 3.

Fotshög eller något deröfver, styf och upprätt, med skottalstrande rotstock; småblad fasta, smalt äggrunda - aflånga, ljusgröna och vanl. småludna; kronsegel småningom afsmalnande till en bred klo; klänge teml. kort.

Berg och ängar; Göt. r.: Hall. Sk. Blek. Kalmarl. spr. Ög. mångenst., Sv. Söd. spr. Upl. t. r.

12. V. hirsúta (L.) Koch, Duf-lins; balja kort, aflång och vanl. luden, vid mognaden svart; frön n. klotrunda. 2,3 .

Späd och grenig, 1-3 fot lång, föga hårig; allm. blomskaft med udd; klase 3-6-blommig, n. kortare än bladet; fodertänder syllika, likformiga och längre än foderpipen; småblad aflångajemnbreda, i spetsen tvärhuggna eller urnupna; blad 6-8-pariga. Ipl. r.

Torra backar och åkrar; Göt. Sv. t. a., Norrl. spr.: Vb. r.,

\section{Ervum. Sparf-lins.}

1. E. tetraspermum L.; balja n. jemnbred, vanl. glatt och vid mognaden gul. 2, 3.

Liknar Vicia hirsuta och är n. glatt; allm. blomskaftet utan udd, af bladets längd; blad 3-5-pariga; småblad med kort spets; stipler helbräddade, halft pillika, de öfre stundom jemnbreda; klänge enkelt eller föga grenigt; fodertänder kortare än foderpipen.

Helst på berg, stundom i åkrar; Göt. Sv. t. a.: Dal. t. r., Norrl. Gestr. r.

\section{Láthyrus. Vial.}

A. Blad med klänge, åtm. de öfre. Stipler halft pillika.

a. Stjelk vingad och glatt; blommor röda eller blåröda. 1. L. silvestris. 2. L. heterophyllus.

b. Stjelk ovingad. Blommor gula eller rödaktiga. 3. L. pratensis. 4. L. tuberosus. 5. L. maritimus.

B. Bladskafiet ej förlängdt till klänge och ej vingadt. (o'robus L.).

a. Stjelk vingad. Stipler halft pillika. Rotstock skottalstrande med knöllikt uppsvälda birötter. 7. L. macrorhizus.

b. Stjelk ovingad. Somliga stipler utan pillik bas. Utan grenskott och rotknölar. 8. L. vernus. 9. L. niger. 
1. L. silvestris L.; blad enpariga med vingade skaft; stipler smalare än stjelken. 3 .

2-6 fot lång och ljusgrön; småblad lansettlika; balja hoptryckt, vid mognaden gulnande; kronsegel rosenrödt; stift vridet.

Berg och steniga ängsbackar; Göt. Sv. t. r.: Sk.-Upl. spl. Gotl. 0, Norr.l. Gestr. Hels. Ang. r.

- platyphyllus; småblad teml. breda, n. aflånga.

Göt. Boh.—sk. Smål. Ög. r.

2. L. heterophyllus L.; bladskaft vingade; de nedre bladen enpariga, de öfre tvåpariga; stipler vanl. bredare än stjelken. 3 .

Något större än föreg. art och blågrön; de öfre småbladen lansettlika eller smalt lansettlika; balja uppblåst och n. trind, vid mognaden gulnande; både kronsegel och vingar rosenröda; stift vridet.

Berg, helst i skogsbygder; Göt. Grotl. Sk. r. Smål. spr. Ög. t. r. Vg. Boh. r., Sv. Söd. Ner. r.

3. L. palustris L., Kärr-vial; bladskaft ovingade; blad 2-3-pariga; stipler mycket smala. 3.

1-2 fot lång och mörkgrön; småblad aflånga-lansettlika ; balja hoptryckt, vid mognaden svartnande; blommor purpurröda, slutl. blåaktiga; stift rakt.

Kärr och fuktiga ängar, helst $i$ slättbygder och nära sjöar; Göt. spr.: Blek. t. r. Boh. r. Dalsl. 0, Sv. spr.: Dal. r. Verml. 0, Norrl. Gestr. spr. Hels.-Vb. r., Ippl.?

4. L. pratensis L., Ängs-vial, Gubbtänder; blad enpariga med ovingade skaft; stipler n. lika breda som småbladen. 3 .

Omkr. fotslång och ljusgrön, glatt eller finluden; småblad lansettlika-aflånga; stjelk fyrkantig; balja boptryckt, vid mognaden svartnande; blommor gula med violettådrigt segel; stift rakt. Ängar; Göt. Sv. a., Norrl. spr.: Gestr. Hels. a. Vh. t. r.

5. L. tuberósus L., Knöl-vial; blad enpariga med ovingade skaft; stipler smala. 3.

2-3 fot lång, $n$. blågrön och glatt med knölbärande rotstock; småblad aflånga, oftast uppåt bredare; stjelk fyrkantig; balja uppblåst och n. trind, vid mognaden gulnande; blommor ljusröda, välluktande; stift vridet.

Åkrar och trädgărdar, r. och ursprungl. odlad; Göt. Sk. Ög., Sv. Söd. Upl. V estm.

6. L. maritimus (L.) Fr., Strandvial, Strandürter; blad 2-5-pariga med ovingade skaft; stipler mycket breda och tandade. 3.

1-2 fot lång, blågrön och vanl. glatt; småblad mycket breda och trubbiga, vanl. ovala; blommor violettröda; stift rakt. Liknar Sockerärter.

Sandiga hafsstränder; Göt. Sk. spr. Hall. r. Boh. t. r., St: Söd. r., Norrl. r.: Gestr. 0. 
7. L. macrorhizus Wimm., Gökmat, Gubbtänder; blad 2-3-pariga. 1, 2.

1/2 fot hög, blågrön och glatt; småblad aflånga-lansettlika, vanligen trubbiga; stjelk enkel och uppstigande; balja n. trind, vid mognaden svartnande; blommor röda, slutl. blågröna. O'robus tuberósus $\mathrm{L}$.

Ängar och skogsbackar; Göt. Sv. a., Norrl. Gestr. a. Hels. Med. spr. Ang. t. r.

8. L. vernus (L.) Wimm.; blad 2-3-pariga med äggrunda långspetsade småblad; stjelk enkel. 1, 2.

Omkr. $1 / 2$ fot hög och upprätt, ljusgrön och $n$. glatt med tumsbreda småblad; balja föga hoptryckt, vid mognaden brun; blommor blåaktiga.

Berg och lundar; Göt. mångenst.: Sk. Dalsl. a. Öl. t. a., Sv. spr.: Söd. Upl. t. a. Dal. r., Norrl. spr.: Vb. 0.

9. L. niger (L.) Wimm.; blad 4-6-pariga med aflånga -ovala, trubbiga eller kortspetsiga småblad; stjelk grenig. 2, 3.

1-3 fot hög och upprätt, n. blågrön och glatt, vid torkning vanligen svartnande; balja något hoptryckt, vid mognaden svart; blommor purpurröda, slutl. blăaktiga.

Berg och lundar; Göt. mångenst.: Gotl. t. a. Boh. r. Dalsl. t. r., Sv. Söd. Upl. spr. Ner. r. Verml. t. r. Vestm. spr. i s. delen.

\section{Pisum. Ärter.}

1. P. arvense L., Vildärter, Gräärter; blad 1-2-pariga; stipler halft pillika. 3.

2-3 fot lång, blågrön och glatt; blommor med violett segel, rödblå vingar och hvitaktig köl; småblad stora, âggrunda -ovala, upptill tandade; frön kantiga, grågröna och brunfläckiga.

Ogräs i åkrar; Göt. Dalsl. Boh. r. Hall. Sk. t. a. Blek.Ög. spr., Sv. Söd. Upl. spr. Vestm. Verml. r., Norrl. Gestr. Med. Ang. Jtl. r.

\section{Astrágalus. Backsöta.}

A. Balja glatt och bågböjd; blommor blekt gröngula; blomklase ej öfverskjutande bladet. Småblad stora.

1. A. glycyphyllus L.; balja långt utskjutande ur fodret och n. upprätt. 3.

Grof och ända till 6 fot lång, nedliggande och illaluktande; blad omkr. 6-pariga, n. glatta och undertill blekgröna, med stora stipler; småblad stora, ända till tumshreda och äggrunda; balja n. trekantig; blommor utvändigt rodnande.

Lundar och skogar: Göt. spr.: Hall. Boh. t. r., Sv. r.: Ner. Verml. spr., Norrl. Hels. Med. Jtl. r.

B. Balja rak och hårig. Blommor blåaktiga, sällan hvita; blomklase öfverskjutande bladet. Småblad teml. små. 
a. Balja till hälften insänkt $\mathrm{i}$ fodret.

2. A. orobóides Horn.; balja aflång-oval och svarthårig; blommor blekblå med mycket korta och slutl. nedböjda skaft. 2,3 .

Teml. spenslig, omkr. fotshög och uppstigande; blad omkr. 6-pariga, glatta och undertill blågröna; småblad aflånga; blomklasar (ax) omkr. 8-10-blommiga.

Ängsmark i fjellen r.; Lpl., Norrl. Jtl. Herj.

3. A. dánicus Retz.; balja hjertlikt äggformig, n. oskaftad och långt hvithárig; blommor blå med mycket korta, slutl. upprätta skaft. 3 .

Några tum hög, uppstigande och småluden; blad 6-12-pariga; småblad äggrunda-aflånga; blomklasar (ax) korta, hufvudlika och omkr. 5-blommiga. Liknar följ. art.

Strandängar vid hafvet, mycket r.; Göt. Sk. Smål.

b. Balja till största delen utskjutande.

4. A. alpínus L., Fjellärter; balja nedhängande, n. trekantig, lansettlik-aflång med utskjutande bas samt vanl. svarthårig; blommor blekblå, sällan hvita. 2, 3.

Spensligare än $A$. oroboides och i början några tum hög, slutl. $1 / 2-1$ fot, ofta nedliggande; blommor välluktande; blad omkr. 9-pariga, undertill finhåriga; småblad ovala; blomklasar korta och hufvudlika.

Ängsmark, helst något fuktig, i fjellen, stundom i lägre trakter nedanför fjellen; Lpl. a., Norrl. Jtl. Herj. a. (i fjelltrakter) Vb. Ång. r. Hels. spr.

- dilútus (Norman); foder och balja gulhåriga.

Norrl. Jtl. r.

5. A. arenárius L.; balja länge upprätt, slutl. slak, n. jemntjock och hvitluden, med $\mathrm{i}$ fodret insänkt bas; blommor rödvioletta. 3 .

Inemot $1 / 2$ fot hög och vanl. nedliggande samt grå- eller hvitluden; blad 3-5-pariga; småblad smala n. jemnbreda; blomklasar något glesblommiga, föga öfverskjutande bladet; rotstock mycket grenig.

Flygsandsfält; Göt. Sk. t. r.

366. Phaca. Fjellvicker.

1. P. frígida L.; balja rak svarthărig, langt utskjutande och hängande. 3.

Upprätt, blågrön och mer än fotshög; blad omkr. 5-pariga, något håriga; småblad trubbiga, äggrundt aflånga och inemot en tum breda; klasarnes skaft ofta öfverskjutande stjelkens topp ; balja aflång och n. trind. Liknar något Astragal. glycyphyllus.

På hård mark, helst bland buskar, i fjellen; Lpl.spr., Norrl. Jtl. Herj. r.

\section{Oxy'tropis. Kloärt:}

A. Stjelkar utdragna. Blomklasar (ax) utgående från stjelkens öfre del. 
1. O. pilósa (L.) D.C.; balja upprätt och lansettlik, n. lika bred som fodret; blommor gula. 3 .

Omkr. fotshög, styf och vanl. upprätt, öfverallt beklädd med mjuka utstående hår; blad omkr. 10-pariga; småhlad aflångajemnbreda; skärmblad långa, lansettlika-syllika; stipler fria och jemnbreda; balja kortskaftad.

Berg nch ängshackar r. och trol. blott på silur. formation; Göt. Gotl. Ög. Smål.

B. Stjelk föga utbildad. Balja slutl. mycket bredare än fodret.

2. O. campestris (L.) D.C.; balja äggformig och upprätt; blommor gula. 3 .

Med tjock rotstock och mycket tufvad; klaseskaft långhåriga; blad omkr. 12-pariga; småblad äggrunda-lansettlika; stipler lansettlika, nedtill vidväxta bladskaftet; balja oskaftad och uppblåst.

Torra fält; Göt. Öl. allm. Gotl. Smål. r.

3. O. lappónica (Wahlenb.) Gaud.; balja n. oval och slutl. nedböjd; blommor blåvioletta. 2,3 .

Hela växten är beklädd med korta tilltryckta silkeshår och är ofta nedtryckt till marken; stjelkar (grenar) $1 / 2-2$ tum långa; blad omkr. 12-pariga; småblad n. lansettlika och spetsade; balja oskaftad, n. trind eller trekantig; blommor smärre än hos föreg. art.

Ängsmark, ofta vid vägar, i fjellen, r.; Lpl., Norrl. Jtl. Herj. 368. Onobry'chis. Helghö.

1. 0 . satíva Lam.; blad mångpariga. $2,3$.

1-2 fot hög och $\mathrm{n}$. ogrenad, mer eller mindre hảrig; stipler hopväxta; frön njurlika.

Akrar och ängar r., ursprungl. odlad; Göt. Gotl. Öl. Sk. Små]. Ög., Sv. Upl.

\section{Coronilla. Kronärter.}

\section{C. Émerus L.; småblad omvändt äggrunda. 2-3.}

Inemot 2 fot hög med gröna, vidjelika och kantiga grenar; blad ungefär nagelstora; balja smal; stipler fria, mycket små och snart vissnande.

Skuggrika ställen på kalkberg, mycket r.; Göt. Gotl. Öl.

$$
\text { 370. Ornithopus. Fogellioürter. }
$$

\section{0 . perpusillus L.; småblad ovala-aflånga. 3}

Stjelkar utbredda, ofta nedliggande, 3-10 tum långa och n. trådsmala; baljor bågböjda, något liknande fogelklor; blommor rödstrimmiga med gul köl.

Torra sandiga betesmarker, mycket r.; Göt. Skåne.
371. Lotus. Gigalsärter, Käringtänder.

1. L. corniculátus L.; stjelk tät; blomhufvud 3-6-blommiga; fodertänder bredt syllika, före blomningen hopstiende; blomkronans vingar krökta vid nedre kanten och bredare än kölen. 2, 3 . 
Omkr. 1/2 fot hög och uppstigande, vanligen glatt; balja jemntjock och utstående; småblad vanligen omvändt äggrunda; kronseglets skifva rund; vingar midtpå bredast. Lpl. r.

Ängar; Göt. S'v. a., Norrl. spr.: Gestr. a. Ång. t. r. Vb. r.,

2. L. ténuis Kit. o. Willd.; blomhufvud 3-5-blommiga; blomkronans vingar smalare än kölen och icke krökta; småblad vanl. smalt lansettlika; eljest som föreg. art. 2. 3 .

Ảngar, helst nära hafvet; Göt. Hall. Smål. r. Sk. spr. mest på v. kusten.

3. L. uliginósus Schk.; stjelk ihålig; blomhufvud 6-12blommiga; fodertänder jemnbreda-lansettlika, före blomningen nedböjda. 3 .

1-2 fot hög, uppstigande eller upprätt, glatt eller luden; balja som hos föreg. art; småblad omvändt äggrunda eller de öfre rutformiga; kronseglets skifva äggrund; vingar omvändt äggrunda, nedtill ej krökta; rotstock skottalstrande.

Fuktiga ängar; Göt. Sk. spr. Hall. t. r. Smål. Gotl. r. Ög.?

\section{Trifólium. Väpling, Klöfver.}

A. Blommor röda (stundom hvitaktiga) utan blomskärmar. Balja innesluten, 1-2-fröig. Smâblad n. helbräddade.

a. Blomkrona högröd, öfverskjutande fodrets tänder. Blomhufrud klotrunda eller bredt äggformiga. Växter med rotstock och teml. stora blommor. 1. T. pratense. 2. T. medium.

b. Blomkrona ljusröd (vanl. i början hvit), oftast kortare än fodrets tänder. Blomhufvud utdragna och n. jemntjocka. Växter med svag pålrot och små blommor. 3. T. arvense. 4. T. striatum.

B. Blommor stödda af små blomskärmar samt hvita, hvitröda eller gulaktiga. Balja stundom utskjutande. Småblad fintandade. Blomhufvud långskaftade.

a. Blommor hvita eller hvitröda. Växter med rotstock. 5. T. montanum. 6. T. hybridum. 7. T. repens. 8. T. fragiferum.

b. Blommor gula och torrhinniga, stundom brunaktiga. Balja utskjutande, skaftad och enfröig. Blomhutvud i börian halfrunda. Blomskaft kortare än foderpipen. Rot svag och enårig. De öfre bladens småblad teml. smala, n. vigglika och upptill fintandade. 9. T. procumbens. 10. T. filiforme. 11. T. agrarium. 12. T. spadiceum.

1. T. pratense L., Rödllöfver; de mellersta stiplernas fria del kort och triangelformig med kort borst; fodertänder oliklånga, den nedersta något längre än foderpipen; småblad äggrunda-ovala. 2-4.

$1 / 2-1$ fot hög eller deröfver, upprätt eller uppstigande med teml. rak stjelk; blomhufvud vanl. oskaftade; stipler hinnaktiga. Ängar, allmän: Vb. Jtl. spr. Lpl. t. r. 
2. T. médium L., Skogsklöfver; de mellersta stiplernas fria del syllik; fodertänder oliklånga, den nedersta dubbelt längre än foderpipen; småblad aflånga-ovala. 3 .

Lika stor som föreg. art, uppstigande eller nedliggande med krokig stjelk; blomhufvud vanl. skaftade, oftast ensamma; stipler n. bladartade.

Skogsängar, berg och backar; Göt. Sv. t. a., Norrl. Gestr. Hels. t. a. Med. Herj. Jtl. spr. Ång. r.

3. T. arvense L., Harklöfver; blomhufvud långskaftade, i början smalt äggformiga, slutl. n. jemntjocka; småblad smalt aflånga eller vigglikt lansettlika. 3, 4 .

Omkr. fotshög och upprätt, enkel eller upptill grenig; blomhufvud enstaka, somliga i toppen af grenarne, andra $i$ bladvecken, utblommade vanl. mycket ludna; blommor i början hvita; fodertänder hetydligt längre än kronan; stipler med långt borst.

Sandiga backar och àkrar; Göt. a.: Boh. t. r. Dalsl. spr., Sv. spr.: Söd. Upl. a. Dal.?, Norrl. Gestr. Hels. r.

4. T. striátum L.; blomhufvud oskaftade, äggformigt aflånga; småblad omvändt äggrunda-hjertlika. 3, 4.

$1 / 2-1$ fot hög, mjukhårig och upprätt med inga eller korta grenar; blomhufvud enstaka (eller de öfversta 2 tillsammans); blommor ljusröda, snart vissnande; fodertänder olika långa, men kortare än kronan; stipler med kort borst.

Torra ängar och backar; Göt. Sk. spr. Hall. Smål. Blek. Öl.r. 5. T. montánum L., Back-klöfver; stjelk upprätt eller uppstigande; småblad (åtminstone upptill på stjelken) smalt aflanga-lansettlika hvasstandade; blomhufvud äggformiga. $2-4$.

1-2 fot hög och något hårig med fast och enkel stjelk; rotstock ofta så tjock som ett lillfinger; stipler lansettlikt syllika, nedtill kort hopväxta; balja innesluten, oskaftad och tvăfröig; blomrnor hvita; foder något hårigt.

Ängshackar; Göt. Vg. t. r. Hall. Blek. r. Sk. Smål. (i ö. delen) spr. Ög. Gotl. Öl. t. a., Sv. Söd. Upl. t. a. Vestm. Ner. spr., Norrl. Gestr. spr. Hels. r.

6. T. hy'bridum L., Alsikeklöfver; stjelk uppstigande; småblad omvändt äggrunda eller ovala, fintandade; blomhufvud klotrunda. 3.

1-2 fot hög och glatt med teml. vek stjelk; rotstock smal; stipler äggrunda långspetsade; balja utskjutande, skaftad och 2-4-fröig; blommor i början hvita, sedan ljusröda; foder glatt.

Fuktiga ängar, helst î slättbygder; Göt. mångenst.: Öl. Gotl. Hall. Boh. r. Sk. Dalsl. Ög. t. a., Sv. a.: Dal. spr., Norrl. t. r.: Gestr. Hels. spr. Herj.?

7. T. repens L., Hvitklöfver; stjelk krypande; småblad omvändt äggrunda fintandade; blomhufvud klotrunda. 3. Med 1/2 fot långa, glatta stjelkar och inemot lika höga, upprätta blomhufvudskaft; stipler sylspetsade; balja utskjutande, 
oskaftad och 3-4-fröig; blommor hvita, vissnade rödaktiga; foder glatt. Liknar föreg. art.

\section{Ängar, allmän.}

8. T. fragiferum L., Strandklöfver; stjelk lerypande; småblad omvändt äggrunda och fintandade; blomhufvud klotrunda eller bredt äggformiga; blomfoder ej öfverskjutande de lansettlika blomskärmarne, slutligen upporicist, 3,4 .

Liknar i början föreg. art, men har smärre blomhufvud (af en ärts storlek), som slutl. blifva mycket större och då något likna hallon; stipler n. syllika; balja innesluten, oskaftad och 1-2-fröig; blommor mycket små och ljusröda; foder hårigt.

Stränder; Göt. Sv. t. a. vid hafvet och vid Mälaren, inuti landet r. (t. ex. vid Stångån nära Linköping), Norrl. Med. r.

9. T. procumbens L., Gulklöfver; blomhufvud slutl. kilotrunda och tätblommiga; alla blad strödda; uddblad med vanligen utdraget skaft; allmänna bladskaftet utdraget och mycket längre än de äggrunda stiplerna. 3,4 .

Antingen låg, upprätt och enkel eller ända till fotslång, ned. liggande och mycket grenig; blommor gula glänsande; stjelk $n$. trådlik; stift kort. Liknar Medicago lupulina, men. har större blomhufvud.

Torra ängar och åkrar, helst i slättbygder och i skärgården; Göt. spr.: Gotl. Öl. Blek. Sk. a., Sv. Söd. spr. Upl. r. (Eljest tillfällig i Vestm. Ner. Verml. och Jtl.)

10. T. filiforme L.; blomhufvud slutl. rundade och glesblommiga; blad strödda; uddblad med intet eller kort skaft; allmänna bladskaftet kort och ej längre än de äggrunda stiplerna. 3,4 .

Liknar föreg. art, men har smärre, blekgula blomhufvud och. finare stjelk.

Ängar i skärgården; Göt. spr.: Sk. a. Gotl. Smål. r. Ög.? Skall äfven vara allmän på slättbygden i Skåne; i det inre Smål. och Vg. likasom i Ög. är denna art sannolikt förvildad.

11. T. agrárium L.; blomhufvud slutl. äggformiga eller ovala och tätblommiga; alla blad strödda; uddblad oskaftadt eller med mycket kort skaft; allm. bladskaftet n. kortare än de äggrunda-lansettlika stiplerna. 3, 4.

Vanl. högre än föreg. art med tjockare och upprätt stjelk: blommor gula glänsande; stift af baljgns längd.

Torra ängar och åkrar; Göt. spr.: Ög. t. a. Gotl. Öl. r. Hall. Boh. t. r., Sv. spr.: Dal. t. r., Norrt. Gestr.-Ång. r. (Jt1. tillfällig).

12. T. spadíceum L., Brunklöfver; blomhufvud slutl. aflånga eller $n$. jemntjocka och tätblommiga; de öf- 
versta bladen n. motsatta; uddblad oskaftadt; bladskaftet längre än de lansettlika stiplerna (åtm. de mellersta). 3, 4 .

Liknar föreg. art, men har brungula, slutl. glänsande bruna blommor.

Något fuktiga ängar och åkrar; Norrl. spr.: Ång. r. Vb. 0, $S v$. spr., Göt. Dalsl. Ög. r. Öl. t. r.

373. Melílotus. Melotenklöfver, Honingsklöfver.

1. M. albus Desrouss.; blommor hvita; kronsegel längre än de öfriga lika långa kronbladen; balja glatt, omvändt äggrund och oskaftad, trubbig med udd. 3.

Upprätt, ofta 2-4 fot hög; småblad vanl. aflånga, glest tandade; balja vid mognaden brun; blommor med svag lukt.

Ruderatväxt; Göt. t. r.: Öl. Dalsl. 0, Sv. t. r.: Söd. spr. Verml. 0; för öfrigt förvildad h. o. d. äfven i Verml. och Gestr. -Ång.

2. M. officinális Willd.; blommor gula; alla kronbladen lika långa; balja småluden, omvändt äggrund, kortskaftad och spetsig. 3 .

Omkr. 2 fot hög; småblad vanl. aflånga, glest hrasstandade; balja vid mognaden svart; blommor mycket välluktande.

Ruderatväxt och ogräs i åkrar; Göt. Sk. t. a. Blek. Smål. Boh. Vg. r. Ög. Gotl. Öl. spr., Sv. Söd. Upl. t. r. Ner. r.; för öfrigt förvildad h. o. d. äfven i Verml. Jtl. Med. och Ang.

3. M. arvensis Wallr.; blommor blekgula; kronköl kortare än de öfriga kronbladen; balja glatt, äggrund, kortskaftad och trubbig. 3.

Liknar föreg. art, men är spensligare; småblad något mindre och vanl. bredare; balja vid mognaden grönaktig: blommor välluktande. Förmodas vara hastard af föreg.: arter.

Åkerrrenar: Göt. Sk. Öl. t. r. Smål. Ög. Hall. Boh. r., Sv. Upl. r.; dessutom tillfällig i Vestm. och Gestr.

4. M. dentátus Pers.; blommor gula; kronsegel längre än vingarne, som öfverskjuta kölen; balja glatt, omvändt äggrund, oskaftad och spetsig. 3, 4 .

Omkring fotshög och spenslig med smärre, mera tätt sittande blommor, kortare klasar och bredare stipler än hos öfriga arter; småblad fint och tätt sågtandade, vanl. lansettlika; balja. slutl. svartbrun.

Strandängar vid hafvet, mycket r.; Göt. Skåne på v. kusten, t. ex. Borreby, Hillesborg.

\section{Medicágo. Lucern.}

A. Balja snäckformigt hoprullad.

1. M. lupulína L.; rot svag, enårig eller tvåårig; blommor gula; balja oöppnad, i midten sluten och icke taggig, vanl. glatt; blomhufvud mångblommiga. 2, 3 . 
1-2 fot hög och nedliggande eller uppstigande; stjelkar n. trådsmala; blomhufvud äggformiga, knappt större än ärter: deras skaft öfverskjutande bladen; fruktsamling slutl. n. jemntjock; småblad omvändt äggrunda med skaftadt uddblad.

Liknar Trifolium procumbens, men blomkronan qvarsitter ej efter blomningen.

Gräsbeväxta ställen, helst i slättbygder; Göt. a.: inre Smål. t. r. Vg. Boh. spr. Dalsl. r., Sv. a.: Vestm. Dal. spr. Verml. r., Norrl. Gestr._Ång. r.

2. M. mínima Lam.; rot tvåårig; blommor gula; balja oöppnad och taggig; blomhufvud 2-5-blommiga. 2, 3.

Stjelkar trådsmala, upprätta eller uppstigande och vanl. blott några tum långa; blomhufvudets skaft föga öfverskjutande bladet; balja mycket större än hos föreg. art och mera vriden; småblad omvändt äggrunda eller $n$. vigglika, i spetsen tandade.

Torra sandiga backar, mycket r.; Göt. Skåne vid Kåseberga och Malmö (Öl. och Söd. tillfällig).

3. M. satíva L., Blå Lucern; med rotstock; blommor blå eller violetta; balja uppbristande och i midten öppen; blomhufvud afläna och teml. glesblommiga; balja finluden. 3.

Omkr. fotshög eller något deröfver, n. upprätt och glatt; blommor större än hos föreg. arter; de nedre bladens småblad omvändt äggrunda eller ovala, de öfres aflånga-jemnbreda eller smalt vigglika.

Gräsheväxta ställen, ursprungl. förvildad, helst i slättbygder; Göt. Sk. Ög. t. r. Blek. Smål. Öl. Gotl. r. (Sv. Söd. Upl. Vestm. Ner. tillfällig).

B. Balja skärformigt krökt och uppbristande. Med rotstock.

4. M. falcáta L., Gul Lucern; blommor gula; småblad aflånga eller smalt vigglika; blomhufvud klaselika och glesblommiga; blomskaft längre än foderpipen; balja finluden, båglikt krökt. 2, 3 .

Lika hög som föreg. art, uppstigande eller nedliggande och något finluden; blommor teml. stora; kronsegel omvändt äggrundt, blott nedtill strimmigt.

Torra backar och åkerrenar; Göt. Boh. Hall. r. Sk. Gotl. Öl. a. Blek. Kalmarl. spr. inre Smål. Ög. r., Sv. Söd. Upl. spr. (Norrl. Gestr. Ång. tillfällig).

5. M. silvestris Fr.; blommor i början gröngula, slutl. violetta; blomskaft kortare än foderpipen; balja cirkelformigt krökt; kronsegel aflångt och strimmigt ända mot spetsen; eljest som föreg. art. 3 .

Ängsbackar och åkerrenar; Göt. Öl. spr. Gotl. Sk. Hall. r., Sv. Söd. Upl. r. 


\section{Tetragonólobus. Kantskida.}

1. T. siliquósus (L.) Roth; småblad omvändt äggrunda; blomskaft långt öfverskjutande bladet; stipler snedt äggrunda. 3.

Stjelkar uppstigande, enkla och omkr. 1/2 fot långa; blad vanl. köttiga och undertill gleshåriga; blommor stora tumslånga. Hafsstränder; Göt. Gotl. Ö]. a. Smål. Blek. spr. Sk. r.; dessutom inuti landet i Sk. vid bäckar vid Benestad.

\section{Klassen. POLYADELPHIA. \\ 1 Ordn. POLYANDRIA. \\ 376. Hypéricum. Johannisört.}

A. Stjelk upprätt. Stift utstående.

a. Stjelk och blad glatta; blad oskaftade.

1. H. quadrángulum L.; stjelk fyrkantig; foderflikar ovala - aflånga och trubbiga utan glandler. 3.

Öfver fotshög; blad äggrunda_-ovala; deras kanter äfvensom undra sidan af kronbladen svartprickiga ; blomvippa qvastlik och teml. rikblommig.

Ängar och backar; Göt. Sv. a.: Gotl. spr., Norrl. Gestr. Hels. a. Med. Jtl. spr. Ang. t. r.

2. H. tetrápterum Fr.; stjelk med 4 vingkanter; foderflikar lansettlika, syllikt spetsade utan glandler. 3 .

Liknar föreg. art, men har mindre och blekare blommor samt alla bladen omfattande.

Fuktiga ställen, t. ex. i skogar; Göt. Skåne h. o. d.

3. H. perforátum L.; stjelk med 2 upphöjda ränder; foderflikar vanl. lansettlika och spetsiga utan glandler. 3.

1-2 fot hög och mycket grenig; blad aflånga och genomskinligt punkterade; kronblad i öfre kanten svartprickiga; blomvippa qvastlik och mycket rikblommig.

Berg och backar; Göt. Sv. a., Norri. Gestr. t. r. Hels.-Ång. r.

4. H. montánum L.; stjelk trind utan ränder; foderflikar lansettlika och spetsiga med skaftade svarta glandler i kanten. 3.

2-3 fot hög och enkel; blad hjertlika-aflånga och halft omfattande, med svarta punkter:"nära kanten; kronblad vanl. utan prickar; blomvippa kort och hufvudlik; blomskaft mycket korta.

Berg; Göt. t. r.: Dalsl. Ög. spr. Öl. 0, Sv. Söd. t. r. Upl. Verml. r.

5. H. pulchrum L., Röd Johannisört; stjelk trind utan ränder; foderflikar omvändt äggrunda och trubbiga med oskaftade svarta glandler i kanten. 3.

Umkr. 2 fot hög, spenslig och grenig, vanligen rodnande 
XVIII. POlyadelPhIA. 376. XIX. SyNGeNeSia. 377. 275

med små blommor; hufvudstjelkens blad hjertlika och omfattande, grenarnes smala och aflånga; vippa rikblommig.

På berg, helst på sandig skogsmark, mycket r.; Göt. Göteborgstrakten nära Partilled.

b. Stjelk och blad ludna; blad kortskaftade.

6. H. hirsútum L., Luden Johannisört; stjelk trind; foderflikar lansettlika spetsiga med svarta glandler i kanten. 3.

2-3 fot hög och grenig; blad äggrunda-aflånga och genomskinligt punkterade; kronblad utan eller med fä prickar; blomvippa pyramidformig och rikblommig; blomskaft mycket kortare än fodret.

Fuktiga berg och ängar; Göt. Öl. a. Sk. spr. Ög. (på silur. form.) spr. Vg. r., Sv. Söd. Upl. Vestm. r.

B. Stjelk nedliggande. Stift nedböjda.

7. H. humifúsum L., Nedliggande Johannisört; stjelk hoptryckt tvåkantig; foderflikar aflånga och trubbiga med kort udd. 3,4 .

Glatt med n. trådlik stjelk och fingerlånga grenar; blad aflånga, n. oskaftade, de öfre genomskinligt punkterade; kronblad svartprickiga; vippa qvastlik; blomskaft af fodrets längd eller längre; ståndare hälften så långa som kronbladen.

Fuktiga och sandiga ställen, t. ex. vid kärr och trädesåkrar Göt. Sk. mångenst. Blek. södra Smål. r.

\section{Klassen. SYNGENESIA.}

\section{Ordn. MONOCLINIA.}

\section{Hypochæris. Oxögon.}

A. Penselhår fjäderlika $i$ en krans. Hela växten sträfhårig. Blad oskaftade.

1. H. maculáta L.; rotblad aflånga, fint tandade; holk äggrund; stängel 1-3-blomstrig. 3 .

Mycket grof och 1-2 fot hög med mörkgröna, till marken tryckta och vanl. violettfläckiga blad; blommor ljusgula.

Ängar; Göt. Sv. Norrl. a.: Boh.-Jtl. Vb. spr., Lpl. r.

B. Penselhår i två kransar, de yttre borstlika fintandade. Stängel glatt. Blad skaftade.

2. H. radicáta L.; rotblad lansettlika, parflikiga med trubbiga flikar; holk kortare än blommorna; rot tjock och mångårig. 3,4 .

Ej så grof som föreg., knappt fotshög och mörkgrön; blad sträfhăriga; blommor ljusgula.

Ängar och betesmarker; Göt. spr.: Sk. a. Öl. t. a. Gotl. r. Ög. Dalsl. 0. 
3. H. glabra L.; rotblad aflanga och bugtigt flikiga med spetsiga flikar; blommor knappt öfverskjutande holken; rot smal och enårig. 2-3.

Mycket spensligare än föreg., $1 / 2$ fot hög, ljusgrön och n. glatt: holk smal och n. rörformig; blommor höggula.

Sandiga ställen, helst i rågåkrar; Göt. Vg. Boh. r. Hall. Sk. spr. Blek. Smål. t. r. Öl. r.

378. Tragopógon. Bockskägg, Hafrerot.

1. T. pratensis L.; blomkorgskaft ej uppblåsta; blommor ljusgula af holkens längd; blad något slaka, nedtill bredare, uppåt afsmalnande, ofta vågiga. $2,3$.

2-3 fot hög nch blågrön.

Ruderatväxt, stundom i ängar, helst i slättbygder; Göt. spr.: Gotl. Öl. Sk. a. Boh. Dalsl. t. r., Sv. spr.: Söd. Upl. a. Verml. Dal. t. r., Norrl. Gestr.-Med. r.

- minor (Fr.); blad slakare; kantblommor hälften så långa som holkfjällen.

Mindre än hufvudarten med smalare stjelk.

Göt. Sk. spr. Boh. Ög. r., Sv. Söd. r.

2. T. porrifólius L.; blomkorgskaft uppblåsta i spetsen; blommor violettröda; blad upprätta långspetsade, ej vågiga. 3.

$2-3$ fot hög med ätlig rot.

Odlade ställen r. och trol. förvildad; Göt. Sk. Hall. Blek.Ög. Gotl., $S v$. Söd.

3. T. crocifólius L.; blomkorgskaft föga uppblåsta; de yttre blommorna violettröda, de inre gula; blad upprätta, något vågiga och nedtill föga bredare. 3 .

Liknar föreg. art, men har omkr. liniebreda blad och smärre blomkorgar.

Betesmarker, mycket r.; Göt. Gotl. på Visby snäckgärde.

379. Scorzonéra. Svinrot.

1. S. húmilis L.; rotblad långskaftade, bågnerviga och aflånga-lansettlika; stjelkblad få och jemnbreda; stjelk vanl. enblomstrig. $2,3$.

Omkr. $1 / 2$ fot hög med blekgula blommor och vanl. ullig holk.

Ängar; Göt. a., Sv. spr.: Ner. t. a. Upl. t. r. Dal. r. 380. Leóntodon. Mjölkblomster, Fibla.

1. L. autumnális L.; blomkorgar vanl. flera, före blomningen upprätta; penselhår smutshvita enradiga och fjäderlika; stängel upptill fjällig; holk uppåt vidgad. 3,4.

Omkr. fotshög; stängel och blad vanl. glatta, stundom något håriga med enkla hår; stängel vanl. flerblomstrig, öfvergående $i$ holken, som är mer eller mindre försedd med bruna eller svarta hår; rotblad vanl. pardelade.

Ängar och backar, allmän, stundom i åkrar. 
* L. pyrenáicus Gouan; blomkorg vanligen ensam och före blomningen lutande; penselhår rödaktiga och tvåradiga, de yttre korta och hårlika, de inre fjäderlika. lika hår.

Omkr. fingerhög och upptill försedd med långa svarta ull-

Berg och ängar i fjellen, trol, något r.; Lpl., Norrl. Jtl. Herj.

2. L. híspidus L.; blomkorg ensam, före blomningen lutande; de yttre penselhåren korta och borstlika, de inre fjäderlika; stängel n. utan fjüll; holk nedtill tjock och rundad. 3.

Omkr. fotshög; hela växten vanl. styfhårig af delade hår, sällan glatt; stängel enblomstrig, upptill föga tjockare; rotblad parklufna eller tandade.

Torra ängar, helst i slättbygder; Göt. Gotl. Öl.r. Ög.-Blek. mångenst. Sk. a. Hall. Vg. spr. Boh. Dalsl. r., Sv. r.: Ner. spr. Dal. 0.

\section{Picris. Bittermjölkört.}

1. P. hieracióides L.; blad aflångt lansettlika och nedåt afsmalnande, de nerre längre och skaftade. 3.

2-4 fot hög och upptill beklädd med krökta borst; blad omfattande, $1 / 2-1$ tum breda; pensel mjuk och snöhvit; holkfjäll kölade. Liknar en stor Hieracium.

Torra sandiga ställen, helst bland buskar, stundom ruderatväxt vid vägar och på åkerrenar; Göt. Skåne mångenst., helst i slättbygden, Ög. förvildad vid Linköping.

\section{Sonchus. Mjölktistel.}

A. Rot tjock och flerårig.

1. S. arvensis L., Fet-tistel; stjelkblad med korta afrundade öronflikar; blomholk och blomkorgskaft vanl. med gula glandelhår; de yttre holkfjällen lansettlika. 3. 3-4 fot hög med stora brandgula blomkorgar och taggbräddade blad; frukt på tvären rynkig; stjelk sträf. På hafsstränder (och sällan inuti landet) äro blomholken och blomkorgskaften mer eller mindre glatta.

Ruderatväxt och ogräs, allmän: Lpl. 0 .

2. S. palustris L.; stjelkblad pillika (med långspetsade flikar vid basen); blomholk och blomkorgskaft med svarta glandelhår; holkfjäll smalt lansettlika-jemnbreda. 3,4 .

Högre än föreg. med smärre och blekgula blomkorgar, längre och vanl. smalare blad samt slät och tjock stjelk.

Sumpiga hafsstränder, mycket r.; Göt. Skåne vid Saxaviken nära Valjö på gränsen till Blekinge.

B. Rot smal och enårig. Stjelk slät och mycket vek. 3. S. oleráceus L., Mjölktistel; stjelkblad pillika (med spetsade flikar vid basen); blomholk och blomkorg- 
skaft i början ulliga och mjöliga, slutl. glatta; holkfjäll lansettlikt jemnbreda. 3.

2-3 fot hög med smärre, blekgula blomkorgar och mjukt taggbräddade, vanl. pardelade blad; frukt sträfprickig och på tvären rynkig.

Ruderatväxt och ogräs, allmän: Lpl. r.

4. S. asper Vill.; stjelkblad med afrundade och vridna öronflikar; frukt slät; blad styft taggiga och vanl. nästan hela; eljest som föreg. art. 3.

Ruderatväxt och ogräs; Göt. Sv. t. a., Norrl. spr. 383. Hierácium. Hökblomster.*).

I. PILOSELLA. Skalfrukter små, i toppen djupt refflade, med fina jemnhöga penselhår.

Förökningen sker genom grenskott eller rosettbärande rotrefvor, som dock stundom felslă. Stammen är antingen stängelformig (bladlös eller enbladig) eller en stjelk med de öfre bladen mycket långa, smala och helbräddade. Småblommor ofta rödrandiga. Blomkorgar vanl. små, sällan (hos $H$. Pilosella) tumsbreda.

A. Xanthostyla. Stift gult; rotblad ofta stjernludna.

a. Pilosellina. Stam stängelformig, bladlös eller nedtill enbladig, vanligen enblomstrig, stundom upptill delad i 2-3 långa blomkorgskaft. Holkfjäll starkt stjernludna, de inre spetsiga. De flesta bladen trubbiga och temligen breda. Grenskott sällan felslående. 1. H. Pilosella.

b. Auriculina. Stam stängelformig, mot basen 1-2-bladig, flerblomstrig med teml. korta blomkorgskaft. Holkfjäll utan eller med glest stjernludd, de inre trubbiga. De flesta bladen trubbiga och teml. breda. Grenskott sällan felslående. 2. H. Auricula. 3. H. pratense.

c. Cymósa. Stam stundom stängelformig och enbladig, oftare flerbladig, och flerblomstrig med de flesta blomkorgskaften teml. korta. Holkfjäll med eller utan stjernludd, de inre trubbiga. De flesta bladen spetsiga och smala, men sällan fintandade. Grenskott ofta felslående. Blomkorgar alltid smärre än hos föreg. arter. Rotstock kort. 4. H. cymosum. 5. H. præaltum.

B. Melanostyla. Stift brunt; rotblad vanl. utan stjernludd.

Aurantíaca. De flesta bladen teml. breda och fintandade; stjelk vanl. rödaktig, åtminstone upptill eller nedtill. 6 . H. suecicum. 7. H. aurantiacum. 8. H. decolorans. II. ARCHIERA'CIUM. Skalfrukter större, i toppen omgifna af en något uppsväld ring med styfva oliklånga penselhår.

*) Ar̀terna i detta slägte äro mycket föränderliga och svăra att begränsa, men sannolikt finnas mănga bastardformer, som böra närmare studeras. 
Förökningen sker antingen genom bladrosetter från rothalsen eller genom dolda knoppar. Stam n. alltid bladbärande, sällan stängelformig; blad oftast tandade. Småblommor alltid gula. Blomkorgar stora och tumsbreda eller deröfver.

A. Pulmonárea. Förökning genom bladrosetter från rothalsen; rotblad vid blomningen vanl. fortvarande; de yttre holkfjällen antingen lika långa som de inre eller betydligt kortare; stjelkblad icke omfattande.

a. Alpína. Holkfjäll teml. lika långa, de yttre föga kortare; stjelk vanl. äfven nedtill glandelhårig; blad med fina glandelhår i kanten; rotblad och holkfjäll utan stjernludd. 9 . H. alpinum. 10. H. nigrescens. 11. H. atratum. 12. H. lingulatum.

b. Oreádea. Holkfjäll stälda nästan i två kransar, de yttre betydligt kortare än de inre och sinsemellan nästan lika långa. Stjelk nedtill styfhårig, sällan glatt; stift gult. De flesta holkfjällen smalt och syllikt spetsade. Blomkorgar mycket stora. Blad utan glandelhår i kanten; rotblad stundom och holkfjäll ofta stjernludna. 13. H. saxifragum. 14. H. Oreades. 15. H. pallidum.

c. Vulgáta. Stjelk nedtill mjukhårig, sällan glatt; stift vanl. brunt, sällan gult. Holkfjäll som hos föreg. afdelning, men sällan sylspetsade. Blomkorgar sällan så stora som hos föreg. afdelning. Blad som hos föreg. afdelning. 1. Rotblad vid blomningen qvarsittande och talrika; de flesta holkfjällen trubbiga och jemnt utdragna, ej sylspetsade; stjelk bladlös eller 1-2-bladig. 16. H. murorum. 17. H. glaucellum. 18. H. cæsium. 19. H. fasciculare.

2. Stjelk och rotblad som hos föreg. afdelning; de flesta holkfjällen sylspetsade. 20. H. plumbeum.

3. Alla eller de flesta rotbladen vid blomningen förvissnade; de flesta holkfjällen jemnt utdragna och $\mathrm{n}$. trubbiga, ej sylspetsade; stjelk vanl. flerbladig. 21. H. diaphanum. 22. H. vulgatum.

B. Accipitrína. Förökning genom dolda knoppar, som ej utveckla bladrosetter; rotblad vid blomningen vanl. förvissnade; holkfjäll oliklånga, stälda i flera rader. Stjelkblad stundom omfattande. Stjelk mångbladig och vanl. mångblomstrig. Stift vanl. brunt, stundom gult.

a. Genuina. Stjelkblad ej omfattande. Skalfrukter vanl. svartbruna. 23. H. norvegicum. 24. H. Iapponicum. 25. H. tridentatum. 26. H. umbellatum.

b. Prenanthóidea. Stjelkblad omfattande eller med omfattande skaft. Skalfrukter svartbruna eller rödbruna. 27. H. prenanthoides. 28. H. dovrense. 29. H. strictum. 30. H. boreale. 31 . H. crocatum. 
1. H. Pilosella L.; holkfjäll med stjernludd och bred blek kant; blad helbräddade, undertill med teml. tätt stjernludd; stängel vanl. enblomstrig; kantblommor vanl. undertill rödrandiga. 2-4.

Vanligen låg, stundom cmkr. fotshög; blomkorgar oftast stora, tumsbreda.

Torra ängar och berg; Göt. Sv. a., Norrl. spr.: Gestr.-Ång. a., $L_{p l}$. r.

- virescens; stundom flerblomstrig; blomkorgar smärre; alla blommor gula.

Troligen r., t. ex. Ög. Upl. Ner.

- auriculæforme (Fr.); stängel vanl. flerblomstrig; kantblommor rödrandiga; blomkorgar teml. små.

Göt. Boh. Sk. Smål. Ög. Gotl. r., Sv. Söd. Upl. r.

* H. stoloniflórum W. K.; blad tunnt och otydligt stjernludna, i kanten långhåriga; stängel upptill delad i mycket långa blomkorgskaft, som hafva långa svarta hår. Liknar till bladen H. Auricula, men har större blomkorgar. Sv. Vestm. vid Loka brunn (C. O. Hamnström!), Norrl. Hels. Jtl. $r$.

Anm. Den närstående $H$. brachiátum Bert., som lär vara funnen på Gotl., är förf. obekant.

2. H. Aurícula L.; holkfjäll med bred blek kant och utan stjernludd; blad helbräddade utan stjernludd och vanl. nästan glatta och endast nedtill hårbräddade, stundom ofvan glest långhåriga. $2-4$.

Omkr. $1 / 2$ fot, stundom 1 fot hög, med smärre blomkorgar än hos föreg. art och blågröna blad.

ngsbackar, allmän: Lpl. r.

3. H. pratense Tausch; holkfjäll med bred blek kant och med stjernludd; blad med obetydligt stjernludd och glesa hår samt i kanten tätt hårbräddade; rotblad ofta fintandade. 3 .

1-2 fot hög med ungefär lika stora blomkorgar som hos föreg. art, men flera; blad n. rent gröna.

Fukt. ängar och odlade torfmossar; Göt. Smål. Ög. t. r. (Sk. förvildad), $S v$. Söd. Upl. Verml. r., Norrl. Gestr. r.

Den närstående $H$. dimorphum (Norrlin) har upptill mera svarthårig och nedtill stjernluden stjelk samt talrikare blomkorgar; en liknande form forrekommer i Ög. i Askeryd och Kisa.

4. H. cymósum L.; stjelk, blomholkar och blomkorgskaft glandelhåriga och stjernludna; blad på båda sidor håriga och stjernludna. 3 .

1-3 fot hög, vanligen med talrika blomkorgar.

Ängar, mångenstädes; de särskilda formernas utbredning ej nog känd. 
a. H. dúbium L. enl. Fr.; vanl. korthårig, stundom långhårig; holkfjäll breda med bred blek kant; oftast med grenskott. Sk. r.

Norrl. Sv. spr.: Verml. t. a., Göt. spr.: Gotl. t. a. Dalsl.-

b. H. glomerátum Fröl. (p. p.); korthårig; holkfjäll smala och utdragna till en trubbig spets; sällan med korta grenskott.

Norrl. Vb.. Ang. r.? Hels. Gestr. t. a., Sv. t. a.: Vestm. r.? Dal.?, Göt. r.: Ög. a. Gotl. Smål. Vg. Dalsl. spr. Hall.?

c. H. pubescens Lindblom; korthårig; holkfjäll som hos föreg.; sällan med grenskott; blomkorgar smà.

Teml. r.; Sv. Ner. Upl., Göt. Ög.?

d. H. cymósum Fr.; vanl. långhårig; holkfjäll som hos föreg.; sällan med grenskott; blomkorgar vanl. mycket små; rotblad ofta bredare (än hos de föreg. formerna af denna art); föga glandelhårig.

Helst nära hafvet och större sjöar; Gotl. Blek.--Hels. spr., eljest t. $r$.

- setigerum (Fr.); med större, mera ullhåriga blomholkar och mycket hreda holkfjäll; gröfre och högre än de öfriga formerna.

Gotl. Öl. Blek. -Upl. Dals]. Ång. r.

5. H. præáltum Vill., var. glandulosum; stjelk n. utan glandelhår; blomholkar och blomkorgskaft med få glandelhår och utan stjernludd; blad ofvan n. glatta, undertill glest och styft långhåriga, sällan svagt stjernludna. 3 .

1/2-1 fot hög med mycket små blomkorgar; holkfjäll smala med smal blek kant; grenskott sällan utbildade; blomkorgskaft utstående.

$$
\text { Ängar, mycket r.; Göt. Gotl., Ihre i Hangvar (Westöö). }
$$

6. H. suécicum Fr.; vanl. långhårig; blad utan stjernludd, ofvan glatta; kantblommor svagt rödrandiga. 3.

$0 \mathrm{mkr}$. fotshög och 1-2-bladig stjelk med teml. stora blomkorgar; grenskott sällan felslående. Liknar vanl. mest $H$. Auricula, men blir i fjellen stundom högre och korthårig med talrikare och något smärre blomkorgar, n. gula (föga rödrandiga) kantblommor och (någon gång) svagt stjernludna blad; sådana former likna mera $H$. cymosum.

Fuktiga ängar, helst i fjelltrakter; Lpl. spr., Norrl. spr.: Herj. a. Vb._Hels. r.?, Sv. spr.: Dal. r.? Ner. Vestm.?, Göt. Ög. Gotl. r.

7. H. aurantiacum L.; långhårig; blad på båda sidor korthåriga; stjelkblad stjernludna; kantblommor och stundom äfven diskblommor röda. 3 .

Omkr. 2 fot hög och 2-3-bladig, vanl. svarthårig stjelk med teml. stora blomkorgar: sällan med grenskott.

Ängar och trädgårdar, förvildad, t. ex. Ög. Söd. Upl. Ner. Dal.

- bicolor (All.); mera korthårig; kantblommor ljusare, diskblommor endast upptill röda.

Ängar r., men otvifvelaktigt vild; Göt. Smål. helst omkr. Ekesjö, Ög. i Askeryds s:n. 
8. H. decolórans Fr.; kort och sträft hårig med långhåriga blomkorgskaft; blad på båda sidor korthåriga; stjelkblad 1-2, stjernludna; kantblommor rödrandiga. 3 . Omkr. 2 fot hög med teml. stora blomkorgar, men sällan med .grenskott.

Ängar i fjellen, helst bland buskar i björkregionen, mycket r.; Lpl., Norrl. Jtl. Herj.

9. H. alpinum L.; blad nedåt afsmalnande, vanl. helbräddade; blomholk n. klotrund; holkfjäll hvithåriga med vanl. gula glandler, de inre jemnt afsmalnande till spets, de yttre bredare och med trubbig spets; stift oftare gult, stundom brunt. 3 .

Omkr. ${ }^{1 / 2}$ fot hög och bladlös eller med 1-2-bladig stjelk och 1-2 mycket stora, i början lutande blomkorgar; stjelk vanl. långhårig. Af deñna och de 3 följ. arterna förekomma ofta former med föga utveckladt kronbräm, kortare än stiften.

Ängsmark, helst på berg, i fjellen; Lpl. a., Norrl.Jtl. Herj. t. a., Sv. Dal. t. a.

foliósum; långhårig, fotshög och 1-2-blomstrig med 2-4 helbräddade stjelkblad.

- ramósum; långhårig, $1 / 2-1$ fot hög och 3-5-blomstrig med långa blomkorgskaft och $2-3$ tandade stjelkblad.

- subnigrescens; korthårig, från basen delad j flera långa blomkorgskaft; blad breda tandade; holk svart.

- melanocéphalum; korthårig, 1-2-blomstrig med breda tandade blad och svart holk.

10. H. nigrescens Willd.; blad tandade, åtm. de nedersta med föga afsmalnande eller $n$. afrundad bas; blomholk aflång; holkfjäll hvithåriga med få gula glandler, de inre tvärt afsmalnande till en syllik spets, de yttre trubbiga; stift brunt. 3 .

1-2 fot hög, liknande både föreg. art och $H$. casium, af hvilka den torde vara bastard; stjelk $\mathrm{n}$. bladlös eller enbladig och korthårig med en eller flera blomkorgar, stundom på teml. korta skaft.

Ängar i fjellen; Lpl. spr., Norrl. Jt]. Herj. r., Sv. Dal. r.

11. H. atrátum Fr.; bladbas afrundad eller tvär; holkfjäll tätt svarthåriga med svarta glandler, alla jemnt afsmalnande och nedtill teml. breda; stjelk 1-3-bladig; eljest som föreg. art. 3 .

Torde vara bastard af $\boldsymbol{H}$. murorum och $H$. alpinum och liknar stundom den förra till blomholken.

Ängar i fjellen; Lpl. spr., Norrl. Jtl. Herj. spr., Sv. Dal.r.

12. H. lingulátum Backh., * depilátum Almqv.; blad nedåt afsmalnande och n. helbräddade; blomholk $n$. rörfor- 
mig; holkfjäll teml. smala och glest svarthåriga med gula glandler, de yttre trubbiga, de inre kortspetsiga; stift brunt. 3 .

Omkr. fotshög med korthårig, 3-5-bladig och flerblomstrig stjelk med smärre blomkorgar än hos de närstående arterna; stjelkblad oskaftade; rotblad snart vissnande.

Ängar i fjellen r.; Norrl. Jtl. Herj.

13. H. saxífragum Fr.; de inre rotbladen smala, lansettlika, helbräddade eller fintandade; holkfjäll något bredare nedtill; blomkorgskaft med talrika svarta glandler. 3.

1-11/2 fot hög, ofta mycket grenig och flerblomstrig; stjelk vanl. flerbladig; rotblad stundom undertill stjernludna; blomholk och blomkorgskaft stjernludna; blomholk aflång.

Berg; Blek.-Vb. spr. Vg. Boh.-Lpl. t. r.

- canescens; blomkorgskaft föga eller icke glandelhåriga; holkfjäll smala.

Göt. Boh. Vg. Hall. Smål. Ög. t. r., Sv. Söd. r.

14. H. oréades Fr.; de inre rotbladen breda, ovalaaflånga, helbräddade eller fintandade; holkfjäll breda. 3.

Lika hög som föreg. art, men ofta mera grof; stjelk vanl. flerblomstrig och flerbladig: rotblad icke stjernludna; blomholk och blomkorgskaft med intet eller obetydligt stjernludd samt få glandler; blomholk bredt aflång.

Berg r.; Göt. Boh. Smål. Ö̉., Sv. Söd. Upl., Norrl. Hels.

* H. onosmóides Fr.; holkfjäll något smalare och mera stjernludna; stjelk längre ned stjernluden; blad stundom teml. groftandade och vanl. talrikare.

Göt. Boh. t. r. Ög. r.

15. H. pállidum Biv.; de inre rotbladen breda, ovalaaflånga, helbräddade eller nedtill groft tandade; holkfjäll smala. 3.

Omkr. $1 / 2$ fot hög och fåblomstrig; stjelk fåbladig, nedtill stundom glatt; blomholk och blomkorgskaft stjernludna och glandelhåriga; blomholk aflång. Torde ej vara nog skild från föreg. art.

Söd. Upl. Ner. r.

16. H. murórum L.; de inre rotbladen breda, äggrundaovala, trubbiga; blomholk rörformig; holkfjäll smala med svarta glandler; n. utan stjernludd. 2-3.

$1^{1 / 2}-2$ fot hög och nedtill mjukhårig; de yttre rotbladen rundade-njurlika; stjelkblad äggrunda. Rotbladens skifva är vanl. tydligt urskiljbar från det smala skaftet.

Lundar och skogar, allmän.

17. H. glaucellum Lindeb.(?); de inre rotbladen smala aflånga-lansettlika, spetsiga; blomholk rörformig; holkfjäll smala med fả glandler och tätt stjernludd. 3 . 
Omkr. fotshög, spenslig och nedtill glatt; de yttre rotbladen n. likformiga med de inre; stjelkblad lansettlika.

Lundar r.; Göt. Smål. Ög.

18. H. cæ'sium Fr.; de inre rotbladen breda, äggrundaovala, spetsiga; blomholk bredt aflång; holkfjäll breda med få glandler och tätt stjernludd. $2-3$.

$1^{1 / 2}-2$ fot hög och nedtill mjukhårig eller glatt; de yttre rotbladen ovala, undertill ofta blågrå; stjelkblad äggrunda-lansettlika. Rotbladens skifva öfvergår vanl. omärkligt i det något breda skaftet.

Ängar och backar, allmän.

Anm. Mellan $H$. casium och $H$. murorum förekomma mellanformer, som sannolikt äro bastarder.

19. H. fasciculáre Fr.; rotblad smala, tunglika-lansettlika; blomholk bredt aflång; holkfjäll breda med få glandler och tätt stjernludd. 3 .

1-2 fot hög och mjukhårig; stjelkblad lansettlika; blomkorgar vanl. talrikare än hos de tre föreg. arterna.

Berg, mycket r.; Göt. Boh. vid Uddevalla, Krokstad (Lindeb.).

20. H. plúmbeum Fr.; de inre rotbladen äggrundt lansettlika spetsiga; blomholk bredt aflång; holkfjäll nedtill breda, med få glandler och obetydligt stjernludd. $2-3$.

Omkr. fotshög och nedtill mjukhårig eller ofta glatt, vanligen 2-blomstrig med korta blomkorgskaft; de yttre rotbladen rundade, ofta undertill blygrå; stjelkblad äggrundt lansettlika eller lansettlika; stift ofta gult; blomkorgar ofta lika stora som hos de flesta Oreadea, hvarifrån denna art mest skiljes genom saknaden af de styfva håren på stjelkens nedre del samt genom de groftandade bladen.

Berg r.; Göt. Blek.-Ög. Vg.

* H. subcæ'sium Fr.; de inre rotbladen äggrunda; holkfjäll nedtill teml. smala med tätt stjernludd. 2-3. Liknar mycket $H$. casium, utom att stiftet stundom i början är gult, och är vanl. flerbiomstrig.

Ängar och berg spridd, trol. i de flesta landskap.

** H. macrolépis Kindb.; de inre rotbladen ovala-aflånga, de flesta trubbiga; blomholk smal och rörformig; holkfjäll n. jemnbreda och sylspetsade med talrika svarta glandler utan stjernludd. $2-3$.

Torde vara en egen art, stående mellan $H$. plumbeum och H. murorum. Omkr. $11 / 2$ fot hög och nedtill glatt, bladlös eller stundom med ett stjelkblad; de yttre rotbladen breda, ovalaäggrunda och upptill afrundade; stjelkblad utdraget äggrundt; stift brunt; blomkorgar lika stora som hos $H$. murorum och ganska talrika; inre rotblad stundom groftandade; holkfjäll mycket långa.

Berg, mycket r.; Sv. Verml. vid Carlstad på Svinbäcksberget (förf.). 
21. H. diáphanum Fr.; de inre rotbladen breda, äggrunda-ovala; blomholk afläng; holkfjäll teml. breda och trubbiga, glandelhåriga utan stjernludd. 3 .

Omkr. 2 fot hög, nedtill mjukhårig; stjelk vanl. fåbladig; stjelkblad bredt lansettlika; stift ofta gult; blomkorgar ofta ganska stora.
Lundar r.; Smål. Ög. Verml. Jtl. Ång.

22. H. vulgátum Fr.; de inre rotbladen ovala-lansettlika; blomholk rörformig; holkfjäll teml. smala och nästan spetsiga, glandelhåriga och stjernludna. 3 .

Ända till 3 fot hög, nedtill mjukhårig eller glatt, vanl. flerbladig och mångblomstrig; stjelkblad äggrunda--lansettlika; fruktfjun vanl. hvitt.

Skogar och ängar; Göt. Sv. allmän, Norrl. Lpl. spr.

* H. anfráctum Fr.; de flesta bladen lansettlika eller lansettlikt jemnbreda; holk utan stjernludd.

Liknar H. tridentatum och är troligen förbisedd.

Troligen ej r.; Smål. Ög. Upl.

23. H. norvégicum Fr.; blad ovala-lansettlika, de nedre oskaftade eller kortskaftade; blomholk aflång; holkfjäll teml. smala, några sylspetsade, de öfriga jemnt utdragna och trubbiga; fruktfjun brungult; stift gult. 3.

Omkr. 2 fot hög, nedtill och vanl. vid bladens fästen sträfhårig; blad grundt tandade, de öfre något olikformiga med de nedre; blomkorgskaft hvitludna. Liknar de arter, som höra till afdelningen Oreadea.

Berg, helst nära hafvet, r.; Göt. Boh. Hall. Ög., Sv. Söd. Upl., Norrl. Vb.

- macránthum (Lindeb.); blomkorgar större; blad groftandade; stjelk vanl. lägre, mera ullhårig.

Göt. Boh. spr. Hall. i n. delen t. r.

24. H. lappónicum Fr.; blad jemnbredt lansettlika, de nedre oskaftade eller kortskaftade; blomholk bredt aflång; holkfjäll teml. smala, några sylspetsade, de öfriga jemnt utdragna och trubbiga; fruktfjun $n$. rent hvitt; stift brunt. 3 .

$1 / 2-1$ fot hög och spenslig; blad föga olikformiga; blomkorgskaft gråludna.

I fjellen $r_{\text {. }}$ L $L l$.

Anm. Den trol. närstående H. linifólium Sælan, som blifvit funnen i L Lpl. och Jtl., är förf. obekant.

25. H. tridentátum Fr.; de nedre bladen ovala-aflånga skaftade, de öfre lansettlika; blomholk rörformig; holkfjäll teml. smala, de inre med trubbig och något utdragen spets; fruktfjun brungult; stift brunt. 3,4 . $2-3$ fot hög, nedtill sträfhårig, mjukhårig eller glatt; blad 
groftandade, temligen olikformiga; blomkorgskaft hvitludna; holkfjäll stundom utböjda.

Lundar och skogar h. o. d.

* H. Friesii Hartm.; de nedre bladen stundom oskaftade de öfre stundom äggrunda; blomholk bredt rörformig; holkfjäll breda trubbade.

Lpl. Norrl. spr., Sv. spr.: Verml. Ner. r. Dal.?, Göt. Ög. Vg. Boh. Hall. spr. Smål. Blek. t. r.

- angustifólium; blad smala, lansettlika och n. likformiga; stjelk vanl. mycket sträf.

Fjelltrakter h. o. d., t. ex. Lpl.; förvexlas ofta med H.lapponicum.

26. H. umbellátum L.; blad lansettlika-jemnbreda oskaftade; blomholk aflång; holkfjäll breda och trubbade, nästan utan stjernludd och glandler; blomkorgar vanl. flocklikt stälda. 3,4 .

$1 / 2-2$ fot hög; blad föga tandade, likformiga och vanl. tätt sittande; blomkorgskaft ej hvitludna; holkfjäll vanligen utböjda; blomkorgar vanl. talrika.

Ängar, allmän; Lpl. spr.?

* H. sparsifólium Lindeb.; glesbladig och fâblomstrig; holk vid; holkfjäll tilltryckta, somliga med något smalare spets; blomkorgarnes ställning ej flocklik.

\section{Ängar i fjellen; Lpl. r.?}

** H. æstívum Fr.; tätbladig och flerblomstrig; holk vid; holkfjäll tilltryckta, somliga något spetsiga; blomkorgarnes ställning ej flocklik; blomkorgskaft hvitludna. Ängar r.; Göt. Boh. Ög.

*** H. mongólicum Fr.; de nedre bladen skaftade; inre holkfjäll spetsiga; blomkorgskaft hvitludna; frukter "röda".

Sv. Verml. i Långseruds s:n (Larsson enl. Fries).

27. H. prenanthóides Vill.; blomholk rörformig och teml. smal; de inre holkfjällen trubbiga ; blomkorgskaft glandelhåriga. 3, 4 (Augusti).

a. genuínum (Fr.); stjelk vanl. glatt eller korthårig; blad teml. smala, vanl. lansettlika (de nedre ofta på midten hopdragna), helbräddade eller fint tandade, de öfre med hjertlik bas, de nedre skaftade; skalfrukter slutl. gulbruna.

Är vanligen $2-3$ fot hög med teml. smala blomkorgskaft.

Löfskogsängar, helst i fjellen; Lpl. spr., Norrl. r.: Vb.-Med. 0, $S v$. Dal. Verml. Upl. r.

b. elátum (Fr.); stjelk vanl. långhårig, stundom n. glatt; blad bredare, aflånga eller bredt lansettlika, 
vanl. groftandade, de öfre öronflikade, de nedersta kortskaftade; skalfrukter slutl. svartbruna.

Något högre och gröfre än hufvudarten; holk vanl. med mera stjernludd och färre glandler; blomkorgskaft teml. korta och tjocka.

I fjellen mycket r.; Norrl. Jtl. på Storli vid norska gränsen (S. Almq vist).

28. H. dovrense Fr.; holk aflång; de flesta inre holkfjällen spetsiga, de yttre trubbiga; blad teml. breda, aflanga eller bredt lansettlika, teml. fint tandade; rotblàd ovala, ofta qvarsittande; skalfrukter rödbruna; blomkorgskaft med glandler. 3. (Juli).

1-2 fot hög och vanl. făblomstrig. Liknar något $H$. vulgatum. Herj. $\mathrm{r}$.

Löfskogsängar ofvan barrskogsregionen i fjellen; Norrl. Jtl.

29. H. strictum Fr.; holk vid och bredt aflång; holkfjäll trubbiga; blad smala lansettlika, helbräddade eller teml. fint tandade; skalfrukter svartbruna; blomkorgskaft n. utan glandler. 3, 4. (Augusti).

1-3 fot hög och vanl. fåblomstrig; utmärkt genom de mycket breda blomholkarne och de icke mycket omfattande bladen. Löfskogsängar, högt upp i fjellen, mycket r.; Norrl. Jtl.

30. H. boreále Fr.; holk aflång; holkfjäll trubbiga; blad äggrundt lansettlika och tandade; skalfrukter svartbruna; blomkorgskaft n. utan glandler. 3 .

1-3 fot hög och föga rikblomstrig, sträfhårig särdeles vid bladens fäste på stjelken. Liknar något $H$. umbellatum, men bladen äro tydligt omfattande. H. commutatum Beck.?

Ängar, mycket r.; Göt. Gotl. vid Lunderhaga i Fleringe (funnen år 1852 af förf.).

31. H. crocátum Fr.; holk aflång med vanl. tvär bas; holkfjäll trubbiga; blad äggrundt-jemnbredt lansettlika, fint tandade; skalfrukter rödbruna; blomkorgskaft n. utan glandler. 3 .

1-3 fot hög och vanl. föga rikblomstrig; de öfversta bladen vanl. korta och äggrunda-hjertlika.

Ängar, helst i lägre fjelltrakter; Lpl. spr., Norrl. r.: Hels. Med.?, Sv. Dal. Verml. Upl. r.

* H. corymbósum Fr.; vanl. mera rikblomstrig; blomholkens bas mindre tvär; alla blad lansettlika spetsade; bladbas föga omfattande.

Liknar H. umbellatum * astivum och är måhända ej derifrån skild.

Lpl. spr., Norrl. Vb. Ång. Hels. Jtl. r., Sv. Verml. r.

384. Crepis. Fibler, Krepe.

A. Med stjelk och med blomkorgar i qvast.

a. Pensel snöhvit och mjuk. Holk med bleka hår. Rot 1-2-årig. 
1. C. tectórum L., Klofibler; de yttre holkfjällen utstående; stjelkblad med nedvikna kanter samt stundom med pillik bas; märken bruna; skalfrukt lika lång som penseln och med utdraget spröt. $2-4$.

Ända till 2 fot hög och finhårig; blad smala och jemnbreda eller smalt lansettlika samt n. glatta, de nedre ofta parklufna; blomkorgar små och blekgula; rot enårig; skalfrukter mörkbruna. Ruderatväxt, äfven förekommande på berg, allmän: Lpl.t.r.

2. C. nicæensis Balb.; de yttre holkfjällen utstående; stjelkblad med platta kanter och pillik bas; märken slutl. bruna; skalfrukt hälften kortare än penseln och upptill något afsmalnande. 2-3.

Högre och något gröfre än föreg. saint nedtill styfhårig jemte bladen, af hvilka de flesta äro parklufna; blomkorgar något större; rot tvåårig; skalfrukter gulaktiga.

Ruderatväxt på torr ängsmark; $S v$. Upl. flerst. omkr. Stockholm, Göt. Gotl. r.

3. C. biennis L.; de yttre holkfjällen utstående; stjelkblad öronflikade med platta kanter; märken gula; skalfrukt längre än penseln och upptill något afsmalnande. 3,4 .

Gröfre än de föreg., 2-3 fot hög och sträfhårig; de flesta bladen parklufna eller pardelade; blomkorgar stora, omkr. tumsbreda; rot tvåårig; skalfrukter gulaktiga.

Ruderatväxt, helst vid vägar och på åkerrenar; Göt. Sk. allm. Haill. r. (Smål. tillfällig), Sv. Söd. Upl. r.

4. C. virens Vill.; holkfjäll tilltrychta; stjelkblad med platta kanter och pillik bas; märken gula; skalfrukt kortare än penseln och upptill föga smalare. 3,4 .

Spensligare än de föreg. arterna, ljusgrön och n. glatt; stjelk ofta mera grenig, vanl. omkr. fotshög; de flesta bladen n. hela; blomkorgar små och blekgula eller n. rödgula; rot enårig; skalfrukter grågröna.

Ogräs i åkrar och ruderatväxt, trol. införd från utlandet Göt. Gotl. Öl. r. Sk. vid Broby (Hamnström), Ög. förvildad.

b. Pensel brunaktig och skör. Holk med svarta glandelhår. Rotstock kort.

5. C. paludósa (L.) Mönch, Kärrfibler; blad bredt lansettlika-aflånga. 3.

Omkr. 3 fot hög med tumsbreda mörkgula blomkorgar; stjelkblad stora och teml. breda, platta och med n. hjertlikt omfattande bas; holkfjäll tilltryckta; stift mörkt; frukt blekbrun med släta åsar och lika lång som penseln; holk n. rörformig.

Fuktiga ängar; Göt. spr.: Sk. a. Boh. r. inre Smål. t. r. Öl. r. Gotl. 0, Sv. spr.: Söd. t. r., Norrl. spr.: Ang. a. Herj. Vb.?, Ipl. r.

B. Med stängel och med blomkorgar i klaselik vippa. 
6. C. præmorsa (L.) Tausch, Spirfibler; holkfjäll tilltryckta och n. glatta utan glandler; blad aflånga och n. helbräddade; pensel hvit och mjuk; rotstock kort. 2,3 .

1-2 fot hög och ljusgrön med små blekgula blomkorgar; blad stora och teml. breda; frukt slät och något kortare än penseln: holk rörformig.

Ängar; Göt. mångenst.: Gotl. Hall. t. a. Boh. r., $S v$. spr.: Verml. t. r. Dal. r., Norrl. Gestr. r.

\section{Mulgédium. Mjölkstut, Tolta.}

1. M. alpínum (L.) Less.; upptill glandelhårig; blomkorgar i klaselik vippa. 3,4 .

4-6 fot hög med mjuk och tjock stjelk; blad pardelade med mycket stor och triangelformig (stundom pillik eller spjutlik) ändflik och pillikt omfattande bas, ett par tum breda och $1 / 2$ fot långa samt undertill blågröna: blommor stundom hvita. Hos nyskottens blad blifva stundom de nedre flikarne ej utbildade.

Något fuktiga och skuggrika ställen, helst $i$ lägre fjelltrakter, sällan ofvan barrskogsregionen; Lpl. t. a., Norrl. spr.: Hels. r. Gestr. 0, Sv. Dal. spr. Verml. t. r.

2. M. sibíricum (L.) Less.; glatt; blomkorgar stälda i qvast. $3,4$.

1-2 fot hög med något styf stjelk, smalare än hos föreg. art, samt med betydligt mindre och smalare blad, som äro tandade (de nedre sällan parflikiga), lansettlika och oskaftade samt föga omfattande.

Något fuktiga lundar, helst vid stränder af elfvar och åar; Lpl. t. r., Norrl. Vb.-Med. r.

\section{Lactúca. Vildsallad.}

1. L. murális (L.) Fresen.; glatt; blad tunna och reka, n. lyrformiga och undertill blågröna eller blåröda. 3. Stjelk omkr. 3 fot hög, spenslig och pipig med omkr. ${ }^{1 / 2}$ fot långa blad och omkr. 5-blommiga blomkorgar.

Steniga ställen i lundar och skogar; Göot. Sv. t. a.: Boh. t. r. Dal. spr., Norrl. Gestr. spr. Hels.-Vlb. r.

2. L. Scariola L.; taggig, särdeles på stjelkens nedre del och bladens medelnerv; blad fasta, hela eller nedåt parflikiga, blågröna och i kanterna sträfhåriga. 3, 4 .

Stjelk omkr. 5 fot hög, styf och föga pipig med teml. rikblommiga blomkorgar.

Ruderatväxt, mycket r.; Göt. vid Lund, Kalmar och Linköping.

387. Taráxacum. Smörgubbar, Maskrosor.

1. T. officinále Web.; de yttre holkfjällen lansettlika, nedböjda och utan knöl i spetsen. 1-4.

Omkr. ${ }^{1} / 2$ fot hög; blad aflånga med vanl. triangelformiga flikar. Penslarne kallas Kavaljers-paroler.

Ruderaträxt, äfven förekommande i åkrar och ängar, allmän. 
- oblíquum; de yttre holkfjällen äggrundt lansettlika, vanligen upprätta och ofta tilltryckta samt försedda med knöl i spetsen.

Fingerhög med tegelröda frukter och något mindre blom. korgar än hos hufvudarten.

Backar h. o. d., helst i Göt. och Sv.

- palustre; yttre holkfjäll äggrunda och tilltryckta; stängel midtpå uppblåst.

Liknar mera hufvudarten och har liksom denna grågröna frukter, men har ofta hela blad.

Våta ställen h. o. d., helst i Göt.

388. Lápsana. Tomtört.

1. L. commúnis L.; de nedre bladen lyrformiga, de öfre äggrunda-lansettlika och skaftade, alla tandade. 3, 4 .

1-2 fot hög; rot enårig.

Ogräs, helst i trädgårdar; Göt. Sv. a., Norrl. Gestr. Hels. a. Med. Ang. spr. Jtl. Vb. r.

\section{Arnóseris. Klubbfibler.}

1. A. pusilla Gärtn.; blad aflånga-tunglika tandade. 2, 3. Omkr. $1 / 2$ fot hög eller något högre med rödaktiga stänglar och enårig rot; holk slutl. tjock, af en ärts storlek; blommor invändigt citrongula; blad sträfva och teml. små.

Ruderatväxt på sandiga ställen; Göt. r.: Sk. spr. Gotl. Ög. tillfällig, Dalsl. Boh. 0.

390. Cichórium. Cikoria.

1. C. I'ntybus L.; de nedre bladen nedåt parflikade, de öfre n. hela, lansettlika och stjelkomfattande. 3, 4 .

Stjelk 2-4 fot hög och upptill grenig; blonıkorgar platta.

Torra ställen, helst i slättbygder; Göt. r.: Öl. t. a. Gotl. Sk. a. Vg. Dalsl. 0; eljest tillfällig eller förvildad: $S v$. Söd. Upl. Ner. Verml., Norrl. Jtl.

\section{Centauréa. Klint.}

a. Frukt utan pensel; holkfjäll med runda kupiga bihang.

1. C. Jacéa L., Fürgklint; blommor röda; holk klotrund. 3.

Stjelk 1-2 fot hög (stundom högre) och styf, upptill vanl. med korta grenar; blad rent gröna, de nedre lansettlika inskurna, de öfre aflånga och $\mathrm{n}$. hela.

Ängar och åkerrenar; Göt. Sv. allmän, Norrl. spr.

b. Pensel nästan af fruktens längd; holkfjäll tilltryckta och franskantade.

2. C. Scabiósa L., Väddklint; blommor röda; holk klotrund. 3.

Högre och gröfre än föreg. art; blad mörkgröna, stora och breda, vanl. pardelade; holkfjällens kant bred och svart.

Ängar, helst i slättbygder; Göt. mångenst.: Gotl. Öl. Sk. Hall. a. Boh. Dalsl. t. r., Sv. spr.: Vestm. Dal. r. Verml. t. r. 


\section{C. Cy'anus L., Blåklint; blommor blå eller blå-} hvita; holk äggformig. 2,3 .

2-3 fot hüg och spenslig med smala blad; holkfjällens kant smal och hvit eller brun; rot tvåårig.

Akrar, helst rågåkrar; Göt. Sv. a., Norrl. a.: Jtl. Ång. Vb. spr. 392. Échinops. Bolltistel.

1. E. sphærocéphalus L.; blad pardelade, undertill hvitludna med bugtigt tandade flikar. 3,4 .

Omkr. 2 fot hög, fint glandelhårig och klibbig. Vid torkning (äfvensom vid fruktmognaden falla blommorna lätt isär.

Ruderatväxt; Göt. Smål. r. Ög. spr. helst i ö. delen, Sv. Söd. t. r. Upl. r.

\section{Lappa. Kardborre.}

A. Holkfjäll kortare än blommorna och håriga.

1. L. tomentósa Lam.; holkfjäll tätt spindelväfshåriga, de flesta med rak och trubbad mörkröd spets; holk efter utslagningen klotrund. 3,4 .

$2-4$ fot hög med teml. långa blomkorgskaft och undertill hvitulliga blad.

Ruderatväxt, helst i slättbygder; Göt. t. a.: inre Smål. Dalsl. r., Sv. spr.: Söd. Upl. a. Dal. t. r. Verml.?, Norrl. Gestr. Med. Ang. $r$.

2. L. intermédia Lange; holkfjäll tunnt spindelväfshåriga: de yttre med krökt och smal spets, de inre rakspetsade, bredare än de yttre och upptill mörkröda; holk efter utslagningen n. äggformig. 3,4 .

3-5 fot hög med korta blomkorgskaft och undertill småludna blad; skalfrukter dubbelt större än hos följ. art.

Ruderatväxt, helst i slättbygder; Göt. spr.: Boh. Hall. r. Gotl. r.? Vg. Dalsl. 0, Sv. Söd. Upl. spr., Norrl. Ång. r.

3. L. minor D.C.; holkfjäll tunnt spindelväfshåriga med krökt och smal spets, alla vanligen gröna och n. likformiga; holk efter utslagningen n. klotrund, något plattad. 3, 4 .

$1 \frac{1}{2}-2^{1} / 2$ fot hög och mycket lik föreg. art, men med mera groft tandade blad och smärre blomkorgar.

Ruderatväxt; Göt. Sv. a., Norrl. Gestr. Hels. a. Med. spr. Ång. $V b$. $r$.

B. Holkfjäll längre än blommorna och glatta.

4. L. major (Schk.) Gärtn.; holkfjäll gröna med krökt och smal spets; holk som hos föreg. art. 3, 4 .

3-4 fot hög och n. glatt med dubbelt större blomkorgar än hos föreg. art samt med teml. långa blomkorgskaft.

Ruderatväxt, helst i slättbygder; Göt. spr.: Sk. t. a. Gotl. inre Smål. Hall.' Vg. Dalsl. r., Sv. r.: Söd. Upl. spr. Verml.? 394. Carlína. Spaimanstistel.

1. C. vulgárls L.; de inre holkfjällen torrhinniga, fär- 
gade och strålformigt utstående; de yttre holkfjällen n. jemnbreda med kort udd, som ej öfverskjuter strålarne; pensel af fruktens längd. 3 .

$1 / 2-1$ fot hög med lansettlika-aflånga och läderartade blad; stjelk stundom blåaktig.

Berg och andra torra ställen; Göt. spr.: Gotl. Smål. Ög. t. a. Hall. Boh. t. r., Sv. spr.: Söd. Upl. t. a. Verml. t. r. Dal. 0, Norrl. Gestr. r.

\section{Saussúrea. Fjell- Ängskära.}

1. S. alpína (L.) D.C.; holkfjäll tilltryckta, de yttre äggrunda, de inre trubbiga och aflanga-lansettlika; de öfre bladen lansettlika-jemnbreda, oskaftade och vanl. n. helbräddade, de nedre vanl. aflånga och svagt tandade; rotstock skottalstrande. 3, 4 .

Stjelk omkr. fotshög och i början täckt af ett spindelväfslikt ludd; blad ofvan glatta, undertill i början gråludna, slutl. ofta n. glatta; de nedre bladen vanl. afsmalnande mot skaftet; blomkorgar kortskaftade och tätt sittande i qvast; yttre holkfjäll vanl. spetsiga.

Något fuktiga och skuggrika ställen i fjellen, sällan utom fjellen; Ipl. a., Norrl. r.: Jtl. t. a. Herj. spr. Gestr. 0, Sv. Dal. r., Göt. Vg. r.

Anm. Somliga exemplar kunna hafva de yttre holkfjällen trubbiga och bladen bredt äggrunda-hjertlika med utdragen spets samt ofta bugtigt tandade, de öfre bladen något nedlöpande. Beskrifningen pä den i Franska fjell förekommande Sauss. macrophylla Saut., som dock torde vara föga skild art, öfverensstämmer nästan helt och hållet härmed.

\section{Serrátula. Ängskära.}

1. S. tinctória L.; de yttre holkfjällen ovala-lansettlika, de inre jemnbreda; blad fint sågtandade, stundom parklufna-pardelade, icke nedlöpande. 3 .

Stjelk omkr. 2 fot hög, teml. spenslig och sträf med glatta blad; holk aflångt äggformig; holkfjäll violetta och n. glatta: blomkorgar i qvastlik vippa; blommor tvåbyggare.

Något fukt. ängar, helst i slättbygder; Göt. mångenst.: Sk. Ö1. a. inre Smål. Boh. r. Vg.? Dalsl. 0, Sv. Söd. Upl. spr. Ner. Dal. r. Vestm. spr. i s. delen.

\section{Círsium. Tistel.}

A. Alla blommor samkönade och fruktbärande.

a. Stjelkblad nedlöpande; rot tvåårig. Blomkorgar vanligen talrika.

1. C. Ianceolátum (L.) Scop., Vügtistel; blad ofvan småtaggiga; holkfjäll lansettlika med lång utstående, trekantig och stickande spets; holk n. klotrund. 3, 4.

Omkr. 2 fot hög med hvithårig och grof stjelk och mycket stora blomkorgar (ungefär af valnötters storlek), vanl. enstaka i spetsen af grenarne; blad pardelade eller parklufna, undertill 
gråludna; bladflikarnes spetsar styfva och tagglika; blommor någon gång hvita. I skogar och på åkrar blifva växtens tagglika delar mindre styfva och bladen undertill hvitludna. Holkfjällen kunna någon gång utväxa till blad och blifva då mycket utstående.

Ruderatväxt, mindre ofta på åkrar och i skogar; Göt. Sv. Norrl. a.: Dal.-Jtl. Vb. spr.

2. C. palustre (L.) Scop., Kärrtistel; blad på båda sidor ludna; de yttre holkfjällen aflångt lansettlika med kort, utstående spets; de inre jemnbreda och i spetsen torrhinniga, såsom hos följ. arter; holk äggformig. 3.

2-6 fot hög med vek stjelk och smärre n. oskaftade blomkorgar, ungefär af hasselnötters storlek; blad pardelade; bladflikarne med en teml. stark tagg i spetsen.

Kärrängar, allmän utom fjellen: Lpl. $r$.

b. Blạd icke nedlöpande, ofvan glatta; rotstock. Blomkorgar vanligen få, stundom en enda.

3. C. heterophyllum (L.) All., Brudborste; blad undertill hvitludna, med hårlika taggar i kanten; de nedre bladen skaftade; stjelk nedtill bladig, upptill bladlös; holk n. klotrund. 3 .

Omkr. 2 fot hög och ofta enkel med vanl. blott en stor blomkorg i stjelkens spets: stundom utbildas tillika $1-4$, vanl. mycket långa sidogrenar (blomkorgskaft); de mellersta bladen stundom parklufna, de öfversta öronflikade: ofta äro alla bladen hela; de yttre holkfjällen jemnbredt lansettlika med kort och stickande spets.

Lundar och skogsängar; Lpl. t. a., Norrl. mångenst.: Jtl. t. a., Sv. spr.: Verml. t. a. Vestm. t. a. i n. delen, Göt. spr.: Dalsl. t. a. Boh. Hall. Blek. Öl. r. Gotl. 0.

4. C. oleráceum (L.) Scop.; blad blekgröna och vanl. glatta, med hårlika taggar i kanten; stjellblad osleaftade och omfattande med stora bladöron; stjelk äfven upptill bladig; holk aflangt äggformig. 3 .

Lika hög som föreg. med något smärre och vanl. gyttrade blomkorgar; blad parklufna eller stundom hela; de yttre holkfjällen lansettlika med vek udd. Olik de öfriga arterna genom gula småblommor samt stora gulaktiga skärmblad nedanför blomkorgarne. Vg. r.

Fuktiga ängar och stränder; Göt. Sk. a. Hall. Blek.-Ög.

5. C. acáule (L.) All., Joratistel; blad undertill gröna finludna, alla sliaftade och parklufna eller pardelade med taggspetsade flikar; stjelk vanligen bladlös, mycket kort och enblomstrig (mindre ofta några tum hög, flerbladig och flerblornstrig); holk äggformig. 3, 4 .

Med rosettlikt till marken nedtryckta rotblad och vanligen en stor blomkorg; de yttre holkfjällen korta och lansettlika med kort och stickande spets. 
Betesmarker, helst i slätthygder; Göt. spr.: Sk. Öl, a. Gotl. t. a. Ög. t. a. på slätten, inre Smål. Boh. r. Dalsl. 0, Sv. Söd. Ner. r. Upl.?

B. Alla blommor enkönade (då antingen ståndarne eller pistillen blifva förkrympta); blad ofvan glatta samt vanligen (utom på hafsstränder) icke nedlöpande. Blommor röda eller hvita. Pensel slutl. öfverskjutande blommorna. Blomkorgar talrika.

6. C. arvense (L.) Scop., Akertistel; holk äggformig; blad undertill ofta livitludna, tandade eller parklufna, med teml. starka taggar i spetsen af flikarne. 3 .

Omkr. 2 fot hög och upptill grenig med teml. sinå, ofta n. oskaftade blomkorgar; blad fasta; de yitre holkfjällen lansettlika med utstående, kort och stickande spets.

Ogräs i åkrar och ruderatväxt, stundom på hafsstränder; Göt. Sv. a., Norrl. t. a.: Jtl. Vb. spr.

Anm. Inom detta slägte finnas följ. bastarder:

C. heterophyllo-acáule Näg.; lik C. heteroph. genom blomkorgarne, men bladen äro ej omfattande. Göt. sk. Vg. r.

C. oleráceo--heterophyllum Näg.; lik C. oleraceum genom blommorna, men de nedre bladen äro skaftade. Göt. Vg. pă Mösseberg.

C. acauli-oleráceum Näg.; lik C. oleraceum genom blommorna, C. acaule genom bladen. Göt. Skåne t. r.

C. palustri-oleráceum Näg.; blommor gula; blad pardelade, de nedre nedlöpande. Göt. Skåne r.

\section{Cárduus.}

1. C. crispus L., Krustistel; blomkorgar flera tillsammans, n. upprätta och kortskaftade; de yttre holkfjällen aflånga med vek udd; grenar ända till spetsen vingade. 3,4 .

$2-3$ fot hög med mörkgröna, vektaggiga, vanl. ofvan håriga och undertill hvitulliga blad; blomkorgar teml. små, ungefär af hasselnötters storlek; blommor rödvioletta; blad parflikiga.

Ruderatväxt och ogräs t. a.: Jtl. spr. Gotl. t. r.

2. C. acanthóides L., Piggtistel; blomkorgar enstaka (sällan 2-3 tillsammans), n. upprätta och teml. kort skaftade; de yttre holkfjällen bredt aflånga med styf och stickande udd; grenar ända till spetsen vingade. 3,4 .

Liknar föreg., men har något större blomkorgar och röda blommor; blad ljusgröna, styft taggiga och nästan glatta. Förmodas vara bastard af föreg. och föli. art.

Ruderat- och hafsstrandväxt; Göt. Hall. r. Sk. t. a. Gotl. spr. Öl. Blek. Smål. r. (Norrl. Hels. tillfällig).

3. C. nutans L., Nicktistel; blomkorgar enstaka, lutande och långskaftade; de yttre holkfjällen nedom midten hopdragna och afsmalnande till en mycket utstående, 
styf och stickande udd; grenar och blomkorgskaft upptill ovingade. 3,4 .

1-2 fot hög och grof med mycket stora blomkorgar och röda blommor; blad djupt parflikiga och på nerverna ulliga; stjelk ullig; de inre holkfjällen med en fin tagg i spetsen.

Ruderat- och hafsstrandväxt; Göt. Boh. r. Smål. Blek. Öl. r. Gotl. t. r., Sv. Söd. Upl. r., Norrl. Gestr.-Ang. r.

399. Onopórdon. Bomullstistel.

1. 0. Acánthium L.; blad aflånga nedlöpande, taggigt tandade och hvitulliga; holkfjäll smalt lansettlika med utstående, trekantig och stickande spets. 3 .

2-5 fot hög, stor och vanl. grenig med spindelväfshårig och klotrund blomholk; blomkorgar enstaka.

Ruderatväxt, helst i slättbygder; Göt. spr.: Blek. r. Gotl. Vg. Dalsl. 0 (Boh. tillfällig), Sv. Söd. Upl. spr. Vestm. r., Norrt. Giestr. r. (Hels. tillfällig).

\section{Ordn. POLYCLINIA.}

\section{Eupatórium. Flockblomster, Hampört.}

1. E. cannábinum L.; blad 3-delade med lansettlika, sågade och undertill glandulösa flikar; vippa rikblomstrig och qvastlik; pensel längre än frukten. 3,4 .

Omkr. 3 fot hög och n. enkel med omkr. 5-blommiga blomkorgar; har stark lukt.

Stränder af sjöar och åar, sällan vid hafvet; Göt. t. r.: Sk. Blek. Smål. spr. Gotl. 0, Sv. t. r.: Dal. 0, Norrl. Gestr. r.

\section{Linósyris. Guldborste.}

1. L. vulgaris D.C.; blomkorgar stälda $i$ qvast. 4 .

Omikr. $1 / 2$ fot hög, uppstigande och glatt, med n. trådsmala och enkla stjelkar och föga bredare, tätt sittande och stela blad. Blommorna likna Solidago.

Något fuktiga betesmarker; Göt. Öland mångenst.

\section{Solidágo. Guldris.}

1. S. virga áurea L; ; blomkorgar något glest sittande i vippa; rotblad ovala trubbiga och tandade; stjelkblad lansettlika, spetsiga och n. helbräddade. 3 .

1-2 fot hög med styf och något kantig stjelk; grenarne någongång, t. ex. i fjellen, blott enblomstriga.

Ängsbackar, stundom på hafsstränder, allmän.

\section{Erígeron. Binka.}

A. Blomkorgar talrika och teml. små, ofta med föga utskjutande strålblommor. Rot vanl. tvåårig.

1. E. acris L.; hela växten mycket hårig; stjelk upptill grenig; rotblad vanligen korta och spadlika, stundom långt utdragna och tunglika; stjelkblad vanl. långa och n. jemnbreda; strålblommor n. trådlika, ej längre än penseln. 3 . 
Omkr. fotshög och mångblomstriø; vippa klaselik.

Torra ställen, allmän: Lpl. r. Jtl. spr. Vb.?

Mülléri (Lund); föga hårig med hårbräddade blad och n. glatt holk; strålblommor rödaktiga och vanl. något längre än penseln, som är (liksom hos hufvudarten) omkr. 3 gånger längre än frukten; rot tvåårig (liksom hos hufvudarten). 3 .

Torra ställen, helst pă berg i fjelltrakter, stundom utom fjellen; Ipl. spr., Norrl. Ang. spr. Jtl. Herj. r., Sv. Verml. r., Göt. Dalsl. Vg. Boh. Smål. r.

* E. elongátus Led.; nästan glatt; de öfversta bladen ofta mycket korta och äggrunda; grenar vanl. mycket smalare än stjelken; strålblommor vanl. rödaktiga, något breda och betydligt längre än penseln, som är omkr. dubbelt så lång som frukten; rot troligen mångårig. På berg i fjellen; Lpl. spr., Norrl. Jtl. Herj. spr.; utom fjellen "Vb.-Hels. r." (månne ej förvexlad med föreg. varietet?)

B. Blomkorgar stora och få, ofta en enda. Strålblommor långt utskjutande öfver holken. Holkfjäll upptill utstående. Rot mångårig.

2. E. alpínus L.; hela växten vanl. hårig; stjelk enkel eller med få och svaga sidogrenar upptill; rotblad och nedre stjelkblad med kort udd; holkfjäll sylspetsade och smala med vanl. oledade hår. 2, 3.

3-8 tum hög; stjelk vanl. rödaktig; rotblad vanl.tunglika; strålblommor vanl. rödaktiga, mycket längre än penseln, som vanl. är föga längre än frukten, stundom dubbelt så lång.

Klippor, helst i fjellen, sällan (i Jtl.) utom fjellen; Lpl. r., Norrl. Jtl. Herj. r.

3. E. uniflórus L.; nedtill vanl. glatt; stjelk n. alltid enblomstrig; blad utan udd; holkfjäll teml. breda, lansettlika och spetsiga, tätulliga af tydligt ledade hår. 2,3 .

Liknar föreg. art, men är vanl 2-4 tum hög; stjelk ofta grön; strålblommor vanl. hvita, sällan längre än penseln, som är föga längre än frukten.

Något fuktiga ställen på berg i fjellen; Lpl. spr. Norrl. Jtl. Herj. spr.

\section{Aster.}

1. A. Tripólium L.; vippa bladlös och qvastlik; de yttre holkfjällen ovala trubbiga, de inre smalare. 3,4 .

Omkr. fotshög, grenig och glatt, upptill rodnande eller violett; strålblommor saknas någongång.

Hafsstränder; Göt. Sv. t. a., Norrl. r.: Med.?

105. Petasítes. Pestilensrot.

A. Blad med n. rund omkrets och afrundade öronflikar. Blomkorgar utan (tunglika) strålblommor. 
1. P. vulgaris Desf.; blommor röda; hanväxtens (den icke fruktbärande växtens) blomkorgar n. oskaftade med breda blomskärmar och stälda i utdraget ax. 1.

I början omkr. $1 / 2$ fot hög; blad bredt hjertlika och n. trubbigt tandade, undertill gråludna. Den ganska sällsynta honväxten har hälften så stora och mera skaftade blomkorgar.

Ruderatväxt på fuktiga ställen, i äldre tider odlad; Göt. r.: Sk. spr. Ög. t. r. Blek. Gotl. Öl. Dalsl. 0, Sv. Söd. Upl. spr. Vestm. t. r. Ner. Verml. r.

2. P. alba (L.) Gärtn.; blommor hvita; blomkorgar skaftade med smala blomskärmar och stälda i qvastlik klase. 1.

Ungefär lika hög som föreg.; blad n. njurlika med spetsiga tänder och undertill hvitulliga, sällan glatta; honväxtens klase mera utdragen.

Fuktiga skuggrika ställen t.' ex. vid åar; Göt. Skåne t. r. B. Blad n. trekantiga med utspärrade flikar nedtill. Blomkorgar vanl. med (tunglika) strålblommor.

3. P. frigida (L.) Fr.; strålblommor hvitgula, de öfriga blommorna rödletta; blomkorgar i qvastlik klase; blad djupt inskurna. 1.

Högre än föreg. art, nedtill försedd med stora bladslidor, som stundom ega en liten bladskifva; stängelns fjäll jemte holkarne mörkröda; blad undertill grått filtludna med tandade flikar.

Kärr, helst bland videbuskar, i fjelltrakter; Lpl. a., Norrl. spr.: Med. Hels. r. Vb.? Gestr. 0, Sv. Dal. r.

4. P. spúria (Retz.) Rchb.; blommor hvita; blomkorgar i hopdragen, n. qvastlik klase; blad trubbigt tandade med djupt inskurna flikar nedtill. 1,2.

Omkr. $1 / 2$ fot hög och gulaktig med undertill hvitulliga blad. Sandiga stränder; Göt. Skåne r., t. ex. vid Ringsjön.

\section{Tussilágo. Hästhof.}

1. T. Fárfara L.; blad rundadt hjertlika, vinkligt tandade, undertill hvitt filtludna; blomkorg före och efter blomningen lutande; stängelns fjäll violettgröna. 1.

Omkr. 1/2 fot hög med större blomkorgar än hos föreg. slägte.

Leriga ställen; Göt. mångenst.: Blek. Hall. t. r. Sk. Gotl. Ög. a., Sv. spr.: Ner. Söd. Upl. t. a., Norrl. spr.: Jtl. Ång. t. a. Vb. r., Lpl. t. r.

\section{Arníca. Hästfibler.}

1. A. montána L.; strålblommor brandgula; stjelk enkel eller upptill med 2 korta, motsatta sidogrenar; hvarje blomkorg stödd af 2 (hvarje sidogren af 1 ) smala och närmade skärmblad; rotblad aflånga eller omvändt äggrunda och trubbiga. 3.

Stjelk 1-2 fot hög, beklädd af' korta glandelhår, samt med en stor blomkorg $i$ spetsen så väl af stjelken som af hvarje gren; 
stundom utbildas 4 sidogrenar, då de 2 nedersta kunna blifva stödda af blad, likformiga med rotbladen; holkfjäll trubbiga eller kortspetsiga. Hela växten luktar starkt.

Ängar, helst i skogsbygder; Göt. spr.: Sk. Smål. Dalsl. a. Hall. t. r. Gotl. Öl. 0, Sv. r.: Söd. t. r. Ner. Verml. t. a., Norrl. Hels. r.

2. A. alpína Murr.; strålblommor ljusgula; stjelk enkel med en blomkorg i spetsen utan skärmblad; stjelkblad 2, aflägsnade från blomkorgen, äggrundt lansettlika och långspetsiga; de nedersta rotbladen n. trubbiga, aflånga-lansettlika, de öfriga likformigu med stjelkbladen. 3 .

Stjelk omkr. fingerhög med korta ullika hår utan glandler; holkfjäll långspetsiga.

Angar högt upp i fjellen,. mycket r.; Lpl. flerst., mest omkring Qvickjock.

\section{Senécio. Boört.}

A. Blad hela och blott sågade. Holk klocklik. Strålblommor långa, utstående. Blomkorgar teml. stora. 1. S. paludósus L.; holk föga hårig; strålblommor 10 - 12; stjelkblad oskaftade, men ej omfattande. $3,4$.

Stjelk 3-4 fot hög, styf och pipig; rotstock något krypande; blomkorgar stälda i qvast; blad tätt sittande och i början undertill tätulliga, med hvassa framåtrigtade sågtänder; bladen likna den vanliga Skörpilens. något $r$.

Kärr och sjöstränder i vatten bland Starr; Göt. Skåne flerst.

B. Blad parklufna eller pardelade.

a. Holk rörformig; strålblommor mycket korta och tillbakarullade, eller felslående. Blomkorgar teml. små.

2. S. vulgaris L.; holk glatt; yttre holkfjäll mycket kortare än de inre och med svart spets; frukt korthårig. $2-4$.

$1 / 2-1$ fot hög med mjuk och något spindelväfshårig stjelk; blad parflikiga eller pardelade. Strålblommor finnas sällan.

Ruderatväxt och ogräs, allmänt: Vb. spr. Lpl. r.

3. S. viscósus L.; holk glandelhårig; yttre holkfjäll hälften kortare än de inre och föga svarta i spetsen; frukt n. glatt. 3,4 .

$1 / 2-1$ fot hög och af glandelhår klibbig med fast stjelk; blad som hos föreg. art.

Ruderatväxt, stundom på hafsstränder; Göt. r.: Sk. spr. Dalsl. 0 , Sv. Söd. Upl. spr. Dal. r., Norrl. Hels. r. 'Gestr. Ång. tillfällig).

4. S. silváticus L.; holk glatt eller finluden; yttre holkfjällen mycket kortare än de inre samt gröna och borstlika; frukt korthårig. $2-4$. 
Omkr. fotshög med fast, sträf och finhårig stjelk; blad pardelade.

Ruderatväxt, helst på svedjeland; Göt. Sv. spr.: Hall. Dalsl. Verml. t. a. Gotl. r., Norrl. Gestr. Hels. Ang. r.

b. Holk klocklik eller äggformig; strålblommor utstående och vanl. långa, sällan felslående. Blomkorgar teml. stora.

5. S. erucæfólius L.; yttre holkfjäll talrika; frukter håriga; inre holkfjäll nedom midten bredare samt långspetsade; blomkorgskaft utstående; alla blad parclclade med jemnbreda spetsade flikar. 3, 4 .

Stjelk 2-3 fot hög, styf och ullig; rotstock krypande; blad något stela och smalflikiga, de öfre stjelkomfattande med tvåflikiga bladöron.

Ruderatväxt, helst på jordvallar: Göt. Skåne h. o..d. på slättbygden, năgot $\mathrm{r}$.

6. S. Jacobæa L.; yttre holkfjäll 1-2, mycket korta; de yttre frukterna glatta, de inre finludna; inre holkfjäll jemnbreda-lansettlika; blomkorgskaft upprätta; de nedre bladen lyrformigt pardelade eller parflikiga. 3,4 .

2-3 fot hög och styf med mjuka och gröna blad; rot afstympad; blomkorgar större än hos de föreg. arterna och stälda $i$ en . qvastlik vippa.

Ängar och åkrar, helst nära hafvet eller sjöar; Göt. spr.: Sk. Öl. a. Ög. Vg. Dalsl. r., Sv. Söd. Upl. spr., Norrl. Gestr. Jtl. r. (Med. Ang. tillfällig?).

7. S. aquáticus Murr.; yttre holkfjäll 1-2, mycket korta; de inre frukterna n. glatta; inre holkfjäll n. aflånga; blomkorgskaft något utstående; de nedre bladen med stor ändflik och föga utbildade sidoflikar. 3, 4 .

Föga skild från föreg. art, men mera vek, alldeles glatt och stundom nedliggande; blomkorgar något större; blommor blekare; rot ofta klotformig.

Stränder; Göt. Gotl. r. Hall. Boh. t. r. Vg. Dalsl. r. 409. Cinerária. Nocka.

1. C. palustris L., Kärrnocka; alla blad aflångt lansettlika och tandade; stjelkblad tätt sittande, de öfre oskaftade; blomkorgar stora, stälda i qvast med delade grenar. 3,4 .

Blekgrön och klibbluden, inemot 2 fot hög och upptill grenig med mjuka blad; frukter glatta och gụla med snöhvit pensel.

Kärr och torfgrafvar; Göt. Sk. t. a. Öl. r. Blek. Smål. t. r. Hall. Vg. r.

2. C. campestris Retz., Fältnocka; stjelkblad glest sittande, omvändt äggrunda-aflånga, oskaftade och föga tandade, de öfversta smala jemnbreda; rotblad skaf- 
tade, bredt äggrunda; blomkorgar teml. små, stälda enkel flock. 2. håriga.

Hvitullig, enkel och vanl. omkr. $1 / 2$ fot hög; frukter styf-

Torra backar; Göt. Skåne t. r.

410. Artemísia. Malört, Gråbo.

A. Holk halfrund; blomfäste hårigt. Blomkorgar större och lutande.

1. A. Absínthium L., Malört; holk hvitluden; blad ovala skaftade med teml. breda, trubbiga och uddlösa flikar. 3,4 .

1-2 fot hög, hvitluden oeh starkt luktande; stjelk örtartad, vanl. upprätt; blomkorgar kortskaftade; vippans grenar utstående; de yttre holkfjällen jemnbreda, de inre ovala och i kanten torrhinniga; rotblad 3-dubbelt parflikiga och teml. stora.

Ruderatväxt; Göt. Sv. t. a., Norrl. Gestr.-Med. spr. Ång. r. (Jtl. odlad).

2. A. rupestris L.; holk n. glatt; blad aflånga oskaftade och parbladigt findelade. 3-4 (Augusti).

Omkr. $1 / 2$ fot hög, finhårig och välluktande; stjelkar uppstigande; blomkorgar något större än hos föreg. samt mera skaftade, vanl. stälda i klaselik vippa; blad små, de öfre omkr. 1/2 tum långa; yttre holkfjäll jemnbreda.

Kalkberg; Göt. Öl. t. a. Gotl. t. r.

B. Holk äggformig eller n. klotrund; blomfäste glatt; öfre blad oskaftade. Blomkorgar små.

a. Bladflikar trubbiga utan udd. Hela växten hvitluden.

3. A. maritima L.; stam nedtill stundom träaktig; holk äggformig; de nedre bladen dubbelt parbladigt delade med platta, n. trådsmala flikar; yttre holkfjäll ovala. 3-4 (Augusti).

Stam nedliggande eller uppstigande, antingen omkr. fingerhög och föga grenig med små blad eller omkr. fotshög och mycket grenig med större blad; blomkorgar n. oskaftade, nedböjda eller upprätta. Något illaluktande.

Hafsstränder; Göt. Boh. t. r. Hall. r. Sk. spr. Blek. t. r. Smål. r. Öl. spr. Gotl. t. r.

b. Bladflikar uddspetsiga. Växten mer eller mindre glatt.

4. A. vulgaris L., Gràbo; ört; holk luden och aflångt äggformig; de nedre bladen pardelade; bladflikar platta och med nedvikna kanter och kort udd; yttre holkfjäll lansettlika. 3,4 .

2-3 fot hög, gråluden och luktancie, oftast upprätt; blad ofvan glatta, undertill gråludna; blomkorgar oskaftade och slutl. upprätta.

Ruderatväxt, allmän: Lpl. r. Jtl. spr. 
- coarctáta; blomställning sammanträngd axlik; bladflikar smala, undertill snöhvita.

Hafsstränder; Göt. Boh. Blek. spr. Öl. t. r. Gotl. Smål. Ög. r., Sv. t. r., Norrl. Gestr. Hels. Vb. t. r.

5. A. campestris L.; halfbuske; holk glatt och n. klotrund; blad dubbelt parbladigt delade med n. trådlika flikar; yttre holkfjäll ovala. 3,4 .

2-3 fot hög och uppstigande, glatt och n. luktlös; vippans grenar utstående; blomkorgar kortskattade; nedersta bladen stundom silkesludna.

Ruderatväxt, helst i slättbygder; Göt. spr.: Gotl. Öl. Sk. a. inre Smål. Boh. Dalsl. r., Sv. Söd. Upl. spr. Ner. Verml. r. Vestm. spr. i s. delen, Norrl. Gestr. Ång. r. Vb.?

A. bóttnica Lundström; i början silkeshårig; blomkorgar och skalfrukter något större; holkfjäll stundom aflånga .

Hafsstränder, mycket r.; Norrl. Vb. vid utloppet af Piteelf (A. N. Lundström).

6. A. laciniáta Willd.; ört; holk n. klotrund, finhårig eller n. glatt; blad parbladigt delade med platta lansettlika småflikar; yttre holkfjäll ovala. 3, 4.

Omkr. fotshög, n. upprätt och småluden eller n. glatt; vippans grenar upprätta; blomkorgar skaftade och mycket små; rotbladens flikar (småblad) pardelade, stjelkbladens djupt parklufna; småflikar $1 / 2-1$ linie breda.

Betesmarker och åkerrenar; Göt. Öland mångenst., men min. dre ofta blommande.

\section{Tanacétum. Renfana.}

1. T. vulgare L.; holkfjäll trubbiga; blomkorgar långskaftade; bladflikar jemnbreda-lansettlika med spetsiga finsågade småflikar; de öfre bladen oskaftade öronflikade. 3 .

2-3 fot hög, n. glatt och välluktande.

Ruderatväxt; Göt. spr.: Gotl. t. r., Sv. spr., Norrl. spr.: Vb. r., Lpl. r.

\section{Chrysánthemum. Prest7rage.}

A. Strålblommor långa; blad tandade eller flikiga; frukter utan fruktkrona; blomkorgar fa och stora.

1. C. Leucánthemum L., Hvit Prestkrage; strålblommor hvita; blad sågtandade; rotstock krypande. 2-4.

Omkr. 2 fot hög, glatt eller luden; de nedersta bladen spadlika-tunglika, de öfre aflånga-jemnbreda, de yttre holkfjällen lansettlika och hrunkantade.

Ängar och åkrar, allmän: Jtl. Vb. spr. Lpl. r.

2. C. ségetum L., Gul Prestkrage; strålblommor guldgula; blad djupt tandade eller parflikiga; rot späd pålrot. 3,4 . 
Omkr. fotshög och glatt; de nedersta bladen tunglika, de öfre aflånga; de yttre holkfjällen ovala med blek hinnkant.

Åkrar, helst i slättbygder,.. ofta sporadisk eller tillfällig; Göt. spr.: Hall. Sk. t. a. Gotl. Ög. r. Öl. 0, Sv. r.: Ner. Dal. 0, Norrl. r.: Herj.?

B. Strålblommor korta; blad enkelt parbladigt delade; frukter med fruktkrona; blomkorgar talrika, stälda i qvast.

3. C. Parthénium (L.) Pers., Mattram; strålblommor hvita; alla blad skaftade; bladflikar parflikiga. 3, 4.

Omkr. fotshög, mycket grenig och finluden; de yttre holkfjällen lansettlika och hinnkantade. Har stark lukt.

i Skåne.

Ruderatväxt, ursprungligen förvildad; Göt. $S v$. t. r., ymnigast

\section{Matricária. Sötblomster.}

1. M. inodóra L., Baldersbrå; blomfäste inuti tätt; holkfjäll med brun kant, de yttre smalare och lansettlika; bladflikar undertill rännformiga. 3,4 .

$1 / 2-1$ fot hög och glatt med svag lukt; bladflikar trådsmala, på hafsstränder (helst vid v. kusten) stundom korta och köttiga. Ruderatväxt och ogräs i åkrar, allmän: Vb. Lpl. spr.

2. M. Chamomilla L., Kamillblommor, Sötkullor; blomfäste inuti ihåligt; holkfjäll med blek kant, alla n. lika breda och aflånga; bladflikar platta. 3,4 .

Omkr. fotshög, glatt och spenslig, med stark vällukt; bladflikar $n$. borstlika; blomkorgar mindre än hos föreg. art.

Ogräs i åkrar; Göt. Sv. t. a.: inre Smål. Hall.-Dal. spr., Norrl. Lpl. r.

\section{Bellis.}

1. B. perennis L.; blad spadlika långskaftade; holkfjäll aflånga trubbiga. $2-4$.

Några tum hög med rotstock och smala strålblommor; diskblommor talrika och gula.

Ängar, , helst nära hafvet; Göt. Hall. r. Sk. a. Blek. spr. Kalmarl. Ög. r. Öl. spr. Gotl. a.

\section{A'nthemis. Kullor.}

A. Blomfäste halfrundt, ej slutl. kägellikt; strålblommor gula; holkfjäll spetsiga.

1. A. tinctória L., Guldkullor; holk luden; blomfästets fjäll qvarsittande, jemnbreda och uddspetsiga. 3.

Omkr. 2 fot hög och luden; strålblommor någon gång (t. ex. Ög.-Upl.) gulhvita, sällan (t. ex. vid Kristianstad: Wahlstedt) felslående.

Ruderatväxt och ogräs i åkrar; Göt. t. r.: Gotl. Ög. Smål. Vg. spr. Dalsl. Hall.?, Sv. spr.: Dal. r., Norrl. r.: Jtl. t. a.

B. Blomfäste slutl. kägellikt; strålblommor rent hvita.

2. A. arvensis L., Akerkullor; holk luden; holkfjäll upp- 
XIX. syngenesia. $415-417$.

till bredt hinnkantade; blomfästets fjäll qvarsittande, lansettlika och spetsade samt öfverskjutande diskblommorna. 3,4 .

1-2 fot hög och luden med svag lukt.

Åkrar; Göt. Sv. a., Norrl. spr.: Ang. Vb. r.

3. A. Cótula L., Surkullor; holk vanl. glatt; holkfjäll upptill smalt hinnkantade; blomfästets fjäll affallande, n. jemnbreda och borstlika, kortare än diskblommorna. 3,4 .

1-2 fot hög och vanligen glatt; illaluktande.

Ruderatväxt, helst i slättbygder, stundom på hafsstränder; Göt. Vg. Boh. r. Hall. spr. Sk. a. inre Smål. r. Blek. t. r. Kalmarl. Ög. Öl. spr. Gotl. t. r., Sv. r.: Söd. Vestm. spr. Ner. 0.

\section{Achillæa.}

1. A. Millefólium L., Rölleka, Renfana, Millefolium; blad dubbelt parbladigt delade med jemnbreda flikar och ovingad medelnerv; strålblommor få, hvita eller ljusröda, med brämet kortare än den äggformiga holken. 3,4 .

1-2 fot hög och luden, med rödaktiga grenskott; blomkorgar små.. och tẳtt sittande; blad till omkretsen aflångt jemnbreda. Är på hafsstränder stundom ullhårig med mera tätt sittande blomkorgar, h. o. d. på Öl. och Gotl., sällan i Boh. och Blek.-Ög.

Ängar och backar, allmän.

3. A. Ptármica L., Tusensköna; blad hela, hvassågade och jemnbredt lansettlika; strålblommor teml. talrika och hvita, med brämet lika långt som den halfrunda holken. 3.

1-2 fot hög och n. glatt med större blomkorgar än hos föreg. art.

Ängar, åkerrenar och stränder; Göt. spr.: Gotl. Öl. r. Dals]. t. a., Sv. spr.: Vestm. t. r. Verml. t. a.. Norrl. Gestr. Hels. Ang. $r$.

\section{Bidens. Skära.}

1. B. tripartíta L., Brunskära; blomkorgar upprätta; holk n. rörformig; blad 3-delade, sällan hela och tandade, alla skaftade. 3,4 .

2-3 fot hög och n. glatt; de inre holkfjällen bruna med gula kanter; blad aflånga-lansettlika; har aldrig strålblommor.

Våta ställen, helst nära bostäder; Göt. Sv. a., Norrl. spr.: Heri ? Jt]. 0, Lpl. r.

- frondósa (Retz.); de yttre holkfjällen mycket längre och större än de inre; blad vanl. 3-5-delade, stundom odelade.

Göt.' Hall. Sk. Ög. r. 
2. B. cérnua L., Färgskära; blomkorgar lutande; holk halfrund; blad tandade och oskaftade, nedtill omfattande och något hopväxta. 3,4 .

Något lägre än föreg. och n. glatt; de inre holkfjällen gula; blad lansettlika: har stundom gula strålblommor.

Våta ställen; Göt. spr.: Sk. a. Gotl. r. Boh. t. r., Sv. spr., Norrl. Gestr.-Ång. r.

\section{I'nula.}

A. Skalfrukt trind. Blad teml. smala. Blomkorgar omkr. tumsbreda. Holkfjäll smala och n. syllika, de inre blekare och smalare än de yttre.

1. I. salícina L.; de yttre holkfjällen från teml. bred bas syllikt afsmalnande, de inre n. jemnbreda; blomkorgar långskaftade; blad oskaftade, lansettlika och vanl. spetsiga; de öfre vanl. öronflikade; frukt glatt. 3 (Juni, Juli).

Omkr. 1-2 fot hög, vanl. upprätt och flerblomstrig, samt glatt, utom att bladen äro sträfva i kanten; blad stela, pà undra sidan med upphöjdt ådernät.

Ängar; Göt. t. r.: Gotl. Öl. a. Sk. Ög. spr., Sv. Söd. Upl, spr. Ner. t. r. Vestm. Dal. r.

2. I. ensifólia L.; holkfjäll och frukt som hos föreg. art; blomkorgar kortskaftade; blad oskaftade, n. svärdlikt jemnbreda och spetsiga, ej omfattande eller öronflikade. 3 (Juli).

Liknar föreg. art, men har uppstigande stjelk och smalare, omkr. liniebreda blad, som undertill vanligen hafva föga upphöjda ådror; är oftast enblomstrig och är bladig ända upp till blomkorgen.

Ofruktbara kalkhedar, mycket r.; Göt. Gotl. i Bunge och Fleringe socknar.

3. I. británnica L.; alla holkfjäll smalt syllika, n. jemnbreda; blomkorgskaft utdragna; blad lansettlika, de nedre afsmalnande till skaft, de öfre oskaftade; frukt luden. 3,4 .

1-2 fot hög och upprätt, mer eller mindre hvithårig; blad mjuka, glestandade, undertill utan upphöjdt ådernät; blomkorgar vanl. flera.

Fuktiga ställen, t. ex. vid sjöstränder och vattengrafvar; Göt. Öl. t. a. Gotl. Sk. t. r. Hall. r. (Smål. Verml. tillfällig).

B. Skalfrukt fyrkantig. Blad mycket stora och breda. Blomkorgar mycket stora. Älla holkfjäll mycket breda och n. ovala eller äggrunda.

4. I. Helénium L., Alantrot; blad tandade och undertill hvitludna; de nedre långskaftade. 4.

3-5 fot hög och luden; blad mjuka, de nedre ända till fotslånga, de öfre hjertlikt omfattande; rotstock köttig. 
Ruderatväxt på fukt. ställen, ursprungligen förvildad; Göt. Sv. t. r.: Dal. 0.

\section{Pulicária.}

1. P. vulgáris Gärtn.; blad aflångt lansettlika och vågiga, de nedre kortskaftade, de öfre oskaftade. 3,4 .

Stjelk upptill grenig och omkr. fotshög, upprätt eller uppstigande; blad mjukhåriga, omkr. tumslånga; blomkorgar talrika och n. klotrunda, föga större än en stor ärt, med stark lukt; rot enårig.

Ruderatväxt på feta fuktiga ställen; Göt. Hall. t. r. Sk.t.a. Blek. Öl. Kalmarl. s. delen spr.

\section{Gnaphálium. Noppa.}

a. Blomkorgar förenade $\mathrm{i}$ hufvud. Rot enårig.

1. G. uliginósum L.; stjelk vanligen nedifrån grenig och mångbladig, utan rotskott; blad nedåt afsmalnande och n. trubbiga, vanl. på båda sidor hvitulliga, stundom $n$. glatta; blomkorgar oskaftade och tätt gyttrade i bladiga hufvud; holkfjäll i spetsen gulbruna; frukt $n$. glatt. 3,4 .

${ }_{1 / 2}$ fot hög eller lägre, mycket hvitullig, med smala n. jemnbreda blad, sällan alldeles glatt; blommor gulhvita.

Fuktiga ställen, helst vid vägar, allmän: Jtl. spr. Lpl. r.

2. G. lúteo-album L.; stjelk vanl. enkel; hela växten hvitullig utom de glatta och hinnaktiga holkfjällen; blad stjelkomfattande, de öfre spetsiga; blomkorgar $n$. oskaftade och förenade i bladlösa hufvud; frukt grynprickig. 3,4 .

Inemot fotshög; de öfversta bladen nedtill mycket breda; blommor gula med hvitaktiga holkfjäll.

Ruderatväxt på sandiga ställen; Göt. Öl. spr. Smål. Blek. r. Sk. flerst. i s. v. delen.

b. Blomkorgar stälda i ax. Rot mångårig. Stjelk enkel.

3. G. silváticum L.; stjelk mångbladig med fă, nedtryckta eller uppstigande rotskott; blad vanligen ofvan glatta, undertill hvitulliga, ennerviga; blomkorgar oskaftade i långt utdraget ax; holkfjäll i spetsen ljusbruna; frukt med korta och täta hår. 3, 4 .

Omkr. fotshög med styf stjelk; nedre blad smalt lansettlika, öfre blad smala och jemnbreda.

Skogsängar, allmän: Jtl. Vb. Lpl. spr. (Torn. Lpm. 0).

4. G. norvégicum Gunn.; stjelk fåbladig utan rotskott; blad på båda sidor hvitulliga, trenerviga; blomkorgar oskaftade i utdraget ax; holkfjäll i spetsen mörkbruna; frukt med korta och täta hår. 3,4 . 
Liknar föreg. art isynnerhet genom den styfva stjelken; $1 / 2$ fot hög och mycket hvitullig med 2-3 tum långt och tätblomstrigt ax; stjelkblad lansettlika - aflånga, ofta större än rotbladen.

Ängar i fjelltrakter, helst i fjellens björkregion; Lpl. a., Norrl. Jtl. Herj. mångenst., $S v$. Dal. spr. (i fjellen) Verml. r. 5. G. supínum L.; stjelkar fåbladiga och tufvade med talrika rotskott; blad grå- eller hvitulliga, ennerviga; blomkorgar något åtskilda, stundom kortskaftade i ett föga utdraget ax; holkfjäll i spetsen mörkbruna; frukt med korta och glesa hår. 3,4 .

Vanl. blott 1-2 tum hög med veka, n. trådsmala och fåblomstriga stjelkar samt jemnbreda blad.

Något fuktiga och ofruktbara ställen i fjellen, helst ofvan barrskogsregionen; Lpl. t. a., Norrl. Jtl. Herj. spr.

421. Helíchrysum. Evighetsblomster, Eternell.

1. H. arenárium (L.) D.C.; blomkorgar klotrunda; de yttre holkfjällen ovala trubbiga, de inre omvändt äggrunda, alla slutl. utspärrade. 3, 4.

Stjelkar vanl. talrika, omkr. $1 / 2$ fot höga eller något högre, och styfva, jemte bladen hvitulliga; de nedre bladen omvändt äggrunda -aflånga och trubbiga, de ötre smalt lansettlika spetsade.

Sandfält; Göt. Hall. r...Sk. t. a. (helst i ö. och mell. delen) Blek. t. r. Smål. Gotl. r. Öl. t. r.

\section{Antennária. Kattfötter.}

1. A. dióica (L.) Gärtn.; med nedliggande eller uppstigande rotskott, $i$ hvilkas spets bladen äro gyttrade i rosett; rotskottens blad spadlika; stjelkblad n. jemnbreda med kort spets; holkfjäll i spetsen rundade, något kupiga. 1, 2 .

Vid blomningen 1-2 tum, slutl. ända till $1 / 2$ fot hög; hanblomkorgar korta och vanl. med hvita holkfjäll, som äro kortare än småblommorna, i hvilka stiftet, är enkelt; honblomkorgar längre och vanl. med rosenröda holkfjäll, som äro längre än småblommorna, i hvilka stiftet är tvåklufvet; alla bladen vanl. ofvan glatta och gröna, undertill hvitulliga, sällan på båda sidor hvita.

Ängar och backar, allmän.

2. A. alpina (L.) Gärtn.: rotskottens blad tunglika; stjelkblad n. jemnbreda med kort spets; holkfjäll platta, vanl. spetsiga, stundom (isynnerhet hos hanväxten) med kort och trubbig spets. 1, 2.

Vanl. något lägre än föreg. art; holkfjäll brunaktiga; blad stundom äfven ofvanpă hvitulliga.

Torrare ställen i fjellen, helst ofvan barrskogsregionen; $L p l$. spr., Norrl. Jtl. Herj. spr.; hanväxten mycket r., t. ex. Torn. Lim. 3. A. carpáthica (Wahlenb.) Bl. o. Fingerh.; utan rotskott, men med upprätta bladtofsar från den korta rot- 
XIX. syngenesia. 423. XX. gynandria. 424. 307

stocken; alla blad n. likformiga, lansettlika och utdraget spetsiga; holkfjäll platta med kort och vanl. trubbig spets. 1, 2.

Är năgot lägre än föreg., liknar späda exemplar af Gnaphal. norvegicum och har liksom denna trenerviga och på båda sidor hvitulliga blad, men är lätt urskild derigenom, att blomkorgarne äro stälda i flock; holkfjäll brunaktiga.

Något fuktiga klippbranter nära snögränsen; $L p l$. t. r.

423. Filágo. Ullblomster.

A. Blomgyttringar fåblomstriga, af $2-7$ blomkorgar. Holkfjäll slutl. stjernlikt utbredda.

1. F. montána L.; gråullig; blomkorgar äggformiga och öfverallt gråulliga; blomstödjeblad lika långa som blomgyttringarne. 3,4 .

Omkr. $1 / 2$ fot hög, enkel eller med upprätta grenar; blad upprätta; holkfjäll trubbade.

Berg och steniga backar; Göt. a.: inre Smål. spr. Boh.r., Sv. a., Norrl. Gestr.-Ång. t. a. Vb. spr.

- arvensis; grenar utdragna med blomkorgarne mest gyttrade i spetsen; omkring fotshög.

Göt. Sk. Öl. a. Gotl. Blek.-Ög. spr. Hall. Boh. r., Sv. Verml. Dal. r.

2. F. mínima Fr.; med kort och grått $l u d d$; blomkorgar kägelformiga och åtminstone upptill glatta; blomstödjeblad kortare än blomgyttringarne. 3, 4.

Lägre och spensligare än föreg. art; blomkorgar smalare, stälda i en tvådelad vippa; blad tätt sittande och tilltryckta; holkfjäll trubbade.

Sandbackar; Göt. spr.: Sk. t. a. Gotl. t. r. Dalsl. r., Sv. Söd. r.

B. Blomgyttringar mångblomstriga. Holkfjäll ej stjernlikt utbredda.

3. F. germánica L.; gråullig; blomkorgar kägellikt äggformiga, upptill glatta; blomstödjeblad kortare än blomgyttringarne. 3,4 .

Stjelkạr ända till fotshöga, något tjockare än hos de föreg. arterna, samt upptill greniga; blad tilltryckta; holkfjäll spetsade, upptill gula eller röda.

Torra ställen, helst i sandiga åkrar; Göt. Hall. r. Sk. flerst. helst i s. v. delen.

\section{Klassen. GYNANDRIA.}

1 Ordn. MONANDRIA.

424. Orchis. Yxne, Nyckelblomster.

I. Läpp bred, flikig eller inskuren. Frömjölsmassornas skaft inneslutna af en gemensam pung. Ståndareknappens rum ned- 
till sammanstötande. Stamknölar hela, klufna eller delade. Ax mer eller mindre utdraget, vanl. tätblommigt. (Slägtet Orchis hos de flesta förf.).

A. De fem öfre kalkbladen hjelmlikt hopstående. Stamknölar hela. 1. 0. Morio. 2. 0. ustulata. 3. 0. militaris.

B. De två yttre kalkbladen slutl. utstående eller nedböjda.

a. Stamknölar hela. 4. 0. mascula. 5. 0. Iaxifiora.

b. Stamknölar klufna eller delade. 6. 0. sambucina. 7.0. maculata. 8. 0. incarnata.

II. Läpp bred och treflikig. Frömjölsmassornas skaft utan pung. Ståndareknappens rum nedtill sammanstötande. Stamknölar delade. Ax smalt, vanl. långt och teml. tätblommigt. (Gymnadénia $\mathrm{R}$. Br.). 9. 0. conopsea. 10. 0. odoratissima. 11. o. albida.

III. Läpp smal, jemnbred och helbräddad. Frömjölsmassornas skaft utan pung. Ståndareknappens rum àtskilda. Stamknölar hela. Ax utdraget och glesblommigt. Sporre lång. (Platanthéra Rich.). 12. 0. bifolia. 13. O. montana.

IV. Läpp teml. smal, n. jemnbred och i spetsen tretandad. Frömjölsmassornas skaft utan pung. Ståndareknappens rum åtskilda. Stamknölar djupt klufna. Ax föga utdraget, teml. bredt och något glesblommigt. Sporre kort och punglik. (Coeloglossum Hartm.). 14. 0. viridis.

1. O. Mório L.; läpp treflikig med n. likformiga och lika stora rundade fikar och urnupen mellanflik; sporre omkr. hälften så lång som fruktämnet eller föga kortare. 2.

Omkr. ${ }^{1 / 2}$ fot hög; de nedre bladen aflånga, omkr. $1 / 2$ tum breda, utstående och sittande nära hvarandra; skärmblad rödvioletta och lika långa som fruktämnet; blommor stora och $f a ̊$, omkr. 8, glest sittande och purpurröda, slutl. mörkvioletta; sporre n. rak och utstående; stamknölar n. runda.

r. Öl. a. Gotl. spr.

2. O. ustuláta L., Krutbrännare; läpp tredelad med mycket mindre sidoflikar och tvåklufven mellanflik; sporre $3-4$ gainger kortare än fruktämnet. 2 .

Spensligare än föreg. art och vanl. något lägre; de nedre bladen aflanga-lansettlika, omkr. $1 / 2$ tum breda; skärmblad hinnaktiga, föga kortare än fruktämnet; blommor smà och talrika, tätt sittande och i början svartröda, slutl. inuti ljusröda med mörkare prickar; sporre rak och nedböjd; stamknölar n. runda.

Torrare ängar; Göt. Gotl. Öl. t. a. Blek. r. Sk. mångenst. i s. och mell. delen.

3. O. militáris L., Johannes' nycklar; läpp tredelad med mycket mindre sidofikar och förlängd, mot spetsen bredare och tvåflikig mellanflik; sporre hälften så lång som fruktämnet. 2,3 .

Ofta gröfre än de föreg. och omkr. fotshög; de nedre bladen aflånga, ofta öfver en tum breda; skärmblad äggrunda, 3-4 
gånger kortare än fruktämnet; blommor teml. stora och långa, talrika och tätt sittande, invändigt ljusröda och nedtill prickiga, utvändigt gråaktiga; sporre krökt; stamknölar äggformiga. delen.

Fuktiga ängar; Göt. Öl. a. Gotl. t. a. Blek. r. Sk. spr. i ö.

\section{0. máscula L.; läpp grundt treflikig med n. lika} stora, breda och naggade flikar; sporre n. lika liang som fruktämnet, tjock och utstående eller uppát rigtad. $2-3$.

Teml. grof och ofta en fot hög; de nedre bladen lansettlika, mot spetsen något bredare och omkr. $1 / 2$ tum breda; skärmblad rödaktiga ennerviga, ungefär. lika långa som fruktämnet; blommor något större än hos Orchis maculata, talrika och något glest sittande i utdraget ax, violettröda och inuti rödfläckiga; sporre jemntjock; stamknölar aflånga, starkt luktande. Blad stundom fläckiga.

Skogsängar och busksnår; Göt. Gotl. Öl. a. Smål. r. Blek. spr. Sk. a. (utom i furubygden) Hall. spr. Dalsl. r.

5. 0. laxiflóra Lam.; läpp treflikig med stora sidoflikar och liten vigglik mellanfik; sporre kortare än fruktämnet. 3 .

Spenslig och omkr. fotshög; de nedre bladen lansettlikt jemnbreda och spetsiga, föga bredare än stjelken; skärmblad hinnaktiga, flernerviga och otydligt nätådriga, vanl. kortare än fruktämnet; blommor större än hos föreg. art, teml. $f a$ och glest sittande, mörkröda; sporre jemntjock; stamknölar aflånga.

Vid träsk på stränderna; Göt. Gntl. t. r.

\section{O. sambúcina L., Fläderyxne; läpp grundt treflikig} och n. rund; sporre lika lång som fruktämnet, tjock och mot mynningen vidare, nedåt rigtad. 1, 2 .

Stjelk omkr. 1/2 fot hög, slutl. högre, ihålig; de nedre bladen tunglikt aflånga-lansettlika, omkr. 8 linier breda, ljust blågröna och ej fläckiga; skärmblad breda och flernerviga, de nedre öfverskjutande blommorna; blommor teml. stora, något glest sittande $\mathrm{i}$ ett ovalt ax, ljusgula eller hvitaktiga med rödprickig läpp, stundom $n$. purpurröda; stamknölar grundt klufna. Blommorna lukta nästan som Fläder, men svagare.

Ängar, helst i skärgården vid Östersjön samt nära sjöar; Göt. Gotl. Öl. Blek.-Ög. spr. Sk. inre Smål. Vg. r., Sv. Söd. Upl. spr. Vestm. r.

7. 0. maculáta L., Jungfru Marie hand; läpp grundt treflikig och n. rund; sporre n. trådlik och kortare än fruktämnet; stjelk (vid blomningstideñ) tät; blad aflånga-lansettlika, ofvan midten bredast. $2,3$.

Umkr. fotshög, stundom dubbelt högre; blad mörkt blågröna och svartfläckiga; skärmblad $n$. jemnbreda och trenerviga, de nedre längre än fruktämnet; blommor tätt sittande $i$ ett aflăngt ax, hvitaktiga eller blekt violetta med mörkare strimmor; stamknölar djupt klufna och handlika.

Fuktiga ängar, allmän: Dal.-Lpl. Vb. spr. 
8. O. incarnáta L. (enl. Fr.); läpp grundt treflikig; sporre n. trådlik, mot mynningen vidare, samt kortare än fruktämnet; stjelk ihălig; blad n. jemnbreda eller lansettlika-aflånga, bredast nedom (eller på) midten. $2,3$.

Omkr. fotshög eller högre med stundom fläckiga blad; skärmblad lansettlika och trenerviga, de flesta längre än fruktämnet; blommor vanl. tätt sittande $i$ ett aflångt eller äggformigt ax, röda eller hvita, stundom med mörkare strimmor; stamknölar djupt klufna.

Fuktiga ängar, helst i slättbygder; Göt. Gotl. Öl. a., Ög. a. på silur. form. eljest spr., Kalmarl. Blek. spr. Sk. a. inre Smål. Hall. t. r. Vg. spr. Boh. Dalsl. r., Sv. Söd. Upl. t. a. Vestm. t. r. Ner. Dal. spr. Verml. r., Norrl. r., Lpl. r.

- cruenta (Müll.); blommor mörkröda; blad brun- eller rödfläckiga.

Lpl, r., Norrl. Ång.-Hels. r. Jtl. spr.

- angustifólia; med mycket smala blad och kort, något glest och trubbigt ax.

Göt. r.: Gotl. spr. Blek.?, Sv. Verml. r.

- latifólia; blommor bleka (liknande dem hos 0. maculata); stjelk stundom 2 fot hög; blad breda, vid midten bredast.

Kärr; Göt. Hall. Sk. Gotl. r. Ög. t. r., Sv. Söd. Upl. r.

Anm. En närstående form med mycket fläckiga blad, möjligen bastard af 0 . incarnata och 0 . maculata, förekommer i Ög. i Kärna mosse.

9. O. conópsea L., Brudgran; blad lansettlikt jemnbreda; ax långt utdraget och något glesblommigt; sporre vanl. mycket längre än fruktämnet; läpp mycket bred med korta flikar. $2,3$.

Omkr. 2 fot hög med röda eller hvita, något välluktande blommor; yttre kalkblad utstående.

Ängar; Göt. t. a.: Ög. spr. Boh. r., Sv. t. a., Norrl. spr.: Gestr. a. Med.-V Vb.?, $L_{p l}$. spr.

- densiflóra; ax mera tätblommigt; stjelk högre; blad bredare.

Göt. Gotl. a. Öl. Sk. spr. Hall. Smål. r.

- alpina (Kindb.); ax något glesblommigt och kort, 1-2 tum långt; sporre stundom något kortare än fruktämnet eller föga längre; stjelk omkr. $1 / 2$ fot hög med något trubbiga blad, kortare än hos hufvudarten.

I fjellen; Lpl. r., Norrl. Jtl. r.

10. O. odoratíssima L.; blad smalt jemnbreda; ax långt utdraget, jemntjockt och teml. tätblommigt; sporre lika lång med fruktämnet; läpp mera lång än bred. 3. 
Lik föreg. art, men med hälften mindre, röda och mycket välluktande blommor samt smalare ax och blad; yttre kalkblad utspärrade.

Ängar, helst (blott?) på silur. formation: Göt. Gotl. t. r. Blek. Ög. V g. r.

11. 0. álbida (L.) Scop.; de nedre bladen omvändt äggrunda--aflånga, de öfre lansettlika och mycket spetsiga; ax långt utdraget och $\mathrm{n}$. ensidigt; sporre hälften så lång som fruktämnet. 3 .

Spenslig, omkr. $1 / 2$ fot hög eller något högre med mycket små gulhvita och välluktande blommor i smalt ax; yttre kalk. blad hjelmlikt hopstående; stamknölar mycket djupt delade.

Magra ängar, stundom något fuktiga, äfven i fjellen; $L p l$. r., Norrl. Jtl. Herj. t. r., Göt. Dalsl. Boh. r. Hall. t. r. Sk. spr. Blek. r. Smål. spr. i v. delen.

12. 0. bifólia L., Nattviol; ståndareknappens rum något närsittande och parallela. 2, 3 .

1-2 fot hög med vanl. 2 stora, aflånga och trubbiga blad vid stjelkens bas och små smala stjelkblàd; sporre längre än fruktämnet; blommor hvita, särdeles på aftnarne och nätterna välluktande.

Ängar; Göt. Sv. t. a., Norrl. t. r.: Vb. 0, Lpl. r.

13. O. montána Schm.; ståndareknappens rum nedtill mycket afägsnade från hvarandra. 2, 3.

Liknar föreg. art, men har grönaktiga och vanl. större blommor med svagare lukt. Platanthera chlorantha Cust.

Ängar; Göt. spr.: Gotl. t. a. Smål. t. r. Öl. Blek. Boh. Dalsl. r. Hall.?, Sv. spr.: Vestm. t. r. Verml. Dal. 0, Norrl. Hels. Jtl. r. 14. 0. víridis (L.) Crantz, Pungyxne; de nedre bladen aflånga trubbiga; de nedre blomskärmarne längre än blommorna; läpp n. jemnbred, den mellersta tanden kortast. 3 .

1/2-1 fot hög med aflångt blomax; de öfversta bladen $n$. lansettlika och spetsiga; blommor gulgröna; yttre kalkblad hjelmlikt hopslutna.

Ángar; Lpl. spr., Norrl. spr.: Ång. a., Sv. Upl. Söd. spr. Ner. r. Verml. Dal. t. r. Vestm. spr. i n. delen, Göt. Vg. Ög.Blek. r. Öl. Sk. t. r.

\section{Anacámptis. Klotyxne.}

1. A. pyramidális (L.) Rich.; läpp treflikig med n. lika stora flikar; sporre jemntjock och n. trådlik, lika làng som fruktämnet eller något längre. 3 .

Omkr. en fot hög och teml. spenslig; de flesta bladen sittande vid stjelkens bas, n. jemnbreda och ett par linier breda; blommor teml. små och talrika; yttre kalkblad utstăende; stamknōlar n. runda eller äggformiga. Liknar Orchis conopsea, men har omkr. tumslångt ax.

Torra betesmarker; Göt. Gotl. t. r. Öl. flerst. 


\section{Nigritella. Brunkulla, Brunyxne.}

1. N. angustifólia Rich.; blad jemnbreda; blomskärmar öfverskjutande blommorna; läpp $\mathrm{n}$. hel och äggrund. $2-3$.

Omkr. 1/2 fot hög; blad ej bredare än stjelken; kalkblad utstående; stamknölar klufna. Blommorna lukta som vanilj.

Något torra och öppna ängar; Norrl. Jtl. t. a. Herj. Hels. -Ång. r.

\section{Herminium. Honingsblomma.}

1. H. Monórchis (L.) R. Br.; de inre sidokalkbladen mycket längre än de yttre; läppens flikar jemnbreda, den mellersta längre än de utspärrade sidoflikarne. 2,3 .

Knappt $1 / 2$ fot hög med egentligen 3 stamknölar, ofta blott en utbildad; blad aflånga-lansettlika; ax långt utdraget.

Fuktiga ängar, helst på silur. formation; Göt. Öl. a. Gotl. t. a. Ög. mångenst. Smål. t. r. Sk. spr. Hall. Boh. r. Vg. t. r., Sv. Verml. Dal. t. r. Ner. Vestm. r. Söd. Upl. spr., Norrl.Gestr. r. 428. Ophrys. Flugyxne, Flugblomma.

1. 0. myódes Jacq.; de 3 yttre kalkbladen aflånga, trubbiga och gröna, de 2 inre n. trådsmala och bruna; läpp mot spetsen bredare och midtp̊̊ försedd med en n. fyrkantig, blåaktig fläck. 2.

Omkr. fotshög med 2 stamknölar; hlad aflånga-lansettlika.

Kärrängar, n. alltid på silur. formation; Göt. Gotl. Öl. Ög. spr. Smål. r. Sk. Vg. t. r., Sv. Upl, r. Ner. t. r., Norrl. Gestr. r. Jtl. t. r.

\section{Chamæórchis. Ripört.}

1. C. alpina (L.) Rich.; de nedre blomskärmarne öfverskjutande blommorna; blad jemnbreda; läpp aflång med 2 sidotänder. 3.

Omkr. 2-4 tum hög med omkr. tumslångt ax; blad knappt liniebreda och föga bredare än stjelken, men stundom längre.

Jord- och sandkullar bland lägt gräs, helst högt upp i fjellen; Lpl. r., Norrl. Jtl. Herj. r.

\section{Epipactis. Zymbel.}

A. Utan rotskott; läpp spetsig eller med inböjd spets; fruktämne tjockt och ovalt eller rundadt.

1. E. latifólia (L.) All.; läpp i spetsen n. afrundad, kortare än de yttre kalkbladen samt med 2 otydliga bucklor. 3 (Juli, Aug.)

1-2 fot hög; blad ofta 2 tum breda, äggrunda-ovala, alla. längre än stjelkens ledstycken samt med sträfva nerver; blommor grönhvita, brunaktiga eller ljusröda, slutl. n. platta; de nedre: skärmbladen vanl. öfverskjutande blommorna; blomskaft vanl. kortare än det föga håriga fruktämnet. 
Skogar och herg; Göt. t. r.: öl. Gotl. Ög. spr. Hall.?, Sv. t. r.: Söd. Upl. spr., Norrl. Gestr. Jtl. r.

2. E. média Fr.; läpp lika lång som de yttre kalkbladen, dess yttre del oval och spetsig samt ined 2 knöliga bucklor. 2-3 (Juni, Juli).

Liknar föreg. art, men är vanligen lägre och spensligare med n. klocklika, mörkröda ocb mera välluktande hlommor; blad smalare, de nedre ovala, de öfre aflånga-lansettlika och vanl. sträfva; de nedre skärmbladen sällan öfverskjutande blommorna; fruktämne tätludet.

Skogar och berg; Göt. Gotl. Öl. Smål. r. Ög. spr. Dalsl. t. r., Sv. r.: Verml. t. r. Vestm.?, Norrl. Jtl. r.

* E. microphylla Sw.; läpp något kortare än de yttre kalkbladen.

Har släta och glest sittande blad, som ej täcka stjelken, făblommig och mera gles klase; kalkblad nästan hopslutna; blommor rödaktigt gröna; fruktämne stundom glatt.

Skuggrika ställen, mycket r.; Göt. Öland mellan Ekerum och Halltorp (Sjöstrand).

B. Med rotskott, utgående från en lång rotstock; läpp med utböjd och trubbig mellanflik och 2 aflånga sidoflikar; fruktämne smalt och aflangt.

3. E. palustris (L.) Crantz, Kärr-zymbel; läpp lika lång som de öfriga kalkbladen samt med rundadt hjertlik och krusig mellanflik; blad lansettlika. 3.

$0 \mathrm{mkr}$. fotshög med större blommor, glest sittande i ensidigt ax ; fruktämne finhårigt; de öfre skärmbladen kortare än fruktämnet; de yttre kalkbladen utvändigt grönaktiga, inuti jemte de inre kalkbladen hvita; läpp hvit och rödstrimmig med en fyrsidig hvitgul buckla.

Kärr, helst pà silur. form.; Göt. r.: Öl. a. Gotl. t. a. Sk. Hall. spr. Ög. spr. (på silur. form. t. a.), Norrl. Gestr. r.

\section{Cephalanthéra. Syssla.}

1. C. rubra (L.) Rich.; läpp lika lång som de öfriga kalkbladen; alla kalkblad spetsiga; fruktämne finludet. 3 .

Inemot 2 fot hög och bladrik med fă, tumsvida, rosenröda och n. upprätta blommor; blad smalt lansettlika spetsade, långa och omkr. fingerbreda, starkt nerviga och n. tvåsidiga; blomskärmar bladlika, längre än fruktämnet. Upl. r.

Skogsängar; Göt. Gotl. t. r. Smål, Ög. Dalsl. r., Sv. Söd.

2. C. Xiphophyllum (L. fil.) Rchb.; tre yttre kalkblad spetsiga, två inre trubbiga, längre än den trubbiga läppen; fruktämne glatt. $2-3$.

Ungefär lika hög som föreg. art med något mindre och vanl. hvita blommor; blad lansettlika spetsade och n. tvåsidigt stälda; blomskärmar vanl. mycket korta. C. ensifólia Rich.? 
Skogsängar och lundar nära hafvet; Göt. Sk. Blek. Öl. r. Gotl. spr., Sv. Upl. t. r.

3. C. grandiflóra (L.) Bab.; alla kalkblad trubbiga; läpp

kortare än de inre kalkbladen; fruktämne glatt. 2-3.

Liknar föreg. art, men har bredare, n. aflånga och kortspetsade blad; blomskärmar ofta längre än fruktämnet.

Ängar, mycket r.; Göt. Gotl. i Stånga s:n vid slottsruinen.

\section{Listéra. Tveblad.}

1. L. ováta (L.) R. Br.; de yttre kalkbladen ovala och n. hjelmlikt hopstående; läpp klufven i 2 trubbiga flikar; blad ovala, sittande nedom stjelkens midt. 2, 3.

1-2 fot hög och storbladig med gröngula blommor i lång och smal klase.

Fuktiga ängar; Göt. t. a.: Småll. Hall. Boh. Vg. spr. Blek. "t. r"., Sv. spr.: Söd. Upl. t. a. Vestm. t. r., Norrl. spr.: Hels.Ång. r. Vb. 0.

2. L. cordáta (L.) R. Br; alla kalkbladen utstående, de yttre lansettlika; läpp med 2 större, spetsade flikar och 2 mindre; blad rundade och hjertlika, sittande vid stjelkens midt. 2,3 .

Lägre och spensligare än föreg. art med n. trådsmal stjelk och smärre blad; blommor brungröna i kort klase.

Skogsmark bland mossa h. o. d., troligen i alla landskap.

\section{Goodyéra. Knärot.}

1. G. repens (L.) R. Br.; de yttre kalkbladen utstående, de inre hopstående; de nedre bladen närsittande, ovala och långskaftade; blommor småludna. 3 .

Omkr. $1 / 2$ fot hög med krypande och skottalstrande rotstock; de öfre bladen jemnbreda, spetsiga och tilltryckta; blomskärmar längre än fruktämnet.

Skogar, bland mossa; Göt. r.: Ög. Smål. Vg. Dalsl. spr. Boh.?, Sv. spr., Norrl. Gestr. Hels. spr. Ång. Jtl. r., Lpl. r.

434. Neóttia. Fogelborot.

1. N. nidus avis (L.) Rich.; kalkblad n. hjelmlikt hopstående, ovala och trubbiga; läpp med omvändt äggrunda och utspärrade flikar. 2 .

Omkr. fotshög, teml. grof och styf; blommor utstående; skärmblad mycket kortare än fruktämnet.

Lundar och skogar; Göt. r.: Gotl. Öl. Sk. spr. Hall. Ög. t. r., Sv. r.: Söd. Upl. spr. Dal. 0, Norrl. Gestr. r.

\section{Maláxis. Myggblomma.}

A. Läpp kortare än de yttre kalkbladen; könpelare mycket kort; ax rikblommigt och utdraget.

1. M. paludósa (L.) Sw.; blad fånerviga, spadlika--aflånga och trubbiga; läpp äggrund och spetsig; stängel 5-kantig. 3. 
3-5 tum hög och spenslig med små (ungefär nagelstora) och ljusgröna blad och gröngula, mycket små blommor.

Ijupa kärr bland hvitmossa; Lpl. r., Norrl. Vb. Ång. r. Med.-Gestr. spr., Sv. t. r.: Upl. Söd. spr., Göt. r.: Ög. Blek. spr. Smål. t. r. Öl. 0.

2. M. monophyllos (L.) Sw.; blad mångnervigt, vanligen ensamt och ovalt; läpp äggrund eller nästan rundad med utdragen spets; stängel 3-kantig. 2, 3 .

5-8 tum hög och spenslig med något smärre och mera gulaktiga blommor än hos föreg. art; blad 1-2, blekgröna och lăngslidade.

Kärr, helst på silur. formation; Norrl. Jtl. t. r. Ång. Med. Gestr. r., Sv. r.: Ner. Verml, 0, Göt. Vg. Smål. Ög. Gotl. r.

B. Läpp lika lång som de öfriga kalkbladen; könpelare förlängd; ax fåblommigt.

3. M. Loesélii (L.) Sw.; blad aflånga-lansettlika, på längden veckade; läpp aflång och trubbad; stängel 3kantig. 2, 3.

4-5 tum hög och gröfre än de föreg. arterna med dubbelt större och gulaktiga blommor; blad ljusgröna, nästan spetsiga.

Dyiga kärr, helst på silur. formation; Göt. Gotl. t. r. Öl. Sk. Ög. r., Sv. Upl. r., Norrl. Gestr. r.

436. Caly'pso. Norna, Nordisk Toffelblomma.

1. C. boreális (Willd.) Salisb.; blad äggrundt, kortspetsadt och rutigt nätådrigt; läpp brunfläckig med gulaktigt rosettlikt bihang; de öfriga kalkbladen likformiga, n. syllika och rosenröda. 1 .

Omkr. fingerhög med öppen, af ett smalt rosenrödt skärmblad stödd blomma.

Solöppna ängsbackar, helst nära större elfvar; Lpl. och Norrl.: spr. i Pite, Lule och Kalix ådalar.

\section{Corallorhíza. Korallrot.}

1. C. innáta R. Br.; kalkblad hopstående, jemnbredt aflånga och spetsiga; ax fảblommigt. 2, 3 .

Omkr. $1 / 2$ fot hög med fast stängel.

Skogar; Lpl. Norrt. Sv. spr., Göt.r.: Dalsl. Vg. Smål. Ög. spr. 138. Epipógium. Skogsfrublomma.

1. E. Gmelíni Rich.; kalkblad utstående, de yttre jemnbreda, de inre jemnbredt lansettlika. 3 .

Omkr. $1 / 2$ fot hög, vek och spenslig; parasit.

Skuggrika ställen i skogar, ganska r.; Lpl.; Norrl. (utom Vb. och Herj.); Sv.; Göt. Ög. Sk. (fordom i Smål.).

\section{Ordn. DIANDRIA.}

439. Cypripédium. Toffelblomma, Gökskor, Guckuskor. 1. C. Calcéolus L.; blad ovala, spetsiga och stjelkomfattande; blomma lutande, stödd af ett bladlikt skärmblad; kalkblad utstående, något längre än läppen. 2, 3 . 
1-11/2 fot hög med vanl. ljusgröna och nảgot sträfva blad.

Lundar och ängar, helst på silur. formation; Lpl. r., Norrl. Jtl. t. r. Ång. Hels. Gestr. r., Sv. t. r.: Upl. spr. Söả. 0, Göt. Gotl. r. Öl. Vg. t. r. Ög. mångenst. på silur. form.

\section{Klassen. MONOECIA.}

\section{Ordn. MONANDRIA.}

\section{Pinus. Tall, Fur.}

1. P. silvestris L.; kottar nedböjda; barr långa, något blågröna. 1.

Med utstående grenar och pyramidlik krona; hanhängen små, aflånga och tätt gyttrade nedanför somliga årsskott; kottar sittande i spetsen af andra årsskott.

Skogar, allmän.

\section{A'bies. Gran.}

1. A. excelsa De C.; kottar hängande; barr korta och gröna. 1.

Med rak stam, utspärrade eller hängande grenar och pyramidlik krona; hanhängen skaftade och spridda längs efter grenarne; kottar enstaka i spetsen af grenarne och i början röda; smågrenar ofta platta, då barren äro tvåsidigt stälda.

Skogar, allmän.

- viminális, Slokgran; grenar långa, fina och hängande med längre och rundtomkring stälda barr.

Förekommer h. o. d., vanligen enstaka träd.

\section{Callítriche.}

A. Blommor med 2 hvita skärmblad nedtill.

Blad nedtill smalare, de öfre vanligen rosettlikt gyttrade, stundom felslående. Frukterna utvecklas under våren och sommaren.

a. Stift lika långa som de mogna frukterna.

1. C. stagnális Scop.; alla bladen likformiga, breda 3-5nerviga; skärmblad qvarsittande; stift qvarsittande och bågformigt tillbakaböjda; frukter runda med vingade kanter, mogna blekgula. 1-3.

$1 / 4-1$ fot lăng och ljusgrön; blad runda eller spadlika, tvärt afsmalnande till skaft; skärmblad halfmånlika.

Stillastaende grundt vatten; Göt. t. r.: Sk. t. a. Hall. spr. Ö1.?, Sv. Söd. Upl. r. Vestm. spr., Norrl.?, Lpl. r.

2. C. verna Kütz.; de öfre gyttrade bladen omvändt äggrunda eller spadlika, flernerviga; de nedre bladen smala, jemnbreda och ennerviga; skärmblad qvarsittande; stift korta, af frukternas längd, affallande och n. upprätta; frukter mycket små, ovala med smalt vingade kanter, mogna svartaktiga. $1-3$. 
Vanligen mycket liten, ett par tum eller stundom $1 / 2$ fot lång, vanl. ljusgrön; bladrosetterna felslå ofta, då de öfre bladen blifva năgot bredare än de nedre; alla blad korta; skärmblad halfmånlika.

Kärr och andra fuktiga ställen, troligen $t$. a.

b. Stift längre än de mogna frukterna.

3. C. polymorpha Lönnr.; blad som hos föreg. art; skärmblad qvarsittande; stift flera gånger längre än frukterna, qvarsittande och slutl. utspärrade; frukter bredare än hos föreg. art, runda med ovingade kanter, mogna ljusgrå. $1-3$.

Omkr. fotslång och vanl. ljusgrön, fullt utvecklad i stillastående vatten, i rinnande utan bladrosetter och ej fruktbärande; skärmblad skärformiga.

Stillastående eller rinnande vatten, troligen allmän.

4. C. hamuláta Kütz.; blad som hos föreg. art, men de nedre i spetsen tvåuddiga; skärmblad vissnade vid fruktmognaden; stift föga längre än frukterna; qvarsittande och slutl. nedböjda; frukter som hos föreg. art, men mogna mörkgrå. 1-3.

0mkr. 2 fot lång och vanl. mörkgrön, sällan med bladrosetter; de smala bladen ofta tumslånga; skärmblad halfcirkelformigt böjda om hvarandra.

Kärr och bäckar; Göt. t. r., Sv. Upl. Vestm. r.

B. Blommor utan skärmblad; alla blad jemnbreda, nedtill ej smalare. Frukterna utvecklas under hösten.

5. C. autumnális L.; blad närmade till hvarandra och ennerviga; stift af frukternas längd, qvarsittande och slutl. nedböjda; frukter mycket större än hos föreg. arter, n. runda och bredt vingade, mogna mörkgrå. 3,4 .

Omkr. 1/2 fot lång och mörkgrön, stundom fotslång, alltid nedsänkt under vattnet.

Åar och sjöar spr.: Gotl. r. Öl.?

\section{Zannichéllia.}

1. Z. pedicelláta Fr.; nötter tydligt skaftude, med taggigt tandad rygg; stift nästan af nötens längd. 3 .

Omkr. 1-2 fot lång och ljusgrön med $n$. hårfin stjelk; nötter nästan halfmånlika, men föga krökta, oftast blott 2 tillsammans. Hafsvikar, helst i Östersjön; Göt. Sk. Gotl. Öl. spr. Blek.r.? Smål. spr. Ög. t. a., Sv. spr., Norrl. Gestr. Hels. Ång. r.

2. Z. polycarpa Nolte; nötter oskaftade med slät eller stundom tandad rygg; stift omkr. $1 / 3$ af nötens längd. 3 .

Lik föreg. art, men mörkgrön med năgot smärre nötter.

Helst i hafvet, sällan i sött vatten; Göt. r.: Smål. spr. Boh.? Dalsl. 0, Sv. Söd. Upl. Vestm. r., Norrl. Gestr. Hels. r. 
3. Z. major Bönn.; nötter oskaftade med tagglikt tandad rygg; stift n. lika långt som nöten. 3 .

Något gröfre än de föreg. med ungefär dubbelt så stora, stundom bågböjda nötter.

Hafsvikar; Göt. spr.: Sk. a. Hall. Boh. r. Ög. 0.

444. Euphórbia. Räfmjölksört, Törel.

A. Allmänna blomskaft (af 1:sta ordningen) 3-5; pålrot enårig.

1. E. Helioscopía L.; blad omvändt äggrunda, upptill finsaigade, blott de nedersta afsmalnande till skaft; skärmblad omvändt äggrunda. 3,4 .

Omkring $1 / 2$ fot hög. Allmänna blomskaft af 1 :sta ordningen vanligen 5 ; blad stundom vigglika; karpeller släta och ovingade; skärmblad stundom gula.

Ruderatväxt och ogräs, helst i trädgårdar; Gröt.Sv. a., Norrt. spr.: Ång. r. Vb. 0.

2. E. Peplus L.; blad omvändt äggrunda och helbräddade; stjelkblad skaftade; skärmblad bredt äggrunda. 3,4 .

Något spädare än föreg. art. Allmänna blomskaft omkr. 3; karpeller med 2 smala vingar: skärmblad ljusgröna.

Ruderatväxt och ogräs; Göt. a.: inre Smål. Vg. Boh, t. r. Dalsl. 0, Sv. Söd. Upl. t. a. Vestm. Ner. spr. (Verml. tillfällig), Norrl. Gestr. spr. (Ång. tillfällig).

3. E. exígua L.; blad helbrëddade och oskaftade, de nedre n. jemnbreda. $3,4$.

2-6 tum hög och späd, enkel eller grenig; allmänna svepets blad jemte de öfre stjelkbladen äggrundt - hjertlikt lansettlika spetsiga; stjelkblad omkr. liniebreda, trubbiga eller spetsiga; karpeller n. släta med hvass och ovingad köl; skärmblad ljusgröna.

Ruderatväxt och ogräs (helst bland pepparrot), någon gång förek. på hafsstränder; Göt. Sk. Gotl. r., Sv. Upl. Vestm. r., Norrl. Hels. Med. r.

B. Allmänna blomskaft talrika; stjelkblad smala; rotstock krypande. Blad oskaftade. Skärmblad under blomningen gula.

a. Skärmblad med borstlik udd.

4. E. Esúla L:; blad helbräddade eller otydligt fintandade, något glest sittande och bredare än stjelken; de öfre skärmbladen bredt hjertlika. 2.

Inemot 2 fot hög; blad lansettlika; karpeller n. släta.

Ruderatväxt och ogräs; Gät. Hall. Sk.-Ög. Öl.r., Sv. r: Ner. t. r. Verml. 0, Norrl. Gestr. Hels. r.

b. Skärmblad utan udd.

5. E. Cyparíssias L.; blad helbräddade, tätt sittande och något smalare än stjelken, särdeles på de blomlösa. grenarne; de öfre skärmbladen njurlika. $2,3$. 
$1 / 2-1$ fot hög; blad n. jemnbreda, på de finare grenarne borstlika; karpelier knottriga; de flesta grenarne blomlösa.

Ruderatväxt och ogräs, stundom på kyrkogårdar; Göt. Vg. Hall. r. Sk. t. r. Smål. spr. Ög. t. r. Gotl. r., Sv. Söd. Upl. r. 6. E. palustris L., Kärrtörel; blad helbräddade, stundom glest sittande och ofta bredare än stjelken; skärmblad ovala-äggrunda. $2,3$.

Omkr. 3-4 fot hög med tjock stjelk och bredt lansettlika blad; karpeller knottriga, större än hos de föreg. arterna. Liknar $\mathbb{E}$. Esula, men är större, gröfre och mera grenig.

Sumpiga hafsstränder; Göt. Gotl. Öl. Boh. spr.

\section{Ordn. TRIANDRIA.}

\section{Carex. Starr.}

A. Ax ensamt och enkelt utan skärmblad. Märken 2. Monostáchya distigmática.

Tvåbyggare eller med hanblommor i axets topp. Blad $n$. borstlika. Rot tufvig. 1. dióica. 2. pulicáris. 3. capităta. 4. nảrdina.

B. Ax ensamt och enkelt utan skärmblad. Märken 3. Monostáchya tristigmátice.

Med hanblommor i axets topp. Blad platta eller borstlika. Rotstock krypaude. 5. paucifióra. 6. microglóchin. 7. rupestris. 8. obtusảta.

C. Ax flera (hos C. chordorhiza och C. incurva stundom ensamt); märken 2. Polystáchyœ distigmática.

a. Somliga ax upptill försedda med hanblommor*) (androgynska), de offriga enkönade. Axsamling vanligen hopträngd till ett sammansatt ax; småax teml. små och vanligen korta, vanligen utan skärmblad eller med korta horstlika skärmblad. Blad platta. Homostáchye acroarrhénce. 1. Rotstock lång och krypande. Fruktgömme med spröt. Småax hopträngda. Chordorhizea. 9. chordorhiza. 10. incurva. 11. disticha. 12. arenária. 13. Schrebéri.

2. Rot tågig. Fruktgömme med (utdraget) spröt. Småax mångblommiga, vanl. hopträngda. Muricata. 14. teretiúscula. 15. paradóxa. 16. paniculáta. 17. vulpina. 18. muricáta.

3. Rot tågig. Fruktgömme utan spröt. Småax fåblommiga och glest sittande. Erostráta. 19. tenella.

b. Somliga ax nedtill försedda med hanblommor (androgynska), de öfriga enkönade. Axsamling vanligen hopträngd till ett sammansatt ax (de nedre eller alla småaxen stundom glest sittande); småax som i föreg. afdelning (dock hos $C$. remota med långa skärmblad). Blad platta, sällan n. borstlika. Rotstock vanl. föga utbildad (utom hos $C$. remota). Homostachya hyparrhéna.

*) Hanblommorna igenkännas på de till utseendet tomma axfjällen (som blott innehălla ståndare). C. Schreberi har stundom hanblommor i nedre delen af småaxen. 
1. Småax fåblommiga och blekgröna; fruktgömmen utan hinnkant och utan spröt, slutligen utspärrade eller utstående. Lolicicea. 20. loliácea. 21. tenuiflóra.

2. Småax vanl. flerblommiga, gröna eller gulaktiga; fruktgömmen utan hinnkant, men med kort spröt, slutl. upprätta eller föga utstảende. Canescentes. 22. remóta. 23. canescens. 24. microstáchya. 25. norvégica.

3. Småax flerblommiga, slutl. bruna; fruktgömmen utan hinnkant, men med tydligt spröt, slutl.n. upprätta. Lagopínce. 26. elongáta. 27. glareósa. 28. heleonastes. 29. lagopina.

4. Småax flerblommiga, länge gröna, slutl. brunaktiga; fruktgömmen upptill smalt hinnkantade, med utdraget spröt, slutl. utspärrade. Echináta. 30. echináta.

5. Småax flerblommiga och bruna; fruktgömmen rundtomkring bredt hinnkantade, med utdraget spröt, slutl. upprätta eller föga utstående. Leporínce. ${ }^{*}$ ) 31. leporina.

c. Alla småax utom toppaxet endast med honblommor; toppax antingen enkönadt eller med hanblommor antingen nedtill eller upptill. Axsamling hopträngd med n. jemnhöga, små och teml. korta småax. Blad platta, småningom öfvergående till slidbärande skärmblad. Fruktgömme med otydligt spröt. Bicolóres. 32. bicolor.

d. Smàax alltid åtskilda, ej sammanträngda, nästan allitid långa, täta rikblommiga och enkönade, de ötre med endast hanblommor (sällan med honblommor nedtill). Blad platta, småningom öfvergående till nästan slidlösa skärmblad (som sällan felslå). Fruktgömme med kort spröt. Heterostáchyæe distigmátice **).

1. Honaxfjäll med icke utlöpande medelnerv; endast de nedre af honaxen stundom skaftade. Strån vanligen tufvade. Caspitósa. 33. rígida. 34. acúta. 35. stricta. 36. cæspitósa. 37. vulgaris. 38. aquátilis.

2. Honaxfjäll med utlöpande, grön medelnerv och med 2 sidonerver; alla småax långt skaftade och vanl. hängande. Strån föga tufvade. Marítima. 39. maritima.

3. Honaxfjäll med föga utlöpande medelnerv och med 2 sidonerver; alla småax vanligen skaftade och upprätta. Strån föga eller icke tufvade. Salínce. 40. salína.

D. Ax flera; märken 3. Polystáchya tristigmática. (C. paludosa och C. vesicaria * saxatilis hafva stundom blott 2 märken).

Hos de flesta arterna har toppaxet vanligen endast hanblommor (sällan med honblommor redtill, då de öfriga axen äro enkönade); de nedre hafva endast honblommor. Hos 3 arter $(C$. atrata, misandra och Buxbaumii) är toppaxet vanligen akrogynt d. v. s. med honblommor i toppen: stundom har det hos dessa blott honblommor. Samma förhållande kan inträffa hos andra arter, t. ex. C. irrigua, flava, Oederi och Pseudo-Cyperus.

*) Till denna afdelning skulle äfven en form af C. Schreberi kunna räknas.

**) Hit kunna former af C. paludosa och C. vesicaria räknas. 
a. Honax med utdragna skaft (dock hos C. Buxbaumii och C. atrata stundom alla eller de flesta oskaftade).

Anm. Till denna afdelning skulle äfven kunna hänföras C. distans $\mathrm{m}$. fl.

1. Fruktgömme sträfprickigt nch trubbigt samt med ett kort spröt; skärmblad utan slidor; hanax vanl. 1, stundom akrogynt; honax tätblommiga, stundom oskaftade. Strå vanl. äfven upptill bladigt. Trachycarpœ. 41. gláuca. 42. Buxbáumii. 43. atrảta.

2. Fruktgömme glatt, afsmalnande till ett utdraget spröt; skärmblad med utdragna slidor; hanax 1; honax mer eller mindre utdragna, stundom glesblommiga. Strå äfven upptill bladigt. Leiocarpe vaginatce longirostrate. 44. ustuláta. 45. misandra. 46. capilláris. 47. silvática.

3. Fruktgömme (slutl. nedböjdt) tätnervigt glatt, afsmalnande till ett utdraget spröt; skärmblad utan slidor; hanax 1, stundom akrogynt; honax utdragna tätblommiga. Strå äfven upptill bladigt. Cyperoidea (Leiocarpa evagináta longirostrate). 48. Pséudo-Cypérus.

4. Fruktgömme glatt, upptill trubbigt, med kort spröt; skärmblad utan eller med korta slidor; hanax 1, sällan akrogynt; honax korta och vanl. tätblommiga. Strå ofta blott nedtill bladigt. Leiocarpce evaginatce brevirostrate. 49. pallescens. 50. limósa. 51. irrigua. 52. rariflóra.

5. Fruktgörmme glatt, upptill trubbigt, med vanl. kort spröt; skärmblad med utdragna slidor; hanax 1; honax utdragna, stundom något glesblommiga. Strå vanl. blott nedtill bladigt. Panicere (Leiocarpre vaginatce brevirostratce). 53. laxa. 54. lívida. 55. panicea.

6. Fruktgömme ludet och upptill trubbigt, med kort spröt; skärmblad med utdragna slidor; hanax 1, stundom felslående; honax utdragna, smala och glesblommiga. Strå blott nedtill bladigt. Lasiocarpa (Digitatc). 56. digitáta.

b. Det öfversta honaxet oskaftadt (eller stundom med mycket kort skaft hos C. hirta, vesicaria, ampullacea, distans, punctata och speirostachya).

Anm. Stundom utbildas blott ett honax (t. ex. hos C. precox) som kan vara skaftadt.

1. Fruktgömme glatt, med năgot utdraget spröt; skärmblad mycket korta och borstlika med korta slidor; hanax 1; honax korta tjocka, något glesa och fåblommiga. Strå blott nedtill bladigt. Pedáte. 57. pedáta.

2. Fruktgömme ludet, med kort spröt; skärmblad utan (eller hos C. precox med korta) slidor; hanax 1; honax korta, tjocka och tätblommiga. Strå blott nedtill bladigt. IMontana*). 58. præcox. 59. ericetórum. 60. pilulifera. 61. montána. 62. globuláris. 63. tomentósa.

3. Fruktgömme glatt, med utdraget spröt; skärmblad utdragna och bladlika med slidor (dock mycket korta sli-

*) C. Buxbaumii, som kunde räknas hit, skiljes lätt genom stråslidorna m. m. 
dor hos C. extensa samt stundom äfven hos C. flava och Oederi); hanax 1, någongång akrogynt; honax korta, tjocka och rikblommiga (hos C. distans, punctata och speirostachya något utdragna). Strå vanl. äfven upptill bladigt. Fulvellœ. 64. extensa. 65. Oedéri. 66. flava. 67. speirostáchya. 68. distans. 69. punctáta. 4. Fruktgömme glatt med vanl. utdraget spröt; skärmblad utan slidor; hanax vanligen flera; honax tjocka, tätblommiga och vanl. utdragna. Stră bladigt, äfven upptill. (Stora och höga växter). Vesicária*). 70. ampullácea. 71. Iævirostris. 72. vesicária. 73. ripária. 74. paludósa.

5. Fruktgömme ludet med utdraget spröt; skärmblad med eller utan slidor; hanax flera; honax 1jocka, tätblommiga och utdragna. Strå bladigt äfven upptill. Hirta. 75. hirta. 76. evolúta. 77. filliformis.

1. C. dióica L.; honax n. jemntjockt och tätblommigt; fruktgömme äggformigt, tjockast nedtill; honaxfjäll äggrunda, qvarsittande; strå vanl. sträft. 2 .

$0 \mathrm{mkr} .1 / 2$ fot hög och löst tufvad; vanligen tvåbyggare, sällan sambyggare; fruktgömmen vanl. utspärrade; ax bruna.

Kärrängar, teml. allmän.

- paralléla (Somf.); strå n. slätt; fruktgömmen föga utstående.

I fjellen; Lpl. h. o. d.

2. C. pulicáris L.; honblommor slutl. glesa; fruktgömme aflångt, nedåt afsmalnande; honaxfjäll äggrunda, snart affallande. 2 .

Lika hög som föreg. och tätt tufvad, med kölade blad; alltid sambyggare; strå slätt : fruktgömmen slutl. nedböjda; ax bruna.

Kärrängar; Göt. spr.: Gotl. Ög. t. a. Boh. r., Sv. spr.: Vestm. Verml. r. Dal. 0, Norrl. Gestr. r.

3. C. capitáta L.; honax n. rundt och tätblommigt; fruktgömme äggformigt, tjockast nedtill; honaxfjäll n. runda, qvarsittande. 2 .

$1 / 2-1$ fot hög och tufvad med n. borstlika, rännformiga blad och brungrönt ax; honblommor teml. talrika, hanblommor få; alltid sambyggare; strå slätt; fruktgömmen utstående.

Kärr i fjellen; Lpl. mångenst., Nor•rl. Jtl. Herj. mångenst., $S v$. Dal. $\mathrm{r}$.

4. C. nárdina Fr.; honax ovalt och tätblommigt; fruktgömme n. äggformigt, nedtill något afsmalnande; honaxfjäll äggrunda, qvarsittande. 2.

Omkr. 2 tum hög och tätt tufvad med borstlika blad, som ofta öfverskjuta strået, och ljusbruna ax; hanblommor fă och otydliga; honblommor få; n. alltid sambyggare; strå slätt; fruktgömmen upprätta. Liknar en Kobresia.

I fjellregionen, mycket r.; Ipl. Lul. Lpm., t. ex. vid Virihaure.

*) En form af C. hirta skulle äfven kunna räknas hit. 
5. C. pauciflóra Lightf.; honblommor något åtskilda; fruktgömme slutl. nedböjdt, lansettlikt; stift syllikt och långt utskjutande ur fruktgömmet; honaxfjäll lansettlika, snart affallande. 2,3 .

Omkr. $1 / 2$ fot hög och föga tufvad, med blekgröna eller $\mathrm{n}$. hvitgula ax; hanblommor 1-3, honblommor $2-5$.

Torfkärr: Lpl. a., Norrl. t. a., Sv. spr.: Verml. a. Söd. r. Göt. spr.: Dalsl. a. Blek. r. Gotl. Öl. 0.

6. C. microglóchin Wahlenb.; honblommor något åtskilda; fruktgömme slutl. nedböjdt, lansettlikt; stift trådlikt och föga utskjutande; frukt stödd af ett syllikt borst, som långt utskjuter ur fruktgömmet; honaxfjäll lansettlika, snart affallande; blad borstlika. 2.

Liknar mycket förez. art, men är lägre och mera tufvad; hanblommor umkr. 5, honblommor 4-10.

I fjellen ofvan barrskogsregionen, r.; Lpl., Norrl. Jtl. Herj.

7. C. rupestris All.; honax n. jemntjockt eller aflångt och teml. tätblommigt; fruktgömme upprätt, omvändt äggformigt med kort spröt; honaxfjäll n. ovala, qvarsittande och längre än fruktgömmet; blad platta kölade. 2.

Omkr. ${ }^{1 / 2}$ fot hög med teml tjock rotstock, omkr. liniebreda blad och bruna ax; blommor teml. talrika; strå, trekantigt.

Hård, stenig mark i fjellen, helst ofvan barrskogsregionen; Lpl., Norrl. Jti. Herj. mångenst.

8. C. obtusáta Liljebl.; honax n. jemntjockt och tätblommigt; fruktgömme n. upprätt och äggformigt med mycket kort spröt; honaxfjäll äggrunda-aflånga, qvarsittande och kortare än fruktgömmet; blad $n$. borstlika och rännformiga. 2.

Lik föreg. men med finare strån och mycket lång rotstock. Anses af $\mathrm{F}$. Areschoug vara en form af $C$. supina Wahlenb.

Sandfält; Göt. Öland spr., t. ex. vid Runsten.

9. C. chordorhíza Ehrh.; alla småax bredt ovala och tätt gyttrade utan skärmblad; fruktgömme n. utstående, ovalt med vanl. kort spröt; honaxfjäll n. äggrunda, lika långa som fruktgömmet. 2, 3.

Omkr. fotshög med smal rotstock, mycket smala blad och bruna, fåblommiga ax; fruktgömme utan hinnkant; de öfre stråbladen mycket korta. Axsamlingen Jiknar stundom ett enkelt ax.

Kärr; Lpl. a., Norrl. t. a., Sv. spr.: Verml. t. a., Göt. Dalsl. t. a. Vg. inre Smål. Ög. spr. Kalmarl. Sk. Gotl. r.

10. C. incurva Lightf.; småax n. rundade och tätt gyttrade utan skärmblad; fruktgömme utstående eller nedböjdt, bredt äggformigt med vanl. kort spröt; honaxfjäll $n$. äggrunda, kortare än fruktgömmet. $2,3$. 
Liknar föreg., men är vanl. blott ett par tum, sällan $1 / 2$ fot hög med mera rikblommig och hufvudlik, n. rund eller bredt äggformig axsamling och tjockare strån; blad ofta längre än strået.

Ängsmark på hafsstränder r.; Göt. Boh.—Sk.

11. C. dísticha Huds.; småax äggformiga och vanl. något âtskilda; det nedersta skärmbladet utdraget; fruktgömme n. upprätt, ovalt med n. utdraget spröt; honaxfjäll äggrunda. 2.

1--2 fot hög med tjock rotstock, något breda blad och bruna rikblommiga ax; fruktgömme med smal hinnkant. Axsamlingen är stundom något hopgyttrad.

Fuktiga ängar; Göt. Sv. t. a.: Dalsl.—Dal. t. r., Norrl. Gestr. t. a. Hels. spr.

12. C. arenária L., Sandstarr; småax äggformiga och mer eller mindre åtskilda, de nedersta med teml. utdragna skärmblad; fruktgömme n. utstående, äggrundt lansettlikt med utdraget spröt; honaxfjäll lansettlika långspetsade. 2, 3 .

Omkr. $1 / 2$ fot hög med mycket lång och tjock rotstock, något breda blad och ljusbruna, rikblommiga ax; fruktgömme upptill med bred hinnkant. De öfversta småaxen hafva vanligen endast hanblommor.

Sandiga stränder; Göt. Boh. r. Hall. Sk. a. Blek. Gotl. spr. Öl. t. a. Smål. r. (vid Nissan och i skärgården) Ög. spr. vid Vettern, Vg. r. vid Venern, Sv. i skärgården r. Verml.?

13. C. Schrebéri Schrank; småax jemnbredt lansettlikaaflìnga och tätt sittande; skärmblad korta eller inga; eljest som föreg. art. 2, 3 .

Liknar mycket föreg. art och är föga skild, men har mörkare bruna ax och bladen föga bredare än strået. Stundom hafva småaxen hanblommor nedtil.

Sandiga ställen, ganska r.; Göt. Öl. Blek.

14. C. teretiúscula Good.; fruktgömme på båda sidor kullrigt och $\mathrm{n}$. nervlöst, tvärt afsmalnande till spröt; stra trubbkantigt med kullriga sidor; blad smala. 2, 3.

1-2 fot hög och något tufvad med kort, teml. smalt och brunt ax; småax äggformiga och ej sammansatta; fruktgömme bredt äggformigt och n. upprätt; honaxfjäll äggrunda; stråets nedersta slidor stundom upplösande sig i trådar.

Kärr och stränder; Göt. spr., Sv. t. a.: Verml. spr. Dal. r., Norrl. t. r., Lpl. r.

- crássior; med tjockare ax och något bredare blad. Teml. r., t. ex. Ög. Gestr.; trol. äfven annorstädes.

15. C. paradóxa Willd.; fruktgömme på båda sidor kullrigt och nervigt, tvärt afsmalnande till spröt; strå trubbkantigt med kullriga sidor; blad smala. 1, 2.

Högre och gröfre än föreg. art och tätt tufvad, med utdraget och brunt ax; småax äggformiga och vanligen sammansatta; 
fruktgömme bredt äggformigt och något utstående; honaxfjäll äggrunda, lika långa som fruktgömmet; stråets nedersta slidor upplösande sig i svarta trådar.

Kärr och stränder, helst på silur. formation: Göt. t. r.: Ög. spr. (p̊̊ silur. form.) Hall. Dalsl. 0, Sv. Söd. Up]. spr. Vestm. t. r. Ner. Dal. r., Norrl. Gestr. Med. Jtl. r.

16. C. paniculáta L.; fruktgömme på ena sidan platt, på den andra kullrigt, otydligt nervigt och tvärt afsmalnande till spröt; strå hvasskantigt med platta sidor; blad breda. 1, 2.

Omkr. 2-3 fot hög och liknande föreg. art, men vanl. med mera sammansatt ax, äggformigt fruktgömme, bredt hinnkantade honaxfjäll samt de nedersta stråslidorna fjällika och svarta, ej upplösta $\mathrm{i}$ trådar.

Kärr och sjöar, helst på silur. formation; Göt. r.: Sk. Öl.t. r. Gotl. Hall. Dalsl. 0, Sv. Upl. r.

17. C. vulpína L., Räfstarr; fruktgömme nervigt, på ena sidan platt, på den andra kullrigt, smainingom afsmalnande till spröt; strå hvasskantigt med rännformiga. sidor; blad breda. 2,3 .

Omkr. 2 fot hög, mycket grof och tufvad, med tjockt, utdraget och brunaktigt, sällan năgot grönaktigt ax; småax äggformiga; fruktgömme större än hos le 3 föreg. arterna, äggrundt lansettlikt och slutl. utstående; honaxfjäll äggrrunda, med smal hinnkant; stråets nedersta slidor upplösande sig i trådar.

Fukt. ängar, helst i slättbygder; Göt. t. a.: Vg. Boh. spr. Dalsl. r., Sv. spr.: Ner. t. a. Verml. Dal. r.

18. C. muricáta L.; fruktgömme blott undertill siagt nervigt, på ena sidan platt och på den andra kullrigt, småningom afsmalnande till spröt; strå hvasskantigt med platta sidor; blad teml. breda. 2, 3.

Vanligen lägre än föreg. art och ej så grof, med kortare och vanligen grönbrunt ax; småax korta och 11 . runda; fruktgömmen (lika stora som hos föreg. art) äggformiga och slutl. utspärrade; honaxfjäll äggrunda, stundom langspetsade, med bred hinnkant; ,..stråets nedersta slidor stundom upplösande sig i trådar. Vb. 0 .

Ängar; Göt. Sv. t. a.: Boh. -Dal. spr., Norrl. spr.: Ång. r.

* C. divulsa Good.; hela växten ljusgrön; ax utdraget och slutl. lutande; de nedre småaxen teml. långt åtskilda; fruktgömmen föga utspärrade.

Lundar; Göt. r.: Ialsl. Vg. Hall. 0, Sv. Söd. Vestm. r.

19. C. tenella Schk.; honax vanl. 2-3-blommiga och n. runda utan (eller med korta borstlika) skärmblad; fruktgömme på båda sidor kullrigt, ovalt, finnervigt och n. uppräit; honaxfjäll äggrunda, något kortare än fruktgömmet. $2,3$. 
Omkr. fotshög och mycket spenslig med $n$. borstlika blad samt med kort rotstock och föga tufvad; strå hvasskantigt och sträft; hanblommor f̊a och otydliga; fruktgömmen små och $\mathrm{n}$. hvita; honaxfjäll svagt ljusbruna. Hela växten blekgrön, liknande följ. art.

Fuktiga skogsängar; Lpl. r., Norrl. Vb.-Med. spr. Hels. Gestr. r., Sv. Upl. Dal. Verml. r.

20. C. Ioliácea L.; småax runda åtskilda; fruktgömme aflångt, något kullrigt och nervigt; honaxfjäll äggrunda, trubbiga och mycket korta. 1-3.

Något öfver fotshög, spenslig, smalbladig och något tufvad; honblommor 2-7 i hvarje småax; honaxfjäll genomskinliga med grön nerv.

Fukt. skogsängar; Lpl. t. a., Norrl. spr., Sv. spr.: Vestm. t. r., Göt. Ög. spr. Smål. Hall. Dalsl. r.

21. C. tenuifóra Wahlenb.; småax rundade eller omvändt äggrunda och hopträngda utan skärmblad; fruktgömme något kullrigt och aflångt, finstrimmigt och slutl. utstående; honaxfjäll äggrunda trubbiga och föga kortare än fruktgömmet. 2, 3 .

Liknar föreg. art; strå trubbkantigt och n. slätt; honblommor 4-8 i hvarje småax; honaxfjäll genomskinliga med grön nerv.

Kärr och fuktiga skogsängar, helst i fjellen; Lpl. t. a., Norrl. Jtl. Herj. Ång. Hels. r., S $v$. Dal. Verml. r.

22. C. remóta L.; småax aflånga, de nedre lảngt âtskilda samt med mycket lainga, n. borstlika skärmblad; fruktgömme nervigt och äggformigt, pá ena sidan platt; honaxfjäll lansettlika, kortare än fruktgömmet. 3 .

2 fot hög, ljusgrön, mycket spenslig och tufvad med rotstock; småax blekgröna och fåblommiga; blad mycket smala med lảng borstlik spets; honaxfjäll spetsiga, hinnaktiga med grön nerv; toppax långt och sammansatt af flera småax.

Fuktiga ställen i lundar; Göt. r.: Sk. spr. Smål. Ög. t. r. Gotl. 0, Sv. Söd. spr. Upl. t. r. Ner. Verml. r.

23. C. canescens L.; småax slutl. ovala och åtskilda;

fruktgömme n. äggformigt, på ena sidan platt; honax-

fjäll äggrunda, något kortare än fruktgömmet. 2, 3.

Omkr. fotshög eller lägre, med teml. smala blad, och tufvad; honaxfjäll vanligen spetsiga.

a. genuina; småax flera och utdragna med talrika bonblommor; fruktgömme med föga tydligt spröt; honaxfjäll $\mathrm{n}$. helt och hållet genomskinliga och hinnaktiga; blad blågröna eller grågröna, omkr. liniebreda.

Fuktiga ställen, allmän.

b. paludósa (Fr.); småax något tjockare; fruktgömme med tydligt spröt; honaxfjäll blott i kanten genomskinliga, för öfrigt gulaktiga; blad grågröna.

Förekommer h. o. d., t. ex. Upl. Ög. 
c. subloliácea (Fr.); småax få och korta med få honblommor; fruktöommets spröt otydligt; honaxfjäll n. alldeles genomskinliga: blad blekgröna och $1 / 2$ linie breda; strå mycket spensligt. Liknar något $C$. loliacea.

I fjellen r.; Lpl.

d. vitilis (Fr.); småax flera och vanl. utdragna samt teml. tjocka; honblommor talrika; de öfre småaxen stundom korta och vanl. hopträngda; fruktgömmets spröt något utdraget; honaxfjäll genomskinliga, helt och hållet eller blott $i$ kanten; blad teml. rent gröna, omkr. liniebreda eller smalare; strå något groft.

Helst i fjellen, stundom utom fjellen; Lpl. a., Norrl. spr., Sv. Dal. Verml. spr. Vestm. r., Göt. Dalsl. Smål. r.

24. C. microstáchya Ehrh.; småax lansettlitea och tätt hopträngda; fruktgömme ovalt, på ena sidan platt; honaxfjäll äggrundt ovala, nästan lika långa som fruktgömmet. 2,3 .

Liknar mycket föreg. art, men är vanl. något högre, blekgrön eller blăgrön; honaxfjäll vanl. trubbiga och föga genomskinliga, gulaktiga med hinnaktig kant. Toppaxet är vanl. olikformigt med de öfriga småaxen, jemnbredt och med få honblommor; blad smala, af omkr. ${ }^{1 / 2}$ linies bredd.

Gräsrika kärr; Lpl. r., Norrl..r.: Jtl. Herj.? Gestr. 0, Sv. r.: Vestm. spr. Verml. 0, Göt. Vg. Ög. Smål. Sk. r.

- hélvola (Blytt); alla axen vanl. n. likformiga; toppax vanl. med talrika honblommor; blad omkr. liniebreda.

Kärr r.; Lpl., Norrl. Vb. Herj., Sv. Upl. Söd., Göt. Smål. Boh. - Troligen äfven annorstädes.

25. C. norvégica Willd.; småax ovala och îtskitda; fruktgömme ovalt eller n. klotrundt, på båda sidor kullrigt; honaxfjäll äggrundt ovala och vanl. lika långa som fruktgömmet, sällan föga kortare. 2,3 .

Liknar mest $C$. canescens, men är gulgrön med tjockare småax; blad omkr. linielbreda; honaxfjäll vanl. trubbiga, gulaktiga och i kanten föga genomskinliga.

Kärr nära hafvet; Norrl. Vb. Ang. Gestr. r., Sv. t. r., Göt. Ög. Smål. t. r. Öl. Blek. Boh. r.

26. C. elongáta L.; småax talrika, aflånga och åtskilda; fruktgömme nervigt, aflångt-lansettlikt, på ena sidan

n. platt och på den andra svagt kullrigt; honaxfjäll

n. utan hinnkant, äggrunda och hälften kortare än fruktgömmet. 2,3 .

$2-3$ fot hög, med långa, omkr. liniebreda (eller ännu bredare) ljusgröna och sträfva blad och ljushruna ax; strå hvasskantigt och sträft; honaxfjäll vanl. trubbiga.

Fukt. ängar; Göt. t. r.: Hall. Sk. Kalmarl. spr.: Ög. t. a., Sv. spr.: Ner. t. a. Verml. Dal. t. r., Norrl. t. r.: Gestr. Hels. spr. 27. C. glareósa Wahlenb.; småax fả, ovala och hopträngda; fruktgömme svagt nervigt och äggformigt, 
på ena sidan platt och på den andra kullrigt, samt med mycket kort spröt; honaxfjäll med smal hinnkant, äggrundt ovala och lika långa som fruktgömmet. 2,3 .

Omkr. $1 / 2$ fot hög med korta, n. borstlika och icke sträfva blad och ljusbruna ax; strå trubbkantigt och slätt; honaxfjäll vanl, trubbiga.

Grusiga stränder vid Bottn...viken och Östersjön; Norrl. r.: Gestr. spr., Sv. Upl. spr., Göt. Ög. r.

28. C. heleonastes Ehrh.; småax få, ovala och hopträngda; fruktgömme n. nervlöst, äggformigt aflångt och n. trekantigt (eller på ena sidan platt och på den andra kullrigt) med något'utdraget spröt; honaxfjäll med brect hinnkant, äggrundt ovala och föga kortare än fruktgömmet. 2,3 .

Omkr. fotshög med långa, omkr. $1 / 2$ linie breda och något sträfva blad och mörkbruna ax; strå hvasskantigt och något sträft; honaxfjäll vanl. spetsiga.

Vestm. flerst.

Djupa kärr; Ipl. spr., Norrl. Jtl. Ång. Hels. r., Sv. r.:

29. C. lagopína Wahlenb.; småax få, ovala och hopträngda; fruktgömme svagt nervigt och äggformigt, på era sidan platt och på den andra kullrigt, med utdraget spröt; honaxfjäll n. utan hinnkant, äggrunda och kortare än fruktgömmet. 2, 3 .

Omkr. 1/2 fot hög med korta, omkr. $1 / 2$ linie breda och något sträfva blad och mörkbruna ax: strå trubbkantigt och $n$. slätt; honaxfjäll vanl. trubbiga.

Något fuktig ängsmark, teml. högt upp i fjellen; Lpl. a., Norrl. Jil. Herj. spr., Sv. Dal. r.

30. C. echináta Murr., Piggstarr; småax teml. fa och slutl. rundade, åtskilda eller stundom något hopträngda; fruktgömme svagt nervigt, på ena sidan platt och på den andra svagt kullrigt, äggrundt-lansettlikt; honaxfjäll hinnkantade, äggrundt ovala och hälften kortare än fruktgömmet. 2,3 .

$1 / 2-1$ fot hög med långa och vanl. smala, något sträfva och ljusgröna blad samt vanl. ljusgröna ax; strå trubbkantigt och $n$. slätt; honaxfjäll vanl. trukbiga. C. stellulata Good.

Fuktiga ställen; Göt. Sv. a.: Gotl. t. r., Norrl. t. a., Lpl.r. 31. C. leporína L., Harstarr; småax teml. få, omvändt äggrunda och hopträngda; fruktgömme nervigt, på ena sidan platt, samt äggrundt lansettlikt; honaxfjäll bredt hinnkantade och äggrunda eller äggrundt lansettlika, lika långa som fruktgömmet. 2,3 .

Fotshög eller något högre, med långa och teml. breda, sträfva 
och ljusgröna blad och vanl. ljusbruna ax; axsamling vanl. utdragen; honaxfjäll vanl. spetsiga, stundom $\mathrm{n}$. silfverhvita.

Ängsbackar, allmän: Lpl. r. Vb. r.? Jtl. spr.

- festíva (Dew.); småax mörkbruna, tätt gyttrade i ett hufvudlikt ax; honaxfjäll äggrunda trubbiga.

I fjellregionen; $I p l$. h. o. d.

32. C. bícolor All.; småax fi̊ och aflånga; fruktgömme svagt nervigt och hoptryckt, mycket trubbigt och glatt; honaxfjäll ovala trubbiga, svartröda med grön nerv, lika långa som fruktgömmet eller föga kortare. 2,3 .

Omkr. fingerhög och tufvad med något krypande rotstock och smala blad; strá trubbkantigt och n. slätt, upptill lutande; småax tätblommiga, stundom skaftade; toppax vanl. med hanblommor nedtill. Liknar något C. rigida.

I fjellen, mycket r.; Lpl., Norrl. Herj.

Anm. C. rufina Drej., som stundom har längre blomskärmar och bågböjdt strå samt toppaxet bestående af endast hanblommor, synes blott vara en form af nyss beskrifna art.

33. C. rígida Good.; fruktgömme nervlöst; blad platta, mycket bredare än strået; strå n. hvasskantigt; stråslidor ej upplösande sig i trådar, alla eller de flesta med utbildad bladskifva; honaxfjäll n. lika breda som fruktgömmet samt med otydlig eller smal nerv. 2,3 . Föga tufvad med styft och upprätt, mer eller mindre sträft strå och vanl. något krypande rotstock med grenskott; honax korta (sällan tuminlånga) jemntjocka eller aflånga-klubblika, stundom n. klotrunda, de flesta oskaftade; fruktgömme van]. äggrundt-aflångt och kullrigt; honaxfjäll svartaktiga (stundom. svartröda), vanl. lika långa som fruktgömmet och oftast trubbiga; skärmblad vanl. korta och smala, det nedersta med slidlikt omfattande (ofta svarta) bladöron; hanax vanl. ett. I lägre trakter mer än fotshög med något slaka blad, högre upp på fjellen lägre, ofta blott fingerhög, med styfva blad.

Torra steniga ställen i fjellen; Lpl. a., Norrl. Jtl. Herj. t. a., $S v$. Dal. r.

- elytróides (Fr.); det nedersta skärmbladet öfverskjutande stråets topp, stundom med hopväxta bladöron; fruktgömme sträfprickigt.

\section{Lpl. Norrl. Vb.; mycket r.}

34. C. acúta L.; fruktgömme nervigt; blad platta, mycket bredare än strået; stræ̊ hvasskantigt; stråslidor ej upplösande sig i trådar, alla eller de flesta med utbildad bladskifva; honaxfjäll smalare än fruktgömmet, med smal medelnerv. 2, 3 .

Tufvad och oftast med grenskott samt vanl. $2-3$ fot hög: honax utdragna, 1-2 tum långa och oftast jemntjocka; de nedre stundom skaftade; fruktgömme vanl. ovalt och kullrigt, stun- 
dom med föga tydliga nerver; honaxfiäll vanl. svartaktiga, stundom bruna, vanl. längre än fruktgömmet och oftast spetsiga; det nedersta skärmbladet vanl. bredt och ofta öfverskjutande strå ets topp, med åtskilda, ofta otydliga bladöron; hanax vanl. flera.

Former, helst förekommande utom fjellen, med slaka blad:

a. genuína; blågrön; strå sträft: honaxfjäll vanl. spetsiga och något längre än det med flera, vanligen föga tydliga nerver försedda fruktgömmet.

Omkr. 2-3 fot hög med lutande topp; hanax vanl. flera; honax 1-2 tum långa, de nedre teml. kort skaftade; honaxfjäll svartaktiga; skärmblad breda.

Stränder och fuktiga ängar; Göt. a.: Gotl. t. r., Sv. a., Norrl. spr.

b. personáta (Fr.); gulgrön; strå föga sträft; honaxfjäll spetsade och längre än fruktgömmet.

Omkr. 2 fot hög med lutande topp; hanax vanl. flera; honax 1-2 tum långa och teml. smala, de flesta skaftade och hängande; honaxfjäll bruna; skärmblad breda.

Göt. Sv. h. o. d.

c. prolixa (Fr.); blågrön; strå sträft; honaxfjäll långspetsade, mycket längre än fruktgömmet.

Omkr. 3 fot hög med lutande topp; hanax vanl. flera; honax omkr. 2 tum långa, de flesta långt skaftade och hängande; honaxfjäll svarta eller svartröda; skärmblad breda.

Göt. Sk. Hall. Blek. Smål. Ög. t. r., Sv. Söd. Upl. spr. Vestm. Ner. r., Norrl. Gestr.-Ang. r.

d. tricostáta (Fr.); rent grön: strâ sträft; honaxfjäll oftast trubbiga och vanl. kortare än det med 3 upphöjda nerver försedda fruktgömmet.

Omkr. 2 fot hög med styft strå, hanax vanl. flera; honax omkr. 1 tum långa, de nedre kort skaftade; honaxfjäll svartaktiga; skärmblad vanl. breda. Stundom smalbladig och liknande C. vulgaris.

Göt. Blek.-Ög. r., Sv. Upl. r.

Nordiska former med stela blad, styft strå och smala skärmblad:

e. vacillans (Drej.); strå mycket sträft; honaxfjäll spetsiga, mycket längre än det otydligt nerviga och prickiga fruktgömmet.

Omkr. fotshög med korta blad; hanax vanl. flera; honax oskaftade; honaxfjäll svartaktiga med föga tydlig nerv; märken (enligt Hartman) stundom tre.

Kärr i fjellen, r.; Ipl., Norrl. Jtl.

f. Límula (Fr.); strå mycket sträft; honaxfjäll vanl. trubbiga och kortare än det otydligt nerviga fruktgömmet.

Blekgrön och omkr. fotshög eller högre; hanax vanl. ett; honax omkr. en tum lănga, de nedre stundom något skaftade; honaxfjäll svartaktiga med föga tydlig nerv.

Kärr, r.; Ipl., Norrl. Vb. Herj.

g. hyperbórea (Drej.); strå nästan slätt; honaxfjäll antingen trubbiga och något kortare än det otydligt nerviga fruktgömmet eller spetsiga och längre.

Blekgrön och omkr. fotshög; hanax vanl. ett; honax omkr. 
en tum långa och n. oskaftade; honaxfjäll svartbruna, ofta med mycket tydlig nerv.

Kärr i fjellen r.; Lpl., Norrl. Herj.

35. C. stricta Good.; fruktgömme nervigt; blad platta, föga bredare än strået; strå hvasskantigt; stråslidor upplösande sig $i$ triadar, de nedersta utan utbildad bladskifva; honaxfjäll smalare än fruktgömmet med smal medelnerv. 2,3 .

Omkr. 2 fot hög, med styft upprätt strå och slaka blad, samt bildande hårda tufvor; honax utdragna (mer än tumslånga), n. jemntjocka, vanl. oskaftade; fruktgömme vanl. ovalt och plattadt; honaxfjäll svartaktiga, något kortare än fruktgömmet och kortspetsiga; skärmblad sällan öfverskjutande stråets topp, de öfre vanl. smala, det nedersta vanl. bredare och föga omfattande; hanax vanl. flera.

a. genuína; blågrön, utan grenskott; strå sträft; honax tjocka , fruktgomme tydligt nervigt och vanl. plattadt.

Kärr och stränder; Göt. Sv. t. a.: Bnh.-Verml. spr. Dal.?, Norrl. Gestr. spr. Hels. t. r.

b. turfósa (Fr.); mörkare grön, ofta med grenskott; strå n. slätt; honax smala; fruktgömme otydligt nervigt och på ena sidan något kullrigt.

Torfkärr t. r.:; Göt. Hall. Boh. Ög., Sv. Söd. Upl. Ner. Dal., Norrl. Gestr.-Ång.

36. C. cæspitósa L. (enl. Fr.), Tufstarr; fruktgömme nervlöst; blad platta, föga bredare än strået; strå hvasskantigt; de nedre stråslidorna upplösande sig i trådar och vanligen utan utbildad bladskifva; honaxfjäll smalare än fruktgömmet, med smal medelnerv. $1,2$.

I början fotshög, slutl. dubbelt högre, ljusgrön med styft, spensligt och upprätt strå och slaka blad, starkt tufvad och sällan med grenskott; honax teml. korta (inemot tumslånga eller kortare) och n. jemntjocka, vanl. oskaftade; fruktgömme ovalt och kullrigt; honaxfjäll svartaktiga, föga kortare än fruktgömmet och n. trubbiga; skärmblad mycket smala och korta; hanax vanligen ett.

Ängar; Sv. Ner. Vestm. Upl. Söd. t. a., Göt. Boh. r. Sk.t.r. Ög. t. a. utom i skogsbygden. - Öfriga uppgifna ställen äro i allmänhet tvifvel underkastade. Att denna art saknas eller är sällsynt i de vestra och norra landskapen, är teml. visst.

37. C. vulgaris Fr.; fruktgömme nervigt; blad vanl. rännformiga och föga bredare än strået, stundom platta och bredare; strå hvasskantigt; stråslidor icke upplösande sig i trådar, alla eller de flesta med utbildad bladskifva; honaxfjäll vanl. föga smalare än fruktgömmet, med smal medelnerv. 2, 3 . $1 / 2-2$ fot hög och mörkt blågrön, med styft och upprätt 
strå samt slaka blad, starkt tufvad och oftast med grenskott; honax antingen utdragna (tumslånga eller något deröfver) och n. jemntjocka eller korta och tjocka, stundom n. runda, vanl. oskaftade; fruktgömme vanl. ovalt och något kullrigt; honaxfjäll svartaktiga eller bruna, föga längre eller stundom kortare än fruktgömmet, antingen trubbiga eller kortspetsiga; skärm. blad smała, det nedersta något bredare, sällan öfverskjutande stråets topp; hanax ranligen ensamt.

Anm. Bredbladigare former häraf kunna med svårighet skiljas från C. acuta.

Fuktiga ängar, skogar och berg, allmän.

* C. juncella (Th. Fr.); blad slutl. trådlikt hoprullade; honax smala; strå spensligt; de nedre stråslidorna vanligen bladlösa.

Ipl. a., Norrl. a.?, Sv. spr., Göt. r.: Boh. Vg. Blek. Gotl. 0. 38. C. aquátilis Wahlenb., Vattenstarr; fruktgömme nervlöst; blad rännformiga, vanl. breda och något plattade; strå vanl. trubbkantigt och slätt; stråslidor ej upplösande sig i trådar, alla bladbärande; honaxfjäll smalare än fruktgömmet, vanligen med bred medelnerv. 2,3 .

1-5 fot hög och blågrön med styft upprätt strå och slaka blad, stundom med grenskott; fruktgömme vanl. bredt ovalt och plattadt; honaxfjäll brungröna och kortare än fruktgömmet, vanl. trubbiga; skärmblad breda och vanl. öfverskjutande stråets spets; hanax vanl. flera; honax vanligen utdragna, omkr. 2 tum lănga, och smala, ofta upptill klubblika, de nedre ofta skaftade.

Stränder; Ipl. a.?, Norr. spr., Sv. spr.: Verml. t. r. Vestm. r. Ner. 0, Göt. Og. t. r. Smål. r. Blek.?

- boreális (Lang); blad teml. smala och vanl. plattade; strå n. slätt; honax vanl. korta (omkr. tumslånga), stundom ovala (sällan upptill klubblika), de nedre sällan skaftade; honaxfjäll oftast något spetsiga.

Omkr. fotshög med någnt styfva och teml. korta blad.

Helst i fjelltrakter; 'Lpl. spr., Norrl. Jtl. Herj. Vb. Ang. r.

* C. arcuáta (C. P. Læst.); blad mycket smala och rännformigt hoprullade; strå upptill sträft; honax långa och smala samt upptill klubblika, de nedre skaftade; honaxfjäll trubbiga med teml. smal nerv.

Omkr. 2 fot hög med mycket långa blad.

I fjellen, myeket r.; Ipl. Torn. Lpm. (C. P. Læstadius).

39. C. maritima Miill.; fruktgömme otydligt nervigt; blad platta och mycket bredare än det n. trubbkantiga strået; de nedersta stråslidorna upplösande sig i trådar samt utan utbildad bladskifva; honaxfjäll föga smalare än fruktgömmet. 3 .

$1-1^{1} / 2$ fot hög och gulgrön eller snart blekgul, stundom 
med grenskott; strå styft och slätt med lutande topp och styfva blad; honax mycket tjocka och jemntjocka eller aflånga samt vanl. kortare än skaften; fruktgömme vanl. bredt äggformigt och kullrigt; honaxfjäll rundade--ovala och trubbiga, vanl. betydligt kortare än den långt utskjutande medelnerven; skärmblad breda med omfattande bladöron; hanax vanl. 2.

Hafsstränder; Göt. Boh. t. r., Norrl. Vb. r.

40. C. salína Wahlenb.; fruktgömme otydligt nervigt; blad platta och omkr. dubbelt bredare än det ranl. trubbkantiga strået; de nedre stråslidorna ej upplösande sig i trådar samt utan utbildad bladskifva; honaxfjäll föga smalare än fruktgömmet. 3 .

Lika hög som föreg. art och ljust blågrön, ofta med grenskott; strå styft, upprätt och vanl. slätt; blad teml. styfva; honax teml. smala, omkr. tumslånga, n. jemntjocka eller aflånga samt längre än skaften; fruktgömme bredt äggformigt och kullrigt; honaxfjäll brunaktiga eller svartröda, utdraget äggrunda med vanl. ej långt utskjutande medelnerv samt n. lika långa som fruktgömmet; skärmblad breda, stundom med slidlik bas; hanax 1 eller 2 . Liknar något $C$. acuta eller C. glauca.

Hafsstränder; Göt. Boh. t. r. Hall. r.
41. C. gláuca Scop.; fruktgömme nervlöst och slutl. rundadt kullrigt; stråslidor ej upplösande sig i trådar, alla med utbildad bladskifva. 2, 3.

1-2 fot hög och blågrön med hvasskantigt och åtm. upptill sträft strå och platta, omkr. liniebreda blad; alla honaxen åtskilda och vanl. jemntjocka, alltid skaftade; fruktgömme ovalt: honaxfjäll något smalare än fruktgömmet och stundom något längre, äggrunda, grönaktiga, bruna eller svartaktiga med vanl. bred och stundom utlöpande nerv. Står temligen nära följ. art.

Fukt. ängar; Göt. 't. a.: Vg. spr. Boh. Dalsl. r., Sv. Söd. Upl. t. a. Vestm. spr. Ner. t. r. Verml. r., Norrl. Gestr. spr. Hels. Àng. r., Lpl. r.

42. C. Buxbáumii Wahlenb.; fruktgömme nervigt och slutl. trekantigt eller på ena sidan platt och på den andra kullrigt; stråslidor upplösande sig $i$ tricdar, de nedersta utan utbildad bladskifva. 2,3 .

Blågrön och omkr. 2 fot hög, med hvasskantigt, åtm. upptill sträft strå och teml. smala, platta blad; ax mer eller mindre utdragna, de öfre tätt sittande och oskaftade, det nedersta något aflägsnadt och stundom skaftadt; fruktgömme vanl. bredt ovalt samt bredare än de brunaktiga, n. äggrunda och spetsiga axfjällen.

Fukt. ängar och stränder; Lpl. spr., Norrl. r.: Med.?, Sv. r.: Upl. spr. Söd. t. r., Göt. r.: Ög. t. r. Hall.?

- alpícola; ax vanl. korta och ovala, det nedersta sällan skaftadt; honaxfjäll n. lika breda som fruktgömmet, ovala och trubbiga, mörkbruna eller svartaktiga med föga tydlig, ej utlöpande nerv; det nedersta skärmbladet smalt och teml. kort. 
Omkr. fotshög med något hreda blad.

I fjellen h. o. d.

43. C. atráta L.; fruktgömme otydligt nervigt och slutl. trekantigt (eller på ena sidan platt och på den andra kullrigt), stundom något hoptryckt; stråslidor ej upplösta i trådar, alla med bladskifva. 2 .

Ljusgrön med hvasskantigt och vanl. slätt (stundom upptill något sträft) strå; ax tätt sittande, mer eller mindre skaftade; fruktgömme vanl. ovalt, stundom aflångt; skärmblad sällan öfverskjutande stråets topp.

a. genuina; ax vanl. aflånga, de flesta skaftade; honaxfjäll lika breda som fruktgömmet och vanl. längre, äggrunda och spetsiga samt svartröda (stundom svarta eller mörkbruna); det nedersta skärmbladet vanl. năgot bredt.

1-2 fot hög med breda blad; strå upptill lutande och vanl. långt upptill bladigt; ax vanl. större än hos öfriga former af denna art.

Fuktig ängsmark, helst i lägre fjelltrakter; Lpl. a., Norrl. Jtl. Herj. t. a. i fjellen, $S v$. Verml. r.

b. nigra (All.); ax ovala, alla eller de flesta oskaftade; honaxfjäll lika breda och $\mathrm{n}$. lika långa som truktgömmet, ovala trubbiga och svarta; skärmblad smala och korta.

Omkr. 1/2 fot hög med breda blad; strå styft och upprätt, vanl. långt upp bladigt.

I fjellregionen, mycket r.; Lpl., Norrl. Jtl.

c. subnigra; ax ovala-rundade, alla eller de fiesta oskaftade; honaxfjäll något smalare och kortare än fruktgömmet, ovala trubbiga och svarta; skärmblad smala och korta.

Omkr. ${ }^{1 / 2}$ fot hög, sällan högre, med teml. breda blad; strå styft upprätt och vanl. långt upp bladigt.

I fjellen ofvan barrskogsregionen; Norrl. Jtl. Herj. r.

d. alpina (Sw.); ax vanl. rundade, alla eller de flesta oskaftade; honaxfjäll något smalare och ofta dubbelt kortare än fruktgömmet, ovala trubbiga och svarta; skärmblad smala och korta.

Omkr. fotshög eller lägre med vanl. smala blad; strå styit upprätt, spensligt och vanl. upptill bladlöst; fruktgömme oftare trekantigt än hos de föreg. formerna (af denna art) samt med tydligare spröt; ax mindre än hos dessa former.

Helst i lägre fjelltrakter; Lpl. a., Norrl. Jtl. Herj. spr. Vb. -Med. r., Sv. Dal. r.

44. C. ustuláta Wahlenb.; fruktgömme nervlöst, ovalt och hoptryckt, slätt och upptill hopdraget mot sprötet; honax ovala tätblommiga; honaxfjäll smalare och vanl. längre än fruktgömmet, äggrundt lansettlika och spetsiga, svarta utan hinnkant samt med otydlig nerv; skärmblad korta syllika och vanl. svarta. 2 .

$1 / 2-1$ fot hög och ljusgrön, upptill lutande, föga tufvad, men med grenskott; strå trubbkantigt, slätt och vanl. ända upptill bladigt; blad platta, teml. breda och föga sträfva; honax tjocka och närmade samt hängande, vanl. tre; toppax vanl. kort och 
tjockt, stundom akrogynt; axskaft n. hårfina; frukter sällan (aldrig?) mognande. Liknar C. atrata.

Sumpiga ställen i fjellen; Lpl. Norrl. Jtl. Herj. t. a.

45. C. misandra R. Br.; fruktgömme nervlöst, äggrundt lansettlikt och något hoptryckt (eller på ena sidan platt och på den andra kullrigt med upphöjd ås), upptill fintandadt och afsmalnande till spröt; honax aflånga-lansettlika tätblommiga; honaxfjäll lika breda som fruktgömmet, men kortare och äggrunda-ovala trubbiga, bruna och smalt hinnkantade, med föga tydlig nerv; skärmblad korta syllika och ofta bruna. 2, 3. Omkr. $1 / 2$ fot hög och ljusgrön samt upptill lutande, starkt tufvad utan grenskott; strå trubbkantigt, slätt och upptill med korta blad; de nedre bladen platta, teml. breda och sträfva; honax teml. tjocka och hängande, vanl. 3-4, de öfre närmade; toppax n. alltid akrogynt; axskaft hårfina.

Högt upp i fjellen, helst i fjellregionen, på teml. sumpig mark; Lpl. $\mathrm{r}$.

46. C. capilláris L.; fruktgömme nervlöst, aflångt och trekantigt; honax n. jemntjocka eller aflånga glesblommiga; honaxfjäll lika breda som fruktgömmet, men betydligt kortare, omvändt äggrunda och trubbiga, till största delen hinnaktiga och genomskinliga, med grön nerv; skärmblad vanl. smala, teml. korta. $2,3$.

Omkr. $1 / 2$ fot hög, ljusgrön och tätt tnfvad, utan grenskott; strå lutande; blad teml. smala; honax ofta hängande, smala och små, de öfre närmade, alla med långa hårfina skaft.

Fukt. ängar; Lpl. t. a., Norrl. spr., Sv. spr.: Vestm. t. r. Verml. blott i n. delen, Göt. Ög. mångenst. Gotl. spr. Öl. Kalmarl. Blek. r. Sk.? Boh. r. Vg. r.?

47. C. silvática Huds., Lundstarr; fruktgömme nervlöst och tapplikt trekantigt; honax jemntjocka glesblommiga; honaxfjäll smalare än fruktgömmet och föga kortare, lansettlika sylspetsade och hinnaktiga med grön nerv; skärmblad långa. 2.

Omkr. fotshög, ljusgrön och tufvad med grenskott; strå lutande; blad teml. breda; honax hängande, smala och långa, glest sittande på fina skaft.

Lundar, helst i ekskog; Göt. r.: Gotl. a. Öl. t. a. Sk. spr. Dalsl. 0, Sv. Ner. r.

48. C. Pséudo-Cypérus L.; fruktgömme starkt och tätt nervigt, äggrundt lansettlikt, på båda sidor kullrigt med upphöjd ås (eller n. trekantigt), samt med djupt klufvet spröt; honax jemntjocka; honaxfjäll föga kortare än fruktgömmet, syllika och gröna; skärmblad. breda och långa. 2,3 . 
2-3 fot hög och grof, ljusgrön och tufvad; strå styft upprätt, hvasskantigt och sträft; blad mycket (omkr. 2 linier) breda ; honax ofta hängande, stora, tjocka och närmade, med trådlika skaft. Liknar năgot $C$. vesicaria.

Kärr och stränder; Göt. r.: Sk. Ög. spr., Sv. Söd. Upl. spr. Vestm. r. Ner. t. r., Norrl. Gestr. r.

49. C. pallescens L.; fruktgömme nervlöst, ovalt och kullrigt; honax aflånga-ovala; honaxfjäll lika breda och långa som fruktgömmet, äggrunda och spetsiga, n. genomskinliga med grön nerv; skärmblad n. slidlösa. 2,3 .

Omkr. en fot hög och ljusgrön, med omkr. liniebreda och mjuka blad; det nedersta skärmbladet bredt; honax teml. närmade till hvarandra och vanligen hängande.

Ängar och lundar a.: Lpl. och i fjellen t. r.

50. C. limósa L., Dystarr; fruktgömme nervigt aflàngt, på båda sidor kullrigt och n. hoptryckt utan upphöjda åsar; honax aflånga-ovala; honaxfjäll lika breda och långa som fruktgömmet, stundom något längre, äggrunda och $\mathrm{n}$. trubbiga, rödbruna och ogenomskintiga med vanl. grön, teml. bred och ofta något utlöpande nerv; skärmblad med mycket korta slidor. $2,3$.

Omkr. fotshög och grågrön, med hvasskantigt och åtm. upptill sträft strå och platta, omkr. $1 / 2$ linie breda och sträfva' blad; det nedersta skärmbladet smalt och nående till hanaxet; honax närmade intill hvarandra, vanligen 2 , hängande; hanax stundom akrogynt.

Kärr, teml. allmän: Blek. Gotl. r. Ö1. 0 .

51. C. irrigua Sm.; fruktgömme otydligt nervigt, bredt ovalt, på båda sidor kullrigt med upphöjd ås; honax n. jemntjocka eller aflånga; honaxfjäll något smalare och längre än fruktgömmet, från äggrund bas utdragna och sylspetsade (stundom kortspetsiga), rödbruna och ogenomskinliga med utlöpande, mer eller mindre tydlig nerv; skärmslidor korta. ${ }^{-2}, 3$.

Liknar föreg. art, men är mera rent grön och ofta lägre med n. slätt strå och omkr. en linie breda, n. släta blad; det nedersta skärmbladet ofta bredt och stundom öfverskjutande hanaxet; honax närmade och hängande, ofta 3 ; hanax stundom akrogynt.

Kärr; Lpl. Norrl. a., Sv. t. a., Göt. spr.: Dalsl. Hall. Sk. Blek. r. Vg. r.? Öl. Gotl. 0.

52. C. rariflóra Sm.; fruktgömme aflångt; honax glesblommiga; honaxfjäll n. lika långa och lika breda som fruktgömmet, svartbruna med något utlöpande nerv; skärmblad med något utdragna slidor; eljest som föreg. art. 2, 3 .

Omkr. $1 / 2$ fot hög och något blågrön eller ljusgrön med 
trubbkantigt och slätt strå samt korta och släta blad; det nedersta skärmbladet smalt och knappt nående hanaxet; honax åtskilda, små och hängande, vanl. 2; hanax ternl. kort.

Herj. $r$.

Kärr i fjellen, helst i björkregionen; Ipl. spr., Norrl. Jtl.

53. C. laxa Wahlenb.; fruktgömme otydligt nervigt, äggformigt aflångt, på ena sidan platt och på den andra kullrigt med upphöjd ås; honax n. jemntjocka och något glesblommiga; honaxfjäll lika breda och långa som fruktgömmet, äggrunda trubbiga samt rödbruna och ogenomskinliga med smal och ej utlöpande nerv; honaxskaft långt utskjutande ur de uppblåsta slidorna. 2,3 .

Omkr. fotshög och blekgrön med grenskott och icke tufvad; strå spensligt och nedböjdt samt trubbkantigt och slätt; blad smala platta, teml. långa och upptill sträfva; det nedersta skärmbladet teml. smalt, ej nående till det öfre honaxet; honax vanl. 2, hängande och teml. långt åtskilda, något större än hos föreg. art, som denna mycket liknar; hanax lăngt och smalt; axskaft n. hårfina; fruktgömmets spröt mycket kort.

Kärr i fjelltrakter; Lpl. flerst. t. r., Nor»l. Jtl. Herj. r.

54. C. lívida Willd.; fruktgömme n. nervlöst, äggformigt trekantigt och stundom något hoptryckt; honax jemntjocka, något glesblommiga; honaxfjäll lika breda som fruktgömmet och något kortare, ovala-äggrunda och trubbiga, rödbruna och i kanten smalt hinnaktiga, eljest ogenomskinliga med grön, bred och ej utlöpande nerv; axskaft föga utskjutande ur de icke uppblista slidorna. $2,3$.

Omkr. fotshög och blekt blågrön, något tufvad, stundom med grenskott; strå upprätt, trubbkantigt och slätt; blad smala inrullade, långa och släta; det nedersta skärmbladet stundom bredt och ofta, öfverskjutande stråets topp; honax vanl. 2, upprätta och närmade; hanax vanl. kortskaftadt; fruktgömmets spröt mycket kort. Stundom finnes hos denna och följ. art ett långskaftadt honax från stråets bas.

Djupa kärr; Lpl. spr., Norrl. Sv. t. r., Göt. Ög. Smål. Vg.r.

55. C. panicea L.; fruktgömme mera uppblåst och otydligt nervigt samt stundom betydligt längre än axfjällen; blad platta, något mörticive och bredare (än hos föreg. art) samt något sträfva; skärmblad kortare med något uppblåsta slidor och 2 mera åtskilda (stundom 1) honax; hanax långskaftadt; - eljest som föreg. art. 2, 3.

Fuktiga ängar, allmän: Lpl. spr.

- sublivida (Hartm.); ax och fruktgömmen dubbelt min- 
dre; blad och skärmblad dubbelt smalare, de senare 2-3 gånger längre än axskaftet.

Göt. Sk. r. (Lektor P. Olsson), Sv. Söd. Upl.r. (enl. Hartman).

C. sparsiffóra Fr.; afviker genom föga uppblåst och något plattadt, stundom tydligt nervigt och aflångt fruktgömme med tydligare spröt, ej hinnkantade honaxfjäll, rent gröna samt bredare och föga sträfva blad; axskaft mera utskjutande ur de starkt uppblåsta slidorna; skärmblad vanl. mycket kortare; hanax ofta nedböjdt och vanl. längre skaftadt.

Kärrüngar; Lpl. a., Norrl. t. a., Sv. spr., Göt. Ög.t.r. Smål. spr. Sk. Dalsl. r. Vg. r.?

56. C. digitáta L.; fruktgömme trekantigt, omvändt äggformigt med en svag nerv på hvarje sida; skärmslidor utan eller med ett kort ämne till bladskifva; honaxfjäll lika breda som fruktgömmet; rot tufvad utan grenskott, med mer eller mindre utdragen rotstock. 1,2.

a. genuina; axskaft långt utskjutande ur den vanl. rödbruna slidan; det nedre axet vanl. långt skildt från de öfre, som vanl. öfverskjuta hanaxet; honaxfjäll brunröda med föga tydlig. nerv, omvändt äggrunda, trubbiga eller tvärhuggna, upptill genomskinliga och hinnaktiga, sarnt lika långa som fruktgömmet; strå trublikantigt och slätt; blad rent gröna.

Omkr. fotshög eller lägre.

Berg och steniga lundar; Göt. mångenst.: Blek. Boh. t. r., Sv. t. a.: Dal. r., Norrl. spr.: Vb.?, Lpl. r.

b. pallens (Frist.); axskaft teml. långt utskjutande ur den blekgröna; i kanten bruna slidan; ax vanl. närmade; honaxfjäll blekbruna med tydlig grön nerv; blad ljusgröna; eljest som föreg. form.

Fjelltrakter; Norrl. Jtl. Herj. Ång. Med. r.

c. pediformis (C. A. Mey.); honaxfjäll omvändt äggrunda och trubliga eller ovala och kortspetsiga, i kaaten vanl. hinnaktiga; strå hvasskantigt och sträft; blad blågröna och sträfva; omkr. fotshög eller något högre; eljest som föreg. form.

Något fuktiga ängar; Norrl. Jtl. r.

d. ornithopodióides (Kindb.); axskaft teml. långt utskjutande ur den blekgröna, i kanten bruna slidan; ax vanl. närmade; honaxfjäll blekbruna med tydlig grön nerv, i kanten vanl. hinnaktiga samt vanl. trubbiga, stundom kortspetsiga, betydligt kortare än fruktgömmet; strå och blad som hos hufvudformen.

Berg; Göt. Ög. r., t. ex. på Omberg (förf.); trol. äfven annorstädes.

* C. ornithópoda Willd.; axskaft föga utskjutande ur den ljusbruna slidan; ax närmade; honaxfjäll ljusbruna med föga tydlig nerv och upptill genomskinliga, omvändt äggrunda och trubbiga med kort udâ samt betydligt kortare än fruktgönmet; strå trindt och slätt; blad ljusgrö̀na.

Till alla delar något mindre än de föreg. formerna. 
Berg, lundar och något fuktiga ängar; $L p l$, r., Norrl. Jtl. t. r. Ång. Herj. r., Sv. r.: Upl. Vestm. 0, Göt. Gotl. a. Öl. Smål. r. Ü. mångenst. helst på silur. formation.

57. C. pedáta Wahlenb.; fruktgömme nervlöst och $n$. klotrundt eller äggformigt samt $n$. tvärt hopdraget mot sprötet; honax rundade-ovala; honaxfjäll betydligt kortare än fruktgömmet, bredt äggrunda trubbiga, mörkt rödbruna och smalt hinnkantade samt med smal nerv. 2.

Omkr. fingerhög, ljusgrön och starkt tufvad utan grenskott; strå styft upprätt och spensligt, trubbkantigt och slätt; blad inrullade och $n$. borstlika, stundom sträfva; honax två, små och korta samt tätt sittande, blott det nedersta med teml. kort, styft och trådlikt skaft; hanax mycket smalt. Liknar något $C$. digitata * ornithopoda. Jtl. Herj.

Torra ängsbackar, högt upp i fjellen, mycket r.; Lpl., Norrl.

58. C. præcox Jacq.; fruktgömme nervlöst, päronformigt trekantigt, nästan tvärt hopdraget mot sprötet; honax aflånga-ovala; honaxfjäll lika breda och långa som fruktgömmet, ljusbruna och ogenomskinliga, äggrunda-lansettlika och $\mathrm{n}$. trubbiga, med grön utlöpande nerv. $1,2$.

Omkr. $1 / 2$ fot hög, rent grön och föga tufvad, mer grenskott; blad teml. korta och teml. smala, ofta sträfva; honax vanl. $2-3$, närmade men åtskilda, då de nedre hafva ett upprätt och trådlikt skaft (stundom blott ett honax utbildadt, som kan hafva ett kort skaft); skärmblad smala borstlika, det nedersta med kort slida och ej nående hanaxet.

Ängsbackar, helst i slättbygder; Göt. Sv. mångenst.: Boh. -Dal. r., Norrl. Gestr. spr. Hels. Herj. r.

59. C. ericetórum Poll., Hedstarr; fruktgömme nervlöst, omvändt äggformigt trekantigt, tvärt hopdraget mot sprötet; honax aflianga-ovala; honaxfjäll lika breda och långa som fruktgömmet, bruna och upptill genomskinliga, rundade eller omvändt äggrunda och mycket trubbiga, med otydlig, ej utlöpande nerv. 1,2.

Omkr. $1 / 2$ fot hög, blågrön och föga tufvad, med grenskott; blad något bredare och stelare än hos föreg. art; honax vanl. 2 (stundom 1) oskaftade och närmade, men åtskilda; skärmslidor mycket korta och svartbruna, sällan rned kort bladämne.

Hedar osh torra backar; Göt. Sv. t. a.: Verml. spr. Dalsl.?, Norrl. r.: Gestr. Hels. a. Vb. 0.

60. C. pilulífera L.; fruktgömme otydligt nervigt, päronformigt eller rundadt trekantigt, tvärt hopdraget mot sprötet; honax n. klotrunda; honaxfjäll lika breda som fruktgömmet, men något längre, grönaktiga eller 
ljusbruna med smal hinnkant, äggrunda och något spetsiga med tydlig nerv. 2.

Omkr. 1/2 fot hög, ljusgrön och något tufvad, utan grenskott; blad teml. långa och smala; honax 3-5 (sällan 1, då de båda nedre felslå), oskaftade, de öfre tätt sittande, det nedre något frånskildt; det nedre skärmbladet borstlikt och kort utan slida.

Skogar och torra backar; Göt. Sv. t. a., Norrl. spr.: Jtl. Ång. r. $\mathrm{Vb}$. 0 .

61. C. montána L.; fruktgömme nervigt, omvändt äggformigt eller aflångt trekantigt, afsmalnande mot sprötet; honax klotrunda eller bredt äggformiga; honaxfjäll lika breda som fruktgömmet, stundom något kortare, mörkt rödbruna och n. utan hinnkant, ovalarundade och vanl. trubbiga med grön nerv. 1, 2.

Omkr. $1 / 2$ fot hög och ljusgrön, nedtill med rödbruna bladslidor, tätt tufvad.med förlängd rotstock, utan grenskott; strå slakt och niågot sträft; blad smala, stundom teml. långa och slaka, föga sträfva; honax 1 eller 2 oskaftade, tätt sittande eller närmade; skärmblad utan slida.

Lundar och ängar; Göt. Sv. spr.: Sk. a. Ög. t. a. Öl. Blek. inre Smål. Boh.-Dal. r.

62. C. globuláris L.; fruktgömme nervigt, äggformigt trekantigt, afsmalnande till spröt; honax klotrunda; honaxfjäll lika breda som fruktgömmet, men kortare, rödbruna med smal hinnkant, äggrunda-ovala och trubbiga, med föga tydlig nerv. 2,3 .

Omkr. fotshög, ljusgrön och föga tufvad, med grenskott: strå spensligt, slakt och slätt; blad lănga och teml. smala, mjuka och slaka; honax 2-3 oskaftade och långt skilda; det nedersta skärmbladet vanl. något bredt och nående åtm. till hanaxet, stundom smalt och kort, utan slida; hanax långt och smalt.

Mossar; Lpl. Norrl. .t. a., Sv. Dal. a. Verml. t. a. Ner. Vestm. spr. Upl. r., Göt. Ög. Smål. Vg. Dalsl. r.

63. C. tomentósa L.; fruktgömme otydligt nervigt, omvändt äggformigt och trekantigt samt trubbigt med mycket kort spröt; honax aflinga eller jemntjocka; honaxfjäll lika breda som fruktgömmet, men kortare, mörkbruna utan hinnkant, n. äggrunda och spetsiga med tydlig nerv. 2,3 .

Omkr. fotshög, ljusgrön och föga tufvad, med grenskott; strå spensligt, upprätt och sträft; blad smala och mjuka; honax 1-3 oskaftade (eller det nedersta skaftadt), något skilda; det nedersta skärmbladet teml. bredt och stundom öfverskjutande hanaxet, öronflikadt; hanax teml. utdraget.

Något fuktiga ängar; Göt. Gotl. Öl. t. a. Smăl. r.

64. C. extensa Good.; fruktgömme äggformigt, på båda sidor kullrigt, småningom afsmalnande till spröt; hon- 
axfjäll gulaktiga med vanl. utlöpande nerv; blad snart inrullade och nästan traidsmala. 3.

Omkr. ${ }^{1 / 2}-1^{1} / 2$ fot hög och blekgrön; strå stundom bågböjdt; blad vanl. långa och stela; honax $2-3$, vanl. klotrunda, stundom äggformiga-ovala: de öfre n. oskaftade och n. slidlösa, vanl. närmade till hanaxet, det nedre (som stundom felslår) åtskildt och försedt med ett inom slidan inneslutet skaft; honaxfjäll n. lika breda som fruktgömmet och föga kortare: fruktgömmen n. upprätta med teml. kort spröt; skärmblad likformiga med stråbladen, vanl. långt öfverskjutande hanaxet.

Hafsstränder, helst vid Östersjön; Göt. Sk. Öl. Gotl. r. Blek. -Ög. spr., Sv. r., Norrl. Hels. r.

65. C. Oedéri Ehrh.; fruktgömme uppblåst och n. klotrundt, tvärt hopdraget till spröt; honaxfjäll gröngula med kort, icke utlöpande nerv; blad rünnformiga. 2, 3 .

Från fingerhög till fotshög och rent grön, med talrika bladtofsar; strå trubbkantigt och slätt, vanl. blott nedtill bladigt; blad teml. smala, mjuka och släta; honax 2-3, vanl. ovala, de öfre vanl. närmade och $n$. oskaftade med korta slidor, det nedersta (som stundom felslår) aflägsnadt och försedt med ett ur slidan något utskjutande skaft; honaxfjäll trubbiga; fruktgömmen utstående (de nedersta sällan nedböjda) med vanl. utdraget och rakt spröt; skärmblad likformiga med stråbladen, det nedersta vanl. öfverskjutande det kortskafiade hanaxet.

Kärr och stränder, teml. allmän: Ang. Vb. Lpl. r.

- oedocarpa (Anders.); honax teml. långt åtskilda; hanax långskaftadt; fruktgömmets spröt mera utdraget. Göt. Sk.-Boh. Gotl. Öl. r., Sv. Upl. Ner. r.

66. C. flava L.; fruktgömme uppblast och äggformigt eller omvändt äggformigt, snart hopdraget till spröt; honaxfjäll som hos föreg. art; blad platta och kölade. 2,3 .

Liknar mycket föreg. art, men företer följ. olikheter: strå hvasskantigt, vanl. äfven upptill bladigt; blad hredare och gulgröna; fruktgömmen slutl. utspärrade och nedböjda, dubbelt större; fruktgömmets spröt längre och snart nedböjdt.

Kärrängar; Göt. a.: Blek. Boh. r. Gotl. 0, Sv. a., Norrl. t. a.: Jtl. Ang. spr. Vb. r.?, Lpl. t. r.

- lepidocarpa; fruktgömme något smärre, mera jemnt afsmalnande; honaxfjäll ljust brunaktiga; honax 2, teml. långt åtskilda; strå upptill sträft.

Göt. Sk. Smål. Ög. Gotl. Öl. spr.

67. C. speirostáchya Sm.; fruktgömme äggformigt, på båda sidor kullrigt, småningom afsmalnande till spröt; honaxfjäll bruna med genomstintig hinnkant och lång, n. utlöpande nerv; blad platta. $2,3$.

Omkring fotshög och rent grön eller blågrön, föga tufvad och vanl. med grenskott; strå trubbkantigt: honax $2-3$ aflånga, 
vanligen långt åtskilda och slidbärande, de nedre skaftade; honaxfjäll ofta spetsade eller kortspetsiga; fruktgömmen föga utstående med teml. långt och rakt spröt; skärmblad teml. korta, sällan öfverskjutande det långskaftade hanaxet. C. Hornschuchiana Hoppe.

Fukt. ängar, helst i slättbygder; Göt. spr.: Gotl. Öl. a., Sv. spr.: Vestm. r. Verml. Dal. 0, Norrl. Gestr. Jtl. r.

* C. fulva Good.; honax tjockare, de öfre teml. närmade; fruktgömme större och något uppblåst, utan mogen frukt; rot tufvad; skärmblad öfverskjutande hanaxet; strå sträft.

Fukt. ängar; Göt. t. r.: Hall. Sk. Öl. spr. Dalsl. 0, Sv. Söd. Upl. Ner. r., Norrl. Gestr. Jtl. r.

68. C. distans L.; fruktgömme omvändt äggrundt och på båda sidor kullrigt, hopdraget till ett kort spröt; honaxfjäll gulaktiga med något utlöpande nerv; blad platta och kölade. 2, 3 .

$1 / 2-1$ fot hög och blågrön; strå hvasskantigt; honax $2-4$, nästan aflånga, långt àtskilda och vanligen alla skaftade, det nedersta med lång slida; honaxfjäll trubbiga med udd; fruktgömmen n. upprätta; det nedersta skärmbladet likformigt med stråbladen och icke nående till hanaxet. Från stråets bas utgår vanligen ett långskaftadt honax.

Hafsstränder; Göt. spr.: Öl. Ög. r. Boh. r.? Hall.?, Sv. r.

69. C. punctáta Gaud.; fruktgömme ovalt, glänsande och finprickigt, n. uppblasst och hopdraget till ett kort spröt; honaxfjäll brunaktiga med bred grön nerv med lång finsågad spets; blad platta. 2,3 .

Rent grön, något liknande föreg. art och C. pallescens, af hvilka den förmodas vara en bastard; strå trindt, 7-10 tum högt; honax $3-4$, jemntjocka; de nedre utdraget skaftade, det nedersta långt aflägsnadt; blad smala, något stela och $\mathrm{n}$. upprätta med långa slidor; honaxfjäll spetsade; fruktgömmen upprätta; det nedersta skärmbladet nående stråets spets. koster.

Hafsstränder, mycket r.; Göt. Boh. nära lotsstugan på Nord-

70. C. ampullácea Good.; fruktgömmen n. klotrunda (sällan äggformiga), tvärt sammandragna till spröt och slutl. utspärrade; strå trubbkantigt; blad rännformiga. $2,3$.

Omkr. 2 fot hög och blågrön; blad föga sträfva och vanligen smala; honaxfjäll (antingen lansettlika och spetsiga samt föga kortare än fruktgömmet eller äggrunda och trubbiga samt betydligt kortare) bruna med grön nerr; hanax 2-3, sällan 1, med vanl. trubbspetsade axfjäll.

Stränder och kärr, allmän.

- rotundáta (Wahlenb.); hanax vanl. ett; honax 1-2. korta; det öfre n. klotrundt, det nedre ovalt och kort- 
skaftadt; fruktgömme uppblåst, otydligt nervigt med kort spröt, och föga längre än de rundade svartbruna axfjällen; blad inrullade och trådlika.

Fjelltrakter; Lpl. a., Norrl. Jtl. Herj. spr., Sv. Dal. r.

71. C. Iævirostris Blytt o. Fries; fruktgömmen nerviga, klotrunda och uppblåsta, tvärt hopdragna till spröt och slutl. utspärrade; strå hvasskantigt; blad platta. $2,3$.

Omkr. 3 fot hög och grof samt rent grön; blad sträfva och mycket breda; honaxfjäll kortare än fruktgömmet, jemnbredt lansettlika och spetsiga med ej utlöpande nerv; hanax $3-5$ med spetsade axfjäll.

Bäckstränder och kärr. mycket r.; Lpl., Norrl. Vb.

72. C. vesicária L., Skärgräs; fruktgömmen äggformiga. och uppblåsta, afsmalnande till spröt och slutl. utstående; strå hvasskantigt; blad platta. 2, 3.

2-3 fot hög, teml. grof och ljusgrön; blad sträfva (skärande, liksom hos flera af de närstående arterna) och breda; honaxfjäll kortare än fruktgömmet, brungröna och vanl. lansettlika; hanax 2-3 med n. jemnbreda axfjäll; stråslidor upplösande sig i trållar.

Kärrängar och stränder, allmän.

* C. saxátilis L.; hanax vanl. ett; honax 1-2, korta; det öfre n. klotrundt, det nedre n. jemntjockt och kortskaftadt; fruktgömme mera uppblåst, otydligt nervigt med kort spröt, och n. lika långt med de trubbiga, korta och svartaktiga axfjällen; blad smala; märken vanligen 2. Liknar C. ampull. var. rotundata och $C$. rigida.

Fjelltrakter; Lpl. spr., Norrl. Jt1. Herj. spr., Sv. Dal. r.

73. C. ripária Curt., Strandstarr; fruktgömmen äggformiga, på båda sidor kullriga med trubbiga kanter, och något afsmalnande till spröt samt slutl. utstående; strå hvasskantigt; blad platta. 2,3 .

Omkr. 3 fot hög och mycket grof; blad mycket sträfva och breda, ofvan mörkgröna, undertill blågröna; honaxfjäll bruna med grön nerv, äggrundt lansettlika och långspetsade; hanax 3-4, det öfre oskaftadt med syllikt långspetșade axfjäll.

Stränder och kärr; Göt. Hall. Sk. Öl. Ög. słr. Blek. Smål. Boh. r., Sv. Söd. Upl. spr. Vestm. Ner. r., Norrl. Gestr. r.

- gracilescens (Hartm.); blad 2 linier breda, fruktgömme smalare med längre spröt.

Sv. Vestm. mycket $\mathrm{r}$.

74. C. paludósa Good.; fruktgömmen ovala-aflånga, hoptryckta med hvassa kanter och afsmalnande till spröt samt slutl. utstående; strå hvasskantigt; blad platta. 2,3 . 
Omkr. 3 fot hög och grof, något blågrön, med grenskott; blad mycket sträfva och teml. breda; honax smalare än hos de närstående arterna; honaxfjäll vanl. som hos föreg. art, stundom kortspetsiga; hanax 2-3 oskaftade, med de nedre axfjällen rundadt trubbiga och de öfre sylspetsade; fruktgömmen vid mognaden askgrå; stråslidor upplösande sig i trådar. Liknar Carex acuta eller $C$. stricta och har stundom blott 2 märken.

Kärrängar; Göt. r.: Sk. spr. Ög. t. r. Dalsl. Gotl. 0, Sv. r.: Verml. Dal. 0, Norrl. Med. r.

- spadicea; med smalare honax och 2 märken samt långspetsade honaxfjäll.

$$
\text { Göt. Sk. Ög. t. r. Öl. Vg. r., Sv. Söd. Upl. t. r. }
$$

75. C. hirta L., Luddstarr; fruktgömmen på båda sidor kullriga (eller trubbigt trekantiga), afsmalnande till spröt och slutl. utstående; honaxfjäll smalare än fruktgömmet, grönaktiga, äggrundt ovala och spetsiga; stråslidor ej upplösande sig i trådar, alla med utbildad bladskifva; blad platta. 2,3 .

$1-1^{1} / 2$ fot hög, grof och ljusgrön; blad breda, mjuka och blott i kanten sträfva; honax (ătminstone de nedre) skaftade, alla långt åtskilda sinsemellan och från hanaxen; hanax $2-3$, det öfre långskaftadt. Hela växten vanl. mjukluden: stundom äro blott frukterna ludna.

Stränder, helst i slättbygder; Göt. t. a.: Boh. Dalsl. t. r., Sv. t. a.: Verml. r. Dal. 0, Norrl. Gestr. Hels. Jtl. r.

- hirtæformis; nästan glatt och med något stela blad, men för öfrigt lik hufvudarten.

Göt. Gotl. Öl. Sk.-Ög. t. r., Sv. Söd. Upl. Vestm. t. r.

76. C. evolúta Hartm.; fruktgömmen bredt äggformiga, på båda sidor kullriga, afsmalnande till ett kort spröt och upprätta; honaxfjäll något bredare än fruktgömmet, mörkt rostbruna, äggrunda och spetsiga; stråslidor ej upplösande sig i trådar, de nedersta utan utbildad bladskifva; blad platta. 2,3 .

3-4 fot hög och grof; blad tem]. breda och sträfva; honax af mörk färg, det nedre kortskaftadt: alla åtskilda sinsemellan och från hanaxen; hanax 2--3, det öfre långskaftadt. Liknar C. riparia och föreg. art, af hvilka denna torde vara en bastard. Stränder, mycket r.; Göt. Smål. Ög., Sv. Upl. Vestm.

77. C. filiformis L.; fruktgömmen ovala eller äggformiga, på båda sidor kullriga eller trubbigt trekantiga, afsmalnande till spröt och slutl. utstående; honaxfjäll smalare än fruktgömmet, bruna, äggrunda-lansettlika; stråslidor upplösande sig $\mathrm{i}$ trådar, de nedre utan utbildad bladskifva; blad rännformiga, snart inrullade och tradlitia. $2,3$.

$2-3$ fot hög och n. blågrön; strå spensligt och n. trădlikt; honax 2-3 oskaftade, eller det nedersta kortskaftadt, långt åt- 
skilda; hanax 1-2, det öfre långt och vanl. långskaftadt; fruktgömmen hvitludna. Liknar något Buxbaumii.

Kärrängar; Lpl. Norrl. Sv. t. a., Göt. spr.: Boh. Öl. Gotl.r. 446. Kobrésia. Säfstarr.

1. K. scírpina Willd.; ax (axsamling) ensamt och jemnbredt; småax med en hanblomma och en honblomma; blad borstlika af stråets längd med slidor, som upplösa sig i tina trådar. 3 .

Omkr. $1 / 2$ fot hög och tätt tufvad; strå föga tjockare än bladen; ax tumslångt.

Torra backar och klippor i fjellen ofvan barrskngsregionen; Lpl. spr., Norrl. Jtl. Herj. r.

2. K. caricina Willd.; axsamling bestående af flera sammansatta och enkönade småax, de öfre med hanblommor, de nedre med honblommor; småax nästan enblommiga; blad rännformiga plattade och kortare än strået med hela slidor. 3.

Vanl. något lägre och gröfre än föreg. och ej så tätt tufvad samt med bredare blad; axsamling omkr. tumslång.

Teml. torra öppna ställen i fjellen ofvan barrskogsregionen; Norrl. Jtl. Herj. t. $r$.

\section{Typha. Kafveldun.}

1. T. latifólia L., Bredbladigt Kafveldun; hanax sammanhängande med honaxet; honaxets fäste utan hår; märke tunglikt eller klubblikt. 3 .

3-6 fot hög med omkr. tumsbreda blad; honax ofta n. tumstjockt och slutl. mörkbrunt med fjällig yta.

I vatten, äfven i skärgården; Göt. t. r.: Hall. Sk. a. Ög. spr., Sv. spr.: Ner. Vermil. t. r. Dal. 0, Norrl. Gestr. Hels. Vb.r. 2. T. angustifólia L., Smalbladigt Kafveldun; hanax aflägsnadt från honaxet; honaxets fäste hårigt; märke jemnbredt-syllikt och trådsmalt. 3 .

Lika hög som föreg. art med mycket smalare blad; honax vanligen dubbelt smalare och rödbrunt med trådig yta.

I vattenl; Göt. spr.: Gotl. Öl. r. Smål. Dalsl. t. r., Sv. spr.: Söd. Ner. t. a. Dal. r., Norrl. Gestr. spr. Hels. r.

\section{Spargánium. Igellnopp.}

A. Hanblomhufvud mycket mindre än honblomhufvudena; skärmfjäll upptill hela. Blomhufvud stälda i skiftevisa, bladlösa och vanl. skaftade ax, som utgå från de öfre bladvecken; hvarje ax med få honblomhufvud nedtill och talrika hanblomhufvud upptill.

1. S. ramósum Huds.; blad trekantiga; frukt 3-4 gånger längre än sprötet. 3 .

$2--3$ fot hiig och upprätt, mera grof och bredbladig än de öfriga arterna; blomhufvud vanl. oskaftade, de öfre stundom närmade; hela hlomsamlingen liknande en vippa. 
I vatten; Göt. spr.: Sk. Hall. a., Sv. spr.: Verml.t. r., Norrl. Gestr.-Ang. r.

B. Alla blomhufvud nästan lika stora; skärmfjäll i spetsen tandade. Honblomhufvud (honax) enstaka, sittande i eller ofvanför de öfre bladvecken, de nedre hufvudena skaftade; hanblomhufvud (hanax) blott i stjelkens spets.

Någon gång blir stjelken upptill oordentligt förgrenad; stundom saknas blomstödjeblad hos de öfre honaxen.

a. Blad åtminstone nedtill trekantiga; frukt aflång, tjockast på midten; stjelk vanl. rak och upprätt.

2. S. simplex Huds.; frukt knappt längre än sprötet; honax skilda sinsemellan och från de vanligen talrika hanaxen. 3.

I grundt vatten omkr. "fotshög med"teml. styfva och upprätta, öfver ett par linier breda blad, i djupare vatten längre och flytande, stundom liknande $S$. natans.

I vatten; Göt. Sv. a., Norrl. spr.:' Gestr. a. Jtl. Vb. r., Ipl. r.

3. S. glomerátum Læst.; frukt 3-4 gånger längre än sprötet; de öfre honaxen tätt gyttrade intill det ensamma hanaxet. 3.

$1-1^{1} / 2$ fot hög med lika breda blad som hos föreg. art. S. fluitans Fr.

Kärr och bäckstränder, helst i skogsbygder; Lpl. r., Norrl.

Vb. Ång. Hels. Gestr. t. r., Sv. Verml. spr. Dal. Söd. r., Göt. Ög. Smål. spr. Sk. r.

b. Blad platta; frukt äggformig, tjockast nedtill; stjelk vanl. krokig. Ax åtskilda.

4. S. natans Fr., Flotagräs; frukt långskaftad, nervlös och kortare än sprötet; hanax talrika. 3 .

Omkr. 4-6 fot lång med omkr. liniebreda, alltid flytande och mycket långa blad.

Sjöar; Göt. r.: Smål. spr. Vg.? Ö1. Gotl. 0, Sv. spr.: Verml. t. r. Dal.?, Norrl. r.: Gestr. Hels. spr. Vb. Herj.?

5. S. affíne Schnizl.; frukt kortskaftad, nervig och kortare än sprötet; hanax ett eller två. 3 .

Mindre än föreg. art med dubbelt bredare, alltid flytande blad.

Vid stränder, helst i sjöar; L Lpl. spr., Norrl. Ang. t. a. Jtl. spr., Sv. Dal. spr. Vermil. t. r. Söd. r., Göt. r.: Vg. Blek. Ö1. Gotl. 0. - Är i Norrl. trol. mera vanlig.

6. S. mínimum Fr.; frukt n. oskaftad, nervlös och åtminstone dubbelt längre än sprötet; hanax ett. 3 .

Omkr. ${ }^{1 / 2}$ fot hög med 1-3 linier breda och vanl. flytande blad.

Kärr och diken, helst i skogstrakter; Göt. mångenst.: Smål. Ög. t. a. Gotl. t. r., Sv. a.: Verml. Dal. spr., Norrl. spr.: Vb. r. Jtl.?, Lpl. r.

* S. oligocarpon Ångstr.; frukt kortskaftad, otydligt nervig, ej mycket längre än sprötet; hanax stundom 2 . 
Omkr. fotshög och något lik $S$. simplex samt mera upprätt än hufvudarten; bladslidor mera utvidgade och i kanterna hinnaktiga; de flesta frukterna felslående.

Kärr: Lpl. r., Norrl. r.: Med. Gestr. Herj.?, Sv. r.: Ner. Dal.?, Göt. Dalsl. Vg. Ög. r.

7. S. hyperbóreum Læst.; frukt oskaftad och nästan utan spröt; hanax ett. 3 .

Vanl. blott några tum, stundom öfver en fot hög med $1 / 2-2$ linier breda och vanl. flytande blad, hvars slidor äro mer eller mindre utvidgade.

Kärr i fjelltrakter; Lpl. spr., Norrl. Vb. Ång. t. r. Hels. Jtl. Herj. r., Sv. Dal. r.

\section{Ordn. TETRANDRIA.}

\section{Littorella. Strandpryl.}

1. L. lacustris L.; blad syllika. 3 .

Omkr. tumshög med bruna ståndareknappar och långa, hårfina stift; honblommor oskaftade.

Stränder, helst vid sjöar; Göt. spr.: Gotl. t. a., Sv. spr.: Upl. Vestm. t. r. Dal.?, Norrl. Hels. Ang. r., Lpl. r.

\section{Urtíca. Nässla.}

1. U. urens L., Etternässla; sambyggare; blomkransar förenade i n. enkla och teml. tjocka ax. $2,3$.

Omkr. fotshög och glänsande grö̀n; blad sågtandade, vanl. ovala och föga längre än skaftet; blommor gröna; rot enårig.

Allmänt ogräs.

2. U. dióica L., Brännässla; tvåbyggare; blomkransar stälda i vippa. $2,3$.

2-3 fot hög och mörkgrön; blad sågade, vanl. äggrundahjertlika och oftast betydligt längre än skaftet; blommor gulgröna. Mindre brännande än föreg. art. Mångårig.

Allmänt ogräs och ruderatväxt.

\section{Bétula. Björk}

A. Honhängefjällens flikar olikformiga.

a. Honhängefjäll grundt inskurna; blad tunna med föga upphöjda ådror; nöt lika bred som vingkanten eller ofta smalare. Dessa arter sätta sällan frukt, förr än de antagit trädform.

1. B. verrucósa Ehrh., Stenbjörk, Masurbjörk; yngre grenar ki̊dprickiga och ej ludna; blad alltid glatta och med stark vaxafsöndring. 1.

Slutligen högt träd med i äldre tillstånd sprickfull bark; blad vanl. dubbelsågade och snedt rutformiga med utdragen spets, stundom äggrunda-ovala; honhängefjäll med vanl. utböjda sidoflikar; nôt alltid smalare än vingkanten; honhängen och blad långskaftade.

Skogar; Göt. Sv. a., Norrl. spr.: Gestr. Hels. a. Ång. Vb. r., Lpl. r. En form med djupt klufna blad (forma laciniảta) är 
funnen i Dal. Ög. Vg. och Smål., en form med klufna blad i Dalsl. och Verml.

2. B. odoráta Bechst., Glaskjörk; grenar utan kådprickar; de yngre grenarnes toppar finludna; blad utan vaxafsöndring, undertill ofta med bladtofsar. 1 .

Slutl. högt träd (stundom äfven såsom buske fruktbärande) med slät bark; blad vanl. enkelsågade och äggrunda utan utdragen spets; honhängefjäll oftare med icke utböjda sidoflikar; nöt vanl. smalare än vingkanten; honhängen vanl. långskaftade, i fjelltrakter ofta upprätta; yngre blad ofta ludna.

Skogar och fuktiga ängar, teml. allmän.

b. Honhängefjäll flikiga; blad tjocka rned upphöjda ådror; nöt lika bred som vingkanten eller något, bredare. Högre buske eller lägre träd, fruktbärande redan såsom buske.

3. B. intermédia Thom., Fjellbjörli; yngre grenar kådprickiga med småludna toppar; blad med stark vaxafsöndring. 1.

Med alltid brunaktig bark; blad vanl. rundadt hjertlika och kortspetsiga, vanl. sågade, stundom n. naggade, med teml. utdragna skaft; honhängefjällens sidoflikar framåt rigtade; honhängen teml. långskaftade och upprätta. Denna art anses af Spach vara bastard af $B$. odorata och $B$. nana och innefattar former, som mer eller mindre närma sig den ena af dessa arter.

Helst i fjellen i björkregionen, stundom i lägre fjelltrakter, sällan utom fjellen; Lpl. a.?, Norrl. spr.?, Sv. Dal. Upl. r. Verml. t. r., Göt. Boh. Smål. r.

B. Honhängefjällens flikar likformiga: sidoflikarne framåtrigtade. Blad kortskaftade och tjocka med upphöjda ådror samt utan vaxafsöndring. Låga buskar med ofta till jorden nedtryckta grenar; de yngre grenarne gråludna n. utan kådprickar.

4. B. alpestris Fr.; honhängefjäll djupt klufna; nöt lika bred som vingkanten eller föga bredare. 1 .

Liknar mest följ. art, men är ofta något högre med vanl. ej nedtryckta grenar; bladen äro något större och rundade (stundom bredt eller omvändt äggrunda) naggade eller $n$. sågade.

I fjellen, helst $\mathrm{i}$ öfversta delen af björkregionen; Lpl. spr., Norrl. Jtl. Herj. r. Hels.?

5. B. nana L., Dvergbjörk, Vivang; honhängefjäll delade; nötens vingkant mycket smal. 1, 2.

1-2 fot hög och risig buske; blad n. cirkelrunda, naggade. Skogsmossar och myrar; Lpl. a., Norrl. a.: Hels. Gestr. spr., $S v$. Dal. a. Verml. t. a. Ner. Vestm. spr. Upl. r., Göt. Vg. Dalsl. -Hall. Ög. r. Smål. spr.

Anm. B. urticæfólia Spach (enl. Larss.), som (i Flora öfver Verml. och Dal sid. 312) uppgifves vara vild i Verml. i 
Gräsmarks s:n vid Granbäck och Granbäckstorp, beskrifves (af Lektor Larsson) med följ. kännetecken:

Blad triangelformigt hjertlika eller rutformiga, långt tillspetsade, flikigt inskurna och hvasst dubbelsågade, tjocka och af vaxafsöndring hvitfläckiga; yngre grenar tätt mjukhăriga; honhängen kortskaftade, långa och smala; honhängefjäll med mycket korta sidoflikar; fruktvinge mycket smal.

Som den uppgifna arten knappt torle vara funnen såsom vild i Europa, synes ifrågavarande form tvifvelaktig. Förf. har ej granskat fruktbärande exemplar deraf.

\section{Alnus. $A$.}

1. A. glutinósa Willd., Svartal, Fetal; blad klibbiga, med hårtofsar undertill i nervernas vinklar, för öfrigt glatta (i äldre tillstånd). 1.

Teml. högt träd med svartaktig och knölig bark; blad mörkgröna, rundade-ovala eller omvändt äggrunda, upptill vanl. urnupna, nedtill vanl. vigglika, i kanten dubbelsågade.

Fuktiga ställen i skogar och på stränder; Göt. a.: Gotl. t. r. Boh. spr., Sv. a.: Verml. Dal. spr., Norrl. Gestr. a. Hels.Ang. spr.

2. A. incána Willd., Alder, Arre, Grial, Hvital; blad ej klibbiga, slutl. undertill tätt finludna. 1.

Lägre än föreg. med gråhvit och slät bark; blad ljusare gröna, undertill stundom blågröna, med vanl. vigglik bas och utdragen spets, i _kanten dubbelsågade. Blommar något tidigare än föreg. art.

Stränder; Lpl. spr. i barrskogsreg., Norrl. a., Sv. spr.: Dal. Verml. a. Söd. r.,..Göt. Dalsl. spr. Boh.' r.? Vg.t.r. Hall. r. Smål. (i n. delen) spr. Ög. (v. om Stångån) spr.

- pubescens (Tausch); blad oftast trubbiga, nedtill ofta rundade och undertill mindre ludna.

Helst i fjelltrakter; Lpl. t. a., Norrl. spr.: Jtl. Herj.? Ång. t. a. Gestr. r.?, Sv. Upl. r.

Anm. Hos dessa arter äro bladen någon gång n. parklufna, sällan pardelade.

\section{Ordn. POLYANDRIA.}

\section{Sagittária. Pilört.}

1. S. sagittæfólia L.; blommor motsatta eller 3 i hvarje krans. 3 .

1-2 fot hög; de inre kalkbladen hvita och nedtill röda; fruktsamling klotrund, pă ett halfrundt fäste; rotstock med lökformiga knölar.

I vatten; Göt. t. a.: Blek. r. Boh. r.? Öl. Gotl. 0, Sv. t. a., Norrl. spr.: Jtl. r., Lpl. r.

\section{Myriophyllum. Vattenslinga.}

A. Alla blommor kranssittande.

1. M. verticillátum L.; skärmblad pardelade eller parklufna, öfverskjutande blornmorna. 3. 
Stjelk omkr. 1-2 fot lång och vanl. grön; ofvan blomsamlingen sitter vanligen en bladtofs.

Vatten, i synnerhet i diken, helst i slättbygder; Göt. t. r.: Gotl. t. a. Sk. Kalmarl. Ög. spr. Dalsol. 0, Sv. Söd. Upl. spr. Vestm. Ner. r., Norrl. Gestr. spr. Hels. Ång. r.

2. M. spicátum L.; skärmblad ej öfverskjutande blommorna, de nedre tandade, de öfre hela. 3.

Stjelk omkr. 2-4 fot lång och vanligen grön.

Sjöar och åar; Göt. spr.: Smål. r. Dalsl. Boh.?, Sv. spr.: Vestm. r. Verml. Dal.?, Norrl. r.: Ång. Med. Jtl. Herj.?, Lpl. r. - squamósum Læst.; nedre stjelkblad små med korta och breda flikar, liknande skärmbladen hos föreg. art. Lpl. r., Norrl. Jtl. r.

B. De öfre blommorna enstaka och skiftevis stälda. 3. M. alterniflórum D.C.; skärmblad hela, ej öfverskjutande blommorna; de nedre blommorna stundom stödda af blad. 3 .

Stjelk vanl. rödaktig, flera fot lång och finare än hos de föreg. arterna samt med kortare blad.

Helst i sjöar, stundom i åar, trol. allm.: Gotl. Öl. 0.

455. Potérium. Får- Pimpinell.

1. P. Sangvisorba L.; småblad rundade-aflånga sågade; ståndare långa och nedböjda. 3.

Glatt eller nedtill hårig, 1-2 fot hög och n. upprätt; stjelk kantig; blad 6--9-pariga.

Torra betesmarker eller trädesåkrar, r.; Göt. Sk. Smål. (Ög. vid Motala trol. tillfällig), $S v$. Söd. Upl.

456. Ceratophyllum. Hornserf.

1. C. demersum L.; frukt med 2 taggar nedtill; blommor ensamma i bladvecken och oskaftade. 3 .

Omkr. 1-2 fot lång och mörkgrön med n. trådsmal stjelk och taggtandade bladflikar; stift längre än frukten.

Sjöar, åar, dammar och hafsvikar; Göt. Boh.-Sk. spr. Blek. r. Smål. t. r. Ög. t. a. Vg. Dals]. r., $S v$. Söd. Upl. spr. Ner. t. r., Norrl. Hels.-Ång. r.

* C. submersum L.; frukt utan taggar och längre än stiftet; blad ljusgröna och finare delade.

Åar och vattengrafvar; Göt. Skåne t. r. i v. delen.

\section{Arum. Munkmössa.}

1. A. maculátum L.; blomkolf upptill klubblik, innesluten inom hölstret. 2 .

1/2-1 fot hög, något lik Calla; kolf upptill mörkviolett; bär röda; hölster omkr. dulıbelt längre än kolfven. Är mycket giftig.

Fuktiga skogar och parker; Göt. Skåne t. r.

458. Córylus. Hassel.

1. C. Avellána L.; blad rundadt hjertlika, tvärt kortspetsade och undertill blekgröna. 1. 


\section{XXI. monofcia. 458-461. XXII. n’oecia. 462. 351}

Hög buske med gråludna årsgrenar; nöt vanl. äggformig, stundom n. klotrund. En form med grundt parflikiga blad ầr funnen på ett par ställen i Regna s:n i Ög.

Lundar och ängsbackar; Göt. a., Sv. a.: Verml. t. a. Dal.t. r., Norrl. Gestr. spr. Hels.-Ång. r.

\section{Carpínus. Annbok, Avenbok.}

1. C. Bétulus L.; blad kortskaftade, ovala eller aflängt äggrunda. 1, 2.

Vanligen buske, stundom träd med slät askgrå bark, hård hvit ved och bruna, slaka hanhängen; blad omkr. 2 tum breda; nötter mindre än ärter.

Skogsängar; Göt. Hall. Smål. t. r. Sk. t. a. Blek. spr. Öl. t.r. 460. Quercus. Ek.

1. Q. Robur L.; blad n. aflånga, upptill bredare, bugtigt. flikiga med trubbiga flikar. 2.

Stort träd med mycket hård ved, knölig stam och utbredda grenar; ollon vanl. smalt äggformigt eller aflångt.

a. pedunculáta (Ehrh.), Sommarek; blad affallande före vintern, med vanligen korta skaft; ollon oskaftade på ett utdraget gemersamt fäste.

Lundar; Göt. a., Sv. Söd. Upl. a. Ner. t. a. Vestm. Verml. spr. Dal. r.

- Ianceoláta (v. Post); blad utdraget lansettlika och ej flikiga. Göt. Smål. i Högsbo s:n på ön Keanäs.

h. sessiliflóra (Salisb.), Vinterek; blad qvarsittande under vintern, med năgot utdragna skaft; ollon oskaftade på ett mycket kort gemensamt fäste.

Lundar; Göt. t. r.: Öı. a. Smål. Sk.-Boh. spr.

\section{Fagus. Bol.}

1. F. silvática L.; blad ovala, skaftade och hårbräddade. 2.

Högt och lummigt träd med blekgrå och slät bark och utspärrade grenar; nöt trekantig.

Lundar; Göt. Boh. t. r. Dalsl. Vg. r. Hall. t. a. Sk. Blek. a. Smål. spr. Ög. r.

\section{Klassen. DIOECIA.}

\section{Ordn. MONANDRIA.}

462. Najas. Taggnate.

1. N. marina L.; blad motsatta eller 3 i krans, tagglikt bugttandade; nöt aflångt äggformig. 3,4 .

Hela växten nedsänkt och blommande under vattnet, spröd och stundom rödaktig, torkad grön och n. genomskinlig; ofta flera $1 / 2-1^{1 / 2}$ fot höga, upptill klynnedelade, stjelkar från roten; hölstrets filkar hos honblommorna med lång udd, hos hanblommorna med kort udd. Hanväxten är föga grenig. 
Grunda hafsvikar, sällan (på Gotl.) i sött vatten; Göt. Hall. Sk. r. Blek. Kalmarl. spr. Ög. t. r. Gotl. (i Fardume träsk) r., Sv. spr., Norrl. Gestr. r.

2. N. fléxilis Rostk. o. Schm; de nedersta bladen ofta motsatta, de öfre 5-6 i hvarje krans, ofvan midten glest finsågade; nöt smalt äggformig. 3, 4 .

Lik föreg., men betydligt spädare; blad knappt tumslånga.

Dyiga insjöar, mycket r.; Sv. Upl. i sjön Hederviken nära Braheberg i Närtuna s:n.

\section{Juníperus. En, Enbuske.}

1. J. commúnis L.; barr syllika, 3 i hvarje kraus. 1.

Vanl. låg buske, förkrympt genom inverkan af insekter, som efterlikna bären genom hopvikning af 3 barr, utväxande till s. $k$. kikbär; om insekterna kunna aflägsnas t. ex. genom svafvelrök o. d., făr växten likhet med en cypress och kan blifva ganska hög. Bären blifva först 3:dje året mogna och svartblå.

Skogar och hedar, allmän.

-- nana, Fjell- En; barr mycket korta och hopträngda samt något bredare än hos hufvudarten.

Helst uppe i fjellen, någon gång i skärgården; Lpl. a., Norrl. Jtl. Herj. spr. Ång. r., Sv. Söd. r., Göt. Gotl. r.

\section{Taxus. Idegran, Barrlind.}

1. T. baccáta L.; barr platta och bladlika. 1, 2.

Buske eller mindre träd med platta grenar och tumslånga barr.

På berg, helst vid hafvet och i Dalslands "fjellbygd"; Göt. r.: Dalsl. spr. Boh. Snıål. Blek. Gotl. t. r., Sv. Söd. Upl. t. r. Ner. Verml. r., Norrl. Gestr. r.

\section{Ordn. DIANDRIA. \\ 465. Salix. Pil eller Vide.}

A. Pilar. Hängefjäll ljusgula, vanl. snart affillande (hos S. triandra längre qvarsittande). Fröhus glatta med kort eller intet stift. Hängen med bladigt skaft. Blomning teml. sen, samtidig med bladens utveckling. Träd eller högre buskar.

a. Fröhus n. oskaftade. Stipler aftallande. 1. S. pentandra. 2. S. fràgilis. 3. S. alba.

b. Fröhus skaftade. Stipler stora, qvarsittande. 4. S. triandra.

B. Korgviden, Bandpilar. Hängefjäll upptill svartbruna. Fröhus oskaftade med liingt stift. Häng'en oskaftade bladlösa, utslående före bladen (tidigt pă våren). Grenar långa och "sega (vidjelika). Träd eller högre buske. 5. S. daphnóides.

c. Viden. Hängefjäll vanl. upptill svartbruna (hos $S$. vagans och $S$. myrtilloides ljusgula). Fröhus med utdraget skaft. Smågrenar teml. korta. Oftare buskar.

a. Stift kort. Blomning före bladens utveckling. Blad skrynkliga och vanl. ludna. Buskar eller träd med teml. tjocka hängen. 6. S. caprea. 7. S. cinerea. 8. S. aurita. 
b. Stift kort eller intet. Blomning vanl. samtidig med bladens utveckling. Blad släta, teml. små och vanl. äldre glatta. Buskar med smala hanhängen. 9. S. vagans. 10. S. repens. 11. S. myrtilloides.

c. Stift utdraget. Blomning vanl. samtidig med bladens utveckling. Buskar ined ofta släta blad och teml. tjocka hängen. 12. S. nigricans. 13. S. hastata. 14. S. phylicæfolia.

D. Fjellviden. Hängefjäll vanl. upptill svartbruna (hos $S$. glauca ofta rödaktiga och ej bruna upptill). Fröhus n. oskaftade med utdraget (eller hos $S$. glauca och $S$. arbuscula ofta kort) stift. Teml. låga buskar med korta, vanl. knöliga smågrenar. Hängen utgående antingen (liksom hos föreg. arter) från sidan af grenarne eller (ofta hos S. lanata och S. myrsinites) från grentopparne.

a. Hängen oskaftade, bladlösa och vanl. utslående före bladen. Stipler stundom utbildade. Blad mjuka. 15. S. Lapponum. 16. S. Ianata.

b. Hängen med långt bladigt skaft, vanl. samtidiga med bladen. Stipler sällan utbildade. Blad stela eller (hos $S$. glauca) mjuka. 17. S. glauca. 18. S. arbuscula. 19. S. myrsinites.

E. Högfjellviden. Hängefjäll brunaktiga eller (hos S. herbacea) gula. Fröhus n. oskaftade med tydligt stift. Hängen utslående efter bladen och sittande blott i toppen af grenarne. Låga buskar, hvars grenar till största delen äro dolda under jordytan, med stela blad.

a. Hängen korta. Blad släta, glatta och mycket små. Grenar rödbruna. 20. S. herbacea. 21. S. polaris.

b. Hängen utdragna och smala. Blad skrynkliga, undertill upphöjdt nätådriga och ludna. Yngre grenar rödvioletta.

\section{S. reticulata.}

1. S. pentándra L., Hilster, Jolster; hanhängen upprätta; honhängen slaka och hängande; stipler äggrundt aflånga; blad klibbiga; ståndare vanl. 5, stundom 4-12.

6-10 fot hög buske, nästan till alla delar glatt; bladskaft körtelbärande; hängets axel glatt; blad äggrunda-lansettlika och spetsade, undertill blekgröna; hängefjäll äggrunda eller omvändt äggrunda; ståndareknappar guldgula.

Fuktiga skogsängar, allmän: Lipl. spr. i lägre trakter.

2. S. frágilis L., Skörpil; hängen slaka och hängande; stipler halft hjertlika; blad ej klibbiga: ståndare 2.

Träd med (isynnerhet vid blomningstiden) i grenvecken mycket bräckliga grenar, som ofta afblåsas; bladskaft ej körtelbärande; blad i början ovala, trubbade och undertill silkeshåriga (på somliga skott äfven i början lansettlika), slutligen lansettlika med utdragen, vanl. sned spets och glatta, undertill isgrå eller blågröna; hanhängen före utslagningen långhåriga; ståndareknappar halmgula; frukter vid torkning svartnande Honhängen förekomma sällan (t. ex. i Ög. och vid Stnckholm). 
Stränder och vägar, helst nära bostäder; Göt. Sv. a.: Boh. -Dal. spr., Norrl. Gestr. spr. Hels. r.

3. S. alba L., Hvitpil; hanhängen bågböjda; honhängen slaka och hängande eller nedböjda; stipler lansettlika; blad ej klibbiga; ståndare 2.

Högt träd, som teml. liknar den föreg., men med upprätta, föga bräckliga grenar; blad rent gröna eller af hårbeklädnaden hvitaktiga, vanl. lansettlika (stundom teml. breda) och rakspetsade, på båda sidor mer eller mindre silkeshåriga; ståndareknappar guldgula; stift otydligt.

Nära bostäder, ursprungl. planterad och förvildad; Göt.spr.: sk. Blek. a. Vg. Boh. Dalsl. 0, Sv. Söd. Upl. spr.

4. S. triándra L., Mandelpil; hängen upprätta eller utstående; stipler snedt hjertlika och tandade; blad ej klibbiga; ståndare tre.

Hög buske eller träd; stammens bark lätt lossnande och ofta styckevis affallande; grenar gulaktiga och sega; bladskaft stundom körtelbärande; blad lansettlika-aflånga, ofta med rak och utdragen spets, glatta och undertill ofta blågröna; hanhängen före utslagningen finhåriga, slutl. glesa; ståndareknappar guldgula; frukter ej svartnande.

Sandiga elfstränder: Norrl. Vb.-Med. Gestr. r., Sv. Upl. r. Dal. spr. Verml. a. vid Klarelfven.

5. S. daphnóides Vill., Blåvide; hängen utstående; stipler snedt äggrunda-aflånga och qvarsittande; blad lansettlika spetsade och slutl. glatta, i kanterna med glandelbärande sågtänder; ståndare två.

Grenar röda, tidtals blådaggiga; hängen i början mycket ulliga och silfverglänsande af de långhåriga hängefjällen; blad ljusgröna och ofta $1 / 2$ fot långa; fröbus glatta.

Sandiga elfstränder; $S v$. Dal. r. vid Dalelfven, Verml. mångenst. vid Klarelfven.

6. S. cáprea L., Sälg; hanhängen ovala-äggrunda; knoppar glatta; yngre grenar nästan glatta eller något finhåriga, slutl. glatta; honhängen oskaftade och n. bladlösa; fröhus gråludna.

Vanligen något högt träd med tjocka och gulaktiga grenar, stundom buske med brunaktiga grenar; blad stora och breda, ovala-aflånga, smånaggade, och vanl. rakspetsade, ofvan slutl. glatta, i början hvitglänsande; hängen tjocka med långhåriga fjäll; stipler njurlika och qvarsittande; ståndareknappar gula; honhängefjäll spetsiga.

Skogsängar, allmän.

7. S. cinérea L., Grivide; hanhängen aflånga; knoppar och smågrenar gråludna; honhängen oskaftade och n. bladlösa; fröhus gråludna.

Hög buske mer föga grenade och teml. tjocka grenar; blad aflånga-lansettlika, vågbräddade, ofvan småludna och undertili 
med upphöjda nerver; honhängen långa och smala med gråludna fjäll; stipler länge qvarsittande; ståndareknappar i början rödbruna, slutl. mörknande. Eljest som föreg. art, som denna står ganska nära.

Fuktiga ängar; Göt. Sv. a., Norrl. spr. utom fjellen: Ång. r. Med.? Vb. 0, Lpl. r.

8. S. aurita L.; hanhängen $n$. jemntjocka; knoppar glatta; smågrenar glatta eller stundom finhåriga (och slutl. glatta); honhängen kortskaftade och något bladiga; fröhus hvitludna (eller sällan n. glatta).

Mycket grenig, ända till 12 fot hög buske med mörkbruna grenar; blad omvändt äggrunda med kort nedböjd spets, glandulöst vågbräddade, ofvan småludna, undertill blăgröna, smärre och skrynkligare än hos de båda föreg. arterna; äfvenså äro hängena och knopparne smärre; hängefjäll föga håriga och blekare; stipler njurlika; ståndareknappar slutl. mörknande; honhängefjäll något trubbiga och rostbruna. Bladen kunna någongång vara på båda sidor glatta.

Fuktiga ängar; Göt. Sv. a., Norrl. spr.: Gestr. Hels. t. a. Med. Vb.?, Lpl. r. i barrskogsreg.

9. S. vagans Ands.; hanhängen smala; honhängen kortskaftade och något bladiga; knoppar och grenar glatta; fröhus finhåriga (sällan glatta); blad med platta kanter.

Låg och merändels upprätt buske med rödbruna eller grönaktiga, mycket fina grenar; blad tunna, n. tunglika eller aflảnga, n. helbräddade; hängen små, men teml. långa; hängefjäll gulaktiga; ståndareknappar gula; honhängefjäll tunglika - jemnbreda ; stipler teml. små. Bladen äro i början nästan lika små som hos följ. art.

a. livida; blad n. parallelt nerviga, glatta och undertill isgrå; knappt fotshög.

b. bicolor; blad nätådriga, undertill i början finludna och slutl. blågrå; stipler ofta njurlika; $1-4$ fot hög.

Fukt. ängar; Lpl. a., Norrl. spr.: Gestr. t. r., Sv. t. r.: Dal. spr. Söd. r. Ner. 0, Göt. Ög. t. r. Vg. Smål. Sk. Gotl. r. - Hufvudformen torde blott finnas i Lpl. och Norrl.

10. S. repens L., Krypvide; hängen vanligen i början ovala; honhängen kortskaftade och n. bladlösa; grenar och fröhus håriga eller glatta; blad med nectvilence kanter.

Vanligen låg buske af $1 / 2-2$ fots höjd. Varierar i hög grad, men är lätt att igenkänna på bladen, som äro smärre än hos dé öfriga arterna och lätt svartnande vid torkning, till formen vanligen aflånga och $\mathrm{n}$. helbräddade, ofta (isynnerhet undertilly mer eller mindre silkeshåriga; hängen små och korta; ståndareknappar slutl. mörknande; honhängefjäll spadlika; stipler otydliga.

Fuktiga ängar; Göt. Sv. a., Norrl. r.: Gestr. Hels. a. Med. Jtl.?

* S. rosmarinifólia L.; blad smalare och längre med platta kanter, undertill silkeshåriga; fröhus hvitludna.

Göt. Hall. Sk. Gotl. r. 
11. S. myrtillóides L.; hanhänǵen jemntjocka; honhängen med liingt bladigt skaft; knoppar, fröhus och grenar glatta; blad vanl. med platta kanter.

Låg och upprätt, n. alldeles glatt buske, liknande Vaccinium uliginosum; grenar bruna och fina; blad aflånga helbräddade, undertill blåaktiga, $\mathrm{i}$ början n. ljusröda, stundom med hjertlik bas; hängen små och korta; hängefjäll gulaktiga; honhängefjäll n. tunglika; ståndareknappar guldgula med röda knappar, slutl. mörknande; stipler små; stift otydligt.

Kärr, helst i lägre fjelltrakter; $L p l$. spr., Norrl. spr.: Ång. -Hels. r. Gestr. 0, Göt. Smål. r. nära Vimmerby och Vexiö.

12. S. nígricans Sm.; honhängefjäll (i synnerhet de nedre) spetsiga och håriga; fröhus och blad glatta eller håriga, lätt svartnande; smågrenar och knoppar vanligen ludna.

4-8 fot hög buske med vanl. mörkröda grenar; blad teml. mjuka, mycket föränderliga till form och beklädnad, ovala-lansettlika, vanl. rakspetsade och vågbräddadt sågade, ofvan mörkgröna och undertill askgrå samt slutl. glatta med upphöjda nerver och hårig medelnerv; stipler halft hjertlika eller n. äggrunda med rak spets; ståndareknappar gula; honhängen med kort och något bladigt skaft.

Fuktiga ängar; Lpl. Norrl. Sv. a., Göt. spr.: Ög. Dalsl. t. a. Boh. Blek. Gotl.?

13. S. hastáta L.; honhängefjäll spadlika och upptill långhåriga; fröhus och blad glatta, ej svartnande vid torkning; smågrenar och knoppar upptill ludna.

$3-5$ fot hög buske med korta svartaktiga grenar; blad snart läderartade, de nedpå grenarne sittande lansettlika, de öfre vanl. ovala, alla undertill blekgröna och nätådriga; stipler vanl. stora och hjertlika, med rak spets, och finsågade; ståndareknappar i början rödaktiga, slutl. gula; honhängen med kort och något bladigt skaft.

Fuktiga ängar, helst i fjellen; Lpl. t. a., Norrl. Jtl. Herj. spr. Ång. Hels. r., Sv. r.: Dal. t.r. Söd. Ner. 0, Göt. Vg. Ög. Sk.t. r. 14. S. phylicæfólia Sm.; honhängefjäll vanl. spetsiga och upptill håriga; fröhus vanl. ludna; blad slutl. glatta och ej svartnande; smågrenar och knoppar glatta.

Omkr. 2- a fot hög med vanl. mörkröda grenar; hlad teml. tunna och fasta, ovala-lansettlika, ofvan glänsande, undertill blågröna med föga upphöjda smånerver; stipler små, (sällan utvecklade) och halft hjertlika; ståndareknappar guldgula; honhängen med kort och föga bladigt skaft; fruktskaft vanl. kortare än hos $S$. nigricans.

I eller nära fjellen på fuktig mark; Lpl. a., Norrl. Vb. Ång. a. Jtl. Herj. spr., Sv. Dal. spr. Verml. Vestm. r. Söd.?

15. S. Lappónum L., Lapskt Vide; honhängefjäll vanl. spetsiga och hvitulliga; fröhus hvitludna; smågrenar 
håriga; stipler (sällan utvecklade) halft hjertlika, snedspetsade och helbräddade.

Ungefär lika hög som föreg. eller ofta lägre; de äldre grenarne bruna; blad tjocka, äggrunda-lansettlika och helbräddade med något nedböjda kanter, ofvan slutl. n. glatta och skrynkliga, undertill vanl. snöhvitt filtludna; ståndareknappar gula, slutl. mörkbruna.

Fuktiga ställen, helst i fjellen; Lpl. a., Norrl. a.: Med. Hels. spr. Gestr. r., Sv. Dal. Vestm. spr. Verml. t. r. Ner. r. Upl. t.r. 16. S. lanáta L., Ullpil; honhängefjäll trubbiga med vanl. guldglänsande hår; fröhus glatta; smågrenar tätulliga; stipler (ofta mycket stora) halft hjertlika, snedspetsade och med glandelbärande sågtänder.

Omkr. 1-4 fot hög; äldre grenar tjocka och svarthruna; blad ofta stora (mer än tumsbreda), tjocka och tätulliga med gråaktig, stundom guldglänsande ull, ovala och n. helbräddade (sällan glatta och smala); ståndareknappar guldgula.

I fjellen, helst i fjellregionen; Lpl. t. a., Norrl. Jtl. Herj. spr., Sv. Dal. r.

17. S. gláuca L., Grått Fjellvide; honhängefjäll trubbiga hvitulliga och vanl. ljusröda; fröhus hvitt filtludna; smågrenar gråludna; stipler äggrunda rakspetsade och något sågade.

Omkr. 3-6 fot hög och mycket grenig med utbredda, teml. smala, rödbruna och glänsande grenar; blad aflånga-lansettlika med vanl. hela och platta kanter, undertill blåaktiga med långa tilltryckta hår (sällan ulliga eller n. glatta), vid torkning lätt svartnande; stift vanl. mycket kort; ståndareknappar mörkt blăröda.

Fuktiga ställen, helst i fjellen; Lpl. a. åtm. i fjellen, Norrl. Vb. r. Ang. spr. Jtl. Herj. a. (åtm. i fjellen), Sv. Verml. r. Dal. a. i fjellen, eljest $r$.

18. S. arbúscula L.; honhängefjäll trubbiga, n. glatta; fröhus vanl. ludna; grenar glatta; stipler små och ovala.

1-2 fot hög med utbredda, smala och glänsande bruna grenar; blad små och tunna (ungefär som hos S. repens), ovalalansettlika fintandade med platta kanter, ofvan glänsande ljusgröna, undertill isgrå, alldeles glatta; hängen smärre än hos de förut beskrifna fjellvidena; stift ofta teml. kort; ståndareknappar rödaktiga. Liknar något $S$. repens och kan förvexlas med former af S. phylicafolia.

Kärr i fjellen, helst i fjellregionen; Lpl. r., Norrl. Jtl. r. Herj. t. r.

19. S. myrsinítes L.; honhängefjäll trubbiga och något håriga; fröhus brunulliga, slutl. glatta; yngre grenar ludna; stipler otydliga.

Omkr. fotshög, sällan 2-3 fot hög, och mycket grenig med teml. tjocka, utbredda och ofta nedtryckta, svartaktiga eller brunröda grenar; blad starkt nätiadriga, ovala-lansettlika, med glandelbärande sågtänder samt på båda sidor gröna, håriga eller slutl. 
glatta, länge qvarsittande, sedan de vissnat; hanhängen teml. små. En form med n. runda eller omvändt äggrunda blad torde vara en bastard af denna och någon annan art (S. herbacea?). Myrar och andra kärr i fjellen; Lpl. t. a., Norrl. Jtl. Herj. spr., Sv. Dal. r.

20. S. herbácea L., Dvergvide; hängen vanl. n. oskaftade; hängefjäll gula och glatta; fröhus glatta; blad n. runda och naggade samt både upptill och nedtill intryckta.

Liknar en ört och har omkr. nagelstora, glänsande ljusgröna och tumna blad; hängen knappt $1 / 2$ tum långa; stift vanl. kort; ståndareknappar rödgula.

Uppe i högfjellen på hård mark; Lpl. a., Norrl. Jtl. Herj. t. a., Sv. Dal. r.

21. S. poláris Wahlenb., Polarvide; hängen med långt och nedtill bladigt skaft; hängefjäll brunaktiga, stundom håriga; fröhus tätludna, sällan slutl. glatta; blad helbräddade, ovala eller omvändt äggrunda (sällan upptill intryckta) med platta kanter.

Liknar föreg. art, men är năgot spensligare med vanl. något smärre och smalare blad; stift năgot utdraget; ståndareknappar gula.

\section{Ipl. spr. i de högsta fjellen, Norrl. Jtl. Herj. r.}

22. S. reticuláta L.; hängen med långt och nedtill bladigt skaft; hängefjäll rödgula eller brunaktiga och ludna; fröhus tätt gråludna; blad helbräddade, ovala-rundade med nedböjda kanter, i början håriga, ofta snart glatta.

Har ofta ända till dubbelt större blad än förut beskrifna högfjellviden och tjockare grenar; blad nästan handnerviga, tjocka och läderartade, ofvan mörkgröna, undertill blăgrå eller $n$. hvita med n. violetta ådror; hängen ofta tumslånga med lika långt skaft; stift mycket kort; ståndareknappar mörkt violetta; hängefjäll nedtill försedda med ett enkelt eller tvåflikigt fjällikt honingsgömme.

I högfjellen; Lpl. a., Norrl. Jtl. Herj. spr.

Anm. Utom dessa arter finnas en mängd svårbestämda former, som anses vara bastarder. De märkligaste äro:

1. S. víridis Fr. (alba + fragilis); grenar mindre bräckliga än hos $S$. fragilis, men ej så mycket utspärrade; blad rent gröna med lång och rak spets; honhängen upprätta.

2. S. cuspidáta Schulz (pentandra + fragilis); lik S. pentandra, men skild genom aflăngt jemnbreda honhängefjäll, honhängets allm. skaft hårigt, mera långspetsade blad och halmgula ståndareknappar.

3. S. livescens Döll (aurita + vagans); lik S. vagans, men med finhåriga och omvändt äggrunda blad.

4. S. ambigua Ehrh. (aurita + repens); lik S. repens till växesättet och de små bladen, men dessa äro omvändt äggrunda och ofta gråludna. 
5. S. Friesiána Ands. (repens + viminalis); grenar långa vidjelika; blad n. jemnbreda, mycket kortare än hos S. viminalis.

6. S. Smithiána Willd. (viminalis + caprea); grenar långa vidjelika men tjockare än hos $S$. viminalis; blad smalt lansettlika; fröhus skaftade; stift utdraget.

7. S. Læstadiána Hartm. (Lapponum + caprea, cinerea, aurita); gråluden och smalbladig med ofta glatta grenar och skattade fröhus.

8. S. versifólia Wahlenb. (myrtilloides + lapponum); blad $\mathrm{n}$. ovala, i hörjan ofta gråludna, slutl. glatta; fröhus skaftade.

9. S. Wichúræ Ands. (phylicæfolia + glauca); lik S.phyliceef. i grenar och blad, S. glauca genom fröhusen, som dock äro skaftade.

10. S. Amandæ Ands. (nigricans + glauca); teml. hög med tunna, täthåriga och tandade blad.

11. S. latifólía Forbes (nigricans + caprea); mest lik S. caprea, men med utdraget stift. S. laurina Sm.?

12. S. glaucóides Ands. (glauca + myrsinites); $2-3$ fot hög med i början ludna, slutl. n. läderartade och ofta tandade blad; hängen ofta sittande $i$ toppen af grenarne och teml. stora.

13. S. punctáta Wahlenb. (nigricans + myrsinites); vanl. högre än $S$. myrsinites med färre qvarsittande vissnade blad; de friska bladen teml. styfva och lätt svartnande; fröhus skaftade. 14. S. norvégica Fr.

a. S. alpestris Ands. (glauca + herbacea); mycket liknande $S$. herbacea, men med något störe, ovala-aflånga och undertill håriga blad och något utdragna honhängeskaft.

b. S. Sommerféltii Ands. (myrsinites therbacea); lik $S$. herbacea till bladformen, men bladen äro styfvare och hängena längre än hos denna art.

c. S. sarmentácea Fr. (hastata + herbacea); mest lik $S$. herbacea, men bladen äro undertill $\mathrm{n}$. blăgrå och håriga samt vanl. omvändt äggrunda, hängefjällen upptill håriga, honhängena kortskaftade.

3 Ordn. TRIANDRIA.

466. Émpetrum. Kråkvis.

1. E. nigrum L.; bär svarta; blommor ljusröda, oskaftade i bladvecken; blad tätt sittande, $n$. jemnbreda och läderartade, undertill med en hvit făra. 1, 2.

Nedliggande, mycket grenig och omkr. fotshög småbuske med klotrunda, saftiga bär och mycket små ihåliga blad; ståndaresträngar mycket långa med svartröda knappar. Är stundom mångbyggare eller sambyggare.

Hedar och kärr, allmän : Öl. spr. Gotl. r.

\section{Ordn. TETRANDRIA.}

467. Myríca. Küllpors, Skogshumle.

1. M. Gale L.; blad vigglika, mot spetsen sågade. 1. Omkr. 2 fot hög och upprätt med små och bruna, oskaftade, 
bladlösa och upprätta hängen; frukter och blad med gula hartsprickar. Har stark lukt.

Stränder och kärr, isynnerhet i skogstrakter; Göt. a.: Sk. t. r. Blek. Gotl. Öl. spr., Sv. a., Norrl. spr.: Gestr. a. Ang. Vb. r. 468. Viscum. Mistel.

1. V. album L.; bär klotrundt, n. genomskinligt och klibbigt; blad lansettlika motsatta. 1, 2.

Stam 1-2 fot hög och mycket grenig.

Parasit på apel, ek m. fl. löfträd; Göt. Vg. Boh. Hall. Blek. r. Boh. t. r., Sv. i Mälaretrakten: Vestm. Söd. t. r. Upl. r.

469. Hippóphaë. Haftorn.

1. H. rhamnóides L.; blad helbräddade och jemnbredt lansettlika. 1, 2.

Omkr. 4-6 fot hög nch grågrön med bruna fjäll på bladens undra sida och på de yngre grenarne; bär gulaktiga af ärters storlek; blommor gula.

Hafsstränder, spr. vid Bottn. viken och Ailands haf. ned till Norrtelje, men ej uppgifven för Ång. och Med.

\section{Ordn. PENTANDRIA.}

\section{Húmulus. Humle.}

1. H. Lúpulus L.; blad skaftade, bredt hjertlika och 3-5-flikiga, med stipler; bladflikar spetsiga och tandade. 3.

Grenig och flera fot lång med starkt luktande kottar.

Berg och stenrös; Göt. spr.: Gotl. r., Sv. spr.: Ner. Dal. r., Norrl. r.: Gestr. Hels. spr. Herj.?

\section{Ordn. POEYANDRIA.}

\section{Pópulus. Poppel.}

1. P. trémula L., $A s p$; hängefjäll vigglika, hårbräddade och upptill flikiga; blad n. runda, bugttandade. 1.

Högt träd med gråludna hängen och veka, platta bladskaft ; de yngre bladen stundom hvitludna och hjertlika, de äldre glatta och runda.

I skogar och vid vägar, allmän: L Ll. spr., stundom i björkregionen.

472. Mercuriális. Bingelört, Purgerkrydda.

1. M. perennis L.; stjelk enkel; blad skaftade, n. äggrunda och sträfhåriga; honblommor enstaka eller flera på ett utdraget gemensamt skaft. 1, 2.

Omkr. fotshög med teml. spenslig stjelk och stora blad, som vid torkning vanligen blifva mörkt blågröna; rotstock lång och krypande; blommor och frukter gröna.

Lundar; Göt. Dalsl. Boh. spr. Hall. Sk. Blek. Öl. a. Gotl. r. Kalmarl, spr. inre Smål. Ög. r. Vg. r.?, Sv. t. r.: Ner. Verml. Dal. 0. 
XXII. diorcin. 473-475. XXIII. polygamia. 476. 361

\section{Rhodiola. Rosenrot.}

1. R. rósea L.; blad platta: de nedre ovala helbräddade, de öfre n. vigglika och upptill tandade. $2,3$.

Glatt och blägrön med omkr. $1 / 2$ fot höga stjelkar från den fingertjocka, fjälliga och välluktande rotstocken; blad breda och n. tegellagda; blommor gula eller rödaktiga.

Fuktiga klippväggar, helst i fjellen ofvan barrskogsreg., sällan utom fjellen; Lpl. a., Norrl. Jtl. Herj. t. r., Sv. Dal. r., Göt. Boh. r.

\section{Stratiótes. Vatten-aloë.}

1. S. alóides L.; blad svärdlika oskaftade. 3 .

Omkr. $1 / 2$ fot hög, liknande en Aloë med sina tjocka och taggiga blad, endast vid blomningen uppflytande på vattnet.

Sjöar och dammar; Göt. Sk. Ög. Vg. spr. Smål. r., Sv. spr.: Vestm. t. r. Verml. r. Dal. 0, Norrl. Gestr. Hels. r.

475. Hydrócharis. Dyblad.

\section{H. morsus ranæ L.; blad långskaftade. 3 .}

Lågväxt med flytande blad, som likna Näckrosens, ehuru mindre och omkr. tumsbreda. Anses af soml. författare vara sambyggare.

Sjöar, åar och dammar; Göt. r.: Sk. a. Ög. t. a. Kalmarl. spr. Öl. 0, Sv. spr.: Vestm. t. r. Verml. Dal. r., Norrl. Gestr. Hels. r.

\section{Klassen. POLYGAMIA. \\ 1 Ordn. MONOECIA. \\ 476. A'triplex. Gråmolla, Molla.*)}

A. Fruktfoderblad med större bredd än längd, bredt äggrunda med kort spets och fintandade. De flesta bladen breda med n. tvär eller kort vigglik bas, n. äggrunda och tandade. Grenar vanl. utspärrade. 1. A. rósea L.; fruktfoderblad föga hopväxta, slutl. hårdnande och försedda med upphöjda nerver; frön glänsande.

Är vanl. uppstigande och ofta mycket mjölig; isynnerhet på bladens undra sida och på fruktfodret.

Hafsstränder; Göt. Öl. t. r. Ög. Smål. r. Sk.?; Sv. Söd.?

2. A. arenária Woods; fruktfoderblad n. till midten hopväxta, slutl. hårdnande och försedda med upphöjda nerver; frön glanslösa.

Liknar föreg. art.

Hafsstränder, mycket r.; Göt. Skåne.

*) Hithörande arter äro höstväxter. 
3. A. Babingtónii Woods; fruktfoderblad föga hopväxta, teml. mjuka och otydligt nerviga; frön glanslösa.

Liknar de föreg. arterna.

Hafsstränder; Göt. Boh.-Sk. r.

B. Fruktfoderblad med större längd än bredd, föga hopväxta och alltid mjuka.

4. A. calothéca Rafn; fruktfoderblad med utdragen spets, groftandade eller parklufna; blad-breda med vigglik eller n. tvär bas och utdraget skaft; de två nedre bladtänderna större än de öfriga; frön glanslösa.

Är vanl. föga mjölig och har större fruktfoderblad än de öfriga arterna; grenar ofta utspärrade. Smål.?

Hafsstränder; Göt. Boh. Hall. spr. Sk. t. a. Blek. Öl. t. r.

5. A. hastáta L., Strandmolla; fruktfoderblad n. liksidigt rutformiga med föga utdragen spets och fintandade; de flesta bladen vanl. breda med kort vigglik eller tvär bas och utdraget skaft, vanligen tandade (sällan helbräddade) med de två nedre bladtänderna större än de öfriga; frön glänsande.

Är mycket mångformig samt mer eller mindre mjölig; grenar vanl. utstående.

Helst förek. på hafsstränder, sällan ruderatväxt inuti landet; Göt. a. vid hafvet, eljest r., Sv. r.: Söd. t. a. vid hafvet, Up]. spr. Dal. 0, Norrl. vid hafvet r.: Gestr. spr.

6. A. pátula L., Vägmolla; fruktfoderblad med utdragen spets, vanl. helbräddade; blad med utdragen vigglik bas och vanl. kort skaft, de flesta smala och ofta helbräddade eller med de två nedre bladtänderna större än de öfriga; frön glänsande.

Är ofta upprätt med vanl. utspärrade grenar.

Ogräs och ruderatväxt, äfven förekommande på hafsstränder; Göt. Sv. a., Norrl. Gestr. a. Hels. Med. spr. Ång. r.

* A. prostráta (Bouch.) Fr.; uppstigande eller nedliggande med utstående grenar; blad teml. breda med utdraget skaft.

Är troligen bastard af $A_{.}$patula och $A$. hastata.

Hafsstränder; Göt. spr.: Ög. 0.

7. A. littorális L., Smalbladig Strandmolla; fruktfoderblad med utdragen och vanl. smal spets, n. helbräddade; blad med utdragen vigglik bas och kort skaft, alla smala och likformigt tandade eller helbräddade; frön glänsande.

Upprätt med föga utstâende grenar; blad'van]. omkr. 2 linier breda, sällan dubbelt bredare 
Hafsstränder; Göt. spr.: Boh. a. Sk. Gotl. t. a. Ög. r., Sv. Söd. t. r., Norri. Med. Ång. r.

477. Hálimus. Saltmolla.

1. H. pedunculátus (L.) Wallr.; blad motsatta, köttiga och vanl. spadlika, de öfre smala. 3,4 .

Hela växten hvitmjölig med omkr. 1/2 fot lång, nedtryckt eller uppstigande stjelk, stundom mer än fotslång; honblommornas skaft långt och ofta nedböjdt.

Hafsstränder; Göt. r.: Sk. Öl. spr. Blek. Ög. 0 .

\section{Ordn. DIOECIA.}

478. Fráxinus. Ask.

1. F. excélsior L.; småblad oskaftade, lansettlika och sågade. 1, 2.

Högt träd med gråaktig bark, motsatta grenar, svarta bladknoppar, mörkröda ståndareknappar och slutl. nedhängande vingfrukter.

Skogar; Göt. Sv. spr.: Dal. r., Norrl. Gestr. Hels. r.

479. Acer. Lönn.

1. A. platanóides L.; blad 5-fikiga, bredt hjertlika, med spetsiga flikar och tänder; blommor i qvast med glatta skaft. 1.

Skuggrikt träd med slutl. handsbreda, gröna blad och plattade, glatta frögömmen med jemnbreda vingkanter.

Lundar; Göt. spr.: sk. Hall. a. Boh. t. r., Sv. spr.: Dal.t.r., Norrl. r.: Gestr. Hels. spr. Herj.? Vb. 0.

2. A. campestre L., Nafver; blad 3-fikiga, bredt hjertlika med trubbiga flikar och tänder; blommor i smal qvastlik vippa med finludna skaft. 1.

Lägre än föreg. och $n$. busklik med smärre, ofvanpå mörkgröna blad; nerverna på bladens undra sida småludna liksom de uppsvälda, med jemnbreda utspärrade vingkanter försedda frögömmena.

Skogar, mycket r.; Göt. Skåne i s. r. delen.

\section{Klassen. CRYPTOGAMIA.}

1 Ordn. ORMBUNKAR.

480. Polypódium.

A. Stamblad enkelt pardeladt, smalt triangelformigt (de nedersta flikarne föga längre än de närmaste); fruktplättar stundom sammanflytande; stambladskaft utan fjäll.

1. P. vulgare L., Stensöta, Bergsöta; bladflikar hela eller svagt tandade, trubbiga. 
$1 / 2-1$ fot hög och glatt med stela stamblad; stambladskaft föga kortare än stambladet, som vanligen är 1 tum, stundom 2-3 tum bredt; rotstock af sötaktig smak.

Berg, allmän utom fjellen: Ång. Vb. spr. Lpl. r.

B. Stamblad nedtill parbladigt deladt, bredt triangelformigt (de nedersta småbladen mycket längre än de närmaste); fruktplättar alltid åtskilda; stambladskaft nedtill fjälligt.

2. P. Phegópteris L.; småblad oskaftade, långspetsade och nedtill pardelade.

$1-1^{1} / 2$ fot hög och finluden; stambladskaft föga kortare än stambladet, hvars största bredd är 3-6 tum; hufvudnerv ofta fjällig; stamblad mjukt med trubbiga och $n$. helbräddade småflikar.

Skogar, allmän: Lpl. spr.

3. P. Dryópteris L.; nedre småblad li̊ngskaftade, kortspetsade och nedtill parbladigt delade.

$1-1^{1} / 2$ tot hög och vanligen glatt; stambladskaft föga kortare än stambladet, som är något bredare än hos föreg. art; hufvudnerv utan fjäll; stamblad mycket tunnt med trubliga och vanl. naggade småflikar. På kalkberg (t. ex. Öl. Gotl. Ög. och Dal.) förekommer en form (P. Robertiánum Hoffm.), som har fastare och undertill fint glandelhårigt stamblad.

Skogar och murar, allmän: Lpl. spr.

C. Stamblad dubbelt parbladigt och lansettlikt; fruktplättar åtskilda; stambladskaft nedtill fjälligt.

4. P. rhæ'ticum L.; småblad af 1 :sta ordningen oskaftade och långspetsade.

Omkr. 2 fot hög och glatt; stambladskaft flera gånger kortare än stambladet, hvars största bredd är omkr. 4 tum; hufvudnerv utan fjäll; stamblad tunnt och mjukt; småblad af 2:dra ordningen aflånga trubbiga och parklufna med sågade (eller sågtandade) och breda småflikar. Liknar Asplenium filix femina, men skiljes genom de runda fruktplättarne, som sakna svepefjäll.

Högt upp i fjellen; Lpl. a. i fjellreg., Norrl. Jtl. Herj. spr.

\section{Aspídium. Ormkagge.}

A. Svepefjäll skaftadt och rundt, fästadt blott $i$ midten af fruktplätten. 1. A. Lonchitis. 2. A. aculeatum.

B. Svepefjäll njurlikt, fästadt både i midten och kanten.

a. Stamblad enkelt parbladigt med vanl. oskaftade småblad, de flesta (eller de nedre) nedtill pardelade.

1. Småblad utdraget triangelformiga eller lansettlika, långspetsade. Stamblad alltid till omkretsen aflångt lansettlikt (de nedersta småbladen kortare än de närmaste).

3. A. Thelypteris. 4. A. Oreopteris. 5. A. filix mas.

2. Småblad bredt triangelformiga kortspetsade. Stamblad till omkretsen antingen aflångt-lansettlikt eller utdraget triangelformigt. 6. A. cristatum.

b. Stamblad dubbelt eller tredubbelt parbladigt, de neder- 
sta småhladen stundom kortskaftade, de öfriga oskaftade. 7. A. spinulosum. 8. A. rigidum.

1. A. Lonchítis (L.) Sw.; stamblad enkelt parbladigt och smalt lansettlikt; småblad kortskaftade, taggbräddade och n. halfmånlikt krökta med tvär eller sned och vigglik bas; stambladskaft mycket kort och ofta fjälligt.

$1 / 2-11 / 2$ fot hög med spetsigt och omkr. 1-2 tum bredt stamblad; småblad glatta nch stela.

Torrare klippspringor; Lpl. r., Norrl. Jtl. t. r. Herj. r., Sv. Vestm. Dal: Verml. r., Göt. Dalsl. Hall. r.

2. A. aculeátum (L.) Döll; stamblad dubbelt parbladigt, lansettlikt-aflångt; småblad n. oskaftade, aflånga med taggspetsade tänder; stambladskaft kort och mycket fjälligt.

1-2 fot hög, något lik Aspid. filix mas; stamblad spetsigt och 3-4 tum bredt; småblad något stela och liksom håriga af smala fjäll.

Skuggrika ställen på berg, mycket r.; Göt. Sk. Öl. Gotl.

3. A. Thely'pteris (L.) Sw.; stamblad föga (eller högst dubbelt) längre än skaftet; stambladflikar n. jemnbreda (eller äggrundt aflånga) trubbiga eller något spetsiga, n. helbräddade.

Omkr. 2 fot hög; stambladets största bredd 3-4 tum, stambladskaft och hufvudnerv utan fjäll; stambladflikar slutl. inböjda; fruktplättar nående ut i spetsen af flikarne; stamblad åtskilda med bräckliga skaft.

Stränder och kärr; Göt. spr:: Blek. Boh. r., Sv. spr.: Ner. r. Dal. 0, Norrl. Gestr. r.

4. A. Oreópteris Sw.; stamblad flera gånger längre än skaftet; stambladflikar aflånga trubbiga, n. helbräddade.

Något högre än föreg. art med ungefär lika bredt stamblad; stambladskaft och hufvudnerv utan fjäll; stambladflikar n. platta; fruktplättar ej sammanflytande och ej nående ut i spetsen af flikarne; stamblad strutlikt hopsittande, med teml. styfva skaft.

Fuktiga, helst skuggrika och steniga ställen; Göt. Sk. Hall.r.

5. A. filix mas (L.) Sw.; stamblad flera gionger längre än skaftet; stambladflikar n. jemnbreda (eller aflångt jemnbreda) och finsiigade (ej taggiga).

1-4 fot hög och grof; stambladets största bredd 3-8 tum; stambladskaftets nedre del och stambladets hufvudnerv brunfjälliga.

Skogar; Göt. Sv. a., Norrl. spr.: Gestr. a. Ång. Vb. r., Lpl.r. 6. A. cristátum (L.) Sw.; stamblad $2-4$ gånger längre än skaftet; bladflikar äggrundt aflånga, trubbiga och taggsågade.

$1-2^{1} / 2$ fot hög; stambladets största bredd omkr. 3 tum; stambladskaftets nedre del och stambladets hufvudnerv med få och glest sittande fjäll. 
Mossar och fukt. skogsängar; Göt. t. r.: Gotl. Öl. spr. Boh. Dalsl. 0, Sv. spr.: Ner. Dal. r. Verml.?, Norrl. Gestr. r.

Denna art synes innefatta 2:ne former:

a. genuinum; stamblad till omkretsen aflångt lansettlikt med kort skaft. Liknar föreg. art.

b. dúbium; stamblad till omkretsen utdraget triangelformigt med långt skaft. Liknar följ. art.

7. A. spinulósum (Müll.) D.C.; stamblad dubbelt parbladigt, 1-2 gånger längre än skaftet; småblad af 1:sta och 2:dra ordningen utdraget triangelformiga, de nedre småflikarne aflånga och vanl. taggsågade, oftast trubbiga.

$1^{1} /{ }_{2}-3$ fot hög; stambladets största bredd 4-6 tum; stambladskaft och hufvudnerv med få och glesa fjäll, stundom $n$. utan fjäll; stambladets omkrets vanl. bredt triangelformig.

I skogar och vid vägar, allmän: Lpl. t. r.

- dilatátum Sw.; stamblad vanl. 3-dubbelt parbladigt med tätt fjälligt skaft.

Mörkare grön och ofta betydligt större än hufvudarten, ända till 4-5 fot hög och 8-10 tum bred; smärre former äro blott dubbelt parbladiga, men utmärka sig genom stambladskaftets talrika fjäll och hafva fliktänderna mindre utbildade; än de äro hos hufvudarten.

Skuggrika och fuktiga ställen i skogar; Göt. spr.: Gotl. Dalsl.?; Sv. Söd. Upl. spr. Ner. r., Norrl. Jtl. r.

8. A. rígidum Sw.; stamblad dubbelt parbladigt, 3-4 gånger längre än skaftet; småblad af 2:dra ordningen

n. jemnbreda, sågtandade och ej taggiga (eller någon gång med kort udd på sågtänderna).

Liknar Aspidium filix mas och har vanligen smalt stamblad med mycket fjälligt skaft, men är ej så grof.

Mycket r.; Sv. Upl. nära Vermdö kyrka i en skogsbacke, Norrl. Jtl. på Åreskutan. - Finnes trol. flerstädes i fjellen.

\section{Cystópteris. Stenbräken.}

1. C. frágilis (L.) Bernh.; stamblad aflängt-lansettlikt med triangelformiga n. oskaftade småblad.

$1 / 2-1$ fot hög, spenslig och glatt; småblad af 1:sta ordningen vanl. motsatta, af 2:dra ordningen äggrunda-aflånga eller stundom $n$. jemnbreda och ofta med vigglik bas; stambladskaft vanl. föga kortare än hladet samt nedtill något fjälligt; stambladens småflikar tandade med $n$. spetsiga tänder.

Berg, teml. allmän: Lpl. spr.

- alpína; stamblad n. tredubbelt parbladigt och smalflikigt.

I fjellen, mycket r.; Norrl. Herj.

2. C. montána (Sw.) Bernh.; stamblad n. liksidigt triangelformigt, tredubbelt parbladigt; småblad triangelformiga, de nedre skaftade. 
Omkr. fotshög, spenslig och glatt med lång rotstock: småblad af 1:sta ordningen vanl. ej motsatta, af 2:dra ordn. utdraget triangelformiga, af 3:dje ordn. n. äggrunda och djupt klufna med något tandade flikar; stambladskaft nedtill fjälligt och vanl. längre än stambladet, hvars största bredd är omkr. 3-4 tum. Liknar något Polypod. Dryopteris.

Skuggrika ställen, helst i björkskog i fjellen, sällan i granskog utom fjellen; Lpl. spr., ,Norrl. Jt1. mångenst. stundom äfven utom fjellen, Herj. spr. Ang. r.

\section{Woódsia. Hällebräkien.}

1. W. ilvensis (L.) R. Br.; stamblad undertill fjälligt och hårigt med slutl. tätt sammanflytande fruktplättar.

Några tum hög; stamblad $1 / 2-3 / 4$ tum breda och tätt tufvade; stambladskaft och hufvudnerv rödbruna med fina och smala fjäll; skaftet n. alltid kortare än stambladet; småblad vanl. äggrunda, spetsiga eller trubbiga, de nedersta kortare än de närmaste.

I bergspringor, sällan (aldrig?) på kạlkberg; Lpl. Norrl. spr., Sv. t. a., Göt. spr.: Boh. Hall. Blek. Öl. r. Gotl. Sk. 0.

2. W. hyperbórea R. Br.; stamblad undertill nästan utan fjäll och hår; fruktplättar något skilda; småblad bredt äggrunda, trubbiga och grundt inskurna.

Omkr. 2-3 tum hög och föga hårig; stamblad tätt tufvade, n. jemnbreda och omkr. $1 / 2$ tum breda med mycket kort och brunt skaft.

I fjellen; Lpl. t. r., Norrl. Jtl. Herj. r., Sv. Dal. r.

* W. glabella R. Br.; stamblad slutl. utan fjäll och hår; fruktplättar skilda; småblad vanl. olikformiga: de nedre njurlika och fint naggade, de öfre spetsiga och parklufna.

Något lägre och smalare än hufvudarten med vanl. grönt och blott nedtill något fjälligt stambladskaft.

Högt upp i fjellen, mycket r.; Lpl.

484. Asplénium.

A. Stambladskaft nedtill fjälligt. Fruktplättar små och korta samt länge skilda. Storbladiga växter med stor rotstock. 1. A. filix femina. 2. A. crenatum.

B. Stambladskaft utan fjäll. Småbladiga, tätt tufvade och vanl. låga växter med spenslig och kort rotstock.

a. Fruktplättar korta och aflănga samt länge skilda.

1. Stamblad långt och $n$. jemnbredt med mycket talrika småblad. 3. A. Trichomanes. 4. A. viride.

2. Stamllad teml. kort och vanl. triangelformigt med teml. få småblad. 5. A. ruta muraria. 6. A. Adianthum nigrum.

b. Fruktplättar n. jemnbreda och utdragna samt länge skilda. Stamblad teml. kort och n. jemnbredt med teml. få småblad. 7. A. Breynii.

c. Fruktplättar snart sammanflytande, mycket långa och n. lika breda som stambladets flikar. 8. A. septemtrionale.

1. A. filix fémina (L.) Bernh.; stamblad till omkretsen 
lansettlikt, flera gånger längre än skaftet; småblad parbladiga, sällan blott pardelade.

1-3 fot hög och glatt; stambladets största bredd 3-5 tum; småblad af 1:sta ordningen utdraget triangelformiga och långspetsade; småblad af 2:dra ordningen aflånga, trubbiga och rundtomkring sågtandade eller parklufna; stambladets hufvudnerv utan fjäll; fruktplättar slutl. svartbruna.

Liknar Aspidium filix mas. Lpl. r.

I skogar och vid vägar o. s. v.; Göt. Sv. a., Norrl. t. a.,

2. A. crenátum Fr.; stamblad bredt och $n$. liksidigt triangelformigt, ungefär af skaftets längd; småblad parbladiga.

Omkr. fotshög, glatt och teml. spenslig; stambladets största bredd 3-6 tum; småblad af 1:sta ordningen lansettlika långspetsade, af $2: d r a$ ordn. äggrundt aflånga trubbiga och djupt parklufna med trubbnaggade flikar. Liknar något Aspid. spinulosum.

Steniga ställen nära fjellen, mycket r.; Norrl. Jtl. vid Tännforsen (enl. Milde). - Svenska exemplar osedda af förf.

3. A. Trichómanes L.; stamblad enkelt parbladigt; småblad rundade-ovala och trubbiga, oskaftade och rundtomkring naggade.

5-10 tum hög och mörkgrön; stamblad omkr. $1 / 2$ tum bredt med kort skaft; stambladets hufvudnerv jemte skaftet svartröda; småblad omkr. $30-40$.

Klippor och murar; Göt. Sv. a. (åtm. på s. k. urformation), Norrl. spr.: Vb. 0.

4. A. Víride Huds.; stamblad enkelt parbladigt; småblad n. ovala och trubbiga med vigglik bas, slaftade och upptill naggade.

Liknar föreg. art, men är ljusgrön och vanl. lägre och vekare med ljusbrunt stambladskaft och grön hufvudnerv.

Något fuktiga klippspringor, helst i eller nära fjellen; $L p l$. r., Norrl. Jtl. t. r. Herj. Ang. Med. r., Sv. Dal. Verml. r., Göt. Smål. r.

5. A. ruta murária L., Murbräken; stamblad enkelt eller dubbelt parbladigt; småblad af 2:dra ordningen ovala, äggrunda eller omvändt äggrunda, vanl. trubbiga, stundom spetsiga, blott i spetsen tandade, de flesta skaftade och vanl. n. hela.

2-4 tum hög; stambladskaft vanl. föga kortare än bladet; stambladets hufvudnerv jemte största delen af skaftet gröna; småblad åtskilda.

Kalkklippor och murar, helst nära hafvet; Göt. r.: Gotl. Öl. spr., Sv. r.: Söd. spr. Ner. 0, Norrl. Gestr. Herj. r.

6. A. Adiánthum nigrum L.; stamblad parbladigt; småblad triangelformiga och pardelade eller parklufna, blott de nedersta skaftade. 
Omkr. ${ }^{1 / 2}$ fot hög; stamblad vanl. kortare än det bruna skaftet; stambladets hufvudnerv grön; småbladens flikar vanl. ovalaaflänga (stundom vigglika), upptill hvasstandade, de öfre närsittande och föga skilda. Liknar något Cystopteris fragilis, men har fastare stamblad, eller små former af Aspid. cristatum.

Steniga ställen i bokskog; Göt. Skåne mycket r., t. ex. Hallandsås, Trollehallar och Gladsaxhallar.

7. A. Bréynii Retz.; stamblad parbladigt; småblad smalt vigglika och trubbiga, blott i spetsen tandade, de flesta skaftade:

2-4 tum hög, spensligare än föreg. art; stambladskaft ungefär lika långt som stambladet, hvars hufvudnerv jemte största delen af skaftet äro gröna: småblad åtskilda och 3-4 linier långa.

Bergspringor, helst nära hafvet och större sjöar; Göt. r.: Smål. Ög. t. r. Gotl. Öl. 0, Sv. Söd. Upl. spr. Vestm. t. r. Ner. r., Norri. Gestr. Hels. Ång. r.

8. A. septentrionále (L.) Hoffm.; stamblad upptill bredare och oregelbundet deladt i smala och fă, i början sammanhängande flikar.

3-5 tum hög och spenslig; stambladskaft längre än bladet och blott nedtill brunt, föröfrigt grönt; stambladets flikar syllikt spetsiga och ofta tumslånga, hela eller med få och smala sidoflikar.

Bergspringor, helst (alltid?) på s. k. urformation; Göt. spr.: Gotl. Öl. 0, Sv. t. a., Norrl. spr.: Vb. 0.

485. Scolopéndrium. Mjeltört.

1. S. officinárum Sw.; stamblad n. lansettlikt, längre än det fjälliga skaftet.

1-2 fot hög och tufvad med vanl. n. helbräddadt, 1-2 tum bredt stamblad, något liknande en tunga.

Skuggrika ställen, mycket r.; Göt. Lilla Carlsön vid Gotl. $i$ en bergshåla på $n$. ö. sidan.

486. Pteris. Örnbräken, Ormbunke.

1. P. aquilína L.; stamblad bredt triangelformigt; småblad utdraget triangelformiga; småflikar med nedvikna kanter samt $\mathrm{n}$. ovala, trubbiga och helbräddade.

Ända till 6 fot hög och mer än 1 fot bred, vanl. glatt; småblad oskaftade; stambladskaft och bladnerver utan fjäll; stambladskaft $n$. lika långt som stambladet och nedtill brunt; rotstock lång, utsändande enstaka stamblad. Lpl. r.

Skogar, hedar och vägkanter; Göt. Sv. a., Norrl. spr.: Vb.?,

487. Struthiópteris. Strutsfjäderbräken, Foderbräken.

1. S. germánica Willd.; stamblad till omkretsen lansettlikt; småblad oskaftade, utdraget triangelformiga och spetsade, de nedersta mycket små, de flesta pardelade eller parklufna.

De ofruktsamma stambladen 2-4 fot höga och 3-8 tum 
breda, de fruktbärande $1-1^{1} / 2$ fot höga och $1-2$ tum breda; de ofruktsamma stambladens skaft mycket korta, något fjälliga, de fruktbärande stambladens skaft lằnga och mycket tjocka; hufvudnerv utan fjäll; småbladflikar korta, n. ovala och n. helbräddade, trubbiga eller snedt kortspetsiga, undertill ofta håriga. Liknar năgot Aspidium filix mas.

Bäckdalar; Göt. spr.: Smål. t. r. Blek. Öl. Gotl. 0, Sv. spr.: Upl. Dal. r., Norrl. Gestr.-Med. spr. Ång. t. a. Jtl. r., Ipl. r. 488. Blechnum. Kambräken.

1. B. Spicant (L.) Roth; stamblad smalt lansettlikt; småblad helbräddade och glatta, trubbiga eller kortspetsiga.

Omkr. 1-2 fot hög; stambladets största bredd omkr. 1 tum; de ofruktsamma stambladens skaft mycket kort. Har någon likhet med Polypodium vulgare.

Steniga ställen, ofta vid bäckar eller diken, i skogstrakter; Göt. r.: Smål. Sk. spr., Sv. Ner. Verml. r., Norrl. Herj. Jtl. Ang. r.

\section{Allosúrus. Krusbräken.}

1. A. crispus (L.) Bernh.; stamblad triangelformigaovala; småblad trubbiga skaftade.

3-6 tum hög och spenslig, ljusgrön och glatt samt något tufvad med kort rotstock; de ej fruktbärande småbladen ovalaaflånga med vigglik och hel bas samt upptill naggade, de fruktbärande lansettlika; stambladskaft n. utan fjäll samt vanl. längre än det 1-2 tum breda stambladet.

Steniga bergssluttningar, högt uppe i fjellen, r.; Lpl., Norrl. Jtl. Herj., Sv. Dal. (enl. Retz.)?

\section{Osmúnda. Safsabuske.}

1. O. regális L.; småblad lansettlika med sned bas.

3-4 fot hög med teml. stora sporgömmen.

Stränder af åar; Göt. Blek. Smål. spr. Sk. t. r. Hall. Vg. r., Norrl. Gestr. (planterad?) r.

\section{Ophioglossum. Ormtunga.}

1. 0. vulgátum L.; ofruktsamma stamblad nätådriga, $n$. ovala och trubbiga, stundom med kort udd.

4-12 tum hög och blekgrön, med vanl. blott ett omkr. tumsbredt och långskaftadt stamblad; sporgömmen mycket stora.

Något fukt. ängar, stundom på steniga hafsstränder; Göt. spr.: Sk. inre Smål. Vg. t. r. Boh. Dalsl. r. Hall.?, Sv. spr.: Dal. r. Vestm. Verml. 0, Norrl. Gestr. t. r. Hels. Vb. r.

\section{Botry'chium. Låsgräs.}

A. Blad fästadt nära. eller ofvan stammens midt, med mycket kort skaft. *)

*) Det som här kallas "stam", torde egentligen vara att anse som motsvarande de föreg. ormbunkarnes stambladskaft; merl "blad" menas här de ofruktsamma stambladen. 


\section{B. Lunária (L.) Sw.; blad enkelt pardeladt, till om-} kretsen n. jemnbredt, upptill något afsmalnande.

2-8 tum hög; småblad vanligen njurlika (n. halfmånlika) hela eller inskurna, otydligt skaftade; hela' bladet $1 / 2-1$ tum bredt. Betesmarker, ofta sparsam, mångenstädes.

* B. boreále Milde; blad iästadt ofvan stammens midt, äggrundt med omvändt äggrunda och klufna småblad samt omkr. tumslångt; fruktsamling vanl. föga öfverskjutande bladet.
Ĺpl. r., Norrl. Vb. Ång. Jtl. r.

2. B. matricariæfólium Al. Br.; blad dubbelt pardeladt, till omkretsen äggrundt; småblad äggrunda med aflånga, trubbiga och $n$. helbräddade flikar.

3-6 tum hög; hela bladet knappt tumslångt och hälften så bredt, sittande ofvan stammens midt.

Ŝkogsdungar; Norrl. Vb.-Gestr. r., Sv. Söd. Upl. r., Göt. Ög. Öl. Dalsl. r. Smål. t. r.

3. B. lanceolátum Ångstr.; blad dubbelt pardeladt, till omkretsen äggrundt; småblad lansettlika spetsade med något spetsiga flikar.

Vanl. omkr. 3 tum hög; blad knappt tumslångt, sittande ofvan stammens midt: fruktsamling n. oskaftad.

Ängar; Lpl. r., Norrl. Vb.-Hels. Jtl. r., Göt. Vg. r.

4. B. virginiánum Sw.; blad dubbelt parbladigt, bredt triangelformigt eller snedt rutformigt.

Omkr. 6 tum hög; småblad af 1:sta ordningen bredt triangelformiga, de nedre skaftade, af 2:dra ordn. äggrundt aflånga och något spetsiga samt djupt parklufna med upptill tandade flikar; hela bladet 1-3 tum bredt och ej fullt så långt; stam nedtill rännformig; fruktsamling långskaiftad, vanl. föga öfverskjutande bladet, som är fästadt n. utan skaft ofvan stammens midt.

Bergssluttningar; Norrl. Ång. Med. Gestr. r. Jtl. t. r., Sv. Dal.r.

B. Blad fästadt nära stammens nedersta del, med långt utdraget skaft.

5. B. rutáceum Sw.; blad dubbelt parbladigt, till omkretsen triangelformigt med skaftade småblad.

2-8 tum hög; småblad af 1:sta ordningen bredt triangelformiga, af 2:dra ordningen vanl. äggrunda-aflånga och trubbiga, ofta inskurna; hela bladet ofta mer än 1 tum bredt och ej fullt så långt. Stundom utbildas 2:ne ofruktsamma blad.

Betesmarker och sandiga ställen i skogar; Lpl. r., Norrl. Vb. r.? Ång. Med. t. a. Hels. spr. Gestr. Jtl. r., Sv. r.: Dal.t. r., Göt. Dalsl. Vg. Ög. Smål. Sk. r.

6. B. simplex Hitchc.; blad odeladt, parflikigt eller pardeladt med rundad omkrets eller hjertlikt.

1-3 tum hög, späd och spenslig; bladflikar fa, sneda och olikformiga, rundadt trubbiga, hela eller inskurna.

Mycket r.; Norrl. Med., Sv. Verml. 
493. Equisétum. Räfsvans, Fräken.

A. Ax trubbigt. Stjelk årligen förvissnande, med eller utan kransgrenar; slidornas tänder qvarsittande helt och hållet. a. Vărväxter. Axbärande stjelk (vid sporernas mognad) med inga eller föga utvecklade kransgrenar; grenar utan större tomrum (lufthåla) i midten samt enkla eller greniga. Stjelkslidor vidgade. 1. E. arvense. 2. E. pratense. 3.E. silvaticum.

b. Sommarväxter. Axbärande stjelk (vid sporernas mognad) ofta med utvecklade kransgrenar; grenar med ett större tomrum (lufthåla) i midten samt alltid enkla. Stjelkslidor föga vidgade. 4. E. palustre. 5. E. limosum. 6. E. litorale.

B. Ax spetsigt. Stjelk öfvervintrande, utan kransgrenar. 7. E. hyemale. 8. E. variegatum.

1. E. arvense L., Ałerfräken; axbärande stjelk vanligen utan kransgrenar; stjelkslidor med 4-12 lansettlika tänder; den ofruktsamma stjelkens grenar vanl. enkla; deras slidor med vanl. 4 äggrundt lansettlika, långspetsade tänder.

Axbärande stjelk upprätt och $1 / 2-1$ fot hög, vanl. utan fåror; den ofruktsamma stjelken stundom nedliggande, $1 / 2-2$ fot hög, med vanl. 4 fåror och åtsittande slidor.

Helst på lerjord, allmän.

2. E. pratense Ehrh., Gökbett; stjelk vanl. med enkla kransgrenar; stjelkslidor med vanl. 12-18 (stundom färre) lansettlika och tillspetsade tänder.

Upprätt och omkr. fotshög; axbärande stjelk otydligt fårad; den ofruktsamma stjelken med vanl. omkr. 12 fåror; grenslidor med vanligen 3 trubbiga tänder.

Ängar och åkrar, teml. allmän.

3. E. silváticum L., Skogsfräken, Grangräs; kransgrenar talrika och greniga; stjelkslidor med 2-6 äggrundalansettlika, trubbade fikar.

Upprätt och omkr. fotshög; axbärande stjelk otydligt fårad ; den ofruktsamma stjelken med 10-15 fåror; grenslidor med vanl. 3-4 lansettlika-syllika tänder.

Något fuktiga skogar eller åkrar, teml. allmän.

4. E. palustre L., Skäfte; stjelk färad och flerpipig, vanl. kransgrenig: dess slidor med 4-12 (vanl. 6-8) bredt lansettlika, hinnkantade och tillspetsade tänder.

Vanl. upprätt och $1 / 2-1$ fot hög; stjelk vanl. 6-8-kantig; grenar 5-6-kantiga: deras slidor med 5-6 lansettlika, ofta tillspetsade tänder; stjelkslidor $n$. dubbelt så långa som breda.

Fuktiga ställen, allmän.

5. E. limósum L., Ålgräs, Fräken; stjelk n. ofärad och n. enpipig, enkel eller grenig: dess slidor med 10-30 (vanl. 15-18) syllika (n. icke hinnkantade) tänder. 
Vanl. upprätt och omkr. 2 fot hög; grenar tjockare än hos föreg. art (n. som en skrifpenna) och 4-8-kantiga: deras slidor med 4-8 lansettlika-syllika tänder; stjelkslidor n. lika så breda som långa.

I och vid vatten, allmän.

6. E. litorále Kühl.; stjelk fiirad och flerpipig, vanl. kransgrenig: dess slidor med $10-15$ bredt syllika, smalt hinnkantade tänder.

Anses af somliga författare vara en bastard af de båda föreg. arterna, men har mera utstående grenar än E. palustre och liknar mera $E$. arvense, då denna saknar ax.

Sjöstränder, mycket r.; $S v$. Upl. i sjön Valloxen.

7. E. hyemále L., Skafgräs, Skurgräs; slidornas tänder till största delen affallande; stjelk med stort tomrum i midten, utvändigt med talrika (8-30, vanl. 18-24) fåror; slidor ej vidgade: deras tänders qvarsittande nedre del mycket kort och rundad eller tvärhuggen. Omkr. fotshög eller deröfver, af en gåspennas tjocklek och med mycket skarp yta; slidornas tänder upptill lansettlika-syllika och hinnaktiga; stjelk bräcklig i lederna.

I skogar och vid stränder, ofta på sandiga ställen: Göt.spr.: Gotl. Öl. Blek. t. r., Sv. spr.: Ner. t. r., Norrl. spr.: Jtl.?, Lpl.t.r. 8. E. variegátum Schleich.; slidornas tänder qvarsittande;

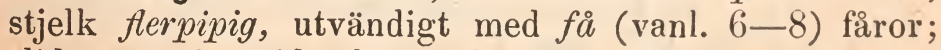
slidor uppåt vidgade: nedre delen af deras tänder kort, antingen tvärhuggen eller spetsad och äggrund.

Omkr. 1/2 fot hög eller deröfver och tufvad med talrika stjelkar, knappt så tjocka som en dufpenna och föga sträfva; slidornas tänder nedtill eller midtpå svarta, upptill syllika eller borstlika och hinnkantade; stjelk något bräcklig i lederna; axskaft ofta något utdraget.

Kärrängar och sandiga stränder; Göt. Gotl. t. r. Sk. Vg. r., Sv. r.: Söd. Ner. 0, Norrl. Jtl. Vb. r., Lpl. spr. åtm. i Torn. Lpm. (Læstad.).

* E. scirpóides Michx; stjelkar n. trådlika och 6-kantiga med 3-tandade slidor; ax vanl. oskaftadt.

Kärr, helst i fjelltrakter; Lpl. spr., Norrl. Jtl. Herj. spr. Vb. Ång. t. r. Hels. Gestr. r. Med.?, Sv. Upl. Dal. r.

494. Pilulária. Furgräis.

1. P. globulífera L.; stjelk trådlik.

Omkr. fotslång, med knippevisa rottrådar; fruktgömmen brunhåriga, liknande pepparkorn.

Öfversvämmade stränder; Göt. r.: Hall. Sk. Smål. spr. Öl. Dals]. Vg. 0, $S v$. Söd. Verml. r.

495. Isoëtes. Braxengräs.

1. I. lacustris L.; blad mörkgröna, n. ogenomskinliga; de större sporerna gulaktiga med låga àsar.

$2-7$ tum hög med styfiva blad. 
I sjöar och åar; Göt. spr.: Gotl. r. Öl. 0, Sv. Norrl. spr.: Jtl. r., Lpl. r.

2. I. echinóspora Dur.; blad ljusgröna och genomskinliga; de större sporerna hvita, tätt taggiga utan åsar.

Liknar föreg. art, men har mindre styfva och mera långspetsade blad.

I sjöar och åar; Göt. trol. ej r.: Gotl. Öl. Hall. Dalsl.?, Sv. Söd. Upl. t. a., Norrl. Jtl. spr. Vb. r.?, Lpl. r.

\section{Lycopódium. Lummer.}

A. Sporgömmen sittande i vecken af skärmblad, som likna de öfriga bladen.

1. L. Selágo L., Lus-lummer; sporgömmen sittande endast på grenarne; stam klynnedelad; grenar jemnhöga. 4-10 tum hög med mycket tjocka grenar; blad stela, lansettlika spetsade, tằtt sittande i 8 rader och $\mathrm{n}$. helbräddade.

Berg; Lpl. Norrl. mångenst., Sv. t. a., Göt. spr.: Öl. Gotl.r.

2. L. inundátum L., Sump-lummer; sporgömmen i ett oskaftadt $a x$ i toppen af grenarne; stam krypande med korta grenar, de axbärande upprätta, smalare än axet. 2-4 tum lång; stam alldeles betäckt af de mjuka, jemnbreda, spetsade och helbräddade bladen.

Kärrängar och stränder, som under .våren öfversvämmas; Göt. r.: Hall. Sk. Blek. t. r. Smål. spr. Ö1. 0, Sv. r.: Vestm. t. r., Norrl. Gestr. Hels. Àng. r.

B. Sporgömmen sittande i ax med skärmblad, som äro olika de öfriga bladen.

a. Ax ensamt och oskaftadt i toppen af grenarne. 3. L. annótinum L., Ref-lummer; stam krypande med upprätta grenar; blad lansettlika-jemnbreda, spetsade och sågtandade.

2-4 fot lång, teml. stel och glatt; blad (isynnerhet på grenarne) vanl. utspärrade; ax smalare än de axbärande grenarne. Skogar teml. allmän.

- alpestre; blad tilltryckta.

I fjellen ofvan barrskogsregionen; Lpl. spr., Norrl. Jtl. Herj. spr., Sv. Dal. r.

4. L. alpínum L., Fjell-lummer; stam krypande med n. upprätta grenar; blad äggrundt lansettlika helbräddade, trubbiga eller spetsiga.

2-3 fot lång med 1-2 tum höga grenar; blad små, mycket stela och tilltryckta med föga utböjd spets och utan hårlik udd; grenar tätt hopknippade och klynnedelade, något plattade ocls täckta af de fyrsidigt stälda bladen; ax $1 / 2-3 / 4$ tum långa. Liknar Lycop. complanatum.

Helst högt uppe i fjellen på öppna hedar. sällan i lägre fjelltrakter; Lpl. t. a., Norrl. Jtl. Herj. mångenst. Vb.--Med.r., $S v$. Dal. r. 
b. Ax flera på ett långt gemensamt skaft i toppen af grenarne.

5. L. clavátum L., Matt-lummer; grenar betäckta af bladen samt trinda och upprätta eller uppstigande; blad mjuka, helbräddade och jemnbreda, med hårlik udd. 2-6 fot lång och mjuk med krypande stam och olikstora smågrenar; blad utstående, sittande i flera rader.

Skogar, allmän: Gotl. r.

- lagópus (Læst.); axskaft omkr. ${ }^{1} / 2$ tum långt; grenar korta med tätt tegellagda blad.

I fjellen; Lpl. r.

6. L. complanátum L., Platt-lummer; grenar platta, uppstigande och ej täckta af bladen; blad stela, lansettlikt aflånga och spetsade utan hårudd.

2-4 fot lång och stel med krypande stam och klynnedelade, utspärrade grenar; blad mycket små; grenblad nedtill tilltryckta och i spetsen utböjda, sittande i 4 rader.

Bergiga skogar; Lpl. t. a., Norrl. a., Sv. spr., Göt. spr.: öl. Gotl. r. Sk. t. r. Blek. Hall.?

* L. Chamæcyparíssus A. Br.; grenar finare och mindre hoptryckta, mera tätt sittande och jemnhöga (n. solfjäderlikt hopstående), grenblad mera tilltryckta och n. lika stora.

Skogshedar; Göt. Sk. Smål. r. Hall. t. r. Vg. Boh. r., Sv. Verml. r., Norrl. Vb. r.

497. Selaginella. Dverg-lummer.

1. S. spinulósa Al. Br.; ax ensamt och otydligt skaftadt, sittande i toppen af grenarne; skärmblad större än de öfriga bladen och liksom dessa lansettlika med syllika tänder.

Stjelk krypande, 1-3 tum lång med uppstigande, 3-4 tum långa grenar. Liknar Lycopodium inundatum, men har glänsande blad.

Fuktiga ängar och kärr, helst i fjellen; Lpl. a., Norrl.spr.: Jtl. a. Ång. t. a., Sv. r.: Dal. spr. Upl. măngenst. i n. delen, Göt. Ög. Boh. r. 


\section{Förklaring öfver de vigtigaste konst- orden (vetenskapliga termerna).}

Aflaing begränsad af bågformiga linier med största bredden på midten och med längden 3 gånger så stor som bredden. Allmänt (blomskaft) uppbärande flera blommor, eller (om svepe) sittande nedanför flera allmänna blomskaft.

$A x$ blomsamling med ett allmänt och nästan inga enskilda blomskaft.

Balja en kapsellik frukt (hos ärtväxterna) med fröfäste vid fogen (sommen), uppspringande både vid fogen och vid undre kanten.

Bas den nedre delen, t. ex. af ett blad.

Bikrona bildad af små blad inuti ett blomhylle.

Bladsnärp ett hinnaktigt fjäll innanför bladslidan hos gräsen. Bladveck vinkeln mellan bladet och stammen.

Blomflock flock.

Blomfoder en fullständig blommas yttre och vanligen gröna blad (hos dikotyledoner).

Blomholk en samling af talrika skärmblad, som omgifva blommorna före utsprickningen och sitta på ett utbredt fäste.

Blomhufvud utan allmänt blomskaft, med korta eller inga enskilda blomskaft samt med icke utbredt blomfäste.

Blomhylle blommans yttre del, bestående af blad.

Blomhölster slidlikt skärmblad, omslutande en eller flera blommor före utsprickningen.

Blomkorg en samling af småblommor, omgifna af en blomholk. Blomknippe blomsamling med flera allmänna blomskaft (utom de enskilda) som ej utgå från en stamdels omedelbara förlängning, - eller en samling af 3 blommor, af hvilka den mellersta utvecklas först.

Blomkrona ett fullständigt blomhylles inre, vanligen högfärgade del (hos dikotyledoner).

Blomqvast qvast.

Blomskärm enstaka skärmblad.

Bräm den öfre delen af ett sambladigt blomhylle.

Bägarfoder ett svepe, som onsluter en nöt.

Bär en alltigenom saftig eller köttig frukt.

Bärlik (frukt) med frögömmets mellersta lager köttigt.

Delad med inskärningar, som gå ungefär så långt som möjligt (till basen eller till medelnerven).

Dikotyledon med 2 motsatta (sällan flera eller ett) hjertblad och vanligen grenigt nerviga blad.

Diskblommor sittande i midten af en blomkorg. 
Enkel (om blad) bestående af en enda, vid förvissnandet sammanhängande bladskifva; eller (om ett blomhylle) utan blomkrona. Enkelgömmig (frukt) med fruktbladen sammanväxta med hvarandras kanter.

Enkönad rned blott ståndare eller hlott pistiller.

Enskildt (blomskaft) uppbärande blott en blomma; eller (om svepe) sittande vid en småflock.

hjertblad.

Fanerogam med blommor i egentlig mening samt med

Fingerlikt sammansatt eller helt och hållet deladt blad, med småbladen stälda $i$ det gemensamma bladskaftets spets.

Fjädernervig med en större nerv genom bladets midt och med derifrån utgående, mindre och förgrenade nerver.

Fjärillik ärtväxternas blomkrona, bestående af 3 fria blad (seglet och vingarne) och två hopväxta (kölen).

Flergömmig (frukt) med frögömmet bestående af blad, som sammanväxt med sina egna kanter och ej bilda karpeller.

Flikig med bågformiga inskärningar, gående hälften så långt som hos delad.

Flock parasollik blomsamling: med endast enskilda, men intet allmänt blomskaft; sammansatt flock en samling af parasollformigt stälda, mindre flockar.

Foder blomfoder.

Foderskal skärmfjäll sittande nedanför gräsens småax.

Fribladig med alla bladen åtskilda.

Frögömme fruktens yttre del, bildad af blad.

Fullständig (blomma) med både foder och krona.

Gapande (läppformig blomkrona) med öppet svalg.

Glandler små saftförande knölar.

Gom uppsvällning af underläppen hos en maskerad blomkrona. Grenskott rotskott.

Groddknoppar knoppar, som skilja sig från växten och tjena till dess förökning.

Halfbuske nedtill af fastare, upptill af lösare byggnad.

Halfgräs med oledadt strå.

Hanblomma med endast ståndare.

Handnervig med flera större nerver, utgående från bladets bas.

Helt (blad) med inga eller obetydliga inskärningar.

Hinnfrukt gräsens frukt, hvars frögömme är hopväxt med fröet. Hjertlik äggrund med 2 afrundade flikar nedtill.

Hjertblad $i$ fröet liggande blad, som vanligen utvecklas vid groningen.

Hjulformig (krona) méd kort pip och platt, deladt bräm.

Holk blomholk.

Holkfjäll skärmbladen i en blomholk.

Honblomma med endast pistiller.

Hufvud blomhufvud.

Hänge ett ax hos träd eller buskar med skildkönade och ofullständiga blommor.

Högfärgad hvarken grön eller torrhinnig.

Hölster blomhölster. 
Inskuret (om blad) med grunda inskärningar.

Kalk ett blomhylle utan krona. Kalkborst borst, som finnas i blomkalkens ställe (hos halfgräs). Kapsel torrt, uppbristande fröhus med flera skal.

Kapselastad, kapsellik med torrt, uppbristande frögömme. Karpell en småfrukt i en skildgömmig frukt.

Klase blomsamling med ett allmänt och med lika långa enskilda blomskaft.

Klo nedre delen ef ett kronblad.

Klufven lika med flikig, men med rätliniga inskärningar. Klynnedelad upprepadt tvådelad.

Klänge trådlik förlängning af en gren eller af ett bladskaft.

Knopplökar löklika knoppar, tjenliga till växtens förökning.

Korg blomkorg.

Kolf ett ax, hvars blommor sitta intryckta i stammen.

Korslik regelbunden (blomkrona) bestående af 4 fria blad (i klassen Tetradynamia).

Krans af blad eller blommor, som sitta lika högt upp på stammen. Krona blomkrona.

Kronskal bladlika delar (agnar), som sitta närmast ståndarne (hos en gräsblomma).

Krypande nedliggande och rotslående.

Kryptogam med ofullkomliga befruktningsorganer och med sporer (frön utan hjertblad).

$K o ̈ l$ bildad af 2 hopväxta blad hos en fjärillik krona.

Könsdelar ståndare och pistiller.

Könlös utan utbildade könsdelar.

Könpelare blomdel, bildad af den med ståndaren förenade pistillen.

Lansettlik begränsad af båglika linier, med mer än 3 gånger så stor längd som bredd och bredast ungefär på midten. Likformig med lika stora blad.

Lyrformigt pardeladt eller parklufvet (blad) med utstående sidoflikar och stor ändflik.

Läpp den ena delen af brämet hos ett läppformigt blomhylle; eller - hos växter i Gynandria - ett vanligen nedböjdt kalkblad, som är olika de öfriga.

Läppformigt sambladigt oregelbundet blomhylle med i 2 större flikar (läppar) deladt bräm.

Maskerad läppformig blomkrona med tillslutet svalg. Monokotyledon med ett (eller sällan med 2 skiftevis stälda) hjertblad och enkelt nerviga örtblad.

Mångbyggare med hanblommor, honblommor och samkönade blommor.

Märke öfversta delen af pistillen.

Naggad med nästan vinkelrätt utstående tänder.

Nedlöpande (blad) då bladet fortsättes nedom skifvans fästepunkt. Nejlikeartad regelbunden krona af 5 fria blad med vanligen smala klor och breda skifvor samt omgifna af ett sambladigt foder. Nerver de trådiga delarne i bladets skifva.

Njurlik med 2 rundade flikar nedtill och med större bredd än längd. 
Nöt torr frukt, affallande oöppnad.

Nötskida genom felslagning icke uppbristande skida.

Odelad utan större inskärningar.

Ofullständig (blomma) utan blomkrona.

Oval begränsad af bågformiga linier, dubbelt så lång som bred och med största bredden på midten.

Oregelbunden icke (eller blott på ett sätt) delbar i 2 lika (symmetriska) delar, emedan bladen ej hafva samma form.

Parasit snyltgäst på en annan växt.

Parbladigt sammansatt blad, hvars småblad sitta på sidorna af det gemensamma bladskaftet: stundom lika med parbladigt deladt. Parbladigt deladt enkelt blad; liknande ett parbladigt blad, men utan leder vid småbladen (bladdelarne).

Pardelad delad och fjädernervig.?

Parklufven klufven och fjädernervig.

Penselhår hår, sittande $\mathrm{i}$ spetsen af en skalfrukt.

Pillik med 2 nedåtrigtade och spetsade flikar vid basen.

Pip nedre delen af ett sambladigt blomhylle.

Pistill blommans honorgan, bestående af fruktämne, stift och märke.

Pålrot enkel rot, utväxande af fröets rotämne.

Qvast blomsamling med ett allmänt blomskaft och med olika lănga enskilda blomskaft nående samma höjd.

Regelbunden med alla bladen af samma form och på flera sätt delbar i 2 lika (symmetriska) delar.

Rosartad regelbunden blomkrona of 5 fria blad med korta klor, omgifna af ett sambladigt foder.

Rotblomskaft bladlösa, örtartade stammar, vanligen enblommiga. Rotskott bladbärande grenar utgående från stammens bas.

Rörblomstrig (korg) med endast rörformiga eller nästan trattlika blommor.

Sambladig med alla bladen sammanväxta.

Sambyggare med hanblommor och honblommor på samma stånd. Samkönad med både ståndare och pistiller i samma blomma.

Sammansatt (blad) bestående af flera med leder fästade småblad, ofta affallande vid lederna.

Segel det öfversta bladet i en fjärillik blomkrona.

Slcalfrukt en vanl. under blomkronan sittande nöt, hvari fröet, frögömmet och fodret äro hopväxta.

Skida kapselartad frukt med 2 skal, åtskilda af en mellanvägg och derifrån vanligen lossnande.

Skifva bladets öfre, utbredda del.

Skildgömmig sammansatt af flera småfrukter i samma blomma. Skildkönad med alla eller åtm. somliga blommor enkönade.

Skärrmblad ombildade blad, sittande i blommornas närhet.

Småblad åtskilda delar af ett sammansatt eller af ett helt och hållet deladt blad.

Snärp bladsnärp.

Spadlik från en smal bas hastigt och betydligt tilltagande i bredd mot den afrundade spetsen.

Spiralstälda (blad) sittande i en sådan ordning, att en spiral (skruflinie) bildas, om man sammanbinder bladens fästepunkter. 
Spjutlik med rätt utstående sidoflikar nedtill.

Sporer kryptogamernas frön, som sakna bjertblad.

Sporre en trådlik eller säcklik utvidgning af någon blomdel.

Stenfrukt bärlik frukt med fruktgömmets innersta lager hårdt. S'tift pistillens smalare del ofvanpå fruktämnet.

Stipler bihang till ett blad, bildade af dess slida.

Stjelk bladbärande örtartad stam.

Stamknöl utsväld underjordisk stamdel meủ knoppar(ögon)på ytan. Strälblommor tunglika blommor i kanten af en blomkorg.

Strailblomstrig med tunglika blommor i kanten och rörformiga eller nästan trattlika blommor i midten.

Strödda spiralstälda (blad).

Staindare blommans hanorganer, bestående af sträng och knapp med deri vanligen inneslutet frömjöl.

Stängel bladlös örtstam, vanligen uppbärande flera blommor.

Svalg gränsen mellan brämet och pipen.

Svepe flera i krans sittande skärmblad.

Sågad med åt ett håll lutande tänder.

Taggar tjocka spetsiga borst $\mathrm{i}$ öfverhuden.

Taggigt (blad) med taggar eller med tagglikt spetsade nerver. Tallriksformig (krona) med platt bräm och utdragen rörformig pip. Torn en med hvass spets slutande gren.

Tungblomstrig bestående af endast tunglika blommor.

Tunglik sambladig krona med tunglikt (bandlikt) bräm; eller (om blad) med något bred bas småningom tilltagande $\mathrm{i}$ brédd mot den afrundade spetsen.

Tvåbyggare med hanblommor och honblommor på olika stånd (individer) af samma art.

Täncler små flikar i bladkanten.

Uddblad udda blad (utom jemna par).

Vigglik liknande en kil med tvär spets.

Vingad (stam eller frukt) med bladartade eller hinnaktiga kanter. Vingar yttre blad i en fjärillik krona; eller kanter i en vingfrukt. Vingfrukt nötlik vingad frukt.

Vippa blomsamling med flera allmänna blomskaft, som utgå från en förlängd stamdel.

Äggrunả begränsad af båglika linier, dubbelt så lång som bred, med största bredden nedom midten.

Aple bärlik frukt, sammanhängande med blomfodret och med frögömmets innersta lager deladt $\mathrm{i}$ rum.

Artbalja balja.

Örtartad (stam) af lös byggnad och helt och hållet vissnande ofvan jordytan.

Örtrefva nedliggande gren, bladlös eller bladbärande på de ställen, der den utslår rötter. 


\section{Några regler vid växternas insamling och inläggning till pressning.}

1. Insamlingen. Tag icke det första exemplar, som påträffas, utan välj de vackraste, och utrota icke sällsynta växter. - De växter, som hafva några för art̉estämningen vigtiga delar under jordytan, upptagas helst med en lång och bred knif; likaså böra rotskott medfölja, då sådana finnas. - Tag icke toppar eller stumpar af växter, som ej äro för stora att $i$ herbariet inrymmas. - Samla icke flera exemplar, än att de kunna pressas samma dag; eljest blifva de ej vackra. - Portörens lock bör. vara anbringadt vid ena ändan, så att alla de insamlade exemplaren på en gång kunna urtömmas. - Finare och ömtåligare växter inläggas helst genast under exkursionen i der medfördt papper.

2. Inläggningen. Saftfulla växter doppas ungefär $1 / 2$ minut i kokhett vatten; blommorna tåla endast vid en hastig doppning. - Inga fuktiga exemplar inläggas, utan fuktigheten aflägsnas genom gråpapper. - Lägg ej exemplaren inuti, men utanpå arket. - Invid finare växter lägges hvitt tunnt papper, som ej ombytes, förr än växterna styfnat. - För att få blommorna utbredda, t. ex. af en Potentilla, inlägges hvarje blomma i en liten pappersbit, som vikes deromkring och får qvarligga, tills växten blir fullt torr och styf. - Göm i portören ett exemplar af hvarje växtart opressadt för att jemföra det med beskrifningen i floran, ifall detta ej genast medhinnes; anteckua växestället och datum för insamlingen på ett papper af ett visitkorts storlek. - Vid pappersombytet afskiljas alla sådana exemplar, som först (och snart) kunna blifva torra, och läggas särskildt; pappskifvor eller tunna brädskifvor inläggas här och der; växterna omflyttas och skrynklade delar utbredas med en pappersknif, ogerna med fingrarne. - Halftorra växter läggas ur pressen $i$ en med pappskifvor omslagen och med starkt segelgarn ombunden packe; om tillräckligt papper användes, behöfves intet vidare omhyte af sådant. - Papperet bör vara fullt torrt, helst upphettadt af solen eller $\mathrm{i}$ en ugn. 


\section{Svårbestämbara slägten och arter:*)}

A. Träd och buskar.

a. Blommor fullständiga med bärlik frukt. Buskar.

Ribes alpinum $(22,5)$ blommor i klasar; Viburnum $(5,1)$ blommor i knippen, blad handnerviga; Sambucus $(5,1)$ blad parbladigt delade; Rhamnus (22,4-5) blad fjädernerviga och hela; Empetrum $(3,1 ; 21,2)$ blad n. barrlika.

b. Blommor fullständiga med vingfrukt. Träd. Acer $(8,1-2 ; 10,1-2)$ blad handnerviga.

c. Blommor fullständiga med kapsellik frukt. Rhododendrum $(5,1)$ låg halfbuske; Fvonymus $(4,1)$ buske.

d. Blommor ofullständiga. Träd eller buskar med barr. Pinus och Abies (21,4), Juniperus och Taxus (22,3-6).

e. Blonımor ofullständiga. Trä̀d eller buskar med blad. Fraxinus $(2,1)$ blad parbladiga; Ulmus $(4-6,1-2)$ blommor i flock; Betula $(21,2-4)$, Salix $(21,2 ; 22,3-6)$ och $M y$ rica $(21 ; 22,6)$ blommor i hängen.

B. Gräs. $(3,1)$.

Festuca sciuroides (1,1); Catabrosa algida, Anthoxanthum och Hierochloa $(2,2)$; Nardus $(3,1)$. Hos Avena elatior, Holcus, Hierochloa, Hordeum och Phragmites finnas ofta enkönade blommor jemte de samkönade.

C. Halfgräs och andra gräslika växter.

Eriophorum alpinum $(\mathbf{I}, 1)$; Cladium, Scirpus setaceus, Cyperus och Rhynchospora alba $(2,1)$; Carex dioica $(22,3)$; Juncus ..(3,1).

D. Orter (sällan halfbuskar) med fullständiga blommor.

a. Blomkrona sambladig.

1. Stam ej (eller blott nedtill) bladbärande.

Cuscuta $(\mathbf{4 , 2})$ slingrande parasit; Petasites $(\mathbf{2 2 , 5 )}$ blommor i korg; Limosella, Littorella $(4,1)$ och Lobelia $(19)$ vattenväxter.

2. Stjelk bladig med motsatta blad.

Valeriana dioica $(22,3)$, Montia $(3,1)$ blommor hvita; Lysimachia $(16 ; 6,1)$ blommor gula; Mentha $(4,1)$ blommor i krans; Gentiana $(4-5,1-2 ; 19)$; Cynanchum $(5,1 ; 16)$.

3. Stjelk bladig med kranssittande blad.

Galium, Sherardia och Asperula (3-4,1-2); Lysimachia $(16,1 ; 6,1)$.

4. Stjelk bladig med strödda blad.

Iasione och Solanum (19); Antennaria, Cirsium arvense och Serratula $(22,5)$ blommor i korgar; Trientalis $(6,1)$ blommor stjernlika; Vaccinium $(\mathbf{1 0 , 1 )}$ halfbuskar med bär.

*) De inom parentes satta nummerna utmärka den klass och ordning, hvartill de anförda växterna skulle kunna hänföras; deras rätta plats igenfinnes lätt på registret. 
b. Blomkrona fribladig.

1. Stam endast blombärande, stundom med blad vid basen. Monotropa (8,1); Myosurus (4); Drosera (5,3-4); Viola (19); Oxalis $(10,4)$.

2. Stjelk med motsatta blad.

Stellaria media $(1-5,4)$, Cerastium (10,3; 4--5,4-5), Ammadenia (22), Sagina $(4,4)$, Spergula vernalis $(5,4)$ och Linum $(5,5)$ blommor hvita; Elatine $(\mathbf{8}, 3 ; 6,3 ; 3,3)$ vattenväxter; $M e$ landrium och Silene acaulis (22) krona nejlikeartad; Adoxa $(4-5,1-4 ; 8-10,1 ; 10,5)$ blommor gröna; Hypericum $(13,3)$, Rhodiola $(10,4 ; 8,2)$ blommor gula.

3. Stjelk med strödda blad.

Draba muralis och Cardamine hirsuta $(4,1)$ med skidor; Rubus Chamamorus $(22,6)$ med sammansatt stenfrukt; Sanicula europea $(\mathbf{2 3 , 1 )}$ blommor i hufvud; Sempervivum $(\mathbf{6}-10)$ blad tjocka köttiga; Spircea $(10,4$; II) med kapsellika karpeller; Ranunculus hyperboreus (5-7) med nötlika karpeller; Geranium och Erodium $(10,4 ; 5,5)$; Viola (19).

c. Blomkrona till en del sambladig och oregelbunden.

Sarothamnus, Ononis och Anthyllis (16) med sammansatta blad; Impatiens (19), Genista och Polygala (16) med enkla blad; Fumaria $(2,1)$.

E. Örter med ofullständiga blommor (utom de förut anförda gräslika växterna).

a. Blad grenigt nerviga. Stjelk vanligen bladig.

1. Blommor enstaka.

Callitriche (1,2), Elatine $(3,3 ; \mathbf{8}, 3)$ vattenväxter med oskaftade blommor; Viola $(2,1)$ blommor utdraget skaftade.

2. Blommor flera tillsammans.

Euphorbia (II,3) mjölksaftiga växter; Herniaria $(4,1 ; 8$ $10,1)$ blad små med stipler; Rumex $(22,6)$ och Polygonum (5$6,1-3 ; 8,1-2)$ med stipelslidor; Lepidium ruderale och Coronopus didymus $(2,1)$ med pardelade blad; Urtica dioica (22) med brännborst; Chrysosplenium $(10,2 ; 4,2)$ med njurlika blad; Chenopodium (I-5,1-2), Blitum (I,2) och Atriplex $(\mathbf{5}, 2 ; \mathbf{2} \mathbf{I})$ landväxter med gyttrade blommor och odelade blad utan stipler; Thesium $(3,1)$ blad n. trådlika; Poterium (23) blad parbladigt delade.

b. Blad enkelt eller otydligt nerviga.

Callitriche, Zannichellia (1) och Ruppia $(2,4)$ i vatten nedsänkta finbladiga växter; Typha $(21,2)$ och Calla $(21,6)$ med blommor i kolf; Zostera (2I), Juncus $(3,1)$ gräslika växter; Sagina $(4,4)$, Scleranthus (5-8,2), Kochia, Schoberia och Salsola $(5,1)$ med små nästan syllika blad.

c. Stam utan blad.

Salicornia $(2,1)$ blommor i kolf; Lemna små vattenväxter; Juncus $(3,1)$ med strålik stam; Asparagus (23) smågrenar borstJika.

F. Med sällan utvecklade eller otydliga blommor.

a. Vattenväxter. Örter.

Lemna med bladlik stam; Montia, Bulliarda, Peplis, Elatine och Callitriche med hela och motsatta blad; Hippuris och 
Zannichellia med hela kranssittande blad; Subularia, Littorella, Stratiotes med stängellik stam; Utricularia, Myriophyllum och Ceratophyllum med findelade blad; Zostera med gräslik stam; Hydrocharis med njurlika blad; Potamogeton, Ruppia, Limosella, Najas och Trapa.

b. Landväxter.

Hedera (buske), Chenopodium, Polygala, Euphorbia, Atriplex med ej delade blad; Fumaria, Corydatis med delade blad.

\section{De vigtigaste odlade växterna.}

\section{Sädesslag.}

1. Triticum vulgare, Hvete. Foderskal äggrunda kullriga.

a. æstivum, Sommarhvete. Kronborst långt.

b. hibernum, Vinterhvete. Kronborst kort eller intet.

Triticum túrgidum, Kubbhvete. Foderskal äggrunda kölade.

2. Secále, Råg. Skiljes från Triticum genom tvåblommiga småax. S. cereále. Kronborst långt.

3. Hórdeum, Korn. Skiljes från Elymus genom långt kronborst. H. vulgare, Fyrradigt Korn; H. hexástichon, Sexradigt Korn; H. distichon, Tvairadigt Korn.

4. Avéna sativa, Hafre. Skiljes från $A$. fatua genom glatta kronskal.

\section{Hushållsväxter.}

1. Solanum tuberósum, Potatis. Ört med parbladigt delade blad och vanl. violetta blommor.

2. Nicotiána, Tobak. Står nära Datura, men har klufvet blomfoder, helbräddade blad och tagglös frukt. N. Tabácum, Virginisk Tobak, med aflångt lansettlika blad och röda blommor, N. Iatíssima, Marylands-Tobak, med äggrundt lansettlika blad och röda blommor, N. rústica, Turkisk Tobak, Bondtobak, med äggrunda blad och gröngula blommor.

3. Petroselínum sativum, Persilja. Skiljes från Conium genom 1-2-bladigt allmänt svepe, månghladiga enskilda svepen och slät frukt.

4. Anéthum gravéolens, Dill. Skiljes från Pastinaca genom dubbelt parbladigt delade blad med trådlika flikar.

5. Coriándrum sativum, Koriander. Parasollväxt med findelade blad och klotrund frukt, hvars karpeller äro inböjda (konkava) på insidan.

6. Beta vulgaris, Röd- och Hvitbeta. Skiljes från Chenopodium genom klufven blomkalk och har blomgyttringarne förenade $i$ ett långt och slutl. bladlöst ax.

7. Allium sativum, Hvitlök, är skild från A. Scorodoprasum genom enbladigt långspetsadt hölster. A. porrum, Purjolök, har platta jemnbreda blad och utskjutande ståndare. A. ascalónicum, Echalottenlök, som har violetta blommor, och A. Cepa, 
Rödlök, som har hvita blommor och nedtill uppblåst stängel, stå nära $A$. sibiricum.

8. Rumex Patiéntia, Patientia, står nära $R$. conspersus, men har längre och större, äggrundt aflånga blad.

9. Fagópyrum, Bohvete. Skiljes från Polygonum genom invikna hjertblad i fröet och har pillika blad och upprätt, ej slingrande stjelk. F. esculentum har täta blomklasar, F. emarginàtum har glesa klasar.

10. Prunus doméstica, Plommonträd, saknar tornar; qvistarne äro glatta, blomskaften och undra sidan af bladen finhåriga. 11. Cérasus ácida, Körsä̋̈r ; blommor i kortskaftade flockar, blad glatta, bladskaft utan vårtor.

12. Origanum Majorána, Mejram; blad gråludna, små, ovala och trubbiga; blomskärmar n. runda.

13. Thymus vulgaris, Timjan; stjelk n. upprätt, blad med nedvikna kanter.

14. Lepidium satívum, Sommarkrasse; skida rundtomkring vingad, blad pardelade, truktskaft upprätta.

15. Brassica olerácea, $K a ̊ l$; blad stora och köttiga.

16. Raphanus satívus, Rätticka och Rädisa; kronblad upptill violetta, skidor syllika.

17. Linum usitatíssimum, Lin; blommor.. blå, blad strödda.

18. Pisum satívum, Gula och gröna Ärter; kronsegel hvitt, frön ofläckade och klotrunda.

19. Vícia Faba, Wälska Bönor, Bondbönor; blad stora 1-3pariga, klasar kortskaftade, stjelk upprätt.

20. Phaséolus vulgaris, Turkiska Bönor; blad trefingrade; blommor hvitaktiga i korta, fåblommiga klasar; stjelk vanl. klängande, stundom icke (hos en varietet, som kallas Krypböna).

21. Lens esculenta, Zinser, skiljes från Ervum genom upptili urnupen, med spröt försedd ärtbalja samt på båda sidor kullriga frön.

22. Scorzonera hispánica, Scorzonera; stjelk grenig och mångbladig, de nedre bladen fjädernerviga.

23. Lactuca satíva, Sallad ; stjelkblad hjertlika omfattande, veka och ej taggiga.

24. Heliánthus, Solros. Liknar Centaurea genom de könlösa kantblommorna, men dessa äro tunglika. H. tuberósus, Jordärtskocka, med tjocka stamknölar, upprätta blomkorgar och vanl. kranssittande blad. H. ánnuus, Solros, utan stamknölar, med lutande blomkorgar och vanl. skiftevis stälda blad.

25. Cúcumis satívus, Gurka. Skiljes från Bryonia isynnerhet genom den stora frukten samt de stora gula blommorna, som sitta i oskaftade flockar.

26. Cánnabis sativa, Hampa. Skiljes från Humulus bland annat genom upprätt, ej slingrande stjelk och delade blad samt honblommor i knippen.

27. Spinácia, Spinat. Hör till Dioecia Pentandria och liknar Chenopodium, men har honblommans kalk tandad. S. olerácea med vanl. pillika blad och taggig frukt, S. glabra med vanl. hela blad och ej taggig frukt.

28. A'triplex hortensis, Trädgårdsmolla, har somliga blommor 
samkönade, åtskilda och rundadt äggrunda samt helbräddade fruktfoderblad och stora, hjertlikt triangelformiga, på båda sidor gröna blad. A. nitens liknar denna art, men har undertill hvitmjöliga blad och spetsiga fruktfoderblad.

\section{Parkträd och buskar.}

1. Syringa vulgaris, Syrén. Hör till Diandria Monogynia, nat. fam. Oleineæ. Blomkrona sambladig, frukt kapsellik fåfröig, blad hjertlika.

2. Ly'cium bárbarum, Bocktörne. Skiljes från Solanum genom trattlik blomkrona och vidjelika grenar; blommor violetta.

3. Lonicera Caprifólium, Äkta Kaprifolium, skild från L. Periclymenum genom de på blomgrenarne hopväxta bladen och genom oskaftade blomhufvud.

4. Sambucus racemósa, Klasehyll; bär röda, blommor i äggrund vippa.

5. E'sculus Hippocástanum, Hästkastanje. Hör till Heptandria IMonogynia,-nat. fam. Acerineæ, och har 5-7-fingrade blad.

6. Spiræa salicifólia, Pilbladig Spirea; blad aflångt lansettlika och sågade, blommor ljusröda.

7. Rubus odorátus, Lukthallon; blad 5-flikiga, blommor stora röda $n$. i qvast, stam utan taggar.

8. Larix europæa (L. decídua), Lärkträd. Står nära Abies, men har mjuka, på hösten affallande, knippevisa harr.

9. Abies pectináta, Silfvergran; kottar upprätta, barr undertill silfverhvita.

10. Pinus Cembra, Cembratall; kottar upprätta, barr föga utstående, fem tillsammans inom slidan; frön mandellika ovingade.

11. Salix acutifólia, Smalbladigt Blaivide, skiljes från S. daphnoides genom smalare blad och lansettlika stipler. S. purpurea, Rödvide; ståndare nästan alldeles hopväxta med röda, slutl. svarta knappar; blad lansettlika, hängen små, utslående på bar qvist; hängefjäll bruna; fröhus oskaftade. S. babylónica, Târpil, skild från $S$. fragilis genom n. jemnbreda blad och mycket långa, vidjelika och nedhängande grenar. S. viminális, Korgvide, Bandpil, har långa vidjelika grenar med gröngul bark och mycket långa och smala blad med nedböjda kanter.

12. Pópulus, Poppel. A) de unga grenarne håriga: P. alba, Silfverpoppel, blad undertill silfverhvita, smågrenarnes flikiga, P. canescens, Gråpoppel, blad bugttandade, undertill gråludna. B) Grenar glatta utstående: P. monilífera, Kanadapoppel. blad med tvär bas och större längd än bredd, P. nigra, Svartpoppel, blad n. hjertlika. C) Grenar glatta upprätta: P. pyramidális $(P$. dilatata). Utom dessa märkas $\mathbf{P}$. cándicans, $O n$ tariepoppel med hjertlika blad och P. balsamifera, Balsampoppel med äggrunda blad: bảda hafva klibbiga knoppfjäll.

13. Acer Pséudo-Plátanus har blommorna stälda i hängande klasar. 


\section{Förvildade och tillfälligtvis före- kommande växter.}

1. Plantago arenária W. K.; skild frán våra vilda arter genom grenig stjelk; blad smala jemnbreda. Vid Malmö på sandiga ställen.

2. Dípsacus pilósus L., Kardtistel; skild från Scabiosa genom nedböjda svepeblad; tistellik, omkr. 3 fot hög växt med taggig stjelk, hvit fyrklufven blomkrona och bredt äggrunda, skaftade blad med en aflång flik på hvar sida om skaftet. Ruderatväxt r. i Skåne och vid Söderköping.

3. Lolium multiflórum Lam.; skild från $L$. perenne genom borstbärande kronskal. På gräsplaner, t. ex. i Ög. och Sk. L. festucáceum Link; skild från L. perenne genom jemnbreda småax och mycket korta foderskal; förmodas vara bastard af Lol. perenne och Festuca pratensis. I Skane, mycket $r$.

4. Glyceria loliácea Godr.; skild från $G$. fuitans genom kort bladsnärp och stundom sammansatta småax; förmodas vara bastard af $G$. fluitans och Lolium perenne. På fuktiga ställen vid Lund och Kristianstad.

5. Phálaris canariensis L., Kanariegräs; klass. Triandria, ordn. Digynia, afdeln. Phalaridece; vippa tät axlik och n. äggformig; foderskal på ryggen vingade; strå $1-2$ fot högt. Nära bostäder.

6. Crocus vernus All., Saffran; skild från Iris bl. a. genom likformigt 6-klufven kalk med lång pip; låg lökväxt med mycket smala blad och en stor, blå eller hvit blomma. På gräsplaner i Upl. r.

7. Narcissus, Narciss, skild från Galanthus genom sambladig kalk med lång pip. N. poëticus L., Pingstlitja, med hvit blomma och skålformig, kort och rödkantad bikrona. I gamla trädgårdar t. ex. Sk.-Hels. - N. Pseudo-Narcissus L., Påsklitja; blomma gul med lång hikrona. I gamla trädgårdar, sällan $\mathrm{i}$ ängar, t. ex. i Sk. och på Gotl.

8. Muscári botryóides (L.) Mill., Perlhyacint; familj. Liliacea, klass. Hexandria ordn. Monogynia; blomkalk sambladig med klotformig pip och litet bräm; stängel med jemnbreda blad och små blå blommor i klase. I parker och ängar r.; Göt. Hall. Öl. Smål. Ög. Vg., Sv. Söd. Upl. Norrl. Gestr.

9. Lilium Mártagon L., Kroll-lilja; blommor lutande i klase; blad kranssittande, bredt lansettlika - äggrunda; kalkblad tillbakarullade, ljusröda och brunfläckiga. Lundar och parker t. r.; Göt., Sv., Norrl. Gestr. Hels.

10. Cólchicum autumnále L., Tidlösa; fam. Colchicácea, klass. Hexandria ordn. Trigynia; lökväxt med sambladig kalk, 3-rummig kapsel och en stor och lång, ljusröd eller blekblå 
blomma, som utbildas på hösten före de på våren utväxande, larnsettlika bladen. Parker och gamla trädgårdar i Upl. och Ög. r.

11. Rheum Rhapónticum L., Rabarber; fam. Polygóneae. klass. Enneandria ordn. Trigynia; kalk 6-bladig; nöt med 3 vingade kanter; hög växt, lik en Rumex, men med mycket stora, hjertlika blad och grönhvita blommor. Ruderatväxt på torra ställen r., t. ex. Og. Ner. Upl.

12. Dianthus barbátus L., Borstnejlika; blommor gyttrade och n. oskaftade; blomfoder rörformigt; svepeblad ovala med långt borst; mörkgrön och n. glatt med rotstock. Nära trädgårdar t. r., t. ex. i Ög. och Upl.

13. Siléne Arméria L.; glatt; blomfoder slutl. uppåt vidgadt; blommor i qvastar; kronblad rosenröda och n. hela; stjelkblad n. ovala. Ogräs i trädgårdar h. o. d., t. ex. Gotl. - S. gállica L.; foder rörformigt; blommor i klase; de blekröda kronbladens skifva n. hel; blad n. jemnbreda. På torra backar i Skåne r. - S. dichótoma Ehrh.; blomfoder något uppblåst och ludet; blommor i ax; kronblad hvita med djupt klufven skifva; stjelkblad n. lansettlika. På torra backar i Sk. r.

14. Reseda lútea L.; blad pardelade; ballastväxt.

15. Potentilla pilósa W.; stjelk upprätt sträfluden; blad 5fingrade grofsågade, långhåriga och på båda sidor gröna; blommor stora. Ruderatväxt r., t. ex. Ög. Söd. Vestm.

16. Papaver somníferum L., Opiiört; blad stjelkomfattande och grundt flikiga; kronblad hvit- eller rödaktiga. Ogräs och ruderatväxt, helst i Göt. och Sv. - P. Rhœeas L.; blad pardelade, ej omfattande; foder långhårigt; fröhus kort och n. klotrundt. Ogräs och ruderatväxt i Göt. och Sv. t. r.

17. Ballota fœetida Lam.; fodertänder halfrunda med kort udd. Ballastväxt $r$.

18. Scutellaria altíssima L.; blad hjertlika; blommor i ensidiga klasar; blomkrona ljusblå med bvit underläpp. Nära trädgårdar $\mathrm{i}$ Skåne, mycket $\mathrm{r}$.

19. Draoocephalum thymiflórum L.; blad sågade äggrunda -aflånga; blomkrona föga längre än fodret. Ruderatväxt, helst på torftak, i Upl. och Hall.

20. Elzhólzia cristáta W.; skild från Mentha genom nedtill frånstående rum i ståndareknappen; blommor små och blekvioletta $i$ ensidiga ax med tvåsidigt stälda, rundadt äggrunda skärmblad; blad ovala-äggrunda. Ogräs t. r.; Göt. Sk. flerst. Hall. Smål. Gotl., $S v$. Söd. Upl. Verml.

21. Linaria repens (L.) (L. striáta D.C.); blommor blåaktiga i gles klase; sporre kort. Ruderatväxt r.; Göt. Boh., Sv. Söd. Upl. Ner., Norrl. Gestr. Med. - L. supina (L.) Desf.; blommor stora och gula i tät klase; sporre lảng. Ballastväxt $r$. vid Göteborg, Gefle och Sundsvall. - Båda arterna hafva uppstigande stjelk och smala blad, de nedre kranssittande.

22. Sisymbrium Loesélii L.; kronblad gula, längre än fodret; skidor utspärrade, dubbelt längre än skaften; blad pardelade. Ruderatväxt; Söd. Upl. r. - - S. I'rio L.; lik föreg. men vanligen glatt; skidor föga utstående, 4-5 gånger längre ä̀n skaften; blad parflikiga med nedåt rigtade flikar. Ogräs och hallastväxt mycket $r$. 
23. Diplotaxis murális D.C., lik $D$. tenuifolia, men lägre och blott nedtill bladig med smärre blommor och djupt bugttandade blad. Ballastväxt r., t. ex. vid Visby.

24. Oxalis stricta L.; hlommor gula, 2-3 i flock; stjelk upprätt och $1 / 2-1$ fot hög; bladskaft utan stipler. Ruderatväxt och ogräs; Sk. flerst. i trädgårdar, Smål. vid Vestervik, Ög. vid Motala. - 0. corniculáta L.; lik föreg., men nedliggande och med stipelbärande bladskaft. Mycket $r$. vid Lund i Sk.

25. Althæa officinalis L., Alté-rot; skild från Lavateru genom svepe af $6-12$ blad; mjukt grăluden med flikiga, n. hjertlika blad och upprätt, omkr. 2 fot hög stjelk. På strandängar i Sk. r. vid Malmö och Treleborg.

26. Corydalis nóbilis Pers.; olik öfriga arter genom rotstock, pardelade blad och gula blommor. Ogräs i trädgårdar t. r. upp till Gestr.

27. Ulex europæus L.; skild från Genista genom tvådeladt blomfoder och båtlik kronköl; taggig buske med syllika blad och gula blommor. Ballastväxt vid Vestervik och på Gotl.

28. Trigonella ornithopodióides D.C.; skild från Melilotus genom mångfröig balja; stjelk utbredd och låg; blommor rödaktiga, 2-4 tillsammans i klasar. I ängar r. på Gotl, och vid Vestervik.

29. Trifolium incarnàtum L.; blomhufvud långskaftade, i början äggformiga, slutl. jemntjocka; blommor röda; småblad omvändt äggrunda. I klöfvervallar r.: Smål. Vestm. Verml.

30. Senecio saracénicus L.; olik S. paludosus genom mer än tumsbredaroch glatta blad, de nedre kortskaftade; strålblommor 7-8. I och vid trädgårdar r., t. ex. vid Stockholm. - S. vernális W. K.; strålblommor långa; blad som hos S. vulgaris, men större; stjelk gleshårig; yttre holkfjäll 6-12, 3-4 gånger kortare än de inre; rot tvåărig. Vid Fogelsång i Skåne $r$.

31. Matricaria discoídea D.C.: blomkorgar kortskaftade utan strålblommor; blomfäste ihåligt; välluktande. På gator i Upsala och vid Simtuna prestgård.

32. Erigeron canadensis L.; blommor hvitgula; blomkorgar små och talrika; blad smala, hårbräddade eller sågade. Ballastväxt $r$.

33. Inula Conyza D.C.; kanthlommor treklufna och ej utskjutande; blad håriga ovala-lansettlika; blomkorgar talrika $\mathrm{i}$ qvast; 1-2 fot hög med rödbrun holk. På en pilvall vid Lund i Sk.

34. Aristolóchia Clematitis L., Hållrot; fam. Aristolochiácea, klass. Gynandria ordn. Hexandria; kalk gulgrön och n. rörformig med snedt bräm; blad hjertlika; rotstock lång; stjellk omkr. 2 fot hög; dikotyledon. Nära bostäder t. r., t. ex. Sk. Ög. Upl. Vestm.

35. Xánthium strumárium L.; fam. Ambrosiácece, klass. Monoecia ordn. Pentandria; hanblommor i korgar, honblommor utan kalk med slutl. taggigt svepe: stjelkblad stora hjertlika; blommor gröna. Ruderatväxt r., t. ex. vid Örebro och Nyköping.

36. Bryónia alba L., Hundrofva; fam. Cucurbitácea, klass. Monoecia ordn. Pentandria; ståndare 5, hvaraf 2 och 2 hopväxta; 
krona 5-delad; foder 5-klufvet; ört med skiftevis stälda, handnerviga och klufna blad samt ett klänge midt emot hvart blad; blommor grönaktiga; bär slutl. svarta. Ruderatväxt vid gärdesgårdar; Göt. r.: Sk. spr. Boh.?, Sv. r.: Ner. Dal.?

37. Amarantus Blitum L., fam. Amarantácea, klass. Monoecia ordn. Pentandria; lik Chenopodium polyspermum; kalk tredelad med bred hvit hinnkant; blad äggrunda urnupna. Ogräs i trädgårdar; Sk. Smål. Upl. (t. ex. Stockholm).

38. Parietária officinalis L.; fam. Urticácea, klass. Polygamia ordn. Monoecia; kalk klocklik, 4-klufven och grön; ståndare 4; märke sköldlikt; stjelk upprätt; blommor grönhvita, gyttrade i bladvecken. Ruderatväxt i Sk. vid Malmö och Cimbrishamn $r$.

39. Mercurialis ánnua L.; stjelk grenig; blad n. äggrunda och glatta; enårig. Ballastväxt flerst. vid Östersjön och Bottn. viken.

\section{Förkortningar af anförda för- fattares namn.}

Ag. C. A. Agardh.

All. Allioni.

Ands. N. J. Andersson.

Andr\%. Andrzeiovski.

Ard. Arduino.

Aresch. F. W. C. Areschoug. Arrh. J. P. Arrhenius.

$B a b$. Babington.

Backh. Backhouse.

Balb. Balbis.

Bechst. Bechstein.

Bell. Bellardi.

Bernh. Bernhardi.

Bert. Bertoloni.

Bess. Besser.

Bieb. M. v. Bieberstein.

Big. Bigelow.

Biv. Bivona.

A. Br. Alex. Braun.

R. Br. Rob. Brown.

Bönn. Bönninghausen.

Campd. Campdera.

Cham. Chamisso.

Clairv. Clairville.

Coult. Coulter.

Curt. Curtis.

Cust. Custor.
D. C., De Cand. De Candolle.

Desf. Desfontaines.

Desp. Desportes.

Desrouss. Desrousseaux.

Desv. Desvaux.

Dew. Dewey.

Drej. Drejer.

Duch. Duchesne.

Dum. Dumortier.

Dur. Durieu.

Ehrh. Ehrhart.

Fl. Bat. Flora Batava.

Fr. E. Fries.

Th. Fr. Th. Fries.

Fresen. Fresenius.

Frist. R. F. Fristedt.

Fröl. Frölich.

Gärtn. Gärtner.

Gaud. Gaudin.

Gibs. Gibson.

Gil. Gilibert.

Gmel. Gmelin.

Godr. Godron.

Good. Goodenough.

Grab. Grabowski.

Gren. Grenier. .

Grev. Greville. 
Hall. Haller.

Haw. Haworth.

Hitchc. Hitchcock.

L'Herit. L'Heritier.

Herm. Hermann.

Hn, Hartm. Hartman.

Hoffm. Hoffman.

Hook. W. J. Hooker.

Hop. Hoppe.

Horn. Hornemann.

Fiuds. Hudson.

Jacq. Jacquin.

Kindb. N. C. Kindberg.

Kit. Kitaibel.

Krock. Krocker.

Kühl. Kühlewein.

Kütz. Kützing.

Köl. Koeler.

I. Linné.

Læest. Læstadius.

Larss. L. M. I arsson.

Lam. Lamarck.

Ledeb. Ledebour.

Leff.. J. A. Leffler.

Lehm. Lehmann.

ILej. Lejeune.

Less. Lessing.

Lightf. Lightfoot.

Liij. Liljeblad.

Lindeb. C. J. Lindeberg.

Lindl. Lindley.

Lois. Loiseleur Deslongchamps.

Lönnr. K. J. Lönnroth.

M. B. M. v. Bieberstein.

Med. Medicus.

Mert. Mertens.

Mey. Meyer.

Mich. Micheli.

Michx. Michaux.

Mik. Mikan.

Mill. Miller.

IM. $K$. Mertens och Koch.

Murr. J. A. Murray.

Nyl. F. Nylander.

Näg. Nägeli.

Panz. Panzer.

P. B. Palisot de Beauvois.

Pers. Persoon.

Poir. Poiret.

Poll. Pollich.

Pourr. Pourret.
Rchb., Reich. Reichenbach.

Retz. A. J. Retzius.

Rich. Richard.

Rostk. Rostkov.

Rottb. Rottböll.

Röhl. Röhling.

$R$. S. Römer och Schultes.

Salisb. Salisbury.

Scheuchz. Scheuchzer.

Schimp. Schimper.

Schk. Schkuhr.

Schleich. Schleicher.

Schlecht. Schlechtendal.

Schnitzl. Schnitzlein.

Schrad. Schrader.

Schreb. Schreber.

Schult. Schultes.

Schum. Schumacher.

Schweig. Schweiger.

Scop. Scopoli.

Ser. Seringe.

Sibth. Sibthorp.

Sm. Smith.

Sond. Sonder.

Spreng. sprengel.

Sternb. Sternberg.

Sw. O. Swartz.

Ten. Tenore.

Thom. Thomasius.

Thuill. Thuillier.

Trin. Trinius.

Tullb. S. A. Tullberg.

Turcz. Turczaninow.

Wahlb. P. F. Wahlberg.

Wng, Wahlenb. G. Wahlenberg.

Wallm. J. H. Wallman.

Wallr. Wallroth.

Web. Weber.

Weig. Weigel.

Whe, Weih. Weihe.

Wib. Wibel.

Vill. Villars.

Willd., W. Willdenow.

Wim. Wimmer.

With. Withering.

Viv. Viviani.

Wolfg. Wolfgang.

Wulf. Wulfen.

Zett. J. E. Zetterstedt.

Angstr. J. Angström.

Örst. Örsted. 


\section{De vigtigaste artnamnens betydelse.}

acutifolius med spetsiga blad. agrarius, agrestis växande på åkrar.

albus hvit.

alpestris växande! i fjelltrakter. alpinus fjellväxt.

amphibius växande både i vatten och på land. angustifolius smalbladig. annuus enårig. aquaticus, aquatilis växande $i$ vatten.

arenarius, arenosus växande på sandiga ställen. arundinaceus rörlik. arvensis på åkrar. autumnatis höstlig. balticus förek. vid Östersjön. bifolius tvåhladig. borealis nordisk. bulbiferus, bulbosus lökbärande. cespitosus tufvig. campestris slättbygdsväxt. cinereus gråluden. coeruleus blå. collinus på backar. communis vanlig. compressus hoptryckt. crispus med krusiga blad. dioicus tvåbyggare.

domesticus vid bostäder. erectus upprätt. fragitis skör. fruticosus buskartad. glaber glatt. glaucus blågrå. glutinosus klibbig. gracitis spenslig. gramineus gräslik. grandiflorus storblommig. grandifolius storbladig. hirsutus, hirtus luden. hispidus sträfhårig. hortensis trädgårdsväxt. hybridus bastard.

lacustris i sjöar. latifolius bredbladig. limosus dyväxt. littoralis på hafsstränder. longifolius med långa blad. luteus gul. maculatus fläckig. magnus stor. marinus i hafvet. maritimus vid hafvet. montanus på berg. multiflorus mångblommig. natans simmande. neglectus förbisedd. nemoralis, nemorosus i lundar. niger svart. norvegicus norsk. nutans lutande. obtusifolius med trubbiga blad. odoratus välluktande. officinalis använd $\mathrm{i}$ medicin. oleraceus köksträdgårdsväxt. orientalis österländsk. paludosus, palustris i kärr. parviflorus småblommig. pauciflorus fåblommig. perennis mångårig. pilosus hårig. precox tidig. pratensis pä ängar. procumbens nedliggande. pubescens finluden. purpureus purpurröd. pusillus mycket liten. repens, reptans krypande. riparius vid åbräddar. rotundifolius med runda blad. ruber röd.

ruderalis ruderatväxt. rupestris på klippor. sativus odlad. saxatilis på steniga ställen. silvaticus i skogar. silvestris vild. 
strictus rak och styf.

suecicus svensk.

tinctorius färgväxt.

tuberosus med stamknölar.

uliginosus på fuktiga ställen.

umbellatus med blomflock. uniflorus enblommig. vernalis, vernus vårlig. viridis grön.

viscosus klibbig.

vulgaris, vulgatus allmän.

Anm. Af dessa adjektiver är endast den maskulina formen anförd. De som i maskulinum ändas på us eller er, få i femininum ändelsen $a$, i netrum $u m$; ändas maskulinum (ocl fem.) på is, får neutrum ändelsen $e$.

\section{Synonymer.*)}

Acrostichum I. 483, 1; 484, 8 . Agropyrum R. S. 21.

Agrostis algida Wng. 34, 2.

, arundinacea L. 49, 7.

$"$ borealis Hn. 51, 4 .

"stolonifera I. 51, 1.

Aira L. 34, 1; 41, 1; 39, 1-2 ; $38,2$.

Aira atropurp. Wng. 42.

Alliaria Adans. 329, 3.

Alnus barbata Mey. 452, 2.

" pubescens Tausch. 452, 2 .

Alsine hirta Hn. 232, 4.

" media L. $229,3$.

"Wng. 231, 1; 233, 1.

Andromerla L. 217.

Anemone L. 275, 1, 3, 4.

Anthericum L. 199, 2; 192.

Antirrhinum L. 308, 2, 3.

$" \quad$ Linaria L. 308, 1. Aphanes arvensis I. 80, 3. Arbutus L. 215, 2.

". uva ursi L. 215, 1. Arctium Bardana W. 393, 1 . Arctophila Rupr. 35, 7.

Arenaria L. 231, 1; 233, 1; 232, 1. Armeria maritima W. 172, 2.
Arundo Calarnagrostis L. 49, 4. Asclepias L. 132.

Aspidium Sw. 482; 484, 1.

Asplenium alternifolium Wulf. 484,7 .

Astragalus L. 367, 1.

"Hypoglottis Hn. 365, 3 .

" leortinus Wng. 365, 2.

Athamantha L. 151, 2.

Atriplex latifolia Wng. 476, 5.

Avena L. 38, 1.

Azalea L. 218.

Baldingera Fl. Wett. 62 .

Batrachium Wimm. 279, 20-23. " circinatum Fr. 279, 21.

Batrachium sceleratum Th. Fr. $279,3$.

Betula alba L. 451, 1.

Bidens subalpina Larss. 451, 3. platycephala Örst. 417,1 . Blitum Bonus Henr. Mey. 125, 1 . " glaucum Koch 125, 4. $"$ rubrum Rehb. 125, 9 . Blysmus compr. Panz. 19, 1. , rufus Link 19, 2. Blyttia svaveolens Fr. 55 .

*) Af andra svenska författare använda namn på här beskrifna växter. Första numret betecknar slägtets, de öfriga angifva arternas nummer i detta arbete.

Anm. Uteslutna äro de flesta sådana synonymer, hvars artnamn bildas ett nytt slägte, som är upptaget på registret, t. ex Arundo Phragmites L. = Phragmites communis. 
Brachypodium gracile P. B. 26, 2 . Braya supina Koch $329,4$. Bromus I. 29, 1; 26, 1; 30, 1, 2, 5 . ,$\quad$ asper Murr. 30, 3 . $"$ erectus Huds. 30,4 . ", pratensis Ehrh. 31, 2. Capsella Fr. 333.

Cardamine L. 326, 3.

Carduus L. 397, 1, 2, 3, 5. Carex*) acutæformis Ehrh. 74 . alpina Sw. 43*.

" borealis Lang. 38 .

", divulsa Good. 18.

" drymeja Ehrh. 47.

", elytroides Fr. 33.

, epigejos Fr. 38.

" festiva Dew. 31.

" flacca Schreb. 41.

" frigida Wng. 45.

, fuliginosa Hoppe 45.

" fulva Good. 67. Goodenowii Gay 37. hæmatolepis Drej. 40. helvola Blytt 24 . Hornschuchiana Hop. 67. hyperborea Drej. 34. intermedia Good. 11. juncella Fr. 37. leucoglochin Ehrh. 5. ligerica Gay 13. Limula Fr. 34. nigra All. 43. ornithopoda W. 56. pacifica Drej. 36. parallela Somf. 1. pediformis Mey. 56. Persoonii Sieb. 23. prolixa Fr. 34 . pulla Good. 72. rotundata Wng. 70. rufina Drej. 32. saxatilis L. 72 . Wng. 33. sparsiflora tir. 55 . stellulata Schreb. 30. tricostata Fr. 34. turfosa Fr. 35. vacillans Drej. 34. vaginata Tausch. 55*. Vahlii Schk. $43^{*}$.
Carex virens Lam. 18. vitilis Fr. 23.

Cephalanthera ensifolia Rich. $431,2$.

Cerastium L. 240.

" brachypetalum Desp. $239,8$. glomeratum Thuill. 239,3 . latifolium L. 239, 3.

$" \quad$ latifuium Curt 239,6

$" \quad$ pumilum Curt. 239,6 .

, tetrandrum Curt. 239,6.

Cerefolium sativum Bess. 145, 2. "2 silvestre Bess. 145, 1. Chærophyllum Anthriscus Wng. $145,3$.

sativum Wng. 145, 2. Chærophyllum silvestre L. 145, 1 . Cheiranthus alpinus Wng. 322,2. Chenopodium Wng. 128.
L. 129 .

$"$ L. 129 viride L. 125,4 .

Cistus 'L. 267, 2, 3.

Helianthemum L. 267, 1. Cnicus L. 397, 4.

Cochlearia Armoracia L. 320, 1. Cornnopus L. 337, 1. Coeloglossum Hn. 424, 11, 14. Convallaria L. 79.

Cratægus I. 253, 4.

Cucubalus Behen L. 228, 1. viscosus L. $228,4$.

Cnscuta Ligustri Aresch.133, 1. Cynosurus coeruleus L. 56. paniceus L. 57.

Cypripedium bulbosum L. 436. Draba androsacea Wng. 343, 2.

, dovrensis Fr. 343, 4.

$"$ muricella Wng. 343, 3.

$"$ rupestris Br. $343,4$. Wahlenbergii Hn. 343, 2.

Elymus caninus L. 21, 3.

Epilobium rivulare Wng. 207, 1. Epipactis atrorubens Hoffm. $430,2$.

Epipactis ensifolia Sw. 431, 2. nidus avis $\mathrm{Sw} .434$ rubra Wng. $431,1$. Equisetum fluviatile L. 493, 5 .
, olidum Curt. 125, 2

*) Vid detta slägte uppgifves blott artens nummer. 
Equisetum umbrosum W. 493, 2. Erica vulgaris L. 204.

Erigeron droebachensis Fr.403,1. " politus Fr. 403, 1. Eriophorum polystachion L. $20,1$.

Eriophorum Scheuchzeri Hop. $20,7$.

Erucastrum Pollichii Schimp. $325,1$.

Ervum hirsutum L. 361, 12.

Erysimum officinale L. 329, 2. " Alliaria L. 329, 3.

Farsetia R. Br. 341, 1.

Fedia olitoria Vahl 13, 1.

Festuca L. 44; 35, 3.

$" \quad$ elatior L. 29, 3.

" litorea Wng. 29, 4.

Filago arvensis Wng. 423, 2.

Fluminia arundinacea Fr. 45.

Fragaria moschata Duch. 260, 2 .

" viridis Duch. 260, 3.

Fumaria bulbosa L. 355, 1, 3, 5 .

Galium infestum Kit. 71, 11.

" Mollugo L. 71, 9.

" pusillum Wng. 71, 6.

". svaveolens Wng. 71, 10.

Gentiana L. 110, 2.

" glacialis Vill. 109, 5 .

" pulchella Sw. 110, 3.

Geranium cicutarium L. 350.

" pusillum L. 349,5 .

Glyceria spectabilis M. K. 35, 1 .

Gnaphalium dioicum L. 422, 1 .

Gymnadenia Br. 424, 9, 10.

Halianthus Fr. 231.

albida Rich. 424, 11.

Heleocharis R. Br. 19, 11, 13.

" multicaulis Lindl. 19, 12.

$"$ uniglumis Link $19,11$.

Heracleum australe Hn. 157, 2.

Hieracium*) æstivum Fr. 26.

\begin{tabular}{|c|}
\hline $\begin{array}{l}\text { anfractum Fr. } 22 . \\
\text { auriculæforme Fr. } 1 . \\
\text { bifidum Kit. 20. } \\
\text { canescens Schleich.13. } \\
\text { collinum Fr. } 4 . \\
\text { commutatum Lindeb. } \\
10 .\end{array}$ \\
\hline
\end{tabular}

Hieracium dulium L. 4.

$" \quad$ elatum Fr. 27.

" floribundum Wimm. 6 .

Friesii Hn. 23.

glomeratum Fr. 4.

gothicum Fr. 25.

macranthum Lindeb. 23.

onosmoides Fr. 14.

paludosum L. 384, 5.

præmorsum L. 384, 6.

rigidum Hn. 25.

setigerum Fr. 4.

sparsifolium Lindeb.

26.

subcæsium Fr. 20.

Taraxaci L. 380, 1.

Hierochloa odorata Wng. 64, 1 .

Holcus L. 64, 1.

Wng. 42.

Hordeum pratense Huds. 24, 2.

Hyoseris minima L. 389.

Hypericum quadrialatum Wng. $376,2$.

Iberis nudicaulis L. 334.

" petræa Wng. 333.

Intybus Fr. 384, 6 .

Juncus bottnicus Wng. 190, 13.

" bulbosus L. 190, 12.

" campestris L. 191, 4.

" effusus L: 190, 1 .

" glaucus Wng. 190, 4.

" nodulosus Wng. 190, 10.

" pilosus L. 191, 1.

" spicatus L. 191, 7.

Lamium incisum W. 290, 2.

Leontodon hastilis L. $\cdot 380,2$.

Lepidium L. 337, 2; 333.

Lepigonum caninum Leffl. 233, 2.

" medium Fr. 233, 2.

Lolium arvense Schrad. 22, 2.

$" \quad$ With. 22, 3 .

Lotus maritimus I. $_{3} 375$.

, siliquosus L. 375.

„, tenuifolius Rchb. 371, 2.

Luzula confusa Lindeb. 191, 5.

$" \quad$ hyperborea Hn. 191, 6.

" multiflora Lej. 191, 4 .

$"$ nivalis Spreng. 191, 6.

Lychnis alpina L. 235, 2.

*) Här angifves hlott artens nummer (utom vid tre arter). 
Lychnis dioica L. 236.

" pratensis Schk. 236, 2.

, silvestris Schk. 236, 1.

Lycopodium sabinæfolium Rupr. $496,6^{*}$.

Lycopodium selaginoides L. 497.

Lycopsis arvensis L. 93, 2.

Malva rotundifolia L. $352,4,5$. Matricaria Parthenium L. 412, 3. Melandrium affine Hn. 237, 2. 237," 1.

Melandrium noctiflorum Fr. 228,5 .

Melandrium pratense Röhl. $236,2$.

Melandrium silvestre Röhl. 236,1 .

Melanosinapis communis D.C. $324,3$.

Melica coerulea L. 36.

Melilotus macrorhizus Pers. $373,2$.

Melilotus vulgaris W. 373, 1 .

Mentha lapponica Wng. 283, 5 . " pratensis Sole 283, 3 . " rubra Fr. 283, 3.

Menziesia coerulea Sm. 217.

Molinia aquatica Wib. 34, 1. " coerulea Mönch. 36 . " maxima Hn. $35,1$.

Myagrum L. 340, 1; 346.

Myosotis alpestris Schm. 94, 3 .

" collina Rchb. 94, 5 .

" deflexa Wng. 97, 2.

$" \quad$ intermedia link 94,4 .

" Lappula L. 97, 1.

" lingulata Schulz 94, 2.

" scorpioides L. 94,1 .

Myrtillus nigra Gil. 203, 1 .

, uliginosa Gil. 203, 2.

Nasturtium aquaticum Wng. 320,6 .

Naumburgia thyrsiflora Rchb. $100,4$.

Nymphæa lutea L. 269, 1.

Ononis arvensis Hn. 358, 2.

Ophrys L. 429; 432; 434; 435.

Orchis L. 425.

, angustifolia Wimm.424, 8 .

" latifolia L. 424, 8.

" palustris Jacq. 424, 9.
Orchis Traunsteineri Saut.424, 8 .

Ornithogalum L. 185, 1, 4.

Orobus L. 363, 8, 9.

tuberosus L. 363, 7.

Osmunda L. 488; 489; 492, 1.

Oxycoccus palustris Pers. 203, 4 .

Panicum viride L. 57.

Pedicularis versicolor Wng. 315, 4.

Pedicularis virescens Wng. 315,4.

Petasites officinalis Mönch.405, 1 . Phaca alpina L. 366.

, Wng. 367.

" montana Wng. 367, 3.

Phalaris arundinacea L. 62.

"phleoides L. 61, 3 . Phellandrium aquaticum L。 164, 1.

Phleum Böhmeri Wib. 61, 3. Pisum maritimum L. 363, 6. Platanthera bifolia Rich. 424, 12. " chlorantha Cust. 424, 13.

" montana Rchb. 424, 13.

Poa aquatica L. 35, 1.

"distans L. 35, 5.

" remota Fors. 35, 2.

Polygala amara (L.) Hn. 356, 3 . Polygonum biforme Wng. 210,9.

$" \quad$ minus Huds. 210, 10.

" mite Schrank 210,10.

Polypodium alpestre Hop. 480, 4 .

" calcareum Sm.480,3.

" filix femina L. 481, 1 .

,$\quad$ fragile I. $482,1$.

Polystichum (Roth) 481.

Potamogeton Friesii Rupr. 85, 20.

" laticaule Wng. 85, 16 .

" nigrescens Fr. 85, 7.

" oblongus Viv. 85, 4.

" rutilus Wolfg. $85,21$.

, zosteraceus Fr. 85, 23.

" zosteræfolius Schum. $85,16$.

Potentilla incana Mönch 262, 10.

" maculata Pourr. 262,8.

Prenanthes muralis L. 386, 1 .

Primula acaulis Jacq. 98, 3. officinalis Jacq. 98, 1.

Prunus avium L. 250, 1 . 
Pulmonaria maritima L. 91. Pyrethrum Parthenium Sm. $412,3$.

Ranunculus aconitifolius Hn. 279, 1.

Ranunculus Friesii Gren. 279, 13.

"nemorosus D.C. 279, 14 . , reptans L. 279, 5.

Rheum digynum Wng. 195. Rosa spinosissima L. 256, 1. Rubus affinis (Arrh.) 257, 2.

" castoræus Lræst. 257, 11. " discolnr (Arrh.) 257, 8.

" Lindebergii Müll. (Aresch.) 257, 8. nemorosus Hayne 257, 5. plicatus Weihe 257, 2. pruinosus Arrh. 257, 5. suberectus Anders. 257, 2. tæniarum Lindeb. 257, 8. umbrosus Weihe 257, 8 . Wahlbergii Arrh. 257, 5. Rumex digynus I. 195.

, divaricatus Fr. 196, 7.

, Friesii Godr. 196, 7. Ruppia rostellata Koch 86, 1. Salix amygdalina L. 465, 4. , depressa (L.) Hn. 465, 9. " limosa Wng. 465, 15. " livida Wng. 465, 9. " majalis Wng. 465, 14. Salsola hirsuta L. 128.

Satyrium L. 424, 11, 14; 426; 433. , Wng. 424, 9, 10, 12 . nigrum L. 426.

Saxifraga adscendens L. 224, 12*. Scabiosa arvensis L. 69.

Scandix L. 147; 145, 3, 2. temulenta Wng. 146.

Sceptrum Rudb. 315, 1 . Schoenus I. 17; 19, 1, 2; 18. Scirpus Bæothryon Ehrh. 19, 10. ,$\quad$ glaucus Sm. 19, 5 . 19,5 . Tabernæmontani Gmel. Selinum L. 151.

lineare Schum. 154.

Senebiera Coronopus Poir. 337, 1. didyma Pers. 337, 2.

Serapias ensifolia Wng. 431, 2. latifolia L. 430, 1.
Serapias rubra L. 431, 1.

Serratula arvensis I. 397, 6 . Sinapis nigra It. $324,3$.

Sison L. 165.

Sisymbrium L. $320,2,3,5 ; 326$, $4 ; 325,2$. anceps Wng. 320, 4 . Nasturtium L. 320, 6 .

Solanum humile Bernh. 108, 2.

Sonchus L. 385.

Sorbus hybrida L. 253, 3.

Soyeria paludosa Godr. 384, 5 . Sprarganium erectum Wng. 448,2. Spartium L. 359.

Spergula nodosa L. 241, 1. Spergularia Presl. 233, 1, 2. Statice rariflora Drej. 173, 1. Stellaria biflora L. 232, 3 .

, cerastioides L. 239, 4 . " glauca With. 229,4 .

Sturmia Rchb. 435, 3.

Succisa pratensis Mönch 70, 3.

Tamarix L. 351.

Thalictrum flexuosum Rchb. 274, 2.

Thalictrum rariflorum Fr. 274,6.

Thlaspi L. $331 ; 332,1$.

Thymus Acinos L. 301.

Tillæa L. 84.

Tordylium Anthriscus L. 142.

Tormentilla erecta L. 262, 7 .

Trichera Schrad. 69. reptans L. 262, 5 .

Trichophorum alpinum Pers. 20, 8.

Trichophorum cæspitosum Hn. 19, 9 .

Tripleurospermum Schz. 413, 1 . Triticum acutum Fr. 21, 7.

, affine Hn. 21, 8 .

" campestre Godr. 21, 7.

" hebestachyum Fr.21, 7 .

". laxum Fr. 21, 8.

Tunica Scop. 225, 3.

Turritis glabra L. 326, 7. hirsuta L. 326, 1.

Tussilago L. 405, 2, 3.

, Petasites L. 405, 1.

" spuria Retz. 405, 4.

Ulmus glabra Mill. 131, 2.

Utricularia pulchella Fr. 9, 6.

Valeriana Locusta L. 13, 1. 
Valerianella dentata Poll. 13, 2. $\mid$ Viola scanica Fr. 123, 1.

Veronica Buxbaumii Ten. 10, 18.

Vicia tetrasperma Fr. $36,1$.

Viola epipsila Led. 123, 1. " stagnina Kit. 123, 10.

" stricta Horn. 123, 9.

", suecica Fr. 123, 1. Viscaria vulgaris Röhl. 235, 1. " pratensis M. K. 123, 10. Zostera nana Roth 3, 2.

\section{Art-statistik.}

De här beskrifna vilda arterna äro till antalet 1433, hvaraf 1379 fanerogamer och 54 ormbunkar. I Skåne förekomma omkr. 1070, i Småland omkr. 1020, i Östergötland omkr. 950, på Gotland omkr. 910, i Lappland omkr. 540. 


\section{Register.*)}

Abies 441.

Acer 479.

Achillæa 416.

Aconitum 273.

Acorus 194.

Actæa 270.

Adonis 280.

Adoxa 212.

Aegopodium 138.

Aethusa 163.

Agrimonia 246.

Agrostemma 234.

Agrostis 51.

Aira 40.

Airopsis 39 .

Ajuga 284.

Alchemilla 80 .

Alisma 200.

Allium 184.

Allosurus 489.

Alnus 452.

Alopecurus 60.

Alsine 232.

Alyssum 341 .

Ammadenia 231.

Anacamptis 425.

Anagallis 101.

Anchusa 93.

Anỏromeda 216.

Androsace 102.

Anemone 276.

Angelica 155 .

Antennaria 422

Anthemis 415 .

Anthericum 189.

Anthoxanthum 63.

Anthriscus 145.

Anthyllis 357.

Antirrhinum 309.

Apera 52.

Apium 168.

Aquilegia 272.
Arabis 326.

Archangelica 156.

Arctostaphylos 215.

Arenaria 230.

Armeria 172.

Arnica 407.

Arnoseris 389.

Artemisia 410.

Arum 457.

Asarum 245.

Asparagus 188.

Asperugo 95.

Asperula 72.

Aspidium 481.

Asplenium 484.

Aster 404.

Astragalus 365.

Atriplex 476.

Avena 37.

Azalea 118.

Ballota 295.

Barbarea 323.

Bartsia 313.

Bellis 414.

Berberis 177.

Betonica 294.

Betula 451.

Bidens 417.

Blechnum 488 .

Blitum 126.

Botrychium 492.

Brachypodium 26.

Brassica 324.

Braya 327.

Briza 33.

Bromus 31.

Bulliarda 84.

Bunias 345.

Bupleurum 137.

Butomus 214.

Cakile 338.
Calamagrostis 49 .

Calamintha 361 .

Calla 193.

Callitriche 442.

Calluna 204.

Caltha 277.

Calypso 436.

Camelina 340.

Campanula 113.

Capsella 331.

Cardamine 318.

Carduus 398.

Carex 445.

Carlina 394.

Carpinus 459.

Carum 166.

Catabrosa 34.

Centaurea 391.

Centunculus 76 .

Cephalantera 431.

Cerastium 239.

Cerasus 250.

Ceratophyllum 456 .

Chærophyllum 146.

Chamænerium 206.

Chamæorchis 429 .

Chelidonium 264.

Chenopodium 125.

Chimaphila 221.

Chrysanthemum 412

Chrysosplenium 209.

Cichorium 390.

Cicuta 162.

Cineraria 409.

Cinna 55.

Circæa 5.

Cirsium 397.

Cladium 18.

Clinopodium 300

Cnidium 154.

Cochlearia 342.

Comarum 261.

*) Siffrorna beteckna slägtets nummer. 
Conium 161.

Convallaria 187.

Convolvulus 112.

Corallorhiza 437.

Cornus 77.

Coronilla 369.

Coronopus 337.

Corydalis 355 .

Corylus 458.

Corynephorus 41 .

Cotoneaster 252.

Crambe 339.

Cratægus 251.

Crepis 384.

Cuscuta 133.

Cynanchum 132.

Cynoglossum 96.

Cynosurus 27.

Cyperus 16.

Cypripedium 439 .

Cystopteris 482 .

Dactylis 28.

Daphne 202.

Datura 105.

Daucus 144.

Delphinium 271.

Dentaria 319.

Dianthus 225.

Diapensia 106.

Digitalis 316.

Digitaria 59.

Digraphis 62 .

Diplotaxis 325 .

Draba 343.

Dracocephalum 299.

Drosera 174.

Dryas 258.

Echinops 392.

Echinospermum 97.

Echium 88.

Elatine 213.

Elymus 25.

Empetrum 466.

Enodium 36.

Epilobium 207.

Epipactis 430.

Epipogium 438.

Equisetum 493.

Erica 205.

Erigeron 403.

Eriophorum 20.
Erodium 350.

Ervum 362.

Eryngium 136.

Erysimum 322.

Erythræa 110.

Evonymus 122.

Eupatorium 400.

Euphorbia 444.

Euphrasia 311.

Fagus 461.

Falcaria 141.

Festuca 29.

Ficaria 278.

Filago 423.

Fragaria 260.

Fraxinus 478.

Fritillaria 182.

Fumaria 354.

Gagea 185.

Galanthus 180.

Galeobdolon 292.

Galeopsis 289.

Galium 71.

Genista 360.

Gentiana 109.

Geranium 349.

Geum 259.

Glaucium 265.

Glaux 87.

Glechoma 288.

Globularia 74.

Glyceria 35.

Gnaphalium 420.

Goodyera 433.

Graphephorum 45.

Gypsophila 226.

Halimus 477.

Haloscias 140.

Hedera 121.

Helianthemum 267.

Helichrysum 421.

Helosciadium 165.

Heracleum 157.

Herminium 427.

Herniaria 130.

Hesperis 321.

Hieracium 383.

Hierochloa 64.

Hippophaë 469.

Hippuris 2.
Holcus 43.

Holosteum 68.

Hordeum 24.

Hottonia 99.

Humulus 470.

Hutchinsia 333.

Hydrocharis 475 .

Hydrocotyle 134.

Hyoscyamus 104.

Hypericum 376.

Hypochæris 377.

Iasione 114.

Impatiens 124.

Imperatoria 139.

Inula 418.

Iris 14.

Isatis 336 .

Isoëtes 495 .

Juncus 190.

Juniperus 463.

Knautia 69.

Kobresia 446.

Kochia 128.

Koeleria 47.

Koenigia 67.

Lactuca 386.

Lamium 290.

Lappa 393.

Lapsana 388.

Laserpitium 149.

Lathræa 305.

Lathyrus 363.

Lavatera 353.

Ledum 219.

Lemna 4.

Leontodon 380.

Leonurus 291.

Lepidium 332.

Lepigonum 233.

Lepturus 23.

Leucojum 179.

Levisticum 150.

Libanotis 143.

Ligustrum 11.

Lilium 183.

Limosella 304.

Linaria 308.

Linnæa 303.

Linosyris 401.

Linum 347. 
Listera 432.

Lithospermum 89.

Littorella 449.

Lobelia 115.

Lolium 22.

Lonicera 117.

Lotus 371.

Lunaria 344.

I.uzula 191.

Lychnis 238.

Lycopodium 496.

Lycopus 7.

Lysimachia 100.

Lythrum 244.

Majanthemum 79.

Malachium 240.

Malaxis 435.

Malva 352.

Marrubium 296.

Matricaria 413.

Medicago 374.

Melampyrum 310 .

Melandrium 236.

Melica 46.

Melilotus 373.

Mentha 283.

Menyanthes 111.

Mercurialis 472 .

Milium 54.

Monotropa 222.

Montia 66.

Mulgedium 385.

Myosotis 94 .

Myosurus 176.

Myrica 467.

Myricaria 351.

Myriophyllum 454.

Myrrhis 147.

Najas 462.

Nardus 65 .

Narthecium 192.

Nasturtium 320.

Neottia 434.

Nepeta 287.

Neslia 346.

Nigritella 426.

Nuphar 269.

Nymphæa 268.

Odontites 312.

Oenanthe 164.
Oenothera 208.

Onobrychis 368 .

Ononis 358.

Onopordon 399.

Ophioglossum 491.

Ophrys 428.

Orchis 424.

Origanum 286.

Ornithogalum 186.

Ornithopus 370.

Orobanche 306.

Osmunda 490.

Oxalis 348.

Oxyria 195.

Oxytropis 367.

Panicum 58.

Papaver 263.

Paris 211.

Parnassia 171.

Pastinaca 158.

Pedicularis 315 .

Peplis 178.

Petasites 405.

Peucedanum 151.

Phaca 366.

Phleum 61.

Phragmites 48.

Phyllodoce 217.

Picris 381.

Pilularia 494.

Pimpinella 167.

Pinguicula 8.

Pinus 440.

Pisum 364.

Plantago 75.

Pleurospermum 160.

Poa 32.

Polemonium 107.

Polygala 356.

Polypodium 480 .

Polygonum 210.

Populus 471.

Potamogeton 85.

Potentilla 262.

Poterium 455.

Primula 98.

Prunella 298.

Prunus 249.

Psamma 50.

Pteris 486.

Pulicaria 419.
Pulmonaria 90.

Pulsatilla 275.

Pyrola 220.

Pyrus 254.

Quercus 460.

Radiola 83.

Ranunculus 279.

Raphanus 317.

Reseda 247.

Rhainnus 120.

Rhinanthus 314.

Rhodiola 473.

Rhododendrum 218.

Rhynchospora 17.

Ribes 119.

Rosa 256.

Rubus 257.

Rumex 196.

Ruppia 86.

Sagina 241.

Sagittaria 453.

Salicornia 1.

Salix 465.

Salsola 127.

Salvia 6.

Sambucus 170.

Samolus 116.

Sanguisorba 81.

Sanicula 135.

Saponaria 227.

Sarothamnus 359.

Saussurea 395.

Saxifraga 224.

Scabiosa 70.

Scandix 148.

Schedonorus 30.

Scheuchzeria 198.

Schoberia 129.

Schoenus 15.

Scirpus 19.

Scleranthus 223.

Scolopendrium 485 .

Scorzonera 379.

Scrophularia 307.

Scutellaria 297.

Sedum 243.

Selaginella 497.

Selinum 152.

Sempervivum 248.

Senecio 408. 
Serratula 396.

Sesleria 56.

Setaria 57.

Sherardia 73.

Sibbaldia 175.

Silaus 153.

Silene 228.

Sinapis 328.

Sisymbrium 329.

Sium 159.

Solanum 108.

Solidago 402.

Sonchus 382.

Sorbus 253.

Sparganium 448.

Spergula 242.

Spiræa 255.

Stachys 293.

Statice 173.

Stellaria 229.

Stenhammaria 91 .

Stipa 53.

Stratiotes 474.

Struthiopteris 487 .
Subularia 335 .

Symphytum 92.

Tanacetum 411. Taraxacum 387.

Taxus 464.

Teesdalia 334.

Tetragonolobus 375 .

Teucrium 285.

Thalictrum 274 .

Thesium 82.

Thlaspi 330.

Thymus 302.

Tilia 266.

Tofielda 199.

Torilis 142.

Tragopogon 378.

Trapa 78.

Trientalis 201.

Trifolium 372.

Triglochin 197.

Triodia 44.

Trisetum 38.

Triticum 21.
Trollius 281.

Tulipa 181.

Tussilago 406.

Typha 447.

Ulmus 131.

Urtica 450.

Utricularia 9.

Vaccinium 203.

Vahlbergella 237.

Vahlodea 42.

Valeriana 12.

Valerianella 13.

Verbascum 103.

Verbena 282.

Veronica 10.

Viburnum 169.

Vicia 361.

Viola 123.

Viscaria 235.

Viscum 468.

Woodsia 483.

Zannichellia 443.

Zostera 3. 


\section{In nehåll:}

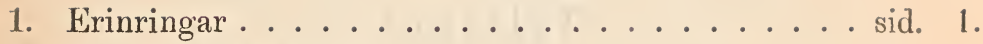

2. Linnés sexual-system .............. . . 2 .

3. Öfversigt af de vigtigaste fanerogama familjerna $\mathrm{i}$ Fries' naturliga system ..........., , 4 .

4. Beskrifning af slägtena ........... , 5 .

๖.,$\quad$, arterna ............, 60 .

6. Förklaring öfver de vigtigaste konstorden (vetenskapliga termerna) .............. , 376 . .

7. Några regler vid växternas insamling och inläggning

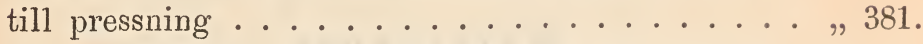

8. Svårbestämluara slägten och arter . . . . . . , , 382 .

9. De vigtigaste odlade växterna . . . . . . , , 384 .

10. Förvildade och tillfälligtvis förekommande växter . , 387.

11. Förkortningar af anförda författares namn . . . , , 390.

12. Förklaring af de vigtigaste artnamnens betydelse . , 392.

13. Synonymer . . . . . . . . . . . , 393.

14. Art-statistik . . . . . . . . . . , 398 . 


\section{Tillägg:}

Sid. 32, rad. 24 ofr.: Resedáceæ; sid 61 r. 3 nedifr.: Vg.; sid. 97 r. 15 ofr.: Smål., Moheda; sid. 123 r. 19 ofr.: Göt. Vg. Ljunghem; sid. 141 r. 4 nfr. Dalsl. 0.

\section{Rättelser:}

Sid. 33, rad. 2 nedifr. läs: strälblomstrig; sid. 182 r. 8 ofr. står B. läs: b.; sid. 191 r. 1-2 nfr. läs: upprätta; sid. 201 r. 18 ofr. står: ovala, läs: äggrunda; sid. 228 r. 9 ofr.: artsiffran 2 tillsättes; sid. 291 r. 1 nfr. läs: vulgaris. 
15.

sit

(3.

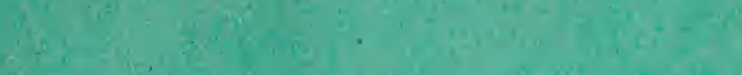

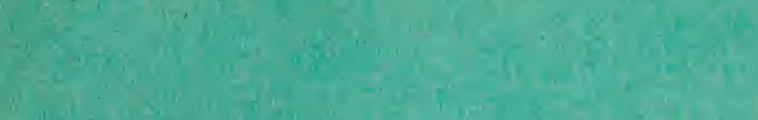

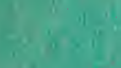

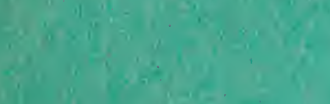

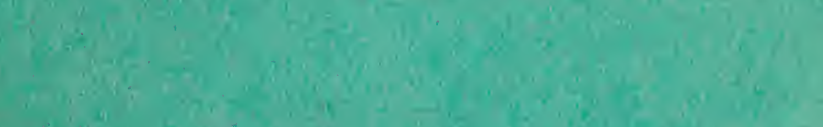

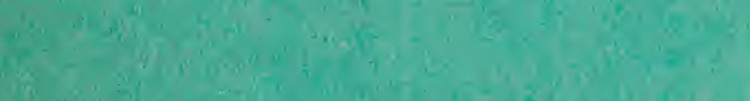

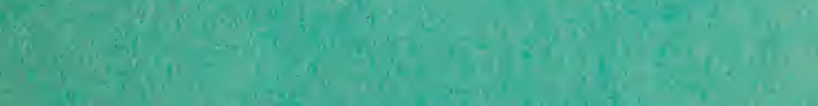

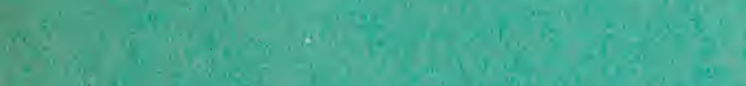

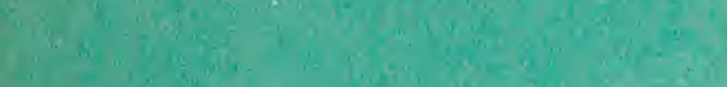

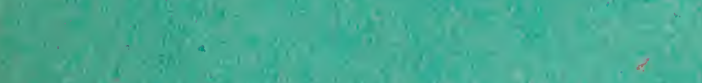

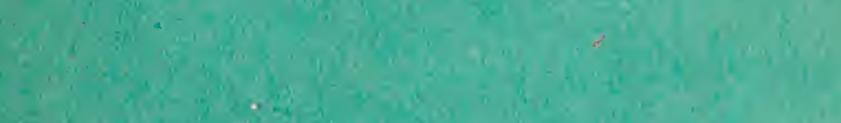

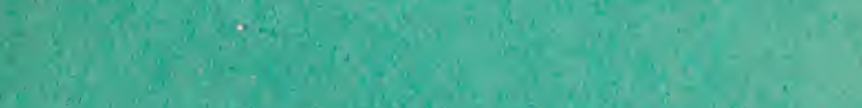

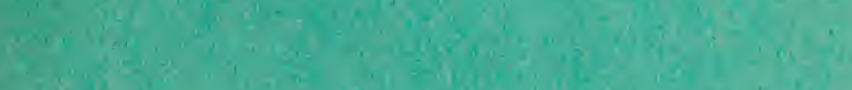

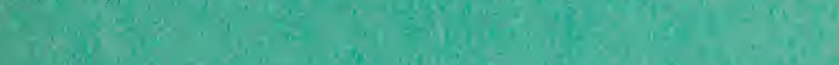

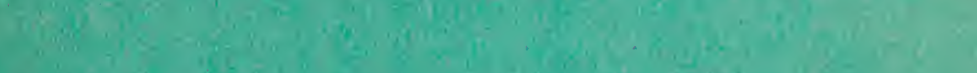

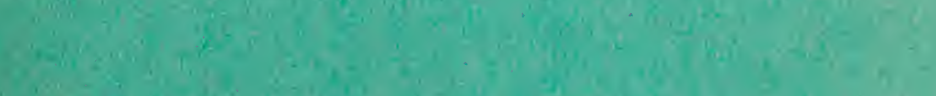

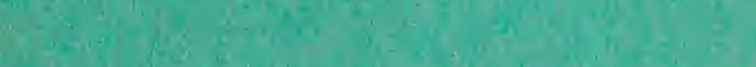

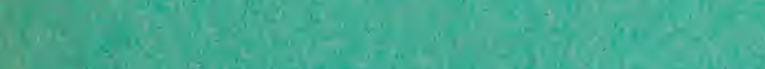
, a

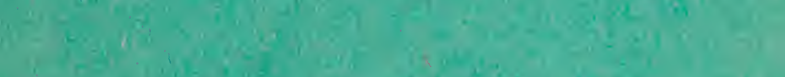

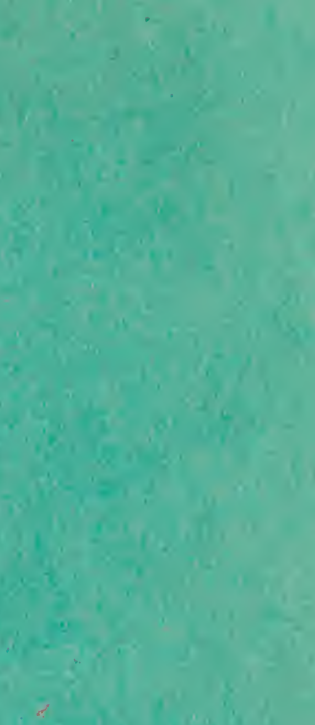

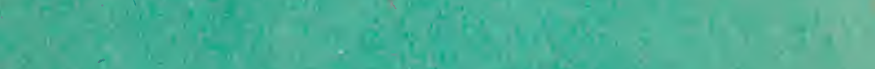

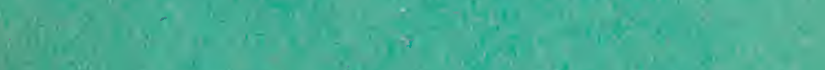

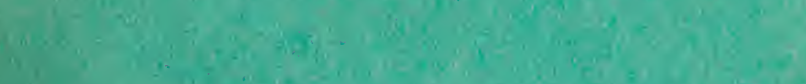

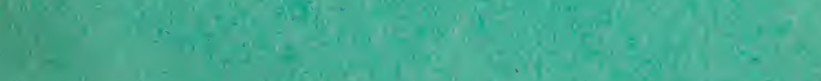

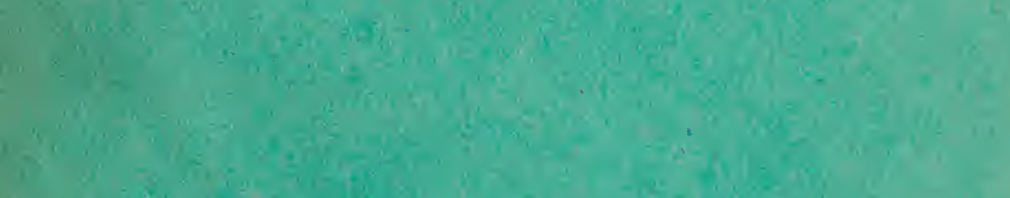

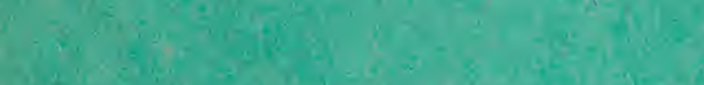

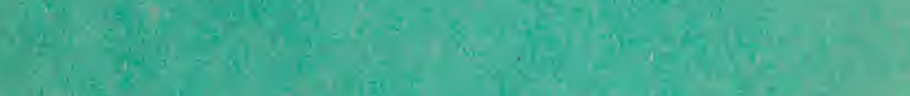

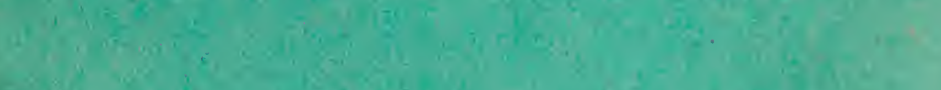

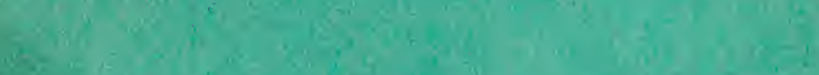

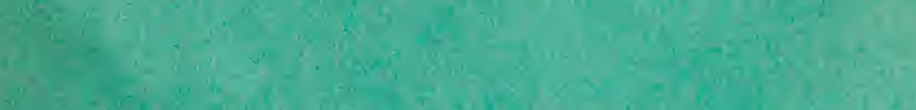

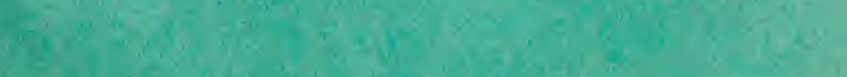

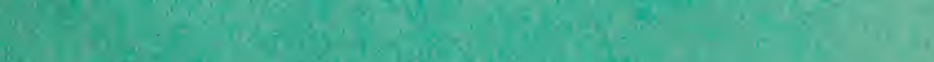

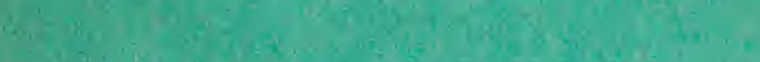

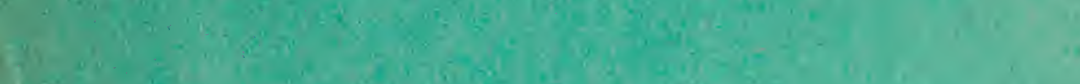

3
4 
I Bokhandeln hafva utkommit följande at Lektor N. C. Kindberg utgifna arbeten:

Sammandrag af Botanikens elementer, 4:de uppl.:

1:sta häftet inneh. beskrifning af 10 växter med färglagda planscher . . . . . . . 0,85.

2:dra häftet inneh, beskrifning af 10 växter med färglagda planscher, Fanerogamernas Organografi med många i texten intryckta figurer samt Sexualsystemet . . . . . . 1,10.

Sammandrag af Botanikens elementer, 3:dje uppl.: 4:de häftet, Fanerogamernas Anatomi, Fysiologi och Morfologi samt Läran om Kryptogamernas vigtigaste oryaner, med många i texten intryckta träsnitt. . . . . . . 0,50.

Östgöta Flora, 2:dra omarbetade uppl... . . . . . 3Sammandrag af Norra Sveriges Flora . . . . . . 1 Om menniskans kroppshyggnad, 2:dra uppl. . . . 0,25.

Zoologisk Lïsebok.

1 :sta häftet. Om däggdjuren $\ldots \ldots \ldots 0,60$ 


